UNIVERSIDADE DE SÃO PAULO

FACULDADE DE FILOSOFIA, LETRAS E CIÊNCIAS HUMANAS

DEPARTAMENTO DE CIÊNCIA POLÍTICA

PROGRAMA DE PÓS-GRADUAÇÃo EM CIÊNCIA POLÍTICA

LAERTE APOLINÁRIO JÚNIOR

A Cooperação Brasileira para o Desenvolvimento Internacional como Instrumento de Política Externa: a Economia Política da Cooperação Técnica Brasileira

Versão corrigida

São Paulo

2019 
LAERTE APOLINÁRIO JÚNIOR

\section{A Cooperação Brasileira para o Desenvolvimento Internacional como Instrumento de Política Externa: a Economia Política da Cooperação Técnica Brasileira}

Versão corrigida

Tese de Doutorado apresentada ao Programa de Pós-Graduação em Ciência Política do Departamento de Ciência Política da Faculdade de Filosofia, Letras e Ciências Humanas, da Universidade de São Paulo, como parte dos requisitos para obtenção do título de Doutor em Ciência Política

Orientadora: Profa. Janina Onuki

São Paulo 
Autorizo a reprodução e divulgação total ou parcial deste trabalho, por qualquer meio convencional ou eletrônico, para fins de estudo e pesquisa, desde que citada a fonte.

Catalogação na Publicação

Serviço de Biblioteca e Documentação

Faculdade de Filosofia, Letras e Ciências Humanas da Universidade de São Paulo

A $643 \mathrm{C}$

Apolinário Júnior, Laerte

A Cooperação Brasileira para o Desenvolvimento Internacional como Instrumento de Política Externa: a Economia Política da Cooperação Técnica Brasileira / Laerte Apolinário Júnior ; orientadora Janina Onuki. - São Paulo, 2019. $300 \mathrm{f}$.

Tese (Doutorado)- Faculdade de Filosofia, Letras e Ciências Humanas da Universidade de São Paulo. Departamento de Ciência Política. Área de concentração: Ciência Política.

1. Cooperação Internacional para o Desenvolvimento. 2. Cooperação Sul-Sul. 3. Ajuda externa. 4. Política externa brasileira. 5. Cooperação Técnica. I. Onuki, Janina, orient. II. Título. 


\section{ENTREGA DO EXEMPLAR CORRIGIDO DA DISSERTAÇÃO/TESE}

Termo de Ciência e Concordância do (a) orientador (a)

Nome do (a) aluno (a): Laerte Apolinário Júnior

Data da defesa: 11/04/2019

Nome do Prof. (a) orientador (a): Janina Onuki

Nos termos da legislação vigente, declaro ESTAR CIENTE do conteúdo deste EXEMPLAR CORRIGIDO elaborado em atenção às sugestões dos membros da comissão Julgadora na sessão de defesa do trabalho, manifestando-me plenamente favorável ao seu encaminhamento e publicação no Portal Digital de Teses da USP.

São Paulo, 05/08/2019

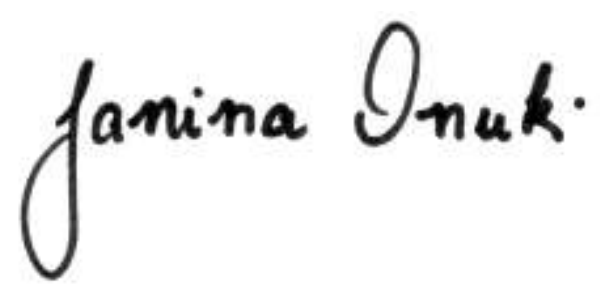

(Assinatura do (a) orientador (a) 


\section{APOLINÁRIO JÚNIOR, Laerte. A Cooperação Brasileira para o Desenvolvimento}

Internacional como Instrumento de Política Externa: a Economia Política da

Cooperação Técnica Brasileira. 2019. 300f. Tese (Doutorado) - Faculdade de Filosofia, Letras e Ciências Humanas, Universidade de São Paulo, São Paulo, 2019.

Aprovado em: 11 de abril de 2019

\section{Banca examinadora}

Profa. Dra.: Janina Onuki

Instituição: Instituto de Relações Internacionais da Universidade de São Paulo (IRI-USP)

Função: Presidente

Prof Dr.: Amâncio Jorge Silva Nunes de Oliveira

Instituição: Instituto de Relações Internacionais da Universidade de São Paulo (IRI-USP)

Função: Titular

Prof. Dr.: Anthony Wynne Pereira

Instituição: King's College London (KCL)

Função: Titular

Prof. Dr.: Carlos Roberto Sanchez Milani

Instituição: Instituto de Estudos Sociais e Políticos da Universidade Estadual do Rio de Janeiro (IESP/UERJ)

Função: Titular 
Aos meus pais,

Laerte Apolinário

Sandra Maria Marchezi Apolinário

A minha companheira, Nathália Scalanti Mateos Valverde

A todos os meus mestres e professores 


\section{AGRADECIMENTOS}

Primeiramente, gostaria de agradecer aos meus pais, Laerte Apolinário e Sandra Maria Marchezi Apolinário, por sempre terem me incentivado a estudar e a buscar novos desafios. Sem esse incentivo contínuo, este trabalho não teria sido realizado. Agradecimentos especiais também à minha noiva, amiga e companheira, Nathália Scalanti Mateos Valverde, por todo apoio e compreensão nesses últimos anos.

Agradeço à minha família de modo geral, em especial, meu irmão, Vinicius Marchezi Apolinário; minhas avós, Filomena Lucas Apolinário e Maria Caloni; meus avôs, Antônio Apolinário e Júlio Marchezi; meus tios, Oslair Pereira, Sérgio Hadachi; minhas tias, Simone Marchezi, Sônia Marchezi e Raquel Apolinário. Meus primos e primas, Alef Marchezi Pereira, Felipe Melani, Henrique Hadachi, Thiago Izumi e Mariana Hadachi; ao meu sobrinho e afilhado, Leonardo Rodrigues Apolinário. E a todos os demais membros da minha família que não foram citados.

Agradeço também aos meus amigos da época do Objetivo de Adamantina e dos tempos de graduação na UNESP, Franca. Agradeço especialmente ao meu grande amigo, desde os tempos de graduação, André Ramalho Gomes, aos grandes amigos que também partiram de Franca rumo a São Paulo, Daniel Malheiros Frare e Vinicius Boff Ciampi. E a todos os meus amigos de São Paulo que fizeram minha vida na metrópole muito mais fácil e prazerosa.

Agradeço também a todos os colegas do Instituto de Relações Internacionais da Universidade de São Paulo (IRI/USP), da época do mestrado, que tornaram as aulas mais ricas. Agradecimentos especiais aos meus colegas do POLMET, do Grupo de Economia Política (GEP) e, principalmente, do Centro de Estudos das Negociações Internacionais (CAENI), pelas valiosas discussões, troca de ideias e pelo apoio de todos durante minha formação acadêmica. Agradeço também a todos os colegas do Departamento de Ciência Política da Universidade de São Paulo (DCP/USP), especialmente aos caros Rodolfo Lima Camargo e Augusto Rinaldi.

Gostaria de agradecer à minha orientadora do mestrado, Profa. Dra. Cristiane de Andrade Lucena Carneiro, por ter me aceitado como orientando em meu ingresso no IRI/USP e por ter me acompanhado durante minha trajetória na Pós-Graduação. Agradeço também aos estimados professores: Profa. Dra. Janina Onuki, Profa. Lorena Barberia e Prof. Dr, Feliciano 
Sá Guimarães, os quais me honraram com suas presenças nas bancas de qualificação e defesa do mestrado.

Gostaria de agradecer especialmente à minha orientadora do doutorado, Profa. Dra. Janina Onuki, não só por ter me aceitado como orientando no programa do DCP/USP, mas também por todo apoio e auxílio durante essa jornada. Agradeço também aos estimados professores: Prof. Dr. Amâncio Jorge Nunes de Oliveira e Prof. Dr. Pedro Feliú Ribeiro, os quais me honraram com suas presenças nas bancas de qualificação do doutorado.

Agradeço também a todos os meus colegas de trabalho na Pontifícia Universidade Católica de São Paulo (PUC/SP), na qual ingressei no ano de 2017. Esses últimos dois anos têm sido inestimáveis no tocante às experiências acumuladas. Não possuo palavras para descrever o crescimento pessoal e profissional que vivenciei nesses últimos anos. Agradeço aos professores: Prof. Dr. Reginaldo Mattar Nasser, Profa. Dra. Cláudia Alvarenga Marconi, Prof. Dr. Tomaz Oliveira Paollielo, Profa Dra. Natália Maria Félix, Prof. Dr. Paulo José dos Reis Pereira, Profa. Priscila Vilella Frascino, Profa. Dra. Terra Friedrich Budini, Profa. Dra. Flávia de Campos Mello, Prof. Arthur Felipe Murta Rocha Soares, Prof. Dr. David Almstadter Magalhães, Prof. Dr. Carlos Gustavo Poggio Teixeira, Prof Dr. Geraldo Nagib Zahran Filho, Profa Dra. Elaini Cristina Gonzaga da Silva e Profa Dra. Luiza Rodrigues Mateo. Agradeço também a todos os meus alunos da PUC/SP, com os quais tive a satisfação de ensinar e o prazer de aprender.

Registro minha gratidão aos docentes do IRI/USP e DCP/USP, com os quais tive o privilégio de aprender nesses últimos anos, em especial aos professores: Prof. Dr. Amâncio Jorge Nunes de Oliveira, Profa. Dra. Maria Hermínia Tavares de Almeida, Profa. Dr. Lorena Barberia, Prof. Dr. Fernando Limongi, Prof Dr. Glauco Peres da Silva, Prof. Dr. Fernando Haddad, Profa Dra. Rossana Reis, Prof. Dr. Florian Rabitz, Prof Dr. Pedro Feliú Ribeiro e Prof. Dr. Umberto Mignozetti. Agradeço também ao caro Prof. Dr. Ivan Filipe de Almeida Lopes Fernandes por todo o auxílio prestado para a realização dessa pesquisa.

Gostaria de agradecer também a todos os meus professores da UNESP, especialmente à minha orientadora do Trabalho de Conclusão de Curso (TCC), Profa. Dra. Suzeley Kalil Mathias. Agradeço também a todos os funcionários da UNESP de Franca, do IRI/USP e do DCP/USP que sempre me auxiliaram em minha jornada acadêmica, em especial, aos funcionários do DCP: Márcia Regina Staaks e Vasne dos Santos. Por fim, agradeço à Coordenação de Aperfeiçoamento e Nível Superior (CAPES) pelo financiamento parcial dessa pesquisa. 


\title{
RESUMO
}

\author{
APOLINÁRIO JÚNIOR, Laerte. A Cooperação Brasileira para o Desenvolvimento \\ Internacional como Instrumento de Política Externa: a Economia Política da \\ Cooperação Técnica Brasileira. 2019. 300f. Tese (Doutorado) - Faculdade de Filosofia, \\ Letras e Ciências Humanas, Universidade de São Paulo, São Paulo, 2019.
}

Ao longo do último século, o Brasil foi basicamente um receptor de ajuda internacional. Nas últimas décadas, entretanto, o país se firmou como um doador de recursos para países em desenvolvimento por meio de suas ações de Cooperação Internacional ao Desenvolvimento (CID). Embora o país não se considere um doador, na medida em que essa ajuda prestada pelo país se inscreveria no contexto da Cooperação Sul-Sul, o país ganhou proeminência no regime de CID nos últimos anos. A influência dos países emergentes na arquitetura da CID trouxe profundas mudanças ao panorama da cooperação. Ao mesmo tempo, os países emergentes, geralmente classificados como países de renda média, ainda permanecem com altos níveis de pobreza, estimulando um debate sobre se tais recursos utilizados na cooperação internacional não teriam um melhor destino no ambiente doméstico. Assim, por que um país em desenvolvimento com graves problemas socioeconômicos forneceria cooperação no cenário internacional? Por um lado, o discurso oficial durante esse período, especialmente entre 2003 e 2014, era o de que a cooperação fornecida pelo Brasil, sobretudo em sua vertente técnica, se sustentaria em ideais de solidariedade e no intercâmbio de experiências comuns não possuindo interesses materiais. Por outro, analistas apontam para os interesses políticos e econômicos na sua execução. Essa pesquisa busca contribuir com esse debate por meio de uma análise empírica inédita acerca dos padrões de alocação dos gastos com projetos de Cooperação Técnica (CT) realizados pelo Brasil entre os anos de 2000 e 2016. Dialogando com a literatura acerca dos determinantes de ajuda externa, foi analisada a relação entre os gastos com CT por parte do governo brasileiro e variáveis econômicas e políticas referentes aos interesses geopolíticos do Brasil no cenário internacional e variáveis socioeconômicas referentes às necessidades dos países recipientes. Assim, a proposta dessa pesquisa foi analisar quais os determinantes para a alocação dos gastos em projetos de CT brasileira. Os resultados indicam uma relação entre a cooperação técnica brasileira e variáveis referentes aos interesses econômicos e políticos, como empréstimos subsidiados via BNDES, exportações e apoio político dos receptores ao Brasil em Organizações Internacionais; e variáveis referentes às necessidades dos receptores, como nível de desenvolvimento socioeconômico e qualidade democrática.

Palavras-chave: Cooperação Internacional para o Desenvolvimento. Cooperação Sul-Sul. Ajuda Externa. Cooperação Técnica. Política Externa Brasileira. 


\begin{abstract}
APOLINÁRIO JÚNIOR, Laerte. The Brazilian Cooperation for International Development as a Foreign Policy Instrument: the Political Economy of Brazilian Technical Cooperation. 2019. 300p. (Doctoral) Dissertation - Faculdade de Filosofia, Letras e Ciências Humanas, Universidade de São Paulo, São Paulo, 2019.

Over the last century, Brazil was basically an international aid recipient. In the last decades, however, the country has established itself as a donor of resources for developing countries through its actions of International Development Cooperation (IDC). Although the country does not consider itself a donor, to the extent that the country's aid is inscribed in the context of South-South Cooperation (SSC), Brazil has gained prominence in the IDC regime in recent years. The influence of emerging countries on IDC architecture has brought profound changes to the cooperation landscape. At the same time, emerging countries, generally classified as middle-income countries, still remain at high levels of poverty, stimulating a debate on whether such resources used in international cooperation would not have a better destination in the domestic environment. Therefore, why would a developing country with serious socioeconomic problems provide international cooperation? On the one hand, the official discourse at the time, especially between 2003 and 2014, was that the Brazilian cooperation, particularly in its technical modality, was based on ideals of solidarity and on the exchange of common experiences having no material interests. On the other, analysts point to the political and economic interests in its execution. This research contributes to this debate through an empirical analysis of the Brazilian Technical Cooperation (TC) allocation patterns between 2000 and 2016. Departing from the literature on foreign aid determinants, this study analyzes the relationship between TC expenditures by the Brazilian government and economic and political variables related to Brazil's geopolitical interests in the international scenario and socioeconomic variables related to the recipient needs. Thus, this research analyzes the determinants of Brazilian TC projects expenditures allocation. The results indicate a relationship between Brazilian technical cooperation and variables related to economic and political interests, such as subsidized loans through BNDES, exports and political support of recipients to Brazil in International Organizations; and variables related to the recipients' needs, such as socioeconomic development and democratic quality.
\end{abstract}

Keywords: International Development Cooperation. South-South Cooperation. Foreign Aid. Technical Cooperation. Brazilian Foreign Policy. 


\section{LISTA DE ILUSTRAÇÕES}

Figura 4.4.4.1. Influências sobre o processo decisório da Cooperação Técnica Brasileira 221

Figura 5.2.1. Evolução dos gastos em projetos de Cooperação Técnica Brasileira.............225

Figura 5.2.2. Evolução dos gastos em Cooperação Técnica Brasileira .................................227

Figura 5.2.3. Evolução do número de projetos de Cooperação Técnica brasileira..............228

Figura 5.2.4. Principais receptores de Cooperação Técnica Brasileira...................................22

Figura 5.2.5. Principais receptores de Cooperação Técnica Brasileira.................................2230

Figura 5.3.1. Total de exportações brasileiras por ano ……….........................................23

Figura 5.3.2. Total de importações brasileiras por ano ......................................................233

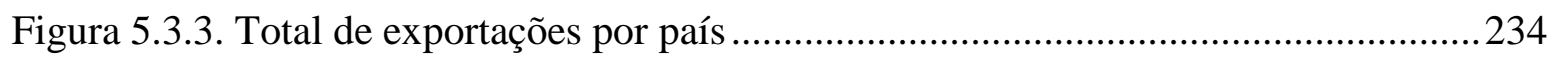

Figura 5.3.4. Total de importações por país .................................................................235

Figura 5.3.5. Investimento Externo Direto Brasileiro no exterior por ano ..........................2236

Figura 5.3.6. Maiores receptores de Investimento Externo Direito brasileiro.....................2237

Figura 5.3.7. Total de empréstimos do BNDES por ano para apoio à exportação de serviços brasileiros

Figura 5.3.8. Principais destinos de empréstimos do BNDES para apoio à exportação de serviços brasileiros.

Figura 5.5.1. Efeitos marginais de cada variável sobre o recebimento de Cooperação

Técnica Brasileira .260

Figura B1. Efeitos marginais de cada variável sobre o recebimento de Cooperação Técnica Brasileira 299 


\section{LISTA DE TABELAS}

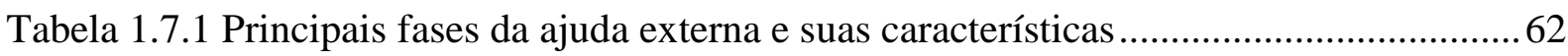

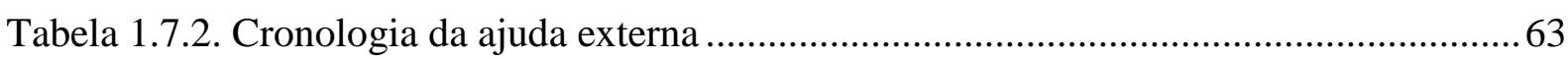

Tabela 2.1.1. Os princípios da Conferência de Bandung (1955)............................................68

Tabela 2.2.1. Objetivos da CTDP definidos no Plano de Ação de Buenos Aires .................... 74

Tabela 2.3.1. "Novas Orientações da CTPD": recomendações principais ............................... 81

Tabela 2.4.1. Interpretações divergentes sobre os princípios de Paris ....................................90

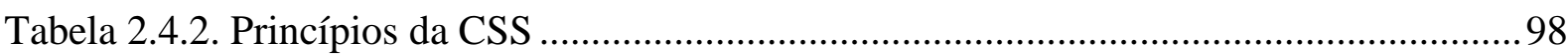

Tabela 2.4.3. Cronologia da Cooperação Sul-Sul para o Desenvolvimento ........................... 99

Tabela 3.5.1.1. Canais, modalidades e categorias da Ajuda Oficial ao Desenvolvimento

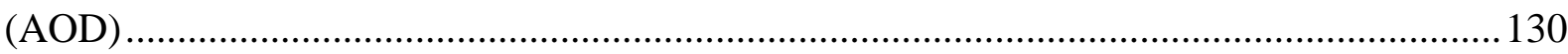

Tabela 3.5.1.2.. Componentes da Ajuda Oficial ao Desenvolvimento (AOD) ...................... 133

Tabela 3.6.2.1. Modalidades da Cooperação Internacional para o Desenvolvimento da CEPAL 146

Tabela 3.6.3.1. Instrumentos e modalidades da Cooperação Sul-Sul .................................... 150

Tabela 3.6.3.4. Indicadores para mensurar a qualidade da CSS ........................................... 153

Tabela 3.7.1. Quadro comparativo das diferentes metodologias de mensuração da cooperação

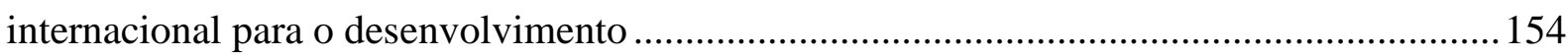

Tabela 4.3.1.1. Modalidades da cooperação brasileira nos relatórios da COBRADI ............ 188

Tabela 4.3.1.2. Recursos incluídos nos levantamentos da COBRADI ................................. 189

Tabela 4.3.1.3. Tipos de gastos por modalidade no levantamento COBRADI...................... 190

Tabela 4.3.1.4. Gastos do governo federal com a cooperação brasileira (2000-2016) (Em R\$)

Tabela 5.2.1. Evolução dos gastos em Cooperação Técnica Brasileira ................................225

Tabela 5.2.2. Evolução do número de projetos de Cooperação Técnica Brasileira ................228

Tabela 5.3.1. Convergência de voto com o Brasil em votações na AGNU (2000-2016) ......240

Tabela 5.3.2. Membros das coalizões brasileiras no FMI e Banco Mundial..........................242

Tabela 5.3.3. Membros das coalizões que o Brasil integra na OMC ....................................243

Tabela 5.3.4. Principais aliados do Brasil na OMC................................................................... 244

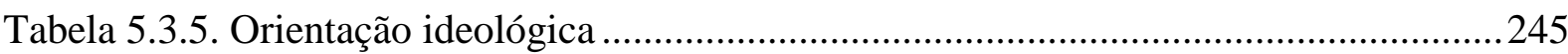

Tabela 5.3.6. Número de viagens oficiais do Presidente da República (2000-2016) .............246

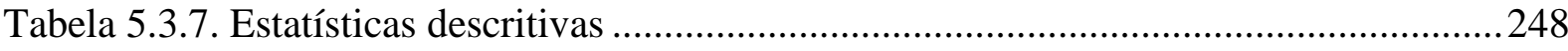


Tabela 5.5.1. Modelos em Painel Dinâmico para a alocação de Cooperação Técnica Brasileira 255

Tabela B1. Modelos em Painel Dinâmico para a alocação de Cooperação Técnica Brasileira 297

Tabela B2. Tabela de correlação entre as variáveis independentes. .300 


\section{LISTA DE ABREVIATURAS E SIGLAS}

ABC - Agência Brasileira de Cooperação

ABDI - Agência Brasileira de Desenvolvimento Industrial

ADB - sigla em inglês para Banco Asiático de Desenvolvimento

AFDB - sigla em inglês para Banco Africano de Desenvolvimento

AGNU - Assembleia Geral das Nações Unidas

AH - Assistência Humanitária

AIEA - Agência Internacional de Energia Atômica

AISA - Assessoria de Assuntos Internacionais

ANA - Agência Nacional de Águas

ANS - Agência Nacional de Saúde Suplementar

ANVISA - Agência Nacional de Vigilância Sanitária

AOD - Ajuda Oficial para o Desenvolvimento

AOs - Ações Orçamentárias

APEC - sigla em inglês para Foro de Cooperação Econômica da Ásia-Pacífico

APEX - Agência Brasileira de Promoção de Comércio e Investimentos

AT - Assistência Técnica

BACEN - Banco Central do Brasil

BID - Banco Interamericano de Desenvolvimento

BIRD - Banco Internacional para Reconstrução e Desenvolvimento

BNDE - (antigo) Banco Nacional de Desenvolvimento Econômico

BNDES - Banco Nacional de Desenvolvimento Econômico e Social

BM - Banco Mundial

BRICS - Brasil, Rússia, Índia, China e África do Sul

CABEI - sigla em inglês para Banco Centro-americano para Integração Econômica

CAD - Comitê de Assistência ao Desenvolvimento (da OCDE)

CAPES - Coordenação de Aperfeiçoamento de Pessoal de Nível Superior

CARICOM - Comunidade de Países do Caribe

CCT - Cooperação Científica e Tecnológica

$\mathrm{CDB}$ - sigla em inglês para Banco Caribenho de Desenvolvimento

CEPLAC - Comissão Executiva do Plano de Lavoura Cacaueira

C\&T - Ciência e Tecnologia 
CF - Cooperação Financeira

CGFOME - Coordenação-Geral de Ações de Combate à Fome

CMBEU - Comissão Mista Brasil-Estados Unidos para o Desenvolvimento Econômico

CNAT - (antiga) Comissão Nacional de Assistência Técnica

CNPq - Conselho Nacional de Desenvolvimento Científico e Tecnológico

CNS - Cooperação Norte-Sul

CNSD - Cooperação Norte-Sul para o Desenvolvimento

COBRADI - Cooperação Brasileira para o Desenvolvimento Internacional

CONAB - Companhia Nacional de Abastecimento

CONSEA - Conselho Nacional de Segurança Alimentar

CONTAP - (antigo) Conselho de Cooperação Técnica da Aliança para o Progresso

CPI-Index - índice de preços do consumidor nos Estados Unidos

CPLP - Comunidade dos Países de Língua Oficial Portuguesa

CT - Cooperação Técnica

CTH - Cooperação Técnica Horizontal

CTI - Cooperação Técnica Internacional

CTPD - Cooperação Técnica entre Países em Desenvolvimento

CTR - Cooperação Técnica Recebida

CTRB - Cooperação Técnica Recebida Bilateral

CTRM - Cooperação Técnica Recebida Multilateral

CSNU - Conselho de Segurança das Nações Unidas

CSS - Cooperação Sul-Sul

CSSD - Cooperação Sul-Sul para o Desenvolvimento

DAG - sigla em inglês para Grupo para Assistência ao Desenvolvimento (GAD)

DCOPT - (antiga) Divisão de Cooperação Técnica do MRE

DCT inicialmente (até 1974) Divisão de Cooperação Técnica e, posteriormente, Departamento de Cooperação Técnica, Científica e Tecnológica (do MRE)

DFID - sigla em inglês para Departamento para o Desenvolvimento Internacional do Ministério do Exterior britânico

DPF - Departamento de Polícia Federal

DPI - sigla em inglês para Database of Political Institutions

EADB - sigla em inglês para Banco da África Oriental de Desenvolvimento

ECA - sigla em inglês para a Administração da Cooperação Europeia 
ECOSOC - Conselho Econômico e Social (das Nações Unidas)

ELETROBRÁS - Centrais Elétricas Brasileiras

EMBRAPA - Empresa Brasileira de Pesquisa Agropecuária

ENAP - Escola Nacional de Administração Pública

EPTA - sigla em inglês para Programa Estendido de Assistência Técnica (das Nações Unidas)

ERP - sigla em inglês para o Programa de Recuperação Europeia

ESAF - Escola de Administração Fazendária

EXIMBANK - sigla em inglês para o Banco de Importações e Exportações dos EUA

FAO - sigla em inglês para Organização das Nações Unidas para Agricultura e Alimentação

FANs - sigla em inglês para a coalizão Friends of Antidumping Negotiations

FCD - Fórum de Cooperação para o Desenvolvimento (das Nações Unidas)

FIESP - Federação das Indústrias de São Paulo

FIOCRUZ - Fundação Osvaldo Cruz

FMI - Fundo Monetário Internacional

FUNAG - Fundação Alexandre de Gusmão

G-77 - Grupo dos 77

GAVI - sigla em inglês para Fundo Global de Combate à AIDS

GATT - sigla em inglês para Acordo Geral sobre Tarifas e Comércio (GATT, em inglês)

GPDEC - sigla em inglês para Parceria Global para a Cooperação para o Desenvolvimento Eficaz

HIPC - sigla em inglês para Iniciativa Países Pobres Muito Endividados

HIV/AIDS - siglas em inglês para Vírus da Imunodeficiência Humana/Síndrome da Imunodeficiência Adquirida

IBAS - Fórum de Diálogo que congrega a Índia, o Brasil e a África do Sul

IBD - sigla em inglês para Banco Interamericano de Desenvolvimento (BID)

IBGE - Instituto Brasileiro de Geografia e Estatística

IBRD - sigla em inglês para o Banco Internacional para Reconstrução e Desenvolvimento (BIRD)

ICOR - sigla em inglês para relação capital/produto incremental

IDA - sigla em inglês para Associação para o Desenvolvimento Internacional (do Banco Mundial)

IDH - Índice de Desenvolvimento Humano

IED - Investimento Estrangeiro Direto 
INCA - Instituto Nacional de Câncer

INMET - Instituto Nacional de Meteorologia

INMETRO - Instituto Nacional de Metrologia, Normalização e Qualidade Industrial

IPEA - Instituto de Pesquisa Econômica Aplicada

IPHAN - Instituto do Patrimônio Histórico e Artístico Nacional

LOA - Lei Orçamentária Anual

MAPA - Ministério da Agricultura, Pecuária e Abastecimento

MCT - Ministério de Ciência e Tecnologia

MD - Ministério da Defesa

MDB - sigla em inglês para Banco Multilateral de Desenvolvimento

MdE - Memorando de Entendimento

MDIC - Ministério do Desenvolvimento, Indústria e Comércio Exterior

MDS - Ministério do Desenvolvimento Social

MERCOSUL - Mercado Comum do Sul

MINUSTAH - sigla derivada do francês para Missão das Nações Unidas para a Estabilização no Haiti

MME - Ministério das Minas e Energia

MNA - Movimento Não-Alinhado

MPT - Ministério Público do Trabalho

MSP - sigla em inglês para o Programa de Segurança Mútua

MTE - Ministério do Trabalho

MTUR - Ministério do Turismo

NAMA11 - sigla em inglês para a coalizão Non-Agricultural Market Access

NOEI - Nova Ordem Econômica Internacional

OCDE - Organização para a Cooperação e Desenvolvimento Econômico

ODM - Objetivos de Desenvolvimento do Milênio

ODS - Objetivos de Desenvolvimento Sustentável

OEA - Organização dos Estados Americanos

OEEC - sigla em inglês para Organização para Cooperação Econômica Europeia

OIT - Organização Internacional do Trabalho

OLS - sigla em inglês para Ordinary Least Squares

OMC - Organização Mundial do Comércio

OMS - Organização Mundial da Saúde 
ONG - Organização não Governamental

ONU - Organização das Nações Unidas

OPEP - Organização dos Países Exportadores de Petróleo

OSC - Organização da Sociedade Civil

OWG - sigla em inglês para Grupo de Trabalho Aberto (das Nações Unidas)

PABA - Plano de Ação de Buenos Aires

PALOP - Países Africanos de Língua Oficial Portuguesa

PCSE - sigla para Panel Corrected Standard Errors

PD - Países Desenvolvidos

PED - Países em Desenvolvimento

PMA - Programa Mundial de Alimentos

PMD - Países de Menor Desenvolvimento relativo (em inglês, LDC)

PNB - Produto Nacional Bruto

PNUD - Programa das Nações Unidas para o Desenvolvimento

POLS - sigla em inglês para Ordinary Least Squares para dados em painel

PROEX - Programa de Financiamento às Exportações

PRSP - sigla em inglês para Papeis de Redução de Pobreza

PTS - sigla em inglês para Political Terror Scale

SAL - sigla em inglês para Empréstimos para Ajuste Estrutural

SAS - Secretaria de Atenção à Saúde

SDH - Secretaria de Direitos Humanos

SENAI - Serviço Nacional de Aprendizagem Industrial

SESA - Secretaria de Estado de Saúde

SESAI - Secretaria Especial de Saúde Indígena

SGEC - Subsecretaria-Geral de Cooperação e Comunidades Brasileiras no Exterior (do MRE)

SIAFI - Sistema Integrado de Administração Financeira (do Governo Federal)

SIDA - sigla em inglês para Agência Sueca para o Desenvolvimento Internacional

SIOP - Sistema Integrado de Planejamento e Orçamento

SPA - sigla em inglês para Programa Especial de Assistência para a África

SUBIN - (antiga) Subsecretaria de Cooperação Econômica e Técnica Internacional (do

Ministério do Planejamento)

SUDENE - Superintendência para o Desenvolvimento do Nordeste

SU-SSC - sigla em inglês para Unidade Especial de Cooperação Sul-Sul (do PNUD). 
SVD - Secretaria de Vigilância Sanitária

SWAP - sigla em inglês para Programas de Ajuda Setoriais

TI - Tecnologia da Informação

UAP - (antiga) Unidade de Administração de Projetos (da ABC)

UNASUL - União das Nações Sul-Americanas

UNCTAD - sigla em inglês para Conferência das Nações Unidas para o Comércio e Desenvolvimento

UNESCO - sigla em inglês para Organização das Nações Unidas para a Educação Ciência e Cultura

UNHR - sigla em inglês para o Alto Comissariado das Nações Unidas para os Refugiados (ACNUR)

UNICEF - sigla em inglês para o Fundo das Nações Unidas para a Infância

UNIDO - sigla em inglês para Organização das Nações Unidas para o Desenvolvimento Industrial

UNRRA - sigla em inglês para a Administração das Nações Unidas para Auxílio e Reabilitação

UNTA - sigla em inglês para Programa Regular das Nações Unidas para Assistência Técnica URSS - (antiga) União das Repúblicas Socialistas Soviéticas

USAID - sigla em inglês para Agência dos Estados Unidos para o Desenvolvimento Internacional

USP - Universidade de São Paulo

W52 - sigla da coalizão dos patrocinadores da proposta TN/C/W/52

WP-EFF - sigla em inglês para o Grupo de Trabalho sobre Eficácia da Ajuda (da OCDE) 


\section{SUMÁRIO}

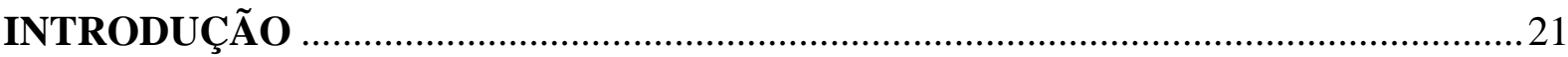

CAPÍTULO 1. A COOPERAÇÃO INTERNACIONAL PARA O

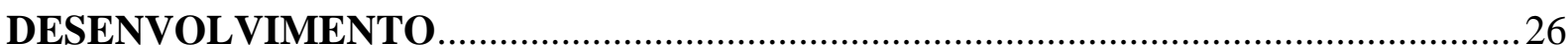

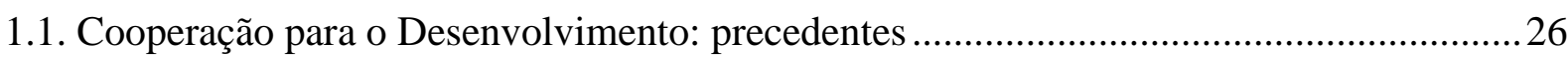

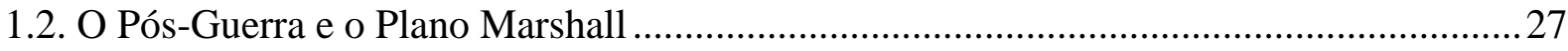

1.3. Décadas de 1950 e 1960: institucionalização da CID ........................................................ 31

1.4. Anos 1970: crise internacional e expansão das organizações multilaterais ......................37

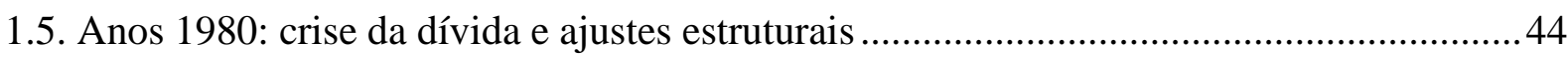

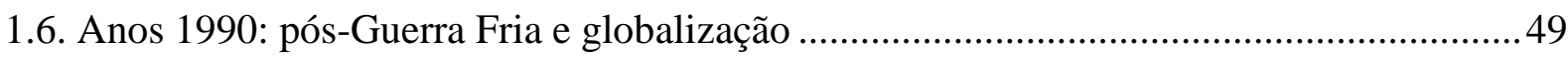

1.7. Século XXI: novas agendas internacionais e fragmentação da CID ...............................55

CAPÍTULO 2: A COOPERAÇÃO SUL-SUL PARA O DESENVOLVIMENTO

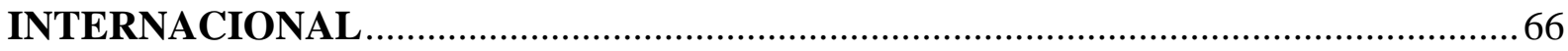

2.1. Anos 1950 e 1960: gênese da Cooperação Sul-Sul ............................................................66

2.2. Anos 1970: institucionalização da Cooperação Sul-Sul.................................................... 72

2.3. Décadas de 1980 e 1990: crise e desmobilização da CSS ................................................ 77

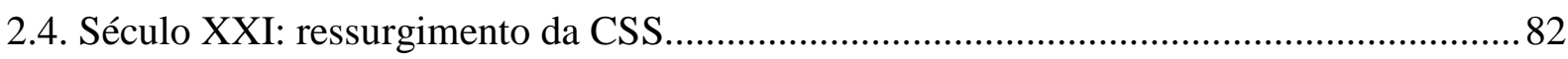

CAPÍTULO 3. A COOPERAÇÃO INTERNACIONAL PARA O

DESENVOLVIMENTO: CONCEITO, CLASSIFICAÇÕES E EXPLICAÇÕES ......... 101

3.1.1. Motivos morais altruísticos e humanitários................................................................. 101

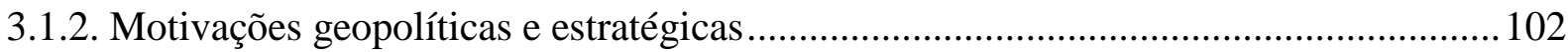

3.1.3. Motivações econômicas e comerciais............................................................................ 103

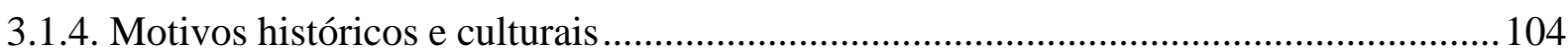

3.1.5. Outras motivações: questões ambientais e fluxos migratórios.................................... 104

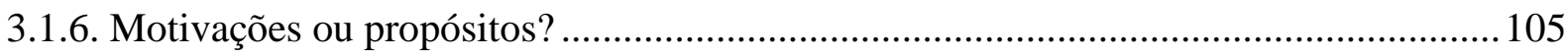

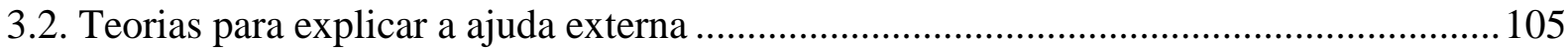

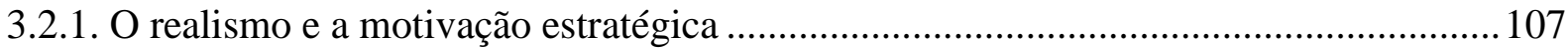

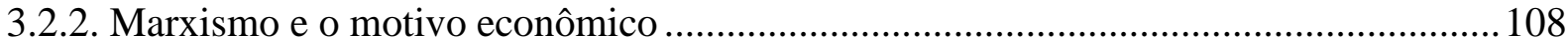

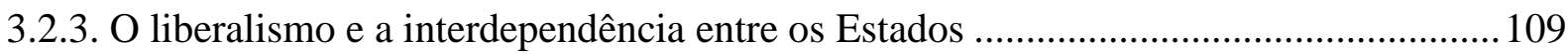

3.2.4. Construtivismo e o motivo humanitário .......................................................................... 110

3.3. Interesses do doador ou necessidades do receptor? ...................................................... 112

3.4. Cooperação para o Desenvolvimento: conceitos e classificação......................................122

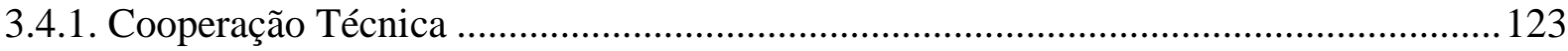


3.4.2. Cooperação Financeira

3.4.3. Ajuda humanitária 126

3.4.4. Ajuda alimentar 127

3.5. Definição e classificação da Cooperação Norte-Sul do CAD/OCDE ............................. 128

3.5.1. A Assistência Oficial ao Desenvolvimento (AOD) ................................................... 129

3.5.2. Total Official Support for Sustainable Development (TOSSD)................................. 136

3.6. Definições e classificações da Cooperação Sul-Sul ....................................................... 138

3.6.1. Proposta da Secretaria Geral Ibero-Americana (SEGIB) ......................................... 141

3.6.2. Proposta da Comissão Econômica para América Latina e Caribe (CEPAL) ................ 144

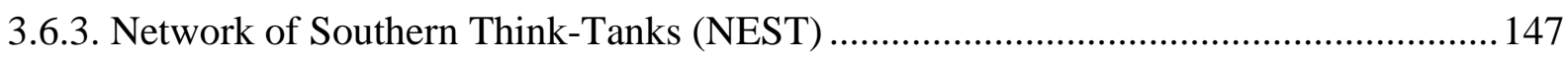

3.7. Comparando as diferentes metodologias acerca da Cooperação Internacional para o

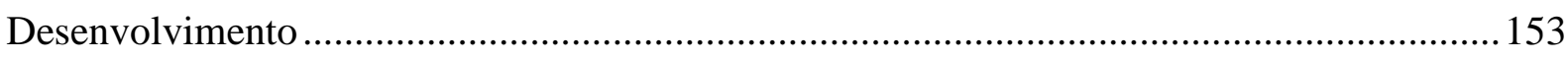

CAPÍTULO 4. O BRASIL E A COOPERAÇÃO INTERNACIONAL PARA O

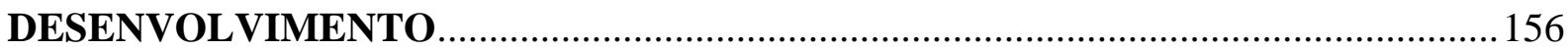

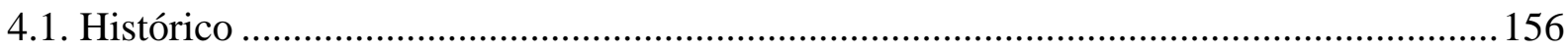

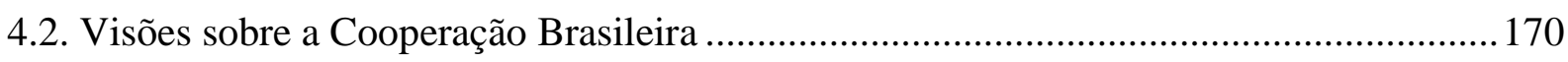

4.3. Modalidades da Cooperação Brasileira para o Desenvolvimento ................................... 178

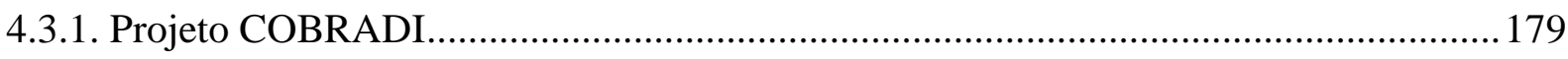

4.3.2. Projeto Articulação Sul - em busca da CSS no orçamento federal.............................. 194

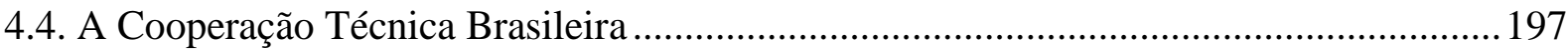

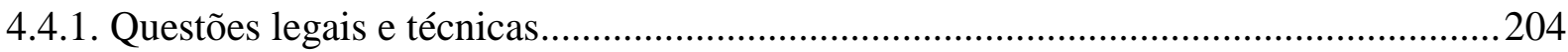

4.4.2. Elaboração de Projetos de Cooperação Técnica Sul-Sul..............................................2210

4.4.3. Diretrizes e orientações para o fornecimento de Cooperação Técnica Brasileira .........213

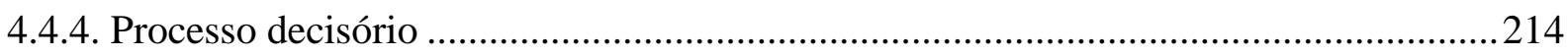

CAPÍTULO 5. DESENHO DE PESQUISA, DADOS, MÉTODOS E ANÁLISE DOS

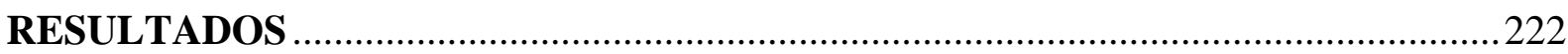

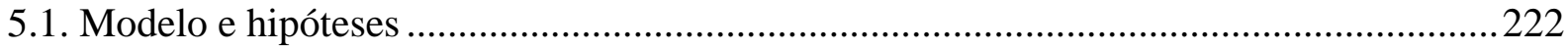

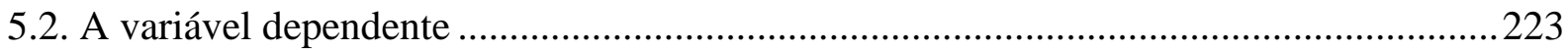

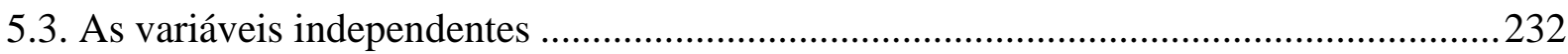

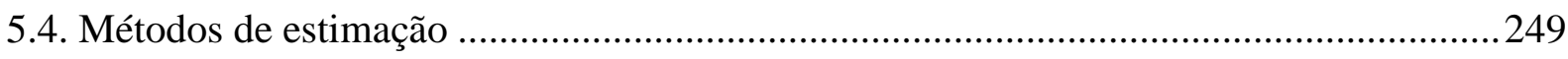

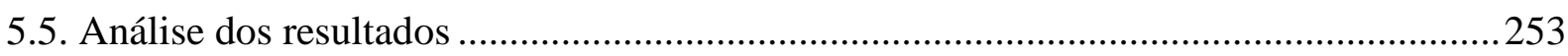

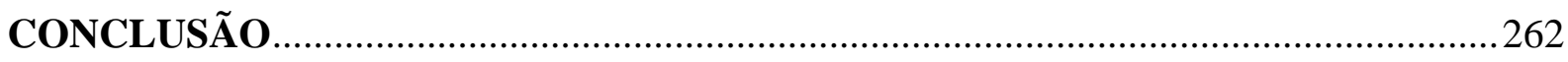

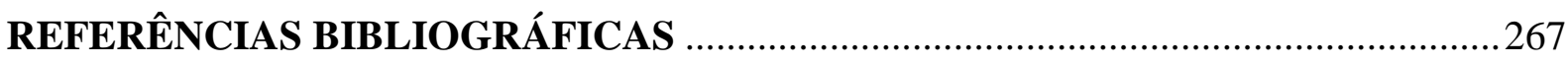




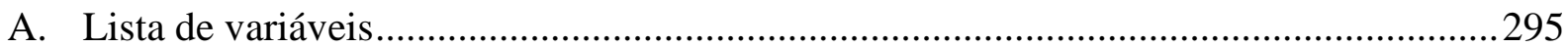

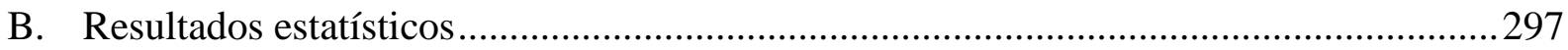




\section{INTRODUÇÃO}

A Cooperação Internacional para o Desenvolvimento (CID) vem sendo estudada desde suas origens por diversas áreas do conhecimento, em função da sua relevância nas relações internacionais e por seus efeitos se mostrarem presentes na vida cotidiana, para os países e para as comunidades locais. Embora o termo seja de difícil conceituação, entende-se que abarcaria as ações e atividades realizadas por atores públicos e privados tendo em vista o desenvolvimento socioeconômico no cenário internacional. O conceito costuma englobar termos como ajuda externa, Ajuda Oficial ao Desenvolvimento (AOD), Cooperação NorteSul (CNS), Cooperação Sul-Sul (CSS) entre outros. Suas ações mais comuns envolveriam doações, créditos subsidiados, perdão de dívidas e transferência de técnicas e conhecimento. Embora esse campo não tenha se constituído como um regime internacional nos moldes de outras temáticas internacionais como o comércio internacional, por exemplo, ao longo dos anos desempenhou um papel central na economia política internacional.

Nesse sentido, a CID pode ser considerada um campo político, constituído por relações de poder, em que inúmeros atores competem por legitimidade, reconhecimento e recursos (MILANI, 2018). Historicamente, os países considerados desenvolvidos foram os principais atores desse campo, sendo responsáveis majoritariamente pela origem dos recursos e por definir e moldar as regras desse regime. Ao longo do tempo, novos atores foram ganhando proeminência nesse campo como organizações internacionais, entidades privadas, organizações não governamentais e países em desenvolvimento. Dentre esses atores, destacam-se os países em desenvolvimento que buscaram influenciar esse regime, alterando sua posição de meros receptores de cooperação para provedores de cooperação, em bases distintas da cooperação recebida. Esse conjunto de atividades realizadas por esses países costuma ser conceitualizado como Cooperação Sul-Sul para o Desenvolvimento (CSSD). Embora as origens da CSSD datem de um contexto de processos de descolonização, de busca por uma terceira via em um mundo bipolar, e de busca por alternativas à ordem econômica definida pelos países do Norte, esse objeto voltou a ganhar relevância no século XXI no contexto de emergência econômica dos países em desenvolvimento.

Ao longo das últimas décadas, o Brasil, que historicamente foi basicamente um receptor de ajuda internacional, juntamente com outros países emergentes, passou a prover cooperação para o desenvolvimento internacional de forma cada vez mais expressiva. De modo que vem se firmando como um importante ator no campo da Cooperação para o 
Desenvolvimento Internacional (CID). Embora o país ainda receba assistência técnica e financeira de fontes bilaterais e multilaterais, o país vem se tornando um provedor de recursos ${ }^{1}$. Essa mudança ocorreu em um momento que o país passava por um processo de crescimento econômico, adquirindo as capacidades materiais para oferecer assistência para outros países em desenvolvimento. Essa virada também é resultante de uma mudança de orientação de política externa, que ganha ênfase a partir de 2003, quando se reforça estratégia de inserção do país por meio da promoção de alianças e acordos com parceiros do Sul na tentativa de reduzir as assimetrias nas relações com os países desenvolvidos (OLIVEIRA; ONUKI; OLIVEIRA, 2006; OLIVEIRA; ONUKI, 2012; PINHEIRO; GAIO, 2014).

O Brasil não se considera um doador, nem conceitua sua cooperação como ajuda externa. O país busca se distanciar, em teoria e práticas, do modelo tradicional de ajuda internacional prestado pelos países desenvolvidos. O governo brasileiro não apenas não integra o Comitê de Ajuda ao Desenvolvimento da Organização para a Cooperação e Desenvolvimento Económico $(\mathrm{CAD} / \mathrm{OCDE})^{2}$ como também rejeita as terminologias ${ }^{3}$ referentes a "doador", "ajuda" e "assistência" utilizadas pelos membros dessa organização (MILANI; CARVALHO, 2013).

Essa "reemergência" do país no campo da CID atraiu a atenção de pesquisadores do mundo todo em relação à cooperação prestada pelo Brasil. Uma ampla e profícua agenda de pesquisa surgiu acerca do objeto em questão. Nos últimos anos, diversos estudos foram publicados acerca da CSSD brasileira. No geral, as pesquisas buscaram compreender quais as características e especificidades da cooperação brasileira, em que medida esta se diferenciaria da cooperação tradicional prestada pelos doadores do CAD/OCDE, quais seriam seus propósitos, e quais os impactos dessas ações para os parceiros receptores e para o Brasil de modo geral. A grande maioria dos trabalhos publicados acerca do tema se utilizou de metodologias qualitativas, destacando-se a utilização de estudos de caso, singulares ou comparados, geralmente acerca da cooperação com países específicos, de áreas temáticas ou de projetos específicos.

A proposta desse trabalho é contribuir com essa agenda de pesquisa por meio de uma análise quantitativa acerca dos padrões de alocação da cooperação brasileira. Dessa forma,

\footnotetext{
${ }^{1}$ De acordo com cruzamento de dados realizado pelo Le Monde Diplomatique Brasil, o governo brasileiro, entre 2005 e 2009, forneceu mais ajuda internacional do que obteve de países e agências multilaterais. Vale destacar que o Brasil continua sendo um receptor de ajuda externa no plano internacional, sendo uma das razões pelas quais o país busca se distanciar da terminologia oficial de CID utilizado pelo CAD/OCDE.

2 Organização multilateral criada em Setembro de 1961, sendo um Fórum Internacional constituído pelos principais doadores bilaterais. Convém salientar que nem todos os membros da OCDE são membros do CAD.

${ }^{3}$ Glossário de termos estatísticos da OCDE (OECD, 2018d).
} 
esse estudo pretende fazer uma aproximação entre a literatura acerca da Cooperação Sul-Sul para o Desenvolvimento (CSSD) com a literatura voltada para a Cooperação Norte-Sul para o Desenvolvimento (CNSD), levando em consideração as diferenças e especificidades de cada modalidade. Para tanto, a via utilizada para essa aproximação fora a metodologia na medida em que há uma vasta literatura quantitativa acerca da CNSD, enquanto ainda são escassos os estudos que tentaram analisar a CSSD a partir dessa abordagem.

Uma das questões mais exploradas acerca da ajuda externa tradicional seria acerca dos determinantes para sua alocação. Ao longo dos anos, vários estudos buscaram compreender os padrões de alocação da ajuda pelo mundo. A problemática que guiava essa agenda de pesquisa seria, por meio da análise desses padrões, jogar luz acerca dos propósitos da ajuda externa, para além da análise de discursos oficiais e entrevistas com policy-makers. A ideia é que seria possível compreender os interesses e propósitos da cooperação a partir da análise da alocação de seus fluxos. Nesse sentido, a discussão foi estruturada em torno de dois principais modelos teóricos, o modelo dos interesses do doador e o modelo das necessidades do receptor, em que se esperaria que os fluxos de ajuda estivessem correlacionados com as variáveis referentes a cada modelo.

Dialogando com a literatura internacional acerca dos determinantes para o recebimento de ajuda internacional, esse estudo pretende analisar por que o Brasil forneceria cooperação no plano internacional. Para tanto, essa pesquisa busca verificar quais os determinantes para a alocação da CID brasileira mundo afora. Dentre as modalidades da CID realizadas pelo Brasil, destaca-se a Cooperação Técnica (CT), que promove capacitação e transferência de conhecimentos em áreas que o Brasil tem projetos bem sucedidos, como agricultura tropical e combate à AIDS por exemplo. O discurso oficial é o de que a CT fornecida pelo Brasil não impõe condicionalidades, baseia-se no principio de não interferência em assuntos internos, é guiada pelas demandas dos países receptores, não visa ganhos materiais e apresenta menos exigências processuais (MELLO E SOUZA, 2012)

Utilizando esses modelos como embasamento teórico, é investigada a relação entre a alocação de CT brasileira e interesses geopolíticos e econômicos do Brasil. Para tanto, é analisada a relação entre a variável referente aos gastos em CT para cada país do mundo entre os anos de 2000 e 2016 e variáveis econômicas e políticas referentes aos interesses brasileiros no cenário internacional, assim como variáveis socioeconômicas referentes aos países receptores. 
Os interesses econômicos foram operacionalizados como fluxos de exportações e importações, Investimento Estrangeiro Direito e empréstimos subsidiados via Banco Nacional de Desenvolvimento (BNDES) para exportação de bens e serviços de empresas brasileiras. Os interesses político-diplomáticos foram operacionalizados como apoio em organizações e fóruns internacionais, como Assembleia Geral das Nações Unidas (AGNU), Fundo Monetário Internacional (FMI), Banco Mundial e Organização Mundial do Comércio (OMC); parcerias internacionais como a Comunidade dos Países de Língua Portuguesa (CPLP); e semelhanças em relação à orientação política dos governos do provedor e recipiente. Já as variáveis referentes às necessidades dos receptores foram operacionalizadas com base em indicadores existentes acerca do nível de desenvolvimento socioeconômico desses países, qualidade democrática e nível de proteção aos direitos humanos.

Assim, a proposta da análise é testar empiricamente a retórica oficial de solidariedade e altruísmo da cooperação brasileira ${ }^{4}$. Ou seja, analisar se os fluxos de cooperação vão, de fato, para os países mais necessitados ou se estariam mais relacionados a interesses políticos e econômicos por parte do provedor da cooperação. O principal achado da pesquisa é o de que haveria determinantes políticos e econômicos na alocação dos gastos em CT. Entretanto, pode-se argumentar que motivações altruístas e promoção de interesses nacionais não precisam ser mutuamente excludentes.

Essa pesquisa parte da premissa de que a CSS não pode ser analisada em toda sua complexidade a amplitude apenas por meio de fluxos financeiros. Reconhece-se que não é possível obter um entendimento completo da dimensão da cooperação brasileira apenas por meio da mera quantificação de gastos. Entretanto, entende-se também que uma análise mais detalhada acerca da alocação de recursos é fundamental para a compreensão das práticas de CSS nacionais, tanto no que diz respeito à sua natureza, como em relação às prioridades estabelecidas ao longo dos anos.

A tese possui a seguinte estrutura. O primeiro capítulo traz uma descrição da evolução do regime de Cooperação Internacional ao Desenvolvimento, apresentando suas origens, fases e características. O capítulo se inicia apresentando os precedentes à institucionalização da CID no plano internacional, destacando algumas medidas que poderiam ser configuradas como CID em épocas anteriores. Em seguida, é apresentado o contexto no qual esse campo se

\footnotetext{
${ }^{4} \mathrm{O}$ princípio da solidariedade foi enfatizado pelo presidente Lula já em seu discurso de posse, quando sublinhou as principais diretrizes de sua política exterior, defendendo a "democratização das relações internacionais sem hegemonias de qualquer espécie" e uma diplomacia orientada por uma "perspectiva humanista"(SILVA, 2003).
} 
origina, apresentando, na sequência, as fases históricas de sua evolução até as discussões mais recentes em torno de sua configuração atual.

O segundo capítulo traz uma discussão sobre a Cooperação Sul-Sul para o Desenvolvimento, apresentando suas origens, evolução e discussões contemporâneas. O capítulo se inicia apresentando o contexto de criação da CSSD no cenário internacional. Em seguida, são apresentadas as fases históricas de sua evolução indo de sua institucionalização nos anos 60 e 70, passando pelo momento de recuo nos anos 80 e 90, até o de reemergêcia no início do século XXI. O capítulo termina apresentando o debate em torno do papel da CSSD no regime contemporâneo da CID, discutindo suas transformações recentes.

O terceiro capítulo apresenta uma discussão teórica e conceitual acerca da Cooperação Internacional ao Desenvolvimento, discutindo suas principais definições, classificações e explicações. Primeiramente, são discutidos os principais motivos apontados pela literatura que levariam os países a fornecerem CID no cenário internacional. Em seguida, é analisado como as diferentes teorias de Relações Internacionais procuram explicar o fenômeno da CID. Na sequência, é realizada uma discussão acerca do conceito de CID, apresentando as diferentes definições e classificações utilizadas pela literatura e por órgãos internacionais. Por fim, é realizada uma discussão conceitual acerca das diferenças entre a CNSD e CSSD, a partir de uma discussão sobre as diferentes definições de ambas as modalidades.

No quarto capítulo, é apresentado o papel do Brasil no regime de CID, apresentando sua evolução de receptor a doador emergente, as características de sua cooperação ao desenvolvimento e uma discussão sobre a literatura sobre o tema, com foco na cooperação técnica. O capítulo se inicia trazendo a história do país no campo da CID, primeiro enquanto receptor até a sua emergência enquanto fornecedor de cooperação em períodos mais recentes. Em seguida, são discutidas as diferentes modalidades de cooperação realizadas pelo Brasil. Ao final, é apresentada a cooperação técnica realizada pelo Brasil e suas características, discutindo-se seus aspectos normativos e técnicos.

O quinto capítulo traz o desenho metodológico da pesquisa. Primeiramente, é realizada uma discussão acerca dos métodos utilizados. Em seguida, é apresentada a operacionalização da variável dependente. Na sequência, são apresentadas as variáveis independentes, discutindo a razão da inclusão de cada variável no modelo, suas características e estatísticas descritivas. Ao final, são apresentados os resultados referentes à análise empírica. Por fim, a última seção traz as considerações finais do trabalho. 


\section{CAPÍtULO 1. A COOPERAÇÃO INTERNACIONAL PARA O DESENVOLVIMENTO}

\subsection{Cooperação para o Desenvolvimento: precedentes}

A Cooperação Internacional para o Desenvolvimento não é um fenômeno recente nas relações internacionais. Embora não haja um consenso acerca de sua definição, suas origens costumam ser localizadas no contexto do pós Segunda Guerra Mundial, com a criação do Plano Marshall e das instituições de Bretton Woods. Entretanto, existem alguns precedentes em relação à ideia de um governo fornecer recursos públicos no intuito de auxiliar outros países. Em especial, o limitado fornecimento de ajuda humanitária ao longo do século XIX, a assistência promovida pelos países europeus às suas colônias especialmente durante o entreguerras, e a limitada assistência técnica fornecida pelos Estados Unidos aos países da América Latina durante a Segunda Guerra Mundial.

Embora no início do século XIX, o fornecimento de recursos públicos de um Estado para o auxílio das condições de vida das populações de outro Estado fosse algo inaceitável para muitos, são registrados casos em que tal ajuda foi despendida ao longo desse século. Geralmente tais ações eram pontuais e seguiam a ocorrência de catástrofes humanitárias. Conforme as informações acerca de desastres naturais em terras distantes chegavam ao público, tais ações se tornavam mais comuns ${ }^{5}$. Além das questões humanitárias, é apontado que tais medidas, que correspondiam ao fornecimento de alimentos na maioria dos casos, respondiam aos interesses de agricultores domésticos que viam nessas ações uma forma de garantirem o escoamento dos excedentes de sua produção (LANCASTER, 2007).

Um segundo antecedente pode ser localizado em ações pontuais das potências coloniais no intuito de desenvolver suas possessões territoriais ${ }^{6}$. Embora o pensamento econômico dominante nas metrópoles fosse que os investimentos realizados nas colônias deveriam ser privados, conforme as condições de pobreza e subdesenvolvimento nas colônias se tornavam cada vez mais alarmantes, investimentos e empréstimos públicos foram realizados nessas regiões. Longe de preocupações humanitárias ditarem as ações dos governos, tais ações foram comumente analisadas como medidas para assegurar a estabilidade dos impérios coloniais para, especialmente, assegurar matérias primas para a economia europeia (HJERTHOLM; WHITE, 2000a).

\footnotetext{
${ }^{5}$ Por exemplo: 1812 Act for the Relief of the Citzens of Venezuela.

${ }^{6}$ Por exemplo: 1929 Colonial Development Act e 1940 Colonial Development and Welfare Act.
} 
Por fim, um terceiro precedente apontado diz respeito ao fornecimento de assistência técnica por parte dos Estados Unidos aos países latino-americanos no contexto da Segunda Guerra Mundial. Como os países europeus, a crença dominante nos Estados Unidos era de que o desenvolvimento econômico em seu hemisfério deveria provir de investimentos privados. No entanto, nesse contexto de conflito mundial, duas agências foram criadas no sentido de gerir essa assistência proveniente de recursos públicos: o Instituto de Assuntos Interamericanos e a Fundação para Educação Interamericana. Novamente, não foi o altruísmo que parece ter guiado as ações do governo estadunidense ou uma mudança da visão em relação ao papel dos investimentos públicos para o desenvolvimento, mas preocupações estratégicas em virtude da Segunda Guerra Mundial, como a necessidade de asseverar a aliança desses países, especialmente frente ao esforço da Alemanha Nazista de se aproximar de alguns governos da região.

\subsection{O Pós-Guerra e o Plano Marshall}

Apesar desses precedentes que consistia na maioria dos casos de ações pontuais e específicas, a Cooperação para o Desenvolvimento como é conhecida nos dias de hoje foi criada em função dos eventos ocorridos durante a Segunda Guerra Mundial. Várias instituições se desenvolveram a partir de organizações criadas no intuito de lidar com as consequências da guerra: a OXFAM lidava primeiramente com refugiados da Grécia; o Centro para Assistência e Alívio para Todos os Lugares (CARE, em inglês) ${ }^{7}$ significava originalmente Centro para Alívio Americano na Europa, tendo sua ação expandida posteriormente para outras regiões. No âmbito das Nações Unidas e nas instituições de Bretton Woods, foram criadas a Agência para Reabilitação e Alívio das Nações Unidas (UNRRA, em inglês $)^{8}$, considerada a primeira agência internacional de ajuda externa e precursora do Fundo das Nações Unidas para a Infância (UNICEF, em inglês) ${ }^{9}$, o Alto Comissariado das Nações Unidas para Refugiados (ACNUR) ${ }^{10}$ e o Banco Internacional de Reconstrução e Desenvolvimento (BIRD) ${ }^{11}$, que realiza seu primeiro empréstimo em 1946 (BROWNE, 1997).

\footnotetext{
${ }^{7}$ Cooperative for Assistance and Relief Everywhere, no original.

${ }^{8}$ United Nations Relief and Rehabilitation Administration, no original.

${ }^{9}$ United Nations International Children's Emergency Fund, no original.

${ }^{10}$ United Nations High Commissioner for Refugees (UNHCR), no original.

${ }^{11}$ International Bank for Reconstruction and Development (IBRD), no original.
} 
Inevitavelmente, os políticos e burocratas americanos consideravam que a ajuda estendida nesses anos aos seus aliados seria de curta duração. Tanto que o Congresso dos EUA estabeleceu datas para o término dos programas de auxílio aos refugiados, de modo que a UNRRA finaliza suas ações na Europa e na Ásia em 1947. Entretanto, em 1947, boa parte do continente europeu ainda estava em ruínas, lutando para se recuperar de uma guerra que havia acabado há dois anos. Enquanto países do leste europeu eram absorvidos ao bloco soviético, como Alemanha Oriental, Polônia, Hungria e Romênia, a privação e dificuldades enfrentadas pelas populações da Europa Ocidental aumentavam as chances de partidos comunistas nacionais chegassem ao poder, especialmente na Itália e França. Ao mesmo tempo, a União Soviética aumentava sua pressão sobre a Turquia por concessões territoriais e a Iugoslávia apoiava um movimento de insurgência na Grécia. A administração americana se sente forçada a agir quando a Grã-Bretanha anuncia que retiraria seu apoio aos governos grego e turco. Nesse contexto, o congresso americano aprova o fornecimento de empréstimos para esses dois países, que são seguidos pela aprovação do Plano Marshall (LANCASTER, 2007).

O Plano Marshall foi o primeiro grande programa de cooperação para o desenvolvimento idealizado pelos planejadores americanos no pós-guerra no intuito de recuperar economicamente o continente europeu arrasado pelo conflito. Oficialmente conhecido como Programa de Recuperação Europeia (ERP, em inglês) ${ }^{12}$, o Plano Marshall despendeu mais de 13 bilhões de dólares entre 1948 e 1952 para os países europeus que constituíam a Organização para Cooperação Econômica Europeia (OEEC, em inglês) ${ }^{13}$, fundada em 1948, que viria a dar origem à Organização de Cooperação e Desenvolvimento Econômico $(\mathrm{OCDE})^{14}$ em 1961. Sendo que mais de $90 \%$ dessa ajuda ocorreu na forma de doações a fundo perdido (WOOD, 1986). O programa foi coordenado por uma agência relativamente independente, a Administração da Cooperação Europeia (ECA, em inglês) ${ }^{15}$. Sendo formalmente concluído em 1952, quando foi fundido ao Programa de Segurança Mútua (MSP, em inglês) ${ }^{16}$.

A ordem internacional construída durante o Plano Marshall teve profundas implicações para o Terceiro Mundo. O Plano Marshall ligou a reconstrução europeia e a campanha dos EUA por multilateralismo com um modelo de desenvolvimento particular a ser

\footnotetext{
${ }^{12}$ European Recovery Program, no original.

${ }^{13}$ Organisation for European Economic Co-operation, em inglês.

${ }^{14}$ Organisation for Economic Co-operation and Development (OECD), em ingles.

${ }^{15}$ Economic Cooperation Administration, em inglês.

${ }^{16}$ Mutual Security Program, em inglês.
} 
perseguido pelo mundo em desenvolvimento (KRAYCHETE, 2012). A despeito das intenções originais dos planejadores americanos, que esperavam que ajuda externa fornecida em larga escala fosse apenas uma exceção temporária das normas previamente defendidas acerca dos fluxos de capital, o Plano Marshall acabou por estabelecer um conjunto de objetivos e mecanismos que asseguraram um lugar permanente para a ideia de assistência ao desenvolvimento com recursos públicos no sistema internacional pós-guerra (WOOD, 1986).

Embora, em retrospecto, o Plano Marshall tenha sido considerado bem sucedido, servindo de paradigma para os programas de ajuda externa ao redor do mundo que iriam surgir a partir daí, há controvérsias acerca de suas motivações e significado. Enquanto as motivações políticas, em especial, o objetivo de fortalecer economicamente os aliados norteamericanos e, assim, conter o avanço do comunismo, são destacadas pela literatura, as motivações econômicas por trás desse programa costumam ser relegadas a um segundo plano. Wood (1986) aponta cinco mudanças na economia internacional que levaram a uma situação de "dollar shortage"17, criando as condições para a realização do Marshall. A primeira foi a cessão do comércio entre a Europa Ocidental com a Europa Oriental. Antes do conflito, essa relação comercial permitia que os países europeus ocidentais trocassem seus produtos manufaturadores por alimentos e matérias primas dos países da Europa Oriental. Em 1948, essas exportações haviam caído pela metade e as exportações em dois terços. Esse declínio significava que os países da Europa Ocidental deveriam recorrer aos Estados Unidos para sanar suas necessidades. A segunda foi a perda de importância das fontes coloniais de dólares. Conforme os movimentos de insurgência contra a opressão colonial se proliferavam nas colônias, em especial na Indochina e Malásia, os custos para combater esses movimentos por parte das metrópoles aumentavam; o que diminuía a lucratividade da relação colonial. A terceira mudança foi a diminuição das remessas de lucros por parte dos investimentos europeus na América Latina. Boa parte pelo fato de que esses investimentos foram liquidados durante a Segunda Guerra Mundial no intuito financiar os esforços de guerra ${ }^{18}$. A quarta mudança foi o constante declínio dos termos de troca prejudicando os países europeus e suas extensões coloniais. Especialmente a queda nos preços do ouro e borracha, duas fontes de dólares importantes para o império britânico. Finalmente, a crescente dependência das economias europeias em relação à economia norte-americana, na medida em que os europeus se viam reféns de flutuações na economia americana. Críticas surgiam por parte dos europeus

\footnotetext{
${ }^{17}$ Falta de dólares - liquidez - na economia mundial.

${ }^{18}$ Wood (1986) aponta que os lucros provenientes desses investimentos pagaram por $20 \%$ das importações europeias em 1938 - 3 bilhões de dólares em preços do pós-guerra.
} 
na medida em que os EUA detentores de metade da riqueza mundial da época, não importavam produtos e realizavam empréstimos na escala necessária para sanar essa deficiência por dólares da economia mundial.

Woods (1986) defende que o caso para um programa de assistência econômica em larga escala foi realizado em termos econômicos ainda antes do início da Guerra Fria. O Departamento de Estado dos Estados Unidos, sob o comando de Cordell Hull, havia desenvolvido uma interpretação econômica acerca das causas Segunda Guerra Mundial, enfatizando a quebra da ordem econômica internacional em função do legado fratricida da Primeira Guerra Mundial, a depressão de 1929 e a guerra econômica que levou a um aumento do controle sobre o comércio internacional e do movimento de capitais.

Um grande esforço para lidar com essas preocupações foi montado durante a guerra. Além dos departamentos de Estado, Comércio e Tesouraria, foram criados órgãos e congressos especiais, como o Escritório de Alívio e Reabilitação Estrangeira, a Administração Econômica Estrangeira e o Comitê Especial do Senado sobre Política e Planejamento Econômico Pós-Guerra. Um consenso sobre a natureza do problema surgiu em 1943 e poderia ser visto em três relatórios do Departamento de Comércio emitidos naquele ano ${ }^{19}$. Nessa época, o governo estava convencido de que o maior obstáculo para o sucesso do sistema multilateral do pós-guerra e para o aumento das exportações americanas era o "dollar shortage" (WOOD, 1986).

De todo modo, ambas as interpretações evidenciam os interesses por parte do doador na execução do programa. Os interesses políticos se evidenciam no sentido de conter a influência soviética e o fortalecimento de partidos comunistas no continente europeu. Os interesses econômicos se tornam latentes, no sentido de permitir que o problema do "dollar shortage" fosse sanado de forma a permitir que as exportações americanas continuassem fluindo para o continente europeu, de modo que os europeus não recorressem a políticas autárquicas de controle do comércio e das finanças.

Ao final do Plano Marshall, as forças conservadoras mantiveram e fortaleceram seu controle político em todos os países da Europa Ocidental. A resistência europeia ao rearmamento foi superada, e a Europa foi organizada militarmente sob a hegemonia dos Estados Unidos contra a União Soviética. E os vínculos econômicos históricos entre a Europa Ocidental e Oriental foram quebrados. Na mente popular, o Plano Marshall impediu a Europa de "se tornar comunista".

\footnotetext{
19 "The United States in the World Economy," "Markets After the War," e "Foreign Trade After the War."
} 
De acordo com Wood (1986), o que realmente salvou a reputação do Plano Marshall foi a continuação de ajuda massiva para a Europa após o fechamento oficial do plano. A afirmação comum de que o Plano Marshall completou sua tarefa com antecedência e com menos dinheiro do que o esperado ignora totalmente o fato de que a ajuda americana para a Europa simplesmente assumiu um novo nome em 1952. A maior parte da ajuda americana para a Europa chegou após o final do Plano Marshall, sob os auspícios do sucessor do ECA, a Agência de Segurança Mútua (MSA, em inglês) ${ }^{20}$.

O Plano Marshall não apenas moldou o contexto internacional dentro do qual o regime de ajuda evoluiu posteriormente, como também criou um conjunto de princípios e procedimentos operacionais que continuaram sendo parte integrante do regime de ajuda. Também foi o precursor de programas de ajuda econômica em larga escala a serem aplicados no mundo subdesenvolvido.

O aparente sucesso do Plano Marshall na reconstrução do continente europeu gerou expectativas no Terceiro mundo de que um programa similar pudesse ser estendido para outras regiões. As esperanças aumentaram quando o presidente Truman fez seu famoso discurso Ponto IV, propondo um programa ambicioso de assistência técnica para a promoção do desenvolvimento no mundo em desenvolvimento. No entanto, o Ponto IV reiterou a mensagem de repúdio a novos "Planos Marshall" em outras regiões do mundo. O principal propósito da ajuda externa no chamado Terceiro Mundo deveria ser estabelecer as condições para que o capital privado pudesse afluir.

Juntamente com as instituições criadas no contexto da Segunda Guerra Mundial e com o Plano Marshall, um terceiro fator essencial para o estabelecimento da Cooperação para o Desenvolvimento a nível internacional foram os movimentos de descolonização mundo afora. As primeiras ondas de independência criaram uma demanda por assistência ao desenvolvimento no Sistema Internacional por parte do mundo em desenvolvimento. Além de expandir a arena de competição ideológica da Guerra Fria, esse fenômeno acabou por encorajar o fornecimento de ajuda externa para os países recém-independentes. Embora em um primeiro momento, a ajuda fornecida a essas regiões tenha sido fornecida basicamente por um país, os Estados Unidos.

\subsection{Décadas de 1950 e 1960: institucionalização da CID}

\footnotetext{
${ }^{20}$ Mutual Security Agency, no original.
} 
Ao longo da década de 1950, os EUA passaram a pressionar seus aliados para criarem seus próprios programas para o fornecimento de ajuda externa e, assim, dividirem os custos políticos e financeiros da CID. Segundo Lancaster (2007), a pressão de Washington teve efeito, porém não foi o único fator causal. A maioria desses países já possuía seu histórico na área de assistência ao desenvolvimento em função de seu passado colonialista. Conforme se recuperavam economicamente, e suas antigas colônias obtinham independência política, esses países buscaram manter sua influência nessas regiões por meio da criação de suas agências de cooperação. Em 1953, o governo alemão começa a prestar assistência para os importadores de produtos alemães, culminando na criação do Ministério para o Desenvolvimento Econômico em 1961. A França cria em 1961 um ministério da Cooperação. No Reino Unido, a Corporação para o Desenvolvimento Colonial é rebatizada de Corporação para o Desenvolvimento da Commonwealth em 1964. A Holanda cria uma posição para Secretário de Estado para o Desenvolvimento em 1963, elevando o cargo para ministro do desenvolvimento posteriormente. Os países nórdicos - Noruega, Suécia e Dinamarca também criam suas próprias agências e começam a fornecer ajuda externa nessa época. $\mathrm{O}$ Japão também cria um Fundo para a Cooperação Econômica nesse contexto. Esses movimentos culminam na criação do Grupo para Assistência ao Desenvolvimento em 1960 (DAG, em inglês $)^{21}$, rebatizado como Comitê de Ajuda ao Desenvolvimento (CAD) no ano seguinte $^{22}$. Fórum criado no âmbito da OCDE para monitorar o fornecimento de ajuda externa por parte dos países doadores (HJERTHOLM; WHITE, 2000a).

Concomitantemente a esses movimentos, os países do bloco socialista buscaram estabelecer seus próprios programas de Cooperação, especialmente a União Soviética. A maior parte da assistência soviética foi fornecida para países em desenvolvimento do bloco comunista como Vietnã do Norte, Coreia do Norte, Cuba e Mongólia, no intuito de estabilizar e subsidiar suas economias. No entanto, países em desenvolvimento fora da aliança com Moscou também receberam assistência como Egito, Síria, Índia e Afeganistão. Ao contrário dos Estados Unidos e dos países ocidentais, os países do bloco comunista não buscaram estabelecer uma presença de longo prazo nos receptores em função de não disporem dos mesmos recursos. Esses países optavam por privilegiar projetos de infraestrutura de maior visibilidade. Destaca-se a disputa entre a China e a URSS na busca pela liderança do bloco comunista. Em que os chineses buscaram fornecer assistência para diversos países, especialmente no continente africano (LANCASTER, 2007).

\footnotetext{
${ }^{21}$ Development Assistance Group, em inglês.

${ }^{22}$ Development Assistante Committee (DAC), em inglês.
} 
A ajuda externa fornecida nesse primeiro momento teve como característica sua natureza bilateral sendo fortemente dominada pelos países ocidentais industrializados. Outra característica importante foi que o financiamento ao desenvolvimento nesse contexto, apesar da retórica oficial, teve grande proporção de fontes privadas. Havia uma preocupação, em especial nos Estados Unidos, de que a ajuda internacional não competisse com os investimentos privados. Assim, o foco da ajuda eram os setores de infraestrutura física, especialmente energia e comunicações. $\mathrm{Na}$ medida em que se acreditava que o desenvolvimento desses setores propiciaria o terreno fértil para os investimentos produtivos por parte da iniciativa privada.

Com a independência, o desenvolvimento se tornou o objetivo principal da maior parte dos governos recém-estabelecidos. Nessa época, o pensamento econômico dominante da época, de inspiração keynesiana, identificava desenvolvimento e crescimento econômico como sinônimos. Esse pensamento se identificava com teorias que ligavam o crescimento econômico com investimento em capital (BROWNE, 1997). No centro dessa teoria estava o “incremental capital-output ratio" (ICOR), uma função linear no tempo, que assumia que aumentos de investimento em capital levariam diretamente ao crescimento econômico. Vários economistas da época consideram que esse modelo de crescimento baseado em injeções de capital poderia ser diretamente transplantado para o mundo em desenvolvimento. Nessa ótica, os países subdesenvolvidos estavam presos a uma armadilha de pobreza por que não conseguiam poupar o suficiente para fazer os investimentos necessários ao desenvolvimento econômico. Assim, dada a falta de poupança interna, seriam necessários aportes externos de capital para que essas economias pudessem "arrancar" rumo ao desenvolvimento. Nesse sentido, a ajuda externa era vista como a ferramenta necessária para que esse processo pudesse ocorrer.

A economia do desenvolvimento do período trouxe conceitos como "big push" (ROSENSTEIN-RODAN, 1943), "balanced growth" (NURKSE, 1953), "take-off into sustained growth" (ROSTOW, 1956) e "critical minimum effort thesis" (LEIBENSTEIN, 1957). Essas teorias tinham em comum a ideia de equalizar crescimento como desenvolvimento e a necessidade de amplas injeções de capital nos países subdesenvolvidos para que esses países pudessem sair dessa condição. A teoria do "big push" enfatizava a importância de economias de escala nos setores de infraestrutura e indústria básica. $\mathrm{O}$ princípio de "take-off' baseava-se na identidade Harrod-Domar que especificava que para que a taxa de crescimento da renda fosse superior à da população (de modo que o crescimento da 
renda per capita fosse positivo), era necessário um patamar mínimo de investimento. A tese do "critical minimum effect" pedia um grande aumento nos investimento no intuito de desencadear um processo cumulativo dentro do qual as forças de crescimento da renda induzidas dominariam as forças induzidas pela redução da renda. O conceito de "crescimento equilibrado" de Nurkse enfatizava as economias externas inerentes ao lado da demanda em uma expansão mutuamente reforçadora de todo um conjunto de atividades de produção complementares que se combinariam para aumentar o tamanho do mercado (THORBECKE, 2007).

Influenciados pelo pensamento keynesiano, pelo sucesso do Plano Marshall na Europa, e por essas teorias econômicas que tinham como centro o modelo Harrod-Domar, os países em desenvolvimento buscaram elaborar seus próprios planos nacionais de desenvolvimento, com foco no crescimento econômico. Objetivos sociais eram vistos como resultantes do aumento do Produto Interno Bruto per capita. Indicador criado na época para mensurar o nível de desenvolvimento dos países. A redução de pobreza não era vista como prioridade, mas como resultante das melhorias em infraestrutura e crescimento baseado na redução do desemprego. O modelo dominante da época, o modelo de desenvolvimento de Rostow, via o crescimento como linear. Em que os países passariam por cinco etapas de desenvolvimento, partindo das sociedades tradicionais até atingirem a etapa da sociedade de consumo em massa, que tinha como parâmetro os países ocidentais industrializados. Nessa visão, a industrialização seria o fator principal que traria o desenvolvimento econômico.

Os anos 50 e 60 viram a consolidação de um desenvolvimentismo associado ao keynesianismo e à ideia de modernização. Nesse contexto, os anos iniciais da CID foram marcados pela ênfase no planejamento e na construção (ou reconstrução) de infraestruturas, na disseminação do desenvolvimento agrícola e na ajuda alimentar (MILANI, 2014). A ligação entre esses objetivos de desenvolvimento e a guerra fria era evidente (WOOD, 1986).

Wood (1986) aponta que predominava nessa época uma mentalidade de "showcase" que marcaria os programas de ajuda externa até a contemporaneidade. Ou seja, projetos que atraíssem uma maior visibilidade pública acerca de seus resultados. Quando a missão Griffin foi enviada para estabelecer uma presença da ajuda externa dos EUA no sudeste asiático, foi encarregada de buscar por projetos que teriam uma imediata significância política que afetaria um considerável número de pessoas, fortalecendo governos existentes, e favorecendo interesses americanos no bem estar das pessoas do sudeste asiático. Como já citado, os programas de assistência do bloco comunista demonstravam uma mentalidade similar, mesmo 
que sua propensão em apoiar governos existentes fosse menor em razão da menor disponibilidade de recursos.

Embora a ajuda externa fornecida durante esse primeiro momento fosse primordialmente bilateral, ao longo dos anos 60 começa a haver um aumento da assistência fornecida via instituições multilaterais, traço que seria marcante na década seguinte. Esse crescimento foi parcialmente resultante da criação de novas instituições multilaterais para o desenvolvimento (WOOD, 1986). No começo da década, o Banco para Reconstrução Internacional e Desenvolvimento (BIRD) e as Nações Unidas proviam quase a totalidade da ajuda multilateral. No decorrer da década, novas instituições foram criadas no sentido de fornecer empréstimos aos países subdesenvolvidos. Embora essas instituições tenham emergido em função das pressões do Terceiro Mundo, ao mesmo tempo elas representam uma derrota por parte desses países em estabelecerem uma agência para o desenvolvimento no âmbito das Nações Unidas, em que eles pudessem exercer maior controle. Ao invés de um Fundo Especial das Nações Unidas para o Desenvolvimento Econômico (SUNFED, em inglês $)^{23}$, eles obtiveram instituições que realizavam empréstimos, a juros mais baixos que os de mercado, mas que deveriam ser pagos de todo modo. Nesse contexto, foram criadas instituições no âmbito do BIRD, que passa a se chamar Banco Mundial, como a Associação para o Desenvolvimento Internacional (IDA, em inglês) ${ }^{24}$ e uma série de bancos regionais de desenvolvimento com modelos de funcionamento similares ao Banco Mundial, como o Banco Interamericano de Desenvolvimento (IBD, em inglês) ${ }^{25}$ em 1959, o Banco Centro-americano para Integração Econômica (CABEI, em inglês) ${ }^{26}$, em 1961, o Banco Africano de Desenvolvimento (AFDB, em inglês) ${ }^{27}$ em 1964, o Banco Asiático de Desenvolvimento (ADB, em inglês) ${ }^{28}$ em 1966, o Banco da África Oriental de Desenvolvimento (EADB, em inglês) $)^{29}$ em 1967 e o Banco Caribenho de Desenvolvimento (CDB, em inglês) ${ }^{30}$ em 1970.

A IDA foi a instituição mais significativa em termos de recursos emprestados. Essa organização serviu como uma forma de o Banco Mundial expandir suas operações emprestando para os países mais pobres que não eram considerados "confiáveis" para tomarem empréstimos às taxas cobradas pelo BIRD. Os modos de funcionamento das

\footnotetext{
${ }^{23}$ Special United Nations Fund for Economic Development, em inglês.

${ }^{24}$ International Development Association, em inglês.

${ }^{25}$ Interamerican Development Bank, em inglês.

${ }^{26}$ Central American Bank for Economic Integration, em inglês.

${ }^{27}$ African Development Bank, em inglês.

${ }^{28}$ Asian Development Bank, em inglês.

${ }^{29}$ East African Development Bank, em inglês.

${ }^{30}$ Caribbean Development Bank, em inglês.
} 
instituições do Banco Mundial e dos bancos regionais de desenvolvimento eram muito simulares. O modelo era centrado em um banco que tomava empréstimos no mercado privado via emissão de títulos de longo prazo e emprestava para governos a taxas de juros mais baixas que as de mercado. Como os títulos emitidos por essas instituições eram apoiadas por subscrições em ouro ou moedas conversíveis dos países-membro, essas organizações conseguiam levantar recursos no mercado de forma mais barata do que a maioria dos tomadores de empréstimos, o que os permitiam também emprestar o dinheiro a taxas de juros mais baixas que as praticadas no mercado ${ }^{31}$ (WOOD, 1986).

A membresia nessas instituições era aberta tanto para os países credores como para os devedores, porém o sistema de votação era proporcional à contribuição financeira de cada membro. A exceção nesse período foi o Banco Africano de Desenvolvimento que permitia que apenas países africanos fossem membros da instituição financeira. Em contrapartida, foi incapaz de levantar recursos suficientes no mercado e como consequência possuía poucos recursos a serem emprestados. Situação que só mudou após a instituição fornecer participação política aos países doadores (WOOD, 1986).

A década de 60 também viu uma reorganização dos programas de ajuda bilateral dos países doadores. Mudanças que refletiam tanto o aumento do número de doadores no Sistema Internacional como uma redefinição da relação entre ajuda econômica e militar. A agência americana foi renomeada passando de Agência de Segurança Mútua (MSA, em inglês) para Agência dos Estados Unidos para o Desenvolvimento Internacional (USAID, em inglês) ${ }^{32} \mathrm{em}$ 1961. Na mesma época, vários países europeus buscaram centralizar seus programas de ajuda, descentralizados em vários ministérios, em agências específicas de cooperação (WOOD, 1986).

Esse período também testemunhou uma crescente insatisfação dos países do chamado Terceiro Mundo tanto em relação ao volume de assistência fornecida pelos países desenvolvidos quanto em relação aos termos em que essa ajuda era fornecida. Os países receptores viam a ajuda fornecida pelas vias bilaterais como insuficiente e respondendo primariamente aos interesses dos doadores, fossem eles políticos ou econômicos. Em relação às vias multilaterais, os países se ressentiam da incapacidade de influenciar as normas dessas organizações dadas suas estruturas de governança e dos termos em que esses empréstimos eram concedidos na maior parte das vezes. Como será discutido posteriormente; essas

\footnotetext{
${ }^{31}$ Em torno de $3 / 4$ das taxas normais de Mercado (Woods, 1986).

${ }^{32}$ United States Agency for International Development, em inglês.
} 
insatisfações, entre outros fatores, levarão à gênese da Cooperação Sul-Sul para o Desenvolvimento (CSSD).

Em suma, essa primeira fase da cooperação para o desenvolvimento foi marcada pela rivalidade Leste-Oeste no contexto de Guerra Fria, pela instrumentalização da ajuda externa para atender a interesses políticos e econômicos dos doadores e pelo crescente acirramento das relações Norte-Sul. Institucionalmente, essa fase foi marcada pela criação e profissionalização de agências especializadas no fornecimento de ajuda externa no mundo desenvolvido e pela criação de instituições multilaterais para o fornecimento de cooperação para o desenvolvimento.

\subsection{Anos 1970: crise internacional e expansão das organizações multilaterais}

Os anos 1970 foram marcados por um período de turbulência econômica que teve seus reflexos na Cooperação Internacional para o Desenvolvimento. O choque do petróleo ocorrido em 1973 e as crises políticas no Oriente Médio levaram a uma instabilidade no mercado mundial de energia com consequências tanto para os países desenvolvidos quanto para os países subdesenvolvidos. Essa época também testemunhou a transição do Sistema Financeiro de Bretton Woods, com taxas de câmbio fixas, porém ajustáveis, para um sistema de taxas de câmbio flutuantes, o que teve consequências para o financiamento do desenvolvimento no Terceiro Mundo.

Essa década também presenciou o surgimento de um grupo de novos doadores, fora do âmbito do CAD/OCDE, composto especialmente pelos países membros da Organização dos

Países Exportadores de Petróleo (OPEP) ${ }^{33}$, e uma maior institucionalização da Cooperação Sul-Sul (CSS). No plano político, essa década presenciou uma diminuição da intensidade da Guerra Fria, período que ficou conhecida como detente, na medida em que algumas das grandes questões de disputa entre as duas superpotências haviam sido pacificados, como a questão cubana, o Vietnã, a situação no leste europeu, a consolidação do governo chinês e a substituição de Taiwan nas Nações Unidas. Esse período também foi marcado pela ocorrência de graves catástrofes humanitárias nos países subdesenvolvidos, especialmente por grandes fomes que ocorreram no continente africano e asiático, nomeadamente na Etiópia e em Bangladesh.

\footnotetext{
${ }^{33}$ Organization of the Petroleum Exporting Countries (OPEC), em inglês.
} 
Esse contexto exacerbou tanto as incertezas quanto as insatisfações em relação à Cooperação para o Desenvolvimento. Por um lado, a efetividade da ajuda externa passou a ser cada vez mais contestada, tanto em função das esparsas evidencias empíricas que corroborassem as teorias econômicas que forneciam a rationale para o provimento de assistência externa no plano internacional, especialmente sobre a relação entre ajuda externa e crescimento econômico. Por outro, os países do Sul passaram a expressar de forma cada vez mais ativa sua indignação com a estrutura da economia internacional, demandando o estabelecimento de uma Nova Ordem Econômica Internacional (NOEI).

As críticas em relação à efetividade da ajuda externa passam por influenciar o regime de CID aumentando a preocupação dos principais atores envolvidos acerca da qualidade da ajuda fornecida. As evidências pareciam demonstrar que a ajuda externa fornecida até então tinha pouco impacto na melhoria da qualidade de vida entre as parcelas mais pobres dos países receptores. Milani (2014) aponta que os anos 1970 foram paradoxais em relação à evolução do regime da CID na medida em que ao mesmo tempo em que as críticas e a desconfiança em relação aos princípios e mecanismos da ODA começaram a ganhar força, também foi o momento em que esse regime passou por um processo de maior institucionalização.

Em 1969, a Comissão sobre Desenvolvimento Internacional, coordenada pelo primeiro-ministro canadense Lester B. Pearson, em seu relatório Partners in Development, conhecimento popularmente como Relatório Pearson, embora pró-ajuda, apontou as deficiências na forma que a assistência estava sendo fornecida (PEARSON, 1969). O relatório apontava que boa parte da ajuda externa sendo fornecida estava utilizada para obter favores políticos de curto prazo dos governos receptores, e obter vantagens estratégicas e promover exportações por parte dos doadores. Suas conclusões apontavam o que já aparentava ser claro para muitos envolvidos. Que a ajuda externa estava sendo utilizada para outros fins que não apenas desenvolver os países receptores. Ademais, o relatório também apontava para os baixos volumes que estavam sendo depreendidos para ajuda externa, propondo uma meta de 0,7\% do Produto Nacional Bruto (PNB) a ser destinada à ajuda oficial ao desenvolvimento, sem a inclusão de fluxos privados de financiamento. Essa sugestão foi oficializada em outubro de 1970, na Resolução no 2.626 da Assembleia Geral das Nações Unidas. Outro estudo relevante no período foi o relatório Brandt, documento produzido pela Comissão Internacional para Assuntos de Desenvolvimento Internacional, popularmente conhecida como Comissão Norte-Sul, que funcionou entre 1977 e 1983, composta por especialistas e 
políticos de vários países, chefiada pelo ex-Chanceler Federal alemão William Brandt. O relatório também apontava para as deficiências existentes nas práticas referentes ao fornecimento de ajuda externa, porém indicava a necessidade da atuação dos países desenvolvidos em auxiliarem as populações do mundo em desenvolvimento a se elevarem de sua condição de pobreza (BRANDT, 1980).

Um marco para essa tentativa de maior institucionalização da CID fora a criação de metodologias objetivas para a avaliação do impacto e efetividade da ajuda fornecida. Dentre essas tentativas, ressalta-se a criação do logical framework analysis, pela Agência dos Estados Unidos para o Desenvolvimento Internacional (USAID, em inglês). Metodologia baseada no modelo "input/output" que procurava estabelecer vínculos entre causas e efeitos em relação ao fornecimento de ajuda externa. Essa ferramenta de gestão de ajuda foi em seguida adotada por outros doadores do CAD e no plano multilateral pelo Programa das Nações Unidas para o Desenvolvimento (PNUD). Ao final da década, esse instrumento de avaliação passa a ser adotado pela grande maioria dos doadores, tanto para a aprovação de projetos de cooperação quanto para a avalição de seus resultados.

Esse paradoxo entre institucionalização e desconfiança também é ilustrado na passagem de Robert McNamara pela presidência do Banco Mundial entre 1968 e 1981, período de grande expansão das atividades dessa organização. Considerando as críticas de que crescimento econômico por si só não gerava automaticamente a redução da pobreza, o Banco Mundial deveria adotar uma abordagem voltada às necessidades individuais básicas dos mais pobres. Essa concepção denominada de abordagem das necessidades básicas resultou em uma mudança de abordagem do banco mundial, em que seria necessário focar as ações da instituição em setores como saneamento básico, educação primária, saúde básica, planejamento familiar e agricultura, com focos geográficos mais bem definidos (FINNEMORE, 1997). Nessa época é publicado o relatório "Redistribution with Growth", coordenado pelo economista-chefe do banco, Hollis Chenery, que lança as bases para essa abordagem voltada ao alivio da pobreza. Ao contrário do que o nome aparentar indicar, o relatório não pregava por uma redistribuição da riqueza existente nas sociedades do Terceiro Mundo, mas que apenas os excedentes oriundos do crescimento deveriam ser redistribuídos por meio de ações que atingissem diretamente os mais pobres (CHENERY et al., 1974).

Uma publicação do Banco Mundial apontava para uma "revolução silenciosa" no pensamento do desenvolvimento que estava ocorrendo nos anos 1970 (UL HAQ, 1978). O CAD também adotou formalmente a abordagem conhecida como "necessidades humanas 
básicas" em outubro de 1977. Essa mudança no pensamento sobre o desenvolvimento ocorreu por vários fatores. $\mathrm{O}$ primeiro foi o reconhecimento de que o crescimento econômico no Terceiro Mundo havia tido pouco efeito na melhoria dos indicadores de pobreza. Outro fator importante foi o caso do Vietnã do Sul. País que mais recebeu ajuda econômica norteamericana entre 1962 e 1975, além da ajuda militar recebida durante toda a guerra. O caso se mostrava como um evidente fracasso da abordagem de que o crescimento econômico geraria melhorias nas condições de vida das parcelas mais pobres da população e estabilidade social (WOOD, 1986). Ademais, os casos de melhorias básicas nas condições de vida dos mais pobres nos países que passavam por uma experiência socialista começaram a se tornar notórios e não poderiam mais ser ignorados pelos governos e organizações internacionais do mundo capitalista. Assim, as instituições de ajuda externa começaram a assimilar as noções de necessidade básicas humanas, como forma de se evitar desfechos revolucionários em outras regiões do mundo em desenvolvimento.

A abordagem das necessidades básicas evoluiu em duas etapas. A primeira foi a emergência de críticas em relação aos indicadores utilizados para se mensurar o desenvolvimento econômico e os objetivos das atividades de ajuda externa, presentes no relatório "Redistribution with Growth", e nas discussões no Congresso Americano acerca da estrutura e das características da ajuda externa fornecida pelos EUA, sob o título de "New Directions". A segunda etapa consistiu na redefinição do que esse "assalto à pobreza" significaria na prática. Sob o Banco Mundial, essa abordagem se direcionou para uma abordagem "orientada pelo consumo". O primeiro documento produzido pelo Banco Mundial sobre o assunto, "First Things First: Meeting Basic Human Needs in Developing Countries" (STREETEN et al., 1981), pregava a redefinição do conceito de pobreza absoluta, em termos de necessidades básicas não atingidas ao invés do nível de renda per capita, e a necessidade de se direcionar programas de assistência para atender essas necessidades de forma direta. No entanto, não houve consenso em relação às quais seriam essas necessidades e quais seriam os serviços necessários para atendê-las, embora algumas categorias tenham sido propostas ${ }^{34}$ (WOOD, 1986).

No plano internacional, a insatisfação dos países do chamado "Terceiro Mundo" com a ordem econômica internacional levaram essas nações a buscaram alternativas para o desenvolvimento. Dentre essas tentativas, destaca-se a criação da Conferência das Nações

\footnotetext{
${ }^{34} \mathrm{O}$ relatório "First things first" definia as necessidades básicas como saúde (expectativa de vida), educação (alfabetização), alimentação (consumo de calorias per capita), fornecimento de agua (porcentagem da população com acesso à agua potável) e saneamento (porcentagem da população com acesso a serviços de esgoto) (STREETEN et al., 1981).
} 
Unidas sobre o Comércio e Desenvolvimento (UNCTAD), que procurou analisar os vínculos entre comércio e desenvolvimento. A partir da UNCTAD, o próprio modelo de cooperação para o desenvolvimento passa a ser questionado, pois esse modelo, na visão dos países em desenvolvimento, estava assentado em bases assistencialistas, com determinantes políticos e estratégicos, conectados a interesses comerciais dos doadores e não atendia às reais necessidades dos países receptores na medida em que se evidenciava a pouca contribuição desses programas no desenvolvimento dos países beneficiados (LEITE, 2011).

Nota-se que essa dupla abordagem contrastante em relação à ajuda externa refletem a evolução do debate sobre o desenvolvimento econômico que se torna mais complexo e ideológico (AFONSO; FERNANDES, 2005). Pode-se dizer que no plano individual, as críticas em relação à efetividade da ajuda externa refletem a emergência do pensamento liberal no mainstream do pensamento econômico. A ortodoxia liberal que volta a ganhar força possui suas bases epistemológicas no individualismo metodológico e na crença da superioridade das forças de mercado sobre o dirigismo por parte dos Estados (RAPLEY, 2007). Assim, em relação à ajuda externa, essa visão tendia a culpar os países receptores acerca do fracasso da ajuda na medida em que esses recursos estavam sendo desperdiçados via empreitadas estatais em setores produtivos da economia que deveriam estar a cabo dos setores privados. Já no plano internacional, as críticas refletiam o pensamento dos teóricos da Dependência, que viam esse conceito como central para explicar as dinâmicas da economia internacional. De acordo com essa visão, o subdesenvolvimento resultava da natureza da interdependência entre o Norte e o Sul. Essa relação de interdependência acabava por perpetuar a situação de dependência do mundo em desenvolvimento. A chave central dessa relação se dava pelo comércio e pela deterioração dos termos de troca, que acabavam por posicionar os países em desenvolvimento em uma situação desfavorecida no plano internacional. Em relação à ajuda externa especificamente, essa escola enxergava-a como uma ferramenta utilizada pelos países doadores como forma de perpetuar essa relação. Na medida em que essa assistência servia aos interesses - econômicos ou políticos - dos doadores.

Esse período também presenciou uma expansão expressiva das organizações internacionais como o Banco Mundial e a Organização das Nações Unidas na participação em matéria de cooperação internacional para o desenvolvimento. Além dessas organizações que forneciam empréstimos a juros mais baixos para os países em desenvolvimento, os bancos comerciais, baseados nos países desenvolvidos, começaram a participar cada vez mais do financiamento ao desenvolvimento no chamado Terceiro Mundo, conforme tanto a oferta de 
crédito quanto a demanda por empréstimos aumentaram de forma substancial ao longo da década.

Parte dessa expansão da atuação dos bancos comerciais no mundo em desenvolvimento pode ser explicada em função dos choques do petróleo ocorridos nessa década. Em função do aumento dos preços do petróleo no mercado internacional, os países da OPEP foram capazes de acumular vultosas reservas em dólares. Parte desse dinheiro foi emprestada diretamente para outros países em desenvolvimento de forma bilateral a taxas de juros concessionais. Outra parte foi emprestada via instituições multilaterais criadas por esses países como o Fundo Árabe para o Desenvolvimento Social e Econômico em 1973, o Banco Árabe para o Desenvolvimento Econômico na África em 1973, o Banco para o Desenvolvimento Islâmico em 1975 e o Fundo da OPEC para o Desenvolvimento Internacional em 1976. Porém, a maior parte dessas reservas foi depositada nos grandes bancos comerciais das econômicas capitalistas avançadas, que puderam reciclar esses recursos por meio da realização de empréstimos para governos ao redor do mundo (WOOD, 1986).

A ajuda externa fornecida pelo Plano Marshall no pós Segunda Guerra foi majoritariamente concedida na forma de doações. No entanto, a maior parte da ajuda concedida aos países em desenvolvimento nos anos 1950 e 1960 foi concedida sob a forma de empréstimos. Com o passar dos anos o serviço dessas dívidas começou a se equiparar ao volume concedido na forma de novos empréstimos. O BIRD recebeu mais recursos em serviço da dívida em 1970 do que gastou com a realização de novos empréstimos. Assim, a expansão da atuação do Banco Mundial nessa década ocorreu sob esse contexto. Durante os anos 1970 o Banco Mundial expandiu sua atuação de forma agressiva tanto em relação ao volume de empréstimos realizados quanto em áreas como coordenação de pesquisas, e coordenação da cooperação internacional. Apesar de ter se mantido uma instituição centralizada, com a maior parte de seu quadro de funcionários atuando em Washington, EUA, a instituição buscou estabelecer uma série de escritórios regionais ao redor do mundo (WOOD, 1986).

A expansão do Banco Mundial nesse período foi complementada por uma série de novas modalidades de empréstimos realizados pelo FMI. As bases institucionais para a expansão dos empréstimos realizados pelo FMI com alta condicionalidade foram estabelecidas nesse período. Em especial, os programas de Extended Fund Facility, criado em 1974, o Supplementary Financing Facility, entre 1979 e 1982 e o Enlarged Access Policy, estabelecido em 1981. Esses novos tipos de empréstimos permitiram ao FMI aumentar sua 
atuação e importância na área do financiamento ao desenvolvimento ao redor do mundo, possibilitando a realização de empréstimos condicionais de maior duração. Embora, o FMI tenha tido uma atuação mais discreta ao longo dessa década, essas novas modalidades colocaram a instituição em uma posição de destaque quando a crise da dívida se abateu sobre os países em desenvolvimento no começo dos anos 1980 (WOOD, 1986).

As maiores inovações ao regime do financiamento ao desenvolvimento não ocorreram no regime de ajuda em si, mas nas práticas dos bancos comerciais. Os anos 1970 viram uma situação de retorno parcial à situação dos anos 1950 em que os fluxos de capital privado equalizaram os fluxos de ajuda oficial ao desenvolvimento. Porém, se na década de 1950, a maior parte desses investimentos consistiam de Investimento Estrangeiro Direito (IED), nos anos 1970, o grosso desses fluxos consistia de empréstimos comerciais. O grande aumento do número de empréstimos comerciais não se deu dado à condição de melhoria da situação macroeconômica dos países em desenvolvimento, mas pelo lado da oferta. Um motivo essencial para que os bancos dos países industrializados pudessem começar a emprestar em larga escala para os países do Terceiro mundo foi o desenvolvimento do mercado de eurodólares $^{35}$. Esse mercado se expandiu rapidamente em função de três fatores principais. Primeiro, os recorrentes déficits na Balança de Pagamentos dos Estados Unidos, que faziam com que os dólares americanos migrassem para os países superavitários. Segundo, as enormes reservas de dólares acumuladas pelos países da OPEP em função dos choques do petróleo ocorridos nessa década. Terceiro, pela expansão ocasionada pela desregulamentação dos sistemas financeiros nacionais no mundo desenvolvido, que permitiram uma grande lucratividade às instituições financeiras privadas que atuavam nesse mercado (WOOD, 1986).

Parcialmente estimulados pelas garantias governamentais americanas dos programas de ajuda externa dos EUA, os bancos comerciais americanos rapidamente expandiram suas operações no mundo em desenvolvimento. O cenário de crescimento baixo e alta inflação nos países industrializados, fenômeno que ficou conhecido como estagflação, impulsionava os bancos a buscarem novos mercados em busca de novos clientes. Concomitantemente, uma série de novos instrumentos técnicos permitiu que os bancos pudessem reduzir seus riscos ao emprestarem dinheiro para países em desenvolvimento. As três invenções mais importantes do período foram syndication, clausulas de cross-default e taxas de juros flutuantes. A syndication permitia aos bancos diversificarem suas carteiras de empréstimos. Do ponto de vista do devedor, significava que a moratória a um empréstimo envolveria um conflito com

\footnotetext{
${ }^{35}$ Termo utilizado para se referir aos mercados financeiros fora dos Estados Unidos.
} 
toda uma gama de bancos. As cláusulas de cross-default estendiam ambas as funções de syndication especificando que a moratória por um devedor para qualquer um de seus credores seria tomado como uma moratória a todos os outros credores. O que evitava que um devedor deixasse de pagar algum credor específico em troca de condições especiais com algum outro credor. As cláusulas de syndication e cross-default reduziam o risco político de uma moratória por parte de algum país. Já as taxas de juros flutuantes lidavam com o risco mais puramente financeiro criado pela inflação, na medida em que elas alteravam os riscos da instabilidade financeira para os devedores (WOOD, 1986).

Essas mudanças ao lado da oferta do financiamento ao desenvolvimento alteraram radicalmente as opções de financiamento externo dos países em desenvolvimento e no regime da Cooperação para o Desenvolvimento como um todo. Em um primeiro momento, esses países puderam gozar de maior autonomia política e econômica na medida em que os bancos comerciais estavam menos preocupados do que os governos dos países industrializados em relação a como esses países utilizariam os recursos. Os bancos estavam satisfeitos em emprestar quantias significativas contanto que o serviço da dívida fosse pago com o tempo. Assim, muitos governos aproveitaram esse período para adotaram políticas autárquicas de desenvolvimento. Opção mais restrita quando os recursos proviam de doadores oficiais como os Estados Unidos, por exemplo, que via com maus olhos o ativismo estatal em países periféricos ocupando um espaço que poderia ser preenchido pelos investimentos privados. Ademais, essas novas fontes de financiamento tornaram os países receptores menos suscetíveis aos interesses comerciais e políticos dos doadores. Na medida em que os bancos não exigiam condicionalidades políticas em relação aos empréstimos e esses empréstimos não estavam amarrados à compra de determinados produtos. Enquanto as taxas de juros americanas se mantivessem baixas e esses países pudessem continuar tomando recursos emprestados no mercado internacional, a situação poderia perdurar por muito tempo (RAPLEY, 2007).

\subsection{Anos 1980: crise da dívida e ajustes estruturais}

Os anos 1980 trouxeram grandes mudanças para o regime da CID. A recessão econômica nos países doadores, o aumento da taxa de juros americana e a crise da dívida no mundo em desenvolvimento acabaram por gerar transformações radicais tanto na doutrina do desenvolvimento quanto na da ajuda externa. Essa fase é marcada por duas características 
principais: a emergência do liberalismo como pensamento econômico dominante e uma mudança de foco em relação aos objetivos e práticas da ajuda externa. A assistência prestada sofre reduções e é orientada para os chamados "ajustes estruturais". As instituições financeiras internacionais como o Banco Mundial e o FMI passam a exigir cada vez mais "condicionalidades" para a realização de empréstimos, levando a um descontentamento cada vez maior por parte dos países receptores em relação à cooperação prestada pelos países desenvolvidos e pelas instituições internacionais.

Essa década foi marcada pelos efeitos das crises do petróleo ocorridas na década anterior, que acabou por alimentar as recessões econômicas nos países desenvolvidos e os desequilíbrios nas contas externas e consequente endividamento dos países em desenvolvimento. Os superávits globais de poupança nos anos 1970 haviam estimulado os empréstimos comerciais aos países em desenvolvimento e seu consequente endividamento. $\mathrm{Na}$ virada da década, a recessão econômica nos países desenvolvidos havia aumentado os custos para a realização de novos empréstimos. Enquanto alguns economistas apontaram para a deterioração dos termos de troca e as condições desiguais da estrutura da economia internacional como responsáveis pela situação que o Terceiro Mundo estava passando. O consenso logo emergiu nos países desenvolvidos de que os culpados pela situação eram as políticas adotadas países em desenvolvimento (PLEASE, 1984).

A obtenção de equilíbrio externo - balança de pagamentos - e estabilidade interna orçamento - tornaram-se os objetivos centrais e as condições necessárias para a restauração do crescimento econômico e alívio da pobreza. Nessa visão, antes que o desenvolvimento econômico ou o combate à pobreza pudessem ser retomados, era necessário que os países adquirissem estabilidade macroeconômica por meio de dolorosas políticas de ajuste. Embora as preocupações com o desenvolvimento tenham sido interrompidas na medida em que a maior parte da atenção da comunidade do desenvolvimento se voltou à questão da estabilização da economia, ocorreram algumas contribuições acerca do pensamento sobre o desenvolvimento nesse período. A primeira foi uma maior atenção ao papel do capital humano como motor do desenvolvimento. A chamada Escola do crescimento endógeno (LUCAS, 1988; ROMER, 1990) apontaram para o baixo investimento em capital humano como o principal obstáculo para o aproveitamento das economias de escala que viriam com a industrialização. Essa nova concepção acerca do capital humano transformou a ideia de progresso técnico de um fator essencialmente exógeno para um fator parcialmente endógeno. Uma segunda contribuição, baseada primordialmente entre estudos empíricos, diz respeito à 
relação entre comércio e crescimento econômico. As evidências de que as estratégias de crescimento "voltadas para fora" (export-oriented) eram superiores às estratégias voltadas "para dentro" (import-oriented) começaram a ganhar corpo. Os mecanismos causais propostos iam da difusão de conhecimento e tecnologia ao maior equilíbrio das contas externas do país (WOOD, 1986).

Esse pano de fundo da economia política internacional é complementado pela ascensão de governos "conservadores" nos países capitalistas industrializados, especialmente com as eleições de Ronald Reagan nos EUA e Margareth Thatcher no Reino Unido. Esses governos buscaram implantar políticas econômicas que visavam a redução da intervenção do Estado em certas atividades da economia e das despesas do erário público. A ideologia liberal por trás dessas medidas defendia uma maior confiança nas forças de mercado para uma alocação mais eficiente dos recursos econômicos das sociedades, de modo que para um bom desempenho da economia seria necessário uma maior liberalização dos setores econômicos, especialmente o comércio, e maior estabilidade macroeconômica, que se traduzia em um maior controle das taxas de inflação pelo mundo. Essa retórica pró-mercado gerou um forte sentimento para a eliminação da ajuda externa e sua substituição por capitais privados. Assim, no início da década de 1980, a administração Reagan criou um ambiente fértil para os críticos conservadores da ajuda externa que sentiram que a assistência econômica distorcia o livre funcionamento do mercado e impedia o desenvolvimento do setor privado.

A relação entre a crise da dívida da década de 1980, inaugurada com a moratória mexicana de sua dívida em 1982, e o regime de cooperação para o desenvolvimento é complexa. A maioria das análises realizadas na época tratou a crise da dívida como uma questão exclusivamente referente aos empréstimos realizados pelos bancos comerciais fora do regime de ajuda externa. Nessa ótica, as instituições de ajuda deveriam intervir como parte da solução para a crise, tanto por meio de novos empréstimos quanto pelo auxílio na aplicação das medidas de ajuste nos países receptores. No entanto, o próprio regime teve um efeito causal em relação à crise. Primeiramente, vale destacar que o regime de ajuda por si só gerava dívida, na medida em que boa parte da ajuda prestada, tanto via bilateral quanto pela via multilateral, consistia de empréstimos que deveriam ser pagos futuramente. Embora os termos de grande parte dessa dívida fossem altamente favoráveis pelos padrões de mercado, a dívida oficial no início dos anos 80 passou a ser um fardo considerável em muitos países em desenvolvimento, representando quase metade de toda a dívida pública de longo prazo em 1983. Ademais, embora quase metade da ajuda fornecida na época fosse dispensada na forma 
de "doações", a maior parte dessa ajuda era concedida sob a forma de assistência técnica, cujo valor em dólares era muitas vezes inflado e que comumente tinha interesse limitado para o destinatário (WOOD, 1986).

Em segundo lugar, conforme os países cresciam e se tornavam mais "confiáveis" financeiramente, eles se tornavam inelegíveis para determinadas fontes de financiamento. Vale lembrar que o regime da ajuda funcionava com base em um sistema de gradação. Se por um lado, alguns países em desenvolvimento não podiam mais requisitar certos empréstimos concessionais em razão de sua classificação de desenvolvimento. Outros, que ainda poderiam requisitar empréstimos por certas vias, optavam por buscar empréstimos comerciais em função do contexto financeiro internacional dos anos 1970, ilustrados nas baixas taxas de juros e abundância de crédito. Por fim, vale destacar que muitos países se endividaram buscando os bancos comerciais no intuito de fugir das condicionalidades impostas no regime de ajuda. Boa parte da ajuda externa fornecida, de capital ou commodities, ocorria na forma de empréstimos para projetos específicos e pré-determinados. A pequena proporção de empréstimos para programas carregavam geralmente altas taxas de condicionalidade. Assim, esses países viam os empréstimos comerciais como mais despolitizados na medida em que poderiam obter maior autonomia na gestão dos recursos obtidos e na execução de suas políticas econômicas, especialmente as com foco na substituição de importações e maior papel do Estado em setores produtivos da economia.

A crise enfrentada por esses países no início dos anos 1980 refletiu e acentuou a crise no regime de ajuda. O reagendamento das dívidas oficiais no Clube de Paris no intuito de salvaguardar o status privilegiado dos Bancos Multilaterais de Desenvolvimento (MDBs) e bancos comerciais privados não pareciam mais surtir efeito em 1982. As demandas oriundas da crise da dívida representaram um de uma série de choques externos que atingiram os países em desenvolvimento. Os problemas financeiros enfrentados pelos países do Terceiro Mundo eram de tal magnitude que o regime de ajuda parecia irrelevante para desenvolvimento dos países endividados (WOOD, 1986). Os custos do serviço das obrigações de dívida pendentes dos países em desenvolvimento tornaram-se tão substanciais que tenderam a diminuir as entradas de fundos concessionais, levando a um fluxo inverso líquido de recursos para o mundo desenvolvido durante a década (BROWN, 1990; RAPLEY, 2007).

O papel e a concepção da ajuda externa passaram por uma transformação radical. $O$ objetivo primário da ajuda externa passou a ser salvaguardar a estabilidade do Sistema Financeiro Internacional, permitindo que os países devedores pudessem honrar ao menos 
parcialmente o serviço de suas dívidas públicas e privadas. E encorajar a implantação de políticas de ajuste por meio de condicionalidades atadas aos novos empréstimos. Assim, a Cooperação para o Desenvolvimento prestada pelos doadores foi direcionada para os chamados "ajustes estruturais". Modalidade de empréstimo fornecida pelo Banco Mundial, inaugurado em 1980, que seria amplamente realizado da década. Esses ajustes eram defendidos como modelo a ser seguido no enfrentamento das crises de endividamento dos países do Sul (BROWNE, 1997).

Nesse cenário de crise, o foco da ajuda externa passa por uma mudança em relação ao “combate à pobreza" e a "satisfação das necessidades básicas" para um enfoque no ajuste das economias dos países por meio de políticas macroeconômicas. O discurso da cooperação para o desenvolvimento passou a abandonar os conceitos referentes a transformações estruturais nas relações Norte-Sul e na melhoria das condições de vida dos mais pobres e passou a adotar a ideia e o uso de "condicionalidades" (HJERTHOLM; WHITE, 2000a). Assim, para que os países pudessem receber assistência dos países doadores ou das instituições multilaterais, deveriam se submeter a pacotes de austeridade fiscal, financeira e econômica que seguiam os preceitos do que ficou conhecido como Consenso de Washington (WILLIAMSON, 2009) ${ }^{36}$.

Essa década presenciou o surgimento de uma nova fase da ajuda externa marcada por questões de governança macroeconômica. Essa fase também é marcada por um maior consenso entre os doadores acerca da gestão da ajuda externa. Os doadores estavam mais determinados a definir os parâmetros e as condições em que a assistência seria provida, inclusive atando-a aos seus próprios interesses comerciais. Esse novo enfoque nas questões de governança macroeconômica colocaram as instituições financeiras internacionais como o Banco Mundial e o FMI, que passaram a expressar esse consenso, em uma posição de proeminência global inédita até então. Essas instituições se tornaram capazes de definir as políticas econômicas dos países tomadores de empréstimos sendo responsáveis pelo futuro de sociedades inteiras ao redor do globo (BROWNE, 1997).

A diminuição do foco no combate à pobreza não ocorreu sem críticas. Estudos começaram a evidenciar as consequências das medidas de ajuste para as parcelas mais vulneráveis das populações dos países do mundo em desenvolvimento, especialmente, mulheres e crianças (CORNIA; JOLLY; STEWART, 1987; GRANT, 1990). Os efeitos da aplicação prática dos preceitos do "Consenso de Washington" são controversos. Por um lado,

\footnotetext{
${ }^{36}$ Consenso entre políticos e oficiais públicos dos países desenvolvidos e OIs sobre livre mercado, comércio e redução do Estado na economia. Governos deveriam desregulamentar e privatizar a economia e mudar o foco de substituição de importações para crescimento baseado em exportações, adotando politicas monetárias e fiscais rígidas e orçamentos equilibrados (RAPLEY, 2007)
} 
seus defensores apontam que tais medidas foram importantes para e estabilização macroeconômica de diversos países, evidenciado pelo controle da inflação em muitos casos. Por outro, seu detratores destacam as baixas taxas de crescimento apresentadas pelos países em desenvolvimento nesse período e para as consequências negativas para os grupos mais vulneráveis da sociedade. Ao final dá década e ao longo da seguinte, conforme essas críticas se multiplicaram, o Banco Mundial volta a trabalhar em políticas voltadas a lidar com a questão da pobreza e consequências dos ajustes. A publicação do relatório "New Poverty Agenda" do Banco Mundial (WORLD BANK, 1990) é comumente apontado como o ponto de partida para o reaparecimento da questão da pobreza como foco da agenda das agências de desenvolvimento (HJERTHOLM; WHITE, 2000a).

Por fim, outra tendência importante que marcou essa década foi o aumento da participação de Organizações Não-Governamentais (ONGs) no regime da ajuda internacional. Essas organizações passaram a ganhar preeminência especialmente em relação à execução de ajuda humanitária, embora tenham passado a atuar cada vez mais nas demais áreas da cooperação, especialmente nas décadas seguintes (PUENTE, 2010).

\subsection{Anos 1990: pós-Guerra Fria e globalização}

As principais alterações ocorridas no Sistema Internacional, com um impacto profundo sobre o regime de Cooperação para o Desenvolvimento, foram o final da Guerra Fria e a intensificação dos processos de globalização econômica. Nessa época, os países do antigo bloco socialista deixaram de serem doadores e reapareceram como receptores. Também ocorre um retorno da preocupação com o combate à pobreza nas doutrinas de desenvolvimento, acompanhada com um enfoque renovado na questão das instituições e das práticas de boa governança. Embora as preocupações com a estabilidade macroeconômica tenham continuado como objetivos dominantes da agenda do desenvolvimento, especialmente durante a primeira metade dessa década, conforme os efeitos adversos dos planos de ajuste e liberalização econômica se tornam mais evidentes as preocupações se voltam para o papel das instituições.

O final da Guerra Fria prometia um cenário internacional mais pacífico de modo que a cooperação para o desenvolvimento pudesse se tornar prioridade na política Internacional. No plano da retórica, os dois principais documentos produzidos pelo então secretário-geral das Nações Unidas, Boutros Boutros-Ghali iam nesse sentido: Agenda para a Paz (1992) e 
Agenda para o Desenvolvimento (1994) (MILANI, 2012b, 2014). O que se viu na prática, porém, foi uma intensificação do número de conflitos pelo globo. Em especial, o alastramento da violência de caráter étnica e religiosa e a emergência de novas preocupações em matéria de Segurança Internacional e de novas áreas para a cooperação como a prevenção de conflitos, a diplomacia preventiva, a reabilitação pós-conflito e as operações de manutenção de paz (AFONSO; FERNANDES, 2005).

Nesse contexto, a ONU reconheceu a natureza multidimensional do conceito de desenvolvimento em torno de cinco eixos centrais: a paz como seu fundamento, o desenvolvimento econômico como a base para o progresso, a sustentabilidade ambiental, a justiça social e a democracia (BOUTROS-GHALI, 1995). Assim, os anos 1990 presenciaram uma ampliação da agenda da cooperação para o desenvolvimento com a inclusão de temas como o combate à disseminação de doenças infecciosas, proteção ao meio-ambiente, combate ao tráfico de pessoas, armas e drogas, combate ao trabalho escravo e exploração infantil, refugiados, direitos das mulheres e descriminação racial entre outros. Essa ampliação fícou evidente na realização de diversas conferências patrocinadas pela ONU sobre os mais diversos temas. Temas como a educação para todos, Jomtien, em 1990; a proteção ambiental, Rio de Janeiro, em 1992; os direitos humanos, Viena, em 1993; os direitos reprodutivos e a demografia, Cairo, em 1994; os direitos da mulher e a problemática do gênero, Pequim, em 1995; o desenvolvimento social, Copenhague, em 1995; a gestão urbana e a internacionalização das cidades, Istambul, em 1996; bem como a discriminação racial, Durban, em 2001 (MILANI, 2014).

Nesse contexto, se consolidou a ideia de bens públicos globais, definidos como aqueles cujos benefícios ultrapassam as fronteiras, sejam entre Estados, gerações, populações ou classes sociais (KAUL, 2001; KAUL; FAUST, 2001). O debate em torno dos bens públicos globais trouxe para a CID algumas implicações como a necessidade de diálogo e cooperação crescente entre os Estados e a configuração de uma agenda de grandes temas que supunha a comunicação entre três áreas fundamentais das Nações Unidas, que são o desenvolvimento, os direitos humanos e a segurança (ANTONINI; HIRST, 2009).

Nessa década, o chamado "cansaço da ajuda" se tornou mais evidente. Embora a preocupação com a efetividade da ajuda não fosse nova no pensamento sobre o desenvolvimento, passa a ganhar uma nova proeminência nos anos 1990 por uma série de razões. Uma foi justamente o final da Guerra Fria, que reduziu a preocupação estratégica dos países doadores em termos de Segurança Internacional, diminuindo também a força do 
argumento que justificava o fornecimento de ajuda externa para esses objetivos, que acabavam por blindar a ajuda das críticas recebidas em função de sua falta de efetividade. Em segundo lugar, a melhoria da coleta de dados econômicos nos países em desenvolvimento tornou as pesquisas acerca dos impactos da ajuda mais precisas. Tornou-se cada vez mais evidente que os países, especialmente da África subsaariana, que recebiam volumes elevados de ajuda externa apresentavam performances socioeconômicas pífias, o que acabava por fortalecer as posições contrárias ao fornecimento de ajuda externa (EASTERLY, 2003, 2006).

Vários relatórios do Banco Mundial acerca da efetividade da ajuda corroboraram essa posição de que ajuda externa parecia ser ineficaz. O primeiro nesse sentido, "World Bank Portfolio Management Task”, conhecido como “Wapenhans Report” (WORLD BANK, 1992) apontava para os resultados decepcionantes das ações realizadas pela instituição chamando atenção para a falta de comprometimento local em relação aos projetos e para a falta de coordenação entre os múltiplos doadores. O relatório "Assessing Aid: What Works, What Doesn't and Why", de 1998, trazia como conclusões que a ajuda era menos eficaz em países que não possuíam um ambiente econômico e político favorável para o desenvolvimento (DOLLAR; PRITCHETT, 1998). Essas críticas, não apenas dos habituais detratores da ajuda externa, mas também de seus apoiadores, acabaram por refletir em uma diminuição dos fluxos de ajuda externa nessa década. Também acabaram por impulsionar uma série de reformas nas agências responsáveis pelo fornecimento de ajuda. Essas reformas incluíram gerenciamento de projetos baseado em resultados, critérios de seletividade para o fornecimento de ajuda, papeis de redução de pobreza (PRSPs, em inglês) ${ }^{37}$ e formulação de programas de ajuda setoriais (SWAPs, em inglês) ${ }^{38}$. Nessa época, várias agências também concordaram em restringir a ajuda para propósitos comerciais. Ação exemplificada na assinatura do "Arrangement on Guidelines for Officially Supported Export Credits", também conhecido como "Acordo de Helsinki", negociado sob os auspícios da OCDE (WORLD BANK, 1990). $\mathrm{O}$ acordo constrangia o uso do financiamento condicionado à aquisição de serviços e produtos exportados pelo doador (LANCASTER, 2007).

Nessa época, duas visões competiam acerca das medidas a serem adotadas para o desenvolvimento. A primeira, associada ao Banco Mundial, comumente vista como "top down", enfatizava as reformas econômicas como forma de estimular o crescimento. A segunda, geralmente associada às ONGs, vista comumente como "bottom up", enfatizava a redução de pobreza por meio de ações localizadas. Os anos 1990 presenciaram uma trégua

\footnotetext{
${ }^{37}$ Poverty Reduction Strategy Papers.

${ }^{38}$ Sectoral Wide Assistance programs.
} 
entre as duas visões. O Banco Mundial, sob a presidência de James Wolfensohn passou a assimilar a ideia acerca da necessidade de dar maior agência aos receptores na gestão dos projetos e no combate à pobreza como objetivo do desenvolvimento. Assim, o Relatório anual do Banco Mundial em 1990 traz o combate à pobreza de volta ao centro da agenda (WORLD BANK, 1990). A proposta especificava uma dupla estratégia: a promoção de crescimento intensivo em trabalho e aumento dos investimentos em saúde e educação. O relatório destacava que as populações mais vulneráveis às crises econômicas não conseguiam se beneficiar do crescimento econômico e, portanto, deveriam ser protegidas por redes de proteção social (HAAN, 2009).

Nessa época, a discussão sobre as melhores formas para se mensurar o desenvolvimento socioeconômico ganham novo fôlego. $\mathrm{O}$ primeiro Relatório de Desenvolvimento Humano (HDR) foi publicado pelo Programa das Nações Unidas para o Desenvolvimento (PNUD) ${ }^{39}$, em 1990, sob a liderança do paquistanês Mahbub ul Haq e pelo indiano vencedor do prêmio Nobel Amartya Sem (UNDP, 1990). O documento traz uma crítica contundente em relação ao fato de se utilizar a expansão física da economia de um país, no caso, o PIB per capita, como indicador de desenvolvimento socioeconômico. O documento traz como alternativa um novo indicador, chamado de Índice de Desenvolvimento Humano (IDH) ${ }^{40}$ (HAAN, 2009).

Os estudos acerca do desenvolvimento econômico se tornam cada vez mais complexos. A evolução dos métodos de estimação juntamente com uma melhoria na coleta de dados, especialmente nos países africanos, permitiu a realização de uma série de trabalhos mais robustos analisando dados entre países e ao longo do tempo, relacionando a variável crescimento com outras variáveis como educação, saúde e comércio, por exemplo. Ademais, tornou-se possível comparar dados sobre pobreza a partir do momento que um conjunto comparável de preços ficou disponível a nível internacional. O resultado foi a medida do "dólar por dia" 41 (HAAN, 2009).

Entretanto, a principal contribuição acerca do pensamento sobre o desenvolvimento nesse período foi a maior atenção dada ao papel das instituições. Abordagem que ficou conhecida como "nova economia das instituições" (NABLI; NUGENT, 1989; NORTH, 1990;

\footnotetext{
${ }^{39}$ United Nations Program for Development (UNDP).

40 Índice que mede as conquistas dos países em termos de expectativa de vida, taxa de alfabetização, e PIB per capita. Índice composto que vai de 0 a 1 calculado com base nessas três dimensões.

${ }^{41} \mathrm{O}$ dólar não representa um dólar real, para ser convertido com taxas de câmbio normais; sim, representa um pacote de consumo contendo as necessidades mínimas em diferentes partes do mundo.
} 
WILLIAMSON, 1991). A maior contribuição desse pensamento reside no papel central das instituições em gerar incentivos para as ações dos indivíduos no contexto de mercados incompletos. Esse pensamento defendia que instituições apropriadas e as regras do jogo eram essenciais para a promoção do desenvolvimento econômico (THORBECKE, 2007). Essa nova abordagem considerou muitas das críticas anteriores, concluindo que as prescrições políticas não estavam erradas - em relação à necessidade de estabilidade macroeconômica mas que os ajustes por si só eram insuficientes. Essa abordagem enfatiza o papel complementar do Estado em relação ao mercado, esperando que processos de democratização apoiem uma economia de mercado dinâmica (HAAN, 2009).

Essa abordagem da governança inclui uma ênfase no crescimento econômico para a redução da pobreza e os papeis do setor privado e comércio. Porém, também reconhece o papel do Estado na provisão de investimentos públicos em áreas como saúde básica e educação primária. Esse recém-construído consenso baseado no desenvolvimento humano, participação e capacitação foi ilustrado no Relatório de Desenvolvimento Mundial de 2000/2001 intitulado “Attacking Poverty" (WORLD BANK, 2001). Este relatório destacou o papel central do desenvolvimento econômico na redução da pobreza, mas também que a pobreza é o resultado de processos econômicos, sociais e políticos que interagem e podem se reforçar. O relatório utilizou um novo quadro de três partes para analisar e abordar a pobreza: expandir as oportunidades, a capacitação e a segurança das pessoas pobres (HAAN, 2009).

Assim, embora a ênfase na questão da estabilidade macroeconômica não tenha perdido importância e as demais prescrições do "Consenso de Washington" não tenham sido abandonadas, o pensamento sobre o desenvolvimento nos anos 1990 passou por uma transformação substancial. Parte dessas mudanças pode ser explicada pelo fato de as Instituições Financeiras Internacionais terem sido crescentemente desafiadas a responderem às críticas recebidas. Especialmente após as crises financeiras que atingiram diversos países ao final dessa década, com destaque para a crise asiática de 1997. Ao invés de simplesmente enfatizar a estabilização de curto prazo após a crise, a resposta implicou uma ênfase reforçada na redução da pobreza e na proteção dos mais pobres contra os efeitos das crises. Com essa ênfase renovada, o pensamento de desenvolvimento focou cada vez mais nas condições políticas e institucionais que contribuem para o crescimento e o desenvolvimento. Sob a influência da crítica da ajuda ao desenvolvimento na década de 1990, um número crescente de estudos passou analisou as condições em que a ajuda externa poderia se tornar mais efetiva (HAAN, 2009). 
A tendência de se privilegiar os fluxos de capital privado e de comércio ao invés de recursos públicos se manteve. A ajuda deveria desempenhar um papel catalisador, interagindo com os fluxos privados, promovendo a eficácia e as práticas de boa governança. A composição setorial da ajuda sofre alterações, passando a priorizar setores para os quais não existe mercado, como serviços sociais básicos. Nesse sentido, há uma diminuição significativa da ajuda para setores produtivos da economia. Essas alterações são consequência dessa nova ênfase que os doadores dão à ideia de desenvolvimento das capacidades humanas e institucionais. Ou seja, a criação e/ou o fortalecimento de instituições que possibilitem o desenvolvimento de longo prazo. A Conferência Mundial para o Desenvolvimento Social em Copenhague, em 1995, teve um papel importante sobre o pensamento dominante acerca do desenvolvimento ao colocar o desenvolvimento social como objetivo central a ser atingido. Nessa conferência, é estabelecida como prioridade a erradicação da pobreza, salientando a necessidade de o Estado e a sociedade civil fornecerem os serviços sociais básicos aos mais vulneráveis (AFONSO; FERNANDES, 2005).

Nota-se uma ampliação da agenda da Cooperação para o Desenvolvimento de projetos e intervenções pontuais, para programas e políticas mais gerais, aumentando significativamente a envergadura temática e o raio de ação da Cooperação para o Desenvolvimento. Se, no começo de seu processo de institucionalização, a CID deu ênfase a diálogos técnicos sobre capital financeiro, tecnologia e organização das infraestruturas, nos anos 1990, as agendas abrangeram políticas sociais, instituições e governos. De uma cooperação interestatal, passou-se gradualmente a um sistema de cooperação que envolveria múltiplos atores como Estados, organizações internacionais, ONGs e setor privado (MILANI, 2014).

Como resultado dessas mudanças, ao final da década, a ajuda havia adquirido quatro novos propósitos: promoção das transições políticas e econômicas, solução dos problemas globais, expansão da democracia e resolução de conflitos. As ações realizadas para auxiliar os países em transição, especialmente os do antigo bloco socialista, foram de auxílio à realização de novas constituições e sistemas legais, reformas judiciárias, reformas nos sistemas financeiros e regulatórios, treinamento de mídia e partidos políticos a fortalecimento de organizações sociais. Para lidar com os problemas globais, as ações iam de programas específicos para preservação de certas espécies da fauna e flora global, a medidas para redução de gases específicos para a atmosfera, redução de poluição do solo, agua e ar, e combate a pandemias como HIV/AIDS. A ajuda para a promoção de democracia, 
especialmente na África subsaariana, incluía o financiamento de eleições, treinamento de mídia, partidos políticos e elaboração de novas constituições. A ajuda para recuperação de conflitos foi fornecida por várias agências, incluindo Estados Unidos, Banco Mundial, PNUD, para regiões como os Balcãs, Haiti, Angola, Moçambique, Serra Leoa, Libéria entre outros países assolados por conflitos (LANCASTER, 2007).

Essas transformações ocorridas ao longo dessa década engendraram o pano de fundo para a formulação dos Objetivos do Milênio (ODMs), acordados após a Declaração do Milênio no ano 2000. Esses objetivos possuem suas origens em uma série de metas e propostas assinaladas nas últimas décadas em várias organizações e conferências internacionais ${ }^{42}$. Constituem-se de um conjunto de metas acompanhadas de indicadores de monitoramento e avaliação. Esses objetivos reúnem oito temas como norteadores para a Cooperação para o Desenvolvimento: 1) Redução da pobreza; 2) Universalização do ensino básico; 3) Igualdade entre os sexos e autonomia da mulher; 4) Redução da mortalidade infantil; 5) Melhoria da saúde materna; 6) Combate ao HIV/AIDS, à malária e a outras doenças endêmicas; 7) Garantia da sustentabilidade ambiental; e 8) Estabelecimento de uma parceria mundial para o desenvolvimento (UNITED NATIONS, 2000). Embora esses objetivos ambiciosos pudessem gerar ceticismo em relação à factibilidade de seu cumprimento. Os ODMs representaram um comprometimento renovado dos governos com o desenvolvimento internacional, criando um ponto focal para discussões na comunidade do desenvolvimento.

\subsection{Século XXI: novas agendas internacionais e fragmentação da CID}

O início do século XXI trouxe consigo eventos e tendências que marcaram o regime de Cooperação para o Desenvolvimento de forma significativa. Em especial, o atentando terrorista em solo americano no dia 11 de setembro de 2001. Dentre as consequências do atentando para o sistema internacional, costuma ser apontado o fenômeno de securitização da agenda internacional. O combate ao terrorismo ganhou um papel de destaque na formulação e na implementação da Cooperação para o Desenvolvimento, especialmente na ajuda fornecida pelos doadores do CAD/OCDE.

\footnotetext{
42 1990: Cúpula Mundial pelas Crianças (1990); Rio 92 - Agenda 21 (1992); Conferência de Viena sobre Direitos Humanos (1993); Conferência Internacional sobre População e Desenvolvimento (1994); Cúpula Mundial sobre Desenvolvimento Social em Copenhague (1995); Conferência Mundial sobre a Mulher (1995); Comitê de Ajuda ao Desenvolvimento (OCDE): Revisão da AOD (1996).
} 
A Primeira Conferência das Nações Unidas sobre o Financiamento ao Desenvolvimento, ocorrida em Monterrey em 2002, foi um acontecimento importante na agenda da cooperação em que os países doadores fizeram promessas de aumentar a ajuda externa fornecida. Lancaster (2007) aponta que o atentado de 11 de setembro teve um papel importante em predispor as elites políticas e opinião pública dos Estados Unidos e países europeus a aumentarem a ajuda fornecida ao desenvolvimento. Analistas apontaram para a ligação entre "Estados falidos" e terrorismo, na medida em que esses países poderiam virar bases para organizações terroristas caso não fossem auxiliados pelos países desenvolvidos. Consequentemente, essa década presenciou um aumento da ajuda fornecida em comparação à década anterior. Vale destacar, no entanto, que esses indicadores incluem o perdão de dívidas.

Em paralelo a essa securitização da agenda, a efetividade da ajuda continuou sendo uma questão central na agenda do desenvolvimento. Duas conferências do CAD/OCDE, Paris, em 2005 e Accra, em 2008, enfatizaram esse tema buscando soluções que passam por meio de um maior aumento da participação dos receptores na gestão da ajuda; maior coordenação por parte dos doadores em relação aos programas implementados; e maior alinhamento entre as políticas de cooperação realizadas pelos doadores e as próprias políticas domésticas dos países receptores (MILANI, 2014).

Nesse período, essa ampla agenda foi codificada em um conjunto de princípios estabelecidos durante o Segundo Fórum de Alto Nível sobre a Efetividade da Ajuda, em Paris, em 2005. Os doadores tradicionais reuniram agências multilaterais e representantes do mundo em desenvolvimento. A declaração final foi endossada por 61 doadores bilaterais e multilaterais, bem como por 56 beneficiários. Estes "Princípios de Paris" reuniram uma perspectiva gerencial de "efetividade da ajuda" com um arranjo político baseado nas ideias de parceria e corresponsabilidade. A "reforma" englobou cinco princípios: apropriação da agenda de desenvolvimento pelo país beneficiário; alinhamento entre doadores com as prioridades e metas de um país parceiro e maior confiança nos sistemas de seus países; ações coordenadas, simplificadas e harmonizadas entre múltiplos doadores; responsabilidades mútuas; e gestão por resultados (ESTEVES; ASSUNÇÃO, 2014).

As diretrizes centrais do regime de cooperação para o desenvolvimento foram firmadas em torno da "Declaração de Paris" e dos "Princípios de Paris". Essa perspectiva gerencial que sustentava os princípios de "responsabilidade mútua" e "gestão por resultados" deveria responder às demandas dos doadores, pelo menos quanto à legitimidade perante seus próprios eleitorados. A harmonização e a transparência eram condições para o 
estabelecimento de um quadro de monitorização coerente, que proporcionaria consistência à sua posição enquanto doadores. O princípio da propriedade (ownership), o pilar fundamental da declaração, procurava colocar os destinatários no "banco do condutor", transformando as assimetrias tradicionais no campo. Além disso, a Declaração de Paris assumia que a ajuda ao desenvolvimento deveria ser orientada para a redução da pobreza e para a consecução dos ODMs. Assim, os Princípios de Paris pareceram alinhar o campo da cooperação internacional para o desenvolvimento com a agenda mais ampla dentro das Nações Unidas ${ }^{43}$ (ESTEVES; ASSUNÇÃO, 2014).

Outra mudança ocorrida com a virada do século diz respeito às iniciativas de perdão de dívida de países altamente endividados. O movimento Jubileu 2000 ajudou a colocar o tema do perdão de dívidas do Terceiro Mundo no centro das estratégias de cooperação para redução da pobreza (AFONSO; FERNANDES, 2005). Essas ações culminaram na Iniciativa Países Pobres Muito Endividados (HIPC, em inglês) ${ }^{44}$ no âmbito do Clube de Paris. Outras iniciativas no intuito de sensibilizar a opinião pública a respeito da ajuda externa tiveram um papel importante em moldar as ações dos governos no tocante a essa questão, como o movimento $1 \%$ nos Estados Unidos e o Movimento pró 0,7\% na Alemanha (LANCASTER, 2007).

O aumento da importância das questões relativas às mudanças climáticas que seguiram a publicação dos relatórios do Painel Intergovernamental das Mudanças Climáticas (IPCCC), também teve um efeito nas políticas de ajuda. A elaboração de relatórios acerca da questão desenvolvimento como o "Human Development Report", de 2007, buscou analisar ligações entre mudanças climáticas e pobreza (UNDP, 2008).

Em relação às visões predominantes acerca do pensamento sobre o desenvolvimento, $\mathrm{o}$ século XXI trouxe uma continuidade em relação às controvérsias da década anterior. A publicação do Relatório de Desenvolvimento Mundial de 2000/2001 foi marcada por polêmica (WORLD BANK, 2001). O principal autor e coordenador do relatório, Ravi Kanbur, ex-economista do Banco Mundial, renunciou porque os autores do relatório foram pressionados a enfatizar o crescimento econômico e mudar a ordem dos capítulos sobre os três principais temas de oportunidades, capacitação e segurança (HAAN, 2009). O Banco Mundial e os funcionários do Tesouro dos EUA acreditavam que a questão do crescimento deveria ser o foco do Banco Mundial e, mesmo que o Relatório sobre o Desenvolvimento

\footnotetext{
${ }^{43}$ Assunto que será discutido de forma mais aprofundada no segundo capítulo.

${ }^{44}$ Highly indebted poor countries.
} 
Mundial não represente a política do Banco Mundial ${ }^{45}$, havia uma necessidade percebida de garantir que um capítulo com foco no crescimento viria primeiro. Durante a preparação do relatório, houve outra controvérsia significativa, mas menos discutida. Um artigo de Lundberg e Squire (1999), usando dados internacionalmente comparáveis encontraram evidências de que durante os processos de crescimento econômico, os mais pobres nem sempre se beneficiam. O Banco Mundial, então, buscou argumentar que o crescimento beneficiava os pobres. Uma das suas publicações mais citadas sobre as ligações entre crescimento e pobreza foi um estudo intitulado "Growth Is Good for the Poor" (DOLLAR; KRAAY, 2002). A questão do aumento da desigualdade não recebeu muita atenção do Banco Mundial na época, embora tenha se tornado tema central do Relatório de Desenvolvimento Mundial de 2006 (HAAN, 2009).

O foco na importância das instituições e das práticas de boa governança continuou ao longo da nova década sendo enriquecido em dois aspectos. A lista das reformas necessárias cresceu exponencialmente, incluindo aumento da participação, a prestação de contas, previsibilidade da ação governamental, transparência, fluxo de informações, Estado de direito, legitimidade, constitucionalidade, pluralismo sociopolítico, descentralização, políticas orientadas para o mercado e as preocupações socioeconômicas acerca da desigualdade e pobreza. O otimismo do início dos anos 90 sobre a implantação da boa governança deu lugar a uma melhor compreensão das influências do contexto local na implementação de reformas e ideias mais viáveis e realistas sobre "boa governança suficiente" (GRINDLE, 2004, 2007).

A ênfase na boa governança levou a chamadas para uma melhor compreensão da política local. Formas de análise política foram introduzidas em agências, por exemplo, a "análise de poder" da Agência Sueca de Cooperação para o Desenvolvimento Internacional (SIDA, em inglês) ${ }^{46}$, "revisão institucional e de governança", do Banco Mundial; e "Drivers of Change" do Departamento de Desenvolvimento Internacional do Reino Unido (DFID, em inglês $^{47}$ (CHHOTRAY; HULME, 2009). O termo economia política tornou-se comum, enfatizando que política e poder não podem ser separados da economia. A política também entrou no debate sobre o desenvolvimento por meio do Consenso de Monterrey, que enfatizou que os governos dos países desenvolvidos e em desenvolvimento precisam desenvolver apoio

\footnotetext{
45 Mawdsley e Rigg (2002) destacam que por trás da imagem pragmática e de solução de problemas que os Relatórios do Banco Mundial buscam promover, há uma posição estreita e pré-estruturada para no intuito de desconstruir agendas alternativas.

${ }^{46}$ Swedish International Development Cooperation Agency, em inglês.

${ }^{47}$ Department for International Development, em inglês.
} 
público para traduzir as aspirações do desenvolvimento em ação e enfatizou a necessidade de liderança política no Sul para realizar reformas institucionais e políticas (HAAN, 2009).

Estudos sobre o desenvolvimento continuaram cada vez mais preocupados com a efetividade da ajuda externa. Surgiu certo consenso de que a ajuda deveria ser dada a países com um grande número de pessoas pobres e àqueles que têm governos comprometidos com a redução da pobreza e que possuem capacidade para utilizar a ajuda de forma adequada. Além disso, a adoção dos Objetivos do Desenvolvimento do Milênio (ODM) por 189 nações das Nações Unidas, em setembro de 2000, impulsionou a defesa política da ajuda, além de ser um novo insumo no campo dos estudos de desenvolvimento. Em algumas organizações de ajuda internacional, os ODMs vieram a constituir a base para relatar o trabalho das agências, conforme ilustrado claramente no Relatório Anual 2007 do DFID. Foram realizados vários estudos para avaliar o progresso dos ODM; em que a conclusão geral foi de "progresso substancial, mas desigual" (HAAN, 2009).

O início do século XXI também presenciou uma atuação cada vez mais ativa e organizada por parte das Organizações Não-Governamentais voltadas para a questão do desenvolvimento, rompendo o monopólio dos Estados. Embora muitas dessas organizações atuem no regime da cooperação desde os anos 1950, como a britânica OXFAM, por exemplo. Nas últimas décadas esses atores passaram a ganhar mais visibilidade e importância política. Destaca-se o papel crescente do setor privado no campo da CID, apoiado por novos programas oficiais, novas formas de financiamento, parcerias e narrativas (MCEWAN et al., 2017). Destacam-se também as fundações privadas oriundas de grandes corporações, como a Fundação Bill e Melissa Gates, que possuem orçamentos voltados à cooperação maiores do que muitos países. Ademais, novos fundos e mecanismos têm sido desenvolvidos como o "Fundo Global contra a AIDS" (GAVI, em inglês) ${ }^{48}$, o Mecanismo de Desenvolvimento Limpo, no âmbito do Protocolo de Kyoto, o "Global Environmental Facility", criado após a Rio-92, entre outros. Destacam-se também alguns instrumentos financeiros e de capital de risco, a exemplo do "International Finance Facility for Immunization", iniciativa lançada em 2005 que permite aos seus gestores aumentar o capital nos mercados globais, graças ao lastro de títulos garantidos por Estados doadores e negociáveis nas bolsas de valores; dos mecanismos de taxação sobre bilhetes aéreos; e da taxa Oudin-Santini, que, em 2005, permitiu que autoridades locais e agências de saneamento e fornecimento de água alocassem até $1 \%$ de seus orçamentos para projetos de cooperação neste setor (MILANI, 2014).

\footnotetext{
${ }^{48}$ Global Fund Against Aids, em inglês.
} 
No plano da economia internacional, a primeira década dos anos 2000 trouxe consigo o chamado "boom das commodities", que permitiu que muitos países em desenvolvimento exportadores de matérias primas apresentassem altas taxas de crescimento ao longo da década. Essa bonança associada ao crescimento da economia chinesa e ao descontentamento com as consequências das políticas liberais adotadas nos anos 1980 e 1990 no bojo do "Consenso de Washington" criou o pano de fundo para a "reemergência" da Cooperação SulSul para o Desenvolvimento ${ }^{49}$. Assim, os chamados "novos doadores", como China, Índia, Rússia, Brasil, Turquia, África do Sul, entre outros, passaram a desempenhar um papel cada vez mais importante no regime da Cooperação Internacional para o Desenvolvimento.

A crise dos subprimes de 2008 trouxe uma reconfiguração de forças da economia internacional na medida em que alguns países emergentes sentiram menos os efeitos da crise em um primeiro momento. Essa nova reconfiguração de forças deu maior legitimidade para que esses países pudessem adotar uma posição mais ativa no regime de Desenvolvimento (STUENKEL, 2013).

Esse período também está sendo marcado pela transição dos Objetivos do Desenvolvimento do Milênio (ODM) para os Objetivos do Desenvolvimento Sustentável (ODS). Enquanto os ODM tinham um foco maior em aspectos socioeconômicos ${ }^{50}$, os ODS propõe uma abordagem mais holística sobre a questão do desenvolvimento, focando em três pilares centrais: a inclusão social, o desenvolvimento econômico e a proteção ambiental. Os objetivos foram acordados após um intenso processo de negociação que teve origem na Cúpula Rio + 20 em 2012. O documento endossado nessa Conferência, "O Futuro que Queremos”, destacava a necessidade do estabelecimento de metas para se atingir o desenvolvimento sustentável ${ }^{51}$. Como resultado imediato, foi criado um Grupo de Trabalho Aberto (OWG, em inglês), composto por representantes dos países membros das Nações Unidas, técnicos da ONU, stakeholders da sociedade civil e comunidade científica.

Após três anos de contínuas negociações, os 193 países membros aprovaram por consenso, na 70 ${ }^{\mathrm{a}}$ Sessão da Assembleia Geral das Nações Unidas (AGNU), em 2015, a resolução A/70/L.1 estabelecendo a Agenda 2030, por meio da adoção do documento "Transformando Nosso Mundo: a Agenda 2030 para o Desenvolvimento Sustentável”, que contém: 1) Declaração delineando a visão, princípios e objetivos que deverão guiar o comportamento dos membros da ONU no período pós 2015; 2) 17 objetivos aspiracionais e

\footnotetext{
49 Tema que será discutido no próximo capítulo.

${ }^{50}$ Apenas um dos oito objetivos formulados fazia referência explicita à preservação ambiental.

51 "O desenvolvimento que procura satisfazer as necessidades da geração atual, sem comprometer a capacidade das gerações futuras de satisfazerem as suas próprias necessidades (Relatório Brundtlant, 1987)
} 
169 metas quantitativas e qualitativas que representam o resultado de 3 anos de negociação intergovernamental sobre as três dimensões do desenvolvimento sustentável; 3) uma seção sobre os meios de implementação e a revitalização da Parceria Global para o Desenvolvimento Sustentável e; 4) uma seção para o acompanhamento das metas e objetivos e processo de revisão. Sendo os ODS o núcleo da Agenda que deverão ser alcançados até o ano 2030 (ONU, 2018).

Espera-se que os ODS desempenhem um papel central na agenda do desenvolvimento internacional ao longo das próximas décadas (KATES; PARRIS; LEISEROWITZ, 2005; SACHS, 2012; GRIGGS et al., 2013). Os ODS respondem às prioridades globais, incluindo a erradicação da pobreza e a fome, redução da desigualdade social, enfrentamento da mudança climática e preservação dos recursos naturais do planeta. Os 17 objetivos são vistos sob a luz da pluralidade de outros acordos e esquemas legais negociados no âmbito da ONU como a Agenda de Ação de Adis Abeba, fruto da Terceira Conferência Internacional sobre o Financiamento ao Desenvolvimento. A Agenda de Ação de Adis Abeba contém mais de 100 medidas concretas. Ela contempla todas as fontes de financiamento e cobre a cooperação sobre uma variedade de questões incluindo tecnologia, ciência, inovação, comércio e fortalecimento de capacidades. Seus resultados baseiam-se em duas conferências prévias sobre Financiamento para o Desenvolvimento, em Monterrey, México, e em Doha, Catar ${ }^{52}$. Nessa conferência, os países também reafirmaram seu compromisso com a Ajuda Oficial ao Desenvolvimento (AOD), principalmente com os países menos desenvolvidos e se comprometeram a alcançar a meta de $0,7 \%$ do rendimento nacional bruto para a ajuda pública ao desenvolvimento, e os países menos desenvolvidos, entre 0,15 a 0,20\%, (AAAA, 2015).

Apesar das críticas constantes em relação à efetividade da AOD e aparente eminência do "fim da AOD" no pós-Guerra Fria (SEVERINO; RAY, 2009), a ajuda externa continua sendo um elemento importante das relações internacionais. Apesar da fragmentação de objetivos, atores e instrumentos nas últimas décadas, a CID continua sendo um tema central nas discussões internacionais, continuando a ser um dos pontos de clivagem nessas negociações. As organizações internacionais que compõem o campo seguem atuando na formulação de estratégias econômicas destinadas aos Estados nacionais, na configuração dos ideários do desenvolvimento, no financiamento de programas, assim como na definição de normas e padrões internacionais. De modo que boa parte do conteúdo referente às políticas e modelos contemporâneos de desenvolvimento é concebida no âmbito da cooperação para o

52 Fonte: https://nacoesunidas.org/adis-abeba-paises-alcancam-um-acordo-historico-para-gerar-financiamentopara-a-nova-agenda-de-desenvolvimentol. Acesso em agosto de 2018. 
desenvolvimento (MILANI, 2014). Assim, nota-se como os debates sobre a CID na comunidade internacional acompanharam a evolução e as complexidades da agenda internacional. O teor dos debates geralmente reflete o clima mais amplo da política mundial da época. De modo que as reconfigurações de forças no século XXI definirão o futuro do campo para as próximas décadas.

Tabela 1.7.1 Principais fases da ajuda externa e suas características

\begin{tabular}{|c|c|c|c|c|}
\hline & $\begin{array}{c}\text { Principais } \\
\text { Organizações } \\
\text { Internacionais }\end{array}$ & $\begin{array}{l}\text { Ideologia do } \\
\text { doador }\end{array}$ & Foco do doador & Tipos de ajuda \\
\hline $\begin{array}{l}\text { Pós-2 } \\
\text { Guerra }\end{array}$ & $\begin{array}{c}\text { Plano Marshall e } \\
\text { Sistema ONU }\end{array}$ & Planejamento & Reconstrução & Ajuda programada \\
\hline $\begin{array}{c}\text { Anos } 1950 \text { e } \\
1960\end{array}$ & $\begin{array}{l}\text { Agências para } \\
\text { cooperação } \\
\text { bilateral }\end{array}$ & $\begin{array}{l}\text { Anticomunista, } \\
\text { com foco na } \\
\text { atuação do } \\
\text { Estado }\end{array}$ & $\begin{array}{l}\text { Setores } \\
\text { produtivos e } \\
\text { infraestrutura }\end{array}$ & $\begin{array}{l}\text { Ajuda alimentar, } \\
\text { projetos, } \\
\text { assistência técnica } \\
\text { e apoio ao } \\
\text { orçamento }\end{array}$ \\
\hline Anos 1970 & $\begin{array}{l}\text { Expansão da } \\
\text { atuação das } \\
\text { Organizações } \\
\text { Multilaterais } \\
\text { (Banco Mundial, } \\
\text { FMI e Bancos de } \\
\text { Desenvolvimento } \\
\text { Regionais) }\end{array}$ & $\begin{array}{l}\text { Apoio para } \\
\text { atividades do } \\
\text { Estado e } \\
\text { necessidades } \\
\text { básicas das } \\
\text { populações }\end{array}$ & $\begin{array}{c}\text { Pobreza } \\
\text { (agricultura e } \\
\text { necessidades } \\
\text { básicas) }\end{array}$ & $\begin{array}{l}\text { Queda na ajuda } \\
\text { alimentar e } \\
\text { aumento do apoio } \\
\text { às importações }\end{array}$ \\
\hline Anos 1980 & $\begin{array}{l}\text { Proeminência das } \\
\text { Organizações } \\
\text { Multilaterais e } \\
\text { ascensão da } \\
\text { atuação das ONGs }\end{array}$ & $\begin{array}{l}\text { Ajustes } \\
\text { estruturais via } \\
\text { políticas pró- } \\
\text { mercado }\end{array}$ & $\begin{array}{c}\text { Reformas } \\
\text { macroeconômicas }\end{array}$ & $\begin{array}{c}\text { Ajuda Financeira e } \\
\text { reestruturação de } \\
\text { dívidas }\end{array}$ \\
\hline Anos 1990 & $\begin{array}{l}\text { Novas instituições } \\
\text { voltadas à } \\
\text { cooperação, } \\
\text { principalmente } \\
\text { para regiões do } \\
\text { antigo bloco } \\
\text { comunista }\end{array}$ & $\begin{array}{l}\text { Políticas pró- } \\
\text { mercado com o } \\
\text { fortalecimento de } \\
\text { instituições }\end{array}$ & $\begin{array}{l}\text { Pobreza e } \\
\text { governança }\end{array}$ & Apoio a setores \\
\hline Século XXI & $\begin{array}{c}\text { Doadores } \\
\text { emergentes, } \\
\text { Cooperação Sul- } \\
\text { Sul e organizações } \\
\text { internacionais }\end{array}$ & $\begin{array}{l}\text { Fortalecimento } \\
\text { das instituições e } \\
\text { infraestrutura }\end{array}$ & $\begin{array}{c}\text { Pobreza, } \\
\text { governança e } \\
\text { desenvolvimento } \\
\text { sustentável }\end{array}$ & Apoio a setores \\
\hline
\end{tabular}

Elaborada pelo autor, com base em Hjertholm e White (2000a, p. 8-9). 
Tabela 1.7.2. Cronologia da ajuda externa

\begin{tabular}{|c|c|}
\hline 1812 & Congresso dos EUA aprova o "Act for the Relief of the Citzens of Venezuela". \\
\hline $1870 s$ & $\begin{array}{l}\text { Primeiras discussões no Reino Unido sobre financiamentos oficiais para colônias } \\
\text { sob Chamberlain. }\end{array}$ \\
\hline 1896 & $\begin{array}{l}\text { Início da transferência do excedente de alimentos (sob o Ministério da Agricultura) } \\
\text { nos EUA com intenção de desenvolver novos mercados. }\end{array}$ \\
\hline 1918 & $\begin{array}{l}\text { Seguindo os navios da Primeira Guerra Mundial, 6,23 milhões de toneladas de } \\
\text { alimentos são fornecidos para a Europa, levando ao Ato de } 1933\end{array}$ \\
\hline 1929 & Primeira "Lei de Desenvolvimento Colonial" do Reino Unido. \\
\hline 1933 & $\begin{array}{l}\text { Lei de Ajustamento Agrícola de } 1933 \text { (esquema de apoio a preços operado por meio } \\
\text { do Commodity Credit Corporation) marcou o início das remessas sistemáticas fora } \\
\text { de período de situação de emergência }\end{array}$ \\
\hline 1942 & Formação das Nações Unidas (formalmente surgiu em 1945). \\
\hline 1943 & $\begin{array}{l}\text { Formação da Administração das Nações Unidas para Auxílio e Reabilitação } \\
\text { (UNRRA, em inglês). }\end{array}$ \\
\hline 1944 & Conferência de Bretton Woods de 1944. Criação da Oxfam e CARE. \\
\hline 1945 & Criação da ONU (FAO, UNESCO). \\
\hline 1946 & Criação da UNICEF. \\
\hline 1947 & $\begin{array}{l}\text { Lançamento do plano Marshall (Aproximadamente } 25 \text { por cento da ajuda concedida } \\
\text { sob o Plano Marshall foi na forma de alimentos, ração para animais e fertilizantes; } \\
\text { com o fim do Plano Marshall os agricultores americanos pressionaram para } \\
\text { continuação da ajuda alimentar, resultando na PL480, aprovada em 1954). }\end{array}$ \\
\hline 1949 & $\begin{array}{l}\text { É criado na ONU o Programa Estendido de Assistência Técnica das Nações Unidas } \\
\text { (EPTA, em inglês). }\end{array}$ \\
\hline 1950 & $\begin{array}{l}\text { Lançamento do Plano Colombo. Nos EUA: Ato de Desenvolvimento Internacional e } \\
\text { discurso dos "Quatro Pontos" de Truman. }\end{array}$ \\
\hline 1950 & Crescimento do Movimento de Desenvolvimento Comunitário (MDL). \\
\hline 1951 & Ato de Segurança Mútua dos EUA. ONU recomenda a criação do SUNFED. \\
\hline 1954 & $\begin{array}{l}\text { Lei de Desenvolvimento e Assistência ao Comércio Agrícola (PL480). A Seção } 2 \\
\text { declara: "É declarada a política do Congresso de expandir o comércio internacional } \\
\text { entre os Estados Unidos e nações amigas, para facilitar a conversibilidade da moeda, } \\
\text { promover a estabilidade econômica da Agricultura Americana e o bem-estar } \\
\text { nacional, para fazer uso eficiente máximo de excedentes de commodities agrícolas } \\
\text { em prol da política externa dos Estados Unidos, e estimular a expansão do comércio } \\
\text { exterior de commodities agrícolas produzidas nos Estados Unidos" (Na primeira } \\
\text { década, o PL480 financiou cerca de } 30 \% \text { das exportações agrícolas dos EUA). }\end{array}$ \\
\hline 1956 & $\begin{array}{l}\text { Khrushchev anuncia um programa ampliado de ajuda soviética. Os soviéticos } \\
\text { assumem o financiamento da barragem de Aswan, no Egito. }\end{array}$ \\
\hline 1958 & $\begin{array}{l}\text { Formação da India Aid Consortium pelo Banco Mundial e cinco principais } \\
\text { doadores. }\end{array}$ \\
\hline 1959 & Fundo Especial da ONU inicia operações. Criação do BID. \\
\hline 1960 & $\begin{array}{l}\text { Criação da Agência para o Desenvolvimento Internacional (IDA, em inglês) sob os } \\
\text { auspícios do Banco Mundial. Formação do grupo de Assistência ao } \\
\text { Desenvolvimento (renomeado Comitê de Assistência ao Desenvolvimento, CAD, }\end{array}$ \\
\hline
\end{tabular}




\begin{tabular}{|c|c|}
\hline & em 1961). Kennedy lança Aliança para o Progresso em 1961. \\
\hline 1961 & $\begin{array}{l}\text { Criação do Comitê de Ajuda ao Desenvolvimento no âmbito da OCDE } \\
\text { (CAD/OCDE) }\end{array}$ \\
\hline 1963 & $\begin{array}{l}\text { "Relatório Clay" anuncia redução na ajuda dos EUA. Criação do Programa Mundial } \\
\text { de Alimentos (PMA) - principal canal multilateral de ajuda alimentar, mas apenas } \\
\text { para projetos. O PMA tem sido uma pressão importante para o uso para o } \\
\text { desenvolvimento da ajuda alimentar. }\end{array}$ \\
\hline 1965 & $\begin{array}{l}\text { Fundo Especial da ONU e EPTA fundem-se para formar o PNUD (UNDP, em } \\
\text { inglês). }\end{array}$ \\
\hline 1966 & PL480 vinculado à assistência ao desenvolvimento. \\
\hline 1968 & CAD concorda definição de Ajuda Oficial ao Desenvolvimento (AOD) \\
\hline 1969 & $\begin{array}{l}\text { O Relatório Pearson propõe uma meta de } 0,7 \text { por cento para o volume de AOD a ser } \\
\text { fornecido pelos doadores. }\end{array}$ \\
\hline 1973 & $\begin{array}{l}\text { Robert McNamara fala sobre a reorientação do Banco Mundial em direção ao } \\
\text { combate à pobreza. }\end{array}$ \\
\hline 1975 & $\begin{array}{l}\text { Lei do Desenvolvimento Internacional e Assistência Alimentar ( } 75 \text { por cento do } \\
\text { PL480 para países com renda per capita inferior a US \$ 300). Primeira convenção de } \\
\text { Lomé. }\end{array}$ \\
\hline 1980 & Primeiros Empréstimos para Ajuste Estrutural (SAL, em inglês). \\
\hline 1982 & "Início" da crise da dívida. \\
\hline 1987 & $\begin{array}{l}\text { Lançamento do Programa Especial de Assistência para a África (SPA, em inglês). } \\
\text { Publicação do estudo patrocinado pela Unicef, "ajuste com uma face humana". }\end{array}$ \\
\hline 1989 & Banco Mundial lança agenda da "governança". \\
\hline 1990 & $\begin{array}{l}\text { "Fim" da Guerra Fria. Primeiro Relatório de Desenvolvimento Humano (PNUD) e } \\
\text { Relatório sobre o Desenvolvimento Mundial (Banco Mundial) sobre pobreza: } \\
\text { Mudanças mais óbvias na política dos doadores para a redução da pobreza. }\end{array}$ \\
\hline 1994 & $\begin{array}{l}\text { Cúpula de Copenhagen: iniciativa de } 2020 \text { e formulação do que se tornaram } \\
\text { "objetivos do CAD". }\end{array}$ \\
\hline 1996 & $\begin{array}{l}\text { Banco Mundial e FMI lançam conjuntamente uma iniciativa de alívio da dívida dos } \\
\text { países pobres endividados (HIPC, em inglês). }\end{array}$ \\
\hline 1997 & $\begin{array}{l}\text { Vários doadores emitem "white papers" ou outros documentos de política } \\
\text { envolvendo parcerias para cooperação. }\end{array}$ \\
\hline 2000 & $\begin{array}{l}\text { Cúpula do Milênio da ONU: Declaração do Milênio. Posteriormente, formulação } \\
\text { dos oito Objetivos do Milênio (ODM) a serem alcançados até } 2015 .\end{array}$ \\
\hline \multirow[t]{2}{*}{2002} & $\begin{array}{l}\text { Primeira Conferência sobre Financiamento para o Desenvolvimento em Monterrey, } \\
\text { no México. }\end{array}$ \\
\hline & I Fórum de Alto Nível de Eficácia da Ajuda, em Roma, no âmbito do CAD/OCDE. \\
\hline 2005 & II Fórum de Alto Nível de Eficácia da Ajuda, em Paris - Agenda de Paris. \\
\hline \multirow{2}{*}{2008} & $\begin{array}{l}\text { Segunda Conferência sobre Financiamento para o Desenvolvimento em Doha no } \\
\text { Qatar. }\end{array}$ \\
\hline & $\begin{array}{l}\text { III -Fórum de Alto Nível de Eficácia da Ajuda, em ACCRA - Agenda de Ação de } \\
\text { Accra. }\end{array}$ \\
\hline & $\begin{array}{l}\text { IV Fórum de Alto Nível de Eficácia da Ajuda, em Busan - criação da Parceria } \\
\text { Global para a Cooperação para o Desenvolvimento Eficaz (GPEDC, em inglês). }\end{array}$ \\
\hline
\end{tabular}


\begin{tabular}{l|l}
\hline 2015 & $\begin{array}{l}\text { Terceira Conferência sobre Financiamento para o Desenvolvimento em Adis Abeba, } \\
\text { na Etiópia. Conferência do Desenvolvimento Sustentável das Nações Unidas: } \\
\text { Agenda } 2030 \text { contendo 17 Objetivos de Desenvolvimento Sustentável (ODS) a } \\
\text { serem alcançados até 2030. }\end{array}$ \\
\hline \hline
\end{tabular}

Fonte: elaborada pelo autor, com base em Hjertholm e White (2000b, p. 5-7). 


\section{CAPÍtUlo 2: A COOPERAÇÃo SUl-SUl PARA O DESENVOLVIMENTO INTERNACIONAL}

\subsection{Anos 1950 e 1960: gênese da Cooperação Sul-Sul}

As últimas décadas trouxeram transformações profundas no sistema internacional, especialmente no campo da Cooperação Internacional para o Desenvolvimento (CID). Países emergentes, de coadjuvantes, tornaram-se protagonistas nesse regime, desempenhando um conjunto de ações que, apesar das suas diferenças, contrastam com as práticas da Assistência Oficial ao Desenvolvimento (AOD). Essa emergência de "novos doadores" e de "novas práticas" no campo da CID tem resultado em uma descentralização desse campo, na medida em que a arquitetura institucional da CID tem se tornado palco de intensa disputa política entre os doadores tradicionais e esses "novos doadores" (BESHARATI; ESTEVES, 2015). Entretanto, vale destacar que a atuação dos países em desenvolvimento nesse campo não é tão recente como pode parecer em uma primeira vista. Desde os primórdios do regime da Cooperação para o Desenvolvimento, no contexto pós $2^{\mathrm{a}}$ Guerra, os países em desenvolvimento buscaram influenciar nas regras e práticas desse regime, obtendo mais ou menos sucesso ao longo das décadas.

Os processos de descolonização em meados do século XX, somados à conscientização dos países em desenvolvimento quanto ao seu atraso estrutural em relação aos países desenvolvidos e o acirramento da Guerra Fria trouxeram a questão do desenvolvimento ao primeiro plano das discussões internacionais (VALLER FILHO, 2007). Os países em desenvolvimento não tiveram papel significativo no desenho da arquitetura internacional do pós-guerra estabelecida na conferência de Bretton Woods. Esses países buscaram apresentar suas demandas quanto à independência política e desenvolvimento econômico na ONU especialmente, instância em que constituíam uma maioridade numérica. Efetivamente, os países em desenvolvimento conseguiram inserir o tema do desenvolvimento nas discussões internacionais e, nos anos 50, foi criado o Fundo Especial das Nações Unidas para o Desenvolvimento. Esse fundo atuaria direcionando recursos dos países desenvolvidos para o financiamento de projetos de infraestrutura no mundo em desenvolvimento (PINO, 2013).

A partir de uma maior concertação entre os países e regiões em desenvolvimento, esses países buscaram influenciar na orientação da Cooperação Norte-Sul. Um dos resultados 
obtidos fora a aprovação da Resolução $\mathrm{n}^{\circ}$ 1.383/1959, da Assembleia Geral das Nações Unidas, que revisou o conceito de assistência técnica substituindo-o pelo termo cooperação técnica. Ao menos na retórica, a intenção era a de que o conceito cooperação passasse a ideia de uma relação mais simétrica que envolvesse benefícios mútuos. Essa medida possibilitou aos países em desenvolvimento adotarem uma posição comum em relação à cooperação recebida, de modo que a mesma seria uma ferramenta para impulsionar o desenvolvimento desses países, e não apenas assistência técnica vinculada a fins políticos e estratégicos ou à recepção passiva de recursos (PINO, 2014).

Para compreender a gênese da Cooperação Sul-Sul é necessário contextualizar o processo de surgimento de uma consciência do Sul Global. O mundo pós-segunda guerra apresentava uma ordem definida pelos países desenvolvidos, que buscavam concertar posições comuns em diversas organizações internacionais. Do outro lado, os países sob a órbita soviética também criavam suas próprias alianças para fazer frente aos países do bloco ocidental. Nesse contexto de acirramento da Guerra Fria, passa a se tornar evidente a necessidade de maior diálogo e aproximação entre os países em desenvolvimento para que esses pudessem influir minimamente nos rumos do Sistema Internacional.

Leite (2012) aponta três marcos fundamentais para a criação de uma identidade do Sul que serviria como base para a gênese da Cooperação Sul-Sul: (1) o discurso de posse de Truman em 1949, que, ao assumir para seu governo o papel de resolver os problemas das "áreas subdesenvolvidas", conferiu, de certa forma, uma ideia de unidade a esse grupo de países; (2) a Conferência Afro-Asiática de Bandung, em 1955, a primeira realizada apenas entre países em desenvolvimento e (3) a criação do Movimento dos Não-Alinhados (MNA) na Conferência de Belgrado (1961), que marcou a convergência, entre os países do Sul, acerca da necessidade de defenderem sua autonomia em um contexto de Guerra Fria.

Pino (2014) aponta também, como um marco importante para a criação dessa consciência sulista, a Conferência de Colombo em 1954, em que se reuniram os Primeiros Ministros de Ceilão, Birmânia, Índia, Paquistão e Indonésia, no intuito de discutir os problemas comuns que afetavam as relações entre esses países em seu contexto regional. A aproximação entre China e Índia nesse ano, com a visita do primeiro ministro chinês, Zhou En Lai, à Índia, em 1954, visando solucionar o conflito bilateral do Tibete, serviu para afirmar os cinco princípios da coexistência pacífica: i) o respeito mútuo da integridade territorial e da soberania; ii) a não agressão mútua; iii) a não ingerência mútua; iv) a igualdade e o benefício mútuo; e v) a coexistência pacífica. Princípios que seriam debatidos posteriormente em 
Bandung, na Indonésia, e que se tornariam as principais diretrizes da Cooperação Sul-Sul para as décadas seguintes.

Nessa época, intensificaram-se as discussões sobre a possibilidade de uma nova ordem econômica mundial em que as relações entre os países desenvolvidos e em desenvolvimento ocorressem de forma menos assimétrica. Evidencia-se a importância da Conferência de Bandung nesse processo, ocorrida em 1955, em que vinte e nove Estados e trinta movimentos de libertação nacional se reuniram para discutir as possibilidades de um movimento não alinhado. O clima propício a uma maior aproximação entre os países do chamado Terceiro Mundo possibilitou a ênfase nas relações Sul-Sul nas suas agendas internacionais, que seriam vistas como um instrumento para propiciar o diálogo político e a articulação entre países em desenvolvimento, com a finalidade de aumentar o peso relativo desses países nas discussões internacionais (PINO, 2014).

$\mathrm{Na}$ Conferência de Bandung os líderes dos países em desenvolvimento buscaram debater alternativas em face à ordem bipolar que se anunciava. Como resultado, foram anunciados vários princípios que deveriam guiar as relações entre os países em desenvolvimento tendo em vista aumentar sua influência no Sistema Internacional. Nesse sentido, a cooperação entre os países em desenvolvimento, seria vista como uma ferramenta solidária para que os países do Sul pudessem se desenvolver socioeconomicamente. Aspiração associada a consensos políticos básicos como o não alinhamento em relação ao conflito entre as superpotências, o combate ao racismo, ao colonialismo nas relações internacionais e a aposta na cooperação horizontal para fomentar o desenvolvimento (PINO, 2014).

A declaração final de Bandung afirmou esses consensos na medida em que os países em desenvolvimento expressaram sua vontade de liberar-se dos laços de dependência econômica e política com seus antigos colonizadores. Os princípios de Bandung tornaram-se referência-chave na atuação internacional dos países em desenvolvimento (ANTONINI; HIRST, 2009). Assim, a Cooperação Sul-Sul, constituída do intercâmbio horizontal de especialistas, assistência técnica, e estabelecimento de instituições regionais de pesquisa seria o instrumento chave para se alcançar esses objetivos.

Tabela 2.1.1. Os princípios da Conferência de Bandung (1955)

1) Respeito aos direitos humanos fundamentais e aos propósitos e princípios da Carta das Nações Unidas. 
2) Respeito à soberania e à integridade territorial de todas as nações.

3) Reconhecimento da igualdade entre todas as raças e entre todas as nações, grandes e pequenas.

4) Não intervenção ou não interferência em assuntos internos de outros países.

5) Respeito aos direitos de cada nação à sua própria defesa, seja individual ou coletiva, em conformidade com a Carta das

Nações Unidas.

6) Abstenção do uso de pactos de defesa coletiva para beneficiar interesses específicos de quaisquer grandes potências

e abstenção do exercício de pressões sobre os demais países.

7) Rechaço a ameaças e agressões, ou ao uso da força contra a integridade territorial ou a independência política de qualquer país.

8) Emprego de soluções pacíficas em todos os conflitos internacionais, em conformidade com a Carta das Nações Unidas.

9) Promoção dos interesses mútuos e da cooperação.

10) Respeito à justiça e às obrigações internacionais.

Fonte: Conferência Afro-Asiática de Bandung na Indonésia

Os dez princípios da Conferência de Bandung orientam a Cooperação Sul-Sul até os dias de hoje. Sua relevância consistiu na aproximação de um grupo de países recémindependentes que buscavam caminhos alternativos em face à Guerra Fria, a partir da identificação de interesses comuns e da tentativa de formação de uma identidade própria em oposição ao colonialismo e suas consequências políticas e econômicas. Seu principal resultado foi o de inaugurar o processo de diálogo e coordenação de ações entre os países em desenvolvimento em temas de interesse comum, criando-se uma identidade dos países do Sul (MILANI, 2014).

As diretrizes firmadas em Bandung permearam os discursos dos líderes dos países em desenvolvimento nas décadas seguintes, sendo invocadas em diversas instâncias do Sistema Internacional. Porém, os princípios não ficaram apenas na retórica, sendo traduzidos na cooperação fornecida por países em desenvolvimento. Países como China e Índia começaram a estabelecer suas próprias agências de cooperação no intuito de prestar cooperação horizontal para outros países em desenvolvimento. A Índia iniciou seu Programa de Cooperação Técnica e Econômica em 1964, atuante até os dias de hoje (CHATURVEDI, 2012b). A China, seguindo os princípios de Bandung, anunciou nos oito princípios de Accra, expresso no discurso de Zhou Em Lai, em 1964, que a cooperação chinesa baseava-se na igualdade e no benefício mútuo, não se constituindo de mera ação assistencial (KRAGELUND, 2008, 2011; PINO, 2014). 
Assim, é comum identificar a emergência da Cooperação Sul-Sul na Conferência de Bandung em 1955. O comunicado final da conferência distingue a cooperação realizada entre países em desenvolvimento, com base em interesses mútuos e respeito à soberania nacional, da realizada pelos países desenvolvidos. A cooperação nas regiões pós-coloniais seria uma estratégia não apenas para fortalecer as capacidades individuais dos Estados recémindependentes, mas também para criar capacidades coletivas (ESTEVES; ASSUNÇÃO, 2014).

A cooperação econômica firmada em Bandung deve ser vista como parte de um contexto maior de construção de coalizões entre Estados recém-independentes que seguiria nos próximos anos com o surgimento do Movimento dos Não-Alinhados (MNA) e com a criação da Conferência das Nações Unidas sobre Comércio e Desenvolvimento (UNCTAD). Após Bandung, foi consolidada a ideia de que a independência política obtida pelos novos Estados não eliminaria sua dependência econômica das antigas metrópoles. A ênfase no discurso sobre a necessidade de obtenção de autonomia política e econômica por parte desses países levou a uma confrontação direta entre os países do Sul e os do Norte na ONU e em outros fóruns internacionais. O desdobramento institucional dessa confrontação levaria os países do Sul a enfatizarem a estrutura organizacional relacionada não apenas à Assembleia Geral da ONU ou ao Conselho Econômico e Social (ECOSOC), mas especialmente à UNCTAD. Para os países do Sul, a Organização das Nações Unidas, de adesão universal, seria o cenário institucional natural e principal para essa contestação (ESTEVES; ASSUNÇÃO, 2014).

Outro marco significativo nesse contexto foi a Conferência de Belgrado, em 1961, que marcou a convergência entre os países em desenvolvimento, por meio do estabelecimento do Movimento Não-Alinhado (MNA). Esse movimento deve ser entendido como parte desse contexto que remete ao pós Segunda Guerra, quando as conferências de Ialta e Postdam haviam dividido o mundo em áreas de influência dos EUA e URSS, ao mesmo tempo em que se desenrolavam os movimentos de libertação nacional pelo globo. Seus precedentes costumam ser localizados na Conferência de Bandung, quando os países do chamado Terceiro Mundo, buscaram firmar posições comuns na busca de autoafirmação em face ao conflito eminente entre as duas superpotências (BRENER, 1987).

Porém, é na Primeira Conferência dos Chefes de Estado e de Governo NãoAlinhados, em Belgrado, que o movimento é instituído formalmente, sendo composto inicialmente por vinte e seis países. Em pouco tempo, o movimento cresce de forma 
considerável. Na Segunda Conferência, no Cairo, em 1962, são quarenta e sete países, reforçados pela independência de diversas ex-colônias, tendo como líderes do movimento, os nacionalistas Nehru e Nasser, além de Tito, da Iugoslávia. Assim, em muitos casos a participação no Movimento dos Não-Alinhados (MNA) foi associada a uma luta por maior independência política e econômica (RENZIO; SEIFERT, 2014).

Outro marco fundamental para a institucionalização da CSS foi criação da Primeira Conferência das Nações Unidas sobre Comércio e Desenvolvimento (UNCTAD), em 1964. Já na sua primeira reunião, os participantes se juntaram para estabelecer o Grupo dos 77 Países em Desenvolvimento (G-77). A conferência, realizada a cada quatro anos, tornou-se a principal plataforma para os países em desenvolvimento coordenarem seus interesses para as negociações com os países desenvolvidos durante as décadas seguintes (RENZIO; SEIFERT, 2014). A UNCTAD também teve o papel de embasar estratégias com vista à autonomia industrial dos países em desenvolvimento ao reconhecer que a independência política não poderia ocorrer sem uma redução das relações assimétricas da economia mundial (VALLER FILHO, 2007).

Com a UNCTAD, o modelo de cooperação tradicional passa a ser questionado de forma mais assertiva. Havia uma crença de que esse modelo, sustentado em bases assistencialistas, conectado fortemente aos interesses dos doadores, não considerava as reais necessidades dos países receptores, acentuando e perpetuando suas condições de dependência no cenário internacional. $\mathrm{Na}$ visão dos críticos, a cooperação internacional não poderia ser eficaz para o desenvolvimento se não viesse acompanhada de reformas no sistema multilateral de comércio (CORRÊA, 2010; PUENTE, 2010).

Assim, a UNCTAD, de forma mais geral, agregou à agenda da CSS o consenso em torno do comércio internacional como ferramenta de promoção do desenvolvimento econômico. A organização desempenhou um papel importante da defesa de um sistema multilateral de comércio mais simétrico, em que os países em desenvolvimento pudessem se inserir por meio de sistemas preferenciais de comércio $^{53}$. Nessa época, são estabelecidos os primeiros acordos preferenciais de comércio entre países em desenvolvimento em bases regionais, como o Mercado Comum da América Central, em 1960; a Associação LatinoAmericana de Livre-Comércio, em 1960; a Organização da União Africana, em 1963; a União Econômica e Aduaneira da África Central, em 1964; a Associação das Nações do Sudeste Asiático, em 1967; e o Pacto Andino, em 1969 (LEITE, 2012).

\footnotetext{
${ }^{53}$ Que viria a se institucionalizar apenas após a Rodada Tóquio no âmbito do GATT, em 1988.
} 
Em relação à Cooperação Internacional para o Desenvolvimento, havia uma crescente percepção nos países em desenvolvimento de que os princípios estabelecidos dentro do CAD/OCDE apenas perpetuariam as desigualdades estruturais do Sistema Internacional. Esses países viam o foco na AOD por parte dos países desenvolvidos como uma forma de reprodução das assimetrias do sistema internacional. A percepção era de que a relação entre doador e receptor era uma maneira de transformar as assimetrias econômicas em hierarquia política. Essa hierarquia estava incorporada na maioria das organizações internacionais, como o CAD e o Banco Mundial. Criados como clubes, suas estruturas de governança e mecanismos de tomada de decisões reproduziam as linhas divisórias entre o Norte e o Sul (ESTEVES; ASSUNÇÃO, 2014).

Enquanto o regime de desenvolvimento internacional foi estruturado nas linhas da relação doador e receptor, a coalizão dos países em desenvolvimento buscou questionar a legitimidade de tal hierarquia e defender reformas estruturais que poderiam criar as condições necessárias para decisões autônomas sobre políticas de desenvolvimento no Sul global. Além disso, a criação do G77 forneceu o veículo institucional para os países Sul se organizarem na tentativa de impor sua visão de mundo no plano internacional (ESTEVES; ASSUNÇÃO, 2014).

As décadas de 1950 e 1960 presenciam a formação de uma identidade comum aos países em desenvolvimento e a necessidade de afirmarem seus interesses e posições frente aos países desenvolvidos. Nessa época, a cooperação entre países em desenvolvimento começa a ser considerada como uma alternativa para a transferência de experiências entre os países do chamado Terceiro Mundo. Porém, uma maior institucionalização dessa modalidade de cooperação só aconteceria na década seguinte por meio da adoção de critérios e terminologias comuns firmadas em diversas conferências internacionais.

\subsection{Anos 1970: institucionalização da Cooperação Sul-Sul}

Seria apenas após a virada da década que ocorreriam as primeiras tentativas de institucionalização da Cooperação Sul-Sul. A agenda do desenvolvimento, antes focada em comércio e ajuda oficial ao desenvolvimento, torna-se mais ambiciosa, visando alterar a estrutura da ordem internacional, vista como prejudicial aos países do Sul (PINO, 2014). Um ponto importante para esse processo foi a Declaração pelo Estabelecimento de uma Nova Ordem Econômica Mundial (NOEI). A NOEI delineava a visão de mundo dos países em 
desenvolvimento, receptores de recursos no regime de cooperação internacional ao desenvolvimento vigente, acerca das relações econômicas mundiais. Foi nesse contexto de insatisfação dos países em desenvolvimento com a ordem internacional, e com a proeminência das relações Sul-Sul, que surge a Cooperação Técnica entre os Países em Desenvolvimento (CTPD) (SOARES, 1994).

Em 1972, a Assembleia Geral das Nações Unidas reconhece a importância de que os países em desenvolvimento se reúnam para discutir formas de melhorar a assistência técnica recebida de terceiros ou para exercerem-na entre si, constituindo um grupo de trabalho sobre Cooperação Técnica entre Países em Desenvolvimento (CTPD). Em 1974, é criada uma Unidade Especial para Cooperação Técnica entre Países em Desenvolvimento, ligada ao Programa das Nações Unidas para o Desenvolvimento (PNUD). Desde então, essa unidade se converteu em um dos pontos centrais da CSS no âmbito da ONU ao promover e coordenar essa cooperação, estabelecendo um elo entre o PNUD e o G-77. Ao longo dessa década, a Assembleia Geral e o Conselho Econômico e Social da ONU (ECOSOC) fazem diversas recomendações nesse sentido (PINO, 2014).

Em 1976, é aprovada uma recomendação realizada pelo ECOSOC na AGNU prevendo a convocação de uma Conferência sobre a Cooperação Técnica entre os Países em Desenvolvimento sob a égide do sistema ONU. Dois anos mais tarde, 138 países se reúnem em Buenos Aires para a realização dessa reunião. O documento final desse encontro estabeleceria o quadro conceitual e operacional da CTPD, ficando conhecido como "Plano de Ação de Buenos Aires (PABA)" ${ }^{54}$. O Plano de Ação de Buenos Aires, resultado da Conferência das Nações Unidas sobre Cooperação Técnica entre Países em Desenvolvimento (CTPD), realizada de 30 de agosto a 12 de setembro de 1978, estabeleceu de forma sem precedentes as diretrizes da Cooperação Sul-Sul (CSS), em termos do seu componente técnico. Em 19 de dezembro de 1978, a resolução n²2/134 é aprovada na AGNU reconhecendo o conteúdo do Plano (PINO, 2014).

A elaboração do Plano de Ação de Buenos Aires foi resultado do trabalho de um grupo de peritos que, trabalhando em reuniões intergovernamentais preparatórias durante cinco anos, detalharam as necessidades e possibilidades da CTPD. O Plano de Ação de Buenos Aires foi o documento básico que estabeleceu os princípios orientadores da CSS em sua modalidade técnica, estabelecendo conceitos e definições que seguem como referência até os dias de hoje (PINO, 2014). O Plano, cuja implementação seria monitorada pelo PNUD,

\footnotetext{
${ }^{54}$ A data de 12 de setembro, dia em que o Plano de Ação de Buenos Aires foi adotado, passa a ser comemorada como "Dia das Nações Unidas para a Cooperação Sul-Sul (PINO, 2014).
} 
estabeleceu 9 objetivos da CTPD e 38 recomendações, 16 dos quais foram abordados globalmente, 14 governos nacionais, 7 espaços regionais e 1 a nível inter-regional (PIFCSS, 2017).

Entre as principais diretrizes desse Plano de Ação, destacam se que a CTPD: i) deveria ser entendida como um processo multidimensional, devendo ser organizada por e entre governos, ainda que com a participação de organizações públicas e privadas; ii) não deveria ser vista como substituta à cooperação tradicional norte-sul; e iii) deveria basear-se na observância à soberania nacional, igualdade de direitos, independência econômica e não ingerência nos assuntos de terceiros (MENON, 1980; PUENTE, 2010).

Dentre seus objetivos principais, localiza-se a promoção do diálogo, troca de experiências e recursos técnicos entre os países em desenvolvimento, de modo a superarem de forma conjunta os entraves ao desenvolvimento na periferia. O Plano de Ação identificou 15 áreas focais de atuação da CTPD, estabelecendo as diretrizes para assegurar sua implantação e monitoramento. Um Comitê de Alto Nível da AGNU foi criado para realizar avaliações periódicas dos resultados a cada dois anos, conhecida como Unidade Especial para a Cooperação Sul-Sul (SU-SSC, em inglês). Desde 1979, o Comitê de Alto Nível para a CSS, órgão subsidiário da $\mathrm{AGNU}$, é o processo intergovernamental para a revisão dos processos referentes à CTPD, sendo a principal entidade normativa a respeito dessa matéria no sistema ONU (PINO, 2014).

Tabela 2.2.1. Objetivos da CTDP definidos no Plano de Ação de Buenos Aires

i) Promover a capacidade dos países em desenvolvimento de usar seus próprios meios, aumentando sua capacidade criativa para encontrar soluções para problemas de desenvolvimento de acordo com seus próprios valores, aspirações e necessidades especiais;

ii) Promover e fortalecer entre os países em desenvolvimento a capacidade coletiva de usar seus próprios meios, trocar experiências, compartilhar e usar seus recursos técnicos de maneira combinada e desenvolver capacidades complementares;

iii) Fortalecer a capacidade dos países em desenvolvimento para identificar e analisar os principais problemas encontrados no seu desenvolvimento e para desenvolver as estratégias necessárias para abordar as relações econômicas internacionais, através da partilha de conhecimento que está disponível nesses países e por estudos conjuntos realizados por instituições existentes, com vistas a estabelecer a nova ordem econômica internacional;

iv) Aumentar o volume e melhorar a qualidade da cooperação internacional e aumentar a eficácia dos recursos destinados à cooperação técnica geral por meio da união de capacidades;

v) Fortalecer a capacidade técnica nos países em desenvolvimento, incluindo o setor tradicional, aumentar a eficiência com que a capacidade é utilizada para criar novas capacidades e possibilidades, e, neste contexto promover a transferência de tecnologia e conhecimentos adequados para os recursos disponíveis para aqueles países e seu potencial de 
desenvolvimento, de modo que sua confiança individual e coletiva seja fortalecida em suas próprias capacidades;

vi) Aumentar e melhorar a comunicação entre os países em desenvolvimento, levando a uma maior conscientização dos problemas comuns e maior acesso aos conhecimentos e experiências disponíveis, bem como à criação de novos conhecimentos para lidar com os problemas de desenvolvimento;

vii) Melhorar a capacidade dos países em desenvolvimento de absorver e adaptar a tecnologia e os conhecimentos necessários para atender às suas necessidades específicas de desenvolvimento;

viii) Reconhecer e resolver os problemas e necessidades dos países menos desenvolvidos, sem litoral, insulares e mais afetados.

ix) Assegurar que os países em desenvolvimento estejam em posição de alcançar um maior grau de participação nas atividades econômicas internacionais e expandir a cooperação internacional.

Fonte: Plano de Ação de Buenos Aires (1978)

A Conferência de Buenos Aires representou um importante marco nas discussões acerca as possibilidades de uma nova ordem econômica mundial. Sua principal contribuição reside na institucionalização da CTPD enquanto um instrumento da CSS para fomentar a cooperação entre os países em desenvolvimento. O plano tornou-se referência nos debates sobre o tema, contribuindo para que os países pudessem se organizar e definir posições em comum acerca da cooperação internacional para o desenvolvimento (VALLER FILHO, 2007).

Entretanto, apesar desse ímpeto inicial e do otimismo momentâneo de seus formuladores, os progressos obtidos nos anos seguintes ao encontro foram modestos. Puente (2010) aponta que um dos principais motivos para o pouco resultado efetivo da CTPD reside na baixa capacidade material dos países envolvidos. Embora a CTPD, ao menos na retórica, transmitisse uma ideia de "horizontalidade", na prática, é necessário que ao menos um dos países envolvidos possua condições mínimas de prestar a cooperação. Ou seja, um dos "parceiros" deve dispor de recursos técnicos, material humano, e condições institucionais e financeiras para transferi-los para outros países, ainda que não nos mesmos moldes da Ajuda Oficial ao Desenvolvimento realizada pelos países do CAD/OCDE.

Partindo dessa premissa básica, nota-se que o número de países que cumpriam esses requisitos, e que poderiam desempenhar um papel mais efetivo no fornecimento e institucionalização da CTPD, era muito reduzido nessa época. Estima-se que menos de dez países pudessem praticar essas ações, destacando-se China, Índia e Brasil, países com graves problemas socioeconômicos internos. Embora a CTPD, via de regra, não pressuponha necessariamente grandes dispêndios de recursos por parte dos prestadores, para países que 
enfrentavam grandes constrangimentos domésticos e externos, novos dispêndios poderiam gerar enormes pressões sobre seus orçamentos públicos (PUENTE, 2010).

Um fenômeno importante para o regime da Cooperação Internacional para o Desenvolvimento nesse período foi o surgimento dos países exportadores de petróleo enquanto doadores internacionais. Especialmente os países membros da Organização dos Países Exportadores de Petróleo (OPEC, em inglês). Esses países, especialmente, após o choque do petróleo ocorrido em 1973, foram capazes de acumular imensas reservas financeiras em função de suas exportações. Parte significativa desses recursos foi "reciclada" via bancos comerciais do ocidente, como discutido no capítulo anterior, tornando-se um componente importante para o endividamento dos demais países do mundo em desenvolvimento.

Porém, os governos desses países, principalmente Kuwait, Líbia e Iraque, e seus fundos multilaterais de desenvolvimento, como o Fundo Árabe para o Desenvolvimento Econômico e Social e o Fundo do Kuwait para o Desenvolvimento Econômico Árabe, também buscaram fornecer empréstimos concessionais para países em condições menos favorecidas, principalmente da África e o Oriente Médio. Essa ajuda foi muitas vezes motivada pela busca por apoio diplomático em questões envolvendo Israel e os palestinos. Israel, como parte desta "guerra fria" com os árabes, também forneceu ajuda a vários governos, especialmente na África (LANCASTER, 2007).

A década de 1970 trouxe enormes dificuldades para a economia internacional, destacando-se a crise do petróleo e o aumento da inflação mundial. Ainda que os países em desenvolvimento, em especial os de renda média, tenham conseguido continuar se financiando externamente via bancos comerciais no intuito de manterem seus planos nacionais de desenvolvimento em vigor. Já no final da década essa fórmula parecia se esgotar, especialmente após segunda crise do petróleo em 1979.

O final da década presenciou um momento de transição no sistema internacional. O fim do padrão ouro-dólar, os choques do petróleo, as mudanças paradigmáticas no pensamento econômico dominante sobre a questão do desenvolvimento e a ascensão de governos conservadores nos Estados unidos e Reino Unido especialmente, trouxeram dificuldades adicionais para o financiamento da CTPD. De modo que as décadas seguintes presenciaram de forma ainda mais acentuada a desmobilização da CSS, na medida em que as crises econômicas e a desarticulação política do Sul global iam reduzindo o ímpeto e otimismo por formas alternativas de cooperação para o desenvolvimento. 


\subsection{Décadas de 1980 e 1990: crise e desmobilização da CSS}

As décadas de 80 e 90 são vistas como um período de desmobilização da CSS. Como discutido anteriormente, a década de 80 trouxe consigo enormes dificuldades para os países em desenvolvimento. Concomitantemente aos problemas econômicos, vários países em desenvolvimento, especialmente os da América Latina, vivenciaram um período de transição democrática de modo que suas políticas externas se tornaram mais reativas ao cenário internacional. Ademais, a ascensão de um novo modelo econômico a ser adotado, baseado no “consenso de Washington", com foco nos investimentos privados de origem externa, levaram os países em desenvolvimento a competirem por esse capital, prejudicando a mobilização conjunta desses países nas esferas internacionais. Por fim, o colapso da URSS e o consequente encerramento da guerra fria gerou uma crise de identidade no movimento terceiro-mundista, na medida em que não haveria mais um mundo bipolar para se buscar uma terceira via (LEITE, 2012).

Essa desmobilização costuma ser interpretada como um período de transição de um mundo baseado pela lógica da Guerra Fria, no papel acentuado do Estado na economia, e políticas de substituição de importação nos países em desenvolvimento, para um mundo marcado pela unipolaridade estadunidense e globalização econômica. Nota-se que a CSS pouco avançou nesse período frente a essas dificuldades políticas e econômicas que se abaterem sobre os países em desenvolvimento. Mesmo os países que mantiveram a vontade política para impulsionar a CSS embarraram em dificuldades financeiras, derivadas especialmente da crise da dívida e dos ajustes macroeconômicos. Em alguns casos, mesmos os gastos mais básicos com a CSS, como pagamento de especialistas nos países receptores da cooperação se viu comprometida (ABARCA AMADOR, 2001; PINO, 2014).

Essa desarticulação dos países do Sul e desmobilização da CSS podem ser explicadas também pela mudança de orientação em matéria de política econômica dos países em desenvolvimento, especialmente na América Latina, das questões exógenas, marcadas pela visão sobre as estruturas internacionais que impediriam o desenvolvimento, para as questões endógenas, especialmente a saúde de suas contas públicas e suas estruturas burocráticas de governo. Ademais, no plano simbólico, ganhou ímpeto um processo de deslegitimação das demandas dos países em desenvolvimento. A suposta superioridade moral dos países do Sul passa a ser questionada de forma mais contundente, na medida em que é apontado que esses 
países buscariam os mesmos objetivos dos países desenvolvidos no cenário internacional como poder, riqueza e controle das organizações internacionais. Nessa linha, a própria natureza da CSS passa a ser questionada quanto as suas supostas diferenças em relação à CNS frente aos objetivos de política externa dos países envolvidos (PINO, 2014).

Essa desmobilização em relação à CSS verifica-se não apenas na mudança de retórica de determinados países em desenvolvimento e na redução dos gastos com a cooperação, mas também na diminuição de eventos internacionais voltados a essa temática. Leite (2012) aponta que enquanto na década de 70 ocorreram seis eventos especificamente voltados à discussão a CSS, nos anos 80 apenas um evento de destaque foi registrado sobre o tema, a Conferência de Alto Nível sobre Cooperação Econômica entre Países em Desenvolvimento, na Venezuela, em 1981, que originou o Plano de Ação de Caracas. Pino (2014) destaca alguns outros marcos para a CSS nesse período como a constituição do Fundo Pérez Guerrero para a Cooperação Técnica e Econômica entre os Países em Desenvolvimento, administrado pelo PNUD e pelo G-77; e a primeira rodada de negociação do Sistema Global de Preferências Comerciais, concluída em 1987 em Belgrado.

Outro acontecimento relevante para CSS fora a criação da Comissão de Seul, em 1987, criada no âmbito do MNOAL, durante a conferência de Harare, em setembro de 1986. A comissão formada por especialistas, intelectuais e líderes de países em desenvolvimento teve como objetivo analisar e propor soluções para os problemas do Sul. O documento final apresentado em 1990, intitulado "Desafio para o Sul”, trouxe uma série de recomendações no sentido de que as soluções para superar os entraves ao desenvolvimento deveriam vir dentro dos países. A comissão também sugeriu a rearticulação da CSS, por meio da identificação de complementaridades entre os países em desenvolvimento (PINO, 2014).

A despeito dessas iniciativas, era evidente a falta de perspectivas em relação a um revigoramento da CSS no final dos anos 80. Além das dificuldades econômicas e da perda de capacidade material enfrentadas pelos países em desenvolvimento, a crescente diferenciação nos ritmos de crescimento apresentados por esses países foi um fator adicional para a fragmentação das coalizões do Sul. Na medida em que diferentes países se adaptaram com mais sucesso às novas diretrizes da economia mundial, vários países em desenvolvimento começaram a priorizar suas relações com os países do Norte em detrimento das relações SulSul.

Dentre os fatores mais endógenos para a perda de interesse na CSS, destacam-se os próprios fracassos das políticas desenvolvidas por esses países, como os resultados modestos 
das ações realizadas e a baixa institucionalização dessas políticas no plano nacional. Desde o início das atividades, esses países tiveram dificuldades em criar mecanismos efetivos de coordenação da cooperação prestada. Na maioria dos casos, a dispersão institucional caracterizou suas ações, na medida em que não conseguiram estabelecer estruturas governamentais necessárias para coordenar e revisar as politicas realizadas por varias agências internas. Ademais a falta de um desenho institucional claro dificultou a avaliação dos projetos realizados, de modo que se tornou uma tarefa difícil comparar as políticas realizadas por esses doadores emergentes (QUADIR, 2013).

Essa falta de ações efetivas em CTPD diminuiu o ímpeto inicial da Conferência de Buenos Aires. $\mathrm{O}$ assunto foi aos poucos sendo relegado a um segundo plano nos debates sobre o desenvolvimento. Apesar dessas dificuldades, a CPTD continuou ocorrendo em escala diminuta em iniciativas especialmente no âmbito bilateral em bases regionais. No plano multilateral, o PNUD buscou organizar e coordenar as ações realizadas nas regiões mais pobres, como África, América Latina e Ásia. No plano do discurso, vários projetos de resoluções das Nações Unidas foram aprovados nesses anos conclamando os países desenvolvidos e em desenvolvimento a integrarem essas iniciativas (PUENTE, 2010).

O encerramento da Guerra Fria trouxe uma nova configuração de forças no sistema internacional. Como visto, essa reorientação significou uma mudança de foco por parte dos doadores tradicionais para as regiões do antigo bloco socialista, especialmente no leste europeu. Ocorrendo, na prática, uma brusca redução dos volumes de AOD para os demais países em desenvolvimento. Ademais, com os critérios estabelecidos de "graduação" para a distribuição de $\mathrm{AOD}$ pelos países do $\mathrm{CAD} / \mathrm{OCDE}$, vários países em desenvolvimento de renda média foram excluídos da possibilidade de receber ajuda internacional, especialmente cooperação financeira. Essa diferenciação também impactou na cooperação técnica recebida por esses países. Pois, com base nos critérios adotados, alguns países só poderiam receber assistência técnica caso os custos fossem compartilhados entre os doadores e receptores à razão mínima de $50 \%$ de contrapartidas por parte dos receptores. De modo que boa parte da cooperação técnica prestada acabou sendo redirecionada para outros países em desenvolvimento (PUENTE, 2010).

Por outro lado, a globalização também trouxe novos desafios aos países em desenvolvimento. Especialmente, após o término da rodada do Uruguai no âmbito da OMC. Os países em desenvolvimento se viram tendo que se inserir em uma economia mundial mais globalizada e com menos barreiras tarifárias. Nesse contexto, vários países buscaram acelerar 
seus processos de integração regional com vistas a se inserirem globalmente. Na medida em que os países buscaram fazer uma melhor articulação entre a cooperação técnica e a cooperação econômica, os processos de integração regional passaram a assumir o papel de principal mecanismo da CSS. Nessa época, diversos processos de integração regional foram aprofundados no mundo em desenvolvimento, destacando-se o MERCOSUL.

Seria apenas na segunda metade da década de 1990 que a CSS voltaria a se expandir após mais de uma década de imobilismo, retomando espaço nas discussões internacionais (GONÇALVES, 2011). O crescimento econômico de alguns países em desenvolvimento, fortalecendo suas capacidades internas, somado a perda da elegibilidade desses países para o recebimento de AOD, fizeram com que a CSS voltasse a soar como uma alternativa complementar à CNS. A ONU auxiliou nesse processo, buscando dar novo ímpeto à CSS, aprovando na Assembleia Geral, a proposta sobre novas orientações, elaborada pelo Comitê de Alto Nível para a Cooperação Técnica entre Países em Desenvolvimento, divulgando o documento de título, "Novas Orientações da CTPD”. Iniciando uma nova fase da CSS cujo protagonismo caberia aos "países-chave", considerados primordiais para o crescimento econômico de seus respectivos entornos regionais. Esses países, somando 22 no total ${ }^{55}$, foram identificados como aqueles com mais capacidades materiais para fornecer cooperação (LOPES, 2013; PINO, 2014).

O documento "Novas orientações da CTPD" trazia entre suas principais recomendações a necessidade de se integrar melhor a cooperação técnica com a econômica; maior colaboração entre centros de pesquisa em torno da CTPD; o emprego dos avanços na tecnologia da informação (TI) para melhorar as trocas de experiências e conhecimento no âmbito das relações Sul-Sul e, especialmente, a promoção de acordos de cooperação triangular, em que os doadores tradicionais financiariam os projetos de cooperação a serem realizados pelos países em desenvolvimento. Ademais, ainda no âmbito da ONU, O PNUD elaborou o "Primeiro Marco para a Cooperação Técnica entre Países em Desenvolvimento 1997-1999”, com o intuito de promover o desenvolvimento sustentável e erradicar a pobreza. Em 1995, a Assembleia Geral das Nações Unidas reconheceu a importância da CSS como forma de auxiliar os países em desenvolvimento a se inserirem na economia mundial.

\footnotetext{
${ }^{55}$ Brasil, Chile, Colômbia, México, Costa Rica, Cuba, Peru e Trinidad-Tobago, na América Latina; China, Índia, Indonésia, Malásia, Turquia, Egito, Tunísia, Coreia do Sul e Tailândia, nas regiões da Ásia-Pacífico, do Oriente Médio e do norte da África; e Nigéria, Gana e Senegal na África, aos que se somaram pequenos países de outros âmbitos, como Malta e Ilhas Maurício.
} 
Tabela 2.3.1. "Novas Orientações da CTPD”: recomendações principais

1. Adoptar uma abordagem mais estratégica ao TCDC em termos de iniciativas que teria implicações importantes para o desenvolvimento e em que um grande número de países em desenvolvimento participaria;

2. Selecione as questões prioritárias, como comércio e investimento, dívida, ambiente, redução da pobreza, produção e emprego, coordenação de política macroeconômica e gestão da ajuda para a abordagem estratégica;

3. Promover uma integração operacional mais próxima entre o TCDC e o ECDC;

4. Diminuir a distinção tradicional entre "promoção" e "operacional" do TCDC;

5. Formular políticas nacionais abrangentes sobre o TCDC;

6. Fortalecer os pontos focais nacionais do TCDC, elevando seus categoria e garantir a sua localização adequada dentro da estrutura governamental

7. Reestruturar as atividades de correspondência de capacidade e necessidades;

8. Aumentar o papel dos escritórios nacionais do PNUD como facilitadores TCDC;

9. Converta o TCDC-SOI em um banco de dados multidimensional;

10. Selecione os países "essenciais" para o TCDC;

11. Promover acordos de cooperação triangular para a execução de Atividades de TCDC;

12. Documentar e transferir as experiências inovadoras dos projetos entre países em desenvolvimento;

13. Formular "produtos" específicos da TCDC que podem atrair financiamento especial com base na sua importância intrínseca;

14. Conceder o prêmio do Grupo dos 77 e do PNUD para o TCDC e o ECDC;

15. Expandir as funções do Comitê de Alto Nível para assegurar uma supervisão mais rigorosa do CCTT na sua inter-relação com o CEPCD;

16. Realizar uma revisão abrangente dos arranjos institucionais em nível nacional fortalecer a capacidade de gestão nacional da TCDC;

17. Fortalecer os vínculos entre a Unidade Especial para a CTPD e as organizações regionais com capacidade de servir como um canal para o TCDC;

18. Fortalecer o papel do sistema de desenvolvimento das Nações Unidas para apoiar a CTPD e assegurar a supervisão contínua do Comitê Administrativo de Coordenação;

19. Estabelecer ligações com organizações não governamentais e com o setor privado para tentar promover a TCDC;

20. Determinar novos arranjos de financiamento.

Fonte: (ONU, 1995). 
Pino (2014) aponta que, com o tempo, a dimensão política da CSS foi perdendo força em favor de seus componentes mais econômicos e técnicos. Assim, o componente ideológico, que no início, fez da CSS um símbolo de solidariedade entre os países em desenvolvimento, com o final da Guerra Fria e a intensificação da globalização, passa a perder importância em face às motivações pragmáticas de cunho econômico. Ademais, se em suas origens não estavam disponíveis as condições materiais, especialmente técnicas e financeiras, para a materialização da CSS, com o passar das décadas, os avanços institucionais, a acumulação de conhecimentos e experiências bem sucedidas, e o crescimento econômico de certos países serviram forneceram as bases para o revigoramento da CSS na década seguinte.

\subsection{Século XXI: ressurgimento da CSS}

O século XXI presenciou o "renascimento" da CSS após décadas de imobilismo. Diversos países de renda média, especialmente aqueles com mais condições materiais, buscaram intensificar suas ações de cooperação internacional nesse período. Esse movimento costuma ser visto dentro de um fenômeno maior de transição da ordem global em que o poder pareceu migrar dos países desenvolvidos para os chamados países emergentes (IKENBERRY, 2008; IKENBERRY; WRIGHT, 2008; ZAKARIA, 2008a, 2008b). Tanto o sistema político internacional quanto as estruturas do capitalismo global passaram por um período de transformação, estando, atualmente, em um estado de fluidez e incerteza. Uma consequência desse processo foi a pressão das potências emergentes para reformar o sistema multilateral de governança global, especialmente após a crise financeira de 2008 (HURRELL, 2006, 2009, 2010). Assim, essa discussão sobre "mudanças de poder" dos países desenvolvidos, principalmente do G-7, para os países emergentes, entrou em voga nas discussões sobre política internacional (CHENG et al., 2007; BAN; BLYTH, 2013; BRÜTSCH; PAPA, 2013; ARMIJO; ROBERTS, 2014; GRIFFITH-JONES, 2014).

Dentre esses países emergentes, os chamados BRICS - Brasil, Rússia, Índia, China e África do Sul - ganharam espaço na economia mundial, na medida em que esses países apresentaram taxas de crescimento constantes no início do século XXI, de maneira que, somados, os PIBs de seus países passaram a representar uma parcela cada vez maior do PIB mundial. Impulsionados por esse ritmo de crescimento, diversos estudos se concentraram em 
estudar esses países ${ }^{56}$. Essas potências emergentes buscaram investir na consolidação de seu recém-adquirido status no sistema internacional, ao intensificar sua atuação nas diferentes esferas da governança global no sentido da promover mudanças e políticas, que garantam que suas posições tenham um peso relativo no processo decisório equivalente ao peso efetivo de suas economias na economia mundial.

Nota-se que os regimes internacionais são o palco privilegiado no qual estes embates têm ocorrido, em função das mesmas serem vistas como espaços capazes de possibilitar acordos entre Estados, que por outros meios seriam impossíveis de se concretizar, além de afetarem a compreensão que os Estados têm em relação aos papeis a serem cumpridos, a ajudarem a compreender como são definidos os interesses e como as ações são interpretadas (KEOHANE, 1989; KEOHANE; NYE (JR.); HOFFMANN, 1993). Nesse contexto, o regime da Cooperação para o Desenvolvimento Internacional ganhou destaque na medida em que esses países, no âmbito da Cooperação Sul-Sul (CSS), se tornaram doadores de recursos após décadas sendo configurados apenas como receptores ${ }^{57}$. A influência desses países emergentes na arquitetura da Cooperação Internacional para o Desenvolvimento tem trazido profundas modificações aos processos de cooperação.

A prestação de cooperação por parte desses doadores emergentes atraiu mais atenção da comunidade internacional a partir da crise financeira global de 2008, que levou muitos críticos a questionarem as políticas predominantes na agenda do desenvolvimento internacional. Os últimos 60 anos de experiência dos países em desenvolvimento com os modelos formulados no âmbito do CAD/OCDE prepararam o terreno para que esses países pudessem explorar opções alternativas. Muitos passaram a observar com cada vez mais atenção as políticas dos países emergentes em busca de lições e melhores práticas, incluindo como equilibrar o Estado e o mercado, manter a autonomia e, ao mesmo tempo, integrar-se à economia mundial, promovendo o desenvolvimento social (CHIN; QUADIR, 2012).

Zimmermann e Smith (2011) classificam esses "doadores emergentes" da cooperação para o desenvolvimento em três categorias: países que não integram o $\mathrm{CAD}$, mas que estão estabelecendo novos programas de ajuda alinhados com as normas da CAD/OCDE, como países da Europa Central e Oriental; os fornecedores de cooperação Sul-Sul para o desenvolvimento, como Índia, China, Brasil e Venezuela, que não se consideram doadores e

\footnotetext{
${ }^{56}$ Sobre essa discussão ver Pimentel (2013), Hurrell, 2009; Armijo, 2015; Ikenberry \& Wright, 2008; Zakaria, 2008b; Spektor, 2009; Barbé, 2010; Baumann, 2010; Pimentel, 2012; Narlikar, 2013 entre outros.

${ }^{57}$ Vale lembrar que tanto a Rússia, enquanto URSS, quanto a China foram doadores importantes de recursos no período referente à Guerra Fria. Porém, após a desintegração da URSS, a Rússia se tornou um receptor relevante de ajuda externa.
} 
não gostam de ser descritos como tais; e doadores árabes, como a Arábia Saudita e o Kuwait, que se sentem confortáveis em serem vistos como doadores, mas não alinham sua ajuda com as normas do $\mathrm{CAD}^{58}$.

Alguns autores apontam, no entanto, que Cooperação Sul-Sul (CSS) prestada atualmente difere fundamentalmente das primeiras manifestações no início dos anos 1970. Essas diferenças são significativas para a prática material da CSS e para a função ideológica da retórica da CSS. Os autores argumentam que as ideias contemporâneas sobre a CSS não possuem o caráter radical da formulação original, mas se configuram em um novo contexto de relações entre o Norte e o Sul e entre Estados e mercados. Nesse sentido, a CSS expandiria o potencial de integração global dos mercados, especialmente as áreas produtoras de commodities do Sul à economia global (MORVARIDI; HUGHES, 2018).

Outro ponto é o de que a "cooperação triangular", ou formas de cooperação que incorporam tanto atores do Sul quanto do Norte, tornou-se mais significativa e frequente nos últimos anos (PINO, 2010a, 2013; MCEWAN; MAWDSLEY, 2012; ABDENUR; FONSECA, 2013). Embora essas configurações não sejam inteiramente uma novidade, esse tipo de arranjo parece ter se expandido significativamente em número e tamanho na última década, com mais países (doadores, pivôs e receptores) participando de configurações trilaterais, com diferentes funções e graus de envolvimento (CHATURVEDI, 2012a).

Nesse contexto de transformações sistêmicas, os anos 2000 trouxeram um novo ímpeto à CSS. Os fluxos de recursos referentes a essas atividades aumentaram significativamente em volume e número de beneficiários ao longo da década (BESHARATI; ESTEVES, 2015; GU et al., 2016). No plano multilateral, logo no início do século, o G77 realizou a primeira Cimeira em Havana, Cuba. Sua declaração final destacou a necessidade dos países em desenvolvimento tornarem os processos de globalização mais inclusivos, por meio de uma maior participação do Sul global nos mecanismos de tomada de decisão internacional. Para tanto, a declaração enfatiza a necessidade de se revitalizar e fortalecer o papel do sistema ONU na promoção do desenvolvimento e da cooperação internacional no contexto de globalização; e a importância da Cooperação Sul-Sul, como mecanismo para os países em desenvolvimento enfrentarem os problemas globais ${ }^{59}$.

A Conferência de Monterrey para o Financiamento ao Desenvolvimento, em 2002, também teve um papel relevante em trazer a CSS para o centro das discussões internacionais.

\footnotetext{
${ }^{58} \mathrm{O}$ primeiro desses grupos costuma ser conceitualizado como "doadores emergentes", mas uma convenção mais comum na literatura é descrever todos os três desta forma (ZIMMERMANN; SMITH, 2011).

${ }^{59}$ Programa de Ação de Havana formulado na Cimeira do G77 em Havana, entre os dias 10 e 14 de abril de 2000 .
} 
A declaração final da conferência fez referências à importância da cooperação triangular e da CSS como instrumentos importantes para prestação de cooperação de forma eficaz. Especificamente, o ponto 19 do documento final ressalta a importância de se fortalecer as capacidades materiais dos países em desenvolvimento. E que, para tanto, o documento encoraja a "cooperação Sul-Sul, inclusive por meio de cooperação triangular, para facilitar a troca de opiniões sobre estratégias, práticas e experiências de sucesso e replicação de projetos" (ONU, 2002, p. 9). Ademais, o ponto 43 destaca a necessidade dos países doadores, e das instituições internacionais tornarem a AOD mais efetiva. Para tanto, uma das recomendações é justamente a de "fortalecer a cooperação triangular, e a CSS, como ferramentas de cooperação" (ONU, 2002, p. 15). A partir de então, a CSS passou a ser citada com mais frequências nos documentos finais de praticamente todas as a reuniões internacionais sobre cooperação para o desenvolvimento.

Nesse contexto, a ONU teve um papel de destaque para o ressurgimento da CSS. Sua maior legitimidade para lidar com o tema do desenvolvimento, dado o caráter representativo da instituição; sua estrutura descentralizada; sua neutralidade e experiência se mostraram pontos importantes para a escolha dessa instituição pelos países em desenvolvimento para discutirem esses temas sensíveis. No sistema ONU, foi criado o Fundo de Cooperação para o Desenvolvimento (FCD), em 2005, sob os auspícios do Conselho Econômico e Social das Nações Unidas (ECOSOC). O FCD é considerado mais representativo do que o WP-EFF (KILLEN; ROGERSON, 2010), e muitos países em desenvolvimento, por exemplo, os BRICS, consideraram o processo de Paris como uma agenda dos doadores. Gore (2013) aponta, porém, que ao contrário do WP-EFF, o FCD não tem buscado responsabilizar os países nos esforços para melhorar a eficácia da cooperação para o desenvolvimento. Em vez disso, seu objetivo seria rever as tendências da cooperação internacional para o desenvolvimento, incluindo estratégias, políticas e financiamento; promover maior coerência entre as atividades de desenvolvimento dos diferentes parceiros de desenvolvimento; e fornecer orientação política e opções, bem como recomendações sobre medidas práticas para melhorar a coerência e eficácia da cooperação para o desenvolvimento (ONU, 2018).

Desde 2008, o Fórum de Cooperação e Desenvolvimento (FCD) do Conselho Econômico e Social das Nações Unidas (ECOSOC) liderou os esforços a favor de uma maior coordenação de debates sobre a CSS e a eficácia da ajuda internacional competindo, assim, com as iniciativas do CAD/OCDE. Os relatórios do FCD destacaram a importância da CSS e a necessidade de fortalecer a ONU como o espaço de debate mais apropriado entre países 
desenvolvidos e em desenvolvimento. Ademais, os posicionamentos do FCD tornaram-se referências para a compreensão das visões dos países em desenvolvimento sobre as diferenças e particularidades da CSS (PINO, 2014).

Outro acontecimento de relevo que marca o revigoramento da CSS foi a Conferência de Alto Nível sobre Cooperação Sul-Sul, em dezembro de 2009, em Nairóbi, que comemorou os 30 anos do Plano de Ação de Buenos Aires. Sua declaração final foi ratificada pela Assembleia Geral da ONU por meio da resolução no 64/222. Sua importância reside na reafirmação dos princípios tradicionais da CSS, pela reivindicação da autonomia dos países em desenvolvimento para dirigir a agenda da CSS e por uma tentativa de incorporação das recomendações sobre eficácia da cooperação oriundas dos fóruns de alto nível promovidos pela OCDE. Dentre os pontos mais importantes trazidos nessa resolução, destacam-se: i) o reconhecimento das diferenças históricas e das particularidades da CSS e de que esse tipo de cooperação é uma expressão de solidariedade entre os povos do Sul; ii) que a CSS deve ser estabelecida entre países do Sul e deve se guiar pelos princípios de respeito à soberania nacional, independência, igualdade, não condicionalidade, não ingerência em assuntos de internos e benefícios mútuos; iii) que a CSS não deve ser considerada AOD, pois trata-se de uma colaboração entre iguais baseada na solidariedade; iv) a importância de se aprimorar os mecanismos de transparência, prestação de contas e de avaliação das ações de CSS; e v) a importância de se aprimorar a coordenação e integração das atividades de CSS com os planos nacionais de desenvolvimento dos parceiros receptores da cooperação (PINO, 2014).

No âmbito da OCDE, iniciou-se um processo de reconhecimento da CSS como instrumento para o desenvolvimento, em especial, no decorrer dos Fóruns de Alto Nível sobre Eficácia da ajuda, em Roma, em 2003, em Paris, em 2005, em Accra, em 2008 e em Buzan, em 2011. Pino (2014) aponta que o crescente interesse dos países desenvolvidos pela CSS pode ser explicado por quatro motivos: i) por certo sentimento de ameaça por parte do avanço dos países do Sul nesse campo, em função de seu potencial competidor; ii) pelo reconhecimento de resultados positivos das ações de CSS, consideradas até então marginais dentro desse campo; iii) pela falta de conhecimento acerca das ações de CSS nos centros de pesquisa do mundo desenvolvido; iv) por receio que a CSS possa vir a gerar um efeito de race to the bottom em relação a princípios e indicadores acordados na agenda da efetividade da ajuda. Nessa linha, Manning (2006) aponta para três possíveis riscos advindos dessas novas fontes de financiamento aos países de baixa renda: i) que a crise do endividamento nesses países seja agravada pela tomada de empréstimos em condições inadequadas; ii) que esses 
países utilizem dessas novas fontes para adiar reformas domésticas necessárias, iii) que eles desperdicem recursos em investimentos improdutivos.

Assim, desde 2003, no âmbito do CAD/OCDE, o Grupo de Trabalho sobre Eficácia da Ajuda (WP-EFF, em inglês), buscou convidar diversos países do Sul, além de organizações multilaterais, instituições privadas e organizações da sociedade civil no intuito de estabelecer um mecanismo de diálogo com os doadores tradicionais. Ademais, o programa do CAD "Portas Abertas" pode ser visto como outra tentativa dos países da OCDE em atraírem os países em desenvolvimento mais relevantes no campo da CSS para o debate sobre a eficácia da cooperação para o desenvolvimento (PINO, 2014). O WP-EFF expandiu-se após 2005 para mais de 80 membros, incluindo doadores e receptores. É esta instituição que geriu o processo de Paris para melhorar a efetividade da ajuda, facilitando o diálogo, monitorizando o desempenho e organizando uma sequência de Fóruns de Alto Nível sobre a eficácia da ajuda.

Em seu terceiro Fórum de Alto Nível realizado em Acra em 2008, o papel das organizações da sociedade civil (OSC) no desenvolvimento e na ajuda também foi explicitamente reconhecido e, como resultado, um Fórum Aberto para a Eficácia do Desenvolvimento das Organizações da Sociedade foi estabelecido pelas OSC, definindo os próprios princípios de eficácia das OSCs como distintos, mas iguais, atores do desenvolvimento (GORE, 2013). Em 2009, para cumprir o mandato do Programa de Ação de Accra, firmado no III Fórum de Alto Nível sobre Eficácia da Ajuda em 2008, a OCDE incentivou a criação da Task Team on South - South Cooperation, que foi inserida ao working party de eficácia da ajuda do CAD (PINO, 2014).

Em 2007, em face às transformações sistêmicas, o G7 buscou iniciar um processo de dialogo com os países emergentes, por meio do que ficou conhecido como "Processo de Heiligendamm". O objetivo era ampliar o fórum internacional para se discutir temas cruciais para a economia mundial. Nesse contexto, os temas da cooperação e desenvolvimento receberam destaque na medida em que esse diálogo buscou identificar os papeis, pontos fortes e principais diferenças entre a CNS e a CSS. Na declaração final da Cúpula de L'Aquila, em 2009, na Itália, foi incorporada uma menção específica sobre a importância da CSS e da cooperação triangular. Assim, o G20 também teve um papel relevante na incorporação da CSS às discussões internacionais. Em Seul, em 2010, a CSS foi incluída como um dos pilares estabelecidos no documento "Consenso do desenvolvimento para um crescimento compartilhado" (G20, 2010). Nesse documento, é reconhecida a importância da CSS e da cooperação triangular como ferramentas importantes para se atingir o desenvolvimento 
econômico. Especificamente, o ponto nove do documento que compartilhar experiências de desenvolvimento por meio de iniciativas Norte-Sul, Sul-Sul e triangulares de intercâmbio de conhecimento "contribui à adoção e adaptação das soluções de desenvolvimento mais pertinentes e eficazes" (PINO, 2014).

Como analisado no capítulo anterior, o novo século começou com alguns processos que tiveram influência direta sobre o campo da CID, como o esgotamento das reformas orientadas para o mercado e as abordagens voltadas ao combate à pobreza extrema incorporadas nos Objetivos de Desenvolvimento do Milênio (ODMs). O crescente criticismo em relação aos efeitos negativos e excludentes das práticas sancionadas sob o consenso de Washington ganha força, minando a legitimidade das abordagens pró-mercado como solução para os problemas da pobreza no mundo.

No campo do desenvolvimento internacional, a legitimidade da estrutura centrada no doador passa a ser cada vez mais criticada e disputada pelos governos dos países em desenvolvimento e pelos movimentos sociais transnacionais. As condicionalidades embutidas na assistência ao desenvolvimento passam a ser o principal objeto de crítica por parte dos contestadores desse modelo. As condicionalidades eram vistas como interferência nos assuntos internos e como uma forma de promover os interesses dos doadores, em vez de estimular o desenvolvimento dos receptores. Paralelamente a essas lutas, os ODM e a Declaração do Milênio culminaram em uma década de conferências da ONU, que mobilizaram governos, movimentos sociais transnacionais e ONGs em torno dos custos sociais da globalização econômica (ESTEVES; ASSUNÇÃO, 2014).

Assim, nessa época, os agentes de desenvolvimento tiveram que lidar com um campo cada vez mais contestado. Tanto as posições dos doadores quanto as práticas de cooperação foram cada vez mais disputadas (MAWDSLEY, 2012). Esses acontecimentos propiciaram o contexto propício à rearticulação do campo em termos de uma parceria renovada entre doadores e receptores, estabelecida em torno da agenda de efetividade da ajuda externa. Diante de uma crise de legitimidade, os doadores do Norte pretendiam restabelecer suas relações entre si e com os países destinatários. Supostamente, os doadores estavam considerando remanejar o controle sobre os projetos e programas de desenvolvimento para os países receptores. Este movimento deveria acabar com as contestadas condicionalidades que violavam os assuntos internos dos países em desenvolvimento (ESTEVES; ASSUNÇÃO, 2014). 
Enquanto doadores tradicionais estavam lutando para rearticular o campo por meio da agenda da efetividade da ajuda externa, a CSS ganhou força com a crescente presença de potências emergentes como protagonistas da cooperação internacional para o desenvolvimento. Embora os doadores tradicionais ainda fornecessem a maior parte da cooperação para o desenvolvimento, o crescente ativismo dos provedores emergentes, particularmente na última década, trouxe um impacto significativo para o regime.

Do ponto de vista dos doadores tradicionais, a crescente relevância da cooperação prestada pelos países emergentes rompia com a lógica de comunidade unificada de doadores. Essa realidade ficou ainda mais clara após a crise econômica de 2008. A AOD e outras formas de fluxos oficiais foram afetadas por pacotes de austeridade fiscal nos doadores do Norte e pelo endividamento dos países em desenvolvimento. Para os provedores do Sul, a crise financeira foi uma oportunidade para destacar as diferenças entre a ajuda externa tradicional e a CSS, bem como para estabelecer novas posições no campo do desenvolvimento internacional.

Desde suas origens, os limites do campo foram concebidos por um conjunto estruturado de posições definidas sob a relação entre "doador" e "receptor". Os chamados “doadores emergentes" do Sul global passaram a desafiar essa lógica, recusando-se a se autodenominarem "doadores", preferindo o termo "parceiros", no fornecimento da cooperação. Assim, esses provedores de cooperação do Sul rejeitam as terminologias referentes a "doador", "ajuda" e "assistência" utilizados pelos países do CAD/OCDE ${ }^{60}$. Esses países partilham, em comum, da definição dada pela UNCTAD de cooperação como os processos, instituições, acordos, designados para promover a cooperação política, econômica e técnica entre países em desenvolvimento que buscam o desenvolvimento comum em uma relação horizontal (MILANI; CARVALHO, 2013)

Apesar do discurso oficial desses países emergentes, suas práticas de cooperação envolvem uma série de dilemas que estão se desdobrando nacional e internacionalmente. Domesticamente, os provedores do sul precisam obter apoio político para suas ações internacionais. Porém, a maioria desses países ainda permanece com altos níveis de pobreza, estimulando um debate sobre se tais recursos empregados na ajuda internacional não teriam melhor destinação no ambiente doméstico com programas de desenvolvimento que gerassem a diminuição da desigualdade social. Além disso, a fim de firmarem suas posições no campo do desenvolvimento internacional, os doadores emergentes precisam concordar com

\footnotetext{
${ }^{60}$ Ver o glossário de termos estatísticos da OCDE (OECD, 2018d).
} 
princípios e metas comuns, o que parece uma dimensão ainda mais complexa, na medida em que precisam não apenas se diferenciar dos doadores do $\mathrm{CAD}$, como também negociar e coordenar suas práticas de forma conjunta. Nesse aspecto, pode haver uma clivagem no Sul global, na medida em que países como Coréia do Sul e México, por exemplo, são membros formais da OCDE, possuindo um diálogo com o CAD, enquanto Brasil ${ }^{61}$, Índia e China não integram essa organização (ESTEVES; ASSUNÇÃO, 2014).

Como visto, a crescente importância da CSS se refletiu nas discussões e acordos globais sobre cooperação para o desenvolvimento que ocorreram nessa última década. A Declaração de Paris de 2005 sobre a Eficácia da Ajuda, promovida pela CAD, e considerada uma referência importante para a cooperação tradicional para o desenvolvimento entre o Norte e o Sul, não fez referência aos atores e modalidades da CSS (RENZIO; SEIFERT, 2014). Ademais, os provedores de CSSD não citam os princípios de Paris sobre a efetividade da ajuda como diretrizes para suas ações. O que não significa necessariamente uma rejeição dos próprios princípios de Paris ${ }^{62}$. Não são os princípios que os provedores de CSSD questionam exatamente, mas a maneira específica pela qual eles são interpretados e implementados pelos doadores tradicionais. Como os provedores de CSSD empregam um modelo de ajuda diferente, é de se esperar que os princípios de eficácia sejam aplicados de maneiras diferentes (CHANDY; KHARAS, 2011; PARK, 2011).

Tabela 2.4.1. Interpretações divergentes sobre os princípios de Paris

\begin{tabular}{lll}
\hline \hline $\begin{array}{l}\text { Princípios de } \\
\text { Paris }\end{array}$ & Membros do CAD & Provedores de CSSD \\
\hline Ownership & $\begin{array}{l}\text { A estratégia nacional de } \\
\text { desenvolvimento delineia as áreas } \\
\text { prioritárias para os doadores, } \\
\text { construídas a partir de discussões } \\
\text { técnicas. }\end{array}$ & $\begin{array}{l}\text { Ministros / altos funcionários } \\
\text { articulam projetos específicos d } \\
\text { cooperação por meio de diálogo } \\
\text { político de alto nível }\end{array}$ \\
& $\begin{array}{l}\text { Busca usar e fortalecer as instituições e } \\
\text { os procedimentos dos destinatários, } \\
\text { sempre que possível. }\end{array}$ & $\begin{array}{l}\text { Entrega de projectos chave em } \\
\text { curto prazo; capacitação como } \\
\text { estratégia de longo prazo. }\end{array}$ \\
& &
\end{tabular}

\footnotetext{
${ }^{61}$ Embora o Brasil tenha entrada com um pedido formal de ingresso à OCDE no ano de 2017.

${ }^{62}$ Pelo contrário, os princípios consagrados na Declaração de Paris poderiam ser usados para descrever muitos aspectos de como os provedores de SSDC abordam a ajuda
} 
Harmonização Busca usar dispositivos comuns para minimizar o ônus dos destinatários. Multilateralização da ajuda incentivada em todas as instâncias.

Resultados Busca usar estruturas de avaliação de desempenho conduzidas pelos beneficiários e apoiar o orçamento baseado em resultados. Promove as melhores práticas internacionais.

Prestação de contas
Busca tornar a ajuda transparente e responsabilizar-se mutuamente pelos compromissos de Paris através de metas e indicadores.
Minimizar o ônus evitando processos burocráticos. Uso ocasional do sistema multilateral quando julgado ser de interesse.

Concentra-se em entregar ajuda rapidamente e a baixo custo. Usa as próprias experiências de desenvolvimento e conhecimento

Assegura-se de que a ajuda seja mutuamente benéfica. Concorda em respeitar plenamente a soberania uns dos outros e evita a condicionalidade política

Fonte: Adaptado de Park (2011)

A Agenda de Ação de Accra, aprovada em 2008 no âmbito do Fórum de Alto Nível de Accra, como um acompanhamento da Declaração de Paris, reconheceu a CSS como um complemento para a cooperação Norte-Sul e encorajou os provedores de CSS a endossarem os princípios de Paris. Essa mudança aconteceu nos anos que antecederam o Quarto Fórum de Alto Nível sobre Eficácia da Ajuda, realizado em Busan, na Coréia do Sul, em 2011, marco importante para o regime de Cooperação Internacional para o Desenvolvimento (RENZIO; SEIFERT, 2014).

Nesse contexto, uma força-tarefa sobre a CSS liderada pela Colômbia e a Indonésia buscou explorar sinergias entre a CSS e a ODA, culminando na realização do Evento de Alto Nível sobre Cooperação Sul-Sul para o Desenvolvimento de Capacidades, em Bogotá, em março de 2010. Essa ação, no entanto, foi interpretada como tendo por objetivo reduzir o impacto da Conferência de Alto Nível da ONU sobre a Cooperação Sul--Sul, realizada em Nairóbi. Em função disso, alguns países como China, Índia e Brasil se recusaram a endossar uma declaração conjunta. Em contrapartida, outros países em desenvolvimento acabaram por adotar de forma independente uma declaração destacando a necessidade de melhorar os sistemas de informação e de impulsionar a cooperação triangular, dando pouco reconhecimento ao papel da ONU. Esse fato ressaltou as divergências existentes tanto entre a ONU e o CAD/OCDE, quanto entre os países em desenvolvimento (PINO, 2014). 
Do lado dos doadores, os efeitos da crise financeira de 2008 e as consequentes políticas de recessão e austeridade adotadas pelos países desenvolvidos minaram o apoio público para os gastos com cooperação internacional. Ademais, a avaliação da eficácia das práticas dos doadores (em 2006, 2008 e 2011) mostrou que pouco progresso havia sido alcançado em relação às metas estabelecidas em 2005, o que dificultava a obtenção de apoio doméstico e internacional por parte das agências de cooperação dos países desenvolvidos. De outro lado, com países do Sul explorando modalidades distintas de cooperação inconsistentes com as definições da AOD, surgiam alternativas para os países receptores dentre de um regime historicamente pouco flexível (MANNING, 2006; ESTEVES; ASSUNÇÃO, 2014).

Com os países do CAD cada vez mais preocupados em trazer a CSS para o bojo dos princípios e instituições existentes da CID, uma força-tarefa especial foi montada e duras negociações se desenrolaram para garantir que importantes atores como China, Índia e Brasil pudessem ser convencidos a assinar a declaração final. O Documento de Parceria de Busan marcou um momento decisivo ao conferir legitimidade à CSS como uma modalidade de cooperação para o desenvolvimento. O acordo de Busan é visto como um ponto de virada dentro do regime, graças ao seu caráter singular em desafiar posições dominantes e divisões dentro do campo por meio do reconhecimento de práticas diversas, e em apontar para os limites das estruturas do CAD dentro da arena multilateral (RENZIO; SEIFERT, 2014). Embora seja prematuro argumentar que um novo paradigma foi estabelecido em Busan, houve um claro impulso político para uma mudança da eficácia da ajuda para a eficácia do desenvolvimento, uma mudança que foi defendida e promovida particularmente pelos novos atores (KIM; LEE, 2013).

Dentre as questões acordadas ao longo do documento, destaca-se o reconhecimento de que a arquitetura do regime da CID evoluiu ao longo dos anos do antigo paradigma Norte-Sul, admitindo a relevância dos provedores de CSS. Destaca que embora a CNS continue sendo a principal forma de cooperação para o desenvolvimento, a CSS continua a evoluir apresentando uma diversidade adicional de recursos. Reconhece que a agenda atual do desenvolvimento está mais inclusiva, na qual novos atores participam com interesses comuns, porém com compromissos diferenciados. Ademais, reconhece que a natureza, as modalidades e responsabilidades que se aplicam à CSS se diferem daquelas que se aplicam à CNS. E que os princípios, compromissos e ações acordados servirão como referência para os parceiros Sul-Sul em base voluntária. Por fim, o documento também destaca o potencial da cooperação 
triangular, especialmente de natureza Norte-Sul-Sul, para o regime da cooperação para o desenvolvimento internacional (OECD, 2011).

A unidade de posições, que deveria ser a principal conquista do processo de Busan, acabou prejudicada pelos "compromissos diferenciais" mencionados acima. A China e o Brasil, em particular, deixaram claro que não assinariam a declaração sem uma linguagem explícita que reconhecesse a natureza voluntária do cumprimento pelos parceiros do Sul dos compromissos, ações e metas específicas. Ademais, essa contradição se tornou evidente no seguimento da reunião de Busan com a criação da Parceria Global para a Cooperação para o Desenvolvimento Eficaz (GPEDC, em inglês), o novo órgão de coordenação destinado a aumentar o número de membros para incluir os atores da CSS (RENZIO; SEIFERT, 2014).

O estabelecimento do GPEDC foi considerado um resultado importante do Quarto Fórum de Alto Nível (HLF4), pois o mesmo deveria substituir o WP-EFF, com a missão de não apenas buscar aumentar a eficácia da ajuda, como também aprimorar cooperação para o desenvolvimento de modo mais amplo, conforme acordado no HLF4. Esta nova instituição teria um número de membros mais amplo do que o WP-EFF, e sua secretaria incluiria tanto o CAD da OCDE quanto o Programa das Nações Unidas para o Desenvolvimento (PNUD) (GORE, 2013).

O GPEDC resulta de uma série de acordos e declarações anteriores liderados pelo CAD, incluindo a Declaração de Paris sobre a Eficácia da Ajuda (2005), e a Agenda de Acra para Ação (2008), que entre outros objetivos procuraram incorporar as perspectivas dos países em desenvolvimento no regime de ajuda internacional. No entanto, essa origem da organização contribuiu para as dificuldades da GPEDC em se consolidar como uma parceria verdadeiramente global. Enquanto a participação de países em desenvolvimento como um todo cresceu, várias potências emergentes, incluindo os BRICS, sinalizaram que identificam o GPEDC com os interesses do Norte e uma continuação da agenda de Paris. Essa percepção persistiu apesar do compromisso assumido em Busan de ampliar sua base e reconhecer a importância da cooperação para o desenvolvimento Sul-Sul, do envolvimento de copresidentes nigerianos e indonésios ao lado do Reino Unido na composição inicial do GPEDC e da liderança demonstrada pelo México em sediar a Reunião de Alto Nível de 2014 (CONSTANTINE; SHANKLAND, 2017).

Os provedores de cooperação do Sul, especialmente os BRICS tendem a adotar a posição de que, apesar de todos os esforços envidados, o GPEDC ainda não abordou adequadamente suas preocupações em três questões: i) legitimidade política, ii) atribuição de 
responsabilidades, e iii) definição de agenda. Sobre a questão da legitimidade política, os países emergentes argumentam que o GPEDC não é o fórum apropriado para acertar compromissos vinculantes sobre a cooperação internacional para o desenvolvimento. Eles insistem que este papel pertence à ONU, que tem suas próprias estruturas de deliberação sobre a política de cooperação internacional para o desenvolvimento, como o Fórum de Cooperação para o Desenvolvimento e o Fórum Político de Alto Nível. Sobre a questão da atribuição de responsabilidades, os provedores do Sul temem que a participação no GPEDC possa aumentar a pressão para que eles aumentem a ajuda fornecida a fim de aliviar o ônus sobre os países membros do CAD. Esses países, por sua vez, insistem que não é seu papel aliviar o Norte de suas responsabilidades e que o respeito pelo princípio fundamental de "responsabilidades comuns, mas diferenciadas" é necessário para refletir o fato de que, apesar de sua influência crescente, as potências emergentes ainda estão lutando contra seus próprios desafios de desenvolvimento Sobre a questão da definição da agenda, as potências emergentes argumentam que a mudança da eficácia da ajuda para a eficácia do desenvolvimento ainda não foi adequadamente refletida na agenda da GPEDC. A percepção é de que a agenda da organização continua a refletir as estruturas da ajuda dos doadores do CAD, com ênfase essencialmente em fluxos financeiros concessionais, prestando atenção insuficiente a aspectos-chave da Cooperação Sul-Sul, como a importância do benefício econômico mútuo, o papel central desempenhado pelo desenvolvimento e, em particular, a partilha direta das experiências de desenvolvimento dos próprios países (CONSTANTINE; SHANKLAND, 2017).

Além dessas questões específicas, a questão da confiança se constitui um desafio central para a relação entre o GPEDC e os países emergentes. As potências emergentes do sul, especialmente a China, temem que os poderes estabelecidos do Norte e do Oeste estejam determinados a impedir sua ascensão. É cada vez mais provável que se ressintam das tentativas externas de influenciar os seus debates sobre o desenvolvimento interno, como um ataque à sua soberania. Eles também estão muito conscientes de seu poder crescente no mundo e estão cada vez mais prontos para se ofender quando percebem que foram tratados com respeito insuficiente. Assim, a atitude das potências emergentes ao GPEDC tem sido muitas vezes influenciada por sua desconfiança generalizada dos processos dominados pelo Norte. Eles suspeitam que, quando países do Norte se oferecem para trazê-los para tais processos globais, eles estão de fato buscando manter o controle, neutralizando o desafio das forças emergentes a determinado campo. Essa desconfiança se deve em parte às tensões 
geopolíticas que são inevitáveis em um momento de mudanças globais de poder. No entanto, foi reforçado pelo descontentamento dos países emergentes com determinados processos como a reforma das instituições de Bretton Woods. (CONSTANTINE; SHANKLAND, 2017).

A desconfiança e a frustração das potências em ascensão com instituições e processos de desenvolvimento dominados pelo Norte contribuíram para um crescimento recente no estabelecimento de instituições e processos "minilaterais" próprios. Estes abrangem desde processos de intercâmbio e colaboração, como o Fórum Intergovernamental Índia-Brasil-África do Sul (IBAS) estabelecido em 2003 e a mais recente Rede acadêmica de Southern Think-Tanks (NeST), a grandes instituições como o Novo Banco de Desenvolvimento do BRICS (NDB) e o Banco Asiático de Investimentos em Infraestrutura (AIIB), liderado pela China. Qualquer processo de diálogo significativo sobre a política internacional de cooperação para o desenvolvimento precisará levar em conta os investimentos substanciais que as potências em ascensão já estão fazendo nessas instituições e processos (CONSTANTINE; SHANKLAND, 2017).

Além das questões que derivam do contexto geopolítico geral e das tensões sobre a reforma das instituições de política de desenvolvimento existentes, há outro aspecto que afeta o engajamento do GPEDC com as potências emergentes: capacidade. Apesar da longa história da Cooperação Sul-Sul e do volume crescente de fluxos de cooperação para o desenvolvimento dos provedores do Sul, suas agências e comunidades de políticas de cooperação, geralmente, são recentes e subequipadas quando comparadas às suas contrapartes do Norte. Esses países, portanto, se sentem em uma situação de desvantagem nas discussões internacionais sobre políticas e sistemas de ajuda. Como resultado, ao invés de se engajarem no conteúdo técnico das discussões, onde carecem dos recursos burocráticos, esses países geralmente optam por enfatizar seus posicionamentos políticos em fóruns internacionais mais amplos, onde sentem que os princípios claros e as alianças de longa data dão-lhes uma vantagem estratégica (CONSTANTINE; SHANKLAND, 2017).

Assim, em vez de estabelecer um entendimento comum sobre significados, objetivos e formas de se promover o desenvolvimento internacional, Busan inaugurou um período de intensa contestação (KINDORNAY; SAMY, 2013). O conceito de eficácia no desenvolvimento, por exemplo, potencialmente o produto mais importante de Busan, acabou gerando inúmeras discussões e controvérsias. Enquanto que para os doadores tradicionais o conceito enfatiza tanto os resultados de desenvolvimento como a continuidade 
da eficácia da ajuda. Para os parceiros emergentes, a eficácia do desenvolvimento significa a ampliação das fronteiras do campo, enfraquecendo o papel dos doadores tradicionais e abrindo um espaço renovado para as práticas de CSS (ESTEVES; ASSUNÇÃO, 2014).

A mudança de foco para os países emergentes em geral e seu apelo para "princípios comuns, mas responsabilidades diferenciadas" reforçam as clivagens Norte-Sul no plano internacional. Ademais, a forma dos arranjos institucionais continua sendo uma questão contenciosa. Enquanto a OCDE e os doadores tradicionais apoiam o GPEDC como uma "coalizão de vontade" focada na aprendizagem mútua e na melhoria das práticas de cooperação para o desenvolvimento, alguns parceiros emergentes caracterizam-no como "vinho velho em novas garrafas". Embora as propostas atuais visem representar melhor todo o espectro de agentes dentro do campo, ele ainda mantém a díade doador-receptor no centro do sistema (ESTEVES; ASSUNÇÃO, 2014).

Para Esteves e Assunção (2014), Busan marca a atual fragmentação do campo do desenvolvimento internacional, com o reconhecimento de múltiplas práticas como legítimas, Enquanto os doadores tradicionais estão tentando manter o CAD da OCDE como órgão central desse regime, muitos provedores do sul apoiam o FCD da ONU como a arena legítima para o realinhamento, coordenação e definição de normas do campo. Assim, o GPEDC e o FCD a se tornaram os dois locais de disputa entre os países, no qual doadores e parceiros lutam para desenhar as novas fronteiras do campo do desenvolvimento internacional.

O próximo passo após Busan na construção da arquitetura de cooperação para o desenvolvimento fora a negociação da estrutura pós-2015 para suceder os Objetivos do Desenvolvimento Milênio (ODM). Essa negociação ocorreu em um contexto de uma economia global ainda sob os efeitos da crise financeira de 2008, com os doadores do CAD enfrentando crises fiscais, e com a difícil tarefa de explicar a ajuda internacional aos eleitores domésticos. (GORE, 2013). Assim, uma meta dos países do Norte foi, e continua sendo, fazer com que os países em desenvolvimento mais ricos compartilhem um fardo maior no tratamento de questões globais e também no financiamento da cooperação para o desenvolvimento (GREENHILL; PRIZZON, 2012).

Porém, os provedores de cooperação para o desenvolvimento do Sul não veem suas contribuições financeiras como AOD e sustentam que a CSS não deve ser analisada e avaliada nos mesmos padrões usados para as relações Norte-Sul. Os países em desenvolvimento mais poderosos não querem se amarrar por meio de uma estrutura de monitoramento no compartilhamento de responsabilidades. Mantendo uma posição de cautela frente a uma 
possível "incorporação hegemônica" ao regime do desenvolvimento (VESTERGAARD; WADE, 2013). Assim, eles reafirmam constantemente que a cooperação Sul-Sul deve ser considerada um complemento, e não um substituto, da cooperação Norte-Sul (GORE, 2013).

Mawdsley, Savage e Kim (2014) sugerem que o período 2011-2012 marcou uma mudança de paradigma no campo da cooperação para o desenvolvimento. A autora destaca que o termo "ajuda externa" parece ter se tornado um termo pejorativo pela primeira vez pelos países desenvolvidos. Busan foi apresentado como representando o fim da agenda da "efetividade da ajuda", e um novo começo na busca da "efetividade do desenvolvimento". Muitos analistas apontam que a emergência do paradigma conhecido como "efetividade da ajuda", ao longo dos anos 1990, embora formulado em um contexto de "pós-consenso de Washington", representou, de fato, uma continuidade em relação às práticas e prescrições da década anterior. Já Busan representaria um ponto de ruptura nesse regime, na medida em que essa arquitetura emergente da ajuda integraria em maior medida os "novos doadores" e suas práticas. Mawdsley (2017) defende que essa transição não representa simplesmente uma redistribuição do poder do "Norte" para o "Sul". Os países do Sul e do Norte estão competindo e colaborando, mas também convergindo para uma agenda mais ampla de apoio subsidiado para o crescimento de empresas em favor do desenvolvimento, fundindo elementos de mercantilismo, industrialização e neoliberalismo liderados pelo Estado.

Dentro da comunidade internacional de desenvolvimento, saúde, educação, boa governança e redução da pobreza permanecem preocupações e objetivos proeminentes da agenda. Desde a formulação da "Agenda 2030 para o Desenvolvimento Sustentável", em 2015, buscou-se uma maior integração sobre as dimensões sociais, econômicas e ambientais do desenvolvimento, ganhando cada vez mais proeminência a ideia de "bens públicos globais" sob os Objetivos de Desenvolvimento Sustentável (ODSs). As negociações e o resultado final dos ODS refletem um regime internacional de desenvolvimento mais plural que em momentos anteriores. Além da ascensão dos países do Sul, outros doadores que não integram o CAD contribuíram com a fragmentação do campo, o que dificulta a tarefa de delinear o paradigma dominante vigente sobre desenvolvimento para os próximos anos. Os objetivos e metas acerca do desenvolvimento propostas atualmente, no âmbito dos ODS, parecem estar sendo reconfigurados dentro de uma crença revigorada de que o crescimento econômico liderado pelo setor privado, subsidiado publicamente, se constitui no principal motor do desenvolvimento (MAWDSLEY, 2017). 
Se no passado a cooperação para o desenvolvimento era geralmente entendida como assistência oficial ao desenvolvimento (AOD). Havendo uma noção clara do que era a AOD, com uma arquitetura bem definida por meio da qual três instituições principais - o Fundo Monetário Internacional (FMI), o Banco Mundial e o Comitê de Assistência ao Desenvolvimento (CAD) da Organização para Cooperação e Desenvolvimento Econômico (OCDE) - regulamentavam as práticas de doadores e receptores. Essa arquitetura está em processo de ser substituída por um cenário mais complexo e diversificado de cooperação para o desenvolvimento, caracterizado por novos atores e novas abordagens, sendo agora entendido como algo mais amplo do que a ajuda externa. Assim, uma nova arquitetura de cooperação para o desenvolvimento está formação, mas sua forma futura ainda é incerta (GORE, 2013).

Tabela 2.4.2. Princípios da CSS

\begin{tabular}{|c|c|c|c|}
\hline $\begin{array}{l}\text { Bandung } \\
(\mathbf{1 9 5 5 )}\end{array}$ & $\begin{array}{c}\text { Buenos Aires } \\
\text { (1978) }\end{array}$ & Nairóbi (2009) & Bogotá (2010) \\
\hline $\begin{array}{l}\text { Respeito aos } \\
\text { Direitos } \\
\text { Humanos }\end{array}$ & Autossuficiência & Multilateralismo & $\begin{array}{l}\text { Desenvolvimento de } \\
\text { capacidades }\end{array}$ \\
\hline $\begin{array}{l}\text { Respeito à } \\
\text { soberania }\end{array}$ & $\begin{array}{c}\text { Trocas e } \\
\text { compartilhamento }\end{array}$ & Sustentabilidade ambiental & $\begin{array}{l}\text { Direitos Humanos e } \\
\text { Igualdade }\end{array}$ \\
\hline Igualdade & $\begin{array}{c}\text { Desenvolvimento } \\
\text { de capacidades }\end{array}$ & $\begin{array}{l}\text { Benefícios mútuos, soma } \\
\text { positiva e horizontalidade }\end{array}$ & Sustentabilidade ambiental \\
\hline $\begin{array}{c}\text { Não- } \\
\text { indiferença }\end{array}$ & $\begin{array}{l}\text { Transferência de } \\
\text { conhecimentos }\end{array}$ & $\begin{array}{l}\text { Desenvolvimento de } \\
\text { capacidades }\end{array}$ & $\begin{array}{l}\text { Solidariedade e } \\
\text { colaboração }\end{array}$ \\
\hline $\begin{array}{l}\text { Interesses } \\
\text { mútuos e } \\
\text { colaboração }\end{array}$ & $\begin{array}{c}\text { Respeito à } \\
\text { soberania nacional }\end{array}$ & $\begin{array}{l}\text { Aprendizado mútuo, troca } \\
\text { de conhecimentos e } \\
\text { transferência de tecnologias }\end{array}$ & $\begin{array}{l}\text { Benefícios mútuos e soma } \\
\text { positiva }\end{array}$ \\
\hline \multirow[t]{7}{*}{$\begin{array}{c}\text { Justiça } \\
\text { internacional }\end{array}$} & $\begin{array}{l}\text { Independência } \\
\text { econômica }\end{array}$ & $\begin{array}{c}\text { Transparências e prestação } \\
\text { de contas mútua }\end{array}$ & $\begin{array}{c}\text { Transferência de } \\
\text { conhecimentos, } \\
\text { intercâmbios e aprendizado }\end{array}$ \\
\hline & Igualdade & $\begin{array}{l}\text { Respeito à soberania } \\
\text { nacional }\end{array}$ & $\begin{array}{c}\text { Especificidade da CSS e } \\
\text { complementaridade em } \\
\text { relação à CNS }\end{array}$ \\
\hline & Não-interferência & $\begin{array}{l}\text { Domínio nacional e } \\
\text { independência }\end{array}$ & Inclusividade e participação \\
\hline & & Igualdade & $\begin{array}{l}\text { Flexibilidade, adaptação ao } \\
\text { contexto }\end{array}$ \\
\hline & & Não-condicionalidade & $\begin{array}{l}\text { Parceria, equidade, } \\
\text { confiança, e respeito }\end{array}$ \\
\hline & & Não-interferência & $\begin{array}{c}\text { Ownership e guiada pelas } \\
\text { demandas }\end{array}$ \\
\hline & & Inclusividade e participação & Transparência e prestação \\
\hline
\end{tabular}




\begin{tabular}{l|c|c|c}
\hline & & & de contas \\
\hline & & $\begin{array}{c}\text { Resultados, impactos e } \\
\text { qualidade }\end{array}$ & \\
\hline
\end{tabular}

Fonte: Adaptado de NEST (2017, p. 8-9).

Tabela 2.4.3. Cronologia da Cooperação Sul-Sul para o Desenvolvimento

\begin{tabular}{|c|c|}
\hline 1955 & nferência de Bandung e proclamação dos princípios gerais da CSS. \\
\hline 1961 & Fundação do Movimento dos Não-Alinhados (MNA), na Conferência de Belgrado. \\
\hline 1964 & Criação da UNCTAD e do G-77. \\
\hline 1966 & Constitui-se na Conferência de Havana a Ospaal. \\
\hline 1974 & $\begin{array}{l}\text { Criação da Unidade Especial para Cooperação Técnica entre os Países em } \\
\text { Desenvolvimento, ligada ao PNUD. }\end{array}$ \\
\hline 1978 & $\begin{array}{l}\text { Conferência sobre Cooperação Técnica entre os Países em Desenvolvimento e adoção } \\
\text { do Plano de Ação de Buenos Aires. }\end{array}$ \\
\hline 1981 & $\begin{array}{l}\text { Conferência de Alto Nível sobre Cooperação Econômica entre Países em } \\
\text { Desenvolvimento e adoção do Plano de Ação de Caracas }\end{array}$ \\
\hline 1986 & $\begin{array}{l}\text { Reunião de Alto Nível sobre Cooperação Econômica entre Países em Desenvolvimento } \\
\text { no Cairo. }\end{array}$ \\
\hline 1995 & $\begin{array}{l}\text { Lançamento do documento da ONU intitulado Novas direções para a CTPD. } \\
\text { Identificam-se os países pivôs que podem impulsionar a CSS }\end{array}$ \\
\hline 1997 & $\begin{array}{l}\text { Realização da Conferência Sul-Sul de Comércio, Investimentos, Finanças e } \\
\text { Industrialização e adoção do Plano de Ação de São José }\end{array}$ \\
\hline 2000 & Cúpula do Sul de Havana. \\
\hline 2001 & $\begin{array}{l}\text { X Reunião do Comitê Intergovernamental de Cooperação entre Países em } \\
\text { Desenvolvimento, em Teerã, no marco do G-77. }\end{array}$ \\
\hline 2002 & $\begin{array}{l}\text { Conferência de Financiamento do Desenvolvimento em Monterrey. A CSS e a } \\
\text { cooperação triangular são identificadas como relevantes para aumentar a eficácia da } \\
\text { ajuda. }\end{array}$ \\
\hline \multirow[t]{3}{*}{2003} & $\begin{array}{l}\text { Mudança de denominação da Unidade Especial de CTPD do PNUD para Unidade } \\
\text { Especial de Cooperação Sul-Sul e proclamação, pela Assembleia Geral da ONU, do } \\
\text { Dia da Cooperação Sul-Sul, pelo } 25 \text { o aniversário da Conferência de Buenos Aires. }\end{array}$ \\
\hline & $\begin{array}{l}\text { 58o período de sessões da Assembleia Geral na qual se decide substituir o termo CTPD } \\
\text { por CSS em todo o Sistema ONU. }\end{array}$ \\
\hline & I Cúpula do Sul em Marrakesh, comemorativa dos 25 anos do PABA. \\
\hline 2004 & I celebração do Dia Especial da ONU para a CSS, em 19 de dezembro. \\
\hline 2005 & $\begin{array}{l}\text { II Cúpula do Sul, em Qatar, na qual se aprova plano de ação para posicionar a CSS em } \\
\text { um lugar destacado da agenda global de desenvolvimento. }\end{array}$ \\
\hline \multirow[t]{2}{*}{2008} & $\begin{array}{l}\text { Impulso desde o Conselho Econômico e Social (ECOSOC) à CSS. Criação do Fórum } \\
\text { de Cooperação para o Desenvolvimento (FCD). Constitui-se grupo de trabalho no } \\
\text { âmbito deste fórum sobre CSS. }\end{array}$ \\
\hline & $\begin{array}{l}\text { A CSS recebeu reiterado apoio na Assembleia Geral da ONU. A Resolução no 62/209, } \\
\text { de } 11 \text { de março, incentiva os Estados- membros a "aprofundar, intensificar e melhorar a } \\
\text { CSS". }\end{array}$ \\
\hline
\end{tabular}




\begin{tabular}{l|l}
\hline & $\begin{array}{l}\text { III Fórum de Alto Nível de Eficácia da Ajuda, em Gana. O Programa de Ação de Accra } \\
\text { reconhece, em seu ponto 19, as contribuições da CSS e reafirma a complementariedade } \\
\text { da CNS com a CSS. }\end{array}$ \\
\hline 2009 & $\begin{array}{l}\text { O apoio à CSS é repetido na Conferência Internacional de Prosseguimento sobre o } \\
\text { Financiamento para o Desenvolvimento (Doha). }\end{array}$ \\
\hline $\begin{array}{l}\text { Cria-se o task team sobre CSS, vinculado ao Grupo de Trabalho sobre Eficácia da } \\
\text { (CAD) da OCDE. Realiza-se a Cúpula de Nairóbi das Nações Unidas, comemorativa } \\
\text { dos trinta anos do PABA, de 1o a 3 de dezembro. }\end{array}$ \\
\hline 2010 & $\begin{array}{l}\text { O Grupo dos Vinte (G-20) reconhece na declaração final de Seul o papel da CSS e da } \\
\text { cooperação triangular na criação de sinergias para lograr o máximo impacto no } \\
\text { desenvolvimento. }\end{array}$ \\
\hline 2011 & $\begin{array}{l}\text { O IV Fórum de Alto Nível sobre Eficácia da Ajuda em Busan, Coreia do Sul, } \\
\text { reconhece as diferenças da CSS e o caráter voluntário dos princípios de eficácia para os } \\
\text { "doadores emergentes". O task team sobre CSS apresentou evidências de boas práticas } \\
\text { e estudos de caso desta cooperação e cooperação triangular. }\end{array}$ \\
\hline \hline
\end{tabular}

Fonte: Adaptado de Pino (2014, p. 68). 


\section{CAPÍtUlO 3. A COOPERAÇÃO INTERNACIONAL PARA O DESENVOLVIMENTO: CONCEITO, CLASSIFICAÇÕES E EXPLICAÇÕES}

Ao se analisar a evolução da Cooperação Internacional para o Desenvolvimento desde suas origens até os dias de hoje, nota-se que tais ações passaram por um processo de institucionalização ao longo dos anos de modo que hoje em dia a CID se tornou um elemento permanente das relações internacionais. Entretanto, vale lembrar que a ajuda internacional envolve, na maior parte dos casos, recursos públicos. Logo, a questão acerca das razões que levam os Estados a fornecerem seus recursos escassos a outros países surge de forma natural.

Entender quais os motivos que levam os Estados a fornecerem ajuda externa é uma tarefa complexa. Alguns autores (AFONSO; FERNANDES, 2005; PUENTE, 2010) apontam como motivações, motivos morais, altruísticos e humanitários; motivos geopolíticos e estratégicos; motivos econômicos e comerciais; motivos históricos e culturais; entre outros como considerações acerca de fluxos migratórios e questões ambientais.

\subsubsection{Motivos morais altruísticos e humanitários}

A base das motivações humanitárias decorreria da ideia de que indivíduos em melhores condições socioeconômicas teriam a obrigação moral de ajudar indivíduos em situações menos favorecidas. A base desse argumento seria de origem filosófica e religiosa. Assim, essa obrigação moral seria transplantada para as relações internacionais de modo que os países desenvolvidos teriam a obrigação de auxiliar os países subdesenvolvidos. Entretanto, raramente apenas o argumento moral é utilizado para se justificar o fornecimento de ajuda externa (AFONSO; FERNANDES, 2005).

$\mathrm{O}$ argumento moral comumente vem associado à ideia de que o desenvolvimento dos países receptores trariam vantagens aos países doadores no longo prazo. Seja por questões de segurança internacional, seja por questões econômicas. No plano da segurança, a ideia é que haveria uma associação entre subdesenvolvimento e instabilidade política. Assim, o desenvolvimento dos países da periferia seria benéfico aos doadores na medida em que a estabilização desses países reduziria os focos de conflitos e instabilidades no sistema internacional. Já em relação à questão econômica, essa ideia subscreveria uma visão liberal da economia internacional na medida em que o desenvolvimento de economias menos desenvolvidas seria benéfico para as economias dos doadores na medida em que a economia 
global seria vista como um jogo de "soma positiva". O crescimento econômico da periferia geraria um maior mercado consumidor para as exportações dos países doadores e aumentariam suas opções para importações.

Nessa linha, em 1969, o relatório Pearson, da Comissão de Desenvolvimento Internacional, defendia que a ajuda internacional ao desenvolvimento seria uma obrigação moral que tenderia, porém, a beneficiar os doadores no longo prazo (PEARSON, 1969). O relatório Brandt também apresenta essa visão, ao considerar que a AOD seria uma condição necessária para assegurar a continuidade do progresso e do bem estar dos países do Norte no longo prazo (BRANDT, 1980). No plano multilateral, essa motivação teria um papel importante para explicar os programas de ajuda das Nações Unidas, na medida em que essas ações seriam vistas como menos relacionadas com os interesses dos países doadores (PUENTE, 2010).

\subsubsection{Motivações geopolíticas e estratégicas}

Embora as motivações geopolíticas não costumem aparecer nas justificativas oficiais dos países doadores em relação aos seus programas de cooperação ao desenvolvimento, é comumente a motivação mais apontada na literatura de Relações Internacionais para se explicar por que países fornecem ajuda externa. Essas motivações envolveriam os interesses políticos por parte dos países doadores no fornecimento da ajuda. Assim, a ajuda externa seria utilizada a fim de obter aliados e comprar apoio político no plano internacional. Essa motivação seria evidenciada especialmente em cenários de guerras e disputas internacionais, tendo como exemplos mais notórios a ajuda externa fornecida por ambas as superpotências durante a Guerra Fria. Também se destaca a ajuda fornecida ao Egito e Israel no contexto dos conflitos no Oriente Médio, entre outros exemplos. Sob essa óptica, a ajuda externa seria vista também como uma ferramenta para se comprar apoio político nas Instituições Internacionais. Em especial, nas organizações que possuem processos de tomada de decisão baseados em votações ou formação de consensos. Sendo os exemplos mais notórios a Assembleia Geral das Nações Unidas (AGNU) e as instituições financeiras internacionais como o Fundo Monetário Internacional e o Banco Mundial.

Com o final da Guerra Fria, no início da década de 90, esperava-se que as motivações geopolíticas e estratégicas perdessem relevância para o fornecimento de ajuda externa por parte dos países desenvolvidos. A diminuição dos fluxos de ajuda externa nesse período 
parecia corroborar essa hipótese. Entretanto, o aumento do fornecimento de ajuda externa, especialmente por parte dos Estados Unidos, após os atentados de 11 de setembro, pareceu evidenciar que, de fato, as motivações geopolíticas e estratégicas possuem um grande peso para se explicar o porquê dos países fornecerem ajuda internacionalmente. Essas motivações também aparecem como evidentes ao se analisar os padrões de alocação da ajuda externa pelo mundo, na medida em que até os dias de hoje, os países doadores privilegiam seus aliados políticos em seus programas de cooperação ${ }^{63}$.

\subsubsection{Motivações econômicas e comerciais}

As motivações econômicas e comerciais comumente são apontadas como fatores importantes para explicar por que países fornecem ajuda externa e para quem. Embora em relação ao período da Guerra Fria haja certo consenso de que as motivações geoestratégicas foram prioritárias na alocação da ajuda externa, especialmente por parte dos Estados Unidos, os motivos econômicos também tiveram um peso importante. Os países muitas vezes utilizam a ajuda externa para obter vantagens econômicas mais gerais junto aos receptores e para responder a lobbies domésticos específicos. Dentre as principais vantagens econômicas que um país doador poderia obter com sua ajuda destacam-se o acesso a mercados externos para exportações, investimentos e importação de matérias primas.

É comumente apontado que com o fim dos impérios coloniais em meados do século $\mathrm{XX}$, a ajuda externa foi utilizada pelas antigas metrópoles como forma de manter as economias desses países atreladas às suas economias. De modo mais específico, destaca-se a chamada "ajuda amarrada" (tied-aid) em que a ajuda é fornecida sob algumas condicionalidades específicas, que incluem a aquisição de produtos e serviços por parte dos doadores. Assim, a ajuda pode e costuma ser utilizada pelos doadores como parte da estratégia nacional desses países para apoiar a internacionalização de suas empresas e aumentar suas exportações. Logo, fica evidente que tal política pode estar sujeita a interesses domésticos particulares. Os exemplos mais evidentes dizem respeito aos interesses domésticos nos Estados Unidos na execução da ajuda externa. Especialmente os lobbies agrícolas para o fornecimento de "ajuda alimentar" (food aid), em que o governo adquire os excedentes agrícolas dos produtores para realizar as doações (LANCASTER, 2007). Por fim, vale destacar que a ajuda externa sob a forma de empréstimos concessionais também pode

\footnotetext{
${ }^{63}$ Fuchs, Dreher e Nunnenkamp (2012) trazem uma extensão revisão bibliográfica sobre essa literatura.
} 
responder aos interesses do doador. Embora na maioria dos casos esses empréstimos sejam realizados com juros abaixo dos preços praticados pelos mercados, tais empréstimos precisam ser pagos futuramente, criando uma relação de dependência entre o doador e receptor.

\subsubsection{Motivos históricos e culturais}

As motivações culturais costumam ser apontadas para explicar certos padrões de alocação de ajuda externa. Como, por exemplo, o fato de que certos doadores costumam privilegiar em seus programas de ajuda receptores que possuem ligações culturais e históricas. É comumente visto como uma forma de perpetuar os vínculos existentes entre o doador e o receptor. Os exemplos mais claros se dão entre as antigas metrópoles e colônias do sistema colonial. Casos da Inglaterra e suas antigas colônias que formaram a commonwealth, da França com suas ex-colônias francófonas. Ou em casos mais recentes, da cooperação entre países árabes dentro da Organização dos Países Exportadores de Petróleo (OPEP) e dos países da Comunidade dos Países de Língua Portuguesa (CPLP).

Vale destacar também que motivações culturais raramente explicam por si o porquê de certos doadores alocarem mais ajuda externa para determinados receptores. Embora seja uma das motivações mais apontadas nos discursos oficiais dos doadores para a justificação da ajuda fornecida a um país, na realidade é uma motivação subalterna a outros objetivos. Em especial, políticos ou econômicos (PUENTE, 2010).

\subsubsection{Outras motivações: questões ambientais e fluxos migratórios}

Outras motivações apontadas para o fornecimento de ajuda dizem respeito a preocupações mais recentes das relações internacionais como a questão dos refugiados e migrantes em geral e as questões ambientais. $\mathrm{O}$ aumento dos fluxos globais de migrantes do mundo em desenvolvimento para os países desenvolvidos nas últimas décadas tem aumentado a predisposição das elites políticas nesses países a auxiliarem os países emissores de migrantes a se desenvolverem economicamente como forma de tentar conter esses fluxos. A ajuda nesses termos é vista como autointeressada na medida em que, em última instância, os doadores estão preocupados com seus problemas domésticos.

As questões ambientais tem ganhado destaque na agenda internacional nas últimas décadas, especialmente após a Conferência de Estocolmo em 1973. A partir de então, os 
problemas ambientais, largamente negligenciados até então, passaram a ganhar maior destaque nas negociações internacionais. A relação entre desenvolvimento econômico e sustentabilidade passou a ganhar ênfase conforme os países subdesenvolvidos passaram a pressionar os países industrializados para que os temas não fossem tratados de forma desvinculada. O marco para essa questão foi a publicação do Relatório Brundtland que recomenda uma abordagem global aos temas ambientais (BRUNDTLAND et al., 1987). Outro marco importante foi a Conferência das Nações Unidas para o Meio Ambiente e Desenvolvimento (Rio 92), que culminou com o estabelecimento da Convenção Quadro das Nações Unidas para as Mudanças Climáticas. Além do Protocolo de Quioto, principal tratado acertado entre os países como forma de conter o aquecimento global, que trouxe cláusulas específicas para que países desenvolvidos auxiliassem os países em desenvolvimento em se desenvolverem de forma sustentável (LANCASTER, 2007).

\subsubsection{Motivações ou propósitos?}

Muitos autores falam em motivações por parte dos Estados. Porém, "motivação" envolve indivíduos, o que pode ser algo difícil de observar. Lancaster (2007) sugere o uso do termo "propósitos", para se referir à gama de objetivos gerais que os doadores pretendem alcançar por meio de sua ajuda externa. Nesse sentido, a autora aponta que o fornecimento de ajuda externa foi utilizado historicamente por quatro motivos principais: diplomáticos, com fins para o desenvolvimento, humanitários e comerciais.

A ajuda externa com fins diplomáticos envolveria questões de segurança internacional, objetivos políticos internacionais, e a gerência da relação entre Estados. A ajuda fornecida com fins para o desenvolvimento teria como objetivo promover o progresso social e econômico em países subdesenvolvidos e aliviar a pobreza, sendo vista como meio e fim para a perseguição de objetivos políticos no cenário internacional. A ajuda para fins humanitários é fornecida frequentemente para países pobres que passam por grandes catástrofes humanitárias. Por fim, a ajuda com propósitos comerciais atua no intuito de expandir as exportações do país e de garantir acesso a mercados consumidores e de matérias primas para o fornecedor.

\subsection{Teorias para explicar a ajuda externa}


Entender o que leva os Estados a fornecerem ajuda externa não é uma tarefa simples. Embora nos dias de hoje a prática do fornecimento de ajuda externa seja uma característica das relações internacionais, o capítulo anterior destacou que nem sempre foi assim. Não é algo trivial ou esperado que governos - eleitos ou não - utilizem seus escassos recursos públicos para beneficiarem outros países. Na seção anterior foram apontadas algumas motivações (ou propósitos) que levariam os Estados a entrarem nessa empreitada. Porém, é necessário organizar essas motivações (ou propósitos) em teorias que possam auxiliar a organizar a realidade empírica. Embora uma teorização acerca dos motivos que levam os Estados a fornecerem ajuda não seja algo simples, várias tentativas foram realizadas desde o surgimento dessa prática nas Relações Internacionais (JULES, 2008).

A alocação da ajuda externa é geralmente explicada em termos modelos estadocêntricos de política externa com ênfases variadas na perspectiva internacional (BELLE, 2004). Partindo da premissa de que o fornecimento de ajuda externa é uma decisão realizada por certos atores (independentemente do nível de análise empregado), que possuem preferências e tomam decisões em face de uma gama de constrangimentos. Um modelo que busque explicar de forma satisfatória por que essa prática ocorre no plano internacional deve levar em consideração esses três fatores (VEEN, 2011). Assim, levando em consideração esses fatores e as motivações que levam os Estados a fornecerem ajuda, destacam-se quatro abordagens principais do campo das Relações Internacionais: realista; marxista/estruturalista; liberal e a construtivista (PINO, 2007).

$\mathrm{Na}$ visão realista, a motivação estratégica e a preocupação com a Segurança tornariam a ajuda externa como uma ferramenta de poder utilizada pelos Estados mais poderosos na persecução de seus objetivos no cenário internacional. Para a abordagem marxista/estruturalista, a ênfase nos motivos econômicos tornaria a ajuda externa como uma ferramenta utilizada pelos Estados capitalistas do centro no intuito de explorar as nações periféricas. Para os liberais, a ênfase nas preferências dos Estados, formadas a partir da interação entre atores dentro da sociedade e das escolhas políticas, tornaria a ajuda externa um reflexo da tendência dos Estados cooperarem entre si no intuito de lidar com os problemas resultantes da globalização e da interdependência complexa. Por fim, a visão construtivista enfatiza o papel das ideias na formulação das políticas, de modo que as questões morais e éticas seriam determinantes na realização dessas iniciativas ${ }^{64}$.

\footnotetext{
${ }^{64}$ Lancaster (2007) aponta, entretanto, que nenhuma dessas teorias consegue explicar de forma adequada toda a complexidade do fenômeno da ajuda externa pelo fato de haver muitas variáveis interativas que justifiquem um modelo que seja ao mesmo tempo parcimonioso.
} 


\subsubsection{O realismo e a motivação estratégica}

Ao longo de suas várias versões, a visão realista sempre focou na questão do poder, da anarquia do Sistema Internacional e no dilema de segurança resultante da interação entre esses elementos (CARR, 1946; MORGENTHAU, 1948; WALTZ, 1979). A falta de hierarquização da política internacional, ou seja, falta de um detentor do monopólio do uso legítimo da violência (WEBER, 2004) transformaria a realidade internacional em um cenário de autoajuda em que cada Estado deveria adotar as medidas necessárias para garantir sua sobrevivência. Nesse contexto, a segurança seria o motivo principal que guiaria os Estados e as dinâmicas do sistema, de modo que as relações internacionais seriam vistas como conflitivas e a política externa como utilitária.

Nessa perspectiva, a ajuda externa não seria separável da política de poder, de modo que os programas de ajuda responderiam primordialmente aos interesses dos doadores. $\mathrm{Na}$ medida em que esses interesses são definidos em termos de poder, categoria objetiva e universalmente válida (MORGENTHAU, 1948), os Estados forneceriam ajuda com o intuito final de aumentar seu poder. Categoria que não possuiria um significado permanente, mas que variaria de acordo com o contexto social e político da época. A política internacional, como qualquer política, consistiria em uma luta pelo poder, sendo sempre o objetivo imediato. Dentre os propósitos da ajuda externa destaca-se a necessidade de aumentar o poder do Estado por meio da obtenção de apoio político no cenário internacional.

Nessa visão, as preocupações humanitárias com os receptores e os imperativos de desenvolvimento econômico destes seriam vistas como ingênuas, na medida em que os princípios morais não poderiam ser aplicados às ações dos Estados. Para Morgenthau (1962), a ajuda externa seria uma espécie de suborno dados pelos países ricos aos países mais pobres. Nessa linha, Liska (1960) defende que ajuda externa seria nada mais que um instrumento político. Embora os objetivos altruístas possam ter alguma importância para explicar o fornecimento da ajuda, serão subordinados a outras motivações como necessidades militares e econômicas, controle pós-colonial, e estabilidade política (KNORR, 1973). Também nessa linha, (GILPIN, 2002) destaca que preocupações humanitárias possuem um papel importante na alocação da ajuda, porém os principais motivos seriam políticos, militares e comerciais.

Os realistas partem de uma concepção estadocêntrica, em que os Estados são atores unitários, havendo assim uma distinção entre política interna e externa. Assim, a 
especificidade da política externa está dada pela premissa de que os Estados são autônomos em relação às suas respectivas sociedades nacionais e pelas suas capacidades de agirem de forma coerente no que diz respeito a outros países. Está presente nos escritos realistas uma determinada percepção de que a política internacional estaria acima da política doméstica pelo fato de estar voltada à defesa dos interesses nacionais e por tratar de questões que afetam a segurança e a sobrevivência dos Estados. Dessa forma, ao tentar explicar a ajuda externa, o analista deveria se voltar aos interesses do Estado, analisando as variáveis que refletiriam as motivações estratégicas do Estado no Sistema Internacional, como alianças e apoio político em Organizações Internacionais, na medida em que estas são vistas como arenas de disputa entre os Estados.

\subsubsection{Marxismo e o motivo econômico}

Embora o marxismo enquanto abordagem teórica se apresente em várias ramificações com distintos níveis de análise. Os pontos em comum às diversas vertentes centram-se na abordagem dialética da sociedade, evidenciando a natureza conflitiva e dinâmica da realidade; na visão materialista da história, em que o desenvolvimento das forças produtivas e as atividades econômicas seriam a base das mudanças históricas; e na visão do Estado como representante dos interesses da elite econômica. Sob essas premissas, a ajuda externa seria vista como uma ferramenta utilizada pelos Estados desenvolvidos para manter os países pobres na periferia do sistema. Nessa visão, os países desenvolvidos, por meio de recursos públicos e privados, ditariam as políticas econômicas e as estratégias de desenvolvimento dos países em desenvolvimento. Assim, os doadores alocariam a ajuda tendo em vista seus próprios objetivos econômicos (WEISSMAN, 1975).

Essa perspectiva ganhou ênfase especialmente nos anos 60 e 70 com os movimentos de descolonização e da defesa por uma Nova Ordem Econômica Internacional. Seus preponentes defendiam que a divisão de trabalho internacional existente favorecia os países desenvolvidos de modo que os programas de ajuda serviam para manter essa divisão. A ajuda seria uma ferramenta utilizada para inserir os países subdesenvolvidos em uma posição subordinada no Sistema Internacional, na medida em que a formação da relação doadorreceptor fortalecia as elites políticas e econômicas nos países da periferia relegando as demais parcelas da população a uma posição de marginalização (HAYTER; WATSON, 1985). 
Os efeitos dessa política se refletiam nos padrões percebidos acerca dos fluxos econômicos internacionais. Os países industrializados se beneficiavam de forma desproporcional com o comércio bilateral com os países em desenvolvimento. Enquanto os países do centro exportavam produtos de maior valor agregado, os países da periferia se mantinham em uma relação de dependência em que apenas a elite agroexportadora do país se beneficiava dessa relação. Assim, a ajuda externa ao ser alocada de modo a atender aos interesses dos doadores encorajava esse desenvolvimento dependente nos países periféricos. Sob essa perspectiva, para se explicar a ajuda externa, o analista deveria se voltar aos interesses econômicos dos países doadores, analisando variáveis que refletiriam as relações econômicas entre os doadores e receptores como fluxos de comércio, de empréstimos e investimentos.

Visões neomarxistas, tomando o Estado como centro da análise, buscaram analisar a Cooperação Sul-Sul, em particular, como uma forma dos Estados da periferia se livrarem das amarras ao desenvolvimento estabelecidas nas relações de exploração com os países do Norte. Para os teóricos da dependência, especialmente, o desenvolvimento do sistema capitalista gerou subdesenvolvimento nos países periféricos cujo excedente econômico havia sido expropriado pelo centro, gerando desenvolvimento econômico nesses países (FRANK, 1970). Portanto, o desenvolvimento só poderia ocorrer através de soluções radicais. Ao cooperar entre si, os países em desenvolvimento poderiam evitar a deterioração dos termos de troca e contornar os laços de dependência que os mantêm subdesenvolvidos e subordinados (JULES, 2008).

\subsubsection{O liberalismo e a interdependência entre os Estados}

Para o liberalismo institucional, os Estados seguem sendo os principais atores das Relações Internacionais, embora não os únicos; e o sistema internacional continua sendo considerado um ambiente anárquico. Porém, de acordo com essa visão, as relações internacionais não correspondem ao Estado hobbesiano como pressupõe a análise realista, na medida em que haveria certo grau de ordenamento no sistema internacional, caracterizado pelas Instituições Internacionais. Assim, a anarquia não seria o principal determinante da relação entre os Estados, visto que esta seria determinada pelo seu grau de institucionalização. As instituições seriam definidas como "grupos de regras, formais e informais, persistentemente conectadas que prescrevem o comportamento, constrangem as atividades e 
definem as expectativas" (KEOHANE, 1989). Assim, as instituições seriam importantes no relacionamento entre os Estados ao influenciarem os incentivos à cooperação.

Para os liberais institucionalistas, entre outras vertentes da perspectiva liberal, a ajuda externa seria vista como um reflexo da tendência dos Estados cooperarem a fim de lidarem com problemas globais que perpassam as fronteiras entre os Estados. A ajuda externa canalizada por instituições multilaterais ou fornecida por vias bilaterais seria utilizada para o provimento de "bens públicos globais". Como o controle de doenças infecciosas, redução da degradação ambiental controles migratórios entre outros (LANCASTER, 2007).

Uma vantagem do modelo liberal na explicação dos padrões de alocação de ajuda externa seria a prioridade dada às preferências dos atores. A interação estratégica entre unidades subnacionais dentro de uma sociedade formando as preferências do Estado seria a chave para se entender por que os Estados fornecem ajuda externa. Partindo da premissa de que os Estados não são atores unitários no sistema internacional, essa perspectiva enfatiza a influência dos fatores domésticos na formulação da política externa. Assim, como há a necessidade de ratificação interna dos compromissos assumidos por determinado Estado. Seria necessário um equilíbrio para conciliar a interação entre condicionantes internos e externos, considerando assim, partidos políticos, grupos de interesse, legisladores e opinião pública como determinantes da ação internacional de um país.

A segurança não seria completamente definida por uma competição de soma zero por poder, havendo margens para a cooperação. Assim, os Estados não estariam preocupados apenas com ganhos relativos, mas principalmente com os ganhos absolutos que poderiam advir da cooperação. O progresso e o desenvolvimento econômico social seriam vistos como forças estabilizadoras no sistema internacional de modo que seria do interesse dos países desenvolvidos que os países pobres se desenvolvessem economicamente (GILPIN, 2002). Sob essa perspectiva, para se explicar a ajuda externa, o analista deveria se voltar às necessidades dos países receptores, de modo que os fluxos de ajuda externa estariam relacionados às variáveis referentes a essas necessidades como medidas de desenvolvimento socioeconômico dos países receptores. Na medida em que o desenvolvimento dos países mais pobres e vulneráveis trariam ganhos a todo o sistema.

\subsubsection{Construtivismo e o motivo humanitário}


A perspectiva construtivista nas Relações Internacionais está ligada ao papel das ideias na formulação da ação internacional dos Estados. A Cooperação para o Desenvolvimento estaria vinculada a imperativos humanitários, como a redução de pobreza no mundo em desenvolvimento em razão de compromissos éticos. Segundo Lumsdaine (1993), um dos principais expoentes do idealismo humanitário, a ajuda externa não poderia ser explicada apenas como base nos interesses políticos e econômicos dos doadores. Assim, as convicções humanitárias dos doadores desempenhariam um papel importante na formulação dos programas de assistência ao desenvolvimento pelo mundo. Ganham importância nessa visão as questões normativas na medida em que as normas refletiriam uma visão moral na política internacional (LUMSDAINE, 1993).

A premissa por trás dessa perspectiva é a de que os Estados nem sempre agem com o fim exclusivo de assegurar seus próprios interesses. No cerne do internacionalismo humanitário estaria o principio de que os governos dos países desenvolvidos teriam a obrigação moral em relação às populações dos países do mundo em desenvolvimento (STOKKE, 2013). Um elemento chave para dessa perspectiva seria o papel da opinião pública na formulação da política externa dos Estados. Na medida em que a opinião pública se mostraria favorável ao fornecimento de ajuda externa, especialmente nos países escandinavos, a prioridade de sua alocação deveria ser dada em razão das necessidades dos países receptores e não de acordo com os interesses políticos e econômicos dos doadores. O apoio à ajuda seria uma resposta à pobreza mundial que surgiu de uma preocupação humanista e, da crença de que a paz e a prosperidade em longo prazo só seriam possíveis em uma ordem internacional e justa, onde todos possam prosperar (LUMSDAINE, 1993).

O paradigma idealista está refletido nos padrões adotados para se definir a qualidade da ajuda prestada pelos doadores, especialmente no âmbito da OCDE e das Nações Unidas. A ajuda multilateral seria preferível à ajuda bilateral, dada a uma suposta natureza menos política e direcionada. A ajuda externa não deveria estar vinculada à exportação de produtos e serviços dos países doadores. Deveria ser fornecida em termos concessionais e não na forma de empréstimos a juros subsidiados. Deveria ser direcionada aos destinatários mais necessitados. E deveria ser fornecida de modo a premiar os países que apresentassem melhoras em seus indicadores sociais, de democracia, de proteção ambiental e de diretos humanos. Essa perspectiva está presente em vários programas de ajuda externa, como o canadense, que desde 1990 foi reorientado para promover o avanço de questões humanitárias, como educação feminina, saúde infantil e fortalecimento de instituições da sociedade civil 
(BELLE, 2004). Assim, para se explicar os padrões de alocação de ajuda externa, o foco deveria ser dado às necessidades dos países receptores no tocante a indicadores como qualidade de vida e proteção a direitos humanos.

\subsection{Interesses do doador ou necessidades do receptor?}

As análises sobre a CID têm presenciado uma forte polarização entre autores que defendem que a ajuda externa é fornecida segundo os interesses dos doadores, e outros que mantêm que a ajuda é uma resposta à pobreza mundial surgindo, sobretudo, por razões ética e humanas (PINO, 2006). Em uma abordagem mais empírica, uma família de literatura, utilizando métodos econométricos, buscou testar essas visões por meio da análise dos determinantes da Cooperação Norte-Sul. Um dos trabalhos seminais nessa área foi o estudo de McKinley e Little (1977) sobre os determinantes da ajuda externa fornecida pelos EUA, que estruturou a discussão em torno de dois modelos alternativos para a explicação da alocação de ajuda externa: o modelo das necessidades do receptor e o modelo dos interesses do doador. De acordo com o modelo das necessidades do receptor, a quantidade de ajuda externa fornecida para cada país de baixa renda seria proporcional às necessidades econômicas e sociais desses países (MCKINLEY; LITTLE, 1977). Especificamente, a hipótese é a de que os indicadores referentes à ajuda externa variariam conjuntamente em relação a indicadores socioeconômicos dos países receptores. Já para o modelo dos interesses do doador, a hipótese é a de que a quantidade de ajuda externa recebida por qualquer país de baixa renda seria proporcional ao nível de interesse do doador naquele país. Sendo os interesses do doador categorizados em termos de interesses econômicos, políticos e de segurança (MCKINLEY; LITTLE, 1977). A partir de análises estatísticas acerca dos fluxos da ajuda, esses autores concluíram a preponderância do modelo relativo aos interesses do doador para a explicação dos determinantes para a alocação de ajuda externa.

Assim, em relação à questão de como a ajuda é alocada no cenário internacional, a literatura é vasta e abrange as fronteiras disciplinares da Economia, da Ciência Política e das Relações Internacionais. Desde McKinley e Little (1977), a maioria dos estudos inclui variáveis de interesse do doador e de necessidades do receptor. As "necessidades" do receptor geralmente incluem renda e, em trabalhos mais recentes, medidas de democracia e direitos 
humanos ${ }^{65}$. As variáveis de interesses do doador remetem amplamente a categorias geopolíticas e econômicas. Os interesses econômicos são mais frequentemente capturados pelos fluxos comerciais e de investimentos. Pesquisadores exploraram uma variedade de variáveis geopolíticas, incluindo votações na ONU, alianças, importações de armas, ajuda de doadores rivais, ameaças de segurança à fronteira, laços coloniais com o doador e linguagem comum (FLECK; KILBY, 2010).

Maizels e Nissanke (1984) buscaram testar variações dos modelos, propostos em McKinley e Little (1977), utilizando classificações e indicadores diferentes. Seus resultados também fornecem apoio para o modelo dos interesses do doador. Com o desenvolvimento de técnicas de estimação mais sofisticadas, uma leva de trabalhos utilizou modelos levando em consideração uma série de preocupações estatísticas no tocante à análise de dados. Assim, McGillivray e Oczkowski $(1991,1992)$ analisaram os padrões de alocação da ajuda externa fornecida pela Austrália e Reino Unido. Gang e Lehman (1990) estudaram a alocação da ajuda externa americana na América Latina.

Um dos trabalhos mais relevantes dessa literatura consiste na pesquisa realizada por Alesina e Dollar (2000) sobre o padrão de alocação de ajuda externa de vários doadores. Seus resultados evidenciam o fato de que a ajuda externa seria guiada mais por interesses políticos e estratégicos dos doadores do que pelas necessidades econômicas e desempenho das instituições políticas dos países receptores (ALESINA; DOLLAR, 2000; ALESINA; WEDER, 2002). Schraeder et al (1998) analisaram os fluxos de ajuda bilateral provenientes dos Estados Unidos, Japão, França e Suécia para o continente africano durante os anos 80 e concluíram que questões econômicas e militares foram fatores decisivos para o fornecimento de ajuda e que questões humanitárias não aparentaram ser decisivas para nenhum dos doadores analisados. Ball e Johnson (1996), analisando a ajuda alimentar americana para a África entre 1971 e 1990, concluem que os maiores determinantes para a alocação da ajuda alimentar dos EUA entre os países africanos foram os fatores geoestratégicos e econômicos e que a Guerra Fria teve uma influência importante nesse processo.

Berthélemy (2006) analisou a distribuição da ajuda externa fornecida por vários países doadores entre as décadas de 80 e 90 e seus resultados mostraram que a maioria dos doadores se comporta de maneira egoísta no que diz respeito ao fornecimento de ajuda externa, na medida em que não apenas esses países utilizam essas políticas para reforçar ligações políticas com os países receptores, como também direcionam a ajuda para seus parceiros comerciais

\footnotetext{
${ }^{65}$ Alguns estudos consideram fatores humanitários adicionais, mas a disponibilidade de dados coloca limites precisos sobre a comparabilidade das análises.
} 
mais significativos. No entanto, os resultados mostram que os doadores também levam em consideração algumas necessidades e méritos dos países receptores, favorecendo, em média, os países com melhores indicadores de governança, de democracia e que apresentam maiores taxas de crescimento.

Uma série de estudos analisou o impacto do fim da Guerra Fria sobre a alocação dos fluxos de ajuda externa. Os resultados em Meernik et al. (1998) indicam que as preocupações com a segurança desempenharam um papel menor na determinação de quanto um país recebeu de ajuda dos EUA após a Guerra Fria. Bermeo (2008) analisou a alocação de ajuda externa de quatro grandes doadores, França, Japão, Reino Unido e Estados Unidos nos últimos vinte anos. Conclui que há diferenças entre fluxos recentes de ajuda externa e àqueles ocorridos ao longo dos anos 80 . Destaca que durante a guerra fria, a ajuda externa era guiada primordialmente por interesses militares e que, atualmente, essa questão ocupa um papel menor nas motivações para o fornecimento de ajuda. Aponta que interesses estratégicos continuam sendo determinantes, embora questões militares tenham perdido espaço para questões de ordem econômica. Por outro lado, Boschini e Olofsgård (2007), usando um painel de ajuda bilateral de 1970 a 1994 de doadores da OCDE, não encontraram mudanças significativas entre os períodos.

Outros buscaram analisar o impacto da Guerra ao Terror sobre a ajuda externa, Moss et al. (2005) examinaram as mudanças na distribuição dos fundos da USAID, comparando os períodos 1998-2001 e 2002-2005. A análise encontra poucas evidências de uma grande realocação resultante da geopolítica da Guerra ao Terror. No geral, eles concluem que não houve grandes mudanças na alocação de ajuda, exceto em alguns casos, que seriam atores importantes na Guerra ao Terror, como por exemplo, Iraque e Afeganistão.

Ainda sobre essa questão, Fleck e Kilby (2010) destacam, porém, que governos "conservadores" tendem a fornecer menos ajuda externa do que governos "liberais", de modo que apenas comparar os fluxos entre os dois períodos poderia levar a resultados enganosos. Portanto, destacam que o orçamento geral estadunidense para ajuda externa aumentou com a Guerra contra o Terror, assim como a ajuda países pobres de pouca importância geopolítica imediata. Ademais, apontam que o peso dado às necessidades do receptor diminuiu no período. Reversão que não seria explicada por outros desenvolvimentos, como a mudança em direção a uma maior seletividade na alocação de ajuda.

Nessa linha, Fleck e Kilby (2010) e Dreher e Fuchs (2011) enfatizam a importância da "Guerra ao Terror" no aumento recente nos orçamentos de ajuda dos doadores selecionados. 
Fleck e Kilby constataram que os Estados Unidos aumentaram significativamente seu orçamento de ajuda após os ataques terroristas de 11 de setembro de 2001. Dreher e Fuchs (2011) mostram que para 22 países doadores o esforço de ajuda aumentou durante o período da Guerra ao Terror, mas não respondeu ao real número de eventos terroristas.

Ainda sobre as motivações geopolíticas da ajuda, Dreher, Nunnunkamp e Thiele (2008) analisaram se a ajuda externa fornecida pelos Estados Unidos influenciaria os votos dos países receptores na Assembleia Geral das Nações Unidas (AGNU), encontrando fortes evidencias empíricas de que, para além dos interesses econômicos, a ajuda externa americana também serviria para comprar influência política dos receptores. Nessa linha, Kuzienko e Werker (2006) encontram evidências empíricas de que os membros não permanentes do Conselho de Segurança da ONU recebem mais ajuda externa dos Estados Unidos, especialmente em momentos de maior enfoque nessa instância de poder. Dreher, Sturm e Vreeland (2009a) mostram também que países que servem como membros temporários do CSNU têm maior probabilidade de receber projetos do Banco Mundial. Dreher, Sturm e Vreeland (2009b) mostram que os membros eleitos do CSNU também seriam mais propensos a receberem empréstimos do FMI. Além disso, seriam estabelecidas condições mais flexíveis para esses países. Lim e Vreeland (2013) destacam também que membros do CSNU receberiam mais ajuda do Banco Asiático de Desenvolvimento.

Vreeland (2011) analisa a relação entre a ajuda externa fornecida pela Suíça e a composição de sua coalizão nos diretórios executivos do FMI e Banco Mundial. Os resultados de sua pesquisa corroboram a hipótese de que os países pobres venderiam seu apoio em instituições de governança global com o intuito de obterem vantagens econômicas como ajuda externa. Na mesma linha, Kaja e Werker (2010) concluem que os países em desenvolvimento que atuam no Diretório Executivo do Banco Mundial recebem mais fundos de desenvolvimento do Banco Mundial. Como o Diretório Executivo dessa OI supervisiona todas as decisões de financiamento, um lugar na mesa poderia melhorar as chances de um país receber um projeto. Boone (1996), Bruce Bueno de Mesquita e Smith (2007) e Bearce e Tirone (2009) também avaliaram como os países utilizam ajuda externa para comprar influência junto aos governos receptores nas instituições internacionais.

Em relação aos interesses comerciais, Berthelemy e Tichit (2004) encontram uma forte influência do comércio bilateral na alocação da ajuda. De acordo com Berthelemy e Tichit (2004), tais interesses relacionados ao comércio variam entre os países doadores. Berthelemy (2006) classifica vários doadores de acordo com a elasticidade da ajuda em relação à 
intensidade do comércio bilateral. A maioria dos doadores é classificada como “moderadamente egoísta”. Dollar e Levin (2006), assim como Claessens et al. (2009), apesar de identificarem interesses comerciais na alocação de vários doadores, constatam que os esses se tornaram mais altruístas recentemente, visando a ajuda em países pobres com boas instituições e políticas econômicas. No entanto, Nunnenkamp e Thiele (2006) concluem que os interesses relacionados às exportações e os laços pós-coloniais continuam importantes.

Younas (2008) argumenta que os países da OCDE alocam mais ajuda aos países que importam bens nos quais as nações doadoras possuem vantagem comparativa. Suas estimativas indicam que uma quantidade substancialmente maior de ajuda é fornecida aos receptores que importam bens de capital, enquanto as importações por outros grupos de categoria não apresentam efeitos significativos. Dado que as nações doadoras desenvolvidas são os principais produtores e exportadores de bens de capital, esse resultado corrobora o modelo dos interesses do doador, em seu aspecto comercial. O autor aponta também que os doadores parecem estar mais preocupados em aliviar as misérias físicas, como mortalidade infantil e recompensar as boas condições de direitos humanos, do que em reduzir as dificuldades econômicas dos receptores, como a pobreza em geral. Destacam, portanto, que as considerações políticas e estratégicas usuais dos doadores continuam sendo os principais determinantes da alocação da ajuda mesmo na era pós-guerra fria.

Quanto aos determinantes domésticos, vários autores esperam que políticos de esquerda apoiem mais a ajuda externa do que os políticos de direita (THÉRIEN; NOËL, 2000; MILNER; TINGLEY, 2010). As ideias socialistas e socialdemocratas preveem a intervenção do governo para redução da desigualdade por meio da redistribuição de renda e riqueza. De acordo com as ideias conservadoras, a intervenção do governo deveria ser mantida em níveis mínimos, evitando a interferência nos mercados. Estando menos preocupados com a desigualdade interna, os conservadores seriam menos predispostos a gastar com a ajuda externa como meio de reduzir a desigualdade mundial (NOËL; THÉRIEN, 1995).

Entretanto, Dreher, Nunnenkamp e Schmaljohann (2015) apontam que a dicotomia de uma esquerda "pró-ajuda" e de uma direita "contra a ajuda" pode ser excessivamente simplista. Dois argumentos principais foram avançados na literatura sobre por que governos de esquerda não necessariamente forneceriam mais ajuda externa. As motivações altruístas da ajuda não se limitam às tradições socialistas de redistribuição. Os governos conservadores podem ser tão generosos quanto os socialistas, uma vez que as raízes cristãs também pedem solidariedade internacional (THÉRIEN; NOËL, 2000). Além disso, pode-se esperar que os 
governos conservadores favoráveis aos negócios privados concedam ajuda para fomentar os interesses econômicos de seus apoiadores políticos, por exemplo, usando a ajuda como um meio de promoção de exportações (ROUND; ODEDOKUN, 2004).

Thérien e Noel (2000), assim como Chong e Gradstein (2008), concluem que os governos de esquerda concedem mais ajuda. Brech e Potrafke (2014) corroboram esse resultado para a ajuda bilateral, embora não para outras formas de auxílio. As variáveis referentes à ideologia do partido mostraram-se insignificantes na análise do esforço de ajuda dos doadores por Lundsgaarde et al. (2010). Segundo alguns estudos, no entanto, o esforço global de ajuda dos governos de direita é ainda mais forte do que o dos governos de esquerda em determinados contextos (ROUND; ODEDOKUN, 2004; GOLDSTEIN; MOSS, 2005). Tingley (2010) conclui que os esforços de ajuda a países receptores de renda média não são afetados quando governos conservadores estão no poder nos países doadores, embora governos conservadores concedam menos ajuda a países de renda baixa do que governos de esquerda.

Em geral, nota-se que os resultados empíricos são inconclusivos em relação ao efeito da ideologia política na solidariedade internacional. Na medida em que essas conclusões parecem variar de acordo com a amostra e o método de estimação (FUCHS; DREHER; NUNNENKAMP, 2014). Às vezes os partidos de esquerda parecem mais generosos (TINGLEY, 2010); outras vezes, os governos conservadores parecer alocar mais ajuda (LECTURER; FELLOW, 2005; DREHER; NUNNENKAMP; SCHMALJOHANN, 2015). Algumas evidências sugerem que atores "progressistas" e "conservadores" enviam ajuda por diferentes razões (FLECK; KILBY, 2006a, 2006b; MILNER; TINGLEY, 2010; BRECH; POTRAFKE, 2014). Greene e Licht (2018) defendem que tanto partidos de esquerda quanto de direita utilizam ajuda externa como uma ferramenta para perseguir objetivos de política externa, dependendo de suas preferências no engajamento com o resto do mundo. Defendem que governos de esquerda tenderiam a fornecer mais ajuda com motivações humanitárias, enquanto governos conservadores favoreceriam mais ajuda com motivações comerciais.

Em suma, grande parte da literatura sobre alocação de ajuda tem se concentrado nos interesses do doador versus as necessidades do receptor como determinantes da distribuição da ajuda. Na literatura de Relações Internacionais, essa dicotomia costuma ser apresentada como explicações neorrealistas versus idealistas na explicação dos fluxos de ajuda externa. Em geral, os pesquisadores encontraram interesses geopolíticos e comerciais particularmente importantes para os EUA (ALESINA; DOLLAR, 2000). Interesses comerciais 
particularmente importantes para o Japão (SCHRAEDER; HOOK; TAYLOR, 1998; ALESINA; DOLLAR, 2000; TUMAN; EMMERT; STERKEN, 2001; TUMAN; AYOUB, 2004; TUMAN; STRAND, 2006) e preocupações humanitárias particularmente importantes para pequenos doadores, nomeadamente Canadá, Países Baixos, Dinamarca, Noruega e Suécia (STOKKE, 1989; ALESINA; DOLLAR, 2000). Vários estudos da ajuda bilateral japonesa consideram se a política japonesa reagiria à pressão dos EUA (gaiatsu) com resultados positivos para África (HICKMAN, 1993; TUMAN; AYOUB, 2004), resultados mistos para a América Latina (KATADA, 1997; TUMAN; EMMERT; STERKEN, 2001), mas nenhuma evidência para a Ásia (TUMAN; STRAND, 2006).

Em relação à ajuda multilateral, trabalhos anteriores encontram uma maior ênfase nas necessidades dos receptores em comparação com a ajuda bilateral como um todo (ALESINA; DOLLAR, 2000; BURNSIDE; DOLLAR, 2000) ${ }^{66}$. No entanto, vários estudos de empréstimos do Banco Mundial revelam padrões de aparente influência do doador (FREY; SCHNEIDER, 1986; WECK-HANNEMANN; SCHNEIDER, 1988; FLECK; KILBY, 2006a) e da ONU (ANDERSEN et al., 2006). Neumayer (2003) analisou a ajuda fornecida por várias instituições multilaterais: Banco Africano de Desenvolvimento, Banco Asiático de Desenvolvimento, Banco Interamericano de Desenvolvimento, PNUD, UNICEF e do Programa Regular das Nações Unidas para Assistência Técnica (UNTA, em inglês). Os resultados indicam que a maioria dos doadores exibe um viés aparente em favor de países menos populosos e mais distantes geograficamente dos centros do mundo ocidental. Enquanto os bancos regionais de desenvolvimento focam mais na necessidade econômica, as três agências das Nações Unidas também levam em conta o desenvolvimento humano em sua alocação de ajuda. Alguns indícios são encontrados de que o respeito pela liberdade política é recompensado com maior recebimento de ajuda no nível multilateral agregado. Por fim, apontam que nem o respeito aos direitos humanos nem os baixos níveis de corrupção percebida desempenham qualquer papel na distribuição da ajuda pelos doadores.

Em relação aos chamados "novos doadores”, Dreher, Fuchs e Nunnemkamp (2013) destacam que a literatura acerca da ajuda internacional fornecida fora do CAD/OCDE ainda é escassa. Embora existam muitas evidências sistemáticas sobre os padrões de alocação de ajuda dos doadores tradicionais, as evidências empíricas são relativamente escassas para os doadores fora do âmbito do CAD. Vale destacar que a análise de doadores não integrantes do CAD só se tornou possível recentemente, na medida em que dados detalhados acerca de seus

\footnotetext{
${ }^{66}$ Embora Canavire et al. (2006) não encontre essa relação.
} 
programas de ajuda internacional foram sendo disponibilizados. Nesse sentido, baseando-se nos dados do projeto AidData (TIERNEY et al., 2011), Dreher, Nunnenkamp e Thiele (2011) avaliam a alocação de ajuda de 16 doadores não pertencentes ao CAD durante o período de 2001-2008. Dreher e Fuchs (2011a) se concentram na China, Fuchs e Vadlamannati (2012) na Índia, Kim e Oh (2012) na Coréia do Sul e Fuchs e Klann (2012) na ajuda emergencial de 105 doadores (83 não CAD).

Assim, essa literatura vem buscando discutir os vários motivos para a concessão de ajuda por parte desses países. Quanto às necessidades do receptor, espera-se que os doadores emergentes direcionem sua ajuda de forma mais efetiva do que os doadores tradicionais do CAD, na medida em que vários "novos" doadores foram receptores de ajuda até recentemente ou ainda o são. Os "novos" doadores poderiam, assim, ter uma melhor compreensão das necessidades dos receptores (DREHER; NUNNENKAMP; THIELE, 2011). Isso também poderia levar os "novos" doadores a desempenhar um papel importante na resolução pósconflito e no socorro a desastres (HARMER; COTTERRELL, 2005).

A principal diferença entre as decisões para alocação de ajuda dos doadores do CAD e fora do CAD pode ser o conceito de "mérito". O "mérito" seria avaliado pelos doadores ocidentais como a qualidade das instituições e políticas econômicas dos países receptores e usado como justificativa para decisões de alocação de ajuda. Por outro lado, a tendência dos grandes doadores que não integram o CAD em fornecer ajuda sem quaisquer amarras significaria que muitas vezes esse "mérito" não seria considerado. A China, em particular, é amplamente vista como prestadora de assistência "sem palestras ocidentais sobre governança e direitos humanos" (THE ECONOMIST, 2010). Isto sugere que a ajuda dos principais doadores não membros do CAD não deve ser afetada pelas estruturas de governança dos países beneficiários. Podendo até acontecer que os "novos" doadores se concentrem nos países beneficiários particularmente "mal governados", a fim de preencher uma lacuna deixada pelos doadores do CAD.

Quando se trata do interesse dos doadores, os doadores CAD e fora do CAD parecem atuar de acordo com seus próprios interesses dados os padrões de alocação de sua ajuda. Os principais países do CAD foram frequentemente acusados de fornecer ajuda principalmente como meio de promover seus interesses econômicos ou de recompensar aliados políticos (ALESINA; DOLLAR, 2000). Dreher, Nunnemkamp e Thiele (2011) destacam que os principais "novos" doadores também não são altruístas em seu comportamento de doação. O principal "vilão" entre os "novos" doadores, conforme identificado pela literatura existente, 
seria a China (DREHER; FUCHS, 2011). Entre outros, a busca de interesses políticos e comerciais também foi atribuída à Índia (KRAGELUND, 2008), países árabes (NEUMAYER, 2004; VILLANGER, 2007) e Venezuela (NAIM, 2007).

Woods (2008) observa que a busca por segurança energética, oportunidades comerciais ampliadas e novas parcerias econômicas são motivos comuns para a maioria dos doadores não pertencentes ao CAD. Fuchs e Vadlamannati (2012) levantam a hipótese de que o interesse próprio é um motor particularmente importante da ajuda na perspectiva dos países doadores mais pobres, dados os problemas de desenvolvimento que um doador "necessitado" continuaria a enfrentar internamente. Para obter o apoio do eleitorado para programas de ajuda, os doadores pobres teriam que enfatizar os próprios benefícios esperados.

As considerações teóricas ambíguas mencionadas acima exigem uma análise rigorosa dos dados. Dreher et al. (2011) fornecem uma primeira tentativa para avaliar a alocação de ajuda por 16 doadores não membros do CAD durante o período de 2001-2008. Seus resultados indicam que os "novos" doadores são menos sensíveis às necessidades dos seus destinatários do que os doadores do CAD. Doadores "novos" e "velhos" parecem se comportar de maneira semelhante em outros aspectos. Por exemplo, os dois grupos não contabilizam o nível de corrupção do país destinatário. As limitações de dados, no entanto, impediram a inclusão da Índia e da China, dois dos doadores quantitativamente mais importantes fora do CAD.

Kim e Oh (2012) compara a alocação da ajuda dos países do CAD com a ajuda fornecida pela Coreia do Sul. Os resultados indicam que a ajuda coreana não está correlacionada com o desenvolvimento socioeconômico ou a pobreza nos países receptores. Essa falta de orientação para o combate à pobreza se assemelha aos resultados de Dreher et al. (2011). Dreher e Fuchs (2011a) são os primeiros a analisar empiricamente a alocação da ajuda da China. Seu estudo baseia-se em dados para os fluxos totais de ajuda, ajuda a projetos, equipe médica e ajuda alimentar. Seus resultados mostram que as considerações políticas orientaram as decisões de alocação de ajuda da China durante toda a história de seu programa de ajuda. Ao comparar com outros doadores, no entanto, a distribuição de ajuda da China mostra-se não mais estratégica do que a de qualquer outro país. Uma desvantagem do estudo é a medida imprecisa da ajuda da China, já que a análise principal se baseia no número de 
projetos concluídos em um determinado ano e país. Não levando em conta o valor monetário dos projetos realizados ${ }^{67}$.

Fuchs e Vadlamannati (2012) se concentram na Índia. A alocação da ajuda da Índia é particularmente intrigante, já que quase metade dos beneficiários da ajuda do país tem um PIB per capita maior do que a própria Índia. Os resultados empíricos confirmam que a alocação da ajuda da Índia é mais estratégica do que a dos doadores do CAD, e menos orientada para os beneficiários necessitados. Infelizmente, o estudo limita-se à ajuda fornecida pelo Ministério das Relações Exteriores da Índia, potencialmente influenciando os resultados. Fuchs e Klann (2012) analisam a ajuda emergencial prestada por 105 doadores. Eles comparam a importância de diferentes motivos para a atribuição de ajuda entre os membros e não membros do CAD, países de alta renda e doadores menos desenvolvidos, e democracias e regimes autoritários. Seus resultados mostram que tanto os doadores do CAD como os fora do CAD proveem ajuda de acordo com seus próprios interesses, mas também levando em conta as necessidades humanitárias dos receptores.

Apolinário Júnior $(2014,2016)$ analisa os padrões de "ajuda" brasileira ao longo da primeira década dos anos 2000 com base nos dados do projeto AidData. Apesar das limitações dos dados, os resultados apontam para interesses políticos na alocação da cooperação brasileira. A principal hipótese testada é de que países que apoiam o Brasil nas organizações financeiras internacionais, como o FMI, receberiam mais cooperação do Brasil dados os demais fatores constantes. Assim, os resultados do estudo, mesmo ao controlar para uma série de fatores que poderiam influenciar a alocação desses fluxos, parecem corroborar essa hipótese. No entanto, outros determinantes políticos, como apoio em outras organizações internacionais, ou econômicos, como IED e cooperação financeira, não são analisados.

Hardt, Mouron e Apolinário Júnior (2017) analisando os fluxos de alocação da Cooperação Técnica brasileira para o período de 2000 a 2016, verificam o impacto de alguns determinantes políticos nessa alocação, como apoio em instituições financeiras internacionais, como FMI e Banco Mundial, e votações na Assembleia Geral das Nações Unidas (AGNU). O estudo encontra uma relação entre apoio político no cenário internacional e recebimento de CT. Entretanto, o estudo se limita aos determinantes políticos, não explorando possíveis interesses econômicos na alocação da CT brasileira.

Dessa forma, analisando em conjunto, a alocação de ajuda por doadores "novos" e "tradicionais" parece seguir regras semelhantes. Assim, as diferenças observadas até o

\footnotetext{
${ }^{67}$ Mais recentemente, novos dados foram classificados e levantados acerca da ajuda chinesa (STRANGE et al., 2017).
} 
momento não justificam a marca de doadores fora do CAD como "doadores desonestos" e auto interessados, se a alocação de ajuda pelos doadores do CAD for o ponto de referência. Como os dados disponíveis são incompletos, pesquisas futuras usando dados mais completos se tornam de grande importância.

\subsection{Cooperação para o Desenvolvimento: conceitos e classificação}

A Cooperação para o Desenvolvimento é um conceito complexo e de difícil operacionalização. Para evitar repetição, esse trabalho utiliza os termos ajuda, ajuda externa, ajuda internacional, ajuda ao desenvolvimento, assistência ao desenvolvimento e cooperação para o desenvolvimento de forma intercambiável. Entretanto, por razões técnicas e políticas, diferentes países adotaram concepções distintas acerca de como se mensurar tais práticas. Os países em desenvolvimento, fora do âmbito da OCDE, como o Brasil, por exemplo, buscam se distanciar do conceito de ajuda externa utilizado pelo Comitê de Ajuda ao Desenvolvimento da Organização para a Cooperação e Desenvolvimento Económico (CAD/OCDE). O Brasil, entre outros países em desenvolvimento, rejeita as terminologias referentes a "doador", "ajuda" e "assistência"68, partilhando da definição dada pela Confederação das Nações Unidas sobre Comércio e Desenvolvimento (UNCTAD) de cooperação como os processos, instituições, acordos, designados para promover a cooperação política, econômica e técnica entre países em desenvolvimento que buscam o desenvolvimento comum em uma relação horizontal (MILANI; CARVALHO, 2013). Essa diferença, além da mera terminologia, traz consigo uma metodologia diversa no tocante à contabilização dos valores gastos com essas práticas (IPEA/ABC, 2010, 2013, 2016), como será discutido no capítulo 4.

Quanto à classificação, Afonso (2005) aponta que a CID pode ser dividida entre quatro categorias básicas, de acordo com a origem, canais de execução, o nível de desenvolvimento dos países e seus instrumentos. Quanto à origem, a cooperação pode ser pública, realizada com recursos governamentais, ou privada, financiada por empresas, organizações não governamentais e indivíduos. Em relação aos canais de execução, a cooperação pode ser bilateral ou multilateral, dependendo do número de atores envolvidos no processo. Em relação ao nível de desenvolvimento dos países, a cooperação pode ser realizada entre países desenvolvidos e países em desenvolvimento - Cooperação Norte-Sul ou Cooperação Vertical -

\footnotetext{
${ }^{68}$ Ver o glossário de termos estatísticos da OCDE (OECD, 2018d).
} 
entre países em desenvolvimento - Cooperação Sul-Sul ou Cooperação Horizontal e a partir da triangulação entre países desenvolvidos, em desenvolvimento e subdesenvolvidos Cooperação Norte-Sul-Sul ou triangular. E de acordo com seus instrumentos, a Cooperação para o Desenvolvimento pode ser dividida em Cooperação Técnica (CT), Cooperação Financeira (CF) e Assistência Humanitária $(\mathrm{AH})$, embora não haja um consenso na literatura em relação a essa classificação.

\subsubsection{Cooperação Técnica}

A Cooperação Técnica se constitui como uma das modalidades mais importantes da Cooperação para o Desenvolvimento. Foi instituída formalmente pela Assembleia Geral das Nações Unidas, por meio da Resolução $\mathrm{n}^{\circ}$ 200, de 1948, recebendo incialmente a denominação de "Assistência Técnica". Com os processos de descolonização e o consequente ingresso de novos países surgiriam as primeiras críticas ao aspecto assistencialista da assistência técnica fornecida até então. Diante dessa nova conjuntura, os países em desenvolvimento se articularam e pressionaram para que houvesse uma mudança na terminologia utilizada para referir-se a essas práticas. Como resultado dessas demandas, a ONU reviu no final dos 1950 o conceito de "Assistência Técnica" substituindo-o pela expressão "Cooperação Técnica" que pressuponha a existência de interesses mútuos em uma relação mais igualitária (CERVO, 1994; ANTONINI; HIRST, 2009).

O conceito de Cooperação Técnica, embora tenha evoluído ao longo dos anos, ainda estão longe de ser matéria pacífica e de possuir um entendimento universal. De acordo com a definição da UNESCO, agência das Nações Unidas, a Assistência Técnica seria:

\footnotetext{
non-financial assistance provided by local or international specialists. It can take the form of sharing information and expertise, instruction, skills training, transmission of working knowledge, and consulting services and may also involve the transfer of technical data. The aim of technical assistance is to maximize the quality of project implementation and impact by supporting administration, management, policy development, capacity building, etc (UNESCO, 2008).
}

De acordo com o glossário de termos e definições da OCDE, a Cooperação Técnica consistiria de: 
personnel as well as teachers and administrators serving in recipient countries, (including the cost of associated equipment). Assistance of this kind provided specifically to facilitate the implementation of a capital project is included indistinguishably among bilateral project and programme expenditures, and not separately identified as technical co-operation in statistics of aggregate flows (OECD, 2018a).

Quanto à sua operacionalização, o Grupo de Trabalho sobre Estatísticas das Finanças ao Desenvolvimento do $\mathrm{CAD} / \mathrm{OCDE}$, no relatório sobre as diretivas para elaboração de estatísticas, destaca que:

427. The term technical co-operation covers a large variety of aid activities. Some technical co-operation is extended in the form of projects (type of aid C01). As their administration does not differ from that of other project-type interventions, they should be reported individually following instructions in section II above. 428. Non-project technical co-operation comprises activities such as the supply of volunteers or experts (type of aid D01), other technical assistance (D02), provision of scholarships (E01) and imputed student costs (E02). Many of these activities are funded through specific TC budget lines, which may or may not be administered by the main aid agency. The exact use of funds is seldom known at the commitment stage. Consequently, data on the sectoral and geographical breakdown of such programmes are often collected on a disbursement basis only. As disbursement data can be very detailed (one "activity" corresponding to one individual expert or student), aggregation by recipient and sector (purpose code) is recommended prior to reporting to the CRS (OECD, 2018b, p. 93).

A partir dessas definições, nota-se que a Cooperação Técnica se apresenta em diversos formatos. Podendo ser utilizada para prover estudos acerca de determinada realidade local, fornecer educação para residentes de outra nacionalidade, formar ou capacitar quadros técnicos de outro país, ou ser utilizada de modo mais gerar para fortalecer as capacidades institucionais de um determinado Estado. No geral, as ações de Cooperação Técnica envolvem algum tipo de transferência de conhecimento, técnicas ou práticas do país doador da cooperação para o país receptor.

\subsubsection{Cooperação Financeira}

Transferências financeiras são o que a maioria das pessoas imagina quando se fala em ajuda externa. É historicamente uma das modalidades mais utilizadas pelos doadores para prover Cooperação Internacional para o Desenvolvimento. A Cooperação Financeira é constituída de diversas práticas sendo as mais comuns os investimentos a fundo perdido, as 
doações diretas de bens ou capital e fornecimento de empréstimos em termos mais favoráveis do que aqueles geralmente disponíveis no mercado. Afonso e Fernandes (2005) distinguem entre dois tipos de Cooperação Financeira, a "ajuda projeto" e a "ajuda programa".

A “ajuda projeto" diz respeito a uma intervenção precisa e direta no país receptor por meio da realização de algum projeto específico. Pode ser gerida por meio do governo doador, em que o país doador tem o controle sobre o planejamento e execução do projeto. Pode ser gerida pelo governo receptor, em que os fundos disponibilizados são manejados pelo receptor. Geralmente os doadores exigem normas de contabilidade específicas para a utilização desses recursos e impõem algumas condições sobre as formas como esses fundos devem ser aplicados. A ajuda projeto também pode ser gerida por meio de uma Organização NãoGovernamental ou alguma entidade privada. Nessa modalidade, o doador fornece os recursos a alguma entidade não governamental, financiando a execução de algum projeto específico (AFONSO; FERNANDES, 2005).

Historicamente, a ajuda na forma de "projeto" foi uma das vertentes de Cooperação mais utilizadas pelos doadores, especialmente nas primeiras décadas de fornecimento de ajuda externa. Havia a crença de que os projetos seriam a forma mais eficiente de sanar os problemas dos países receptores referentes à deficiência de capital. Ademais, acreditava-se que os projetos seriam uma maneira de evitar com que os recursos disponibilizados pelos doadores fossem desviados para outros fins por parte do governo do país receptor. Assim, em meados dos anos 70, um pouco mais da metade, $52 \%$ de toda a ajuda fornecida pelos países da OCDE consistia em ajuda projeto, sendo que a maioria desses recursos era destinada para projetos em de infraestrutura, como estradas, malha ferroviária, obras de saneamento, portos, aeroportos e estações de telecomunicações (AFONSO; FERNANDES, 2005).

Com o passar dos anos, os problemas referentes a esse tipo de cooperação começaram a se tornar mais evidentes. As críticas iam ao sentido de que tal tipo de cooperação não estimulava o fortalecimento institucional e os fatores endógenos ao desenvolvimento dentro do país receptor. Com as crises dos anos 70 e 80 e a consequente mudança no pensamento dominante referente ao desenvolvimento e nas práticas de fornecimento de ajuda por parte do mundo desenvolvido, a ajuda projeto começa a dar lugar à "ajuda programa", outra modalidade de cooperação financeira. Embora a "ajuda projeto" continue sendo realizada até os dias de hoje por parte dos países doadores. A discussão atual referente a essa modalidade vai ao sentido de fazer com que esses projetos façam parte de uma política nacional dos países 
receptores de modo que os projetos ocorram de forma coordenada com a política de desenvolvimento do receptor (AFONSO; FERNANDES, 2005).

A “ajuda programa" seria aquela destinada ao receptor para fins de desenvolvimento, em geral, não direcionada a um projeto específico. Incluiria os recursos voltados a apoiar o orçamento do país receptor, sua balança de pagamentos e seus programas de modo geral. A OCDE divide a "ajuda programa" em quatro categorias: i) ajuda geral a programas, ii) ajuda setorial a programas, iii) ajuda alimentar programa e iv) alívio da dívida. A ajuda geral a programas seriam os recursos colocados à disposição de um país sem serem destinados a um programa específico. Seus objetivos seriam mais gerais, sendo essa ajuda especialmente destinada ao financiamento da balança de pagamentos, o apoio geral ao orçamento e a ajuda financeira em espécie. Os programas de ajuste estrutural realizados no âmbito do FMI e Banco Mundial também se encontram nessa categoria. A ajuda setorial a programas seria a ajuda destinada a um setor econômico ou social específico, como saúde, educação e agricultura. A ajuda alimentar programa seria voltada a promover segurança alimentar nos receptores por meio da transferência recursos financeiros para aquisição de alimentos. Por fim, a ajuda voltada ao "alívio da dívida" teria justamente o objetivo de melhorar o perfil de dívida dos países muito endividados. A redução oficial da dívida passa geralmente pelo "Clube de Paris" sendo tratada caso a caso como complemento de reformas políticas e econômicas nos receptores (AFONSO; FERNANDES, 2005).

\subsubsection{Ajuda humanitária}

A ajuda humanitária seria a ajuda voltada para questões emergenciais. Não há uma definição consensual entre os doadores acerca de sua definição, embora seja uma modalidade que tenha ganhado cada vez mais importância nos últimos anos. No geral, considera-se ajuda humanitária como o auxílio de curto prazo voltado a salvar vidas de modo emergencial. Assim, teria como objetivo primordial preservar vidas humanas em situação de emergência, como consequência de catástrofes naturais ou de conflitos. Possui um caráter pontual e limitado, ocorrendo sob a forma de envio de alimentos, materiais de primeira necessidade como roupas e medicamentos, e equipes médicas. Insere-se nessa categoria também a ajuda voltada a refugiados e deslocados, com o objetivo de fazer frente às consequências negativas de grandes deslocamentos populacionais, auxiliando essas populações até seu estabelecimento definitivo. 
O CAD/OCDE classifica a ajuda humanitária em "reposta emergencial", em que a emergência poderia resultar de uma crise causada pela ação humana ou por desastres naturais. A assistência humanitária seria realizada no intuito de salvar vidas, buscando aliviar o sofrimento e manter a dignidade humana após conflitos, choques e desastres naturais (OECD, 2018c). Nos últimos anos, em especial após os atentados de 11 de setembro de 2001, esse tipo de ajuda, antes reservada preferencialmente às agências especializadas das Nações Unidas, a ONGs e a entidades filantrópicas, passou a ser utilizada de forma mais sistemática pelos países doadores. No âmbito bilateral, passa a integrar o conjunto de temas de interesse de política externa dos países desenvolvidos e, também, em alguns casos, de países em desenvolvimento (PUENTE, 2010).

\subsubsection{Ajuda alimentar}

A ajuda alimentar inclui a doação de recursos, sob a forma de alimentos, bens relativos à produção de alimentos e créditos concessionais destinados à compra de alimentos para países com graves problemas de segurança alimentar. De acordo com Afonso e Fernandes (2005), pode apresentar-se em três modalidades: i) ajuda alimentar programa, ii) ajuda alimentar projeto, iii) ajuda alimentar de emergência. A ajuda alimentar programa envolve a transferência, comumente na forma de alimentos, de governo a governo, para sua venda no mercado. De modo que os fundos dessas transações sejam utilizados para o financiamento de programas específicos, geralmente voltados à segurança alimentar. A ajuda alimentar para projetos é fornecida para apoiar atividades específicas de alívio da pobreza e prevenção de desastres, direcionadas a grupos ou áreas específicas de beneficiários. Geralmente se destina à doação de alimentos ou recursos voltados à aquisição de alimentos para projetos com objetivos e foco bem definidos, como por exemplo, projeto de alimentação em escolas, hospitais ou para grupos de refugiados. Por fim, a ajuda alimentar de emergência consiste na doação de alimentos em caráter de urgência às vítimas de catástrofes naturais ou provocas pelo homem, fazendo parte da Ajuda Humanitária nesse caso.

Na prática, entretanto, nota-se que é cada vez mais difícil fazer essa distinção entre as três modalidades, especialmente, em situação de crises (OCDE, 2018e). Essa modalidade de ajuda levantou muitas críticas ao longo das décadas. Especialmente no sentido de que a mesma seria direcionada para fins políticos, aumentando a relação de dependência do receptor para com o doador, geraria alterações nas dietas tradicionais das populações dos países 
receptores, seria uma forma de promover o alargamento dos mercados agrícolas dos doadores e, principalmente, que geraria muitas distorções nocivas nos mercados agrícolas dos países receptores, na medida em que reduziria os preços dos alimentos no mercado doméstico desestimulando a produção local.

Embora a Ajuda Alimentar exista formalmente desde os fins da $2^{\mathrm{a}}$ Guerra Mundial, seu fornecimento passou por uma expansão significativa nos anos 60 e 70. Nos anos 80, foram realizadas mudanças significativas pelos doadores no tocante a essa modalidade de ajuda, com o intuito de tentar sanar os problemas recorrentes dessas práticas. Nos anos 90, a proporção da ajuda alimentar em relação ao total de ajuda externa passou por uma significativa redução. De acordo com Afonso e Fernandes (2005), passando de 20\% da ajuda externa total em 1972, para 12,5\% em 1981, 6\% em 1990 e 1,9\% em 2002. No entanto, nos últimos anos, em função da revisão da doutrina sobre segurança alimentar essa modalidade voltou ganhar relevo, tendo sido fornecidos 3,7 bilhões de dólares em ajuda alimentar no ano de 2016 segundo a OCDE (OECD, 2018e).

\subsection{Definição e classificação da Cooperação Norte-Sul do CAD/OCDE}

Essa seção apresenta as definições oficiais do CAD/OCDE acerca da classificação e conceptualização da ajuda externa. O CAD é o principal fórum de discussão onde os países doadores, membros da OCDE, buscam harmonizar suas práticas de Cooperação Internacional para o Desenvolvimento. Primeiramente chamado de Grupo de Assistência ao Desenvolvimento (GAD), o comitê foi estabelecido em 13 de janeiro de 1960 sob os auspícios da antiga OEEC, organização criada sob o Plano Marshall, precursora da OCDE. A primeira preocupação do GAD foi estabelecer um parâmetro comum para os países membros reportarem seus fluxos de ajuda ao desenvolvimento. Em março de 1961, o GAD publica seu primeiro relatório, The Flow of Financial Resources to Countries in Course of Economic Development, 1956-59 (FUMAGALLI, 1963), no tocante à mensuração dos fluxos de ajuda externa que definiu muitas das diretrizes utilizadas até hoje, apesar de algumas revisões ${ }^{69}$. No mesmo ano, conforme a OCDE é criada para substituir a OEEC, o CAD surge como sucessor do GAD. Assim, a Resolução Ministerial de 23 de julho de 1960 estabelece como mandato do CAD o compromisso de continuar as consultas acerca dos fluxos de assistência ao desenvolvimento junto aos doadores (FÜHRER, 1996).

\footnotetext{
${ }^{69}$ Em 1966, por exemplo, o Comitê decidiu excluir todo tipo de ajuda militar do sistema de estatísticas e focar em recursos que teriam o desenvolvimento econômico e social como objetivo (OCDE, 2011).
} 
Com a criação do CAD, a mensuração dos fluxos de ajuda externa entre países do Norte e do Sul passa a ganhar contornos cada vez mais bem delineados ${ }^{70}$. Assim, as diretrizes que orientaram as práticas da Cooperação Internacional para o Desenvolvimento realizadas pelos países desenvolvidos foram sendo definidas em torno do CAD. Por meio de reuniões periódicas, eram produzidas as declarações políticas que poderiam virar recomendações formais aos seus membros sem caráter vinculante. A partir dessa organização, também eram realizados os processos de revisão entre pares no intuito de acompanhar as políticas de cada membro no tocante à ajuda externa e monitorar se os compromissos estavam sendo cumpridos.

Ao longo dos anos 1960, os recursos destinados aos países em desenvolvimento consistiam de diversos tipos de financiamento ${ }^{71}$. Restava cada vez mais evidente que algumas dessas modalidades acentuavam as assimetrias globais, de modo que se tornava cada vez mais necessário o estabelecimento de uma medida padronizada para a definição do que poderia ser considerado crédito concessional. Embora essa necessidade refletisse a busca da instituição por mais efetividade da ajuda, também era resultante da pressão por parte dos países receptores, organizados no Grupo dos 77 e na UNCTAD, para que os recursos disponibilizados fossem feitos com maior grau de concessionalidade e a condições mais favoráveis (HYNES; SCOTT, 2013).

\subsubsection{A Assistência Oficial ao Desenvolvimento (AOD)}

Em 1969, o CAD adota o conceito de "Assistência Oficial ao Desenvolvimento (AOD)", separando a ajuda oficial de outros fluxos financeiros ${ }^{72}$. Em 1972, o CAD estabelece uma definição mais rígida para a ODA, válida até os dias de hoje. De acordo com essa definição a ODA consistiria de:

Fluxos para países em desenvolvimento e instituições multilaterais fornecidos por agências oficiais, incluindo governos estaduais e locais, ou por suas agências executivas, atendendo aos seguintes critérios: a) administrado com a promoção do desenvolvimento econômico e do bem-

\footnotetext{
${ }^{70}$ Embora o CAD tenha surgido como uma agência especializada no âmbito da OCDE, nem todos os membros da OCDE fazia parte desse Comitê.

${ }^{71}$ Empréstimos, doações, financiamento associado, investimentos privados, créditos de exportação, etc.

${ }^{72}$ Negociações no Grupo Ad Hoc sobre Problemas Estatísticos resultaram na retirada dos créditos de exportação. Através de consenso, o GT determinou que fluxos privados e públicos ficassem claramente separados nas estatísticas, através das categorias de Ajuda Oficial ao Desenvolvimento5, Outros Fluxos Oficiais (OFO) e Fluxos Privados. (HYNES; SCOTT, 2013)
} 
estar dos países em desenvolvimento como seu principal objetivo, e b) tem caráter de concessão e contém um elemento de doação de pelo menos $25 \%$ (calculado a uma taxa de desconto de 10\%) (FÜHRER, 1996, p. 24)

Nessa época, a publicação do Relatório "Parceiros no Desenvolvimento", conhecido como Relatório Pearson, traz a recomendação para seus membros fixarem em $0,7 \%$ do PNB o montante de sua AOD. Seguindo essa recomendação, a Assembleia Geral das Nações Unidas adotou uma resolução da qual os países desenvolvidos se comprometiam com $0,7 \%$ de seus PNBs para a AOD (FÜHRER, 1996; HYNES; SCOTT, 2013).

Ao longo dos anos 1970, outros componentes entram no conceito de Ajuda Oficial ao Desenvolvimento como concessões empréstimos e cooperação técnica. Em 1978, é realizada uma nova revisão dos critérios da AOD, aumentando o valor de referência para crédito concessional para 86\%. Em 1979, foram incluídos os custos referentes à sensibilização da opinião pública para o fornecimento de Cooperação para o Desenvolvimento (SILVA et al., 2016). Em 1984, são inseridos os gastos referentes ao fornecimento de bolsas de estudo de ensino superior a estudantes oriundos de países do mundo em desenvolvimento. Em 1988, passam a ser considerados os gastos referentes ao apoio de refugiados nos países doadores (HYNESS; SCOTT, 2013). Nos últimos anos, foram estabelecidas diversas modalidades, setores e instrumentos da ajuda externa no âmbito do CAD.

Tabela 3.5.1.1. Canais, modalidades e categorias da Ajuda Oficial ao Desenvolvimento (AOD)

\section{Canais}

-Instituições do setor público

-Organizações não-governamentais (ONGs) e sociedade civil

-Parcerias público-privadas (PPP) e redes

-Organizações multilaterais

-Universidade, centros de ensino e/ou pesquisa ou think-tanks

-Instituições do setor privado

-Outros

\section{Modalidades}

-Apoio orçamentário

-Contribuições e fundos e programas comuns

-Projetos

-Especialistas ou outra assistência técnica

- Bolsas de estudo e custos de estudantes nos países doadores

-Alívio de dívida

•Custos administrativos não incluídos 
- Outros gastos incluídos aos doadores

\section{Setor}

-Infra-estrutura social e serviços (cobrindo educação, saúde, população, água, governo e sociedade civil)

-Infra-estrutura econômica e serviços (cobrindo transporte, comunicações, energia, serviços bancários e financeiros, serviços empresariais)

-Produção (cobrindo agricultura, silvicultura, indústria, pesca, mineração, construção, comércio e turismo)

-Multissetoriais ou transversais (cobrindo proteção ambiental e outros multi-setores como desenvolvimento urbano e rural)

-Sem classificação (para contribuições não classificáveis por setor, tais como apoio orçamentário, ações relacionadas à dívida, ajuda humanitária e transações internas no país doador)

Fonte: OCDE, 2016, adaptado de Silva et al (2016, p. 10).

Além da AOD, o CAD também contabiliza os chamados "Outros Fluxos Oficiais" (Other Oficial Flows) e os Fluxos Privados. Os "Outros Fluxos Oficiais” são as transferências destinadas aos países em desenvolvimento que geralmente atendem a interesses diplomáticos ou comerciais. São considerados os créditos à exportação estendidos a um país receptor, aquisição de títulos emitidos por bancos multilaterais de desenvolvimento a nível de mercado, subsídios ao setor privado para facilitar a obtenção de crédito por parte dos países de menor renda e fundos de apoio a investimentos privados. Nessa modalidade, também são incluídos os fluxos de ajuda que não alcançam os $25 \%$ de concessionalidade (SILVA et al., 2016).

Quanto à mensuração da AOD, há majoritariamente duas fontes únicas para coleta de dados que são padronizadas e comparáveis na forma de questionários. $O$ primeiro questionário, realizado pelo CAD anualmente ${ }^{73}$, tem foco nos dados agregados, explorando os tipos de ajuda, de fluxo, região geográfica e setores. O segundo questionário, Credit Report System (CRS), sistema criado em 1973, é patrocinado e operado de forma conjunta pelo Banco Mundial e pela OCDE. Nesse relatório, os dados consistem da AOD e Outros Fluxos aos países em desenvolvimento e refletem os detalhes de cada projeto ou empréstimo feito bilateralmente. Em ambos os casos, os países submetem as informações a partir do formato conhecido como Unified Standard Input Format (USIF). Além dos membros do CAD, fluxos de outros países ${ }^{74}$, agências multinacionais de cooperação ${ }^{75}$, organizações internacionais $^{76}$ e

\footnotetext{
${ }^{73}$ No ciclo anual de mensuração do CAD há duas atualizações estatísticas. Em abril, os dados de nível agregado integram os números publicados sobre o total da ajuda oferecida pelos doadores do ano anterior. Em dezembro, essas informações são atualizadas com detalhes indicando como o dinheiro é alocado nos países receptores, nos setores, nas regiões geográficas e por grupo de renda dos beneficiários. Neste mês também são disponibilizados dados ao nível dos projetos individuais. Além disso, atualizações parciais de bancos de dados são feitas em junho e setembro de cada ano (OCDE, 2016c apud SILVA et al., 2016).

${ }^{74}$ Turquia, Rússia, Emirados Árabes, Tailândia, Israel e Bulgária, por exemplo.

${ }^{75}$ Islamic Development Bank, Nordic Development Bank, Asian Development Bank.
} 
doadores privados ${ }^{77}$ são recebidos e mensurados pelo fórum como Fluxos Não-AOD (NonODA Flows) (SILVA et al., 2016).

Um aspecto importante para a metodologia de mensuração do $\mathrm{CAD}$ diz respeito à análise do elemento concessional. As regras do CAD determinam que apenas as porções concessionais dos empréstimos sejam consideradas na mensuração da AOD. Esse cálculo concessional é definido por meio de uma análise matemática que considera os termos financeiros de uma transação ou de um conjunto de transações. Assim, é calculada a diferença entre o valor nominal do empréstimo e o valor presente do serviço de pagamento que o devedor fará ao longo da quitação da dívida, expressado em porcentagem (SILVA et al., 2016) ${ }^{78}$.

Para empréstimos bilaterais públicos são exigidos níveis concessionais, em porcentagem, de pelo menos $45 \%$ no caso de empréstimos feitos aos Países Menos Desenvolvidos e aos Outros Países de Baixa Renda (calculado numa taxa de desconto de 9\%); de $15 \%$ no caso dos empréstimos para os Países de Renda Média Inferior (calculado numa taxa de desconto de 7\%); e de 10\% no caso de empréstimos aos Países de Renda Média Superior (calculado numa taxa de desconto de 6\%). De modo que, caso não obedeçam estes limites, os empréstimos bilaterais públicos são registrados como "não concessionais" nas estatísticas e dentro da categoria de "Outros Fluxos Oficiais" (OCDE, 2016 apud SILVA et al., 2016).

Além dessas características, outro aspecto que marca a metodologia da OCDE é o tratamento homogêneo em relação aos fluxos de ajuda. O enfoque é dado ao valor gasto pelos países doadores e não no total recebido pelos receptores. O que pode gerar distorções nas análises sobre a Cooperação Norte-Sul na medida em que o valor anunciado pelos doadores poderia ser superdimensionado. Levando essas questões em consideração, o CAD criou o Country Programmable Aid (CPA, em inglês), em 2007. Essa medida, derivada do CRS, foca

\footnotetext{
${ }^{76}$ Fundo Monetário Internacional, Programa Mundial de Alimentos e Fundo das Nações Unidas para Infância, por exemplo.

${ }_{77}^{77}$ Grupo composto apenas pela Fundação Bill Gates.

${ }^{78}$ Há quatro fatores que determinam o elemento donativo: a) Taxa de juros (porcentagem anual); b) Prazo de carência, isso quer dizer, o intervalo de tempo entre a data que o compromisso foi firmado e a data do primeiro pagamento da amortização da dívida; c) Período de maturação, ou seja, o intervalo temporal entre a data de compromisso e a data do último pagamento de amortização da dívida; d) Taxa de desconto usada para determinar o valor presente dos pagamentos futuros (para cada grupo de país recipiendário é atribuído uma taxa diferente). Ela consiste num valor de base de 5\% que é consistente com as taxas de desconto estabelecidas pelo Fundo Monetário Internacional para o cálculo donativo de seus empréstimos, e com um fator de ajustamento que reflete o risco de inadimplência de 1\% para os Países de Renda Média Superior, 2\% para os Países de Renda Média Inferior, 4\% para os Países Menos Desenvolvidos e Outros Países de Renda Média (OCDE, 2016e apud Silva et al., 2016).
} 
nos fluxos transferidos externamente aos receptores. Assim, a medida resulta da exclusão de certos fluxos bilaterais ${ }^{79}$ da AOD (SILVA et al., 2016).

Entretanto, o CPA apresenta alguns problemas para o cálculo da ajuda externa. Pois, em sua contabilização, são excluídas algumas modalidades como ajuda humanitária, cooperação por meio de governos locais e ajuda alimentar. Ademais, não diferencia ajuda monetária e não monetária, como a cooperação técnica (SILVA et al., 2016). A tabela 3.5.2 sumariza os tipos de fluxos de ajuda externa e suas descrições no sistema AOD:

Tabela 3.5.1.2. Componentes da Ajuda Oficial ao Desenvolvimento (AOD)

\begin{tabular}{l|l}
\hline \hline Apoio em dinheiro & \multicolumn{2}{l}{$\begin{array}{l}\text { Apoio, em dinheiro, destinado diretamente ao governo } \\
\text { recipiendário, gastos a critério do mesmo. Esta modalidade também } \\
\text { pode ser setorial, e, portanto, destinada a contribuir em uma área do } \\
\text { orçamento público (educação ou saúde, por exemplo). }\end{array}$} \\
\hline $\begin{array}{l}\text { Apoio orçamentário base à ONGs } \\
\text { locais }\end{array}$ & $\begin{array}{l}\text { Dinheiro destinado às organizações não governamentais gastos a } \\
\text { critério das instituições. }\end{array}$ \\
\hline $\begin{array}{l}\text { Fundos comuns e outros } \\
\text { de objetivos específicos }\end{array}$ & $\begin{array}{l}\text { Fundos nos quais dois ou mais doadores contribuem para uma } \\
\text { conta autônoma, gerida conjuntamente. Também contemplam as } \\
\text { contribuições monetárias aos fundos geridos por organizações } \\
\text { internacionais com foco setorial, temático ou geográfico. }\end{array}$ \\
\hline Empréstimos & $\begin{array}{l}\text { Empréstimos feitos por doadores aos países em desenvolvimento, } \\
\text { nos termos acordados pelo CAD, respeitando o critério da } \\
\text { concessionalidade financeira. }\end{array}$ \\
\hline $\begin{array}{l}\text { Investimentos em ações } \\
\text { (equity) }\end{array}$ & $\begin{array}{l}\text { Investimento de capital nos países desenvolvidos, não realizados } \\
\text { para adquirir interesse duradouro em uma empresa. }\end{array}$ \\
\hline Apoio em espécie & $\begin{array}{l}\text { Auxílio na forma de suprimento direto de alimentos, que podem ser } \\
\text { adquiridos no país recipiendário, próximo dele ou ainda } \\
\text { provenientes do país doador. O custo de transferência é incluído no } \\
\text { valor da ajuda alimentar. }\end{array}$ \\
\hline Ajuda alimentar & $\begin{array}{l}\text { Apoio direto de especialistas, consultores, professores, acadêmicos, } \\
\text { pesquisadores, voluntários, etc. }\end{array}$ \\
\hline $\begin{array}{l}\text { Mercadorias não } \\
\text { alimentares }\end{array}$ & $\begin{array}{l}\text { Suprimento de itens não alimentícios, incluindo tanto bens de } \\
\text { capital ou bens consumíveis (petróleo, por exemplo). Pode incluir } \\
\text { créditos de exportação envolvidos no fornecimento destes itens. }\end{array}$ \\
\hline
\end{tabular}

\section{Projetos de ajuda combinada}

\footnotetext{
${ }^{79}$ a) fluxos imprevisíveis por natureza (ajuda humanitária e alívio da dívida); b) fluxos não transfronteiriços (custos administrativos, bolsas estudantis, custos de refugiados e refugiadas, etc.); c) fluxos que não integram acordos de cooperação entre governos (ajuda alimentar e ajuda advinda de governos locais); d) fluxos que não são programados para países (financiamento de organizações não governamentais) (SILVA et al., 2016)
} 


\begin{tabular}{l|l}
\hline $\begin{array}{l}\text { Projetos de ajuda } \\
\text { combinada }\end{array}$ & $\begin{array}{l}\text { Ajuda transferida para projetos específicos como uma combinação } \\
\text { de recursos monetários e não monetários. Dados disponíveis não } \\
\text { detalham suficientemente o tipo de ajuda. }\end{array}$ \\
\hline
\end{tabular}

\section{Apoio de base para parceiros e bens públicos globais}

\begin{tabular}{l|l}
\hline $\begin{array}{l}\text { Apoio às ONGs do } \\
\text { Norte }\end{array}$ & $\begin{array}{l}\text { Suporte financeiro à ONGs sediadas em países doadores, no mesmo } \\
\text { molde que aquele realizado para ONGs de países em } \\
\text { desenvolvimento. }\end{array}$ \\
\hline Bens públicos globais & $\begin{array}{l}\text { Gastos em bens públicos globais, cujos benefícios sejam } \\
\text { compartilhados globalmente }\end{array}$ \\
\hline Conscientização pública & $\begin{array}{l}\text { Financiamento de atividades no país doador com vistas ao aumento } \\
\text { do apoio e conscientização pública sobre necessidades e questões } \\
\text { relativas à cooperação internacional para o desenvolvimento. }\end{array}$ \\
\hline
\end{tabular}

\section{Recursos não transferidos do país doador}

\begin{tabular}{l|l}
\hline Alívio de dívida & $\begin{array}{l}\text { Perdão e reescalonamento da dívida e dos juros acumulados e não } \\
\text { pagos. }\end{array}$ \\
\hline Custos administrativos & $\begin{array}{l}\text { Custos administrativos não associados com o fornecimento de } \\
\text { determinado projeto }\end{array}$ \\
\hline Estudantes & $\begin{array}{l}\text { Custos com estudantes de países em desenvolvimento nos países } \\
\text { doadores }\end{array}$ \\
\hline $\begin{array}{l}\text { Refugiados em países } \\
\text { doadores }\end{array}$ & $\begin{array}{l}\text { Custos de habitação e alimentação de refugiados e refugiadas } \\
\text { provindos de países em desenvolvimento nos países doadores }\end{array}$ \\
\hline Bonificação de juros & $\begin{array}{l}\text { Subsídios de governos doadores para empresas privadas em troca } \\
\text { de termos de empréstimos mais leves aos países em } \\
\text { desenvolvimento. }\end{array}$ \\
\hline $\begin{array}{l}\text { Outros gastos dos países } \\
\text { doadores }\end{array}$ & $\begin{array}{l}\text { Dispêndios canalizados através dos governos doadores, gastos } \\
\text { dentro dos países doadores e excluídos das categorias acima. }\end{array}$ \\
\hline \hline
\end{tabular}

Fonte: Development Initiatives, adaptado de Silva et al., (2016, p. 13-14).

A partir da Reunião de Alto Nível do CAD em dezembro de 2014, os países desenvolvidos acordaram em promover maiores esforços para buscar modernizar o sistema de estatísticas de ajuda externa. Os países concertaram em buscar formas de aumentar os fluxos de ajuda, a transparência dos dados e amplitude da captura de informações ${ }^{80}$. Ademais, a partir de 2016, os países-membros concordaram em trabalhar na busca de uma definição mais

\footnotetext{
${ }^{80}$ Entre as mudanças em discussão, está a inclusão dos “instrumentos do setor privado" (PSI, na sigla em inglês). Modalidade de financiamento combinado entre setor público e privado que incluem empréstimos, garantias, financiamento intercalar (mezzanine finance) e capital próprio, que geralmente não oferecem concessionalidade (SILVA et al., 2016).
} 
clara de algumas questões como a elegibilidade de "ações e esforços para paz e segurança" e a metodologia para a determinação de empréstimos concessionais (SILVA et al., 2016) ${ }^{81}$.

Nota-se que o conceito de AOD esteve em constante disputa ao longo das últimas décadas. Muitas críticas e reflexões acompanharam o processo de definição do que poderia ser considerado AOD e como seus fluxos deveriam ser mensurados. Desde críticas acerca da extensão desse conceito, que incluiria muitos elementos que não necessariamente deveriam ser considerados como ajuda ao desenvolvimento. E críticas no sentido de que a definição de AOD seria muito limitada e insuficiente, na medida em que não contabilizaria práticas importantes realizadas internacionalmente em função dessas ações não cumprirem com as exigências do CAD. No geral, as críticas levantadas possuem em comum o fato de apontarem para o anacronismo da metodologia utilizada pelo CAD, e que uma definição mais efetiva dos fluxos de ajuda poderia resultar em diagnósticos mais precisos acerca da efetividade das ações de ajuda externa.

Merecem destaque as críticas realizadas quanto à legitimidade do CAD enquanto ator e fórum de debate central nas discussões referentes à ajuda internacional. Nesse espaço, os doadores desenvolvidos possuem uma clara dominância na agenda da ajuda externa. Tanto em relação à coleta de dados quanto em relação à metodologia de mensuração utilizada. Destacase também a falta de participação de outros atores relevantes nessas discussões, sejam os países receptores, sejam os países considerados como novo doadores, ou mesmo outras organizações multilaterais (ROODMAN, 2015 apud SILVA et al., 2016).

Ainda que existam outras estatísticas que registrem os fluxos de ajuda internacional sob a ótica dos receptores como, por exemplo, os dados da PNUD, estes nunca obtiveram o mesmo nível de reconhecimento que o CAD. Dentre os motivos alegados, costumam ser apontados a falta de rigor na elaboração de estatísticas produzidas pelos escritórios locais da PNUD, e a dificuldade por parte dos receptores em obter informações sobre informações específicas das políticas dos doadores como, por exemplo, os salários dos especialistas envolvidos em projetos de cooperação técnica. Assim, os dados elaborados pelo CAD continuam sendo os mais utilizados para se analisar a ajuda internacional mundo afora.

\footnotetext{
${ }^{81}$ O nível de concessionalidade de $25 \%$ será substituído por um conjunto de valores limiares baseado no nível de renda do país receptor. Para países menos desenvolvidos, serão contabilizados como AOD apenas empréstimos com concessão de mais de 45\%. Países de renda média superior e inferior terão este nível especificado em $10 \%$ e $15 \%$ respectivamente. A mesma lógica será aplicada ao valor da taxa de juros de $10 \%$ utilizada para o reembolso: empréstimos aos países de renda média superior devem aplicar a taxa de juros de 6\%; aos países de renda media inferior, $7 \%$ e aos países menos desenvolvidos e de baixa renda devem ser praticados 9\% (OCDE, 2016).
} 


\subsubsection{Total Official Support for Sustainable Development (TOSSD)}

A Agenda 2030 para o Desenvolvimento Sustentável marca uma mudança dos Objetivos de Desenvolvimento do Milênio para uma agenda mais universal com objetivos ambiciosos de longo alcance. A OCDE examinou o sistema estatístico internacional para entender como poderia promover um melhor monitoramento e análise dos fluxos de recursos alinhados à Agenda 2030. Nesse sentido, foi proposta uma nova medida intitulada "Total Official Support for Susteinable Development (TOSSD) (OECD, 2018f).

De acordo com a OCDE, essa nova medida visa complementar a AOD aumentando a transparência e monitorando novas tendências que estão moldando o cenário internacional de financiamento do desenvolvimento, incluindo: i) o efeito catalítico da AOD, ii) o uso de pacotes de financiamento combinados e iii) o uso de novos instrumentos de mitigação do risco na cooperação para o desenvolvimento. Assim, a TOSSD responderia aos novos imperativos de financiamento implícitos na Agenda 2030, como a importância de mobilizar investimentos de apoio aos ODS por parte do setor privado e de mobilizar mais recursos para o fornecimento de bens públicos globais, investimentos e serviços para promover as condições propícias ao desenvolvimento sustentável e abordar os desafios globais (OECD, 2017a).

O conceito TOSSD surgiu pela primeira vez em 2014 no decorrer dos trabalhos realizados pelo $\mathrm{CAD} / \mathrm{OCDE}$ para alinhar seu sistema estatístico com o cenário contemporâneo de financiamento para o desenvolvimento. As discussões avançaram durante a Agenda de Ação de Addis Abeba em julho de 2015, lideradas pelo CAD/OCDE. E em fevereiro de 2016, a medida foi integrada ao Objetivo 17 da estrutura de monitoramento de ODS como uma contribuição estatística de médio prazo para o indicador 17.9 (OECD, 2017a). De acordo com a OCDE, a medida "inclui todos os fluxos de recursos apoiados oficialmente para promover o desenvolvimento sustentável nos países em desenvolvimento e para apoiar facilitadores do desenvolvimento ou enfrentar desafios globais em nível regional ou global" (OCDE, 2018).

Embora os esforços iniciais tenham sido liderados pelo CAD da OCDE, o trabalho da TOSSD continua sendo realizado sob a égide da ONU. A TOSSD mensurará o financiamento "externo", ou seja, os recursos fornecidos além das fronteiras dos países que o recebem. Abrangendo todos os fluxos de recursos apoiados oficialmente, independentemente do instrumento financeiro utilizado ou do nível de concessionalidade, ou se são prestados através de canais bilaterais ou multilaterais. O objetivo da TOSSD é permitir que a comunidade internacional monitore os recursos que apoiam os ODS além da ODA, incluindo os recursos 
privados que são mobilizados por meios oficiais. Também rastreará o apoio internacional para facilitadores de desenvolvimento e desafios globais - até agora "invisíveis" nas estatísticas globais de finanças de desenvolvimento (OECD, 2017a).

A TOSSD seria composta de dois componentes: um capturando o fluxo de recursos que atravessam a fronteira em um país em desenvolvimento e um capturando recursos para promover facilitadores de desenvolvimento ou enfrentar desafios globais em nível nacional, regional ou global. A medida cobriria uma ampla gama de recursos como: empréstimos concessionais e não concessionais, instrumentos financeiros utilizador pelo setor privado, parcerias público-privadas (PPPs) e ajuda humanitária. Os dados utilizados seriam fornecidos pelos provedores, não havendo requisitos de coleta de dados para os países em desenvolvimento (OECD, 2017a).

O trabalho de estruturação da TOSSD ainda não está completo. A comunidade internacional ainda não chegou a um consenso sobre sua estrutura e características. Os seguintes pontos deverão ser abordados nesse processo: i) classificações e limites estatísticos: os países, setores e organizações elegíveis para o TOSSD precisarão ser bem definidos para garantir que os dados da TOSSD sejam estatisticamente relevantes, comparáveis e sólidos; ii) conformidade com disciplinas e padrões internacionais: normas e padrões universalmente aceitos (trabalho, comércio, meio ambiente, investimento) precisarão ser associados às operações TOSSD para garantir que não provoquem distorções econômicas ou que se sejam prejudiciais aos resultados do desenvolvimento sustentável; iii) coleta de dados e organização de relatórios: a TOSSD precisará ser implementada de maneira flexível, incremental e consistente por toda a comunidade internacional, de modo que o sistema terá de acomodar descontinuidades à medida que a implementação prossegue; iv) estabelecimento de um arranjo funcional, legítimo e representativo de governança e supervisão da TOSSD: a comunidade internacional precisará criar um sistema viável para operacionalizar, consolidar e manter padrões aceitáveis para a estrutura de medição da TOSSD (OECD, 2017a).

Segundo a OCDE, a TOSSD não substituiria a AOD, que continuaria sendo o padrão para monitorar o esforço dos países doadores em relação à meta de $0,7 \%$ do PNB. A TOSSD seria um complemento à $\mathrm{AOD}$, mensurando fluxos de financiamento ao desenvolvimento sustentável mais amplos, não capturados pela definição mais estreita da AOD (OECD, 2017b).

Entretanto, a proposta da TOSSD tem gerado reações e controvérsias na comunidade internacional de desenvolvimento. No geral, os críticos apontam para a falta de clareza acerca 
de quais fluxos financeiros serão mensurados, e como, na medida em que poderiam ser contabilizados fluxos sem caráter de concessionalidade ou que não possuam como objetivo o desenvolvimento socioeconômico. Ademais, também é questionada a legitimidade das instituições responsáveis por esse processo, especialmente a atuação do CAD/OCDE (SILVA et al., 2016; KHARAS; ROGERSON, 2018).

\subsection{Definições e classificações da Cooperação Sul-Sul}

O conceito de Cooperação Sul-Sul não é consensual, sendo utilizado de modo geral para designar um amplo conjunto de fenômenos relativos às relações entre países do "Sul Global". Antes de se buscar uma definição para o conceito Cooperação Sul-Sul, torna-se necessário precisar o conceito de "Sul Global". Esse termo, "Sul Global", não seria uma categoria geográfica, mas designaria simbolicamente um amplo conjunto de países em desenvolvimento. $\mathrm{O}$ conceito vem sendo utilizado sistematicamente como substituto para a expressão "Terceiro Mundo", que costumava ser utilizado para designar os países recémindependentes em um contexto de pós-colonialismo. A expressão vem ganhando força na comunidade epistêmica sobre o desenvolvimento ao longo dos anos. Embora seja cada vez mais difícil delimitar esse conceito na medida em que países com capacidades materiais muito divergentes costumam ser localizados nessa posição.

Bobiash (1992) destaca que a CSS seria um termo usado para descrever diversos tipos de cooperação entre os países desse "Sul Global”, sendo os mais significativos a cooperação política em negociações no âmbito multilateral, a promoção do comércio entre países do Sul, o desenvolvimento de associações políticas e econômicas regionais, e o fornecimento de assistência ao desenvolvimento. Sá e Silva (2009) apontam que a CSS pode ser qualquer iniciativa de cooperação entre dois ou mais países em desenvolvimento. A CSS poderia ser realizada por instituições governamentais, por organizações não governamentais, universidades, profissionais independentes, acadêmicos ou pesquisadores. Nota-se que o consenso na literatura em relação à CSS seria referente às relações entre países em desenvolvimento.

Em geral, a expressão CSS alude às políticas de concertação, diálogo e aproximação entre países do Sul, tanto no nível bilateral quanto no nível multilateral. No entanto, o termo também pode ser usado para designar uma modalidade mais especifica de CSS - a Cooperação Sul-Sul para o Desenvolvimento (CSSD) - fazendo alusão às ações realizadas por 
um governo com o intuito de promover o desenvolvimento econômico em países subdesenvolvidos, considerando-se também, além da assistência técnica, empréstimos e doações (LEITE, 2012; MILANI, 2014). Essa cooperação voltada para o desenvolvimento dos parceiros seria o foco desse trabalho. Existem, porém, inúmeras dificuldades para a operacionalização dessa dimensão da CSS. A principal dificuldade reside na falta de uma normatização comum por parte dos provedores da CSS acerca de quais práticas e atividades deveriam ser consideradas dentro dessa modalidade. Outro ponto fundamental consiste na inexistência de bases nacionais para contabilização de iniciativas oficiais ou de critérios compartilhados a respeito dessa mensuração (LEITE, 2012).

Pino (2014) aponta que quantificar os recursos econômicos utilizados na CSS é uma tarefa controversa. Fazer comparações entre os gastos despendidos pelos provedores de cooperação do Sul implica um exercício árduo, dada essa ausência de definições comuns em torno de quais práticas deveriam ser inclusas nessa modalidade. Poucos governos fornecem dados sobre o alcance de sua cooperação, o que torna difícil estabelecer com exatidão quais os valores envolvidos nessas operações. Assim, inexistem metodologias para sua medição elaboradas a partir das especificidades da CSS. Ademais, os governos do Sul resistem a adotar o sistema de registro do CAD e sua aplicação automática à CSS, pois temem que seus fluxos de cooperação sejam subdimensionados, como consequência da falta de mecanismo equalizador do valor monetário dos insumos que destinam a seus programas de cooperação a custos equivalentes aos dos doadores tradicionais.

Assim, os principais provedores de CSS, em especial os países do BRICS, não seguem os critérios do $\mathrm{CAD} / \mathrm{OCDE}$, não assimilando sua cooperação ao conceito de AOD e nem reportando seus dados. Esses países também rejeitam o rótulo de "novos doadores", "doadores emergentes", ou "doadores não-CAD", na medida em que consideram que sua cooperação partiria de premissas distintas em relação à ajuda externa tradicional. Ademais, o termo "doadores emergentes" foi explicitamente recusado na sessão de 30 de junho de 2008 do FCD, quando os países em desenvolvimento concordaram que essa denominação deveria ser utilizada apenas para os países que prestam cooperação pertencentes à OCDE, mas que não integram o CAD (PINO, 2014).

Pino (2014) aponta para algumas hipóteses para explicar essa falta de transparência em relação aos valores gastos na prestação da CSS. A primeira, de cunho institucional, residiria nas capacidades limitadas por parte desses países em contabilizar seus projetos e calcular os custos de sua execução. A elevada dispersão institucional por parte da cooperação prestada 
por esses países e a falta de agências coordenadoras dos diferentes organismos nacionais implicados no provimento da CSS embasariam esse argumento. A segunda hipótese, de cunho mais político, consistiria na falta de vontade por parte desses governos em tornar públicos seus gastos como forma de evitar o escrutínio internacional acerca de suas atividades e evitar os debates nacionais quanto à adequação de empregar os recursos domésticos escassos para promover o desenvolvimento em outros países.

Conforme a CSS ganhou espaço e importância nas últimas décadas, o interesse pela sua contabilização por parte da comunidade internacional passou a aumentar. A quantificação dessas atividades permitiria visibilizar a contribuição efetiva da CSS ao desenvolvimento, o que possibilita maior credibilidade no âmbito da política exterior, além de aumentar a transparência e a prestação de contas sobre o destino dos recursos públicos assignados à cooperação internacional de modo a fomentar os debates nacionais sobre o tema (PINO, 2014). Entretanto, essa tarefa permanece um desafio para todos os atores interessados. Vale destacar que mensurar a complexidade dos intercâmbios da cooperação Sul-Sul exige mais do que valores monetários (SILVA et al., 2016). O Brasil, a guisa de exemplo, na execução de sua Cooperação Técnica, por meio da Agência Brasileira de Cooperação (ABC), não transfere recursos financeiros aos países receptores. Portanto, os gastos reportados nesses projetos se referem a horas técnicas dos profissionais brasileiros envolvidos, passagens, diárias, seguro viagem e compra de equipamentos e materiais necessários para execução dos projetos ( $\mathrm{ABC}$, 2016).

Mensurar a Cooperação Triangular, ou Norte-Sul-Sul, também é uma tarefa controversa. Isso porque o sistema CAD/OCDE não discrimina quanto da cooperação dos países desenvolvidos é executada pelos países do Sul. A maior parte dos fluxos da cooperação não é contabilizada como aportes adicionais dos países em desenvolvimento, mas é incluída como fluxos dos doadores tradicionais. Havendo, assim, uma quantia de fluxos de cooperação triangular sendo registrados como provenientes dos países do Norte quando deveriam estar sendo contabilizados como de países do Sul (SILVA et al., 2016). Ademais, algumas instituições do Norte estão buscando mensurar os fluxos de Cooperação Sul-Sul, a despeito das posições oficiais dos países em desenvolvimento, utilizando seus próprios critérios e definições.

Em 2010, um estudo encomendado pelo Fórum de Cooperação ao Desenvolvimento do Conselho Econômico e Social da ONU (FCD/ECOSOC) identificou três obstáculos para a criação de uma base de dados comum para a Cooperação Sul-Sul: i) problemas técnicos e 
institucionais dos países em desenvolvimento sobre as definições e coleta dos dados dos fluxos da CSS; ii) falta de coordenação na coleta de dados, especialmente em função da dispersão institucional nesses países para o fornecimento da cooperação; iii) ausência de um fórum para organizar essa coleta de dados, tendo em vista que a maior parte dos países do Sul rejeita as definições do $\mathrm{CAD} / \mathrm{OCDE}$ e discordam entre si acerca dos critérios e definições a serem adotados de forma comum (SILVA et al., 2016).

Diferentemente do sistema CAD/OCDE, em que os doadores acertam posições de forma comum acerca das formas de se definir e mensurar os diversos fluxos de cooperação, a Cooperação Sul-Sul para o Desenvolvimento fornecida pelos países do Sul ainda apresenta um baixo nível de institucionalidade. Essa baixa institucionalidade reflete a dificuldade de se acertar posições comuns entre esses países, especialmente, entre os maiores provedores de CSS, como os países do BRICS. Assim, ainda não há consenso acerca de como se mensurar os fluxos da CSS. Atualmente, existem algumas propostas formuladas por alguns atores importantes no cenário internacional que serão apresentadas a seguir.

\subsubsection{Proposta da Secretaria Geral Ibero-Americana (SEGIB)}

A Secretaria Geral Ibero-Americana (SEGIB) é uma organização intergovernamental criada em 2003, que abarca os países da região ibero-americana. Trata-se de uma plataforma política com secretariado para construção de convergência, supervisão e acordos de cooperação entre os Estados-membros. Possuindo como objetivos implementar e fortalecer a Cooperação Sul-Sul nas áreas de educação, cultura e coesão social (SEGIB, 2018).

A organização publica anualmente o "Relatório em Cooperação Sul-Sul na IberoAmérica" na busca por promover e sistematizar as atividades de Cooperação Sul-Sul na América Latina e Caribe. A primeira edição do Relatório da Cooperação Sul-Sul na IberoAmérica, em 2007, foi impulsionada pela Secretaria Geral Ibero-americana (SEGIB), o Programa Ibero-americano para o Fortalecimento da Cooperação Sul-Sul (PIFCSS) e as Agências e/ou Direções Gerais de Cooperação dos 22 países ibero-americanos. Este relatório é elaborado a partir dos dados fornecidos pelos próprios governos. Sob um marco conceitual comum, desenhado e acordado por todos. O Relatório processa os dados recebidos e explica, a partir destes dados, qual é o estado da Cooperação Sul-Sul na região. A elaboração de cada Relatório permite aos países compartilhar informação, bem como realizar um exercício 
intergovernamental de debate e reflexão sobre o conceito, as modalidades e os princípios da Cooperação Sul-Sul, sua prática e sua medição, entre outros (SEGIB, 2018).

O último relatório, publicado em 2017, destaca que ao longo dos anos, desde a primeira publicação, os países da Ibero-América, acompanhados pela SEGIB pelo Programa Ibero-Americano para o Fortalecimento da Cooperação Sul-Sul (PIFCSS) desde 2010, foram gerando um quadro conceptual e metodológico para a cooperação (SEGIB, 2017). E que um dos principais marcos alcançados foi "não só a identificação das modalidades em torno das quais se instrumentaliza a Cooperação Sul-Sul, mas também a forma como estas se denominam" (SEGIB, 2017, p. 53). Essa conceptualização, para além de uma discussão técnica, envolve decisões políticas, na medida em que os responsáveis da Cooperação IberoAmericana, são os mesmos que dirigem as Agências e Direções Gerais de Cooperação dos países envolvidos (SEGIB, 2017).

No relatório é destacado que os debates em torno do conceito de CSS ainda não permitiram chegar a uma definição concreta e sistematizada. O que resultaria da dificuldade para distinguir entre os programas ordinários de cooperação técnica aqueles especificamente de caráter CSS. Assim, o documento retoma alguns princípios retomados pela SEGIB acerca da CSS:

1) A Cooperação Sul-Sul baseia-se na solidariedade e no compromisso voluntário entre países para o alargamento das capacidades através da cooperação técnica. 2) A associação horizontal entre agentes é o princípio básico da atuação. 3) A Cooperação Sul-Sul pretende articular-se, sempre que possível, com os planos e programas da Cooperação Norte-Sul. O espaço para esta articulação são as exigências dos países em desenvolvimento expressas nos seus planos e prioridades nacionais. A Cooperação Sul-Sul aposta numa relação entre parceiros que oferecem e requerem benefícios em condições de reciprocidade. 4) A Cooperação SulSul facilita a adequação das ações às necessidades e perspectivas comuns, permitindo partilhar modelos de gestão já implementados pelos países do sul. 5) O principal ponto forte da Cooperação Sul-Sul encontra-se no âmbito da cooperação técnica e do fortalecimento de capacidades. Os peritos da CSS envolvem um custo que deve ser reconhecido por outros agentes da cooperação. 6) Os países em desenvolvimento partilham experiências comuns, bem como vínculos culturais que facilitam a compreensão mútua e podem melhorar a eficácia dos projetos e programas de cooperação. 7) Os países fazem uma utilização eficaz das tecnologias dentro da Cooperação Sul - Sul, dadas as suas características de adaptação que facilitam o seu uso, manutenção e conservação. 8) A Cooperação Sul-Sul aposta na eficácia e eficiência do uso de recursos de qualquer tipo. 9) A Cooperação Sul-Sul promove a integração e as boas relações de vizinhança, bem como a relação 
com países parceiros de outras regiões com os quais se podem construir alianças (SEGIB, 2017, p. 49).

Após os exercícios de avaliação realizados nos anos 2008 e 2009, os países membros identificaram e concordaram na definição de três modalidades de Cooperação Sul-Sul: Cooperação Horizontal Sul-Sul Bilateral, Cooperação Sul-Sul Triangular e Cooperação Horizontal Sul-Sul Regional (SEGIB, 2017). Após um processo de revisão ao final de 2016, foi realizado um processo de revisão dessas modalidades, que passassem a se denominar “Cooperação Sul-Sul Bilateral" 82, "Cooperação Triangular"83 e "Cooperação Sul-Sul Regional”.

No relatório, a cooperação é discriminada entre "ações" ou "projetos". As ações de cooperação incluem atividades de cooperação concretas e limitadas, executadas em apenas um setor por meio de modalidades específicas, como consultorias, assessoria, pesquisa conjunta, missão de avaliação, seminários, podendo ser meios para alcançar os objetivos de um projeto ou apenas pontuais. Já os projetos são um conjunto de ações visando atingir um objetivo comum junto a um recipiendário específico, cuja implantação ocorre dentro de um ou muitos setores ou tópicos. Eles possuem um período definido de implantação, resultados esperados, um programa do qual fazem parte e mecanismos de avaliação e monitoramento. Ademais, são aprovados dentro de um marco específico, como uma comissão conjunta, um acordo interinstitucional ou acordo geral de cooperação (SILVA et al., 2016).

Nas primeiras publicações, as ações constavam como principal unidade de análise, que se por um lado trazia uma primeira mensuração dos dados, por outro, incluíam atividades muito diversas entre si. A partir de 2010, a metodologia passa a utilizar uma definição mais restrita para diferenciar ações e projetos. Em relação à divisão das atividades por setores, a cooperação é classificada com base na tabela produzida pelo Comitê de Ajuda ao Desenvolvimento, em novembro de 2004, referente à AOD (SILVA et al., 2016).

No ano de 2014, a SEGIB e o Programa Ibero-Americano para o Fortalecimento da Cooperação Sul-Sul (PIFCSS) criaram uma plataforma regional de dados online denominada Sistema Integrado de Dados da Ibero-América sobre Cooperação Sul-Sul e Triangular (SIDICSS). A plataforma foi concebida de acordo com os seguintes requisitos:

\footnotetext{
${ }^{82}$ Entendeu-se que com o amadurecimento da CSS na região, a ideia de horizontalidade estava bem associada à prática e que enfatizá-lo no termo seria redundante (SEGIB, 2017).

${ }^{83}$ Constatou-se que cada vez são mais as iniciativas triangulares que envolvem vários países do Sul, de modo que o termo Sul-Sul na sua denominação poderia se gerar confusão (SEGIB, 2017).
} 
a) Que o tipo de informação introduzida respondesse aos conceitos criados em torno do Relatório da CSS. b) Que três tipos de agentes de natureza diversa (os países ibero-americanos, a SEGIB e o PIFCSS), embora com diferentes funcionalidades e papéis, pudessem utilizar a plataforma. c) Que permitisse a réplica de algumas das principais fases do processo de revisão e consolidação da informação sobre Cooperação Sul-Sul registada pelos países (mais especificamente, o exercício de "cross-check" que permite cruzar os dados registados pelos países - em especial na modalidade bilateral; eliminar duplicações das iniciativas introduzidas; e agregar e complementar os dados associados até validar uma única iniciativa) (SEGIB, 2017, p. 45).

Um aspecto importante, porém, a ser destacado é que a SEGIB não mensura os fluxos financeiros da cooperação Sul-Sul da região. Na apresentação dos dados, a mensuração apresenta a quantidade de ações ou projetos e o tipo de atividade, mas não o montante financeiro que o intercâmbio representou (SILVA et al., 2016).

\subsubsection{Proposta da Comissão Econômica para América Latina e Caribe (CEPAL)}

A Comissão Econômica para América Latina e Caribe (CEPAL) tem desempenhado um papel importante na agenda acerca da definição e mensuração da Cooperação Sul-Sul. A CEPAL estabeleceu em 2014 um Grupo de Trabalho sobre Quantificação da Cooperação SulSul, em função do aumento dos fluxos de CSS fornecidos por países latino-americanos, especialmente, Brasil, Argentina, Colômbia, Chile, México e Peru. Assim, esse Grupo de Trabalho buscou desenvolver uma metodologia comum para essa medição no âmbito da CEPAL por meio do estabelecimento de indicadores comuns (CEPAL, 2018).

Esses países reconhecem a importância de definir um sistema de levantamento de dados sobre a cooperação Sul-Sul, diferentemente do que é feito pelos países do Norte. Dessa forma, seus principais objetivos seria i) definir um glossário de termos relativos à CSS; ii) definir os elementos da CSS que devem ser objeto de quantificação; iii) definir um sistema comum para os países utilizarem no intuito de avançar com a mensuração; iv) apresentar um desenho metodológico de quantificação em termos monetários para mensurar os custos diretos da cooperação Sul-Sul (CEPAL, 2016 apud SILVA et al., 2016).

Assim, a CSS deveria ser abordada nas suas dimensões política, financeira e técnica. A primeira, embora não seja mensurável, é importante para se definir a dimensão técnica. A dimensão técnica deveria ser analisada no âmbito de cada país a fim de comparar as ações realizadas com as metas nacionais propostas. Esta deveria ser medida antes, durante e depois da execução da atividade de cooperação. Nesta proposta a cooperação abrangeria tanto o nível 
do governo central quanto o nível descentralizado, com a incorporação de ações de outros atores como sociedade civil ou setor privado. Além disso, as unidades de análise acordadas foram as atividades, projetos e programas, contabilizados nos esquemas de cooperação bilateral, regional, triangular ou outros. O tempo de execução dos projetos também estaria contemplado nessa mensuração (DANE 2015 apud SILVA et al., 2016). A quantificação monetária dos técnicos da cooperação seria feita em horas. Um dos debates levantados sobre este ponto foi o uso de metodologias de paridade de poder aquisitivo. Embora os países não tenham chegado a um consenso, concordou-se no exame de um sistema internacional já existente, como o das Nações Unidas (DANE, 2015 apud SILVA et al., 2016).

$\mathrm{Na}$ dimensão financeira, está sendo acordado que os gastos diretos e indiretos devem ser diferenciados. Os primeiros envolveriam despesas com transporte, custos logísticos, gastos de manutenção e despesas relativas a seguros de viagem. Quanto aos gastos indiretos, ficou entendido que entrariam todos os custos ligados à "plataforma administrativa", ou seja, orçamento que permite a execução das atividades de cooperação, envolvendo tanto as organizações que fazem a gestão da CSS como as agências de cooperação e os Ministérios das Relações Exteriores, como as instituições que executam as ações por meio de processos de assessoria ou formação (DANE, 2015 apud SILVA et al., 2016). Os empréstimos podem ser contabilizados por meio do valor total, quando possível. Caso contrário, apenas os valores que corresponderiam às doações concessionais entram nas estatísticas (DANE, 2015 apud SILVA et al., 2016).

Por fim, a Divisão de Estatísticas da CEPAL desenvolveu um trabalho de adaptação do sistema de contas-satélite para a contabilização da Cooperação Sul-Sul. Esta abordagem permite ampliar a capacidade analítica da contabilidade nacional para certas áreas de interesse sem distorcer o sistema central. Nessa proposta, a cooperação internacional é entendida como "uma série de ações mediante as quais se busca combinar políticas ou somar esforços, com o propósito de alcançar objetivos comuns a nível internacional" (CEPAL, 2015 apud SILVA et al., 2016). Nessa proposta de mensuração, supõe-se em um primeiro momento a identificação dos agregados do Sistema de Contas Nacionais (SCN), da Balança de Pagamentos e das Contas de Transações Exteriores que reflitam atividades de CSS. Posteriormente, seria possível analisar e decompor a informação estatística relevante inserida que está dentro do SCN (CEPAL, 2015 apud SILVA et al., 2016).

As ações de CSS deveriam ser registradas dentro de três itens da Balança de Pagamentos: i) cooperação internacional corrente, que corresponderia às transferências 
correntes em dinheiro ou espécie entre governos de diferentes países ou entre governos e organizações internacionais; ii) transferências correntes diversas, em dinheiro ou espécie, são as transferências correntes diversas entre outras unidades; ii) transferências de capital inclui a propriedade de um ativo, exceto dinheiro e ações, de uma parte para outra ou exige que uma ou ambas as partes adquiram ou forneçam um ativo, exceto dinheiro e espécie, ou perdão de dívida (CEPAL, 2015 apud SILVA et al., 2016).

O primeiro passo seria isolar as atividades Sul-Sul dentro dos três itens. Um segundo passo seria determinar a modalidade da cooperação: i) em dinheiro ou ativos financeiros; ii) em espécie, como bens, serviços e ativos não financeiros; iii) outros itens da balança de pagamentos registrados em que se fez o registro da modalidade específica. Dessa forma, a contribuição prevista pelas contas-satélite permitiria dar maior visibilidade ao impacto da CSS. Além de possibilitar o conhecimento sobre as diferentes formas da cooperação Sul-Sul, trazendo também uma visão macro para analisar de forma mais detalhada os esforços de CSS (CEPAL, 2015 apud SILVA et al., 2016).

Tabela 3.6.2.1. Modalidades da Cooperação Internacional para o Desenvolvimento da CEPAL

\begin{tabular}{|c|c|}
\hline Características & Modalidade \\
\hline \multirow{2}{*}{$\begin{array}{l}\text { Características dos fundos e todo tipo de financiamento da ajuda } \\
\text { recebida }\end{array}$} & $\begin{array}{l}\text { Cooperação não } \\
\text { reembolsável }\end{array}$ \\
\hline & Cooperação reembolsável \\
\hline \multirow[t]{2}{*}{ Origem dos fundos } & Ajuda pública \\
\hline & Ajuda privada \\
\hline \multirow[t]{10}{*}{ Atores } & Ajuda bilateral \\
\hline & Ajuda multilateral \\
\hline & Cooperação descentralizada \\
\hline & $\begin{array}{l}\text { Cooperação não } \\
\text { governamental }\end{array}$ \\
\hline & Cooperação empresarial \\
\hline & $\begin{array}{l}\text { Cooperaçãa Norte-Sul } \\
\text { (vertical) }\end{array}$ \\
\hline & Cooperação Sul-Sul \\
\hline & Cooperação triangular \\
\hline & Cooperação horizontal \\
\hline & Cooperação regional \\
\hline \multirow[t]{2}{*}{ Limitação para aplicação dos fundos } & Ajuda "amarrada" \\
\hline & Ajuda "não amarrada" \\
\hline
\end{tabular}

Fonte: CEPAL, 2015, adaptado de Silva et al (2016, p. 27). 


\subsubsection{Network of Southern Think-Tanks (NEST)}

A Rede de Think Tanks do Sul (NeST) foi estabelecida às margens da primeira reunião de alto nível (HLM) da Parceria Global para a Cooperação para o Desenvolvimento Eficaz (Global Partnership for Effective Development Cooperation, GPEDC) no México em abril de 2014, e como um seguimento da Conferência dos Provedores do Sul (Conference of Southern Providers), realizada em Delhi, em abril de 2013. A rede definiu como objetivo a "gerar, sistematizar, consolidar e compartilhar conhecimento sobre as abordagens da cooperação Sul-Sul (CSC) para o desenvolvimento internacional”. As seguintes instituições compõem seu secretariado internacional: Instituto de Pesquisa Econômica Aplicada (IPEA), no Brasil, China Agriculture University, na China, Regional Information Systems for Developing Countries, na Índia e South African Institute for International Affairs, na África do Sul (ARTICULAÇÃO SUL, 2018; NEST, 2018)

Seus membros fundadores foram escolhidos ainda em 2014 em evento paralelo ao Primeiro Encontro de Alto Nível da Parceria Global para Efetiva Cooperação para o Desenvolvimento no México, com o intuito de atender as demandas resultantes da Conferência de Provedores do Sul, em Nova Déli, em 2013, acerca dos desafios relacionados à conceptualização e mensuração da Cooperação Sul-Sul. Em outubro de 2014, representantes de instituições de pesquisa de quatro países: o Instituto de Pesquisa Econômica Aplicada (IPEA), do /Brasil, China Agriculture University, da China, Regional Information Systems for Developing Countries, da Índia e South African Institute for Internacional Affairs, da África do Sul, definiram as linhas gerais do Plano de Trabalho da NEST para os próximos anos (OBSERVATÓRIO O BRASIL E O SUL, 2018).

Esse Plano estabelece atividades no sentido de buscar consolidar posições comuns acerca dos marcos conceituais da Cooperação Sul-Sul; elaborar indicadores para mensurar seus efeitos; aprimorar informações sobre a CSS; promover intercâmbio, experiências e troca de conhecimento entre os parceiros em desenvolvimento; realizar pesquisas empíricas acerca da CSS; oferecer apoio técnico às agências de cooperação dos países em desenvolvimento e auxiliar no desenvolvimento de posições e estratégias comuns entre esses países para sua participação nas negociações internacionais (OBSERVATÓRIO O BRASIL E O SUL, 2018).

Em março de 2015, um grupo de 25 acadêmicos e especialistas em cooperação para o desenvolvimento do Sul global se reuniram em Midrand, na África do Sul, para discutir um 
framework analítico comum para a cooperação Sul-Sul. Este foi o primeiro workshop técnico da Rede de Think Tanks do Sul (NeST). Como parte de uma consulta mais ampla para fornecer subsídios ao trabalho conceitual do NeST, foi organizado um diálogo de política multilateral sobre o tema "Parceiros Emergentes no Desenvolvimento da África" para discutir o papel e a contribuição da cooperação Sul-Sul para o desenvolvimento internacional e estruturas apropriadas para seu monitoramento. $O$ resultado dessas reuniões foi complementado por um grupo de trabalho técnico subsequente do NEST, realizado em Johannesburgo no início de setembro de 2015, para desenvolver indicadores para medir os fluxos Sul-Sul (NEST, 2015).

Devido à heterogeneidade de sua composição, agregando acadêmicos e profissionais de diversos países em desenvolvimento, o documento de referência da instituição Developing a Conceptual Framework for South-South Cooperation, foi apresentado como um esboço para constantes atualizações e revisões futuras. Assim, embora seja um trabalho em andamento, fornece contribuições acerca dos aspectos conceituais e metodológicos da mensuração dos fluxos, da qualidade e do impacto da cooperação Sul-Sul. De acordo com essa primeira proposta, a Cooperação Sul-Sul para o Desenvolvimento (CSSD) seria mais ampla do que a definição da AOD do CAD/OCDE, ao incluir atividades como linhas de crédito, concessões tarifárias, promoção de investimentos (especialmente em infraestrutura), comércio, bolsas estudantis, reduções de custos em remessas, apoio ao desenvolvimento do setor privado e algumas formas de empréstimos para desenvolvimento (considerados pelo CAD como não concessionais). O documento destaca que a definição de Cooperação Sul-Sul para o Desenvolvimento (CSSD) deve ser claramente delineada e distinguida das tradicionais abordagens de ajuda Norte-Sul e de outros tipos de cooperação mais geral. que ocorrem entre os países em desenvolvimento (NEST, 2015).

O documento ressalta que a CSS é multifacetada, incluindo comércio, investimento, ajuda, empréstimo e alívio da dívida, desenvolvimento de capacidades, transferência de tecnologia e conhecimento. Assim como na AOD, o que impulsionaria a definição de CSSD seria o "motivo" por trás da provisão de cooperação. No caso, a promoção do bem-estar econômico e social dos países em desenvolvimento. Alguns argumentam, no entanto, que toda o CSS tem um propósito de desenvolvimento. No âmbito das discussões da ONU (UNDESA), do Fórum das Nações Unidas sobre Cooperação para o Desenvolvimento (UNDCF), os fluxos concessionais são o que diferencia a CSS da CSSD, englobando todos os tipos de ligações do Sul, incluindo comércio e investimento. Com o início da CSS na época da 
cúpula de Bandung, o termo cooperação foi mais usado na esfera política, mas hoje os países do sul usam o termo CSS para abranger grande parte das relações econômicas entre eles (NEST, 2015).

Algumas definições úteis para a CSS oferecidas no workshop técnico do NeST incluíam o seguinte: a Articulação Sul (Brasil) havia definido a CSSD como uma interseção entre a cooperação internacional para o desenvolvimento e a CSS, compreendendo os fluxos de cooperação técnica, doações financeiras ou em espécie e empréstimos concessionais entre países em desenvolvimento voltados para a solução de problemas de desenvolvimento primário. O governo sul-africano havia se referido anteriormente à Cooperação para o Desenvolvimento como "a cooperação entre países no campo da ajuda, comércio, segurança e política para promover o bem-estar econômico e social nos países em desenvolvimento". O que poderia incluir assistência bilateral, bem como apoio a instituições de desenvolvimento regionais e multilaterais. Não sendo relativa apenas à cooperação entre as agências oficiais do governo (nacionais e subnacionais), mas também entre os atores não-estatais, como parlamentos, academia, sociedade civil e setor privado (NEST, 2015).

Embora permanecendo um tópico amplamente contestado, o grupo de trabalho técnico do NeST concluiu que: i) Cooperação Sul-Sul (CSS), Cooperação ao Desenvolvimento (CD), Cooperação Sul-Sul para o Desenvolvimento (CSSD) e Ajuda Oficial ao Desenvolvimento (AOD) são quatro conceitos distintos, cada um definido para cobrir um domínio específico de cooperação internacional, embora possa haver várias sobreposições entre eles; ii) a CSSD é um subconjunto da CSS, que se refere a relações Sul-Sul mais amplas não necessariamente baseadas na promoção de objetivos de desenvolvimento, como, por exemplo, comércio de armas Sul-Sul, intercâmbios linguísticos e culturais, etc.; iii) A CSSD é mais abrangente do que a definição da AOD do CAD/OCDE, incluindo ações como manutenção da paz, alívio da dívidas, bolsas de estudo, apoio humanitário, apoio a refugiados e possivelmente algumas medidas de facilitação do comércio e promoção de investimentos; iv) A CSS deve incluir não apenas a cooperação "oficial" entre os governos, mas também a cooperação entre os povos e as organizações da sociedade civil dos países em desenvolvimento; e v) o grau de concessionalidade de um empréstimo do Sul deve ser ainda descompactado e examinado antes da inclusão na definição de CSSD (NEST, 2015).

A mensuração e contabilização da CSS são dificultadas pelo fato de os parceiros do Sul não concordarem com uma definição e parâmetros comuns para o CSS. A quantificação da CSS é problemática por vários motivos: i) não há maneira consistente e reconhecida de 
registrar o CSS pelos vários países do Sul; ii) as instituições encarregadas de levar a cabo a cooperação para o desenvolvimento em países individuais são muitas vezes altamente fragmentadas e carecem de uma instituição de coordenação central e de um quadro normativo de relato; ii) os dados geralmente não são confiáveis e estão incompletos; iii) transparência e prestação de contas são fracas; iii) falta uma metodologia comum para coleta, análise e relatórios de dados; iv) grande parte da CSS consiste em cooperação técnica e transferência de conhecimento, geralmente ativos intangíveis, aos quais é difícil atribuir um valor monetário; v) não há medição padrão do valor de especialistas e funcionários destacados do SSC e dos intercâmbios de diferentes países (NEST, 2015).

Entretanto, o relatório destaca que para tentar preencher a lacuna de informações acerca da CSS, permitir maior transparência e responsabilização perante os cidadãos dos países em desenvolvimento e para fornecer dados padronizados que permitam a comparação dos fluxos de CSS entre os parceiros do Sul e os doadores tradicionais do CAD/OCDE, é fundamental que uma estrutura conceitual comum seja desenvolvida para a quantificação e contabilização da CSS entre os países em desenvolvimento. De modo que esse processo poderia começar com os componentes do CSSD que são claros, mensuráveis e menos controversos. Assim, o grupo de trabalho técnico do NEST concordou em relação aos seguintes instrumentos e modalidades que poderiam ser incluídos na quantificação do CSSD. Os elementos marcados com um asterisco são mais complexos e controversos e, portanto, exigem mais descompactação em futuras discussões do NeST (NEST, 2015).

Tabela 2.6.3.1. Instrumentos e modalidades da Cooperação Sul-Sul

\begin{tabular}{l|l}
\hline \hline Instrumentos (Como?) & Modalidades (O que?) \\
\hline Doações & $\begin{array}{l}\text { Cooperação educacional e } \\
\text { cultural }\end{array}$ \\
\hline Empréstimos (concessionais e não concessionais) * & $\begin{array}{l}\text { Reconstrução de pós-conflito e } \\
\text { "peace-building” }\end{array}$ \\
\hline $\begin{array}{l}\text { Cooperação técnica (transferência tecnológica, } \\
\text { desenvolvimento de capacidades, intercâmbio de } \\
\text { conhecimento) }\end{array}$ & $\begin{array}{l}\text { Apoio humanitário e assistência } \\
\text { aos refugiados * }\end{array}$ \\
\hline Contribuições em espécie - bens produtos e especialistas & Infraestrutura \\
\hline Apoio ao orçamento direto & $\begin{array}{l}\text { Contribuição às instituições } \\
\text { multilaterais de } \\
\text { desenvolvimento }\end{array}$ \\
\hline Perdão de dívida ou cancelamento & Comércio * \\
\hline Linhas de crédito $*$ & \begin{tabular}{l} 
Investimento * \\
\hline Parcerias público-privadas *
\end{tabular} \\
\hline
\end{tabular}


tecnológica

Bolsas para estudantes

Fonte: Adaptado de NEST (2015, p. 14).

Algumas observações trazidas no relatório destacam que como muitos tipos diferentes de empréstimos e linhas de crédito são fornecidos por diferentes parceiros do Sul, é necessário que haja clareza sobre o nível de concessionalidade dos empréstimos, e sobre como isso será mensurado, antes de considerar tais fluxos como cooperação para o desenvolvimento. Enquanto alguns participantes defendiam a inclusão de créditos à exportação, parcerias público-privadas (PPPs), comércio preferencial e investimento, outros membros não se sentiam confortáveis em incluir tais fluxos na contabilidade da CSSD, assim como seu desenvolvimento vis-à-vis comercial A cooperação em matéria de defesa e as despesas com segurança, por exemplo, precisariam ser avaliadas mais de perto para analisar se contribuem efetivamente para o desenvolvimento e de que forma. Da mesma forma, assistência humanitária, manutenção da paz e apoio a refugiados têm sido tradicionalmente limitados dentro da definição da AOD, portanto, o mesmo nível de escrutínio precisa ocorrer quando se trata de CSSD (NEST, 2015).

Ademais, reconheceu-se geralmente que a monetização da cooperação técnica, a transferência de conhecimento e a implantação de especialistas nos países em desenvolvimento sempre permanecerão um desafio. A monetização da CSS não é apenas metodologicamente desafiadora, mas também politicamente sensível. A CSS não pode ser reduzida a um mecanismo de financiamento do desenvolvimento, mas é um processo de troca de conhecimento que contribui para o desenvolvimento mútuo. Portanto, pode haver resistência política à monetização da cooperação técnica entre países em desenvolvimento. Isso porque uma das características principais da cooperação Sul-Sul é a troca de experiências, conhecimento técnico e políticas públicas anteriormente testadas em países com desafios de desenvolvimento similares. Assim, monetizar o valor das horas de trabalho de funcionários públicos, atores-chave no intercâmbio de experiências, não captaria de modo fidedigno a dimensão dessa relação. Ademais, essa quantificação em valores monetários não permitiria comparações com os valores dos países $\mathrm{CAD}$, devido ao fato de que, em geral, países do CAD operacionalizam sua cooperação por meio de consultores, com diárias desproporcionalmente altas; e que essa padronização de valores em dólares seria desfavorável em relação aos países em desenvolvimento em função das diferenças cambiais, o que poderia subdimensionar seus esforços. Dessa forma, para que os provedores do Sul Global 
estabeleçam seu próprio sistema de mensuração dos fluxos Sul-Sul para o desenvolvimento seria necessário o estabelecimento de um marco conceitual comum e uma padronização dos métodos de coleta de dados. Diante dessas complexidades, existe um consenso entre esses países de que o sistema ONU seria o melhor espaço para hospedar uma plataforma nesse sentido. Discussões iniciais na Conferência das Nações Unidas sobre Comércio e Desenvolvimento (UNCTAD) exploraram a possibilidade de tal agência liderar esses esforços (NEST, 2015).

O grupo de trabalho técnico do NeST que se reuniu em setembro de 2015 havia proposto, como parte da estrutura analítica, um conjunto de indicadores organizados em seis dimensões para avaliar a CSS e sua eficácia. Em setembro de 2016, um ano após a elaboração da tabela inicial de indicadores, especialistas e pesquisadores do sul se reuniram novamente na Cidade do México para revisitar a estrutura de monitoramento e avaliação da CSS. Em 2017, foi publicado um novo documento, intitulado "A Monitoring and Evaluation Framework for South South Cooperation", resumindo o resultado do workshop do NeST realizado no México em setembro de 2016, no qual diferentes experiências nacionais e regionais foram analisadas para aperfeiçoar, simplificar e atualizar a estrutura analítica do NeST (NEST, 2017).

Embora as discussões em torno da definição, contabilidade e relatórios dos fluxos de CSS ainda permaneçam inconclusivas e apresentem uma vasta diversidade de pontos de vista e abordagens, a área em que mais se avançou foi em relação à mensuração da qualidade e da eficácia das parcerias, relações e processos Sul-Sul (NEST, 2017). O documento de 2017 apresenta a tabela atualizada de indicadores qualitativos acordada nessa reunião. Enquanto a reunião do México discutiu certos aspectos conceituais da CSS, bem como o impacto da CSS e suas ligações com os ODS, GPEDC e Apoio Oficial Total ao Desenvolvimento Sustentável (TOSSD), a principal área de convergência diz respeito aos indicadores qualitativos usados para medir a eficácia das parcerias Sul-Sul para o desenvolvimento (NEST, 2017). A estrutura proposta apresenta um novo conjunto de 20 indicadores, organizados em cinco dimensões, que pesquisadores, avaliadores e formuladores de políticas poderiam utilizar para avaliar a qualidade e a eficácia da CSS e sua contribuição para o desenvolvimento sustentável (NEST, 2017). 
Tabela 3.6.3.4. Indicadores para mensurar a qualidade da CSS

\begin{tabular}{lcccc}
\hline \hline Dimensão & $\begin{array}{c}\text { Domínio nacional } \\
\text { inclusivo }\end{array}$ & Horizontalidade & $\begin{array}{c}\text { Independência e } \\
\text { sustentabilidade }\end{array}$ & Eficiência \\
\hline Indicadores & $\begin{array}{c}\text { Parcerias multi- } \\
\text { stakeholder } \\
\text { Inclusividade } \\
\text { centrada nas } \\
\text { pessoas }\end{array}$ & Benefícios mútuos & $\begin{array}{c}\text { Gerenciamento dos } \\
\text { dados } \\
\text { compartilhados }\end{array}$ & $\begin{array}{c}\text { Flexibilidade e } \\
\text { adaptação }\end{array}$ \\
& $\begin{array}{c}\text { Sistemas de } \\
\text { monitoração e } \\
\text { demandas }\end{array}$ & $\begin{array}{c}\text { Eficiência em } \\
\text { relação ao } \\
\text { tempo e custo }\end{array}$ \\
& $\begin{array}{c}\text { Confiança e } \\
\text { solidariedade }\end{array}$ & $\begin{array}{c}\text { Transparência e } \\
\text { acesso à informação }\end{array}$ & $\begin{array}{c}\text { Coordenação } \\
\text { interna e } \\
\text { externa }\end{array}$ \\
& $\begin{array}{c}\text { Não } \\
\text { condicionalidade }\end{array}$ & Coalizões políticas \\
globais & $\begin{array}{c}\text { Prestação de contas } \\
\text { e revisões mútuas }\end{array}$ & $\begin{array}{c}\text { Coerência } \\
\text { política }\end{array}$ \\
\hline \hline
\end{tabular}

Fonte: NEST (2017, p. 11).

Ao longo do documento, são discutidas diversas medidas a serem utilizadas para cada um dos indicadores sugeridos. Por fim, o documento destaca que avaliar os resultados e o impacto da CSS pode ser prematuro, uma vez que muitos países da CSS ainda não têm sistemas de contabilidade básica e monitoramento das ações d CSS, devido à falta de uma definição conceitual comum sobre o que deveria ser contabilizado como CSS. No entanto, o documento ressalta os progressos que foram obtidos nos últimos anos, em especial em relação a essa gama de dimensões e indicadores para se avaliar a CSS (NEST, 2017).

\subsection{Comparando as diferentes metodologias acerca da Cooperação Internacional para o Desenvolvimento}

A discussão apresentada nas seções anteriores evidencia o fato de que definir e mensurar a Cooperação Internacional para o Desenvolvimento não é uma tarefa simples. Quando se trata da Cooperação Sul-Sul para o Desenvolvimento, a atividade torna-se ainda mais complexa. Embora, como visto, a Cooperação Norte-Sul tenha sido mais bem institucionalizada ao longo dos anos, especialmente por meio da criação de instituições internacionais voltadas especificamente para esse fim, como o CAD/OCDE, seus conceitos e classificações não são isentos de problemas, tendo sido alvo de diversas críticas ao longo dos anos. Por outro lado, a Cooperação Sul-Sul não conseguiu obter o mesmo nível de 
institucionalização, mesmo com o estabelecimento recente de iniciativas voltadas para esse fim.

Nota-se que quantificar os esforços e fluxos da CID se tornou um tema cada vez mais relevante nos últimos anos. Os Fóruns de Alto Nível da Efetividade da Ajuda, de Financiamento ao Desenvolvimento e a Agenda 2030 reiteram esta preocupação, apontando para a necessidade de ampliar ou reformar instrumentos já existentes, assim como construir novas metodologias mais abrangentes que possam captar de forma mais efetiva os fluxos referentes à CID.

Dentre as diversas inciativas apresentadas, verifica-se que de um lado se encontra a metodologia do CAD, alicerçada no conceito de AOD, modelo que vem construído desde os anos 1960 majoritariamente pelos doadores do Norte. A proposta mais recente do TOSSD se aproxima de alguns debates feitos por atores da cooperação Sul-Sul. Tal inciativa promete englobar instrumentos financeiros não captados pela AOD, tendo um caráter mais global. Entretanto, tal proposta ainda se encontra em formação e ainda é incerto qual será seu papel no campo da CID. De outro lado, localizam-se os países em desenvolvimento provedores de CSS, que enfatizam a horizontalidade e os benefícios mútuos de sua cooperação. Estes países não se encontram agrupados em uma única organização intergovernamental e nem possuem uma metodologia consolidada para quantificar e analisara os seus esforços de cooperação.

Em geral, as diferentes iniciativas apresentadas trazem elementos pertinentes para o debate acerca da classificação e mensuração da CSSD. No entanto, vale ressaltar que a maior parte dessas propostas ainda se encontra em estágio incipiente. O quadro abaixo traz uma comparação entre as diversas conceitualizões acerca da CID, destacando o contexto em que cada inciativa foi formulada e suas principais características:

\section{Tabela 3.7.1. Quadro comparativo das diferentes metodologias de mensuração da cooperação internacional para o desenvolvimento}

\begin{tabular}{c|c|c}
\hline \hline INICIATIVAS & ORIGEM/CONTEXTO & CARACTERÍSTICAS \\
\hline & Surge na década de & Os fluxos devem advir \\
& de fontes públicas; \\
& contribuir para o bem \\
Ajuda Oficial ao & contabilizar aportes de & estar e desenvolvimento \\
Desenvolvimento & doadores tradicionais & dos beneficiários e conter \\
(CAD-OCDE) & aos países menos & pelo menos $25 \%$ de \\
& desenvolvidos & concessionalidade no caso \\
& de empréstimos. \\
\hline Apoio Oficial Total para & Surge nos marcos do & Medida que incluirá \\
\hline
\end{tabular}




\begin{tabular}{|c|c|c|}
\hline $\begin{array}{c}\text { o Desenvolvimento } \\
\text { Sustentável (TOSSD) }\end{array}$ & debate da Agenda 2030 & $\begin{array}{l}\text { uma vasta gama de } \\
\text { transferências e } \\
\text { recursos voltados } \\
\text { ao desenvolvimento } \\
\text { independente do } \\
\text { instrumento financeiro } \\
\text { utilizado, nível de } \\
\text { concessionalidade ou } \\
\text { canais (bilaterais ou } \\
\text { multilaterais) }\end{array}$ \\
\hline $\begin{array}{l}\text { Relatório Anual da CSS na } \\
\text { Ibero-America (SEGIB) }\end{array}$ & $\begin{array}{l}\text { Surge em } 2007 \text { visando } \\
\text { promover e sistematizar } \\
\text { atividades de CSS na } \\
\text { América Latina e Caribe }\end{array}$ & $\begin{array}{c}\text { São mensuradas a } \\
\text { quantidade de ações ou } \\
\text { projetos de cooperação } \\
\text { Sul-Sul bilateral, } \\
\text { cooperação Sul- } \\
\text { Sul regional e cooperação } \\
\text { triangular }\end{array}$ \\
\hline $\begin{array}{c}\text { Comissão Econômica para } \\
\text { América Latina e Caribe } \\
\text { (CEPAL) }\end{array}$ & $\begin{array}{l}\text { Debates incipientes no } \\
\text { âmbito do Grupo de } \\
\text { Trabalho de Quantificação } \\
\text { da CSS, desde } 2014 \text { e } \\
\text { proposta de metodologia } \\
\text { da Divisão de Estatísticas } \\
\text { da CEPAL }\end{array}$ & $\begin{array}{l}\text { Uso dos registros do } \\
\text { Sistema de Contas } \\
\text { Nacionais a partir da } \\
\text { metodologia de contas } \\
\text { satélite }\end{array}$ \\
\hline $\begin{array}{l}\text { Rede Think Tanks do } \\
\text { Sul (NeST) }\end{array}$ & $\begin{array}{c}\text { Iniciativa voltada para } \\
\text { sistematizar reflexões } \\
\text { de acadêmicos e } \\
\text { profissionais de países em } \\
\text { desenvolvimento sobre a } \\
\text { mensuração da CSS }\end{array}$ & $\begin{array}{c}\text { Inclusão de diversas } \\
\text { modalidades e } \\
\text { instrumentos para } \\
\text { mensurar dados } \\
\text { quantitativos agregados e } \\
\text { desagregados }\end{array}$ \\
\hline
\end{tabular}

Fonte: Adaptado de Suyama, Silva e Waisbich (2017, p. 15). 


\section{CAPÍtULO 4. O BRASIL E A COOPERAÇÃO INTERNACIONAL PARA O DESENVOLVIMENTO}

\subsection{Histórico}

A relação do Brasil com o sistema de Cooperação para o Desenvolvimento Internacional data das origens desse regime, estabelecido em um contexto pós-Plano Marshall, com a expansão dos fluxos de Ajuda Oficial ao Desenvolvimento ao mundo em desenvolvimento. Entretanto, as primeiras iniciativas de cooperação internacional no Brasil datam da década de 30, período marcado por grandes transformações socioeconômicas no país. Nessa época, já ocorriam, de forma pontual, algumas ações de assistência internacional no país, especialmente de caráter técnico. Nesse contexto, marcado pela postura de neutralidade brasileira frente ao conflito que se desenhava na Europa, a diplomacia brasileira fora convocada a negociar de forma simultânea com os Estados Unidos e a Alemanha ajuda econômica para a implantação da Companhia Siderúrgica Nacional. Essas negociações culminariam no acordo firmado com o Export Import Bank (EXIMBANK, em inglês) de financiamento para a construção da usina de Volta Redonda, em setembro de 1940 após uma longa negociação. Um marco em relação à cooperação ao desenvolvimento no país (VALLER FILHO, 2007).

Destacam-se outras ações nesse sentido realizadas nos anos seguintes, como a vinda da missão Cooke, em 1943, ainda durante o Governo Vargas, vinda dos Estados Unidos para auxiliar na formulação das diretrizes para o desenvolvimento econômico. Nesse contexto, a relação com os Estados Unidos seria marcada por mais de um oferecimento de assistência técnica e financeira. Ressaltam-se os empréstimos realizados para a execução do Plano Salte e a vinda da Missão Abbink, em 1949, durante o governo Dutra. O estabelecimento da Comissão Mista Brasil-Estados Unidos para o Desenvolvimento Econômico (CMBEU), sob o novo governo Vargas, em 1951. Comissão que teve como objetivo fazer um estudo acerca de possíveis projetos passíveis de financiamento externo, inserida no escopo do plano americano de ajuda técnica. Como resultado de suas conclusões, seriam criados, em 1952, o Banco Nacional de Desenvolvimento Econômico (BNDE) e, em 1956, o Conselho de Desenvolvimento para a Coordenação Econômica e Financeira (VALLER FILHO, 2007; MILANI, 2017). 
No plano doméstico, foi estabelecida a primeira iniciativa de implantação de um "Sistema de Cooperação Técnica Internacional", por meio do decreto n 28.799/50, em 1950, com a criação da Comissão Nacional de Assistência Técnica (CNAT), composta por representantes governamentais: da Secretaria de Planejamento, do Ministério das Relações Exteriores e de Ministérios setoriais. Sua principal atribuição era a de estabelecer a prioridade dos pleitos de instituições brasileiras solicitantes de ajuda técnica do exterior, fornecida por países industrializados com os quais o Brasil mantinha acordos específicos de transferência de tecnologia sob a forma de cooperação (ABC, 2018). Dentre as demais competências legais da CNAT incluíam-se também os estudos referentes à participação do Brasil em programas de ajuda técnica dos órgãos das Nações Unidas e da Organização dos Estados Americanos (OEA) (PUENTE, 2010; MILANI, 2017).

Em 1959, foi criado por meio do Decreto $n^{\circ} 45.660 / 59$ o Escritório Técnico de Coordenação dos Projetos e Ajustes Administrativos do Ponto IV para gerenciar especificamente as atividades de cooperação oriundas dos Estados Unidos, em função do aumento da importância da assistência vinda desse país. Em 1964, a CNAT foi reestruturada, pelo Decreto 54.251/64, passando a ter a seguinte composição: como presidente, o Ministro das Relações Exteriores, ou em caso de impedimento, o Secretário-Geral Adjunto para Assuntos Econômicos; e como membros, quatro Chefes de Divisão do MRE (das áreas de Nações Unidas, da Organização dos Estados Americanos (OEA), de organismos internacionais, e da cooperação intelectual); além de representantes de diversos Ministérios e outros órgãos (CABRAL, 1998 apud PUENTE, 2010). Em 1965, foi criado um órgão para lidar exclusivamente com a ajuda recebida dos Estados Unidos, no contexto da Aliança para o Progresso, o Conselho de Cooperação Técnica da Aliança para o Progresso (CONTAP), presidido pelo Ministro Extraordinário do Planejamento (CABRAL, 1998 apud PUENTE, 2010).

Assim, em 1965, havia três órgãos responsáveis por gerenciar e coordenar a assistência técnica recebida pelo Brasil: a CNAT, o Escritório Técnico do Ponto IV e o CONTAP. A CNAT estava sob a égide do Itamaraty, o CONTAP era controlado pelo Ministério do Planejamento, e o Escritório Técnico do Ponto IV, que não estava adstrito a nenhum dos dois, contava com a participação de diversos Ministérios em seu Conselho Consultivo (CABRAL, 1998 apud PUENTE, 2010). Essa descentralização institucional gerava dificuldade na coordenação desse sistema na medida em que se aumentava a quantidade de projetos de cooperação recebidos pelo Brasil. Surgia uma demanda pelo 
fortalecimento do sistema, de maneira a adequá-lo às diretrizes e prioridades definidas nos Planos Nacionais de Desenvolvimento (PUENTE, 2010). Como consequência, em 1969, o sistema passou por uma ampla reforma institucional. Nessa ocasião, as competências básicas de cooperação técnica internacional foram centralizadas, via decreto $\mathrm{n}^{\mathrm{o}}$ 65.476/69, na Subsecretaria de Cooperação Econômica e Técnica Internacional (SUBIN), vinculada ao Ministério do Planejamento, e na então Divisão de Cooperação Técnica (DCT, inicialmente e, após 1974, DCOPT), subordinada ao Ministério das Relações Exteriores (MILANI, 2017).

A SUBIN ficaria responsável por desenhar e coordenar a política nacional de cooperação técnica, com a definição de suas prioridades e sua compatibilização com o plano global do Governo. O Ministério das Relações Exteriores, além do papel na formulação da política externa de cooperação técnica, também seria responsável pela negociação de seus instrumentos básicos, via Acordos Básicos de Cooperação Técnica, e pelo encaminhamento das solicitações aos doadores bilaterais e multilaterais. Assim, por meio dessa centralização, buscou-se aumentar a efetividade da cooperação recebida no plano internacional. Até então, cada projeto era negociado diretamente pelas instituições brasileiras e as agências dos países doadores. Com a reforma, toda atividade de cooperação técnica deveria ser avaliada pela SUBIN e pelo MRE, com exceção dos projetos apresentados pela Superintendência para o Desenvolvimento do Nordeste (SUDENE) (PUENTE, 2010).

Valler Filho (2007) aponta que a o governo militar remetia, assim, ao Planejamento as diretrizes, coordenação e execução da cooperação técnica recebida naquele momento, com base no artigo $3^{\circ}$ do Ato Institucional $n^{\circ} 16 / 69$. Nessa época, ainda não havia referência à cooperação prestada pelo país no plano internacional. Outro ponto interessante a ser levantado diz respeito ao duplo comando da política de cooperação nesse período, na medida em que as solicitações de cooperação técnica só seriam encaminhadas aos órgãos estrangeiros após a autorização dos Ministérios do Planejamento e Coordenação Geral e do Ministério das Relações Exteriores. Fato que só seria alterado na década seguinte, quando o Brasil passasse a fornecer cooperação internacional.

Vale destacar que, a despeito dessa mobilização doméstica, o Brasil teve um papel marginal no regime de Cooperação Internacional ao Desenvolvimento em formação. Desde os anos 50, embora o Brasil tenha se beneficiado dos fluxos de ajuda externa dos países da OCDE e de instituições multilaterais, as quantias foram modestas, se pensadas de forma 
comparada a outras regiões do mundo ${ }^{84}$. Em um contexto de Guerra Fria, a América Latina não era considerada uma área prioritária de modo que os volumes de ajuda externa fornecidos à região nesse período estiveram abaixo das expectativas nacionais do país. Ademais, a ajuda oficial ao desenvolvimento foi limitada para os países de renda média após as crises globais ocorridas nos anos 1970, o aumento do "cansaço da ajuda" (aid fatigue) por parte dos doadores e pelos critérios de graduação que foram sendo estabelecidos no regime de cooperação (LEITE et al., 2014).

Leite et al (2014) apontam que os setores brasileiros cobertos pelos fluxos de ajuda internacional mudaram ao longo do tempo de acordo com os modelos nacionais de desenvolvimento e a evolução da arquitetura da cooperação para o desenvolvimento. Inicialmente, durante o período de 1940-1960, o Brasil e os doadores estrangeiros convergiram para um modelo de desenvolvimento baseado no crescimento econômico, embora ainda houvesse diferenças quanto aos meios para alcançá-lo. Durante esse período, o governo brasileiro priorizou a cooperação para apoiar o desenvolvimento de infraestrutura básica e avanços científicos e tecnológicos.

Na década de 1970, o surgimento da abordagem "Necessidades Humanas Básicas" no Banco Mundial e agências dos doadores tradicionais, com o enfoque proposto em ações para combater a pobreza em áreas rurais, estava em desacordo com o foco oficial do Brasil no crescimento econômico. Paralelamente, o suporte direto dos doadores a movimentos sociais e organizações da sociedade civil gerava ruídos junto ao governo militar, que percebia essas atividades como interferências nos assuntos internos do país ${ }^{85}$. Eventualmente, esse apoio teve um impacto significativo no retorno do país à democracia e nas reformas democráticas que se seguiram nos anos 1980.

Nos anos 1970, surgiram as primeiras experiências de cooperação técnica brasileira para o exterior. A experiência adquirida enquanto receptor da cooperação técnica internacional nos anos anteriores, a intensificação da ação da diplomacia brasileira, especialmente, na África e América Latina, e a maior disponibilidade de recursos colaboraram para que o Brasil passasse a se tornar um fornecedor emergente de cooperação no plano internacional (PUENTE, 2010). A cooperação prestada era executada sob a coordenação da

\footnotetext{
${ }^{84}$ Dessa época até 1983, apenas 0,7\% dos 453 projetos financiados pela PNUD em todo o globo beneficiaram o Brasil, embora alguns autores sustentem que a cooperação financeira tenha sido quantitativamente mais relevante (PINO; NOGUEIRA; PUERTO, 2007).

${ }^{85}$ Essa preocupação com a cooperação internacional recebida por ONGs brasileiras ainda está presente no discurso do governo. Em um evento liderado pela OCDE em 2008, a delegação brasileira enfatizou a necessidade de "supervisão do governo sobre as atividades das ONGs em projetos de desenvolvimento" (MRE 2008 apud LEITE et al., 2014).
} 
SUBIN, com apoio do Itamaraty, que atuava no estabelecimento das parcerias, na identificação das demandas e na negociação dos acordos. No quadro de dirigentes da época, fortalecia-se a ideia de que o Brasil poderia utilizar sua experiência e expertise na área da cooperação técnica como uma importante ferramenta de política externa para sua projeção no cenário internacional. Esse movimento interno vai de encontro ao contexto internacional da época que presenciava a emergência do tema da Cooperação Técnica entre os Países em Desenvolvimento na agenda das organizações internacionais, especialmente, nas Nações Unidas (PUENTE, 2010).

Ademais, a redução dos fluxos de Ajuda Oficial ao Desenvolvimento ao Brasil em função de sua graduação com base nos critérios estabelecidos pelos doadores tradicionais para o provimento de ajuda externa impulsionava a criação de ideias alternativas em relação à questão do desenvolvimento. Assim, a redução de recursos provenientes do exterior aliada ao aumento das demandas por Cooperação Técnica Horizontal no mundo em desenvolvimento impulsiona a atuação brasileira nessa temática. Puente (2010) aponta que a estrutura institucional do sistema nacional, preconizada na figura da SUBIN, já não se mostrava adequado para lidar com as novas funções que estavam surgindo. Ademais, havia pouca integração entre a política de fornecimento de cooperação técnica e outras políticas de promoção da presença brasileira no exterior, especialmente, de interesses econômicos.

Valler Filho (2007) destaca que nesse contexto os objetivos da cooperação passam a ser duplos. A cooperação prestada serviria como um instrumento de política externa na medida em que buscaria promover os interesses políticos e econômicos do país no Sistema Internacional. Enquanto o interesse político residiria na tentativa de promoção da imagem do país internacionalmente, o motivo econômico consistiria na busca por promover as exportações do país, abrindo mercados para os produtos brasileiros. Já a cooperação recebida teria a função de atrair para o país tecnologia e know-how para impulsionar o projeto nacional de desenvolvimento.

O Plano de Ação de Buenos Aires teve um papel-chave em impulsionar a relevância do tema da cooperação internacional nas diretrizes da Política Externa Brasileira. Nesse contexto de emergência de "novos doadores" no plano Sul-Sul e consequente expansão da CTPD mundo afora, a ditadura brasileira viu-se na necessidade de fortalecer sua atuação na área da Cooperação Internacional, especialmente na vertente técnica, de modo a impulsionar os interesses nacionais do país em outras regiões do mundo. Nessa década, são firmados diversos acordos de cooperação com países latino-americanos e africanos. Entre 1972 são 
firmados acordos com Colômbia, Venezuela, Bolívia, Costa do Marfim, Camarões, Daomé, Gana, Mali, Nigéria, Senegal e Zaire. E entre 1974 e 1975, são assinados acordos com Chile, Gabão, México e Uruguai (VALLER FILHO, 2007).

Em relação à África, eram priorizados os países de língua portuguesa. Já nessa época, começaram a ser oferecidas as primeiras bolsas de estudo para estudantes estrangeiros. Nessa época, também, começam a ser firmados convênios com entidades técnicas no plano doméstico no intuito de responder as demandas realizadas pelos países em desenvolvimento. Assim, o Itamaraty passa a firmar acordos com órgãos como a EMPRAPA, ELETROBRÁS, SENAI, entre outros. Também ganha ênfase a necessidade de se planejar a cooperação recebida e prestada de forma mais eficiente. O Ministério do Planejamento fica responsável por coordenar esses planos, cabendo ao IPEA, braço técnico e operacional desse ministério, a tarefa de executar esse serviço. Com o tempo, essa importância dada ao planejamento ${ }^{86}$ acaba por deslocar essa competência à Presidência da República, especialmente após a criação da Secretaria do Planejamento e Coordenação da Presidência da República (SEPLAN) (VALLER FILHO, 2007).

Essa ênfase no planejamento centralizado aliada à política externa do período, conhecida como "Pragmatismo Responsável" visava promover o desenvolvimento nacional em um cenário de crise internacional, marcado pela crise do petróleo. No plano interno, o objetivo era captar recursos e tecnologias no plano internacional para serem aplicados nas áreas consideradas estratégicas pelo governo, especialmente os setores de infraestrutura, energia, transportes e comunicações. Em relação à política comercial, a ênfase no modelo de substituição de importações perduraria até o final do governo Geisel, em que o foco seria estabelecer uma interdependência horizontal com os parceiros comerciais, que substituísse o caráter vertical herdado das relações coloniais com os países do Norte. Assim, o sistema de cooperação internacional que estava sendo implantado alinhava-se às diretrizes da política do "Pragmatismo Responsável”, baseada nos pilares do não alinhamento automático e na inexistência de aliados preferenciais. Nesse sentido, a cooperação prestada pelo Brasil subscrevia essa política, na medida em que buscava promover a imagem e relevância do país

\footnotetext{
${ }^{86}$ Esse foco na questão do planejamento inscrevia-se no modelo nacional-desenvolvimentista em voga no período, baseado na centralização e no papel do Estado na organização social e econômica, que seria refletido nos Planos Nacionais de Desenvolvimento. O I Plano Nacional de Desenvolvimento, estabelecido pela Lei 5.727, de 4 de dezembro de 1971, estabelecia as diretrizes e prioridades para a política de desenvolvimento do país para o período de 1972 a 1974. O Plano previa a atuação crescente do governo na gestão da economia, por meio de investimentos públicos e da regulamentação da atividade econômica. O II Plano Nacional de Desenvolvimento, aprovado pela Lei 6151, de 4 de dezembro de 1974, planejava a política de desenvolvimento do país para o período 1975 a 1979 (VALLER FILHO, 2007).
} 
no exterior ao mesmo tempo em que buscava promover os interesses econômicos por meio da expansão de mercados para as exportações brasileiras (VALLER FILHO, 2007).

As diretrizes da política externa estipulavam, assim como a busca por mercados para os produtos brasileiros, estipulavam importância especial à cooperação Sul-Sul e, particularmente, às relações com a América Latina e a África. No final da década, porém, o agravamento da crise econômica internacional, marcada pelo aumento do protecionismo no mundo e pela crise energética, e o deterioramento das condições das condições econômicas domésticas trariam dificuldades para a política brasileira de cooperação. Concomitantemente, a demanda pela cooperação brasileira crescia especialmente nos países da África e América Latina. Aumento que ocorria devido ao próprio esforço da diplomacia brasileira em projetar a atuação do país mundo afora, e também devido à experiência e credibilidade adquirida pelos atores brasileiros prestadores de cooperação internacional.

Assim, em 1984, começam a surgir indícios da necessidade de uma revisão da estrutura institucional que sistematizava a cooperação prestada pelo Brasil. Na medida em que já se delineava a necessidade de um novo reexame dos mecanismos de gestão do Sistema, a fim de dotá-lo de maior eficácia gerencial. A principal preocupação até então era com o duplo caráter da gestão, de um lado o DCOPT, ligado ao MRE, e de outro a SUBIN, ligada ao Ministério do Planejamento. Essas preocupações, somadas à pressão que o sistema vinha recebendo com a expansão dos projetos pelo mundo, e com o processo de redemocratização que se estabelece no país após 1985, com o governo Sarney, abrem o caminho para uma reforma administrativa que viria a redesenhar o sistema brasileiro de cooperação(VALLER FILHO, 2007; MILANI, 2017).

Em 1987, por meio do Decreto 94.973, é criada, pela primeira vez, uma agência específica com o intuito de organizar toda a cooperação recebida e prestada pelo país, a Agência Brasileira de Cooperação (ABC), que absorve as funções e competências dos seus antecessores, SUBIN e DCOPT. Dessa forma, toda a política de cooperação foi centralizada em um único ministério, o das Relações Exteriores, que passa a ficar responsável pela gestão da cooperação tanto no plano interno quanto externo. Assim, caberia a ABC:

planejar, coordenar, negociar, aprovar, executar, acompanhar e avaliar, em âmbito nacional, programas, projetos e atividades de cooperação para $o$ desenvolvimento em todas as áreas do conhecimento, recebida de outros países e organismos internacionais e aquela entre o Brasil e países em desenvolvimento, incluindo ações correlatas no campo da capacitação para a gestão da cooperação técnica e disseminação de informações (ABC, 2018). 
As ações de cooperação brasileira continuaram a constituir-se como instrumento de política externa, do qual o Brasil se serviu para assegurar presença em países e regiões de interesse (ABC, 2018). Para tanto, valendo-se dos seguintes instrumentos: consultorias, treinamentos e a eventual doação de equipamentos. De acordo com a ABC, sua missão seria a de "contribuir para o adensamento das relações do Brasil com os países em desenvolvimento, para a ampliação dos seus intercâmbios, geração, disseminação e utilização de conhecimentos técnicos, capacitação de seus recursos humanos e para o fortalecimento de suas instituições" (ABC, 2018). Havendo sido a ABC criada eminentemente para atuar como eixo da cooperação Sul-Sul brasileira, a estrutura operacional da agência e a composição de seu quadro de recursos humanos e de sistemas gerenciais foram sendo estruturados concomitantemente ao expressivo crescimento dos programas de cooperação horizontal do Brasil, que se ampliaram geometricamente em termos de países parceiros atendidos, projetos implementados e em recursos efetivamente desembolsados (ABC, 2018).

A ABC deu continuidade em boa parte à organização administrativa da SUBIN, reproduzindo a divisão básica entre a cooperação recebida, bilateral e multilateral, e a cooperação realizada entre países em desenvolvimento, a chamada CTPD. Herdando também alguns problemas como a falta de recursos humanos e financeiros para atender às demandas crescentes da cooperação e a falta de um marco legal regulatório para execução da cooperação. Destaca-se também o papel do Programa das Nações Unidas para o Desenvolvimento (PNUD) nesse processo de institucionalização da ABC, tanto em relação ao auxílio prestado na formação e capacitação de material humano, na organização administrativa da $\mathrm{ABC}$, quanto no apoio à implementação de ações de CTPD nos países receptores (PUENTE, 2010; CHEDIEK, 2017).

Essa estrutura dual em relação à cooperação técnica recebida e a CTPD vigoraria até os anos 1990, quando se começa a observar um aumento da cooperação técnica recebida multilateral (CTRM). Essa cooperação abrangia organizações multilaterais, especialmente a PNUD, entre outras agências, e instituições públicas nacionais. Os órgãos públicos visavam, por meio da CRTM, dotar o Estado de maior racionalidade, em um contexto de restrições orçamentárias e emagrecimento do Estado. Resultado em um aumento significativo do número de atividades de CRTM recebidas no período $^{87}$, o que culminou na necessidade de se criar uma unidade específica para o gerenciamento desses projetos, a "Unidade de Administração de Projetos (UAP)". Assim, a estrutura da ABC passa de uma estrutura dual

\footnotetext{
${ }^{87}$ De 17 em 1990 para mais de 300 no início dos anos 2000 (PUENTE, 2010).
} 
para uma estrutura tripartite: a CTPD, a cooperação recebida bilateral (CTRB) e a cooperação recebida multilateral (CRTM) (PUENTE, 2010).

Como visto nos capítulos anteriores, na virada da década, as Nações Unidas, entre outras organizações componentes do regime de Cooperação Internacional para o Desenvolvimento, passam a incentivar de modo mais assertivo que os países receptores passassem a ter um maior controle dos programas de cooperação recebidos. Até então, prevalecia a chamada "Execução Direta", aquela efetuada pelos próprios doadores, que detinham a responsabilidade tanto da gestão como da condução técnica dos projetos nos países beneficiados. Em 1989, a Assembleia Geral das Nações Unidas (AGNU) aprovou a Resolução 44/211 recomendando a implantação de políticas de "Execução de Governo", mais tarde consolidada na expressão "Execução Nacional de Projetos", com o objetivo de promover maior domínio (ownership) e responsabilidade (accountability) dos países receptores sobre os programas de cooperação recebidos (ABC, 2018).

No caso do Brasil, essa execução nacional seria aprovada pelo Decreto 3.751, de 15 de novembro de 2001, e pelo Decreto 5151, de 22 de julho de 2004, que previam que gestão dos projetos de cooperação técnica internacional acordados com organismos e agências multilaterais ficaria a cargo das instituições brasileiras. Nesse sentido é criada uma Unidade de Administração de Projetos, por meio do projeto BRA/90/009, no âmbito da ABC, com o intuito de cumprir com esses objetivos (VALLER FILHO, 2007).

Nos anos 1990, o Brasil abandonou sua tradicional estratégia "desenvolvimentista" em favor da estabilidade macroeconômica. Ao longo da década, diversas medidas foram adotadas no plano econômico em consonância com a inserção internacional, como diminuição dos subsídios à indústria, maior liberalização comercial e financeira e privatização de empresas estatais (VIGEVANI; CEPALUNI, 2007). Seguindo uma tendência global entre os países em desenvolvimento, os programas de ajuste estrutural se tornaram dominantes e a ODA foi reorientada principalmente para projetos de alívio da pobreza. A busca por uma inserção da economia do país na economia global, a reforma estrutural da economia nacional, a retração do papel do Estado e a liberalização do mercado trariam um caráter renovado à cooperação técnica recebida do exterior. Assim, a cooperação passou a ser vista não mais como um instrumento por si só capaz de transformar as estruturas de subdesenvolvimento do país, mas como um facilitador, com custos compartilhados entre o Brasil e os países doadores (PUENTE, 2010). 
Em relação à cooperação recebida, no período até 1989, os principais doadores bilaterais (em número de projetos) foram Alemanha, França, Japão, Itália e Reino Unido. O Programa das Nações Unidas para o Desenvolvimento (PNUD), Organização das Nações Unidas para Agricultura e Alimentação (FAO), Organização das Nações Unidas para a Educação, a Ciência e a Cultura (UNESCO), Organização Internacional do Trabalho (OIT), Organização das Nações Unidas para o Desenvolvimento Industrial (UNIDO), a Agência Internacional de Energia Atômica (AIEA) e a Organização Mundial de Saúde (OMS) figuraram como os principais doadores multilaterais (LEITE et al., 2014).

O governo Collor (1990-1992), apesar de curto, trouxe algumas mudanças em relação à condução da política externa brasileira no período. A partir desse momento há uma tentativa de transformar a agenda do país com as novas questões das relações internacionais, como temas ambientais e de direitos humanos, com um aumento paulatino do número de acordos internacionais firmados nesse contexto nessas temáticas. Uma tentativa de maior aproximação com os Estados Unidos, e de descaracterização do perfil terceiro-mundista do país no cenário internacional. Embora valha destacar que tais mudanças não significavam essencialmente em uma mudança de rumo da política externa quanto aos seus traços essenciais, na medida em que a mesma continuaria figurando como um instrumento para auxiliar no desenvolvimento do país (VALLER FILHO, 2007).

No governo Itamar Franco (1992-1994), a política externa brasileira adotaria um caráter de reciprocidade, seguindo uma linha multilateralista e universalista de orientação. A ênfase da cooperação brasileira nesse período seria direcionada aos países da América do Sul e com os países africanos, especialmente os de língua portuguesa. Foram mantidas as políticas iniciadas anteriormente, concomitantemente à adoção de um posicionamento marcado pela condição de país em desenvolvimento. Assim, o país buscaria continuar o processo de aproximação com os Estados Unidos, apresentando ao mesmo tempo uma atuação mais ativa nos fóruns internacionais, e de aprofundamento dos processos de integração regional, na medida em que o MERCOSUL já não constituía apenas um mecanismo para acelerar o processo de liberalização econômica, mas apresentaria também um sentido estratégico mais abrangente (VALLER FILHO, 2007).

Durante o governo FHC, apesar das dificuldades operacionais, intensificam-se as ações de CTPD, aumentando seu escopo, alcance internacional e as áreas temáticas de atuação. Nesse contexto, as ações de CTPD ganham um novo impulso em consequência da retomada de aproximação com os países latino-americanos e africanos, que havia sido 
diminuída durante o governo Collor, e também pelo aumento das demandas provenientes desses países. Em 1996, por meio do Decreto n 2070/96, a ABC é desvinculada da Fundação Alexandre de Gusmão (FUNAG) e passa a subordinar-se formalmente à Secretaria Geral das Relações Exteriores, mantendo suas atribuições (PUENTE, 2010; MILANI, 2017).

Verifica-se o pragmatismo nessa aproximação, sobretudo na esfera comercial, que norteou as ações de maior relevo na com esses países. A consolidação da CPLP revelou-se paradigmática, na medida em que se tratava de um projeto político, iniciado no governo Sarney, mas institucionalizado no governo FHC. A aproximação com os países lusófonos deram um alento às relações com a África, destacando-se alguns acordos de cooperação CTPD, dentre os quais destaca-se a criação do centro de treinamento técnico de Cazenga, em Angola, construído em 1998 (MENDONÇA JÚNIOR; FARIA, 2015).

No plano internacional, há uma ênfase, especialmente no primeiro mandato, na adesão aos regimes internacionais, de cunho liberal, no intuito de influenciar a formulação dos princípios e regras do SI. Estratégia conceituada como "autonomia pela participação". A atuação internacional do país envolveu ativamente o Ministério da Fazenda, quando a adesão aos valores prevalecentes no cenário internacional se traduziu em ações centradas na busca de estabilidade econômica. O início do século XXI, especialmente o período após o 11 de setembro, trouxe complicações para o governo FHC no cenário internacional, que passou a se preocupar cada vez mais com as dificuldades advindas do unilateralismo norte-americano. Esse contexto propiciou certo redirecionamento da política externa brasileira em relação ao eixo Sul-Sul, que seria aprofundado nas administrações seguintes (VIGEVANI; CEPALUNI, 2007).

A partir de 2003, as atividade de CSS, incluindo a CTPD, ganham ênfase especial durante o governo Lula (2003-2010). Nesse período, as relações Sul-Sul passaram a ser prioridade na agenda da política externa brasileira, havendo um aumento significativo no número de acordos de cooperação firmados pelo Brasil com países em desenvolvimento. De acordo com a Agência Brasileira de Cooperação ( $\mathrm{ABC}$ ), foram assinados 30 projetos e/ou atividades de Cooperação em 2004, 66 em 2005, 147 em 2006, 175 em 2007, 263 em 2008, 386 em 2009 e 472 em 2010 (ABC, 2018).

De acordo com Milani (2018), durante os governos petistas, as decisões em matéria de política externa passam a se fundamentar em uma interpretação da política internacional segundo a qual as transformações no sistema internacional estariam resultado em uma redistribuição de poder do Norte para o Sul. Nesse cenário, o Brasil deveria combinar o uso 
das ferramentas de soft power para além dos limites anteriores de sua atuação diplomática. Assim, a ampliação da agenda da CSS fez parte desse projeto de diversificação de parcerias internacionais, tanto no campo econômico quanto no campo geopolítico.

Milani, Pinheiro e Lima (2017) buscam explicar essa atuação por meio do conceito de "graduação". A "graduação" implicaria agência por parte do ator estatal em relação à sua ambição de protagonismo internacional, ao seu papel como formulador de normas, sua visão geopolítica do Sul e seu compromisso com a integração regional. Assim, ao buscar "graduarse", o Estado se confrontaria com o que os autores conceituam como "dilema da graduação", que envolveria os dilemas existentes em função dos custos e riscos associados, nos planos internacional, regional e doméstico, a essa estratégia. De modo que o resultado dessa equação fora a busca por "graduação" por meio de um revisionismo soft.

Nesse contexto, a CSSD ganha maior ênfase sendo percebida com maior nitidez como instrumento de política externa brasileira. A partir de 2003, reforça-se a estratégia de inserção do país por meio da promoção de alianças e acordos com parceiros do Sul na tentativa de reduzir as assimetrias nas relações com os países desenvolvidos e aumentar a capacidade de negociação brasileira $^{88}$. Assim, os anos 2000 trouxeram mais uma mudança, com a renovação do desenvolvimentismo liderado pelo Estado brasileiro (BRESSER-PEREIRA, 2011), desta vez com maior ênfase na inclusão social (ARBIX; MARTIN, 2010). Nesse sentido, o desenvolvimento social passa a desempenhar um papel importante nas demandas brasileiras pela cooperação para o desenvolvimento (LEITE et al., 2014).

Nesse contexto, a CSS ganha um destaque central na PEB, sendo vista como uma importante ferramenta para perseguição dos interesses nacionais do país no cenário internacional. Enfatizando a necessidade de diversificação de parcerias e da atuação em fóruns multilaterais como forma de ampliar a influência do país nas negociações internacionais. Durante o governo Lula, o Brasil passou a se inserir cada vez mais internacionalmente, mantendo relações estreitas com os países emergentes, especialmente por meio de coalizões, interagindo assiduamente com os demais países latino americanos, sem deixar de lado os laços existentes com os Estados Unidos (VIGEVANI; CEPALUNI, 2007; SILVA, 2015).

O governo Lula procurou enfatizar a cooperação com os países do Sul, especialmente os países dos BRICS, ocorrendo uma maior formação de coalizões de geometria variável em relação ao governo antecessor (SOUTO MAIOR, 2004; CERVO, 2006; VISENTINI; SILVA,

\footnotetext{
${ }^{88}$ Ver Hirst, Lima e Pinheiro, 2010; Oliveira \& Onuki, 2012; Pinheiro e Gaio, 2014; Vigevani \& Cepaluni, 2007, entre outros.
} 
2010). Alguns autores, no entanto, argumentam que as mudanças da política externa durante o governo Lula, se deram a partir de "ajustes e mudanças de programas", representando uma "mudança dentro da continuidade" (ALMEIDA, 2004). De todo modo, é evidente o aumento tanto do número de acordos de cooperação firmados no período, quanto nos valores gastos em relação à CID (IPEA, 2010, 2013).

Em 2004, pelo Decreto 5.032/04, a ABC passou a integrar a então criada Subsecretaria-Geral de Cooperação e Comunidades Brasileiras no exterior (SGEC). A extinção da UAP nesse contexto retira da $\mathrm{ABC}$ a competência para administrar os recursos mobilizados para a cooperação recebida do exterior, sem maiores consequências, porém, sobre a CTPD, que continua a crescer. O Itamaraty junto com o planalto estabelece novos critérios e prioridades para a CTPD, passando a dotar a ABC de maiores recursos financeiros e humanos, embora as dificuldades institucionais e jurídico-legais não tenham sido completamente superadas (PUENTE, 2010).

A literatura aponta também para um aumento da descentralização (ou "horizontalização") da política externa nesse período (CASON; POWER, 2009; FRANÇA; SANCHEZ BADIN, 2010; SILVA; SPÉCIE; VITALE, 2010; FARIA, 2012; MILANI, 2012a; LEITE; SUYAMA; WAISBICH, 2013). Entendida como um aumento da participação de entidades subnacionais na formulação e execução da PEB. Embora não seja um fenômeno recente, esse processo se acentuou nas últimas décadas com o aumento da internacionalização de ministérios, governos subnacionais e atores não governamentais que buscaram ter uma atuação cada vez mais relevante na PEB (LEITE, 2012). Essa descentralização se verifica de forma acentuada na Cooperação Técnica na medida em que há uma diversa gama de atores envolvidos na sua execução. Destacam-se o papel de diversas entidades nacionais de elevada expertise técnica como a Empresa Brasileira de Pesquisa Agropecuária (Embrapa) e a Fundação Osvaldo Cruz (Fiocruz), como será discutido posteriormente.

Em relação à cooperação advinda do exterior, entre 2005 e 2009, o Brasil forneceu mais ajuda internacional do que recebeu de países e agências multilaterais. Entretanto, o país continuou sendo um receptor de ajuda externa no plano internacional (WORLD BANK, 2018a). Apesar do predomínio da narrativa de evolução de receptor para provedor de cooperação internacional, a cooperação com outros países ainda é vista como uma ferramenta importante para apoiar o desenvolvimento do Brasil (LEITE et al., 2014).

Segundo Leite et al (2014), entre 2003 e 2010, o Brasil beneficiou-se de 1.800 projetos de cooperação técnica e, em 2010, recebeu US \$ 661 milhões em fluxos ODA de 
países do CAD, notadamente da Alemanha, Noruega, Japão, França, Espanha e o Reino Unido. Sendo os setores de meio ambiente, educação, agricultura, gestão pública e saúde foram os principais beneficiados. O governo brasileiro também solicita cooperação internacional em setores estratégicos, de alta tecnologia, embora em muitos casos o país tenha evoluído de um receptor para um coprodutor de inovação, indo além do estrito domínio internacional da cooperação para o desenvolvimento. Os laboratórios virtuais da Embrapa LABEX - na China, Coréia, Europa e Estados Unidos são exemplos da evolução dessa relação. A alocação setorial da ajuda recebida em 2010 e 2011 concentrou-se principalmente nos setores sociais e na produção.

A recente reorientação dos doadores tradicionais, visando novas regiões, fechando representações ou transferindo-as para múltiplas partes interessadas e trilaterais, e canalizando a ajuda através de diferentes canais (como ONGs internacionais e o setor privado, por exemplo) foi profundamente sentido por alguns setores no Brasil, particularmente pelas ONGs nacionais (LEITE et al., 2014). As quais alegam que, apesar do status do Brasil como um país de renda média, o país ainda apresenta altos índices de pobreza (BALBIS; FERNÁNDEZ, 2011) e que a assistência e cooperação para o desenvolvimento continuam sendo cruciais para a sustentabilidade das ONGs brasileiras (MASAGÃO, 2011).

A partir do primeiro mandato da presidente Dilma Rousseff (2011-2016), observou-se uma diminuição dos gastos e do número de novas iniciativas da $\operatorname{CSS}^{89}$. Alguns autores apontam para um declínio da PEB nesse período quando comparada ao governo anterior (CERVO; LESSA, 2014; CORNETET, 2014; SARAIVA, 2014). Esse declínio seria verificado na diminuição das viagens presidenciais, na diminuição da formalização de parcerias estratégicas multilaterais, na perda de protagonismo no BRICS e no afastamento do Brasil nos debates de diversas questões internacionais, desde conflitos no Oriente Médio até Meio Ambiente. Ainda assim, o envolvimento do país com a agenda da CSS permaneceu relevante (SUYAMA; SILVA; WAISBICH, 2017).

No governo Michel Temer (2016-2018), verificou-se uma redução de recursos significativos para a condução de ações e projetos com países em desenvolvimento. Além da redução de recursos para ações de CSS, nota-se uma menor vontade política para visibilizar ações externas (SUYAMA; SILVA; WAISBICH, 2017). Ademais, cortes orçamentários em instituições públicas implementadoras importantes de CSSD, como a $\mathrm{ABC}$ e a Fiocruz agravaram a situação da CSS brasileira (FINGERMANN, 2016). Análises mais recentes

\footnotetext{
${ }^{89}$ Ver figuras 5.21.; 5.2.2 e 5.2.3.
} 
parecem concordar que as orientações do novo governo deixaram de priorizar o lugar do Sul Global na política externa brasileira (POMEROY; WAISBICH, 2016; SUYAMA; SILVA; WAISBICH, 2017). A crise institucional instaurada no país, a descontinuidade na liderança do Ministério das Relações Exteriores e as mudanças de rumo adotadas no período recente também aparentam contribuir para a redução da atuação do país no campo da CID. Com recente mudança de governo após as eleições de 2018, o futuro acerca de qual será o papel do país nesse regime permanece incerto.

\subsection{Visões sobre a Cooperação Brasileira}

Embora haja uma literatura consolidada de trabalhos empíricos que buscam explicar os padrões de doações por parte dos países desenvolvidos, nota-se que ainda são incipientes os trabalhos que buscam avaliar empiricamente os determinantes e resultados concretos da ajuda externa prestada pelos países em desenvolvimento, geralmente conceituada como Cooperação Sul-Sul para o Desenvolvimento (CSSD) e da assistência prestada pelo Brasil em particular.

Por um lado, alguns autores apontam que a CSSD envolveria benefícios mútuos na medida em que traria consigo uma ideia de parceria, horizontalidade e relações simétricas baseadas no conceito de "soft power" (HIRST; DE LIMA; PINHEIRO, 2010; PINO; LEITE, 2010; AMANOR, 2013). Em outra linha, a CSSD seria vista como uma forma de inserir os países subdesenvolvidos ao sistema internacional em uma posição subordinada. Essas práticas não seriam tão diferentes das realizadas pelos países desenvolvidos na medida em que atenderiam primordialmente aos interesses dos países doadores (CARMODY, 2011; BOND, 2013b, 2013a; NOGUEIRA; OLLINAHO, 2013; PRASHAD， 2013; MORVARIDI; HUGHES, 2018).

Em relação à cooperação prestada pelo Brasil no exterior, o discurso oficial é o de que a assistência prestada pelo Brasil não é guiada por interesses comerciais, visando atender apenas às demandas dos países receptores, mediante transferência de boas práticas e políticas públicas bem sucedidas. Nas palavras do ex-diretor da Agência Brasileira de Cooperação (ABC), Marco Farani:

o Brasil coloca à disposição de outros países em desenvolvimento as experiências e conhecimentos de instituições especializadas nacionais, sem a imposição de condicionalidades e desvinculada de interesses comerciais ou fins lucrativos, nas áreas consideradas mais relevantes pelos próprios países 
receptores. Ao prover cooperação, o Brasil tem particular cuidado em atuar com base nos princípios do respeito à soberania e da não intervenção em assuntos internos de outras nações (FARANI, 2009).

João Brígido Bezerra Lima, coordenador da COBRADI/IPEA, quando perguntado por alguns deputados, em audiência pública na Comissão de Relações Exteriores da Câmara dos Deputados, por que um país com tantos problemas internos e desigualdades regionais como o Brasil prestaria assistência para outros países, respondeu que era porque estava definido pela Constituição Federal no "artigo $4^{\circ}$ que estabelece em seu inciso IX, o principio da ‘cooperação entre os povos para o progresso da humanidade” (BRASIL, 1988).

O trabalho se fundamenta no texto constitucional, no famoso item 9 do art. $4^{\circ}$, que determina a cooperação. Por que o Brasil está fazendo isso? Muitas vezes eu vou no texto constitucional e menciono que nós temos uma determinação de cooperar para o progresso da humanidade, e mais embaixo, no seu parágrafo único, os povos da América Latina, numa comunidade latino-americana de nações. Vou ainda na Carta das Nações Unidas e mostro no Capítulo I, art. $1^{\circ}$, item 3 , que firmamos um acordo de cooperar para resolver problemas internacionais de múltiplos propósitos: social, econômico, humanitário. Esses são os fundamentos da participação brasileira em tantas frentes (CÂMARA DOS DEPUTADOS, 2012).

Faria e Paradis (2013) defendem que a explicação para o caráter "solidário" da estratégia de inserção internacional do Brasil adotado após a chegada ao poder do presidente Lula, marcada pelo aumento da ajuda concedida pelo Brasil a outros países, pode ser explicado por fatores domésticos, regionais e sistêmicos. Os motivos a nível doméstico residiriam nas diretrizes do Partido dos Trabalhadores (PT) para o exercício de uma política externa com prioridade às relações CSS; pelo crescimento econômico do país nesse período e pelo sucesso de políticas sociais domésticas que puderam ser exportadas para outros países. Os fatores regionais consistiriam na necessidade de se pagar os custos da almejada liderança regional. Por fim, os motivos sistêmicos consistiriam nas janelas de oportunidade abertas às ambições brasileiras decorrentes da política norte-americana de Guerra ao Terror, do surgimento dos BRICS enquanto coalizão política e da crise financeira de 2008.

Os ideais de horizontalidade e não condicionalidade presentes na Cooperação Brasileira para o Desenvolvimento Internacional se alinham aos princípios da PEB, especialmente a não intervenção, a autonomia, o pacifismo e o universalismo, todos fundamentados na identidade sulista do país (LEITE et al., 2014). Historicamente, continuidades da política externa brasileira prevaleceram sobre as rupturas, mesmo em 
diferentes regimes (CERVO; BUENO, 2002; LIMA, 2005; VIZENTINI, 2005; LEITE, 2011). A continuidade também é garantida pelos princípios consagrados no Artigo 4 da Constituição Federal de 1988 (BRASIL, 1988).

A autoimagem do Brasil nos assuntos internacionais também desempenha um papel na formação do envolvimento do país com a cooperação para o desenvolvimento. Uma concepção proeminente compartilhada pelos policy-makers brasileiros é a de que o país está destinado a desempenhar um papel mais relevante nos assuntos internacionais (LIMA, 2005; SARAIVA, 2007; PECEQUILO, 2008). Construir coalizões com outros países do Sul, diversificar parceiros e projetar soft power são vistos como instrumentos que podem ajudar a garantir a liderança do Brasil nos assuntos internacionais e reduzir sua dependência estrutural (LIMA, 2005; VALLER FILHO, 2007; VIGEVANI; CEPALUNI, 2007; PECEQUILO, 2008; PUENTE, 2010; LEITE, 2011; DAUVERGNE; FARIAS, 2012). Com base em seus princípios tradicionais de política externa e em sua identidade sulista, o país também repudia a coerção como um instrumento para atingir as metas internacionais. Portanto, a cooperação seria vista como um instrumento para o engajamento internacional do Brasil (LEITE et al., 2014).

Leite et al (2014) destacam que o Brasil não quer ser visto apenas como um "país em desenvolvimento". O país busca o reconhecimento de sua posição distintiva em relação aos demais países do sul em geral. As narrativas de 'poder médio', intermediário, ou emergente' proeminentes na literatura de PEB (LAFER, 2001; LIMA, 2005; SARAIVA, 2007; HURRELL, 2009; SENNES, 2012), reforçam essa percepção do papel do país como intermediário entre o Norte e o Sul.

Assim, o engajamento na cooperação para o desenvolvimento internacional satisfaria essas narrativas na medida em que possibilitaria ao país construir seu "poder brando" (PUENTE, 2010); reafirmar sua "diplomacia pelo desenvolvimento" e sua identidade como defensor dos países em desenvolvimento (DAUVERGNE; FARIAS, 2012); e cultivar a hegemonia no Atlântico Sul (SÁ E SILVA, 2009) Alguns autores defendem que esse esforço seria motivado por novas ambições internacionais, em que o país almejaria expandir sua presença em negociações globais, nos âmbitos dos regimes e das organizações multilaterais (HARDT; MOURON; APOLINÁRIO JÚNIOR, 2017; HIRST; DE LIMA; PINHEIRO, 2010; PINO; LEITE, 2010; HIRST, 2011; MILANI; CARVALHO, 2013; APOLINÁRIO JUNIOR, 2016). E para a promoção de interesses econômicos, não visando exclusivamente o 
desenvolvimento dos países receptores (CARMODY, 2011; MASAGÃO; SUYAMA; LOPES, 2012; MELLO E SOUZA, 2012; SCHLESINGER, 2012; STOLTE, 2012).

Hirst, Lima e Pinheiro (2010) apontam que a cooperação realizada pelo Brasil combina motivações de política externa com a capacidade de atender demandas de assistência técnica específica dos países receptores evitando reproduzir as lógicas da assistência NorteSul. Por meio da $\mathrm{ABC}$, o país buscaria configurar a cooperação horizontal com ações que visem construir pontes de transmissão e intercambio de conhecimento, lealdades políticas e sociais com outros países em desenvolvimento. De modo que este esforço coincidiria com as mudanças de inserção externa, motivadas por novas ambições internacionais, almejando expandir a presença do país em negociações globais, nos âmbitos dos regimes e das organizações multilaterais e nos assuntos regionais ${ }^{90}$.

Dessa forma, o país buscaria aumentar sua legitimidade como ator relevante no sistema internacional, almejando promover reformas no intuito de ganhar voz nas instituições de governança global. No que concerne aos objetivos estratégicos e de segurança da cooperação internacional brasileira, o estreitamento de laços com os países em desenvolvimento estaria associado à busca de apoio para o pleito do Brasil de um assento permanente no Conselho de Segurança da ONU, objetivo que teria se tornado prioritário para a política externa brasileira durante o governo Lula.

Milani e Carvalho (2013) destacam que embora as fronteiras entre a cooperação técnica, empréstimos subsidiados e abertura de mercados para companhias não sejam claras, não haveria dúvida de que o Brasil reconhece a importância estratégica da CID dentro de sua política externa. O Brasil rejeita as terminologias utilizadas pelo CAD/OCDE, partilhando da definição dada pela UNCTAD de cooperação ${ }^{91}$. Nesse sentido, a CSSD seria apresentada como uma alternativa à cooperação Norte-Sul ${ }^{92}$.

Mello e Souza (2012) destaca que no que concerne às motivações, a cooperação para o desenvolvimento concedida pelos países emergentes é similar àquela oferecida pelos países desenvolvidos, de modo que ambas são usadas como instrumentos político-diplomáticos e de promoção de interesses econômicos, não visando exclusivamente ou prioritariamente o desenvolvimento dos países receptores. Destaca que a CID do Brasil tem contribuído com o financiamento da importação de bens e serviços do país, sobretudo via BNDES. Além disso, a

\footnotetext{
${ }^{90}$ Ver também Lima e Hirst (2006); Lima (2005a, 2005b, 2006, 2010) e Hirst, (2011).

91 Em vez de empregar os conceitos "doador" e "receptor" os países do Sul fazem referência aos países envolvidos na cooperação para o desenvolvimento como "parceiros".

${ }^{92}$ Há, no entanto, diferenças significativas na cooperação concedida pelos países do chamado "Sul”, em especial, Brasil, Índia e China.
} 
disseminação da tecnologia brasileira na produção de biocombustíveis adquire um caráter econômico estratégico, uma vez que há o entendimento de que tais combustíveis somente serão empregados em âmbito global quando existirem diversos fornecedores.

Bond (2013a) aponta que a CSSD efetuada pelo Brasil não é tão "igualitária" e horizontal quanto o termo "cooperação" sugere. As aspirações de soft-power do país no cenário global seriam escoradas em interesses econômicos domésticos. Assim, embora o discurso oficial seja de um tom "anti-imperialista", na realidade o país buscaria promover a expansão de seu capitalismo nacional por meio dessas iniciativas. Werner (2015) destaca que na promoção da CSSD, o Brasil corre o risco de exportar modelos estruturais exploradores para outros continentes, na medida em que esta beneficiaria primordialmente os grandes grupos econômicos domésticos. Destaca que as grandes multinacionais brasileiras foram os maiores financiadores de campanhas eleitorais nas últimas eleições e enfrentam atualmente graves denúncias de corrupção, minando o otimismo sobre as possibilidades da CSSD.

Nogueira e Ollinaho (2013), por meio de um estudo de caso sobre o projeto ProSAVANA no Moçambique, levantam evidências de que esse projeto vai contra ao menos três pilares centrais dos princípios da CID brasileira. Em primeiro lugar, contrário ao discurso oficial de ausência de motivações econômicas, a centralidade de atores privados como força dinâmica para o desenvolvimento faz com que o projeto seja mais um plano de negócios para investidores estrangeiros que um projeto de desenvolvimento para a população local, sendo uma manifestação precisa dos modelos de cooperação agrícolas tradicionais associados à ideia de land-grabbing ${ }^{93}$. Em segundo lugar, ao contrário do discurso de que a CID brasileira é demand-driven, esse projeto não surgiu de um pedido por parte do governo de Moçambique. E, em terceiro, qualquer aspecto de participação popular que o projeto possa ter surgiu por parte de pressão da sociedade civil e organizações campesinas, sendo que em um primeiro momento o projeto não possuía elementos de consulta popular. Dessa forma, os autores concluem que o plano não apenas segue uma abordagem de cima para baixo, como também de fora para dentro, na medida em que as autoridades moçambicanas dificilmente são tratadas como parceiros igualitários.

Inoue \& Vaz (2012) defendem que é possível que motivações altruístas e de promoção dos interesses nacionais não sejam mutuamente exclusivas. Se as relações internacionais forem abordadas por uma óptica de soma positiva, haveria espaço para cooperação e ganhos mútuos, mesmo em uma relação assimétrica de forças. Nesse sentido, a cooperação brasileira

\footnotetext{
${ }^{93}$ Transferências de grandes quantidades de terra de comunidades locais para investidores estrangeiros, sem as devidas consultas públicas às populações que tradicionalmente ocupavam esses espaços.
} 
não seria divorciada de interesses subnacionais, nacionais e setoriais e nem poderia ser vista como desconectada dos objetivos maiores da política externa brasileira e das mudanças de poder no sistema internacional. Dessa forma, o Brasil perseguiria objetivos políticos e econômicos na provisão de CSSD e, ao mesmo tempo, essas ações podem ter um efeito positivo nos países receptores.

Assim, enquanto alguns autores destacam que CID prestada pelo Brasil objetiva fins políticos, especialmente o acumulo de soft power, outros apontam que essa ajuda externa não é desinteressada materialmente, havendo motivações econômicas na alocação da mesma. Desse modo, nota-se que não há um consenso na literatura acerca de quais os propósitos da Cooperação Brasileira para o Desenvolvimento Internacional. Durante o período analisado, a própria $\mathrm{ABC}$ não fazia menções a eventuais ganhos materiais para o Brasil oriundos dessas práticas. No site da agência constava que a missão da CGPD seria "contribuir para o adensamento das relações do Brasil com os países em desenvolvimento, para a ampliação dos seus intercâmbios, geração, disseminação e utilização de conhecimentos técnicos, capacitação de seus recursos humanos e para o fortalecimento de suas instituições" (ABC, 2016) ${ }^{94}$.

No entanto, Leite et al (2014) destacam que diplomatas e acadêmicos brasileiros, em geral, concordam com a ideia de que o engajamento do país com a cooperação técnica seria um instrumento de política externa (CERVO, 1994; VALLER FILHO, 2007; PINO; LEITE, 2009, 2010; PINO, 2010b; PUENTE, 2010; BARBOSA, 2011). A cooperação técnica seria vista como um veículo para fomentar as relações em outros domínios com os países em desenvolvimento; criar condições favoráveis para a consecução de objetivos econômicos no exterior e reunir apoio internacional para elevar o perfil internacional do Brasil em temas como a busca por um assento permanente no Conselho de Segurança da ONU (UNSC, em inglês) e candidaturas brasileiras em outras organizações internacionais.

Em relação à cooperação técnica, Leite et al (2014) constatam que embora estrutura do MRE aponte para uma interpretação da cooperação técnica como instrumento de política externa, assim como sugerem estudos feitos por diplomatas e acadêmicos (CERVO, 1994; VALLER FILHO, 2007; PINO; LEITE, 2009, 2010; PUENTE, 2010; BARBOSA, 2011). As autoras não encontram evidências claras em sua pesquisa de que a $\mathrm{ABC}$ coordenaria a cooperação técnica brasileira seguindo uma única estratégia coerente e publicamente declarada, liderada pelo MRE. Destacam que o MRE trabalha com uma ampla rede

\footnotetext{
${ }^{94}$ Entretanto, mais recentemente, o site da $\mathrm{ABC}$ passou a destacar que a cooperação técnica "tem gerado visibilidade para o Brasil no mundo, sobretudo entre países em desenvolvimento, e aberto oportunidades de exportação de bens e serviços brasileiros, criando emprego e renda no Brasil, entre outros ganhos para o País" (ABC, 2018).
} 
internacional de embaixadas e outros órgãos oficiais, cuja principal tarefa é ajudar a identificar instituições parceiras no exterior, contatar autoridades locais, apoiar na negociação de instrumentos e acompanhar ações no campo.

As autoras apontam ainda que o fato de a ABC estar submetida a Subsecretaria Geral de Cooperação, Cultura e Promoção Comercial do MRE poderia significar que a cooperação técnica estaria intimamente ligada a estratégias que visam difundir a língua portuguesa e promover ou preservar o comércio brasileiro e investimentos no exterior. Leite et al (2014) encontraram algumas coincidências em ambos os casos, na medida em que alguns dos principais beneficiários dos recursos de cooperação técnica brasileiros alocados na $\mathrm{ABC}$ entre 2003 e 2010 seriam países lusófonos e/ou receptores crescentes de bens, serviços e investimentos brasileiros, como os casos de Angola e Moçambique.

No entanto, Leite et al (2014) destacam que os diplomatas tendem a tratar os benefícios econômicos como consequências não intencionais da cooperação técnica (PUENTE, 2010; BARBOSA, 2011). Pois, contrariaria o discurso da cooperação técnica brasileira como isenta de interesses econômicos. Ainda assim, a coincidência entre os países que recebem investimentos, serviços e produtos brasileiros e cooperação técnica pode apontar para este último como um instrumento de preservação ou promoção dos interesses econômicos brasileiros nos países parceiros. Por fim, ressaltam que embora os interesses econômicos não sejam geralmente declarados publicamente no discurso diplomático do Brasil o mesmo não se aplicaria aos interesses políticos. Reunir apoio para as candidaturas brasileiras e propostas relacionadas à reforma da governança global é, de fato, considerado um dos principais objetivos diplomáticos da cooperação técnica brasileira (PUENTE, 2010).

Milani (2018) defende que a ênfase da Política Externa Brasileira, entre os anos 2003 e 2014, no aspecto da solidariedade da Cooperação Sul-Sul, e essa falta de clareza em relação aos interesses envolvidos, dificultaram a coesão entre as elites governamentais e estratégicas. Destaca que durante a transição entre Lula e Dilma, acadêmicos e sociedade civil organizada esperavam que o governo implementasse medidas institucionais no intuito de estabelecer um marco regulatório para a COBRADI, tornando-a mais previsível e transparente, o que não ocorreu. $\mathrm{O}$ autor também aponta que essa ausência de institucionalização e de debate público dificultaram a formação de um consenso na sociedade pró-cooperação internacional ${ }^{95}$.

\footnotetext{
${ }^{95}$ Pelo contrário, nota-se que ao longo dos anos, as críticas de opositores à Cooperação Sul-Sul se tornaram mais vocais. Especialmente em relação aos aspectos mais controversos da Cooperação Financeira, como o perdão de dívidas de outros países.
} 
Assim, coube à sociedade civil, em especial à academia, a tarefa de analisar a cooperação realizada pelo Brasil e buscar identificar quais seriam seus aspectos-chave, objetivos e interesses envolvidos. Em relação à metodologia utilizada nos estudos sobre a COBRADI, nota-se o predomínio de análises qualitativas. Uma ampla leva de estudos se utilizou de estudos de caso, singulares ou comparados, geralmente acerca de áreas temáticas, da relação com algum país específico ou de projetos de CT. Nesse sentido, destacam-se os estudos de caso acerca da área de saúde (ALMEIDA et al., 2010; LIMA; CAMPOS, 2010; CASTRO; VILAR; GERMANO, 2015; SANTOS; CERQUEIRA, 2015; ZARPELON, 2016); sobre países específicos dentro dessa temática como Moçambique (LOPES, 2013; MILANI; LOPES, 2014; FEDATTO, 2017), Angola (ESTEVES; FONSECA; GOMES, 2016), São Tomé (CAIXETA, 2014), e Haiti (REGINA, 2016), para ficar em alguns exemplos; sobre projetos específicos, como o projeto para a construção de uma fábrica de medicamentos em Moçambique (RODRIGUES, 2014; SIQUEIRA, 2014; ALMEIDA, 2016; SILVA; DUARTE; CASTRO, 2017); sobre o projeto de fortalecimento da autoridade sanitária no Haiti (AVELHAN, 2018) e sobre o papel de entidades como a Fiocruz (CARRILLO ROA; BAPTISTA E SILVA, 2015). Sobre a cooperação na área da agricultura, foram produzidos muitos trabalhos especialmente sobre os projetos brasileiros realizados em Moçambique como o Prosavana e o Proalimentos (AVELHAN, 2013; NOGUEIRA; OLLINAHO, 2013; FINGERMANN, 2014; GARCIA; KATO, 2016; SHANKLAND; GONÇALVES, 2016; ZANELLA; CASTRO, 2017); sobre segurança alimentar (BEGHIN, 2014; MALUF; SANTARELLI; PRADO, 2014) e biocombustíveis (FULQUET; PELFINI, 2015). Ademais, destacam-se estudos sobre a área de Segurança (FERREIRA; MIGON, 2016); Direitos Humanos (MILANI, 2012a; ABDENUR; SOUZA NETO, 2013); educação (MILANI; CONCEIÇÃO; M'BUNDE, 2016); administração pública (SCHLEICHER; PLATIAU, 2017); desenvolvimento social (LEITE; POMEROY; SUYAMA, 2015) e sobre o papel de atores sociais na cooperação (GONÇALVES, 2011; VIANA, 2015; MANSUR; TEODÓSIO, 2016);

Ainda há poucos trabalhos que buscaram analisar quantitativamente a COBRADI. Uma das principais razões reside na dificuldade de obtenção de dados por parte dos pesquisadores acerca da cooperação brasileira. Alguns estudos buscaram levantar ou apresentar os dados existentes acerca da atuação brasileira nesse campo (MAGALHÃES, 2013; LEITE et al., 2014; LIMA; CAMPOS; NEVES, 2014; LOPES; COSTA, 2018). No entanto, ainda são escassos os trabalhos que buscaram realizar inferência estatística a partir 
dos dados levantados (DREHER; NUNNENKAMP; THIELE， 2011; APOLINÁRIO JÚNIOR, 2014, 2016; HARDT; MOURON; APOLINÁRIO JÚNIOR, 2017).

\subsection{Modalidades da Cooperação Brasileira para o Desenvolvimento}

Classificar e mensurar a cooperação prestada pelo Brasil não é tarefa fácil. O debate público acerca da cooperação brasileira, ainda que crescente, se restringe a poucos espaços no plano doméstico e internacional sendo conduzido por interessados e especialistas na área ${ }^{96}$. Até o momento, ainda não há definições oficiais por parte do Estado brasileiro acerca de quais seriam as melhores formas de se classificar e operacionalizar a cooperação prestada pelo Brasil. Um dos motivos reside na própria dificuldade de se levantar dados acerca dos dispêndios em cooperação realizados pelo Brasil nas últimas décadas. Outro motivo consiste na dispersão institucional entre as agências nacionais responsáveis pela prestação da cooperação.

Em relação à Cooperação Técnica, embora a ABC/MRE seja responsável por coordenar esses projetos; estima-se que mais de 170 órgãos do governo federal estão envolvidos nesse processo, incluindo ministérios, autarquias, fundações e empresas públicas nas mais diversas áreas, como agricultura, educação, saúde, meio ambiente, administração pública, transportes, energia, saneamento, cultura e justiça. Tais instituições compõem o atual sistema de cooperação técnica brasileira para o desenvolvimento internacional. Neste sistema, destacam-se: a Presidência da República, por meio da chamada diplomacia presidencial; o MRE, por meio da $\mathrm{ABC}$ e sua rede de embaixadas no exterior; e os ministérios e entidades vinculadas setoriais ${ }^{97}$. Vale destacar que a CID realizada pelo Brasil, apesar da preponderância do papel do MRE, vem passando por um processo de descentralização nas últimas décadas em decorrência do desinsulamento dessa burocracia em razão dos processos de democratização nos anos 80 e de liberalização econômica dos anos $90{ }^{98}$.

Assim, atualmente o Brasil não dispõe de uma política pública única, coerente e institucionalizada nacionalmente para o fornecimento de Cooperação Técnica. Pois, os diferentes ministérios desempenham ações e políticas nessa área, o que gera fragmentação.

\footnotetext{
${ }^{96}$ Apesar dos avanços em transparência e prestação de contas (accountability) da CSS ainda verificam-se muitos desafios no sentido previsibilidade, abrangência e nível de desagregação dos dados hoje disponíveis à sociedade brasileira. Vale destacar que os canais de participação da sociedade civil no debate sobre metodologia e no acesso aos dados primários também tem sido escassos e insuficientes (SUYAMA; SILVA; WAISBICH, 2017).

97 Ver relatório elaborado pelo IPEA sobre a Cooperação Brasileira para o Desenvolvimento Internacional (IPEA/ABC, 2013).

${ }^{98}$ Ver Cason e Power, 2009; França e Sanchez Badin, 2010, Faria, 2012; Pinheiro; Milani, 2013 entre outros.
} 
Isso se reflete na ausência de uma institucionalidade fortalecida que atue nos marcos das diferentes áreas para além da cooperação técnica, atualmente coordenada pela Agência Brasileira de Cooperação (ABC), do Ministério das Relações Exteriores. Ressalta-se a inexistência de normativas legais que delimitem papéis e dinâmicas para os processos decisórios neste campo, incluindo uma disposição clara sobre a participação de atores não governamentais (MILANI; LOPES; SUYAMA, 2013; SUYAMA; SILVA; WAISBICH, 2017).

No tocante à Assistência Humanitária, o principal mecanismo institucional responsável por sua execução é o Grupo de Trabalho Interministerial de Cooperação Humanitária Internacional (GTI-CHI). Esse órgão, embora coordenado pelo MRE, é composto por quinze ministérios $^{99}$. A Cooperação Educacional também é realizada por meio de articulação interministerial envolvendo mais diretamente a Coordenação de Aperfeiçoamento de Pessoal de Nível Superior (CAPES), ligada ao Ministério da Educação; o Conselho Nacional de Desenvolvimento Científico e Tecnológico (CNPq), órgão colegiado do Ministério da Ciência e Tecnologia (MCT) e a Divisão de Temas educacionais (DCE) do Departamento Cultural do MRE (IPEA/ABC, 2013).

\subsubsection{Projeto COBRADI}

A primeira tentativa oficial de sistematização e classificação da cooperação brasileira ocorreu por meio do projeto COBRADI, acrônimo que significa Cooperação Brasileira para o Desenvolvimento Internacional. Esse projeto, coordenado pelo IPEA, em parceria com a ABC, buscou levantar informações acerca da cooperação prestada pelo Brasil por meio de uma consulta com as diversas instituições brasileiras envolvidas com a cooperação internacional. O projeto surgiu como uma resposta a uma demanda do Ministério das Relações Exteriores visando aumentar a transparência e prestação de contas em relação aos recursos federais destinos à cooperação internacional. Assim, o projeto surgiu com o intuito de sistematizar os gastos da União, trazendo informações coletadas junto a 95 diferentes instituições do governo brasileiro. O projeto busca, assim, contribuir com o debate acerca das formas de se mensurar a cooperação internacional para o desenvolvimento,

\footnotetext{
${ }^{99}$ Casa Civil, Ministério da Justiça, Ministério da Defesa, Ministério da Fazenda, Ministério da Agricultura, Pecuária e Abastecimento, Ministério da Saúde, Ministério da Integração Nacional, Ministério do Desenvolvimento Social e Combate à Fome, Secretária-Geral da Presidência da República, Gabinete de Segurança Institucional da Presidência da República, Ministério da Educação, Ministério do Desenvolvimento Agrário, Ministério das Comunicações e Secretaria de Direitos Humanos da Presidência da República.
} 
sugerindo que a mesma avance para além da mera contabilização de gastos (IPEA/ABC, 2013). Até o momento foram publicados quatro relatórios da COBRADI, um cobrindo o período de 2005 a 2009, outro cobrindo o ano de 2010, outro para o período de 2011 a 2013 e o último, recém-lançado, cobrindo o período de 2014 a 2016 (IPEA/ABC, 2010, 2013, 2016, 2018).

O primeiro relatório destaca que "nos últimos anos os órgãos e entidades do governo federal intensificaram a destinação de parte dos seus recursos em projetos voltados para a promoção do desenvolvimento de diversos países" (IPEA/ABC, 2010, p. 11). Entretanto, o próprio relatório destaca que essas práticas não foram quantificadas, ou ao menos sistematizadas, no âmbito da administração pública federal, o que limitou o uso desse instrumento como ferramenta de política externa e o "reconhecimento da contribuição do país para a promoção do desenvolvimento em outros países” (IPEA/ABC, 2010, p. 11). É destacado que o caráter descentralizado das atividades brasileiras representa um desafio para a definição do volume do esforço brasileiro para o desenvolvimento internacional.

Assim, é destacado que o Ministério das Relações Exteriores realizou uma proposta ao Presidente da República para a realização de um levantamento de dados referente aos recursos empreendidos com o propósito de auxiliar no desenvolvimento de outros países. Na medida em que esse esforço configura-se como um fator-chave para o fortalecimento de parcerias no plano internacional, especialmente no eixo das relações Sul-Sul. Esse primeiro relatório teria como objetivo "identificar, resgatar e sistematizar os dados e as informações do investimento público para atividades, projetos e programas da Cooperação Brasileira para o Desenvolvimento Internacional no período 2005-2009” (IPEA/ABC, 2010, p. 11).

Em seu prefácio, assinado pelo ex-presidente Luís Inácio Lula da Silva, o relatório reconhece que a cooperação não se trata de uma mera interação entre doadores e receptores, mas que envolveria uma troca entre semelhantes com mútuos benefícios e responsabilidades. Destaca ainda que se trata de um modelo em construção, que apesar de já trazer apresentar algumas características, carece de maior sistematização e debate. Assim, se configuraria como um primeiro passo no sentido de se estabelecer uma política de cooperação para o desenvolvimento "integrada aos objetivos da política externa brasileira, que não esteja sujeita às prioridades de cada governo, mas que possa contar com uma ampla base de apoio no Estado e na sociedade civil" (IPEA/ABC, 2010, p. 6).

Para tanto, foram realizadas diversas reuniões com as instituições envolvidas nesse processo no intuito de se estabelecer um entendimento comum acerca da definição e formas 
de classificação dessa cooperação, o que resultou na metodologia utilizada pela COBRADI. Assim, o primeiro relatório define a Cooperação Brasileira para o Desenvolvimento Internacional como:

a totalidade de recursos investidos pelo governo federal brasileiro, totalmente a fundo perdido, no governo de outros países, em nacionais de outros países em território brasileiro, ou em organizações internacionais com o propósito de contribuir para o desenvolvimento internacional, entendido como o fortalecimento das capacidades de organizações internacionais e de grupos ou populações de outros países para a melhoria de suas condições socioeconômicas (IPEA/ABC, 2010, p. 11).

Ao longo do ano de 2010, foi realizado esse levantamento junto às organizações e entidades do governo federal que contribuíram de forma voluntária para consolidação dessas informações para o período de 2005 a 2009. O relatório destaca que o período pretendido anteriormente cobriria de 2000 a 2009. Porém, essa tentativa se mostrou inviável em função da escassez de registros desses recursos para o período anterior a 2005. Esse relatório classificou a cooperação realizada pelo Brasil em cinco modalidades: "ajuda humanitária, bolsa de estudo para estrangeiro e cooperação técnica, científica e tecnológica e as contribuições para organizações internacionais" (IPEA/ABC, 2010, p. 12). Ademais, as ações categorizadas de acordo com o tipo de cooperação: bilateral ou multilateral. O relatório aponta que a classificação dessas atividades baseou-se em um conjunto de categorias criadas a partir da revisão de metodologias internacionais, tendo em vista permitir "certo grau de comparabilidade dos dados levantados com os disponíveis em âmbito internacional" (IPEA/ABC, 2010, p. 13).

Em relação à cobertura, a intenção inicial era de cobrir todos os ministérios e entidades vinculadas prestadoras de cooperação internacional. De modo que todos esses órgãos públicos ${ }^{100}$ foram convidados oficialmente a participar do projeto, ainda que em um primeiro momento não estivesse claro quais ações seriam incluídas nesse recorte conceitual (IPEA/ABC, 2010). No final, essa coleta de dados foi realizada por meio de um formulário eletrônico que era preenchido de forma voluntária pelas instituições participantes. Para auxiliar nesse processo, foi elaborado um Guia de Orientações Básicas do Levantamento na forma de um manual explicativo com diretrizes em relação a como se quantificar e classificar os recursos.

\footnotetext{
${ }^{100}$ Mais de 60 entidades foram envolvidas no processo.
} 
Nesse processo, foram realizadas diversas reuniões com os órgãos envolvidos no intuito de aprofundar a compreensão acerca da definição da cooperação brasileira e da sua classificação. A partir dessas discussões, chegou-se à seguinte definição de Cooperação Internacional ao Desenvolvimento que guiou todo o estudo:

\begin{abstract}
A totalidade de recursos investidos pelo governo federal brasileiro, totalmente a fundo perdido, no governo de outros países, em nacionais de outros países em território brasileiro, ou em organizações internacionais com o propósito de contribuir para o desenvolvimento internacional, entendido como o fortalecimento das capacidades de organizações internacionais e de grupos ou populações de outros países para a melhoria de suas condições socioeconômicas (IPEA/ABC, 2010, p. 17).
\end{abstract}

A ideia dessa definição foi possibilitar o processo de levantamento de informações, permitindo certa comparabilidade com as definições tradicionais utilizadas para se mensurar a CID prestada por outros países. Embora, tal conceito não seja exatamente o utilizado pelo CAD/OCDE. Nesse sentido, o relatório aponta que há semelhanças e diferenças entre COBRADI e a AOD. Dentre as semelhanças, destacam-se o objetivo desses fluxos de promoção do desenvolvimento econômico e o bem-estar nos países em desenvolvimento, a origem pública desses recursos e o caráter de concessionalidade desses dispêndios. Em relação às diferenças, distinguem-se especificamente o grau de concessionalidade e a dimensão da cooperação. Em relação à concessionalidade, na cooperação brasileira, são contabilizados apenas os recursos oferecidos totalmente a fundo perdido e não apenas àqueles com nível de concessionalidade igual ou maior a 25\% como na AOD. Em relação à dimensão da cooperação, enquanto a AOD foca nos recursos de financiamento a organizações internacionais exclusivamente do Norte, a COBRADI leva em consideração os recursos fornecidos pelo Brasil a uma gama de organizações internacionais, particularmente do Sul Global, de caráter mais diverso (IPEA/ABC, 2010).

Nesse primeiro levantamento, chegou-se a conclusão de que, durante o período de 2005 a 2009, a cooperação brasileira alcançou uma cifra próxima de $\mathrm{R} \$ 2,9$ bilhões em valores correntes. Em que $76 \%$ desse valor foi destinado ao financiamento de organizações internacionais e bancos multilaterais, enquanto $24 \%$ do valor restante foi destinado às demais modalidades de cooperação, como assistência humanitária, bolsas de estudo e cooperação técnica. Ao todo, é apontado que a cooperação dobrou no período considerado, passando de $\mathrm{R} \$ 384,2$ milhões em 2005 para mais de R\$724 milhões em 2009 (IPEA/ABC, 2010). 
Ademais, o relatório destaca que todas as modalidades de cooperação registraram aumentos absolutos expressivos durante esse período.

O primeiro relatório COBRADI, publicado em 2010, teve ampla repercussão nos meios acadêmicos e políticos, especialmente, por ter sido a primeira vez que um país em desenvolvimento, especialmente um dos integrantes dos BRICS, tenha exposto seus dados acerca da sua cooperação prestada com uma metodologia que refletisse as características da Cooperação Sul-Sul. O segundo relatório COBRADI, intitulado "A Cooperação Brasileira para o Desenvolvimento Internacional, 2010”, publicado em 2013, buscou dar continuidade nesse processo, aprimorando o processo de captação, processamento e interpretação dos dados. Para tanto, buscou apresentar o dispêndios dos órgãos da administração pública brasileira com cooperação para o desenvolvimento internacional no ano de 2010, caracterizando os arranjos institucionais para sua execução.

Em relação à definição de cooperação, o primeiro relatório, como apontado, trazia uma definição de cooperação mais próxima à utilizada pelo CAD/OCDE. Entretanto, o segundo relatório não apresenta esse definição, trazendo as práticas de cooperação internacional do governo brasileiro, mas sem balizá-las por uma definição rígida. Assim, o documento destaca apenas que a cooperação seria um propósito estabelecido no item 3 do Artigo $1^{\circ}$ do capítulo I do texto da Carta da Organização das Nações Unidas (ONU), de 1945:

Conseguir uma cooperação internacional para resolver os problemas internacionais de caráter econômico, social, cultural ou humanitário, e para promover e estimular o respeito aos direitos humanos e às liberdades fundamentais para todos, sem distinção de raça, sexo, língua ou religião (ONU, 1945 apud IPEA/ABC, 2013, p. 13).

O relatório destaca que o que se designa como cooperação internacional de forma genérica compõe-se da "cooperação para o desenvolvimento internacional, de regimes internacionais em diversos setores, e de compromissos e obrigações de um Estado junto a outros Estados, organismos internacionais e entidades da sociedade civil” (IPEA/ABC, 2013, p. 13). Ademais, o documento ressalta que "a cooperação entre os povos para o progresso da humanidade figura no Artigo 4o da Constituição Federal (CF) brasileira de 1988 como um dos princípios regentes das relações internacionais do Brasil” (IPEA/ABC, 2013, p. 13).

O relatório destaca que esses gastos são mantidos com recursos do Tesouro Nacional na "consecução de responsabilidades assumidas em tratados, convenções, acordos, protocolos, atos institucionais ou compromissos internacionais" (IPEA/ABC, 2013, p. 14). O relatório 
ressalta que esses gastos provêm de "fontes orçamentárias inscritas na Lei de Orçamento Anual no âmbito das despesas de custeio da administração pública, não configurando investimento ou subvenção a fundo perdido, com exceção às doações oficiais" (IPEA/ABC, 2013, p. 14). Ademais, o documento sublinha claramente que "financiamentos (investimentos com variadas taxas de retorno) e perdões de dívida não constituem gastos/despesas correntes e, portanto, não compõem esta publicação" (IPEA/ABC, 2013, p. 14).

O relatório ressalta que haveria dois grandes tipos de gastos realizados pelo governo federal com a cooperação para o desenvolvimento internacional:

i) com servidores e colaboradores da administração pública federal, incluindo passagens, diárias, salários, horas técnicas, com bolsas de pesquisa, e com doações; e ii) aqueles decorrentes de compromissos e obrigações do governo federal brasileiro junto a organismos internacionais (ABC/IPEA, 2013, p. 14).

Para o levantamento desses dados, novamente, foi disponibilizado um formulário eletrônico em ambiente virtual que foi sendo alimentado por informações fornecidas por diferentes órgãos da administração pública federal. $O$ relatório destaca que os gastos correspondem à:

disponibilização de pessoal, infraestrutura e recursos financeiros mediante a capacitação de indivíduos e fortalecimento de organizações e instituições no exterior; organização ou participação em missões ou operações de manutenção da paz; gestão de programas e projetos científico tecnológicos conjuntos com outros países e institutos de pesquisa; cooperação humanitária; apoio à integração de refugiados em território nacional; pagamento de contribuições e integralizações de participação em organismos internacionais e doações oficiais, organizados por modalidades em conformidade com a nomenclatura internacional vigente (IPEA/ABC, 2013, p. 7).

Para tanto, o levantamento de gastos da União com cooperação para o desenvolvimento internacional foi realizado junto a 91 instituições federais. Nesse período, os gastos com a COBRADI totalizaram R\$ 1,6 bilhão equivalentes a US\$ 923 milhões em moeda corrente, representando um aumento nominal de 91,2\% em relação a 2009. Deste total, $\mathrm{R} \$ 965$ milhões $(66,3 \%)$ correspondem a gastos com a cooperação multilateral e $\mathrm{R} \$ 491$ milhões $(33,7 \%)$ com a cooperação bilateral. No que se refere aos gastos com a cooperação bilateral, R\$ 195 milhões foram vinculados às ações na América Latina e Caribe, correspondendo a 68,06\% do total de dispêndios; $\mathrm{R} \$ 65$ milhões $(22,58 \%)$ destinaram-se a 
ações em países da África; R \$ 6 milhões $(2,04 \%)$ asseguraram a cooperação com países da Ásia e Oriente Médio; R\$ 11 milhões (4,02\%) com países da Europa; R\$ 3 milhões (1,05\%) com países da América do Norte; e R \$ 6 milhões com a Oceania (incluindo- se o TimorLeste), que correspondem a 2,25\% do total (IPEA/ABC, 2013).

Diferentemente do primeiro relatório, as modalidades de cooperação são divididas de forma mais especificada em: "cooperação técnica", "cooperação educacional", "cooperação científica e tecnológica", "cooperação humanitária", "apoio e proteção a refugiados", “operações de manutenção de paz", e "gastos com organismos internacionais". Enquanto no primeiro relatório, havia uma única modalidade para classificar os recursos referentes à "cooperação técnica e científica e tecnológica", no segundo relatório esses gastos são divididos em duas novas categorias, "cooperação técnica" e "cooperação científica e tecnológica". A modalidade bolsa para estrangeiros passa a se denominar "cooperação educacional" (incluindo bolsas e outros programas bilaterais de intercâmbio). A modalidade "contribuições a organizações internacionais" passa a se chamar "gastos com organismos internacionais". A "assistência humanitária" é divida em duas categorias, "cooperação humanitária" (incluindo ajuda alimentar) e "apoio e proteção a refugiados". Por fim, a modalidade "operações de paz" passa a ser denominada "operações de manutenção de paz" (IPEA/ABC, 2013).

O terceiro relatório COBRADI apresenta os dados da cooperação internacional prestada pelo Brasil durante o período de 2011 a 2013. A pesquisa apresenta informações coletadas junto a 95 instituições do governo brasileiro. $\mathrm{O}$ estudo destaca a cooperação brasileira esteve presente em todos os continentes, atuando em 159 países, e envolvendo gastos na ordem de $\mathrm{R} \$ 2,58$ bilhões, destacando-se os dispêndios com organizações internacionais, $53 \%$ do total. O relatório ressalta ainda seu intuito de promover uma reflexão sobre as formas de se mensurar a cooperação internacional para o desenvolvimento, para além da mera quantificação de gastos. No documento é destacado que o IPEA, a partir do projeto COBRADI, busca contribuir com uma nova perspectiva sobre o tema da cooperação para o desenvolvimento no debate internacional, possibilitando leituras alternativas àquela centrada em gastos e oferecendo dados empíricos para pesquisas futuras sobre o tema (IPEA/ABC, 2016).

O documento destaca que a evolução do estudo levou ao abandono de definições préconcebidas como a definição de cooperação brasileira para o desenvolvimento internacional adotada no primeiro relatório, influenciada pela definição da OCDE, abrindo margem para o 
aprofundamento de questões entendidas como fundamentais, como aquelas relativas à execução da cooperação brasileira. O relatório alega que ao longo dos anos de atuação do projeto COBRADI, buscou-se aperfeiçoar e consolidar o método de coleta e apresentação dos dados sobre os gastos do governo federal com a cooperação internacional para o desenvolvimento.

O documento destaca que em nove anos, o governo federal despendeu cerca de $\mathrm{R} \$ 7,9$ bilhões, equivalentes a US\$ 4,1 bilhões, com a COBRADI (IPEA/ABC, 2016, p. 14). Porém, apesar dos valores expressivos, o relatório chama atenção para a necessidade de desmistificar o a ideia de Brasil doador emergente na medida em que o país continua a se configurar como um receptor de ajuda internacional (IPEA/ABC, 2016). Outra peculiaridade da cooperação prestada pelo Brasil que o afastaria do conceito de "doador tradicional" seria os modos de execução de sua cooperação, que priorizaria "a troca de experiências e o uso da máquina pública, com seus funcionários e instituições, como instrumento primordial da contribuição do país para o desenvolvimento internacional” (IPEA/ABC, 2016, p. 15).

O relatório aponta que é justamente nesse sentido de identificação dos conteúdos e técnicas compartilhadas por funcionários e instituições brasileiras, que reside a maior diversidade da COBRADI. Assim, essa terceira publicação busca consolidar a ideia de que a “contribuição brasileira para o desenvolvimento internacional somente é possível a partir do entendimento daquilo que o Brasil faz em complemento a quanto o país gasta" (IPEA/ABC, 2016, p. 16). De modo que, para ter uma visão holística sobre o esforço brasileira para a cooperação para o desenvolvimento internacional seria necessário se debruçar não apenas sobre a mensuração dos valores gastos com a cooperação, mas também sobre o conteúdo dessas atividades.

O documento destaca ainda que a plataforma eletrônica que havia sido formulada inicialmente para a coleta dos dados utilizados na elaboração dos dois relatórios anteriores foi desabilitada em 2011. De modo que para a elaboração do terceiro relatório foram utilizadas planilhas tradicionais, o que dificultou o processo em um primeiro momento, porém dotou-o de maior flexibilidade. Em relação à mensuração dos gastos, aos gastos, foram solicitadas junto às instituições prestadoras de cooperação informações das despesas realizadas com "recursos orçamentários da própria instituição executora e destinados a financiamento e eventuais doações, horas-técnicas, diárias e passagens, materiais e equipamentos, instalações físicas e outros custos associados à execução da cooperação" (IPEA/ABC, 2016, p. 18). O relatório conclui que a análise desses dados confirma a singularidade da cooperação brasileira 
"afastando a referência a fluxos de investimento e confirmando-a como expressão do uso do patrimônio público consolidado na forma de conhecimento e de recursos humanos" (IPEA/ABC, 2016, p. 18).

O terceiro relatório 2011-2013 manteve as modalidades definidas no relatório anterior: cooperação técnica, cooperação educacional, cooperação científica e tecnológica, cooperação humanitária, apoio e proteção a refugiados, operações de manutenção da paz e gastos com organismos internacionais (IPEA/ABC, 2016, p. 19). O relatório aponta ainda que a ênfase dada na descrição das práticas brasileiras de cooperação evidenciou a transversalidade das ações realizadas pelo Brasil, evidenciando a dificuldade de se classificar cada ação em apenas uma modalidade pré-definida. Assim, em relação à apresentação dos dados referentes às práticas da cooperação brasileira, foram adotados dois procedimentos:

i) no que se refere aos gastos, buscou-se estabelecer um padrão mínimo quanto à sua apresentação, com totalizações ano a ano e para o período, detalhando, quando possível, as contribuições de cada órgão envolvido em cada modalidade de cooperação. Tais dados foram apresentados, normalmente em cada capítulo, sob a denominação de dispêndios do governo brasileiro; e ii) no tocante às práticas, respeitando as peculiaridades de cada modalidade, apresenta-se em cada capítulo do estudo o contexto regimental ou fundamento legal da atuação internacional brasileira na área, descrevendo, no mais das vezes, um conjunto significativo de ações que caracterizam a Cobradi (IPEA/ABC, 2016, p. 19).

O relatório ressalta que além de buscar trazer transparência às práticas brasileiras na área de cooperação ao desenvolvimento e sistematizar essas informações, o projeto busca “instigar uma reflexão constante sobre as práticas brasileiras no campo da CID, o que se reflete tanto na evolução do método quanto nas possibilidades que se apresentam para a continuação dos estudos no futuro" (IPEA/ABC, 2016, p. 168). O relatório destaca que apesar do esforço empreendido, o projeto COBRADI ainda não capta todo o esforço brasileiro na área da cooperação para o desenvolvimento internacional. Em parte, pelo caráter voluntário da coleta de dados junto às entidades prestadoras (IPEA/ABC, 2016).

Por fim, o estudo destaca a "inadequação da adoção das modalidades tradicionais para o estabelecimento de uma imagem precisa da cooperação internacional promovida pelo Brasil” (IPEA/ABC, 2016, p. 170). Destaca que se por um lado, a utilização dos conceitos tradicionais possibilitaria certo grau de comparabilidade com outras iniciativas internacionais no campo da cooperação, por outro, limita a compreensão daquilo que de fato é realizado pelo 
Brasil, não dando margem à transversalidade inerente às atividades brasileiras de cooperação para o desenvolvimento (IPEA/ABC, 2016).

A publicação "Panorama do monitoramento dos fluxos da cooperação internacional para o desenvolvimento: oportunidades e desafios para construção de uma metodologia brasileira”, publicado pela Articulação Sul em parceria com a OXFAM, no final de 2016, traz uma comparação acerca das modalidades de cooperação brasileira para o desenvolvimento internacional. Assim, as tabelas abaixo destacam as diferenças em relação às classificações utilizadas nos três primeiros relatórios:

Tabela 4.3.1.1. Modalidades da cooperação brasileira nos relatórios da COBRADI

\begin{tabular}{|c|c|c|}
\hline $\begin{array}{l}\text { COBRADI 2005- } \\
2009\end{array}$ & \begin{tabular}{|l|} 
COBRADI 2010 \\
/ 2011-2013 \\
\end{tabular} & COBRADI 2010 / 2011-2013 \\
\hline \multirow[b]{2}{*}{$\begin{array}{l}\text { 1. Cooperação } \\
\text { técnica, científica } \\
\text { e tecnológica }\end{array}$} & 1. Técnica & $\begin{array}{l}\text { Objetiva a capacitação de profissionais estrangeiros e } \\
\text { o fortalecimento institucional de países em } \\
\text { desenvolvimento, por meio do compartilhamento de } \\
\text { conhecimentos e tecnologias nacionais. }\end{array}$ \\
\hline & $\begin{array}{l}\text { 2. Cooperação } \\
\text { Científica e } \\
\text { Tecnológica }\end{array}$ & $\begin{array}{l}\text { Refere-se à programas e projetos de pesquisa de } \\
\text { interesse de ambos os países cooperantes, que serve } \\
\text { para o desenvolvimento econômico e social e que } \\
\text { possui o aporte de recursos: humanos: cientistas; } \\
\text { recursos físicos: laboratórios e demais instalações; } \\
\text { financeiros; e tecnológicos. }\end{array}$ \\
\hline $\begin{array}{l}\text { 2. Bolsas para } \\
\text { estrangeiros }\end{array}$ & $\begin{array}{l}\text { 3. Cooperação } \\
\text { Educacional } \\
\text { (incluindo bolsas } \\
\text { e outros } \\
\text { programas } \\
\text { bilaterais de } \\
\text { intercâmbio) }\end{array}$ & $\begin{array}{l}\text { Auxílio na formação de capital humano de países } \\
\text { parceiros, em caráter acadêmico ou técnico, através da } \\
\text { concessão de bolsas de estudo e do financiamento de } \\
\text { custos associados. }\end{array}$ \\
\hline $\begin{array}{l}\text { 3. Contribuições } \\
\text { às organizações } \\
\text { internacionais }\end{array}$ & $\begin{array}{l}\text { 4. Gastos com } \\
\text { organismos } \\
\text { internacionais }\end{array}$ & $\begin{array}{l}\text { Relativo às despesas do governo federal com } \\
\text { pagamento de contribuições a organismos } \\
\text { internacionais e com integralização de cotas para } \\
\text { fundos de desenvolvimento de organismos financeiros } \\
\text { internacionais. }\end{array}$ \\
\hline \multirow{2}{*}{$\begin{array}{l}\text { 4. Assistência } \\
\text { humanitária }\end{array}$} & $\begin{array}{l}\text { 5. Cooperação } \\
\text { humanitária } \\
\text { (incluindo ajuda } \\
\text { alimentar) }\end{array}$ & $\begin{array}{l}\text { Representa a forma como o Brasil concede seu apoio } \\
\text { aos países e as populações que lidam com crises e } \\
\text { emergências causadas por guerras, desastres naturais, } \\
\text { entre outros. }\end{array}$ \\
\hline & $\begin{array}{l}\text { 6. Apoio e } \\
\text { proteção ao } \\
\text { refugiado }\end{array}$ & $\begin{array}{l}\text { Método brasileiro de conceder apoio às pessoas que } \\
\text { decidem sair dos seus respectivos países por motivos } \\
\text { de perseguição de natureza racial,religioso, nacional, } \\
\text { entre outros. }\end{array}$ \\
\hline 5. Operações de & 7. Operações de & Participação das forças militares brasileiras em \\
\hline
\end{tabular}




\begin{tabular}{l|l|l}
\hline paz (informações & $\begin{array}{l}\text { manutenção da } \\
\text { anuais (incluídas no } \\
\text { disponíveis, mas } \\
\text { não incluídas no } \\
\text { total de recursos) }\end{array}$ & $\begin{array}{l}\text { operações de paz da Organização das Nações Unidas } \\
\text { tonU). }\end{array}$ \\
\hline \hline
\end{tabular}

Fonte: IPEA/ABC, 2010, 2013, 2016, adaptado de Silva et al. (2016, p. 38-39)

As tabelas abaixo registram os recursos que foram incluídos nos levantamentos da COBRADI (tabela) e os gastos contabilizados em cada modalidade (tabela).

Tabela 4.3.1.2. Recursos incluídos nos levantamentos da COBRADI

\begin{tabular}{|c|c|}
\hline Recursos & O que foi incluído - resumo \\
\hline \multirow{5}{*}{ Horas técnicas } & $\begin{array}{l}\text { Horas disponibilizadas para a educação, a capacitação, o treinamento, entre } \\
\text { outros; }\end{array}$ \\
\hline & Atuação exclusiva e direta na cooperação; \\
\hline & $\begin{array}{l}\text { Horas dedicadas à produção ou adaptação de uma tecnologia destinada à } \\
\text { produtos ou serviços; }\end{array}$ \\
\hline & Forças militares incumbidas de garantir os direitos humanos e civis; \\
\hline & Horas de pessoas do suporte técnico. \\
\hline \multirow{2}{*}{$\begin{array}{l}\text { Passagens e } \\
\text { diárias }\end{array}$} & $\begin{array}{l}\text { Valores de diárias e passagens associados ao transporte e mantimento de } \\
\text { funcionários e demais profissionais do governo federal; }\end{array}$ \\
\hline & $\begin{array}{l}\text { Valores de diárias e passagens de estrangeiros que venham para o Brasil para } \\
\text { capacitação; }\end{array}$ \\
\hline \multirow{3}{*}{$\begin{array}{l}\text { Materiais e } \\
\text { equipamentos }\end{array}$} & Materiais impressos ou eletrônicos; \\
\hline & $\begin{array}{l}\text { Materiais físicos empregados em atividades de educação ou capacitação de } \\
\text { estrangeiros no Brasil ou no exterior; }\end{array}$ \\
\hline & Equipamentos em geral. \\
\hline \multirow{2}{*}{$\begin{array}{l}\text { Instalações } \\
\text { físicas }\end{array}$} & Gastos com utilizações temporárias de bens imóveis e móveis; \\
\hline & Fortalecimento ou construção de infraestrutura em outros países. \\
\hline \multirow{2}{*}{$\begin{array}{l}\text { Custos } \\
\text { administrativos } \\
\text { associados }\end{array}$} & Materiais impressos ou eletrônicos; \\
\hline & $\begin{array}{l}\text { Transporte de equipamentos e materiais do Brasil para os países onde será } \\
\text { realizada a cooperação. }\end{array}$ \\
\hline $\begin{array}{l}\text { Doações em } \\
\text { espécie - } \\
\text { suprimentos }\end{array}$ & $\begin{array}{l}\text { Doações de suprimentos pelo governo brasileiro (medicamentos, alimentos, } \\
\text { sementes, materiais de construção, entre outros). }\end{array}$ \\
\hline \multirow{3}{*}{$\begin{array}{l}\text { Cooperação } \\
\text { financeira }\end{array}$} & $\begin{array}{l}\text { Contribuições a fundos de organismos internacionais aos quais o Brasil não é } \\
\text { beneficiário de empréstimos e outras concessões; }\end{array}$ \\
\hline & $\begin{array}{l}\text { Contribuições do governo federal para a integralização de capital em } \\
\text { organismos financeiros internacionais de desenvolvimento (OFID), dos quais } \\
\text { o Brasil não é beneficiário direto em termos financeiros; }\end{array}$ \\
\hline & $\begin{array}{l}\text { Apoio ao estabelecimento de refugiados e familiares no primeiro ano de } \\
\text { estadia no Brasil; }\end{array}$ \\
\hline
\end{tabular}


Bolsas e materiais de estudo para estudantes e pesquisadores estrangeiros em cursos acadêmicos e técnicos no Brasil.

Fontes: Presidência da República, 2010; IPEA/ABC, 2010, adaptado de Silva et al. (2018, p. 39-40).

Tabela 4.3.1.3. Tipos de gastos por modalidade no levantamento COBRADI

\begin{tabular}{|c|c|c|}
\hline Modalidades & Descrição dos dispêndios & Gastos incluídos \\
\hline $\begin{array}{c}\text { Cooperação } \\
\text { técnica }\end{array}$ & $\begin{array}{l}\text { Dispêndios do governo federal } \\
\text { apresentado por órgãos federais, } \\
\text { associados aos fluxos de } \\
\text { conhecimento e saberes entre } \\
\text { instituições. Não caracterizam fluxos } \\
\text { financeiros do Brasil para o exterior } \\
\\
\text { Estes dispêndios podem ser em } \\
\text { projetos com países ou grupos de } \\
\text { países; atividades regionais; } \\
\text { organismos internacionais ou } \\
\text { regionais; eventos no Brasil e no } \\
\text { exterior; gestão da cooperação } \\
\text { técnica pela ABC }\end{array}$ & $\begin{array}{l}\text { Passagens, diárias, horas técnicas, } \\
\text { aquisição de matérias e equipamentos, } \\
\text { adequação de instalações físicas e } \\
\text { outros } \\
\text { Partiu-se dos dados disponíveis pela } \\
\text { ABC para em seguida complementá- } \\
\text { los com dados das instituições } \\
\text { executoras. Dispêndios das executoras } \\
\text { refere-se apenas as horas técnicas } \\
\text { disponibilizadas }\end{array}$ \\
\hline $\begin{array}{l}\text { Cooperação } \\
\text { educacional }\end{array}$ & $\begin{array}{l}\text { Dispêndios de órgãos federais } \\
\text { (MEC, MCTI e MRE) e uma centena } \\
\text { de instituições de ensino superior e } \\
\text { centros nacionais de pesquisa para a } \\
\text { formação de pessoal estrangeiro }\end{array}$ & $\begin{array}{l}\text { Concessão de bolsas de estudo, oferta } \\
\text { de vagas em instituições de ensino no } \\
\text { Brasil e intercâmbio de professores }\end{array}$ \\
\hline $\begin{array}{l}\text { Cooperação } \\
\text { Científica e } \\
\text { Tecnológica }\end{array}$ & $\begin{array}{l}\text { Dispêndios do Sistema Nacional de } \\
\text { Ciência Tecnologia e Inovação } \\
\text { (MCTI e seu amplo conjunto de } \\
\text { unidades de pesquisa e organizações } \\
\text { sociais, conselhos e empresas } \\
\text { publico-privadas) para promover o } \\
\text { avanço do conhecimento e na busca } \\
\text { de sinergias para inovação e o } \\
\text { enfrentamento dos desafios para o } \\
\text { desenvolvimento }\end{array}$ & $\begin{array}{l}\text { Financiamento de projetos de } \\
\text { pesquisa e desenvolvimento de novas } \\
\text { técnicas e tecnologias (capital, custeio } \\
\text { e bolsas), pagamento pela utilização } \\
\text { de equipamento de ponta e } \\
\text { manutenção de laboratórios no } \\
\text { exterior (Labex da Embrapa) }\end{array}$ \\
\hline $\begin{array}{l}\text { Cooperação } \\
\text { Humanitária }\end{array}$ & $\begin{array}{l}\text { Dispêndios do governo federal, } \\
\text { articulados pela CGFome, para ajuda } \\
\text { humanitária }\end{array}$ & $\begin{array}{c}\text { Contribuições financeiras para ações e } \\
\text { programas de organismos } \\
\text { internacionais, apoio das } \\
\text { representações diplomáticas no } \\
\text { exterior, doação de itens de primeira } \\
\text { necessidade (comida e medicação), } \\
\text { incluindo custos de transporte e } \\
\text { distribuição } \\
\end{array}$ \\
\hline $\begin{array}{l}\text { Proteção a } \\
\text { apoio aos } \\
\text { refugiados }\end{array}$ & $\begin{array}{l}\text { Dispêndios do governo Federal, } \\
\text { orientados pelo CONARE, para } \\
\text { proteção a apoio aos refugiados }\end{array}$ & $\begin{array}{c}\text { Transferências financeiros do MJ para } \\
\text { organizações da sociedade civil, } \\
\text { dispêndios do MJ com deslocamento } \\
\text { e atuação dos servidores e }\end{array}$ \\
\hline
\end{tabular}




\begin{tabular}{c|c|c}
\hline & & $\begin{array}{c}\text { colaboradores para entrevista de } \\
\text { refugiados/as (horas técnicas, } \\
\text { passagens, diárias, material de } \\
\text { consumo), contribuições para Acnur }\end{array}$ \\
\hline $\begin{array}{c}\text { Operações de } \\
\text { manutenção } \\
\text { de paz }\end{array}$ & $\begin{array}{c}\text { Dispêndio das forças armadas com } \\
\text { missões de operações de paz }\end{array}$ & $\begin{array}{c}\text { Contribuição regular (parcela do } \\
\text { custeio), contribuições a fundos } \\
\text { Gastos com } \\
\text { organismos }\end{array}$ \\
$\begin{array}{c}\text { Pagamento de compromissos } \\
\text { financeiros assumidos pelo governo } \\
\text { federal junto com organismos } \\
\text { internacionais }\end{array}$ & $\begin{array}{c}\text { multilaterais de desenvolvimento para } \\
\text { doações, empréstimos e assistência } \\
\text { técnica, contribuições sãos gastos dos } \\
\text { tribunais internacionais }\end{array}$ \\
\hline \hline
\end{tabular}

Fonte: IPEA/ABC, 2016, adaptado de Silva et al. (2016, p. 40-41).

No ano de 2018, foi lançado o último relatório COBRADI até o momento, referente ao período 2014-2016, reunindo os gastos realizados nas várias ações internacionais que integram a cooperação brasileira. O relatório destaca que nesse período foram destinados $\mathrm{R} \$ 4$ bilhões dos orçamentos públicos federais para custear os gastos da COBRADI, sendo 80,5\% dos gastos via multilateral; $9,1 \%$ via bilateral; 4,5\% trilateral. Ademais, aponta que cerca de $26 \%$ dos recursos empregados com a cooperação brasileira foram destinados para países da América do Sul, da América Central e do Caribe e 25\% para países africanos (IPEA/ABC, 2018).

O relatório destaca que "persiste o desafio de delinear o entendimento da política brasileira de cooperação para o desenvolvimento internacional” (IPEA/ABC, 2018, p. 15). Em especial, em relação ao modo de determinar as informações necessárias, os dados a serem utilizados, bem como as fontes a serem consultadas. Também é destacado que a "análise da atuação do governo federal brasileiro somente é possível a partir de dados e informações disponibilizados pelas instituições que executam as atividades do governo federal brasileiro nas relações internacionais" (IPEA/ABC, 2018, p. 15). Sendo assim, o relatório foi produzido “a partir das informações existentes nos órgãos do governo federal que atuaram na Cooperação Internacional para o Desenvolvimento (CID)" (IPEA/ABC, 2018, p. 16). Quanto à base legal da COBRADI, é destacado que:

a base legal que sustenta a Cobradi no sistema internacional está inscrita no Artigo 4o da Constituição Federal, que trata dos princípios que regem as relações internacionais da República Federativa do Brasil e estabelece, em seu inciso IX, o princípio da "cooperação entre os povos para o progresso da humanidade" (IPEA/ABC, 2018, p. 16). 
O documento aponta que para a realização do levantamento da COBRADI no período 2014-2016 retomou-se o procedimento inicial utilizado nos estudos anteriores. A partir dos registros da $\mathrm{ABC}$, com os intercâmbios com um ou mais estados estrangeiros e/ou organismos internacionais com os quais o Brasil mantinha Acordos Básicos de Cooperação Técnica. Esse estudo registrou mais de quatrocentas iniciativas de cooperação técnica realizadas pelo Brasil entre 2014 e 2016, "alcançando 53 países parceiros mediante a parceria de 126 instituições brasileiras da administração pública federal, estaduais, municipais, universidades e organizações não governamentais” (IPEA/ABC, 2018, p. 16). O relatório reitera que:

as despesas orçamentárias destinadas aos gastos na Cobradi são financiadas com recursos do Tesouro Nacional e compreendem dispêndios com salários, material de consumo, pagamento de diárias, contribuições a organismos internacionais e doações classificadas segundo determinação das leis de diretrizes orçamentárias vigentes (IPEA/ABC, 2018, p. 16).

Ainda em relação aos gastos contabilizados, é destacado que:

Os dispêndios da União na Cobradi divulgados nesta publicação originaramse de fontes orçamentárias inscritas nas leis orçamentárias anuais vigentes durante o período de 2014 a 2016 e legitimadas mediante o emprego dos gastos efetivamente realizados disponíveis no Sistema de Informação da Administração Financeira (Siafi) (IPEA/ABC, 2018, p. 19).

Quanto ao levantamento aos dispêndios realizados, estes são apresentados em formato de série histórica, com início em 2005:

Tabela 4.3.1.4. Gastos do governo federal com a cooperação brasileira (2000-2016) (Em $\mathbf{R} \$)$

\begin{tabular}{lcc}
\hline \hline Ano & Valores correntes & Valores atualizados (ano-base 2016) \\
\hline 2005 & 531.984 .391 & 1.002 .050 .113 \\
2006 & 685.023 .329 & 1.251 .014 .670 \\
2007 & 700.975 .368 & 1.225 .517 .482 \\
2008 & 744.317 .659 & 1.228 .762 .486 \\
2009 & 849.829 .126 & 1.344 .957 .054 \\
2010 & 1.625 .141 .181 & 2.428 .489 .947 \\
2011 & 985.253 .701 & 1.382 .388 .174 \\
2012 & 1.004 .421 .523 & 1.331 .538 .967 \\
2013 & 857.299 .155 & 1.073 .076 .035
\end{tabular}


Fonte: IPEA/ABC (2018, p. 265).

O documento chama atenção para os picos registrados, nos anos de 2010 e 2016. Destaca que o os valores extremos em 2010 são explicados em razão do terremoto que atingiu o Haiti em de janeiro de 2010 e pelos esforções empreendidos para reconstrução do país por meio da MINUSTAH. Já os valores registrados em 2016 se referem ao pagamento de parcelas atrasadas junto a organizações internacionais (IPEA/ABC, 2018).

O documento ressalta que os dados acerca da mensuração desses gastos públicos foram "estruturados seguindo modalidades internacionais" e "organizados por região e país" (IPEA/ABC, 2018, p. 16). Nota-se, porém, algumas diferenças em relação a como a cooperação brasileira havia sido classificada nos relatórios anteriores. Nos três primeiros relatórios, os gastos com a COBRADI haviam sido classificados nas seguintes modalidades: i) cooperação técnica; ii) na cooperação educacional; iii) na cooperação científica e tecnológica; iv) na cooperação humanitária; v) na proteção e apoio a refugiados; vi) nas operações de manutenção da paz; e vii) nos gastos com organismos internacionais. No relatório 2014-2016, o relatório é apresentado na seguinte estrutura: i) gestão da cooperação técnica; ii) gestão pública; iii) saúde; iv) meio ambiente; v) ciência, tecnologia e inovação; vi) agricultura; vii) formação de pessoal estrangeiro de nível superior; viii) direitos humanos; e ix) desenvolvimento, programas sociais econômicos.

Assim, enquanto os dispêndios apresentados durante os três primeiros relatórios representavam o somatório dos gastos na cooperação técnica (CT); na cooperação educacional (CE); na cooperação científica e tecnológica (CCT); na cooperação humanitária $(\mathrm{CH})$; na proteção e apoio a refugiados (PAR); nas operações de manutenção da paz (OMP); e nos gastos com organismos internacionais (GOI). O Relatório COBRADI 2014-2016 traz os gastos com i) servidores e colaboradores da administração pública federal; e ii) aqueles decorrentes de compromissos e obrigações do governo federal brasileiro junto a organismos internacionais (IPEA/ABC, 2018, p. 292).

Por fim, o documento ressalta que o caráter descentralizado da COBRADI, embora dificulte o trabalho de caracterização e sistematização dos gastos, não impossibilita configurar “a natureza da inserção do Brasil na agenda internacional da cooperação para o 
desenvolvimento" (IPEA/ABC, 2018, p. 291). Outro ponto de destaque diz respeito à cooperação técnica, em que o documento reconhece explicitamente seu uso enquanto “ferramenta de política externa" (IPEA/ABC, 2018, p. 21).

Os relatórios COBRADI, no geral, foram bem recebidos por parte dos Think Tanks, organizações da sociedade civil, nacionais e internacionais, e pesquisadores que estudam o tema da Cooperação Internacional para o Desenvolvimento. Especialmente em função de seu caráter inovador no sentido de dar publicidade às ações realizadas pelo governo brasileiro na área. Entretanto, alguns obstáculos metodológicos permanecem, especialmente, em razão do elevado grau de dispersão institucional acerca da cooperação brasileira. Dentre esses obstáculos, destacam-se: i) as dificuldades de se mensurar os gastos no auxílio a refugiados, já que boa parte desses gastos são dispêndios de caráter universal, como saúde e educação; ii) as dificuldades em centralizar os gastos com cooperação educacional, em função participação de diversas instituições públicas, federais, estaduais, municipais e privadas na sua execução; iii) o desafio de contabilizar a participação de diversas instituições públicas e privadas na prestação da cooperação técnica e científica; e iv) a dificuldade em contabilizar os gastos decorrentes da participação das ONGs brasileiras nas operações de manutenção de paz (SILVA et al., 2016).

Outro obstáculo relevante para a contabilização do esforço brasileiro na área de cooperação ao desenvolvimento internacional diz respeito à própria definição e classificação das modalidades. Como os próprios relatórios reconhecem, a transversalidade de diversas atividades dificulta com que essas ações sejam alocadas a categorias pré-estabelecidas. Por fim, vale destacar que os relatórios COBRADI foram produzidos com base em uma coleta de dados de caráter voluntário por parte das instituições executoras da cooperação brasileira. De modo que os gastos do Brasil com a cooperação podem estar sendo subdimensionados nesses estudos. O próprio projeto recomenda a criação de um banco de dados acerca da cooperação brasileira, com base em consultas no Sistema Integrado de Administração Financeira do Governo Federal (SIAFI) e no Sistema de Concessão de Diárias e Passagens (SCDP) como ponto de partida para capturar dos gastos do governo (IPEA/ABC, 2016; SILVA et al., 2016).

\subsubsection{Projeto Articulação Sul - em busca da CSS no orçamento federal}

Um projeto recente, liderado pela Articulação Sul e pela OXFAM, com a participação de diversas organizações da sociedade civil e pesquisadores, buscou estabelecer uma 
metodologia própria para contabilização dos recursos da CSS, com base em uma revisão das diversas metodologias existentes. Em sua primeira publicação "Guia para o Monitoramento e Mensuração da Cooperação Sul-Sul", o projeto buscou detalhar sua proposta para o monitoramento e mensuração dos gastos em CSS por parte do governo brasileiro.

A ideia do projeto foi buscar contabilizar os dispêndios realizados com a cooperação brasileira com base em consultas no orçamento federal. Para tanto, foram consultados dos pagamentos realizados pelos diferentes órgãos do Governo Federal e publicamente disponíveis nos sistemas públicos de informação, em especial no Sistema Integrado de Planejamento e Orçamento (SIOP) ${ }^{101}$, no período de 2000 até 2016. A metodologia utilizada permitiu identificar registros de Ações e Planos Orçamentários nas diversas fases do orçamento federal: no projeto de Lei Orçamentária Anual (LOA); o montante aprovado com créditos suplementares; os valores empenhados, liquidados e pagos. No relatório final, foram utilizados os valores registrados como "pagos" no Sistema Integrado de Planejamento e Orçamento (SIOP), em R \$ deflacionados (ano-base 2008) (SUYAMA; SILVA; WAISBICH, 2017; LOPES; COSTA, 2018).

Em relação às modalidades da cooperação brasileira para o desenvolvimento internacional, foram propostas as seguintes categorias: "cooperação internacional" e "contribuições a organizações, bancos, e fundos internacionais". E dentro da Cooperação SulSul, a "cooperação cultural e educacional”, “cooperação humanitária”, “cooperação em defesa e missões de paz", "cooperação em ciência e tecnologia" e "cooperação e integração transfronteiriça", (LOPES; COSTA, 2018, p. 20).

A modalidade "cooperação internacional" inclui "registros que possuem dimensão internacional e narrativa de cooperação, mas de forma por demais genérica" para inclusão em alguma categoria mais específica. Os maiores pagamentos classificados como CI foram feitos pelo Ministério da Defesa (MD), Ministério das Relações Exteriores (MRE), seguidos pelo da Ciência e Tecnologia (MCT) e Saúde (MS) (LOPES; COSTA, 2018, p. 24).

A modalidade "Defesa e Missões de Paz" inclui 09 Ações Orçamentárias (AOs), alocadas apenas no Ministério da Defesa (MD). Elas contemplam "a participação brasileira em missões de paz e missões de observadores militares no Peru e no Equador" (LOPES; COSTA, 2018, p. 40).

A modalidade "Integração Transfronteiriça" está presente no orçamento federal na forma de 19 ações orçamentárias (AOs). Essas ações estão ligadas, em sua maioria, à

\footnotetext{
${ }^{101}$ Sistema informatizado que disponibiliza informações sobre os processos de planejamento e orçamento do Governo Federal
} 
integração de infraestrutura, como ações relacionadas ao corredor MERCOSUL e à construção de pontes e rodovias em municípios de fronteira. No entanto, também foram identificadas atividades com os países do bloco na área de integração energética e à “incorporação de normas do MERCOSUL ao ordenamento brasileiro, tais como cooperação técnica para modernização da administração tributária e aduaneira no âmbito do MERCOSUL, ações para a harmonização de normas” (LOPES; COSTA, 2018, p. 46).

$\mathrm{Na}$ modalidade "Ciência e Tecnologia", foram localizados gastos referentes à cooperação científica e tecnológica Sul-Sul em 19 Ações Orçamentárias (AOs), alocadas entre "o Ministério da Ciência e Tecnologia (MCT), Ministério da Defesa (MD), Ministério da Agricultura, Pecuária e Abastecimento (MAPA), Ministério da Indústria, Desenvolvimento e Comércio (MDIC) e Ministério das Minas e Energia (MME)”. Em geral, elas contemplam três aspectos: “a cooperação espacial, projetos relacionados à Antártida e ações de cooperação em âmbito regional, de difusão e compartilhamento de tecnologias" (LOPES; COSTA, 2018, p. 56).

$\mathrm{Na}$ categoria "Cooperação Cultural e Educacional”, foram discernidos pagamentos referentes à cooperação cultural e educacional Sul-Sul na forma de 09 Ações Orçamentárias (AOs), distribuídas entre o Ministério das Relações Exteriores (MRE) e o Ministério da Educação (MEC). Em geral, elas abrangem dois aspectos: “a cooperação com países de língua portuguesa, combinada, com a concessão de bolsas para a cooperação internacional, desenvolvimento científico e inovação, e ações de apoio a alunos estrangeiros" (LOPES; COSTA, 2018, p. 68).

Na modalidade "Cooperação Humanitária", foram localizadas 16 ações orçamentárias (AOs), distribuídas por sete Ministérios. Essas ações se referem, em geral, "ao combate à fome, participação da sociedade civil, direitos de migrantes e refugiados e resposta a emergência e desastres". Ademais, foram incluídas as ações "de apoio à integração e à cooperação internacional na agricultura familiar e na reforma agrária” (LOPES; COSTA, 2018, p. 80).

Por fim, o relatório traz os dados referentes às ações de financiamento às exportações realizadas pelo governo brasileiro no período. Assim, o projeto buscou identificar registros orçamentários relacionados à promoção da exportação, o que permite o avanço da pesquisa e do debate sobre a conveniência ou não de incluir esses pagamentos na mensuração da CSS 
brasileira. No Orçamento Federal, existem duas ações relativas ao PROEX, que coincidem com as duas modalidades do programa, ambas sob a supervisão do Ministério da Fazenda ${ }^{102}$ :

Financiamento: financiamento direto ao exportador ou importador brasileiro, liberados após as negociações entre o importador e exportador a partir do envio da mercadoria. Voltado, principalmente, a pequenas e médias empresas. E equalização de Juros: o programa arca com parte dos encargos financeiros incidentes ao financiamento da operação, tornando as taxas de juros equivalentes às praticadas internacionalmente (LOPES; COSTA, 2018, p. 94).

Os dados coletados pelo projeto, de 2000 a 2016, totalizaram $\mathrm{R} \$ 17,04$ bilhões (em valores pagos, ano-base 2008), equivalente a aproximadamente USD 5 bilhões. A comparação com os dados levantados pelo projeto COBRADI mostra coincidência entre as tendências apresentadas, sugerindo "potencial de complementariedade entre as duas abordagens" (LOPES; COSTA, 2018, p. 20).

\subsection{A Cooperação Técnica Brasileira}

A Cooperação Técnica (CT) seria uma das vertentes da Cooperação para o desenvolvimento, podendo ser caracterizada como:

uma intervenção temporária, destinada a promover mudanças qualitativas e/ou estruturais em um dado contexto socioeconômico, de forma a sanar ou minimizar problemas específicos identificados naquele âmbito, bem como para explorar oportunidades e novos paradigmas de desenvolvimento. A materialização dessas mudanças dá-se por meio do desenvolvimento de capacidades de instituições/entidades e de indivíduos. Essa nova capacidade, por sua vez, poderá direcionar-se à apropriação de conhecimentos por segmentos da população, ao aperfeiçoamento da ação finalística de instituições públicas e entidades privadas, bem como a intervenções de desenvolvimento em áreas geográficas pré-determinadas (esses três níveis a serem, doravante, denominados "beneficiários") (ABC, 2014, p. 5).

Nesse sentido, a Cooperação Técnica pode incluir as seguintes atividades:

Dar suporte a iniciativas de caráter inovador, voltados à geração, absorção e disseminação de conhecimento e de "boas práticas"; Mesclar conhecimentos e experiências disponíveis no exterior e no próprio país, gerando um novo produto; Promover o intercâmbio de conhecimentos, experiências e de boas-

\footnotetext{
102 Os recursos destinados ao PROEX foram considerados separadamente e não como parte de qualquer outro setor ou prática da cooperação brasileira (LOPES; COSTA, 2018, p. 94).
} 
práticas via mecanismos regionais ou multilaterais, integrados por instituições especializadas; Capacitar instituições nacionais públicas e da sociedade civil para o planejamento, execução e avaliação de iniciativas de promoção de desenvolvimento, sob diferentes formatos e abordagens (ABC, 2014, p. 6).

A ABC destaca que como as ações de Cooperação Técnica têm como foco desenvolver capacidades, instituições e indivíduos nos países beneficiários, essas atividades não se configuram como assistenciais ou humanitárias. A ABC também destaca que a CT não realiza operações de natureza financeira reembolsável ou comercial, dado que essas atividades não criam compromissos financeiros onerosos ao fornecedor da cooperação e que seu objetivo final não visa o lucro. Ademais, a ABC destaca que as ações de CT devem observar o princípio de horizontalidade, “o respeito às prioridades nacionais de desenvolvimento, a governança conjunta das iniciativas de cooperação técnica, o reconhecimento das capacidades nacionais já existentes e a ausência de condicionalidades" (ABC, 2014, p. 6)

A Cooperação Técnica constitui a "mais ampla e diversificada modalidade da Cooperação Brasileira para o Desenvolvimento Internacional" (IPEA/ABC, 2016, p. 23). De acordo com o relatório COBRADI, a CT se configura como:

transferência e compartilhamento de conhecimentos e experiências, em bases não comerciais, entre países ou entre um país e um organismo internacional. $\mathrm{O}$ entendimento prevalecente da cooperação técnica brasileira enseja uma abordagem centrada nos atores da CT quando pensada a partir da lógica dos dispêndios do governo federal, tendo como ponto de ligação as atividades financiadas pela Agência Brasileira de Cooperação (ABC) (IPEA/ABC, 2016, p. 23).

De acordo com o "Manual de Gestão da Cooperação Técnica Sul-Sul”, elaborada pela Agência Brasileira de Cooperação (ABC), em sua primeira edição, no ano de 2013, a CT seria "um instrumento privilegiado para o adensamento das relações do Brasil com outros países, com ênfase na integração política, econômica e social", se configurando como um dos pilares da cooperação internacional. A ênfase da CT seria no "desenvolvimento de capacidades, entendido como a identificação, mobilização e expansão de conhecimentos e competências disponíveis no país parceiro, com vistas à conquista da autonomia local para o desenho e implementação de soluções endógenas para os desafios do desenvolvimento" (ABC, 2013, p. 2).

Nesse sentido, a CT Sul-Sul brasileira seria entendida como "o intercâmbio horizontal de conhecimentos e experiências originados nos países em desenvolvimento cooperantes". 
Visando, desse modo, "compartilhar lições aprendidas e práticas exitosas disponíveis no Brasil, geradas e testadas para o enfrentamento de desafios similares ao desenvolvimento socioeconômico" (ABC, 2013, p. 13). Assim, as bases da cooperação técnica Sul-Sul seriam:

o desenho, a implementação técnica e a gestão compartilhadas de projetos e ações, concretizadas graças ao envolvimento direto e ativo das instituições cooperantes do Brasil e do(s) país(es) parceiro(s) desde a fase de planejamento até o acompanhamento e avaliação de resultados (ABC, 2013, p. 13).

Os arranjos institucionais para o fornecimento de CT centram-se na figura da ABC, que atua como o órgão oficial sob o Ministério das Relações Exteriores. A ABC possui o papel de negociar, promover e monitorar os projetos e programas de CT brasileira. Embora a ABC/MRE seja responsável por coordenar os projetos, mais de 170 órgãos do governo federal participam desse processo, incluindo ministérios, autarquias, fundações e empresas públicas nas mais diversas áreas. (IPEA/ABC, 2013). Leite et al (2014) apontam que essa forte fragmentação e dispersão institucional é justificada, em parte, pela falta de uma legislação específica no Brasil que defina claramente os objetivos, escopo, mecanismos, competências e processos da cooperação para o desenvolvimento.

No centro da arquitetura institucional estabelecida para a execução da CT brasileira está a ABC, criada em 25 de setembro de 1987, à qual compete, em conformidade com o art. 41 do Decreto no 7.304, de 22 de setembro de 2010:

planejar, coordenar, negociar, aprovar, executar, acompanhar e avaliar, em âmbito nacional, programas, projetos e atividades de cooperação para o desenvolvimento em todas as áreas do conhecimento, recebida de outros países e organismos internacionais e aquela prestada pelo Brasil a países em desenvolvimento, incluindo ações correlatas no campo da capacitação para a gestão da cooperação técnica e disseminação de informações (IPEA/ABC, 2016, p. 24).

$\mathrm{Na}$ contabilização desses gastos, por parte da COBRADI, vale reiterar que os dispêndios do governo federal referem-se:

ao pagamento de passagens e diárias, horas técnicas, aquisição de materiais e equipamentos, adequação de instalações físicas e outros custos, associados ao fluxo de conhecimentos e saberes entre pessoas e instituições. Tais dispêndios não configuram fluxos financeiros do Brasil para o exterior, prevalecendo sua aplicação na mobilização dos profissionais brasileiros para 
atendimento das demandas de cooperação técnica internacional (IPEA/ABC, 2016, p. 24).

Vale destacar, porém, que cooperação técnica realizada pelos órgãos da administração pública federal excede em muito os esforços empregados pela ABC. Assim, ainda que o papel da $\mathrm{ABC}$ seja central para a execução da cooperação técnica brasileira, não se pode resumir esse esforço às atividades financiadas ou coordenadas pela $\mathrm{ABC}$ (IPEA/ABC, 2016, p. 24). O projeto COBRADI, no levantamento dos dados sobre a CT, partiu dos dados disponibilizados pela $\mathrm{ABC}$ sobre os gastos com a CT para, em seguida, buscar nas instituições parceiras da agência e nas demais instituições executoras da cooperação técnica brasileira a complementação dessas informações (IPEA/ABC, 2016, p. 24).

Nesse sentido, para melhor dimensionar e qualificar a cooperação para o desenvolvimento implantada pelo governo federal brasileiro, o estudo orientou o levantamento de dados em torno de seis políticas públicas:

Desenvolvimento Social e Combate à Fome (MDS); Desenvolvimento Urbano e Inclusão Bancária (CEF); Direitos Humanos (SDH); Pesquisa Agropecuária (Embrapa); Pesquisa Econômica (Ipea); e Saúde Pública (Fiocruz, Anvisa, Secretaria de Vigilância em Saúde - SVS, Aisa, Secretaria de Gestão do Trabalho e da Educação na Saúde - SGTES, Secretaria de Atenção à Saúde - SAS, Secretaria Especial de Saúde Indígena - Sesai, Agência Nacional de Saúde Suplementar - ANS e Instituto Nacional do Câncer José de Alencar Gomes da Silva - Inca); além da ABC (IPEA/ABC, 2016, p. 24).

A ideia seria obter uma melhor compreensão da dimensão da cooperação brasileira para além da mera quantificação de gastos. Assim, partiu-se "da descrição das suas práticas, agrupadas em conformidade com as políticas públicas a que se referem, destacando-se seu conteúdo - conhecimentos e técnicas a elas atrelados" (IPEA/ABC, 2016, p. 35).

Em relação ao Desenvolvimento Social e Combate à Fome, a Lei Orgânica no 11.346, de 15 de setembro de 2006, em seu art. 6o, enfatiza que "o Estado brasileiro deve empenharse na promoção de cooperação técnica com países estrangeiros, contribuindo assim para a realização do direito humano à alimentação adequada no plano internacional" (CÂMARA DOS DEPUTADOS, 2006a). Para tanto, a cooperação executada pelo MDS foi baseada no:

compartilhamento de experiências por autoridades, especialistas e técnicos do ministério em eventos nacionais e no exterior. Os eventos foram de diversas naturezas, tais como audiências, conferências, debates, encontros, exposições, fóruns, mesas-redondas, missões, oficinas, painéis, reuniões, 
seminários e workshops. Além disso, o MDS desenvolveu os Seminários Internacionais "Políticas Sociais para o Desenvolvimento" e a recepção de missões bilaterais, em articulação com o MRE (IPEA/ABC, 2016, p. 36).

Em relação ao Desenvolvimento urbano e inclusão bancária realizada é conduzida pela $\mathrm{ABC}$ mediante parceria com o $\mathrm{PNUD}^{103}$. A cooperação técnica nessa área inclui, dentre suas práticas, "a gestão de pagamento de benefícios sociais; desenvolvimento urbano (habitação, saneamento etc.); inclusão bancária; correspondentes bancários; desenvolvimento regional e fronteiriço; e estruturação e gestão de fundos” (IPEA/ABC, 2016, p. 38).

Com relação aos Direitos Humanos, o estudo do IPEA aponta que "a Política Nacional de Direitos Humanos observa as diretrizes e os objetivos estabelecidos no III Plano Nacional de Direitos Humanos (PNDH-3)” (IPEA/ABC, 2016, p. 38). De acordo com o PNDH-3, caberia à $\mathrm{SDH} / \mathrm{PR}$ e ao Itamaraty a promoção dos direitos humanos como princípios orientadores da atuação internacional do país. Assim, "a delegação de atribuições para os órgãos da administração pública brasileira no PNDH-3 serve como marco legal para legitimar o uso dos projetos e programas desenvolvidos pela SDH/PR na cooperação técnica" (IPEA/ABC, 2016, p. 39).

Em relação à cooperação técnica prestada na área da pesquisa agropecuária, destaca-se o papel da EMBRAPA, importante instituto de pesquisa para produção de conhecimento e tecnologia para a agropecuária brasileira. A atuação da EMBRAPA na CT brasileira configura-se na “difusão de práticas da pesquisa agropecuária brasileira em todos os continentes por meio da troca de experiências direta com 49 países e mediante acordos regionais na América Latina, na África e com a Caricom" (IPEA/ABC, 2016, p. 39).

.As atividades realizadas pela EMBRAPA nessa área são diversas, incluindo:

capacitação, intercâmbio de experiências e técnicos em questões relativas a: i) pecuária, como a caprinovinocultura (caprinos e ovinos), gado de corte e leiteiro, doenças em animais, genética bovina, leite, mel (apicultura), produção aquícola (peixe) e zoneamento agropecuário; ii) agricultura, como algodão, arroz, café, caju, cana-de-açúcar (setor sucroalcooleiro), castanha de caju, cebola, coco e palmeiras, feijão, frutas temperadas e tropicais, gergelim, hortaliças, horticultura, mandioca, milho, mosca da fruta, palma africana, pastagens, pimentão, pragas agrícolas e de frutas tropicais, processamento de cítricos, de frutas e de coco verde, sementes, soja, tomate e verduras em geral; iii) geração de energia e técnicas alternativas, como biocombustíveis, biofertilizantes, etanol, látex e recursos genéticos vegetais; e iv) gestão do conhecimento, como cadeias e diversificações produtivas, capacitação em sistemas, manejo sustentável, programas de segurança

\footnotetext{
${ }^{103}$ À exceção da parceria mantida com o Banco da Venezuela para intercâmbio de informações sobre segurança bancária e educação corporativa, entre outros temas (IPEA/ABC, 2016, p. 39).
} 
alimentar, sistemas agroflorestais e suporte técnico (IPEA/ABC, 2016, p. 4041).

Em relação à cooperação técnica prestada na área de pesquisa econômica aplicada, destaca-se a atuação do IPEA. A CT nesse setor se realizou por meio de "acordos de cooperação técnica internacional, memorandos de entendimento, visitas oficiais e missões técnicas (ACTs); participação em eventos internacionais; e concessão de bolsas de pesquisa para estrangeiros" (IPEA/ABC, 2016, p. 50). Assim, foi estabelecida uma rede global configurada por mais de quarenta instituições espalhadas pelo mundo, "destacando-se a predominância da cooperação em pesquisa econômica aplicada com instituições sediadas em países da América Latina e do Caribe” (IPEA/ABC, 2016, p. 50-51).

Por fim, em relação à CT na área de saúde pública, destaca-se o papel do Ministério da Saúde (MS), “órgão do Poder Executivo federal responsável pela organização e elaboração de planos e políticas públicas voltados para a promoção, prevenção e assistência à saúde dos brasileiros" (IPEA/ABC, 2016, p. 54). Na sua atuação internacional, o MS conta com a Assessoria de Assuntos Internacionais (AISA), responsável pela:

elaboração das diretrizes, coordenação e implementação da política internacional do Ministério da Saúde, assim como pela posição brasileira sobre temas de saúde em âmbito internacional, de acordo com as diretrizes da política externa do Brasil, e em permanente articulação com as áreas técnicas das secretarias e das unidades vinculadas do Ministério da Saúde (Brasil, 2013 apud IPEA/ABC, 2016, p. 54).

A AISA seria o ponto nefrálgico da atuação do MS no plano internacional. Dentre as secretarias responsáveis pela promoção da CT em saúde, destacam-se quatro especialmente: Secretaria de Atenção à Saúde (SAS), a Secretaria de Gestão do Trabalho e da Educação na Saúde (SGTES), a Secretaria de Vigilância em Saúde (SVS) e a Secretaria de Estado de Saúde (SESA). Assim, por meio dessa estrutura institucional, o MS busca prestar CT internacional, "disseminando políticas e práticas bem-sucedidas do sistema de saúde pública do Brasil para seus parceiros estrangeiros e compartilhando com eles a experiência nacional acumulada na área" (IPEA/ABC, 2016, p. 54).

Além das secretarias, merecem destaque os órgãos da administração pública, como o Instituto Nacional do Câncer (I); fundações públicas vinculadas, como a Fiocruz; e autarquias 
vinculadas ao MS, como a Agência Nacional de Vigilância Sanitária (Anvisa) ${ }^{104}$ e a Agência Nacional de Saúde Suplementar (ANS) (IPEA/ABC, 2016). Para uma melhor compreensão da CT em saúde, o relatório COBRADI dividiu essas ações em três partes: a cooperação implementada pela Fiocruz, a cooperação em vigilância sanitária e epidemiológica e a cooperação técnica dos demais órgãos da área de saúde pública.

A Fiocruz se articula com o MS e com o MRE, por intermédio de suas secretarias técnicas e da $\mathrm{ABC}$, para a disseminação de políticas públicas na área da saúde. Destacam-se os esforços empregados para a

disseminação dos conhecimentos brasileiros sobre bancos de leite humano, melhoria da saúde materna e redução da mortalidade infantil, manejo da tuberculose, apoio aos recursos humanos em saúde pública e fortalecimento de institutos de saúde e de laboratório nacionais, além da implantação de uma fábrica de medicamentos antirretrovirais em Moçambique (IPEA/ABC, 2016, p. 55).

Em relação à vigilância sanitária e epidemiológica,

o governo brasileiro tem cooperado com outros países para a superação de problemas sanitários a partir de experiências exitosas desenvolvidas em território nacional e mediante o compartilhamento dessas práticas em foros, seminários e workshops de blocos regionais e organismos internacionais (IPEA/ABC, 2016, p. 56-57).

Assim, o Brasil buscou compartilhar conhecimentos sobre as normas sanitárias, a adoção de medidas preventivas e de controle de surtos, epidemias e agravos à saúde pública, além de saberes para controlar a importação, exportação e circulação de matérias-primas e mercadorias sujeitas à vigilância sanitária, destacam-se especificamente o papel da ANVISA e da SVS nesse processo. (IPEA/ABC, 2016)

Com relação à atuação de outros órgãos de cooperação técnica em saúde pública, destaca-se a atuação de agências como a Comissão Executiva do Plano de Lavoura Cacaueira (CEPLAC), Companhia Nacional de Abastecimento (CONAB), Instituto Nacional de Meteorologia (INMET), Ministério do Turismo (MTUR), Ministério do Trabalho (MTE), Instituto Brasileiro de Geografia e Estatística (IBGE), Departamento de Polícia Federal (DPF), Instituto do Patrimônio Histórico e Artístico Nacional (IPHAN), Escola Nacional de

\footnotetext{
${ }^{104}$ A Anvisa integra e coordena o Sistema Nacional de Vigilância Sanitária (SNVS), definido como o conjunto de ações executadas por instituições da administração pública direta e indireta da União, dos estados, do Distrito Federal e dos municípios que exerçam atividades de regulação, normatização, controle e fiscalização na área de vigilância sanitária (Brasil, 1990, §1o do art. 60 e arts. 15 a 18). (IPEA/ABC, 2016, p. 57).
} 
Administração Pública (ENAP) e a Escola de Administração Fazendária (ESAF). Esses órgãos atuam nessa área seja via "compartilhamento de conhecimentos e técnicas desenvolvidos no Brasil, seja por meio de capacitação e treinamento, seja por intermédio da participação em eventos para a difusão desses conhecimentos e trocas de experiência" (IPEA/ABC, 2016, p. 60).

De acordo com a ABC, a CT Sul-Sul brasileira pode ser divida em "Cooperação Técnica Sul-Sul Bilateral”, "Cooperação Técnica Sul-Sul Trilateral”, "Cooperação Sul-Sul em Bloco", e "Cooperação Sul-Sul Descentralizada". A “Cooperação Técnica Sul-Sul Bilateral” ocorreria no caso em que ambos os parceiros são países em desenvolvimento. A “Cooperação Técnica Sul-Sul Trilateral", seria dividida em três submodalidades: i) Cooperação Sul-Sul Trilateral entre países em desenvolvimento, em que todos os parceiros, em número de três ou mais, seriam países em desenvolvimento; ii) Cooperação Sul-Sul Trilateral com país desenvolvido, em que dois países em desenvolvimento cooperam entre si, com participação de um país desenvolvido; e iii) Cooperação Sul-Sul Trilateral com organismo internacional, em que dois ou mais países em desenvolvimento cooperariam entre si, com participação de um organismo internacional. "Cooperação Sul-Sul em Bloco" se dá no âmbito de organizações e/ou arranjos sub-regionais, regionais ou inter-regionais concebidos e integrados por países em desenvolvimento e dos quais o Brasil faz parte, como o MERCOSUL, UNASUL e IBAS. Por fim, a "Cooperação Sul-Sul Descentralizada" se daria entre dois ou mais entes subnacionais de países em desenvolvimento. Esta modalidade pode ter uma variante, conhecida como cooperação cruzada, na qual um dos parceiros subnacionais tem origem em um país desenvolvido (ABC, 2013).

\subsubsection{Questões legais e técnicas}

Em relação à base legal para a CT entre o Brasil e seus países parceiros é fornecida por meio de acordos bilaterais. A vontade política de cooperação deve ser expressa em um "Acordo-Quadro". Após a assinatura de um convênio, são realizadas reuniões conhecidas como "Comissão Mista-Comista" para que as partes negociem os detalhes das áreas de concentração e diretrizes para os programas, projetos e atividades a serem implementados no campo. Nessas reuniões, representantes de países parceiros lidam com a ABC, bem como com outras agências governamentais brasileiras que são os principais fornecedores de formas específicas de CT (INOUE; VAZ, 2012). 
Assim, para que alguma atividade de cooperação possa ocorrer, essa ação precisa ser respaldada por um arcabouço jurídico-institucional que orientará a sua execução. $\mathrm{O}$ “Acordo Básico de Cooperação Técnica (Acordo-Quadro)" seria "um ato internacional, ratificado pelo Congresso Nacional, que formaliza as relações de cooperação técnica entre o Governo brasileiro e o Governo parceiro ${ }^{105}$ (ABC, 2013, p. 14)". Ademais, os “Acordos-Quadro" devem ser complementados por instrumentos posteriores, como os Ajustes Complementares ou os Programas Executivos, que implementam seus amplos dispositivos no plano concreto. Esses instrumentos (ABC, 2013, p. 14). Essas ferramentas dão execução ao Acordo de Cooperação, normatizando a implementação de um projeto de cooperação técnica Sul-Sul. Incluem artigos dedicados aos objetivos do projeto, orçamento e gestão e operacionalização do projeto, além de dispositivos específicos acerca das obrigações das partes e da prestação de contas, dispensando aprovação do Congresso (ABC, 2013, p. 15).

Em relação ao marco político para a cooperação técnica Sul-Sul, destacam-se os "Memorandos de Entendimento (MdE) e "Declarações Conjuntas" e o Protocolo de Intenções”. Os MdE e as Declarações Conjuntas seriam atos redigidos de forma simplificada, destinados a registrar a intenção das Partes, que podem ser Governos ou organizações internacionais, em "estabelecer iniciativas de cooperação técnica Sul-Sul, definidas em amplas linhas de ação" (ABC, 2013, p. 16). O MdE é um documento meramente político, não gerando obrigações acerca do desembolso de recursos, não fazendo referências a valores orçamentários. Este instrumento não requer ratificação pelo Congresso Nacional, podendo entrar em vigor na data da assinatura. Já o "Protocolo de Intenções" seria um instrumento "firmado entre um órgão da Administração Pública brasileira e uma entidade do setor privado (uma organização não governamental ou empresa) para registrar a intenção das Partes em atuar conjuntamente" (ABC, 2013, p. 16). Geralmente, é o primeiro documento a ser assinado pelas partes envolvidas, não possuindo valor operacional ou executivo.

Em relação ao marco operacional da Cooperação Técnica Sul-Sul brasileira, o "Manual da Gestão da Cooperação Sul-Sul Brasileira da ABC" faz uma divisão entre "implementação técnica", termo designado para ações de efetiva cooperação técnica (atividade-fim), ou seja, aquelas que envolvem a transferência ou a aplicação de conhecimentos, metodologias ou tecnologias entre os cooperantes; e "execução administrativo-financeira", para procedimentos e tarefas de cunho instrumental (atividade-

\footnotetext{
${ }^{105}$ Vale destacar que, "por falta de amparo legal, Estados e Municípios não podem concluir Acordos com um Estado estrangeiro" (ABC, 2013, p. 15).

Isso é feito pela União, com a intermediação do Ministério das Relações Exteriores.
} 
meio), designando os meios dos quais depende a realização dos produtos técnicos da cooperação (ABC, 2013).

Assim, em relação aos arranjos de execução administrativa financeira, seriam três os principais arranjos administrativos da CT brasileira: i) "Execução pelo Governo brasileiro", quando o Governo brasileiro executa as iniciativas de cooperação técnica no tocante aos seus aspectos administrativos e financeiros; ii) "Execução paralela", quando a execução administrativo-financeira é feita paralelamente pelo Governo brasileiro e por uma outra entidade parceira, a exemplo de projetos da Cooperação Sul-Sul Trilateral com organismos internacionais ou agências de cooperação de outros países, com recursos provenientes de ambas as parte; iii) "Execução descentralizada", quando outra entidade que não o Governo brasileiro é responsável pela execução administrativo-financeira de uma iniciativa de cooperação técnica Sul-Sul, podendo ou não os recursos serem provenientes da Administração Pública, embora o Governo brasileiro mantenha a função de coordenação da iniciativa de cooperação (ABC, 2013).

Em relação aos mecanismos de implementação técnica, há quatro instrumentos: "Programa", "Projeto", "Ação Preparatória" e "Ação Simplificada". O Programa" ${ }^{106}$ seria um “instrumento de planejamento por meio do qual um conjunto de iniciativas de cooperação técnica com objetivos comuns são concebidas e coordenadas de forma centralizada, porém executadas separadamente" (ABC, 2013, p. 17). Cumpre, assim, a função de proporcionar organicidade e planejamento estratégico às atividades de cooperação técnica, permitindo a avaliação da soma dos resultados dos projetos e ações realizados sob a sua égide. O Projeto de Cooperação Técnica Sul-Sul seria "uma ação planejada, com prazo definido, que consiste num conjunto de atividades inter-relacionadas" (ABC, 2013, p. 18). Seria o instrumento por meio do qual a cooperação prevista nos Ajustes Complementares e nos marcos políticos será implementada. Tem como objetivo:

contribuir para um salto técnico qualitativo do país parceiro mediante a organização e o fortalecimento das capacidades locais de uma instituição, grupo de instituições ou segmentos específicos da sociedade, potencializadas pelo acesso a tecnologias, experiências e conhecimentos disponíveis em outros países em desenvolvimento (ABC, 2013, p. 18).

\footnotetext{
${ }^{106} \mathrm{O}$ termo 'Programa' é aqui utilizado em referência a um instrumento de natureza técnico-operacional que não deve ser confundido com o 'Programa Executivo', documento de natureza jurídica que complementa um Acordo de Cooperação Técnica e oferece amparo legal às parcerias (ABC, 2013, p. 18).
} 
A "Ação Preparatória" teria o objetivo de prover os requisitos técnicos e operacionais para a prospecção e formulação conjunta de projetos ou programas de cooperação técnica SulSul. Possuindo três funções principais:

(i) Prover o arcabouço administrativo-financeiro para a realização de missões de identificação, prospecção e formulação conjunta de qualquer tipo de iniciativa de cooperação técnica Sul-Sul; (ii) Subsidiar o desenho e o planejamento participativos de projetos e programas por meio da aplicação de metodologias da Fase Analítica e da Fase de Planejamento (Parte II, Seções 9.1 e 9.2 deste Manual), e (iii) Oferecer a estrutura para a realização de estudos de viabilidade e diagnósticos aprofundados, em caráter complementar, quando necessário (ABC, 2013, p. 19).

Em relação às suas características ${ }^{107}$, seus produtos podem incluir:

Missões de identificação, prospecção e formulação conjuntas de iniciativas de cooperação técnica Sul-Sul e respectivos relatórios/produtos; - Missões de diagnóstico aprofundado (situação/problema), estudos de viabilidade técnica, social, econômica e ambiental e respectivos relatórios/produtos; Mapeamentos de atores e capacidades, pesquisas para coleta de dados de linha de base e desenho de matrizes de indicadores; - Nota conceitual e documentos preliminares (propostas) de projeto ou programa, e Treinamentos pontuais e estritamente vinculados ao objetivo de uma Ação Preparatória, a exemplo de oficinas sobre a aplicação de ferramentas de planejamento, diagnóstico e análise de viabilidade do projeto ou programa ulterior ao qual a Ação Preparatória serve de apoio (ABC, 2013, p. 19).

A "Ação Simplificada" refere-se a iniciativas implementadas em limitado espaço de tempo e que não exigem um escopo técnico complexo, permitindo a execução de ações pontuais de cooperação técnica com maior flexibilidade ${ }^{108}$. Tendo como fim:

(i) atender, separadamente, a solicitações por consultorias pontuais e de curto prazo oferecidas de maneira isolada por instituições brasileiras, com elaboração de produtos específicos, e não relacionadas a outras iniciativas de cooperação técnica Sul-Sul; (ii) a realização de intercâmbios ou treinamentos ad hoc ou recorrentes (desde que estes últimos não configurem objeto de Ação Preparatória ou de Projeto e que sejam amparados por um documento de programa técnico e que não tenham conteúdo cumulativo e evolutivo a ser desenvolvido em etapas diferentes), ou (iii) a participação de técnicos brasileiros ou de representantes de instituições dos países parceiros em

\footnotetext{
${ }^{107}$ A Ação Preparatória poderá contemplar a contratação de consultorias, serviços e materiais de consumo em escala reduzida e consoantes com o escopo operacional restrito deste tipo de iniciativa. Ademais, as Ações Preparatórias tem a duração máxima de 18 (dezoito) meses (ABC, 2013, p. 19).

${ }^{108}$ Uma Ação Simplificada não deve ser confundida com uma Ação Preparatória, pois a primeira não deve ter continuações ou fases subsequentes, enquanto que da segunda derivam, necessariamente, Projetos ou Programas (ABC, 2013, p. 19-20).
} 
eventos pontuais e não recorrentes de cooperação técnica Sul-Sul (ABC, 2013, p. 19).

Os Produtos de Ações Simplificadas ${ }^{109}$ podem incluir:

Produtos pontuais e de curto prazo por consultoria especializada de instituições brasileiras (e.g. estudos, intercâmbios e treinamentos curtos e pontuais, de prazo fixo e não recorrentes) e as respectivas missões de implementação; - Missões de técnicos de instituições brasileiras para participação em eventos pontuais de cooperação técnica Sul-Sul, e - Missões de representantes de instituições dos países parceiros ao Brasil para participação em eventos intercâmbios ou treinamentos de cooperação técnica Sul-Sul pontuais e ou recorrentes (desde que estes últimos não se enquadrem nas definições de Ações Preparatórias ou Projetos e sejam amparados por um Programa técnico) (ABC, 2013, p. 20).

Quanto à estrutura lógica da cooperação técnica, ou seja, os elementos básicos da estratégia de um projeto, desde os objetivos almejados até os insumos necessários para alcançá-los, a $\mathrm{ABC}$ estrutura-os da seguinte maneira: objetivos de desenvolvimento, objetivos específicos, resultados, produtos, atividades e insumos. O objetivo de desenvolvimento seria o objetivo a ser alcançado pela "estratégia de desenvolvimento ou política pública do país parceiro ao qual o projeto está relacionado" (ABC, 2013, p. 21), sendo "benefícios de natureza abrangente e multidimensional que atingem toda a sociedade" (ABC, 2013, p. 21). O objetivo específico seria a "finalidade principal e específica do projeto, pois equivale à solução do problema ou situação inicial que é alvo da iniciativa de cooperação técnica" (ABC, 2013, p. 21) ${ }^{110}$. Os resultados dizem respeito às "capacidades dos beneficiários (habilidades, competências, conhecimentos e métodos de trabalho) a serem desenvolvidas e disseminadas com o apoio da cooperação técnica" (ABC, 2013, p. 21). Os produtos são "bens e serviços tangíveis diretamente produzidos pelo projeto com vistas à geração, consolidação e/ou disseminação dos Resultados" (ABC, 2013, p. 21) ${ }^{111}$. As atividades “correspondem às tarefas e procedimentos que serão executados no âmbito do projeto com vistas à obtenção dos Produtos, sendo realizadas a partir da mobilização e do uso dos Insumos" (ABC, 2013, p. 21).

\footnotetext{
${ }^{109}$ Dentre suas características, destacam-se seu caráter pontual e fixo; tendo duração de 6 meses (ABC, 2013, p. 20)

110 "No horizonte temporal do projeto, o objetivo específico é um elemento intermediário entre a obtenção dos Resultados e a consecução do Objetivo de Desenvolvimento" (ABC, 2013, p. 21).

111 São "estudos, análises, diagnósticos; treinamentos e elaboração de materiais didáticos; ferramentas administrativas e gerenciais; protocolos ou manuais técnicos e operacionais; mapeamentos; instalações ou estruturas físicas construídas, equipadas ou reformadas" (ABC, 2013, p. 21).
} 
Por fim, os insumos seriam "os recursos financeiros, materiais, humanos e técnicos necessários à realização das Atividades do projeto ${ }^{112, "}$ (ABC, 2013, p. 21).

Em relação aos atores envolvidos em um projeto de cooperação, seja um Projeto, uma Ação Preparatória ou uma Ação Simplificada, a ABC destaca que estes "incluem quaisquer indivíduos ou instituições que poderão ser afetados pelo projeto de maneira direta ou indireta, positiva ou negativamente, ou ainda que possuam algum outro tipo de interesse no processo ou nos resultados esperados da iniciativa" (ABC, 2013, p. 24). Ademais, a ABC destaca que "o sucesso e a sustentabilidade a médio e longo prazo das referidas iniciativas depende fundamentalmente da apropriação do processo e dos resultados pelos beneficiários e demais partes interessadas" (ABC, 2013, p. 24). A ABC classifica-os em: instituições cooperantes, beneficiárias e outras partes interessadas.

As instituições cooperantes seriam as "entidades dos países cooperantes envolvidas diretamente na implementação técnica ou na execução administrativo-financeira de uma iniciativa de cooperação" (ABC, 2013, p. 24). Essas entidades podem cumprir o papel de "instituições implementadoras técnicas", "instituições executoras" e de "instituições coordenadoras". As "instituições implementadoras técnicas", que seriam "as instituições governamentais ou não governamentais que disponibilizarão seus recursos humanos e técnicos (conhecimentos e experiências setoriais específicos) para a implementação das ações de cunho técnico das iniciativas" (ABC, 2013, p. 24). As "instituições executoras seriam as “instituições dos respectivos países parceiros encarregadas da execução administrativofinanceira de uma iniciativa de cooperação técnica, quer dizer, dos procedimentos e tarefas de cunho instrumental (atividade-meio)" (ABC, 2013, p. 25). As "instituições coordenadoras" seriam "as entidades governamentais dos respectivos países parceiros que assumirão a responsabilidade legal por um projeto, garantindo a sua realização” (ABC, 2013, p. 25).

Os beneficiários seriam "qualquer ator que se beneficie da implementação do projeto" (ABC, 2013, p. 25), podendo ser classificados em beneficiários diretos e indiretos. $\mathrm{O}$ beneficiário direto seria a "entidade ou o grupo de indivíduos ${ }^{113}$ que receberá a capacitação ou que participará do intercâmbio técnico providos pelo projeto de cooperação com o Brasil" (ABC, 2013, p. 25). Já os beneficiários indiretos seriam as "entidades e/ou o grupo

\footnotetext{
112 "Horas-técnicas de especialistas; instrumentos profissionais; insumos agrícolas; maquinário; aparelhos laboratoriais; material bibliográfico; equipamentos e materiais diversos; instalações físicas indispensáveis à realização das Atividades, além de programas de informática cedidos gratuitamente" (ABC, 2013, p. 21).

${ }^{113}$ Por exemplo, "téenicos vinculados a entidades de países em desenvolvimento treinados por meio de cursos realizados no Brasil no âmbito de um projeto de cooperação técnica Sul-Sul” (ABC, 2013, p. 25).
} 
populacional ${ }^{114}$ do país proponente que passará a usufruir, no médio e longo prazo, de acesso ampliado ou de melhores serviços a serem oferecidos pelos beneficiários diretos do projeto" (ABC, 2013, p. 25).

Por fim, as outras partes interessadas seriam:

Instituições governamentais locais dos poderes executivo, legislativo e judiciário, organizações sociais, associações comunitárias, grupos de pressão, mídia ou outros indivíduos que possuem algum tipo de interesse em se encontrar uma solução para o problema ou situação insatisfatória que será alvo do projeto; órgãos de controle do Brasil e do país parceiro (ABC, 2013, p. 25).

\subsubsection{Elaboração de Projetos de Cooperação Técnica Sul-Sul}

De acordo com o "Manual de Gestão da Cooperação Técnica Sul-Sul”, o processo de elaboração de um projeto de cooperação técnica Sul-Sul possui três etapas distintas e complementares: i) fase analítica, ii) fase de planejamento, iii) fase de elaboração do Documento de Projeto (ABC, 2013, p. 29).

$\mathrm{Na}$ fase analítica, é feito um esforço conjunto entre os potenciais parceiros interessados em relação à proposta de projeto de cooperação. Sendo realizada de forma participativa geralmente durante uma missão de prospecção. Essa fase é composta pelos seguintes componentes: a) mapeamento de atores e capacidades, b) analise de problemas, c) análise de soluções, d) análise de estratégias, e) análise de riscos (ABC, 2013).

O mapeamento de atores e capacidades busca enfatizar a identificação das necessidades dos potenciais beneficiários e de suas capacidades pré-existentes disponíveis para utilização da iniciativa de cooperação. Consiste basicamente em um exercício de coleta e análise de informações com o objetivo de prover dados sobre o problema indicado pelo proponente, sobre o tema no qual se insere o problema e seu contexto socioeconômico, físico, político, jurídico e institucional ${ }^{115}$. Essas informações buscam fundamentar, assim, a concepção e o planejamento dos resultados e dos objetivos esperados com o projeto a ser implantado (ABC, 2013, p. 30).

\footnotetext{
${ }^{114}$ Por exemplo, "População atendida pelas entidades dos países parceiros que enviaram técnicos ao Brasil para os cursos realizados no âmbito de um projeto de cooperação técnica Sul-Sul" (ABC, 2013, p. 25).

${ }^{115} \mathrm{O}$ mapeamento de atores e capacidades é feito com o auxílio de um questionário apropriado. O 'Roteiro para Elaboração de Questionário de Mapeamento de Atores de Capacidades. Esse questionário pode ser respondido por meio escrito ou mediante entrevista, visita de campo, oficina ou por meio de qualquer combinação desses métodos (ABC, 2013, p. 30).
} 
Já a análise de problemas busca identificar os elementos que compõem a situação inicial alvo do projeto. Essa análise é feita com base nas informações obtidas por meio do mapeamento de atores e capacidades. Assim, cabem às instituições cooperantes do lado brasileiro e do lado do parceiro receptor da cooperação estudar essas informações com vistas a adquirirem uma compreensão profunda do problema. A ABC destaca que "o envolvimento do parceiro que receberá a cooperação é um fator-chave nesse processo para a apropriação futura dos resultados do projeto" (ABC, 2013, p. 31).

A análise de soluções busca converter os pontos negativos identificados na análise de problemas em termos positivos por meio da construção de um diagrama de soluções, que fornecerá uma visão global da situação futura caso os problemas sejam resolvidos. Assim, a diferença entre a situação insatisfatória identificada na análise de problemas e da situação futura almejada identificada na análise de soluções corresponderá à mudança almejada mediante intervenção do projeto de cooperação (ABC, 2013).

A etapa de análise de estratégias corresponde à identificação da melhor estratégia de ação para atingir as intenções desejadas. Na prática, trata-se de escolher a solução que dará origem ao objetivo específico do projeto, assim como os meios a serem empregados para sua realização. Dessa forma, a alternativa escolhida deve corresponder à estratégia mais adequada a atender às necessidades dos recipientes, e "à estratégia de ação com maior viabilidade técnica, financeira, econômica, e operacional, além de equivaler ao curso de ação com maior potencial de sustentabilidade" (ABC, 2013, p. 38).

A análise de riscos consiste na última etapa da fase analítica. Corresponde em uma análise acerca da probabilidade de ocorrência de riscos, sejam eles econômicos, políticos, ambientais, administrativos, financeiros ou operacionais, que possam prejudicar a execução do projeto de cooperação. Esse processo é importante para se elaborar um plano de contingência com ações a serem adotadas pelas instituições cooperantes no caso de algum desses riscos venham a ocorrer. As fontes de informação utilizadas nesse processo "incluem o mapeamento de atores e capacidades, a estrutura e a matriz lógica e a experiência e conhecimento dos participantes do grupo de prospecção” (ABC, 2013, p. 47).

A segunda fase da elaboração de um projeto de cooperação técnica Sul-Sul consiste na fase de planejamento. Essa etapa, fundamentada nas informações e resultados obtidos na fase anterior, se constitui na definição dos elementos básicos, tanto técnicos quanto operacionais do projeto de cooperação. Nessa fase são definidos os objetivos, resultados esperados e as metas para mensuração, os meios a serem utilizados, e o planejamento do orçamento e das 
atividades a serem desempenhadas. Esses componentes são organizados por meio de instrumentos como: a) estrutura lógica; b) a matriz lógica; c) o cronograma de execução; d) o orçamento e; e) o plano de trabalho (ABC, 2013).

Quanto à estrutura lógica, seus elementos, resultantes da estratégia de ação escolhida para o projeto, consistem no objetivo de desenvolvimento, nos objetivos específicos, resultados, produtos, atividades e insumos ${ }^{116}$ (ABC, 2013). Em relação à matriz lógica, a mesma consiste de um diagrama com o intuito de permitir uma visualização acerca dos elementos-chave da estratégia de acompanhamento e avaliação de um projeto de cooperação técnica $^{117}$. Assim, sua extensão depende da complexidade e ambição do projeto a ser implementado (ABC, 2013).

O Cronograma de Execução seria um diagrama de barras indicando os prazos estabelecidos para a realização e conclusão das atividades. Assim, é no Cronograma de Execução em que são estabelecidas as metas para a execução do projeto. Geralmente, as informações temporais são apresentadas na forma de trimestres, para projetos de até 36 meses, ou semestres, para projetos de mais 36 meses de duração. Compõe, juntamente com o orçamento e os indicadores da matriz lógica, "o conjunto de parâmetros de monitoramento e avaliação dos projetos de cooperação técnica" (ABC, 2013, p. 62).

O orçamento ${ }^{118}$ é o componente do Documento de Projeto ou Ação Preparatória que apresenta as estimativas dos dispêndios necessários para a execução das atividades previstas. De acordo com o manual de gestão da $\mathrm{CT}$ da $\mathrm{ABC}$, o orçamento pode ser elaborado em duas etapas. Na primeira, no orçamento para os Documentos de Projeto e de Ação Preparatória, é feita uma estimativa preliminar durante a Etapa de Prospecção da iniciativa e concluída na Etapa de Formulação. Para tanto, são produzidas duas tabelas, uma sendo referente aos dispêndios financeiros ao Projeto ou Ação Preparatória e a segunda referente a contribuições complementares não financeiras. Na segunda etapa configurada como orçamento referente ao Plano de Trabalho, é realizada uma versão pormenorizada das tabelas realizadas na versão anterior (ABC, 2013).

O primeiro passo para a composição do orçamento é a identificação dos insumos necessários para a realização das atividades previstas. Sendo necessário identificar as unidades de medida dos insumos, a fonte dos recursos, e a linha orçamentária à qual os insumos estão vinculados. O segundo passo seria realizar uma estimativa do custo dos

\footnotetext{
${ }^{116}$ Elementos já explicados na seção anterior.

${ }^{117}$ A matriz lógica contém os objetivos específicos e resultados esperados do projeto, os indicadores, a linha de base, a meta e os meios de verificação (ABC, 2013, p. 55).

${ }^{118}$ Elemento-chave para a discussão trazida nessa tese.
} 
insumos. Para tanto, são computados a duração prevista da ação, o valor monetário do insumo por unidade de medida, a eventual ocorrência de algum risco referente ao projeto. O terceiro passo seria a elaboração de memória de cálculo, relacionando a quantidade, a unidade da medida, e o seu valor monetário a cada insumo a ser utilizado. Essa etapa é importante para proporcionar transparência à aplicação dos recursos, devendo indicar a unidade de medida do insumo, a quantidade necessária e o valor unitário em dólares americanos (ABC, 2013).

A elaboração do Plano de Trabalho consiste em um processo-chave da Fase de Planejamento. Nessa etapa, é realizada um planejamento pormenorizado das atividades previstas, no intuito de fracionar o trabalho a ser realizado no âmbito dos Projetos e Ações Preparatórias em grupos de tarefas menores. Assim, o Plano de Trabalho facilitar a coordenação das ações de forma integrada, permitindo uma melhor organização das atividades a serem realizadas como um todo. Para tanto, é produzida uma tabela contendo as informações referentes ao cronograma de execução, as atividades, e subatividades, a serem realizadas e o orçamento previsto para realização dessas atividades (ABC, 2013).

Por fim, a última etapa para a elaboração de um projeto de cooperação técnica Sul-Sul seria a preparação do Documento de Projeto, que seria o principal referencial de uma iniciativa de CT. O Documento contém os mecanismos e arranjos necessários para realização das atividades, servindo como base para tomada de decisões em relação aos aspectos técnicos e de coordenação do projeto. O Documento registra todos os elementos componentes do projeto como os problemas a serem sanados, estabelecendo os parâmetros para o sucesso do esforço da cooperação, como objetivos, resultados esperados, prazos e dispêndios ( $\mathrm{ABC}$, 2013).

\subsubsection{Diretrizes e orientações para o fornecimento de Cooperação Técnica Brasileira}

De acordo com as "Diretrizes para o Desenvolvimento da Cooperação Técnica Internacional Multilateral e Bilateral", desenvolvido pela Agência Brasileira de Cooperação (ABC), em sua $4^{a}$ edição publicada no ano de 2014, atualizada em dezembro de 2016, os programas de cooperação técnica devem observar:

i) Alinhamento às prioridades nacionais de desenvolvimento, independentemente se as instituições proponentes de iniciativas de cooperação técnica integram ou não a administração pública; ii) Ênfase em iniciativas com impacto nacional, regional e local, nesta ordem; iii)

Prioridade a propostas com maior potencial de disseminação de 
conhecimento e de boas-práticas; iv) Presença de elementos demonstrativos de sustentabilidade de resultados; v) Ênfase no desenvolvimento de capacidades por meio da transferência e absorção de conhecimentos que se integrem às práticas das instituições brasileiras e que possam ser posteriormente multiplicados, paralelamente ao estabelecimento de condições para a inovação e a criação futuras; vi) Ênfase a iniciativas que integrem os componentes básicos da cooperação técnica internacional, ou seja: consultoria, capacitação de recursos humanos e aquisição de equipamentos, conforme necessidades específicas; vii) Preferência por propostas em que esteja claramente definida a contrapartida mobilizada pelo beneficiário nacional e pelo parceiro externo, em termos técnicos e financeiros; viii) Preferência por iniciativas que provoquem um adensamento de relações e abram perspectivas à cooperação política, comercial e econômica entre o Brasil e os países desenvolvidos ou em desenvolvimento. $\mathrm{Na}$ esfera multilateral, dar ênfase a iniciativas inspiradas nos princípios do multilateralismo, universalidade e neutralidade (ABC, 2014, p. 10).

Nesse sentido, desde 2004, os acordos de cooperação firmados pelo Brasil, no contexto da Coordenação Geral de Cooperação Técnica entre Países em Desenvolvimento (CGPD), têm-se pautado pelas seguintes diretrizes: 1) priorizar programas de cooperação técnica que favoreçam a intensificação das relações do Brasil com seus parceiros em desenvolvimento, principalmente com os países de interesse prioritário para a política exterior brasileira; 2) apoiar projetos vinculados, sobretudo a programas e prioridades nacionais de desenvolvimento dos países receptores; 3) canalizar os esforços de CGPD para projetos de maior repercussão e âmbito de influência, com efeito multiplicador mais intenso; 4) privilegiar projetos com maior alcance de resultados; 5) apoiar projetos com contrapartida nacional e/ou com participação efetiva de instituições parceiras; 6) estabelecer parcerias preferencialmente com instituições genuinamente nacionais (ABC, 2016).

De acordo com a ABC, a CGPD desde 2004 tem concentrado suas ações com base nas seguintes prioridades: 1) compromissos assumidos em viagens do Presidente da República e do Chanceler; 2) países da América do Sul; 3) Haiti; 4) países da África, em especial aos Países Africanos de Língua Portuguesa (PALOPS), e Timor-Leste; 5) demais países da América Latina e Caribe; 6) apoio à Comunidade dos Países de Língua Portuguesa (CPLP); e 7) incremento das iniciativas de cooperação triangular com países desenvolvidos e organismos internacionais (ABC, 2016).

\subsubsection{Processo decisório}

A cooperação técnica é profundamente influenciada pelo arcabouço institucional nacional do país, bem como pelos processos de tomada de decisão na política externa, que são 
permeados por uma variedade de interesses domésticos. Como visto, há atualmente uma forte dinâmica de horizontalização e politização na política externa brasileira, com ministérios, governos subnacionais, OSCs, think tanks, o Congresso e atores privados cada vez mais engajados nas relações internacionais brasileiras, e demandando reconhecimento de suas ações de CSSD reconhecidas pelo Estado. É muito difícil, no entanto, desmembrar interesses particulares de iniciativas lideradas pelo Estado (LEITE et al., 2014).

A principal fonte dessa dispersão é a falta de legislação específica no Brasil que defina claramente os objetivos, o escopo, os mecanismos, as competências e os processos de cooperação para o desenvolvimento (INOUE; VAZ, 2012). Os únicos instrumentos existentes são os Acordos Bilaterais Básicos, que englobam diversas modalidades de cooperação (técnica, científica, cultural, econômica) e devem ser aprovados pelo Congresso, pois envolvem a alocação de recursos nacionais. Iniciativas pontuais de cooperação técnica ganham conteúdo por meio de Ações Complementares. Ajustes e documentos do projeto. Embora os primeiros não tenham sido tradicionalmente submetidos ao Congresso Nacional, isso vem mudando. Nos últimos anos, decretos legislativos aprovando tratados e acordos que foram assinados em 2011 e 2012 incluíram uma cláusula declarando que qualquer ato ou ajuste complementar que implique custos para o tesouro nacional deve ser aprovado pelo Congresso (LEITE et al., 2014).

Como o engajamento brasileiro na CSSD é fragmentado em várias modalidades e espaços de tomada de decisão, formais e informais, obter uma compreensão mais abrangente mais ampla acerca dos determinantes para alocação de recursos públicos é uma tarefa complexa. Durante os anos 2000, um número crescente de atores se organizaram para ter mais influência sobre a CSSD brasileira. Verificou-se o crescente envolvimento de diversos setores domésticos, tais como órgãos públicos executores da cooperação, como agências e Ministérios, setor privado, academia e sociedade civil. Dessa forma, a agenda tem sido permeada por interesses e forças que competem pelos processos decisórios e de implementação (SUYAMA; SILVA; WAISBICH, 2017).

Milani e Pinheiro (2013) destacam que essa fragmentação pode levar a inconsistências na atuação internacional do país, na medida em que esse aumento do número de atores leva a uma maior diversificação de interesses. Os autores defendem, no entanto, que a política externa deve ser vista como uma política pública. Assim, essa diversificação de atores aumentaria o embate político na construção e implementação da agenda externa do Brasil. Suyama e Pomeroy (2014) apontam que embora este formato possa gerar dificuldades no 
diálogo entre as agências implementadoras, a dispersão permitiria que as iniciativas sejam conduzidas por instituições e profissionais especializados nas áreas em questão.

O MRE, em vez de ser o local central de tomada de decisões relacionado à alocação de cooperação técnica, parece ser mais uma agência de veto ${ }^{119}$ e uma agência de facilitação para decisões tomadas fora do ministério. Embora o MRE tenha um forte potencial para liderar a coordenação entre várias modalidades de CSSD, como a única instituição que tem assentos nas principais arenas decisórias e deliberativas, vários fatores prejudicam a influência do ministério. Além dos já citados na subseção anterior, como restrições legais, financeiras e de operacionalização no âmbito do $\mathrm{ABC}$, o crescente papel desempenhado por outros agentes nacionais nos assuntos internacionais brasileiros e a lógica orientada pela demanda na cooperação técnica brasileira também dificultam a MRE para planejar e coordenar iniciativas de cooperação internacional (LEITE et al., 2014).

Dentre os atores que influenciam o processo decisório para tomada de decisão em relação à realização de atividades de cooperação técnica, destacam-se a figura da Presidência da República, os Ministérios e demais agências implementadoras, a sociedade civil organizada e movimentos sociais, o Congresso Nacional e atores internacionais (FONTAINE; SEIFERT, 2010).

Em relação ao papel desempenhado pelo Presidente da República, no site da ABC, dentre as diretrizes para o fornecimento de cooperação técnica brasileira, ressaltam-se os “compromissos assumidos em viagens presidenciais" (ABC, 2016). Ademais, a literatura de Política Externa Brasileira vem cada vez mais reconhecendo a influência do presidente na formulação da política externa do país (PRETO, 2006; VIGEVANI; CEPALUNI, 2007; CASON; POWER, 2009; LIMA; DUARTE, 2013); especialmente, durante os mandatos de FHC (1995-2002) e Lula (2003-2010). .

Leite et al (2014) apontam que durante o segundo governo FHC (1999-2002), a cooperação técnica, especialmente na área da saúde, foi utilizada como instrumento de política externa para os interesses do país, especialmente na tentativa de integração do Conselho de Segurança da ONU e no caso contencioso comercial envolvendo a questão das patentes de medicamentos antirretrovirais. Destacam também a criação da CPLP, em 1996, que resultou em um movimento de aproximação junto aos países africanos no Congresso Brasileiro culminando na criação da Frente Parlamentar Brasil-África em 1999, que um ano

\footnotetext{
${ }^{119}$ Por exemplo, negando demandas de cooperação de países que não hospedam representações diplomáticas brasileiras.
} 
depois destinaria $\mathrm{R}$ \$ 2,5 milhões para financiamento da cooperação técnica junto aos países da CPLP (PUENTE, 2010 apud LEITE et al, 2014).

Durante o governo Lula, a CSSD torna-se central na política externa do país. Em relação à cooperação técnica, a diplomacia presidencial foi um dos principais determinantes para o aumento da demanda por projetos de cooperação. Nessa época, o número de viagens presidenciais, especialmente para países do Sul, aumentou significativamente, tendo sido cruciais para o estabelecimento de diversas atividades de cooperação. A dimensão que assumiu mais visibilidade no governo Lula foi o lançamento, em 2004, da Ação Global contra a Fome e a Pobreza. Resultante de uma conjunção de fatores externos, como os esforços globais para cumprir os ODMs e a busca de soluções para a desordem global no contexto pós11 de setembro, e domésticos, como a criação do Programa Fome Zero. Essa iniciativa levou a mudanças na estrutura da cooperação brasileira para o desenvolvimento, com a criação da CGFOME no MRE, também em 2004 (LEITE et al., 2014).

Embora o governo Dilma tenha tido um perfil mais baixo em termos de política externa, com a priorização das questões econômicas domésticas, destaca-se a renovação das relações com países em desenvolvimento sob uma abordagem mais pragmática. Nesse contexto, foram tomadas medidas para flexibilizar os critérios para concessão de empréstimos feitos pelo Programa de Financiamento às Exportações (PROEX) e pelo Banco Nacional de Desenvolvimento (BNDES). Em relação à cooperação técnica, destaca-se o congelamento do orçamento da ABC em 2011 e os cortes orçamentários em 2012 e em 2013. A presidenta, contrariamente ao seu predecessor, não assinou o prefácio do relatório COBRADI 2010, o que pode indicar que a cooperação com outros países em desenvolvimento não era prioridade no momento. Além disso, a cooperação técnica não é mencionada nos discursos de relações exteriores da presidenta (LEITE et al., 2014).

Em relação ao papel desempenhado pelos Ministérios e demais agências governamentais, estes também possuem um papel de destaque na implementação da CT brasileira, na medida em que possuem mandato legal para assinar acordos de cooperação internacional e representar o país em fóruns internacionais ${ }^{120}$. No entanto, a influência de cada órgão no processo decisório varia de caso a caso. Leite et al (2014) destacam a importância do Ministério da Saúde durante o governo FHC, dos Ministérios do

\footnotetext{
${ }^{120}$ França e Badin (2011) identificaram que, de 170 órgãos ministeriais (gabinetes, secretarias estaduais e executivos, departamentos e 22 ministérios), 61,4\% têm alguma competência em questões internacionais, 37\% têm algumas iniciativas realizadas no exterior e $30 \%$ têm mandato legal para representar os interesses brasileiros internacionalmente (LEITE et al, 2014).
} 
Desenvolvimento Social e Desenvolvimento Agrário durante o governo Lula, e do da Defesa no governo Dilma como exemplos dessa influência díspar.

Até que ponto a influência de diferentes órgãos é de fato verificada varia, no entanto, entre as administrações e também depende do alinhamento institucional interno de cada agência. No caso de atividades coordenadas pela ABC, Leite et al (2014) identificam que o principal mecanismo pelo qual uma agência de implementação ou um grupo de interesse pode influenciar a alocação de recursos é por meio da assinatura de um protocolo de entendimento com a ABC.

Em relação à influência do setor privado na cooperação internacional brasileira, Leite et al (2014) apontam que a participação da indústria e do agronegócio foi guiada primordialmente pelo Estado, como forma de fomentar o desenvolvimento desses setores. Destacam também que a principal forma que o setor privado se beneficiou da cooperação brasileira para o desenvolvimento foi por meio da cooperação financeira. No entanto, enfatizam que não está claro se, e como, a cooperação financeira influencia a cooperação técnica. Algumas pesquisas (MASAGÃO; SUYAMA; LOPES, 2012; MELLO E SOUZA, 2012) indicaram para uma coincidência entre o aumento no financiamento do BNDES para as empresas brasileiras que realizam projetos de infraestrutura na África e os crescentes projetos de cooperação técnica governamental nesses países.

Leite et al (2014) destacam que apesar dos cortes orçamentários, tem havido um crescente interesse por parte do MDIC na CSSD, especialmente nos setores dedicados à promoção de comércio e negócio brasileiros com países africanos. Destacando-se a influência de alguns órgãos como a Agência Brasileira de Promoção de Comércio e Investimentos (APEX), a Agência Brasileira de Desenvolvimento Industrial (ABDI), além da atuação de entidades empresariais como a Federação das Indústrias do Estado de São Paulo (FIESP) e a Confederação Nacional da Indústria (CNI). No geral, ainda sabe-se pouco sobre a relação entre interesses privados e a cooperação brasileira. Os casos de difusão de tecnologias de etanol e soja seriam apontados como exemplos dessa aliança, embora essa relação ainda tenha sido pouco explorada (LEITE; SUYAMA; WAISBICH, 2013; WARNER, 2015).

Em relação à atuação da sociedade civil organizada, Leite et al (2014) destacam que não há muitos espaços permanentes de diálogo para discussão dessas atividades. $O$ envolvimento do governo com a sociedade civil em tais questões tende a ser limitado. Não há indicações de uma estratégia do governo para se envolver com a sociedade na formulação de políticas do CSSD como um todo. Em geral, participam como implementadores da 
cooperação, além de debaterem o engajamento brasileiro na CTPD e em outras modalidades da CSSD. Os espaços de discussão existentes variam em amplitude temática, abrangendo, em alguns casos, inúmeros aspectos da política externa, e em outros focando setores específicos da cooperação. Destacam-se como exemplos a Coordenação-Geral de Ações de Combate à Fome (CGFOME/MRE) e o Conselho Nacional de Segurança Alimentar (CONSEA) (LEITE; SUYAMA; WAISBICH, 2013).

Acerca da participação do Congresso Nacional na condução da PEB, o papel do Poder Legislativo costuma ser negligenciado em detrimento da atuação do Poder Executivo nessa questão. Os motivos que comumente são apresentados como fatores do fraco desempenho legislativo nessa matéria consistem no insulamento do Itamaraty, na complexidade dos temas internacionais, no desenho institucional definido pela Constituição de 1988 e nos baixos incentivos eleitorais. Em termos legais, de acordo com o art. 84 da Constituição da República Federativa do Brasil de 1988, “cabe ao presidente da República, celebrar tratados, convenções e atos internacionais, estando os mesmos sujeitos a referendo do Congresso Nacional" (BRASIL, 1988). E de acordo com o Art. 49 é da competência exclusiva do Congresso Nacional "resolver definitivamente sobre tratados, acordos ou atos internacionais que acarretem encargos ou compromissos gravosos ao patrimônio nacional” (BRASIL, 1988).

Nos últimos anos, uma ampla leva de trabalhos buscou analisar o papel Legislativo na política externa brasileira (LIMA; SANTOS, 2001; OLIVEIRA, 2003; OLIVEIRA; ALBUQUERQUE, 2003; PINHEIRO, 2003; DINIZ, 2005; DINIZ; RIBEIRO, 2008; FELIU; AMORIM, 2009; FIGUEIRA, 2009; OLIVEIRA; ONUKI, 2010; FELIU; MIRANDA, 2011; FERRARI, 2011). Atualmente, predomina a visão de a participação do Legislativo na condução da política externa brasileira se faz mais presente do que se costumar assinalar.

Quanto às atividades de Cooperação Internacional para o Desenvolvimento, ressalta-se que são reguladas pelos Acordos Básicos de Cooperação, sujeitos à aprovação do Legislativo. Leite, Suyama e Waisbich (2013) apontam que o Congresso Nacional se envolve de maneira muito reativa às pautas estabelecidas pelo Executivo nessa área. Entretanto, destacam-se algumas iniciativas específicas como a já citada frente parlamentar Brasil-África em 1999, que resultou em recursos para projetos de cooperação com países da CPLP. Durante os governos petistas, houve mais discussões acerca do papel do Congresso nessa temática. Destacando-se os debates legislativos acerca da assistência alimentar brasileira. Segundo Milton Rondó Filho, coordenador do CGFOME, os partidos da oposição foram contra a aprovação do Projeto de Lei 737/2007, que dispunha sobre as ações humanitárias 
internacionais empreendidas pelo Poder Executivo com a finalidade de auxiliar outros países que se encontrem em situações de emergência (FARIA; PARADIS, 2013).

Outro exemplo seria o Projeto de Lei no 4.128/2004, apresentado em 2004 por um deputado oposicionista, que exigia do Executivo a obtenção de autorização expressa do Congresso para aliviar as dívidas de outros países. Proposta que gerou intensos debates na arena legislativa. Essas discussões se concentraram em aspectos controversos de iniciativas de cooperação financeira para o alívio das dívidas de alguns países, especialmente africanos. No entanto, a PL foi considerada inconstitucional e arquivada no ano de 2005 (CÂMARA DOS DEPUTADOS, 2018).

Ademais, durante os últimos anos, acordos de cooperação aprovados pelo Legislativo passaram a incluir cláusulas no sentido de que quaisquer ajustes que acarretem encargos ao patrimônio nacional sejam submetidos ao Congresso (CÂMARA DOS DEPUTADOS, 2006b, 2009, 2011, 2013, 2015). No entanto, inexiste uma bancada específica pró-cooperação internacional que possa aglutinar interesses específicos em torno dessa pauta no âmbito do Poder Legislativo (LEITE; SUYAMA; WAISBICH, 2013).

Por fim, destaca-se o papel dos doadores tradicionais e das organizações multilaterais que se configuram como centrais no campo da CID. Embora não tenham um papel direto em relação ao processo decisório para aprovação de projetos brasileiros de cooperação, possuem um papel de influência indireta. Em especial, pelo papel de coletar e difundir informações acerca das experiências do Brasil nessa área, bem como na operacionalização, metodologia e financiamento da CTPD brasileira (LEITE et al., 2014).

A figura 4.4.4.1 abaixo busca apresentar visualmente esse processo. Para simplificar a compreensão, os atores nacionais e internacionais são representados de maneira agregada. Deve-se ressaltar que a representação de ministérios, agências implementadoras, grupos econômicos, atores não governamentais, organizações internacionais, outros países e doadores tradicionais de forma unificada esconde sua multiplicidade e complexidade (LEITE et al., 2014).

O MRE, representando a $\mathrm{ABC}$, as embaixadas e o corpo diplomático, foi classificado como um ator facilitador, representado pela cor cinza, uma vez que não implementa a cooperação sozinho. As agências de promoção e os grupos econômicos possuem apenas um impacto indireto na cooperação técnica, relação ainda a ser mais bem explorada pela literatura. Assim, eles foram incluídos na figura representados pela cor amarela. Uma linha azul envolve os atores responsáveis pela implementação direta da cooperação, enquanto as 
instituições com poder de veto e controle são representadas em vermelho (LEITE et al., 2014).

Figura 4.4.4.1. Influências sobre o processo decisório da Cooperação Técnica Brasileira
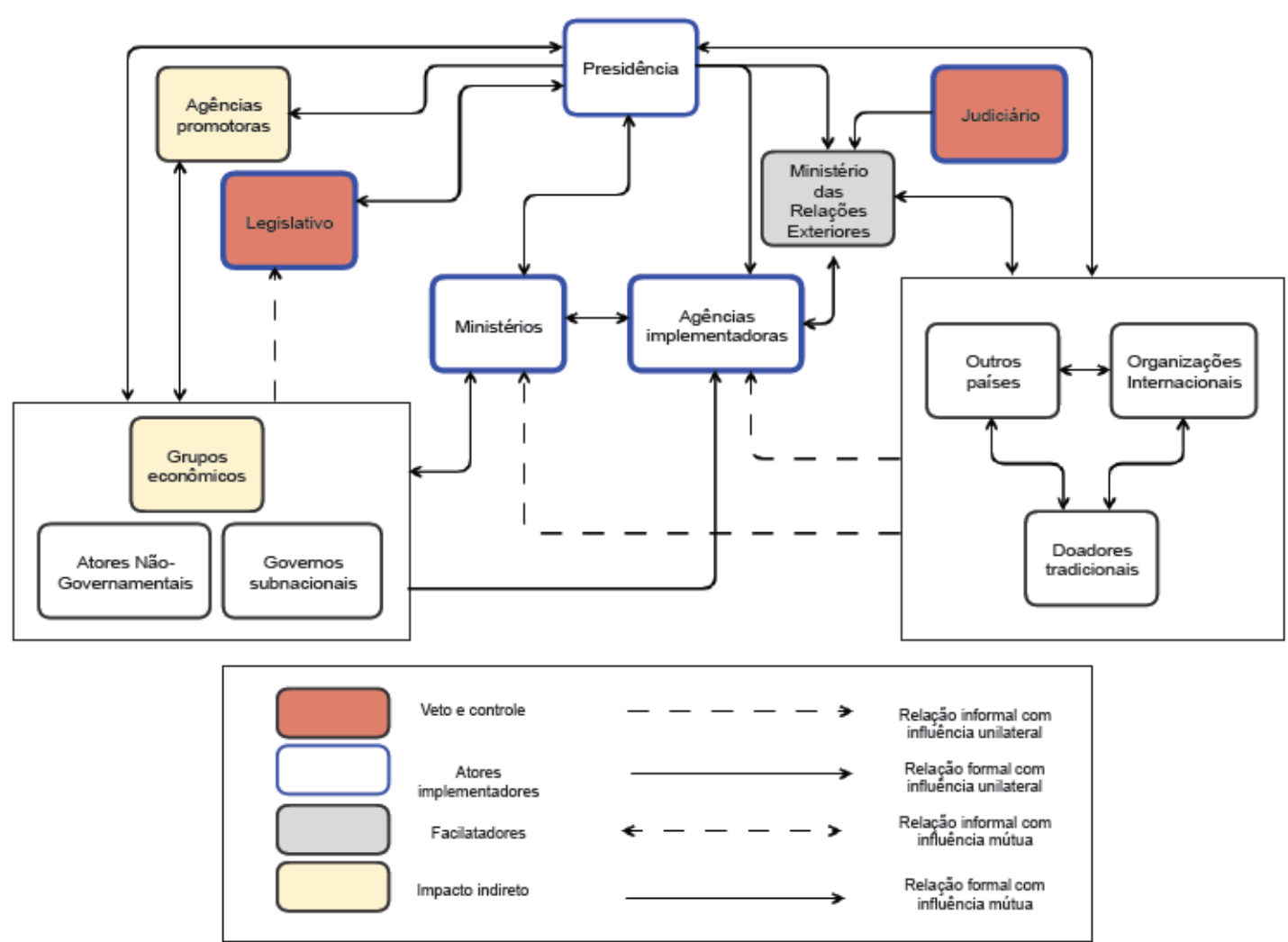

Fonte: adaptado de Leite et al (2014). 


\section{CAPÍtUlO 5. DESENHO DE PESQUISA, DADOS, MÉTODOS E ANÁlise dOS RESULTADOS}

\subsection{Modelo e hipóteses}

Com base nos modelos dos interesses do doador e do receptor propostos por McKinley e Little (1977) para explicar os padrões de alocação da ajuda externa tradicional, esse estudo propõe a aplicação do uso de variações desses modelos na análise da Cooperação Sul-Sul para o Desenvolvimento. Especificamente, essa pesquisa analisa a Cooperação Técnica fornecida pelo Brasil entre 2000 e 2016, buscando contribuir para o debate acerca dos determinantes para o recebimento de cooperação brasileira. As hipóteses 1 e 2 apresentadas abaixo são derivadas do modelo dos interesses do doador enquanto a hipótese 3 deriva do modelo das necessidades do receptor.

Hipótese 1 (H1): a CT haveria interesses econômicos na execução da cooperação técnica. Haveria uma relação positiva entre a CT brasileira e o volume de IED brasileiro nos países receptores e empréstimos subsidiados via BNDES para atuação de empresas brasileiras nesses países. E uma relação positiva entre os gastos em CT e os fluxos de comercio do Brasil com os países beneficiados.

Hipótese 2 (H2): a CT brasileira seria guiada por interesses político-diplomáticos. Haveria uma relação entre a CT brasileira e o apoio ao Brasil por parte dos receptores no cenário internacional. Espera-se uma relação positiva entre os gastos em CT e a convergência dos países receptores em relação ao Brasil na Assembleia Geral das Nações Unidas (AGNU). Uma relação positiva entre a CT provida pelo Brasil e o apoio político desses países nas instituições de Bretton Woods - OMC, Banco Mundial e FMI. Uma relação positiva entre recebimento de CT e pertencimento à CPLP. Uma relação positiva entre a CT e o número de viagens presidenciais brasileiras realizadas no período. E, em razão do fato de o Brasil ter sido governado por governos de esquerda nesse período, seria esperado que países com governo de esquerda recebessem mais CT brasileira nesse período.

Hipótese 3 (H3): os padrões de alocação dos projetos de CT seriam explicados pelas necessidades socioeconômicas e pelas características políticas dos países receptores. Como hipóteses específicas desse modelo, haveria uma relação negativa entre o volume de CT fornecida pelo Brasil e o nível de desenvolvimento dos países receptores. Por outro lado, 
haveria uma relação positiva entre a cooperação provida pelo Brasil e os níveis de democracia e de proteção aos direitos humanos nos países receptores.

Para testar as hipóteses formuladas, foi construído um banco de dados no formato cross-sectional time-series contendo dados sobre 209 países entre o período de 2000 a 2016, contabilizando 3353 observações. Uma descrição mais detalhada das variáveis usadas na pesquisa é apresentada a seguir.

\title{
5.2. A variável dependente
}

A variável dependente de todos os modelos estimados corresponde à Cooperação Técnica Brasileira fornecida entre os anos de 2000 e 2016. Os dados utilizados nessa pesquisa foram obtidos junto à Agência Brasileira de Cooperação $(\mathrm{ABC})$, após solicitação realizada à Direção da ABC. Os dados foram fornecidos pela Coordenação-Geral de Planejamento e Comunicação da $\mathrm{ABC}$ via e-mail em setembro de 2016.

No fornecimento dos dados, o Coordenador geral de Planejamento e Comunicação da $\mathrm{ABC}$ na época, Armando Munguba Cardoso, frisou que:

\begin{abstract}
a $\mathrm{ABC}$ não transfere recursos financeiros aos países parceiros, portanto, o orçamento e a execução financeira constante da planilha se refere a horas técnicas dos profissionais brasileiros envolvidos, passagens, diárias, seguro viagem e, eventualmente, compra de equipamentos e materiais necessários para execução dos projetos. Na cooperação Sul-Sul brasileira, coordenada pela $\mathrm{ABC} / \mathrm{MRE}$, são transferidos conhecimentos, tecnologias, know-how, experiências disponíveis nas instituições brasileiras implementadoras dos projetos e parceiras da $\mathrm{ABC}$ e, em poucos casos, são transferidos equipamentos e materiais. Essa é uma das diferenças entre a cooperação Norte-Sul e Sul-Sul. (ABC, 2016).
\end{abstract}

A planilha fornecida continha os valores gastos pelo Brasil em Cooperação Técnica para cada projeto de cooperação realizado nesse período. A planilha fornecida, com os projetos como unidade de observação, trazia informações referentes ao código do projeto, o título, ano de início, ano de término, situação (concluído ou em execução), o país recipiente, o país parceiros e os valores referentes aos dispêndios em cooperação (orçamento, pagamento e saldo). Como o intuito do modelo seria captar os determinantes para o recebimento de Cooperação Técnica, foram utilizados apenas os valores referentes aos projetos de Cooperação Técnica que contavam como um único país na coluna recipiente e que não 
contavam com o rótulo "trilateral" entre parênteses ao lado do nome do recipiente ${ }^{121}$. Por um lado, essa opção limitou em grande medida os dados a serem utilizados na pesquisa na medida em que não foram considerados os projetos de cooperação multilateral. Por outro lado, ao se analisar apenas os projetos direcionados a um único receptor, a aplicação dos modelos cerca dos determinantes de alocação Cooperação Técnica tornou-se mais coerente.

Ademais, foram utilizados os dados referentes apenas aos valores efetivamente desembolsados na execução dos projetos. Ou seja, apenas os dados relativos à coluna "pagamento" da planilha. Novamente, embora essa opção tenha reduzido os valores utilizados na pesquisa, por outro aumentou seu rigor e precisão conceitual em relação à proposta estipulada. Assim, enquanto a planilha original fornecida pela $\mathrm{ABC}$ trazia um valor total gasto no período de USD 281,93 milhões na coluna "orçamento", a coluna "pagamento" trazia um valor total de USD 223,88 milhões, dos quais foram considerados USD 146,56 milhões para a realização dessa pesquisa.

Quando questionado via e-mail acerca da escala, se nominal ou real, dos valores em dólares americanos referentes a cada projeto, a Coordenação-Geral de Planejamento e Comunicação da $\mathrm{ABC}$ respondeu que os valores em USD foram atualizados com base na cotação do dólar PNUD. Dessa forma, ficou evidente a necessidade de se deflacionar os valores a serem utilizados. O gráfico abaixo ilustra os dados utilizados por essa pesquisa na forma como eles foram disponibilizados e selecionados.

\footnotetext{
${ }^{121}$ Ainda que em alguns casos a coluna "País Parceiro" contivesse mais de um país além do Brasil. No entanto, como a análise frisa identificar os determinantes para o recebimento de CT brasileira, optou-se por manter esses projetos na amostra, tendo em vista que os gastos reportados dizem respeito apenas ao Brasil, contanto que houvesse apenas um país enquanto recipiente.
} 
Figura 5.2.1. Evolução dos gastos em projetos de Cooperação Técnica Brasileira

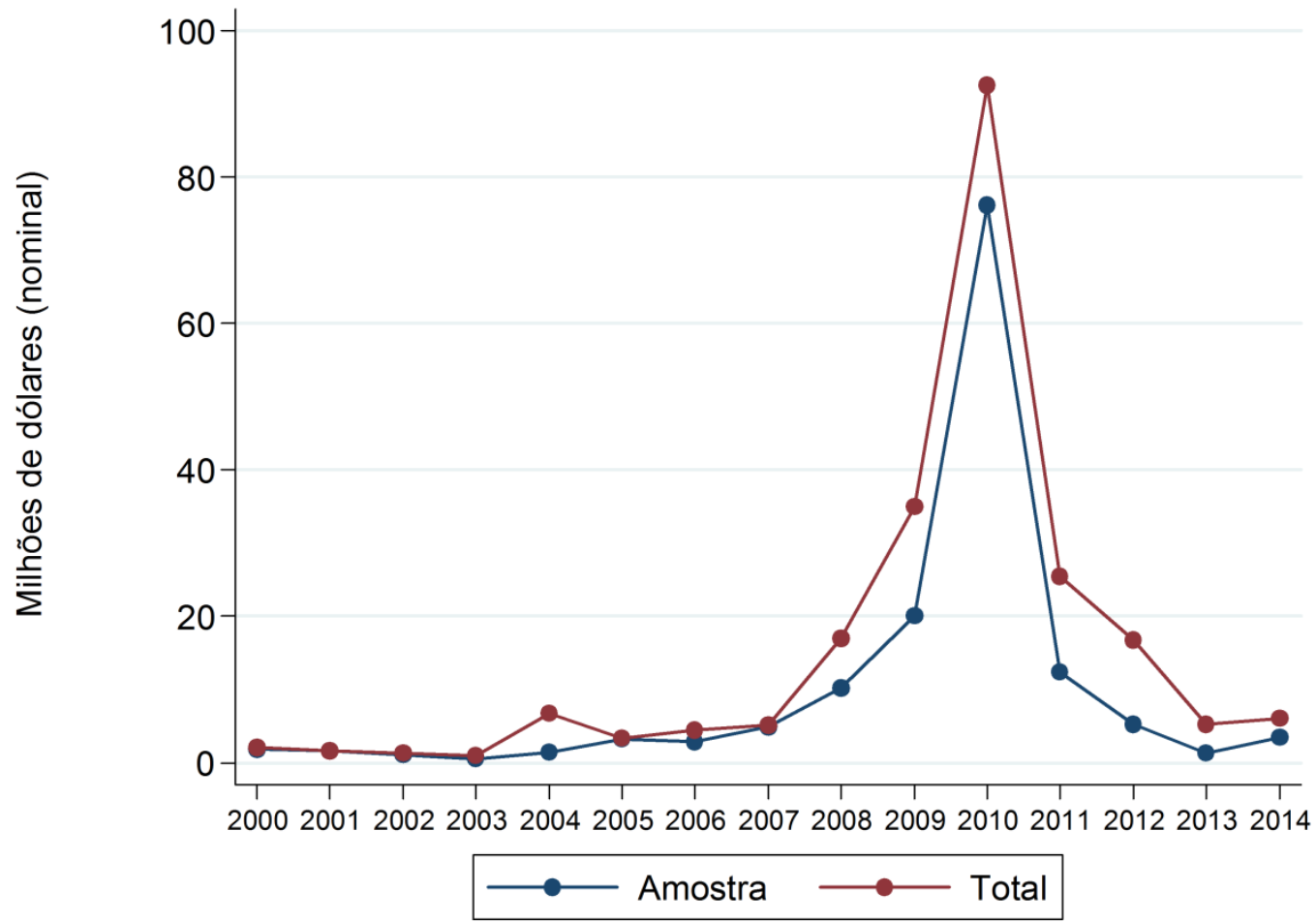

Fonte: elaborado pelo autor com base nos dados fornecidos pela ABC (2016)

Tabela 5.2.1. Evolução dos gastos em Cooperação Técnica Brasileira

\begin{tabular}{ccc}
\hline \hline Ano & Amostra & Total \\
\hline 2000 & 1,85 & 2,11 \\
2001 & 1,60 & 1,63 \\
2002 & 1,11 & 1,26 \\
2003 & 5,43 & 9,52 \\
2004 & 1,39 & 6,68 \\
2005 & 3,28 & 3,35 \\
2006 & 2,93 & 4,52 \\
2007 & 4,93 & 5,18 \\
2008 & 10,22 & 17,01 \\
2009 & 20,03 & 35,00 \\
2010 & 76,17 & 92,61 \\
2011 & 12,43 & 25,53 \\
2012 & 5,29 & 16,75 \\
2013 & 1,29 & 5,29 \\
2014 & 3,50 & 5,99 \\
Total & 146,56 & 223,88 \\
\hline \hline
\end{tabular}

Fonte: elaborado pelo autor com base nos dados fornecidos pela ABC (2016) 
Em seguida, para criar a variável a partir desses valores representando os gastos brasileiros para cada país da amostra em cada ano da análise, foram somados os valores de todos os projetos realizados em um país em um determinado ano. Para os projetos com duração de mais de um ano, foi realizada uma divisão do valor desse projeto para cada ano referente à duração do projeto. Para controlar para variações monetárias artificiais, os valores referentes a essa variável foram deflacionados com base no índice de preços do consumidor nos Estados Unidos (CPI-Index) (BUREAU OF LABOR STATISTICS, 2018). Assim, a variável " $c t$ " reflete os gastos brasileiros com cooperação técnica a partir do valor total recebido por cada país em cada da amostra, de acordo com os valores desembolsados a cada ano em projetos de Cooperação Técnica para cada país da amostra ${ }^{122}$.

O gráfico abaixo ilustra a evolução da variável “ct” entre os anos de 2000 e 2016, operacionalizada com base nos dados fornecidos pela Agência Brasileira de Cooperação. Como se pode notar, o Brasil passou a fornecer CT sistematicamente apenas a partir do governo Lula, especialmente após o ano de 2005. Nesse período, as relações Sul-Sul passaram a ser prioridade na agenda da política externa brasileira, havendo um aumento significativo no volume de cooperação fornecida pelo Brasil para países em desenvolvimento.

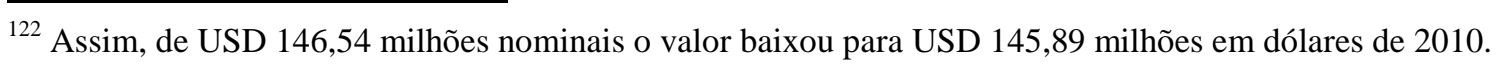




\section{Figura 5.2.2. Evolução dos gastos em Cooperação Técnica Brasileira}

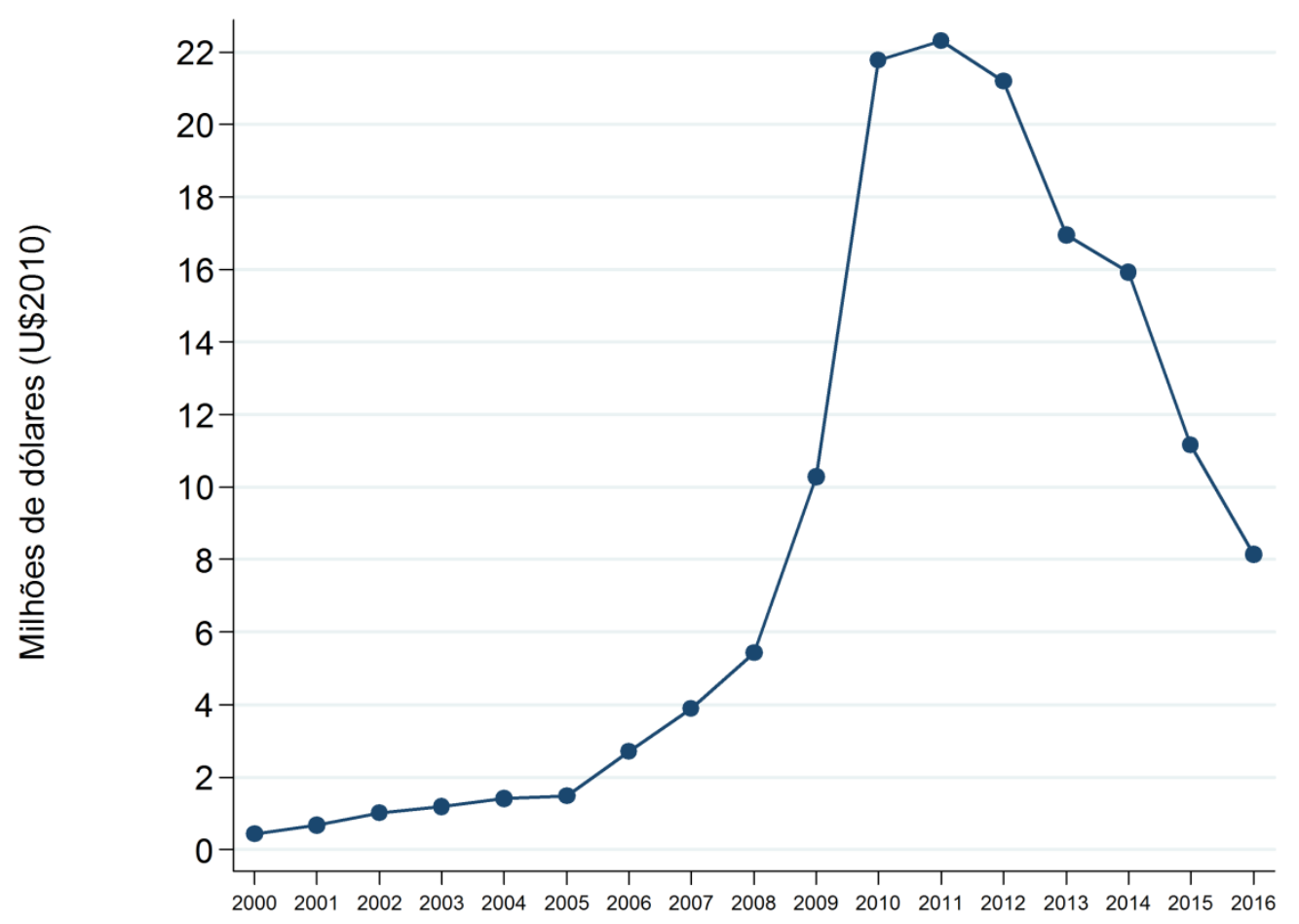

Fonte: elaborado pelo autor com base nos dados fornecidos pela ABC (2016)

O país passa a prover valores expressivos em 2010, ano recorde nos gastos com cooperação técnica, em que o Brasil busca se colocar como um player global buscando ganhar terreno frente aos países desenvolvidos. Por outro lado, nota-se um declínio acentuado a partir de 2011-2012, quando o país começa a sentir os efeitos da desaceleração econômica e da crise econômica que viria atingir o país mais profundamente nos anos seguintes.

Abaixo, é apresentado o gráfico referente ao número de projetos de Cooperação Técnica realizados pelo Brasil por ano. A planilha completa fornecida pela ABC trazia um total de 2634 projetos. Dentre esses, foram considerados 2046 projetos para a realização dessa pesquisa com base nos critérios metodológicos pré-definidos. 
Figura 5.2.3. Evolução do número de projetos de Cooperação Técnica brasileira

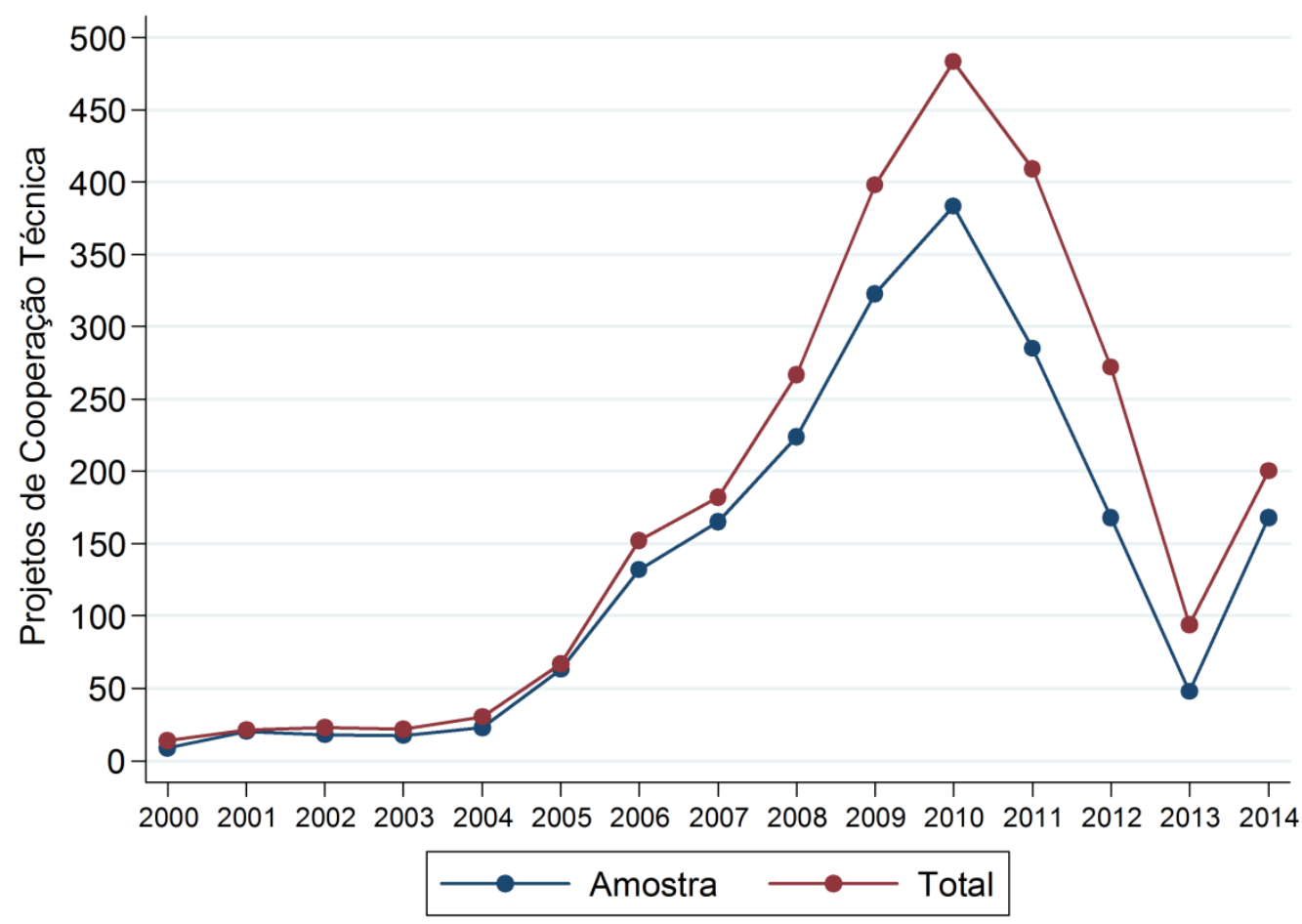

Fonte: elaborado pelo autor com base nos dados fornecidos pela ABC (2016)

Tabela 5.2.2. Evolução do número de projetos de Cooperação Técnica Brasileira

\begin{tabular}{ccc}
\hline \hline Ano & Amostra & Total \\
\hline 2000 & 9 & 14 \\
2001 & 20 & 21 \\
2002 & 18 & 23 \\
2003 & 17 & 22 \\
2004 & 23 & 30 \\
2005 & 63 & 67 \\
2006 & 132 & 152 \\
2007 & 165 & 182 \\
2008 & 224 & 267 \\
2009 & 323 & 398 \\
2010 & 383 & 483 \\
2011 & 285 & 409 \\
2012 & 168 & 272 \\
2013 & 48 & 94 \\
2014 & 168 & 200 \\
Total & 2046 & 2634 \\
\hline \hline
\end{tabular}

Fonte: elaborado pelo autor com base nos dados fornecidos pela ABC (2016) 
Em seguida, os gráficos abaixo apresentam os maiores receptores de Cooperação Técnica nesse período. O gráfico 5.2.4 apresenta os gastos totais com projetos de CT para cada país nesse período e o gráfico 5.2.5 traz os maiores receptores por quantidade de projetos.

Figura 5.2.4. Principais receptores de Cooperação Técnica Brasileira

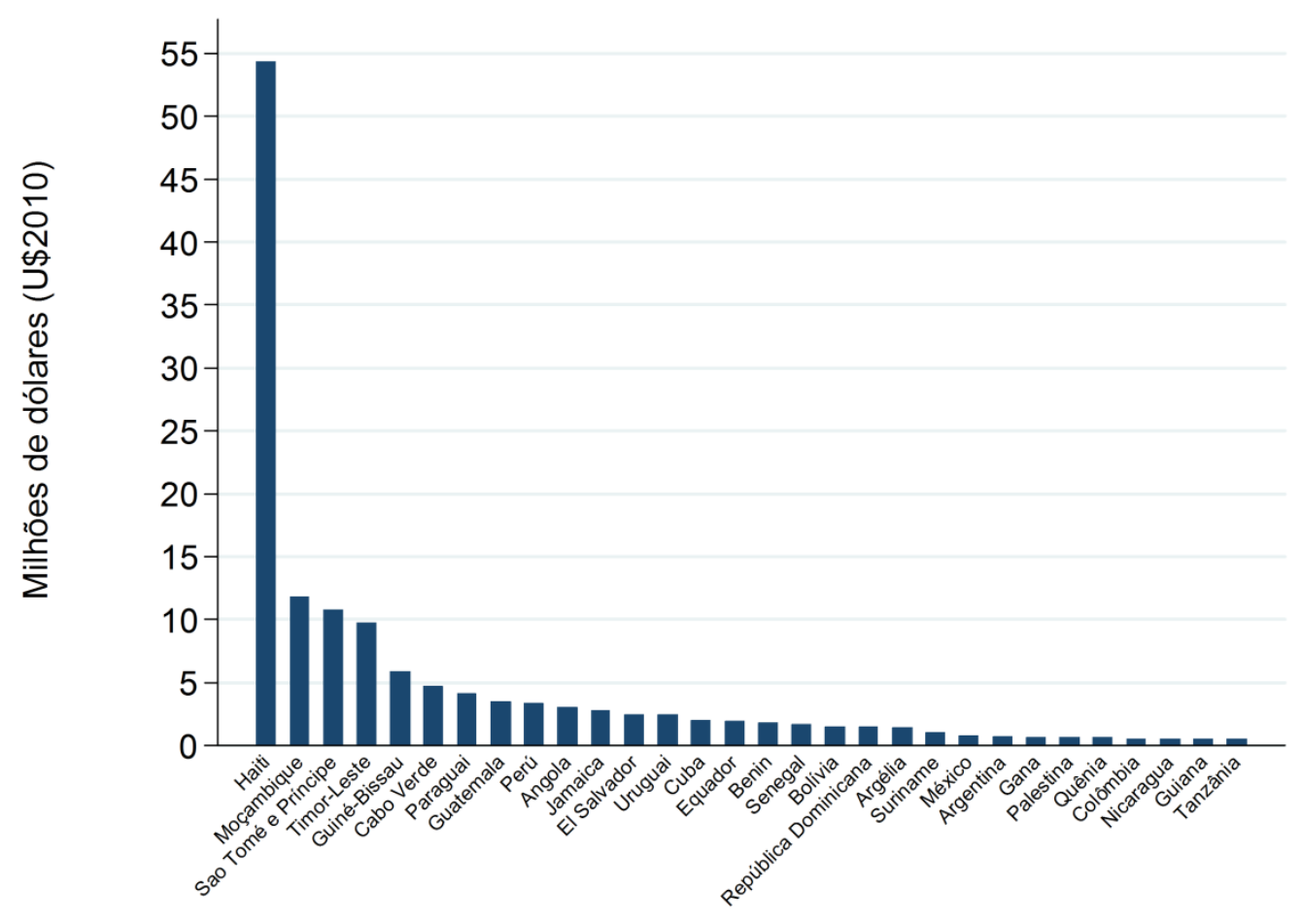

Fonte: elaborado pelo autor com base nos dados fornecidos pela ABC (2016) 


\section{Figura 5.2.5. Principais receptores de Cooperação Técnica Brasileira}

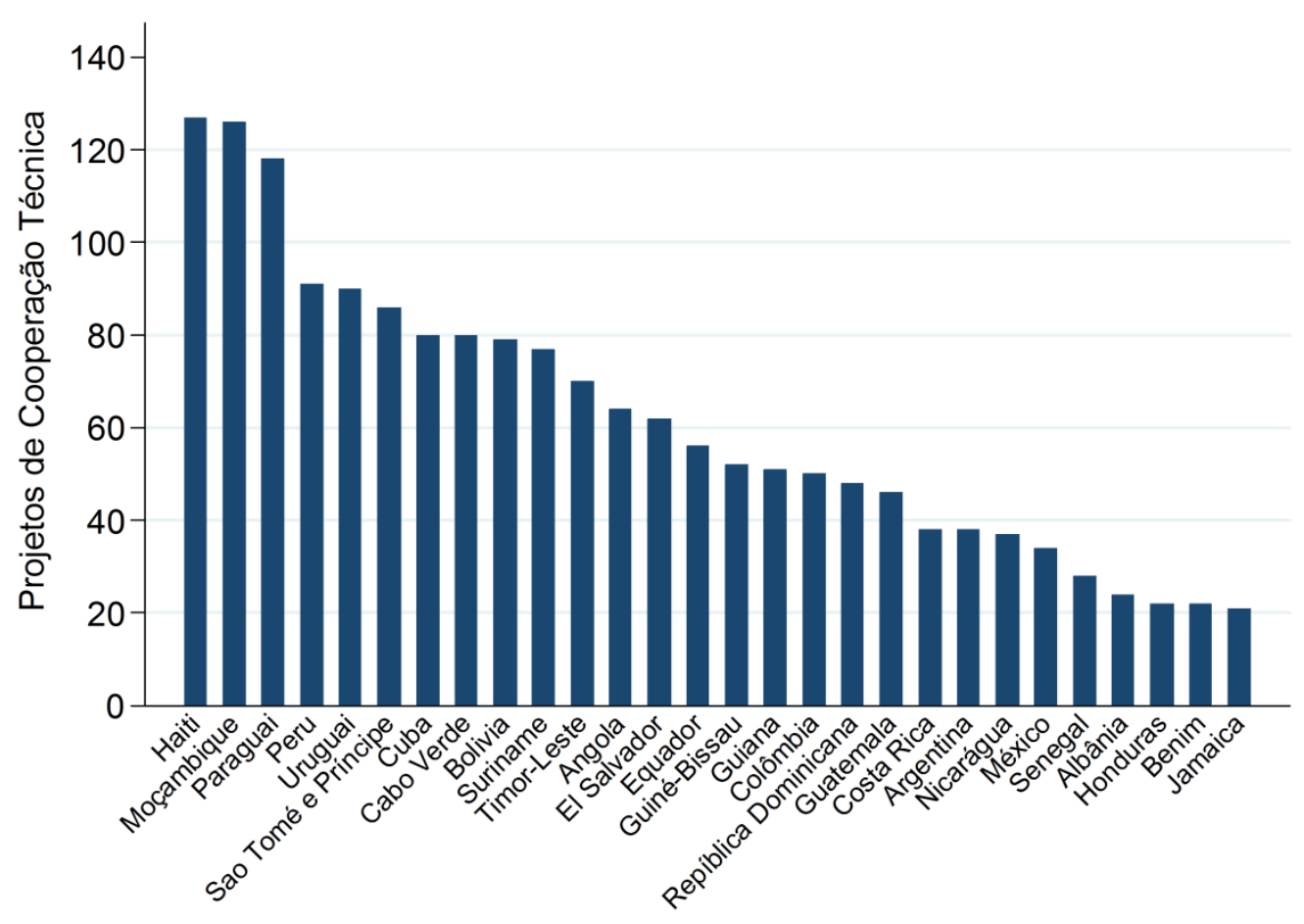

Fonte: elaborado pelo autor com base nos dados fornecidos pela ABC (2016)

O Brasil mantém relações de cooperação técnica com a América Latina, Caribe e África, com atuações pontuais na Ásia (Timor-Leste, Afeganistão e Uzbequistão), Oriente Médio (Líbano e Territórios Palestinos) e Oceania. Como evidenciado em ambos os gráficos, os maiores receptores, de maneira geral, são os países africanos e americanos, em especial, os localizados na América do Sul e na América Central, sendo Haiti e Moçambique os maiores.

Para a estimação dos modelos de alocação de ajuda, há uma série de controvérsias na literatura acerca de qual seria a melhor forma de se operacionalizar a variável dependente referente aos gastos com cooperação ao desenvolvimento. Ainda não há consenso sobre qual a forma mais apropriada de se operacionalizar essa variável. Diferentes formas têm sido utilizadas para se responder a diferentes questões. Em geral, o mais comum é utilizar a quantidade total de ajuda em um determinado ano t para determinado beneficiário i (Ait), a ajuda em percentagem do PIB (Ait/Yit); ou a porcentagem da ajuda ao beneficiário i como proporção da ajuda do doador a todos os países em um determinado ano (Ait/EjAjt) (KILBY, 2006).

A ajuda total e como porcentagem costumam ser utilizadas para captar a quantidade de ajuda que deveria ser destinada ao receptor, tendo sido amplamente utilizadas para testar os 
modelos de necessidade de doador e dos interesses do doador (testando interpretações neorealistas versus idealistas de ajuda). A ajuda como parcela do PIB tem sido mais utilizada para analisar questões referentes ao crescimento econômico (BURNSIDE; DOLLAR, 2000) e dependência da ajuda (O'CONNELL; SOLUDO, 2001), não estando intimamente ligada à justificativa padrão para a alocação da ajuda.

Estudos acerca da ajuda externa tradicional costumam usar variáveis logaritimizadas para minimizar a influência de outliers, para melhorar a estabilidade dos resultados em especificações e amostras e simplificar a interpretação (FLECK; KILBY, 2010). Pesquisadores, particularmente aqueles que usam dados anuais de doadores individuais, precisam lidar com zeros (e, portanto, lidar com a impossibilidade de se calcular o logaritmo natural de zero) nos dados para países que não recebem ajuda em um determinado ano. Com essas considerações em mente, algumas abordagens têm sido mais utilizadas: realizar uma regressão incluindo os zeros (BALL; JOHNSON, 1996; NEUMAYER, 2003; FLECK; KILBY, 2006a) ou adicionando uma pequena constante nas especificações de log (ALESINA; DOLLAR, 2000; KUZIEMKO; WERKER, 2006; BOSCHINI; OLOFSGÅRD, 2007; VREELAND, 2011; BANDYOPADHYAY; VERMANN, 2013); estimar modelos para variáveis dependentes categóricas (ALESINA; DOLLAR, 2000; BERTHÉLEMY; TICHIT, 2004; BERTHÉLEMY, 2006; DOLLAR; LEVIN, 2006; DREHER; NUNNENKAMP; SCHMALJOHANN, 2015); estimar modelos de seleção (MEERNIK; KRUEGER; POE, 1998; DRURY; OLSON; VAN BELLE, 2005; BERTHÉLEMY, 2006); ou em duas partes (BERTHÉLEMY; TICHIT, 2002; BERTHÉLEMY, 2006; FLECK; KILBY, 2006a, 2010; KILBY, 2006).

Na medida em que esse é um dos primeiros estudos que aplica essa metodologia para analisar a alocação da Cooperação Técnica brasileira, buscou-se analisar o assunto da forma mais abrange possível ${ }^{123}$. Para tanto, foram criadas quatro variáveis dependentes a partir da variável original referente aos valores gastos em cooperação técnica para cada país em cada ano da amostra: i) A primeira consiste simplesmente do log da variável referente aos gastos totais para cada país em cada ano $\left(l n \_c t\right)^{124}$; ii) a segunda variável dependente consiste no log da proporção do valor gasto em um país em um determinado ano referente ao valor gasto em cooperação técnica para todo esse ano (ln_ctprop); ii) a terceira variável dependente consiste em uma variável dicotômica, codificada como 1 ou 0 , referindo-se simplesmente ao fato de

\footnotetext{
${ }^{123}$ Estudos anteriores (APOLINÁRIO JÚNIOR, 2014, 2016; HARDT; MOURON; APOLINÁRIO JÚNIOR, 2017) consideraram como variável dependente apenas o total de ajuda para um país em um determinado ano.

${ }^{124}$ Para lidar com os zeros da amostra, foi adicionado um valor insignificante (1) no lugar de cada observação referente ao não recebimento de cooperação técnica em um determinado ano da amostra
} 
um país ter recebido ou não cooperação em um determinado ano da amostra (ctdummy); iv) a última variável refere-se à quantidade de projetos de CT brasileira realizados em um país em um determinado ano (ctcont).

\subsection{As variáveis independentes}

Para testar a primeira hipótese derivada do modelo dos interesses econômicos do doador de que os fluxos de cooperação técnica brasileira acompanhariam variáveis referentes aos interesses econômicos do país no cenário internacional, foram utilizadas variáveis referentes aos interesses econômicos brasileiros no cenário internacional, como o volume de exportações e importações brasileiras para cada país em cada ano, uma variável referente ao volume de investimento estrangeiro brasileiro e uma variável referente aos empréstimos subsidiados via BNDES para a exportação de serviços por parte de empresas brasileiras.

Para operacionalização da variável referente às importações e exportações brasileiras, foram utilizados dados obtidos a partir do banco de dados do COMTRADE, disponibilizado pelo UNCTAD (UNITED NATIONS STATISTICS DIVISION, 2018). Ambas as variáveis estão mensuradas em dólares constantes para o ano de 2010. Nos gráficos abaixo, é possível verificar a evolução do valor total de ambos os indicadores para o período da amostra, assim como os maiores parceiros comerciais do país nesse período. Para estimação dos modelos empíricos, foram utilizados os logs de ambas as variáveis (acrescentando um valor ínfimo nos anos em que não houve comércio com um país para a possibilidade do cálculo). 
Figura 5.3.1. Total de exportações brasileiras por ano

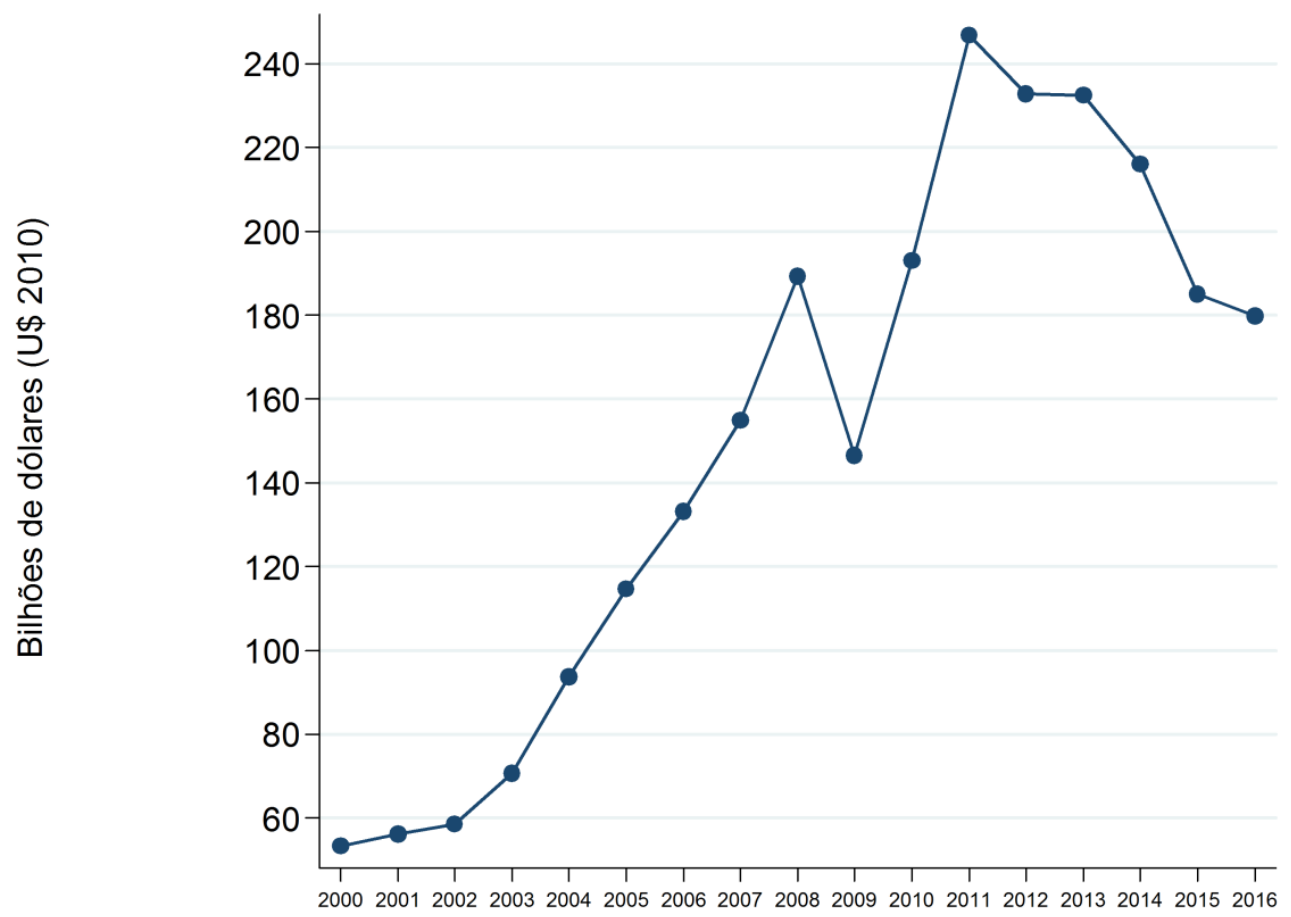

Fonte: elaborado pelo autor com base nos dados disponíveis na plataforma Comtrade (2018)

\section{Figura 5.3.2. Total de importações brasileiras por ano}

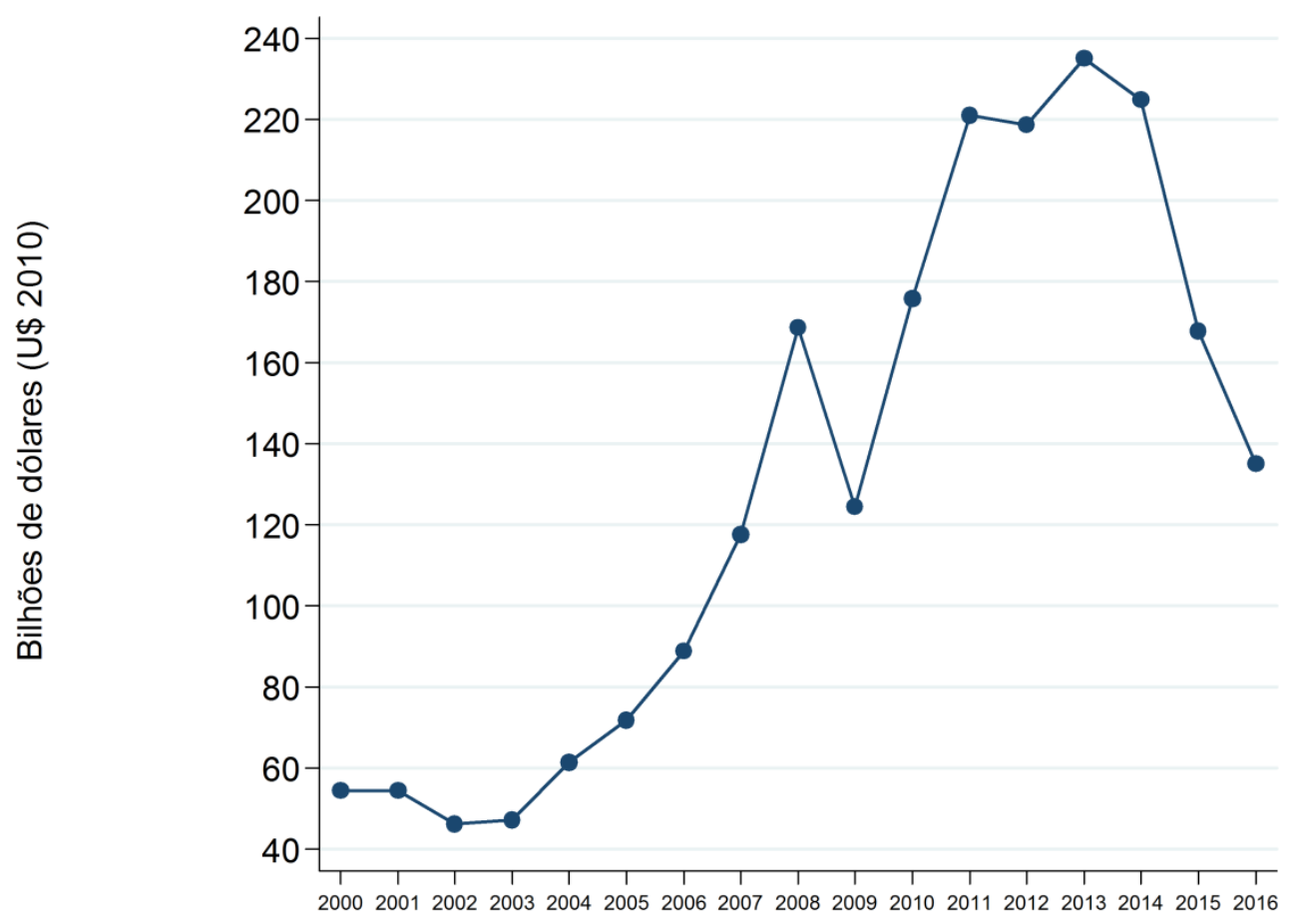

Fonte: elaborado pelo autor com base nos dados disponíveis na plataforma Comtrade (2018) 
Figura 5.3.3. Total de exportações por país

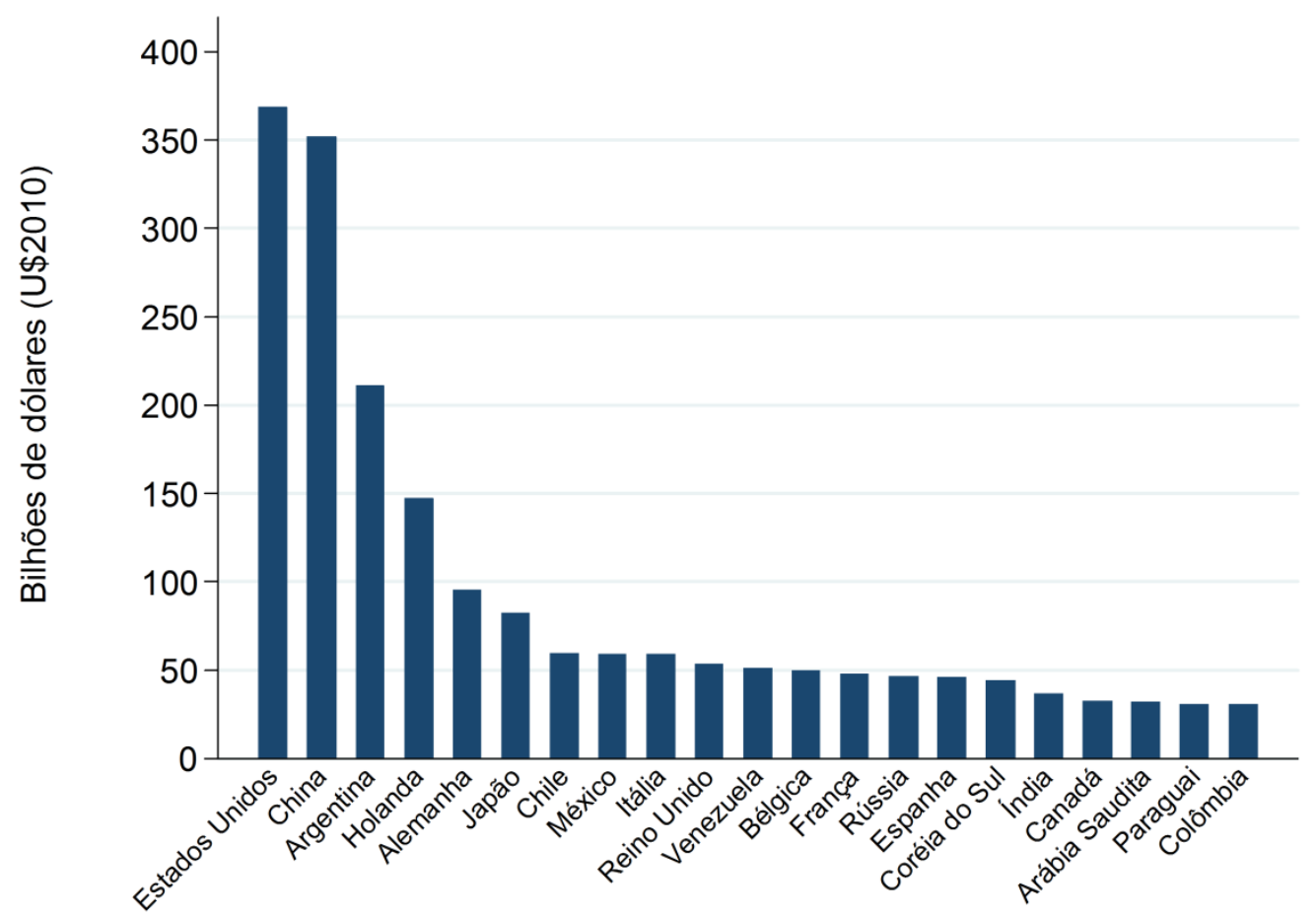

Fonte: elaborado pelo autor com base nos dados disponíveis na plataforma Comtrade (2018) 


\section{Figura 5.3.4. Total de importações por país}

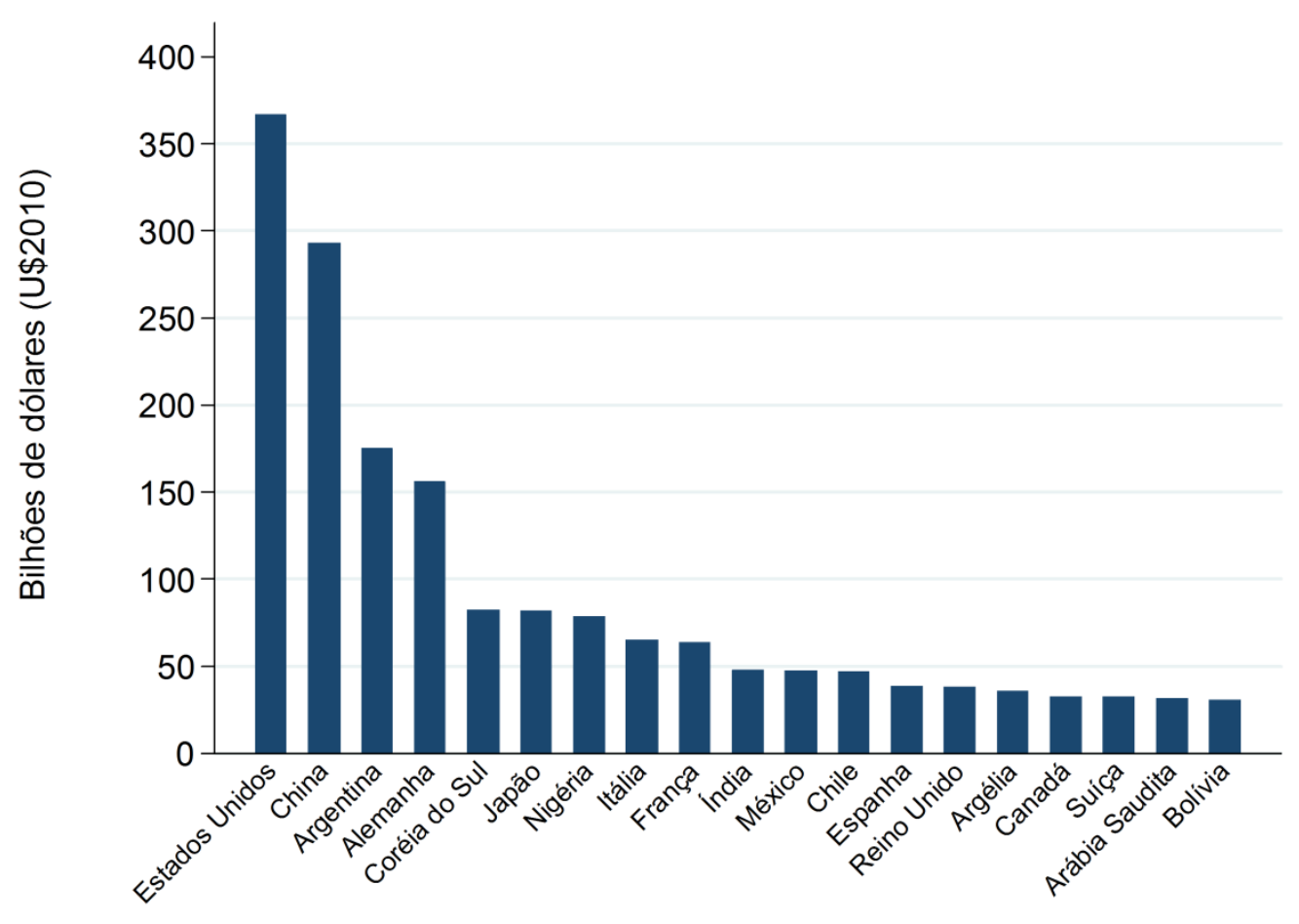

Fonte: elaborado pelo autor com base nos dados disponíveis na plataforma Comtrade (2018)

Para a operacionalização da variável referente ao Investimento Externo Direito brasileiro no período considerado, foram utilizados dados obtidos no site do Banco Central do Brasil (BACEN) (BANCO CENTRAL DO BRASIL, 2018). Como os dados são disponibilizados apenas em dólares correntes (valores nominais), esses valores foram deflacionados com base no índice de preços do consumidor nos Estados Unidos (CPI-Index) para o ano de 2010. Vale destacar, no entanto, que só estão disponíveis os valores a partir do ano de 2006, de modo que a utilização desse dado acaba por restringir significativamente o tamanho da amostra. Para estimação dos modelos empíricos, foi utilizado o log dessa variável, acrescendo um pequeno valor nos anos em que não houve investimentos brasileiros nos países da amostra, com exceção dos anos anteriores a 2006. Nos gráficos abaixo, é possível ver a evolução do valor total investido fora do país assim como os maiores receptores de IED brasileiro no período. 
Figura 5.3.5. Investimento Externo Direto Brasileiro no exterior por ano

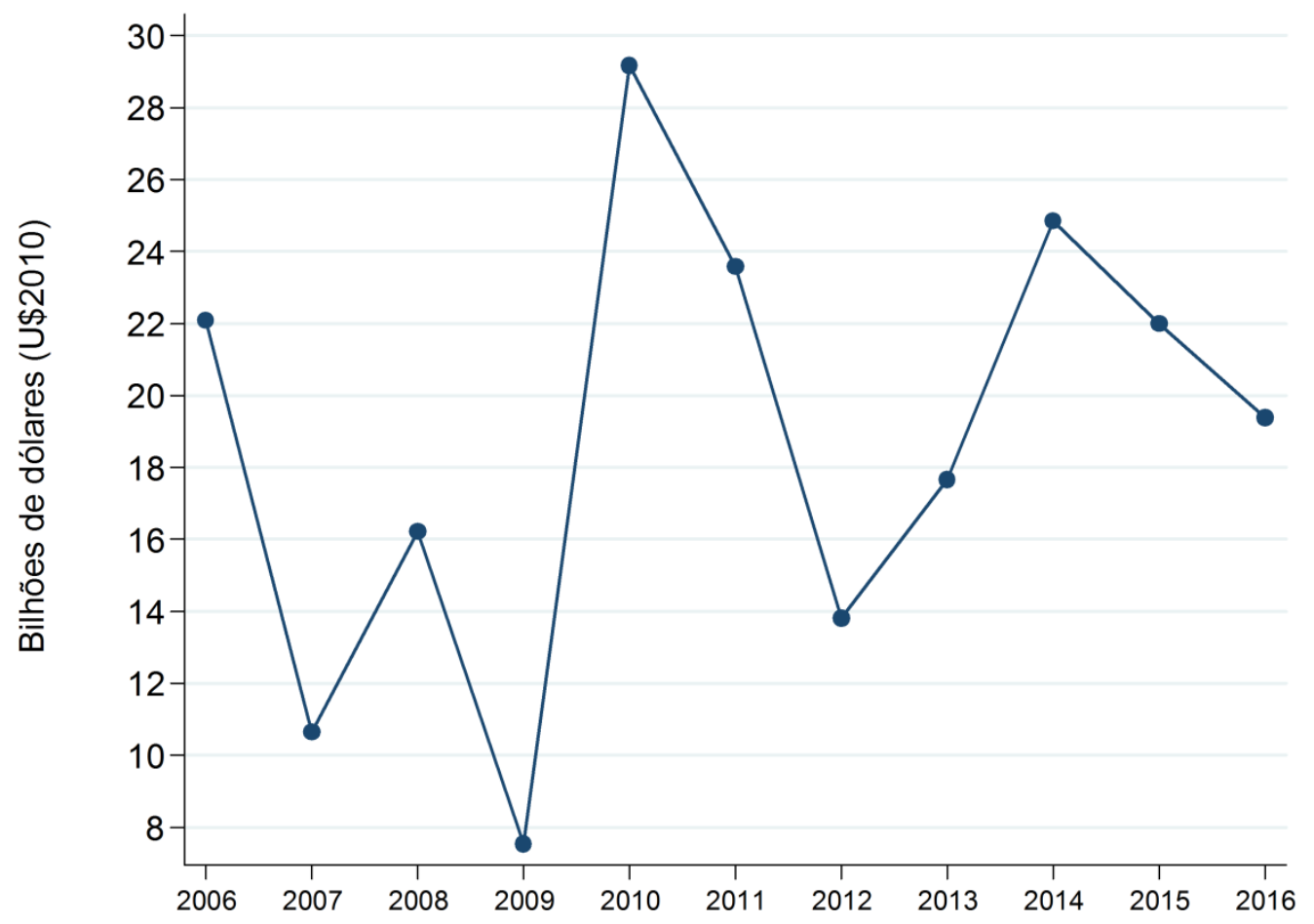

Fonte: elaborado pelo autor com base nos dados do Banco Central do Brasil (2018) 
Figura 5.3.6. Maiores receptores de Investimento Externo Direito brasileiro

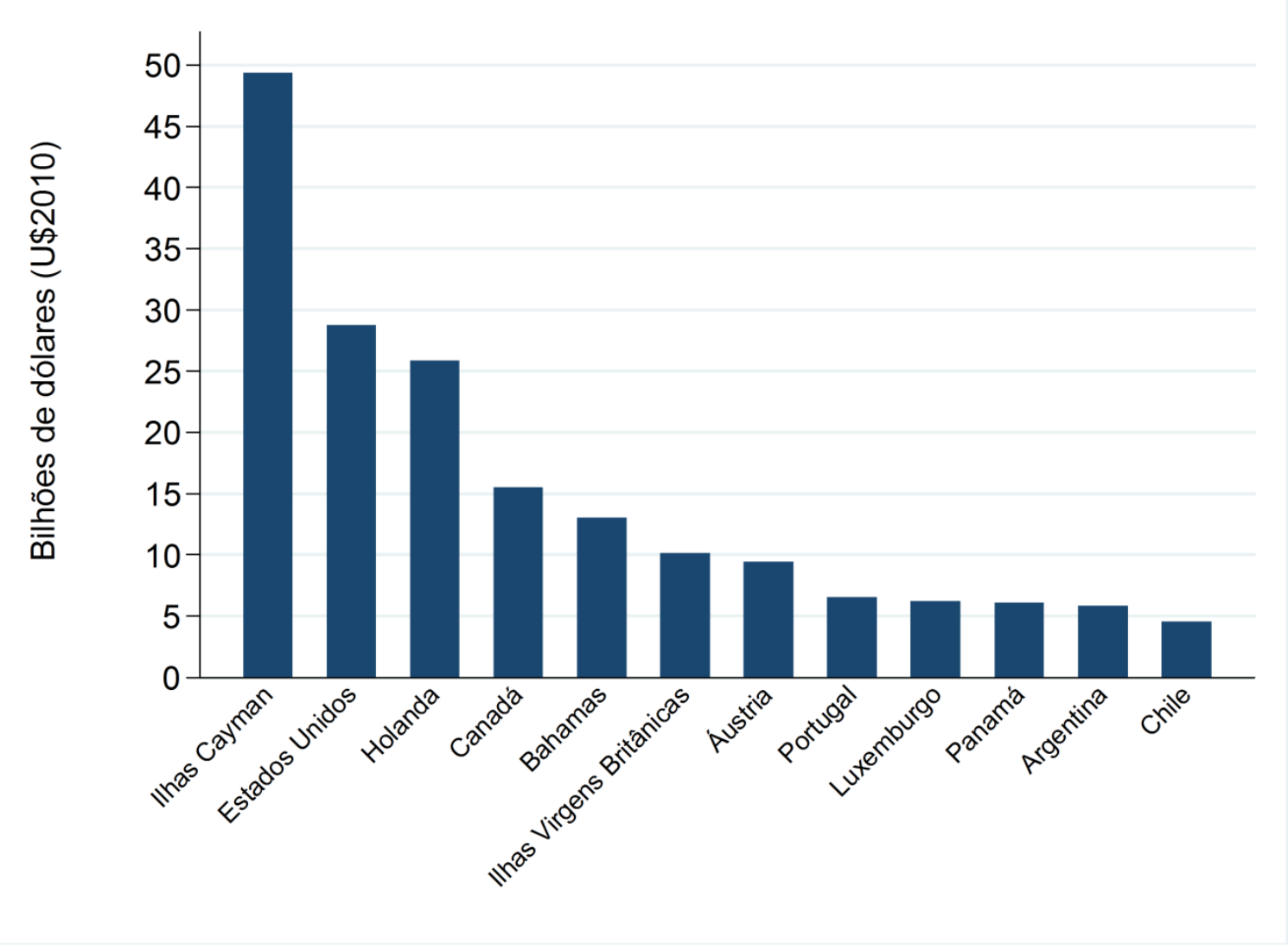

Fonte: elaborado pelo autor com base nos dados do Banco Central do Brasil (2018)

A variável referente aos empréstimos subsidiados via BNDES para a exportação de serviços de empresas brasileiras foi obtida por meio do próprio site da instituição, que recentemente tornou pública as informações acerca dos empréstimos realizados nesse período (BANCO NACIONAL DE DESENVOLVIMENTO ECONÔMICO E SOCIAL, 2018). Novamente, foi utilizada o log dessa variável somando um valor ínfimo nas observações iguais a zero para a possibilidade do cálculo matemático. A evolução do valor total emprestado para empresas atuando fora do país assim como os maiores receptores desses empréstimos são apresentados nos gráficos abaixo: 
Figura 5.3.7. Total de empréstimos do BNDES por ano para apoio à exportação de serviços brasileiros

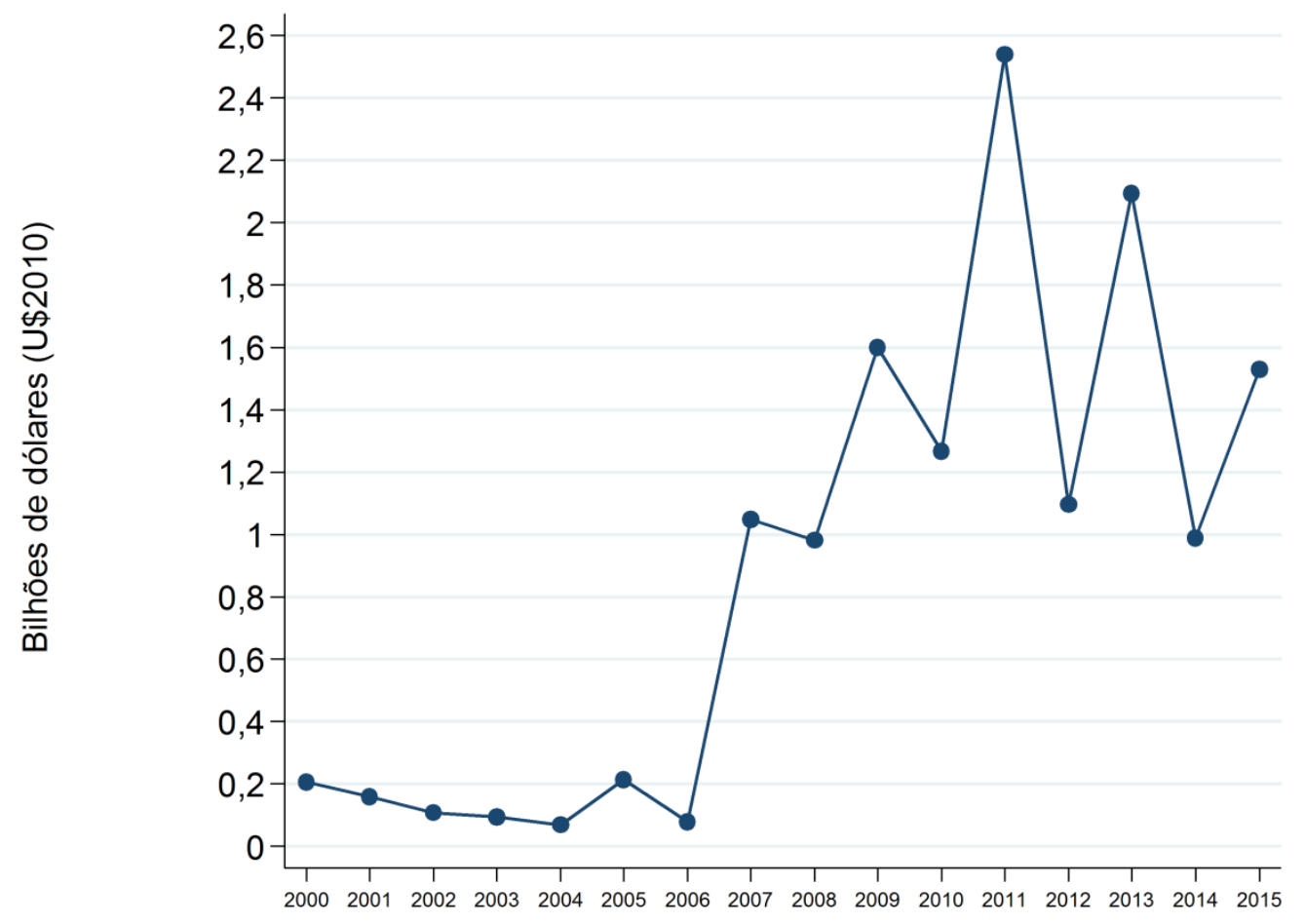

Fonte: elaborado pelo autor com base nos dados do BNDES (2018) 
Figura 5.3.8. Principais destinos de empréstimos do BNDES para apoio à exportação de serviços brasileiros

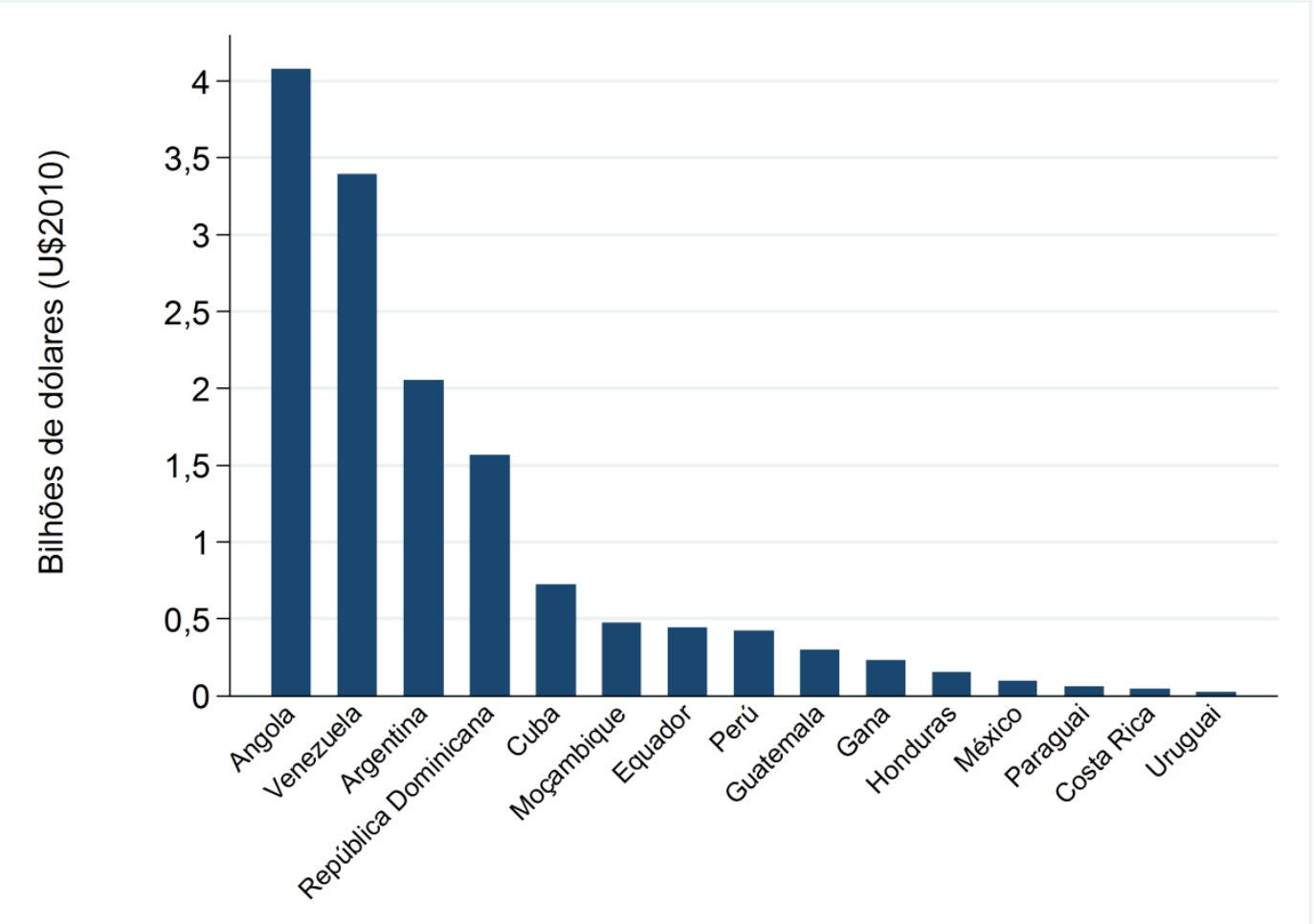

Fonte: elaborado pelo autor com base nos dados do BNDES (2018)

Para testar a segunda hipótese referente aos determinantes políticos para o firmamento de acordos de cooperação, ainda de acordo com o modelo dos interesses do doador, foi utilizada uma variável referente à posição dos receptores em relação ao Brasil nas votações ocorridas na Assembleia Geral das Nações Unidas (AGNU). Variáveis dicotômicas referentes às posições desses países em relação ao Brasil nas instituições financeiras internacionais como o FMI e Banco Mundial. Uma variável dicotômica referente ao pertencimento à CPLP e uma variável dicotômica para os países representados por governos com orientação política de esquerda.

A variável referente à posição dos países em relação ao Brasil na AGNU foi obtida a partir do banco de dados construido pelos pesquisadores Erik Voeten, Anton Strezhnev e Michael Bailey em 2009. Esse banco agrega informações sobre as votações na AGNU para o perído de 1947 a 2015. O banco contém uma série de indicadores acerca das posições do país no plano internacional, incluindo indices de afinidade e pontos ideiais. Para essa pesquisa, optou-se pela utilização do índice de similaridade de votações (0-1) que seria igual ao total de votos em que dois estados concordam divido pelo total de votos conjuntos. Computado 
usando três categorias (1: sim ou aprovação sobre um assunto, 2: abstenção, 3: não ou desaprovação sobre um assunto) (VOETEN; STREZHNEV; BAILEY, 2009).

Tabela 5.3.1. Convergência de voto com o Brasil em votações na AGNU (2000-2016)

\begin{tabular}{|c|c|}
\hline Índice & Países \\
\hline $0,95-1,0$ & $\begin{array}{l}\text { África do Sul, República Dominicana, Bahamas, Madagascar, Maldivas, Lesoto, } \\
\text { Iraque, Timor-Leste, Tailândia, Nigéria, Equador, Namíbia, Mauricio, Paraguai, } \\
\text { Cabo Verde, Cingapura, Suriname, Nepal, Guiné, Benin, Suazilândia, Zâmbia, } \\
\text { Trinidade e Tobago, Senegal, São Vicente e Granadina, Chile, Belize, Níger, } \\
\text { Mali, Eritréia, Moçambique, Barbados, Antígua e Barbuda, Guiana, Burkina } \\
\text { Faso, Filipinas, República do Congo, Camboja, Jamaica, Gabão, Gana, Uruguai, } \\
\text { Mongólia, Seicheles, São Tomé e Príncipe }\end{array}$ \\
\hline $0,9-0,94$ & $\begin{array}{l}\text { Paquistão, República Democrática do Congo, Bielorrússia, Ruanda, Fiji, Irã, } \\
\text { Panamá, Uganda, Cuba, China, Costa do Marfim, Líbia, Egito, Sudão, Honduras, } \\
\text { Cazaquistão, São Cristóvão e Nevis, Mianmar, Granada, Tajiquistão, Nicarágua, } \\
\text { Quirquistão, Venezuela, República Centro Africana, Vietnã, Azerbaijão, Arábia } \\
\text { Saudita, Gâmbia, Zimbábue, Catar, Omã, Malawi, Líbano, Colômbia, Argentina, } \\
\text { Malásia, Kuwait, Comores, Argélia, Bahrein, Etiópia, Butão, Dominica, } \\
\text { Indonésia, Ilhas Salomão, Mauritânia, Brunei, Serra Leoa, Iêmen, Somália, El } \\
\text { Salvador, Costa Rica, Bangladesh, Turcomenistão, Chade, Emirados Árabes } \\
\text { Unidos, Peru, Guiné Equatorial, Haiti, Marrocos, Botsuana, Burundi, Guatemala, } \\
\text { Libéria, Quênia, Sri Lanka, Djibuti, Togo, Jordânia, Laos, México, Tunísia, } \\
\text { Guiné-Bissau, Angola, Afeganistão, Santa Lucia, Bolívia, Tanzânia }\end{array}$ \\
\hline $0,85-0,89$ & $\begin{array}{l}\text { Tonga, Camarões, Tuvalu, Índia, Uzbequistão, Coréia do Norte, Papua-Nova } \\
\text { Guiné, Armênia, Samoa, Síria }\end{array}$ \\
\hline $0,8-0,84$ & Kiribati, Sudão do Sul, Rússia, Vanuatu \\
\hline $0,75-0,79$ & $\begin{array}{l}\text { Espanha, Islândia, Portugal, Finlândia, Noruega, Croácia, Andorra } \\
\text { Geórgia, Moldova, Macedônia, Bósnia e Herzegovina } \\
\text { Grécia, Suíça, Suécia, Liechtenstein, San Marino, Áustria } \\
\text { Irlanda, Coréia do Sul, Ucrânia, Japão, Turquia, Chipre, Nova Zelândia, Malta, } \\
\text { Sérvia }\end{array}$ \\
\hline $0,7-0,74$ & $\begin{array}{l}\text { Albânia, República Tcheca, Hungria, Letônia, Polônia, Holanda, } \\
\text { Alemanha, Lituânia, Bélgica, Mônaco, Dinamarca, Estônia, Montenegro, } \\
\text { Romênia, Eslováquia, Bulgária, Luxemburgo, Itália, Eslovênia }\end{array}$ \\
\hline $0,6-0,69$ & Austrália, França, Canadá, Reino Unido \\
\hline $0,5-0,59$ & Nauru \\
\hline $0,4-0,49$ & Micronesia, Ilhas Marshall, Palau \\
\hline $0,2-0,3$ & Israel, Estados Unidos \\
\hline
\end{tabular}

Fonte: elaborada pelo autor com base em Voeten, Strezhnev e Bailey (2009)

As variáveis referentes ao apoio dos países ao Brasil nas Instituições Financeiras Internacionais, FMI e Banco Mundial, foram operacionalizadas como a (não) participação nas coalizões lideradas pelo Brasil nos diretórios executivos de ambas as organizações. Para tanto, 
foi criada uma variável dicotômica correspondente à participação de determinado país no bloco brasileiro no diretório executivo de cada instituição em determinado ano. Ambas as variáveis foram codificadas com base nos dados fornecidos no site das instituições (INTERNATIONAL MONETARY FUND, 2018; WORLD BANK, 2018a).

No FMI e no Banco Mundial, o processo decisório ocorre com base no poder de voto relativo de seus membros, que é determinado pela sua quota de participação. Em ambas as organizações, a estrutura institucional consiste basicamente na Assembleia de Governadores, Diretório Executivo, Staff e na figura do Diretor-geral. A Assembleia dos Governadores é composta por um governador e um suplente de cada país-membro. É, na teoria, a instância máxima de poder dentro da organização, mas na prática, delega a maioria de suas funções para o Diretório Executivo. É responsável também pela escolha dos Diretores Executivos e se reúne normalmente uma vez por ano durante as Annual Meetings do FMI e Banco Mundial. O Diretório Executivo é, na prática, o órgão mais importante da instituição, composto por vinte e quatro membros, sendo responsável por gerir as operações gerais da instituição e eleger o Diretor-geral além de exercer todos os poderes delegados pela Assembleia dos Governadores (APOLINÁRIO JÚNIOR, 2014, 2016).

Das vinte e quatro cadeiras do Diretório Executivo, apenas oito são ocupadas por países que possuem votos suficientes para indicar seus representes de forma direta: Estados Unidos $^{125}$, Alemanha ${ }^{126}$, Japão ${ }^{127}$, França ${ }^{128}$ e Reino Unido ${ }^{129}$, Rússia ${ }^{130}$, China ${ }^{131}$ e Arábia Saudita $^{132}$. Os demais países, incluindo o Brasil ${ }^{133}$, ocupam as cadeiras restantes por meio de constituencies formadas por vários países, mas liderados por algum em especial. Assim, esses países formam alianças com o intuito de elegerem um representante para atuar em nome dos países que compõem seu bloco. Essas eleições ocorrem a cada dois anos e embora não haja regras formais para a formação dessas coalizões, há normas claras acerca do processo pelo qual essas eleições ocorrem (APOLINÁRIO JÚNIOR, 2014, 2016).

\footnotetext{
125 Atualmente, os Estados Unidos possuem um total de 831.407 votos o que contabiliza 16,52\% do total de votos dentro da organização.

${ }^{126}$ A Alemanha possui atualmente 267.809 votos contabilizando $5,32 \%$ dos votos da instituição.

${ }^{127}$ O Japão possui 309.670 votos, equivalente a $6,15 \%$ do total de votos.

${ }^{128}$ França possui 203.016 votos o que equivale a $4,03 \%$ dos votos.

${ }^{129}$ O Reino Unido possui 203.016 votos, equivalente a 4,03\% dos votos.

130 Mais recentemente, a Síria passou a integrar a coalizão da Rússia. A Rússia possui 130.502 votos que juntamente com os 4.401 votos da Síria somam 2,68\% dos votos.

${ }^{131}$ A China possui 306.294 votos ou $6,09 \%$.

${ }^{132}$ A Arábia Saudita possui 101.391 votos ou 2,02\%.

${ }^{133} \mathrm{O}$ Brasil possui individualmente 111.885 votos, sua coalizão possui 154.590 e 3,07 do total\%.
} 
Tabela 5.3.2. Membros das coalizões brasileiras no FMI e Banco Mundial

\begin{tabular}{ccc}
\hline \hline País & Banco Mundial & FMI \\
\hline Cabo Verde & - & $2012-2016$ \\
Colômbia & $2000-2016$ & $2000-2012$ \\
Equador & $2000-2016$ & $2000-2016$ \\
Filipinas & $2000-2016$ & $2000-2016$ \\
Guiana & - & $2000-2016$ \\
Haiti & $2000-2016$ & $2000-2016$ \\
Nicarágua & - & $2012-2016$ \\
Panamá & $2000-2016$ & $2000-2016$ \\
República Dominicana & $2000-2016$ & $2000-2016$ \\
Suriname & $2000-2016$ & $2000-2016$ \\
Timor Leste & - & $2014-2016$ \\
Trinidad e Tobago & $2000-2016$ & $2000-2016$ \\
\hline \hline
\end{tabular}

Fonte: elaborada pelo autor com base nas informaçõe disponíveis nos sites do FMI e Banco Mundial.

Em relação às posições dos países em face ao Brasil na Organização Mundial de Comércio, foi criada uma variável referente ao apoio político desses países junto ao Brasil nas negociações comerciais internacionais. Nos últimos anos, os países buscaram formar coalizões na OMC. Esses grupos geralmente falam com uma só voz usando um único portavoz ou equipe de negociação (OMC, 2018). Com o tempo, os membros da OMC passaram a se utilizar mais das coalizões como um mecanismo de mobilização, comunicação e negociação, e quase todos os membros agora são representados em múltiplas coalizões que são formadas ao longo de linhas geográficas, setoriais ou outras. Isso representa uma mudança do padrão de representação no final do Acordo Geral sobre Tarifas e Comércio (GATT, em inglês) e nos primeiros períodos da OMC. As coalizões seriam vistas como forma de dar mais voz para que os países pequenos pudessem expressar seus interesses e, assim, aumentar a representatividade nos processos de negociação (NARLIKAR et al., 2012).

Nas negociações agrícolas, mais de 20 coalizões apresentaram propostas ou negociaram com uma posição comum, a maioria ainda ativa. $\mathrm{O}$ crescente número de coalizões envolvendo países em desenvolvimento reflete a disseminação mais ampla do poder de barganha na OMC. Um grupo é visto como politicamente simbólico dessa mudança, o G-20, que inclui Argentina, Brasil, China, Egito, Índia, África do Sul, Tailândia e muitos outros. A construção de coalizões é visto como um meio para os países menores aumentarem seu poder de barganha nas negociações com seus maiores parceiros comerciais e para assegurar que eles sejam representados quando as consultas são realizadas entre grupos menores de membros. Às 
vezes, quando grupos de países adotam posições comuns, o consenso pode ser alcançado com mais facilidade. Às vezes, os grupos são criados especificamente para comprometer e romper um impasse, em vez de aderir a uma posição comum. Mas não existem regras rígidas e rápidas sobre o impacto dos agrupamentos na OMC (WORLD TRADE ORGANIZATION, 2018).

Assim, para operacionalizar essa variável referente ao apoio político ao Brasil nas negociações comerciais internacionais, foi utilizada a razão de participação em cada uma das coalizões conjuntas com o Brasil na OMC pelo total de coalizões que o Brasil integrou no período. Nesse período o Brasil participou de cinco coalizões temáticas: NAMA-11 (Coalizão de países em desenvolvimento que buscam flexibilidade para limitar a abertura do mercado no comércio de bens industriais), Mercosul (união aduaneira composta pelos países do cone sul), W-52 $2^{134}$ (Patrocinadores do TN / C / W / 52, uma proposta de "modalidades" nas negociações sobre indicações geográficas e "divulgação"), FANs (Coalizão buscando mais disciplinas sobre o uso de medidas antidumping), G20T (Coalizão de países em desenvolvimento pressionando por reformas ambiciosas da agricultura em países desenvolvidos com alguma flexibilidade para os países em desenvolvimento) e grupo de Cairns (Coalizão de nações exportadoras agrícolas fazendo lobby pela liberalização do comércio agrícola) (WORLD TRADE ORGANIZATION, 2018).

Tabela 5.3.3. Membros das coalizões que o Brasil integra na OMC

\begin{tabular}{llll}
\hline \hline Cairns & FANs & Mercosul & Nama-11 \\
\hline Argentina, Austrália, Brasil, & Brasil, Chile, Colômbia, & Argentina, & Argentina, Brasil, \\
Canadá, Chile, Colômbia, Costa & Costa Rica, Hong Kong, & Brasil, & Egito, Índia, \\
Rica, Guatemala, Indonésia, & China, Israel, Japão, & Paraguai, & Indonésia, \\
Malásia, Nova Zelândia, Paquistão, & Coréia do Sul, México, & Uruguai & Namíbia, Filipinas, \\
Paraguai, Peru, Filipinas, África do & Noruega, Cingapura, & & África do Sul, \\
Sul, Tailândia, Uruguai, Vietnã & Suíça, Taipé Chinesa, & & Tunísia, Venezuela \\
& Tailândia, Turquia & \\
\hline \hline
\end{tabular}

${ }^{134}$ Coalizão que integra os seguintes países: Albânia, Angola, Antígua e Barbuda, Áustria, Barbados, Bélgica, Belize, Benin, Botswana, Brasil, Bulgária, Burkina Faso, Burundi, Camarões, Cabo Verde, República Centro Africana, Chade, China, Colômbia, Congo, Costa do Marfim, Croácia, Cuba, Chipre, República Tcheca, República Democrática do Congo, Dinamarca, Djibuti, Dominica, Republica Dominicana, Equador, Egito, Estônia, Suazilândia, UE, Fiji, Finlândia, (antiga) Iugoslávia, Macedônia, França, Gabão, Gâmbia, Geórgia, Alemanha, Gana, Grécia, Granada, Guiné, Guiné-Bissau, Guiana, Haiti, Hungria, Islândia, Índia, Indonésia, Irlanda, Itália, Jamaica, Quênia, Quirquistão, Letônia, Lesoto, Liechtenstein, Lituânia, Luxemburgo, Madagascar, Malawi, Mali, Malta, Mauritânia, Mauricio, Moldova, Marrocos, Moçambique, Namíbia, Holanda, Níger, Nigéria, Paquistão, Papua-Nova Guiné, Peru, Polônia, Portugal, Romênia, Ruanda, São Cristóvão e Nevis, Santa Lucia, São Vicente e Granadinas, Senegal, Serra Leoa, Eslováquia, Eslovênia, Ilhas Salomão, África do Sul, Espanha, Sri Lanka, Suriname, Suécia, Suíça, Tanzânia, Tailândia, Togo, Tonga, Trinidade e Tobago, Tunísia, Turquia, Uganda, Reino Unido, Zâmbia, Zimbábue 
Tabela 5.3.4. Principais aliados do Brasil na OMC

\begin{tabular}{ll}
\hline \hline Convergência & País \\
\hline 0,6 & Argentina \\
0,53 & Tailândia \\
0,52 & África do Sul, Indonésia \\
0,47 & Uruguai, Paraguai \\
0,44 & Chile \\
0,43 & Filipinas \\
0,39 & Peru, Colômbia, Paquistão \\
0,36 & China \\
0,35 & Índia, Egito \\
0,3 & Costa Rica, Guatemala \\
0,27 & México \\
0,26 & Bolívia, Venezuela \\
0,23 & Turquia, Cuba, Tanzânia, Nigéria, Equador, Suíça, Zimbábue \\
0,22 & Namíbia, Tunísia \\
0,17 & Austrália, Nova Zelândia, Malásia, Canadá \\
0,14 & Cingapura, Israel, Noruega, Coreia do Sul, Japão \\
& Antígua e Barbuda, Moldávia, St Lucia, Rep Dem do Congo, Barbados, \\
& Albânia, Chade, Malta, Croácia, Irlanda, Moçambique, República Tcheca, \\
& Costa do Marfim, Polônia, Suécia, Guiné-Bissau, Guiana, Papua Nova \\
& Guiné, Quirquistão, Suriname, Finlândia, Geórgia, Luxemburgo, Eslováquia, \\
& Níger, Trinidade e Tobago, Botsuana, Togo, Burundi, Reino Unido, \\
& Espanha, Tonga, Dominica, Liechtenstein, Mali, Latvia, Quênia, Mauritânia, \\
& Eslovênia, Gana, Camarões, Uganda, Suazilândia, Estônia, Áustria, \\
& Mauricio, Lesoto, Haiti, Rep Dominicana, Romênia, Rep Centro Africana, \\
& Macedônia, Irlanda, Dinamarca, Grécia, Cabo Verde, Granada, Lituânia, \\
& Burquina Faso, Zâmbia, Jamaica, Malawi, Holanda, Portugal, Marrocos, \\
& Serra Leoa, Madagascar, São Cristóvão e Nevis, Bélgica, Sri Lanka, Fiji, \\
& Djibuti, Benin, Chipre, Belize, Guiné, Senegal, Congo, Gâmbia, Ilhas \\
& Salomão, Gabão, Ruanda, Itália, França, Alemanha, Hungria \\
Vietnã & \\
\hline \hline & \\
&
\end{tabular}

Fonte: elaborada pelo autor com base nos dados da OMC (2016)

Para testar a hipótese de que a posição política ideológica dos países receptores influenciaria na alocação dos fluxos de CT, foram utilizados indicadores retirados do banco Dataset of Political Institutions (DPI, em inglês), versão 2017 (SCARTASCINI; CRUZ; KEEFER, 2018). O DPI reúne informações sobre 180 países entre os anos de 1975 e 2017 e tem como referência análise qualitativa levantada no Political Handbook of the World (PHW, 
em inglês). A ideologia do chefe do Executivo é codificada como de direita quando seu partido é definido como conservador, democrata-cristão, ou de direita; como de esquerda, quando seu partido é classificado como comunista, socialista, socialdemocrata, ou de esquerda; e de centro quando a posição do partido pode ser mais bem descrita como centrista (por exemplo, quanto um partido advoga o fortalecimento da iniciativa privada em um contexto social-liberal).

Essa categorização refere-se às preferências quanto ao maior ou menor controle estatal a economia. As informações detalhadas sobre plataformas partidárias estão indisponíveis para a maioria dos países a partir das fontes primárias (PHW e o Europe Year Book) ${ }^{135}$. Primeiro, os autores analisaram se a orientação dos partidos era óbvia pelo nome. Se não fosse, ou se as fontes principais discordassem dessa orientação, os autores consultavam outras fontes especializadas como o Political Parties of Africa Middle East e Political Parties of Eastern Europe, Russia, and the Successor States, ambos publicados pela Longman Current.

A partir dessa variável categórica presente no banco DPI, que classifica os países em dimensões políticas, "1" para direita, "2" para centro "3" para esquerda, e "0" para todos os casos que não se enquadram nessas categorias mencionadas (quando a plataforma do partido não se concentra em questões econômicas, ou há alas concorrentes, ou não há informação), foram criadas variáveis dicotômicas, indicando se o governo de um país em um determinado ano se configura como de direita, esquerda ou centro. A partir dessas variáveis, foi criada uma variável dicotômica para os países com governo de esquerda. Seguem os dados descritivos a respeito dessas variáveis:

\section{Tabela 5.3.5. Orientação ideológica}

\begin{tabular}{llll}
\hline \hline Orientação & $\mathbf{N}$ & $\mathbf{\%}$ & $\sum \%$ \\
\hline Direita & 433 & 35.29 & 35.29 \\
Centro & 153 & 12.47 & 47.76 \\
Esquerda & 641 & 52.24 & 100.00 \\
Total & 1227 & 100.0 & \\
\hline \hline
\end{tabular}

Fonte: elaborada pelo autor com base em Cruz, Keefer e Scartascini (2016)

\footnotetext{
${ }^{135}$ Além do PHW, os autores recorrem a especialistas locais e buscam enfrentar alguns problemas de maneira pontual. Por exemplo, se existir evidência de que o chefe do Executivo se distancia das orientações partidárias, a codificação recai sobre a posição da liderança. O mesmo ocorre quando a liderança é classificada como independente.
} 
Ademais, para analisar os derminantes político-diplomáticos para o recebimento de CT brasileira foi criada uma variável referente à Comunidade dos Países de Língua Portuguesa (CPLP) e também uma variável relativa ao número de viagens presidenciais brasileiras para um país em cada ano. A variável de controle referente à Comunidade dos Países de Língua Portuguesa (CPLP) foi codificada por meio de uma dummy relativa aos países pertencentes à CPLP, "1" para os países membros e "0" para os não membros. Organização internacional formada por países lusófonos cujo objetivo é o "aprofundamento da amizade mútua e da cooperação entre os seus membros". Foi criada em 17 de Julho de 1996 por Angola, Brasil, Cabo Verde, Guiné-Bissau, Moçambique, Portugal e São Tomé e Príncipe. No ano de 2002, após conquistar independência, Timor-Leste foi acolhido como país integrante. Em 2014, Guiné Equatorial tornou-se o nono membro de pleno direito (COMUNIDADE DOS PAÍSES DE LÍNGUA PORTUGUESA, 2018).

A variável referente ao número de viagens presidenciais brasileiras foi operacionalizada com base nos relatórios emitidos pela Secretaria de Comunicação Social da Presidência da República do Brasil (2000-2010) e da Secretaria de Planejamento Diplomático do Ministério das Relações Exteriores (2011-2016) (MINISTÉRIO DAS RELAÇÕES EXTERIORES, 2003, 2011; PRESIDÊNCIA DA REPÚBLICA, 2011, 2012, 2013, 2014, 2015, 2016). Para construção dessa variável, foram contabilizadas todas as viagens presidenciais em caráter bilateral realizadas para um país em determinado ano. A metodologia utilizada para esse cálculo segue a metodologia utilizada nos relatórios oficiais de se considerar a distinção entre viagens oficiais bilaterais e multilaterais. Assim, são consideradas multilaterais as visitas sem nenhum registro de encontro com autoridades locais. E bilaterais quando houver compromissos bilaterais e multilaterais na mesma ocasião, a visita é considerada bilateral. O Gráfico abaixa apresenta o número total de viagens para cada país:

Tabela 5.3.6. Número de viagens oficiais do Presidente da República (2000-2016)

\begin{tabular}{|c|c|c|c|c|c|c|c|}
\hline Argentina & 30 & China & 5 & Cabo Verde & 2 & Jamaica & 1 \\
\hline Estados Unidos & 27 & Índia & 5 & Gana & 2 & Argélia & 1 \\
\hline Venezuela & 23 & Moçambique & 5 & Finlândia & 2 & Tanzânia & 1 \\
\hline Uruguai & 16 & Bélgica & 5 & Indonésia & 2 & Vietnã & 1 \\
\hline Peru & 13 & Panamá & 4 & Timor-Leste & 2 & Benin & 1 \\
\hline Chile & 13 & Turquia & 4 & Etiópia & 1 & Guiné & 1 \\
\hline Paraguai & 13 & Suécia & 4 & Jordânia & 1 & Honduras & 1 \\
\hline Bolívia & 12 & Holanda & 4 & Guiné Equatorial & 1 & Burkina Faso & 1 \\
\hline
\end{tabular}




\begin{tabular}{l|r|l|l|l|l|l|l}
\hline Espanha & 11 & Japão & 4 & Namíbia & 1 & Canadá & 1 \\
\hline Portugal & 11 & El Salvador & 4 & Arábia Saudita & 1 & Gabão & 1 \\
\hline França & 11 & Líbia & 3 & EAU & 1 & Egito & 1 \\
\hline Colômbia & 10 & Costa Rica & 3 & Polônia & 1 & Cazaquistão & 1 \\
\hline África do Sul & 10 & Dinamarca & 3 & Guiné-Bissau & 1 & Nicarágua & 1 \\
\hline Itália & 9 & Haiti & 3 & Israel & 1 & Zâmbia & 1 \\
\hline Reino Unido & 9 & Guatemala & 3 & República Tcheca & 1 & República do Congo & 1 \\
\hline Equador & 8 & Ucrânia & 3 & Senegal & 1 & Noruega & 1 \\
\hline Alemanha & 8 & $\begin{array}{l}\text { Coréia do } \\
\text { Sul }\end{array}$ & 3 & Guiana & 1 & Austrália & 1 \\
\hline Suíça & 8 & Angola & 3 & Áustria & 1 & Quênia & 1 \\
\hline México & 8 & Qatar & 3 & Botsuana & 1 & Bulgária & 1 \\
\hline Rússia & 8 & Nigéria & 3 & Suriname & 1 & Trinidade e Tobago & 1 \\
\hline Cuba & 6 & $\begin{array}{l}\text { Republica } \\
\text { Dominicana }\end{array}$ & 2 & Eslováquia & 1 & Camarões & 1 \\
\hline \hline
\end{tabular}

Fonte: elaborada pelo autor com base nas informações disponibilizadas pelo MRE e Secretaria da Presidência da República

Para testar a terceira hipótese, derivada do modelo das necessidades do receptor, foram utilizadas variáveis como nível de renda per capita, nível de democracia e de proteção aos direitos humanos dos países receptores. A ideia foi testar se as necessidades dos países receptores influenciam na alocação dos recursos destinados. Ou seja, se a ajuda fornecida pelo Brasil se destina aos países mais pobres e se a diplomacia brasileira condiciona sua ajuda ao nível de democracia e de proteção aos direitos humanos dos países receptores.

Para a variável referente à renda per capita, foram utilizados dados do World Development Indicators, do Banco Mundial, obtidos diretamente a partir do site da instituição. O PIB per capita é o produto interno bruto dividido pela população no meio do ano. O PIB é a soma do valor bruto adicionado por todos os produtores residentes na economia mais quaisquer impostos sobre produtos e menos quaisquer subsídios não incluídos no valor dos produtos. É calculado sem deduzir depreciação de bens fabricados ou pelo esgotamento e degradação de recursos naturais. Os dados estão em dólares constantes de 2010 (WORLD BANK, 2018b).

Para a variável relativa ao nível de democracia dos países, foi utilizada a variável Polity 2 do projeto Polity IV (MARSHALL; JAGGERS; GURR, 2014), em uma escala que vai de -10 (mais autocrático) para + 10 (mais democrático). A série de dados Polity é uma série de dados amplamente utilizada nas pesquisas de ciência política. A versão mais recente, Polity IV, contém informações anuais codificadas sobre o nível de democracia da maioria dos 
estados independentes com população total superior a 500.000 e abrange os anos de 1800 a 2017. As conclusões sobre o nível de democracia de um estado são baseadas em uma avaliação acerca das eleições em relação à competitividade e abertura, à natureza da participação política em geral e à extensão dos controles sobre a autoridade executiva.

Para a variável referente ao nível de proteção aos direitos humanos, foi utilizada uma variável obtida a partir do banco de dados do projeto Political Terror Scale. O PTS mede os níveis de violência política que um país experimenta em um determinado ano com base em uma "escala de terror" de 5 níveis originalmente desenvolvida pela Freedom House. Os dados usados na elaboração deste índice provêm de três fontes diferentes: os relatórios anuais de países da Anistia Internacional, os Relatórios Nacionais de Práticas de Direitos Humanos do Departamento de Estado dos EUA e os Relatórios Mundiais da Human Rights Watch (GIBNEY et al., 2010).

A escala varia de 1 a 5. Os países com valor "1" estariam sob um Estado de direito seguro, em que as pessoas não são presas por seus pontos de vista, a tortura é rara ou excepcional, e assassinatos políticos são extremamente raros. No valor "2" existe uma quantidade limitada de prisão por atividade política não violenta. No entanto, poucas pessoas são afetadas, tortura e espancamentos são excepcionais e assassinatos políticos são raros. Nos países codificados como " 3 ”, ocorreriam aprisionamentos políticos de forma extensiva, execuççoes e/ou outros assassinatos políticos seriam comuns e prisões, com ou sem julgamento, por opiniões políticas seriam aceitas. No ponto “4”, violações dos direitos civis e políticos são comuns para um grande número da população. Assassinatos, desaparecimentos e tortura são parte comum da vida dos cidadãos, afetando especialmente as pessoas que se envolvem em questões políticas. No ponto "5", o terror se expandiu para toda a população, na medida em que os líderes dessas sociedades não veriam limites aos meios ou minuciosidade com que perseguem objetivos pessoais ou ideológicos (GIBNEY et al., 2010). A tabela 5.3.7 apresenta as principais estatísticas descritivas das variáveis descritas acima:

Tabela 5.3.7. Estatísticas descritivas

\begin{tabular}{lllllll}
\hline \hline Variável & N & Média & Desvio Padrão & Min & Max & Cobertura \\
\hline ct & 3553 & 41061.27 & 345735.9 & 0 & 7906657 & $2000-2016$ \\
ln_ct & 3553 & 1.993856 & 4.226346 & 0 & 15.88322 & $2000-2016$ \\
ctprop & 3553 & .0047847 & .0344009 & 0 & .8796456 & $2000-2016$ \\
ctcont & 3553 & .5758514 & 2.320214 & 0 & 33 & $2000-2016$ \\
ctdummy & 3553 & .1874472 & & 0 & 1 & $2000-2016$
\end{tabular}




\begin{tabular}{lllllll} 
ln_ctprop & 3553 & -40.29205 & 16.80743 & -48.35429 & -.1282362 & $2000-2016$ \\
bndes & 62 & 227000896 & 238912256 & 438714.3 & 981675200 & $2000-2016$ \\
ln_bndes & 3553 & .3212916 & 2.421514 & 0 & 20.70477 & $2000-2016$ \\
ied & 369 & 560.8246 & 1451.345 & 0 & 13420 & $2007-2016$ \\
ln_ied & 2299 & .663983 & 1.82401 & -2.480274 & 9.504501 & $2007-2016$ \\
percapita & 3258 & 13506.8 & 19378.02 & 193.8669 & 144246.4 & $2000-2016$ \\
ln_percapita & 3258 & 8.504756 & 1.520866 & 5.267172 & 11.87928 & $2000-2016$ \\
exp & 3553 & 719568640 & 2766115840 & 0 & 46026153984 & $2000-2016$ \\
ln_exp & 3328 & 17.28792 & 3.333866 & 1.609438 & 24.55247 & $2000-2016$ \\
imp & 3553 & 623045376 & 2579592960 & 0 & 37340606464 & $2000-2016$ \\
ln_imp & 3165 & 15.28523 & 4.771894 & 1.609438 & 24.34335 & $2000-2016$ \\
viagem & 3553 & .108922 & .3902122 & 0 & 5 & $2000-2016$ \\
onu & 2835 & .8656393 & .1268707 & .17105 & 1 & $2000-2014$ \\
pts & 2410 & 2.63029 & 1.113633 & 1 & 5 & $2000-2016$ \\
cplp & 3553 & .0382775 & & 0 & 1 & $2000-2016$ \\
fmi & 3553 & .0413735 & & 0 & 1 & $2000-2016$ \\
bm & 3553 & .0382775 & & 0 & 1 & $2000-2016$ \\
esquerda & 3553 & .224036 & & 0 & 1 & $2000-2016$ \\
\hline \hline
\end{tabular}

Fonte: elaborada pelo autor

\subsection{Métodos de estimação}

Vários estimadores poderiam ser usados para testar as hipóteses da pesquisa. Conforme já discutido, existem algumas opções para lidar com a natureza limitada da variável dependente com base em diferentes suposições. A principal estratégia utilizada nos estudos de alocação de ajuda externa é considerar tanto a decisão da seleção quanto do volume de recursos a ser destinado em um mesmo momento, de modo a se realizar uma regressão para todas as observações da amostra. Em função da presença de zeros na variável dependente, a estratégia a ser utilizada seria a inclusão de valores ínfimos no lugar dos zeros de modo à possibilizar a obtenção do log dessa variável.

Outra estratégia também utilizada na literatura é considerar que o "doador" decide, em um primeiro momento, se deve ou não atribuir ajuda a um país, e, em um segundo momento, decide qual o montante da ajuda a ser dada após a seleção dos receptores. Para o primeiro passo deste modelo, os modelos Logit ou Probit seriam os métodos mais apropriados de estimação. O segundo seria utilizar métodos de estimação para variáveis dependentes contínuas apenas para a amostra de países selecionados. Entretanto, tal estratégia apresenta alguns problemas para análise do caso brasileiro. O primeiro é que, como mostrado nos capítulos anteriores, a cooperação técnica realizada pelo Brasil ocorre de forma muito 
descentralizada, projeto a projeto. Outra questão é que o Brasil não doa dinheiro em espécie na prestação da Cooperação Técnica. De modo que essa abordagem faria menos sentido nesse caso, tendo em vista que esse processo não ocorreria em duas etapas como proposto pelo modelo.

Outra estratégia seria desconsiderar os valores gastos em relação aos projetos, analisando apenas a presença ou não de projetos de cooperação com os países receptores por meio de regressões para variáveis dependentes dicotômicas, como Logit ou Probit, por exemplo. Por fim, outra estratégia, embora não muito comum na literatura, seria considerar a quantidade de projetos iniciados em cada ano em um país, desconsiderando os valores envolvidos nas operações. A partir dessa operacionalização, poderiam ser estimados modelos para dados de contagem, como o modelo de regressão de Poisson, por exemplo. Ambas as estratégias possuem a desvantagem de desconsiderar os valores envolvidos e, assim, a magnitude de cada projeto.

A primeira dentre as abordagens apresentadas acima aparenta fazer mais sentido teórico para o caso em questão na medida em que a aprovação dos projetos de cooperação ocorre de forma concomitante à estipulação dos valores previstos. Ademais, essa estratégia possui a vantagem de considerar os valores gastos para cada receptor, que ainda que não seja uma boa representação da importância desses projetos para a realidade local desses países, traz alguma informação acerca dessa magnitude.

Assim, para analisar quais os determinantes para o recebimento de Cooperação Técnica Brasileira nessa pesquisa, foram estimadas regressões lineares para a variável dependente contínua considerando os valores totais gastos em cada país em cada ano da amostra. Foram utilizadas como variáveis independentes as variáveis da literatura acerca dos determinantes de alocação de ajuda externa descritas acima. Com base no modelo dos interesses do doador foram utilizadas variáveis como volume de importações e exportações brasileiras com o receptor, volume de IED brasileiro, empréstimos subsidiados via BNDES para o modelo dos interesses econômicos. E posição em relação ao Brasil em organizações internacionais como FMI, Banco Mundial, AGNU, OMC, pertencimento à CPLP e orientação ideológica dos governos dos países receptores para os interesses políticos do doador. Com base no modelo das necessidades do receptor, foram utilizadas variáveis como renda per capita, nível de proteção aos direitos humanos e qualidade democrática.

Em relação ao método específico de estimação, não existe consenso na literatura acerca da especificação econométrica apropriada para se estimar os determinantes para 
alocação de ajuda externa. Portanto, foram utilizadas as práticas comumente realizadas na literatura sobre o tema, com foco nas abordagens econométricas mais recentes. Foram realizadas regressões dos modelos mais simples para os mais complexos, para analisar em que medida os resultados encontrados são consistentes a partir de diferentes formas de especificação. Para analisar a questão de pesquisa, foram empregadas as técnicas de estimação para dados em painel ${ }^{136}$, o que oferece uma série de vantagens sobre as análises cross-sectional, na medida em que a análise em painel permite o aumento da precisão da estimativa e o controle da heterogeneidade não observada (HSIAO, 2003; CAMERON; TRIVEDI, 2005).

Dado que alguns dos fatores que poderiam explicar a alocação da cooperação técnica são pré-determinados ou endógenos, e que seus valores atuais dependem de seus valores passados $^{137}$, foram estimados modelos dinâmicos para análise dos dados em questão. A equação básica estimada pode ser sumarizada abaixo. Em que $\boldsymbol{i}$ se refere a um país específico

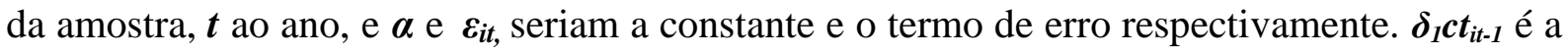
variável dependente defasada, enquanto os demais termos representam as variáveis explicativas.

$$
\begin{aligned}
& c t_{i t}=\alpha+\delta_{1} c t_{i t-1}+\beta_{1} l n \_b n d e s{ }_{i t}+\beta_{2} l n \_i e d_{i t}+\beta_{3} l n \_e x p=\beta_{i t}+\beta_{4} l n \_i m p_{i t}+\beta_{5} f m i_{i t}+\beta_{6} b m_{i t}+ \\
& \beta_{70 m c_{i t}}+\beta_{8} \text { onu }_{i t}+\beta_{9} e s q u e r d a_{i t}+\beta_{10} c p l p_{i t}+\beta_{11} \text { viagem }_{i t}+\beta_{12} l n \_ \text {percapita }_{i t}+\beta_{13} p t s_{i t}+ \\
& \beta_{14} \text { polity }_{i t}+\varepsilon_{i t} \\
& \mathrm{E}\left(\varepsilon_{i t} / \mathbf{X}_{\mathrm{is}}\right)=0 ; \text { for } \forall \mathrm{t} \neq \mathrm{s} \\
& \varepsilon_{i t} \sim \operatorname{IID}\left(0, \sigma^{2}\right)
\end{aligned}
$$

Entretanto, alguns problemas econométricos podem advir desse modelo: i) as variáveis independentes podem ser endógenas, estando correlacionadas ao termo de erro; ii) características invariantes no tempo (efeitos fixos) podem estar correlacionados com as variáveis independentes; iii) a presença da variável dependente defasada pode ocasionar autocorrelação; e iv) o painel possui uma dimensão temporal curta e uma dimensão espacial ampla (N>T) (MILEVA, 2007).

\footnotetext{
${ }^{136}$ Dados de painel (ou dados longitudinais) consistem em observações repetidas na mesma seção transversal de, unidades como, por exemplo, indivíduos, domicílios, empresas ou cidades, ao longo do tempo (WOOLDRIDGE, 2010).

${ }^{137}$ Inclusive, pela forma própria forma como a variável dependente foi operacionalizada.
} 
Para lidar com esses problemas, foram utilizados modelos com base no "Método dos Momentos Generalizados" (GMM, em inglês) ${ }^{138}$ da família Arellano-Bond (HOLTZ-EAKIN; NEWEY; ROSEN, 1988; ARELLANO; BOND, 1991; ARELLANO; BOVER, 1995; BLUNDELL; BOND, 1998). De acordo com Roodman (2009), os estimadores dinâmicos Arellano-Bond são aplicáveis a seis principais situações: i) painéis com $\mathrm{N}$ grande e $\mathrm{T}$ pequeno; ii) nas relações lineares; iii) com a inclusão de variáveis dependentes defasadas; iv) variáveis independentes que não são estritamente exógenas, o que significa que elas podem estar correlacionadas com os valores passados e possivelmente com os valores atuais do erro; v) com efeitos fixos individuais; e iv) com heteroscedasticidade e autocorrelação dentro das unidades.

Esta abordagem controla a endogeneidade, por meio da inclusão dos níveis defasados das variáveis independentes como instrumentos. Segundo Arellano e Bond (1991), os instrumentos necessários para o modelo seriam internos. Em outras palavras, os instrumentos a serem utilizados podem ser baseados nos valores defasados da variável que está sendo instrumentalizada. Assim, o método transforma todas as variáveis, usualmente por primeiras diferenças, e estima as especificações pelo "Método de Momentos Generalizados" (GMM, em inglês). Ao se instrumentalizar a defasagem das variáveis dependente e independentes, atenua-se a questão da precedência temporal dos fenômenos e o problema de variáveis omitidas não observáveis (ROODMAN, 2009).

Os modelos da família Arellano-Bond assumem que: i) o processo pode ser dinâmico, com as realizações atuais da variável dependente influenciadas por variáveis passadas; ii) podem haver efeitos individuais fixos distribuídos arbitrariamente, o que argumentaria contra o uso de regressões cross-sectional; iii) alguns regressores podem ser endógenos; os distúrbios idiossincráticos (aqueles distintos dos efeitos fixos) podem ter padrões específicos de heteroscedasticidade e correlação serial; iv) as perturbações idiossincráticas não são correlacionadas entre os indivíduos; v) alguns regressores podem ser predeterminados, mas não estritamente exógenos; isto é, independente dos distúrbios atuais, alguns regressores podem ser influenciados pelos distúrbios anteriores, em que a variável dependente defasada seria um exemplo; vi) o número de períodos de tempo, $\mathrm{T}$, pode ser pequeno $(\mathrm{N}>\mathrm{T})$ e; vii) os instrumentos disponíveis são "internos", baseados em defasagens das variáveis instrumentadas. No entanto, os estimadores permitem a inclusão de instrumentos externos (ROODMAN, 2009).

\footnotetext{
${ }^{138}$ Generalized Method of Moments, em inglês.
} 
Dentro da família dos modelos Arellano-Bond, foi utilizado o método System GMM (ARELLANO; BOVER, 1995; BLUNDELL; BOND, 1998) ao invés do método Difference GMM (ARELLANO; BOND, 1991) em função de seu melhor desempenho quando aplicado a parâmetros autoregressivos elevados. Ademais, pelo System GMM, pode-se incluir regressores invariantes no tempo, caros a essa pesquisa, que desapareceriam no método Difference $\mathrm{GMM}^{139}$. O nome System GMM é dado em função de a estimação ocorrer por um sistema de duas equações, a original e a transformada. Porém, o modelo System GMM carrega uma premissa adicional de que as variáveis instrumentais das primeiras diferenças não estejam correlacionadas com os efeitos fixos. O que permite a inclusão de mais instrumentos e possibilita uma melhor eficácia na estimação dos resultados. Seguindo as recomendações de Roodman (2009), foram utilizados efeitos fixos temporais em todos os modelos. Pois, o teste de autocorrelação e as estimativas robustas dos erros padrão dos coeficientes assumem que não há correlação entre os indivíduos nos distúrbios idiossincráticos. Assim, o uso de dummies de ano torna esta suposição mais provável.

Para comparação e robustez, também foram rodados modelos via Ordinary Least Squares (OLS) e via Panel Corrected Standard Errors (PCSE). Os modelos foram estimados dos mais simples para os mais complexos. Primeiramente, foram estimados Pooled Regression Models (POLS), que considera todas as informações como unidades crosssectional, ignorando o aspecto temporal dos dados. Em seguida, foram estimados modelos via Panel Corrected Standard Errors (PCSE), usando a opção para estrutura de autocorrelação AR1, assumindo-se a presença de heterocedasticidade (BECK; KATZ, 1995). E, por fim, pelo System GMM de Arellano e Bover (1995) e Blundell e Bond (1998). Em todos os modelos foram utilizados erros padrão robustos e efeitos fixos temporais ${ }^{140}$.

\subsection{Análise dos resultados}

Nessa seção são apresentados os principais resultados da pesquisa. Várias versões da equação básica são analisadas de modo a testar os modelos teóricos dos interesses do doador e das necessidades do receptor para a cooperação técnica prestada pelo Brasil. Os modelos utilizados são POLS, com a variável dependente defasada em t-1; PCSE, com a variável dependente defasa em t-1, assumindo uma estrutura do erro AR1 e presença de

\footnotetext{
${ }^{139}$ As variáveis referentes à CPLP e às coalizões no Banco Mundial

${ }^{140}$ Vale destacar que os modelos completos restringem a amostra para o período para o período 2007-2014, dada à cobertura temporal de algumas variáveis. Período referente ao segundo governo Lula e primeiro governo Dilma Rousseff.
} 
heterocedasticidade; e, por fim, o modelo Arellano-Bond, estimado via System GMM de Blundell-Bond (BB). Todos os modelos incluem dummies de ano e erros padrão robustos.

A tabela 5.5.1 traz os resultados das estimações tomando como variável dependente o $\log$ do valor total referente à Cooperação Técnica brasileira recebida por cada país em cada ano da amostra. Os modelos 1, 2 e 3 representam o modelo dos interesses econômicos do doador, analisando a relação entre os empréstimos realizados via BNDES para expansão de empresas brasileiras nesses países, o volume total de Investimento Estrangeiro Direto (IED) brasileiro, o volume total de exportações e importações e o recebimento de Cooperação Técnica. Os modelos 4, 5 e 6, usando as mesmas técnicas de estimação apresentam os resultados acerca do modelo dos interesses políticos-diplomáticos do doador. Assim, são analisadas como determinantes do recebimento de cooperação técnica as variáveis referentes a questões diplomáticas, como o apoio ao Brasil em organizações internacionais como FMI, Banco Mundial, OMC e AGNU, a orientação política dos governos dos países receptores, pertencimento a coalizões diplomáticas como a CPLP e uma variável referente às viagens presidenciais brasileiras para esses países. Os modelos 7, 8 e 9, também utilizando as mesmas técnicas estatísticas, apresentam os resultados acerca do modelo das necessidades do receptor. É analisada a importância da qualidade da democracia desses países, do nível de proteção aos direitos humanos e do nível de desenvolvimento desses países para o recebimento de Cooperação Técnica. Por fim, os modelos 10, 11 e 12 trazem as equações completas com todas as variáveis utilizadas nos modelos anteriores. 
Tabela 5.5.1. Modelos em Painel Dinâmico para a alocação de Cooperação Técnica Brasileira

\begin{tabular}{|c|c|c|c|c|c|c|c|c|c|c|c|c|}
\hline & $\begin{array}{c}(1) \\
\text { POLS }\end{array}$ & $\begin{array}{c}(2) \\
\text { PCSE }\end{array}$ & $\begin{array}{c}(3) \\
\text { System } \\
\text { GMM }\end{array}$ & $\begin{array}{c}(4) \\
\text { POLS }\end{array}$ & $\begin{array}{c}(5) \\
\text { PCSE }\end{array}$ & $\begin{array}{c}(6) \\
\text { System } \\
\text { GMM }\end{array}$ & $\begin{array}{c}(7) \\
\text { POLS }\end{array}$ & $\begin{array}{c}(8) \\
\text { PCSE }\end{array}$ & $\begin{array}{c}(9) \\
\text { System } \\
\text { GMM }\end{array}$ & $\begin{array}{c}(10) \\
\text { POLS }\end{array}$ & $\begin{array}{c}(11) \\
\text { PCSE }\end{array}$ & $\begin{array}{c}(12) \\
\text { System } \\
\text { GMM }\end{array}$ \\
\hline \multirow[t]{2}{*}{ L.In_ct } & $0.802 * * *$ & $0.625 * * *$ & $0.672 * * *$ & $0.739 * * *$ & $0.486 * * *$ & $0.708 * * *$ & $0.812 * * *$ & $0.673 * * *$ & $0.739 * * *$ & $0.733 * * *$ & $0.575 * * *$ & $0.430 * * *$ \\
\hline & $(0.0233)$ & $(0.0211)$ & $(0.0341)$ & $(0.0274)$ & $(0.0235)$ & $(0.0300)$ & $(0.0228)$ & $(0.0207)$ & $(0.0382)$ & $(0.0373)$ & $(0.0333)$ & $(0.0586)$ \\
\hline \multirow[t]{2}{*}{ ln_bndes } & $0.0868 * * *$ & $0.104 * * *$ & $0.0888 * * *$ & & & & & & & $0.0598 * *$ & $0.0723^{*}$ & $0.0804 * *$ \\
\hline & $(0.0172)$ & $(0.0308)$ & $(0.0257)$ & & & & & & & (0.0209) & $(0.0345)$ & $(0.0261)$ \\
\hline \multirow[t]{2}{*}{ ln_ied } & 0.00746 & 0.0157 & 0.0164 & & & & & & & 0.0894 & $0.117 *$ & 0.135 \\
\hline & $(0.0302)$ & $(0.0393)$ & $(0.0453)$ & & & & & & & $(0.0540)$ & $(0.0593)$ & $(0.0774)$ \\
\hline \multirow[t]{2}{*}{ ln_exp } & $0.0799 * * *$ & $0.138 * * *$ & $0.114 * * *$ & & & & & & & $0.168 * *$ & $0.251 * * *$ & $0.308 * *$ \\
\hline & $(0.0198)$ & $(0.0332)$ & $(0.0301)$ & & & & & & & $(0.0603)$ & $(0.0719)$ & $(0.0941)$ \\
\hline \multirow[t]{2}{*}{ ln_imp } & $-0.0463 * *$ & $-0.0697 * *$ & $-0.0545^{*}$ & & & & & & & -0.0252 & -0.0395 & -0.0325 \\
\hline & $(0.0160)$ & $(0.0237)$ & $(0.0235)$ & & & & & & & $(0.0317)$ & $(0.0436)$ & $(0.0482)$ \\
\hline \multirow[t]{2}{*}{ fmi } & & & & $1.939 * * *$ & $3.158 * * *$ & $2.107 * * *$ & & & & $2.048 * * *$ & $2.949^{*}$ & $3.815 * * *$ \\
\hline & & & & $(0.370)$ & $(0.737)$ & $(0.426)$ & & & & $(0.545)$ & (1.159) & $(0.998)$ \\
\hline \multirow[t]{2}{*}{ bm } & & & & -0.386 & -0.530 & -0.400 & & & & -0.877 & -1.019 & -1.177 \\
\hline & & & & $(0.397)$ & $(0.820)$ & $(0.473)$ & & & & $(0.500)$ & (1.302) & $(0.966)$ \\
\hline \multirow[t]{2}{*}{ omc } & & & & $1.710 * *$ & $3.394 * * *$ & $2.076 * *$ & & & & 0.615 & 0.909 & 1.195 \\
\hline & & & & $(0.631)$ & $(0.704)$ & $(0.685)$ & & & & $(0.872)$ & $(0.995)$ & (1.453) \\
\hline \multirow[t]{2}{*}{ onu } & & & & $2.661 * * *$ & $4.103 * * *$ & 2.736 *** & & & & $4.351 * *$ & $5.972 * * *$ & $7.532 * * *$ \\
\hline & & & & $(0.426)$ & $(0.392)$ & $(0.522)$ & & & & (1.323) & (1.056) & $(2.061)$ \\
\hline \multirow[t]{2}{*}{ esquerda } & & & & 0.218 & $0.430^{*}$ & 0.309 & & & & 0.226 & 0.373 & 0.428 \\
\hline & & & & (0.139) & $(0.167)$ & $(0.169)$ & & & & $(0.220)$ & $(0.250)$ & $(0.337)$ \\
\hline \multirow[t]{2}{*}{ cplp } & & & & $1.941 * *$ & $3.624 * * *$ & $2.164 * * *$ & & & & 1.104 & $1.913 * * *$ & $2.847 *$ \\
\hline & & & & $(0.587)$ & $(0.407)$ & $(0.604)$ & & & & $(0.612)$ & $(0.551)$ & (1.202) \\
\hline \multirow[t]{2}{*}{ viagem } & & & & $0.460 * *$ & $0.427 * *$ & 0.281 & & & & 0.00989 & -0.00533 & -0.0667 \\
\hline & & & & $(0.152)$ & $(0.155)$ & $(0.199)$ & & & & $(0.185)$ & $(0.196)$ & $(0.196)$ \\
\hline
\end{tabular}




\begin{tabular}{|c|c|c|c|c|c|c|c|c|c|c|c|c|}
\hline \multirow[t]{2}{*}{ In_percapita } & & & & & & & $-0.176 * * *$ & $-0.283 * * *$ & $-0.227 * * *$ & $-0.296 * *$ & $-0.438 * * *$ & $-0.531 * *$ \\
\hline & & & & & & & $(0.0474)$ & $(0.0548)$ & $(0.0615)$ & (0.113) & $(0.128)$ & $(0.184)$ \\
\hline \multirow[t]{2}{*}{ pts } & & & & & & & -0.0136 & -0.0304 & -0.00345 & -0.0353 & -0.0695 & -0.0185 \\
\hline & & & & & & & $(0.0651)$ & $(0.0780)$ & $(0.0816)$ & $(0.104)$ & $(0.121)$ & $(0.151)$ \\
\hline \multirow[t]{2}{*}{ polity } & & & & & & & $0.0278 * *$ & $0.0412 * * *$ & $0.0372 * *$ & $0.0544 * *$ & $0.0729 * *$ & $0.0937 * *$ \\
\hline & & & & & & & $(0.00953)$ & $(0.0116)$ & $(0.0127)$ & $(0.0203)$ & $(0.0234)$ & $(0.0340)$ \\
\hline \multirow[t]{2}{*}{ _cons } & 0.0998 & -0.337 & -0.208 & $-2.326 * * *$ & $-3.690 * * *$ & $-2.224 * * *$ & $1.651 * *$ & $2.548 * * *$ & 0 & $-3.413 *$ & $-4.802 * *$ & $-6.496^{*}$ \\
\hline & $(0.314)$ & $(0.445)$ & $(0.427)$ & $(0.386)$ & $(0.370)$ & $(0.462)$ & $(0.544)$ & $(0.628)$ & $(0)$ & $(1.654)$ & $(1.615)$ & $(2.627)$ \\
\hline $\mathrm{N}$ & 2092 & 2092 & 2092 & 2654 & 2654 & 2654 & 2078 & 2078 & 2078 & 1100 & 1100 & 1100 \\
\hline $\mathrm{R}-\mathrm{sq}$ & 0.690 & 0.453 & & 0.695 & 0.463 & & 0.684 & 0.512 & & 0.702 & 0.562 & \\
\hline \multirow[t]{2}{*}{ AB test AR (1) } & & & -7.52 & & & -8.17 & & & -7.03 & & & -6.38 \\
\hline & & & 0.000 & & & 0.000 & & & 0.000 & & & 0.000 \\
\hline \multirow[t]{2}{*}{$\mathrm{AB}$ test $\mathrm{AR}(2)$} & & & 1.26 & & & 1.69 & & & 1.98 & & & 1.55 \\
\hline & & & 0.209 & & & 0.091 & & & 0.048 & & & 0.122 \\
\hline
\end{tabular}

Erros padrão entre parênteses

$* \mathrm{p}<0.05, * * \mathrm{p}<0.01, * * * \mathrm{p}<0.001$ 
Algumas conclusões podem ser tiradas a respeito das informações apresentadas acima. A especificação dinâmica reforça a intuição de que os valores passados da variável dependente tem um peso importante na explicação dos valores atuais da variável, na medida em que os coeficientes da variável dependente defasada se mostram positivos e estatisticamente significativos em todos os modelos. Ademais, os resultados dos testes Arellano Bond para autocorrelação ${ }^{141}$ também indicam que os modelos dinâmicos seriam mais apropriados para análise dos dados em questão.

Em relação aos interesses econômicos do doador, os coeficientes referentes aos empréstimos subsidiados via BNDES, “In_bndes”, se mostram positivos e estatisticamente significativos em todos os modelos estimados. Por outro lado, a variável referente ao IED brasileiro, "In_ied”, não se mostrou estatisticamente significativa na maioria dos modelos ${ }^{142}$. Em relação às variáveis referentes ao comércio com o Brasil, a variável referente às exportações, "In_exp", mostrou com sinais positivos e estatisticamente significativos em todos os modelos. Já a variável referente às importações, "In_imp”, não mostrou significância estatística na maioria dos modelos, com exceção do primeiro modelo, sem a inclusão das outras variáveis, em que apresentou um coeficiente negativo.

Em termos substantivos, esses indícios sustentam a hipótese de que haveria uma relação entre a cooperação financeira e a cooperação técnica, na medida em que haveria uma relação entre recebimento de empréstimos via BNDES e projetos de cooperação técnica dados os demais fatores constantes. Ademais, países que importam mais produtos brasileiros também tendem a receber mais cooperação técnica, ceteris paribus. Analisando a magnitude dos indicadores ${ }^{143}$, para os interesses econômicos, o modelo Blundell-Bond indica que a cada $1 \%$ de aumento de empréstimos realizados via BNDES aumenta em $0,08 \%{ }^{144}$ a CT recebida e $1 \%$ de aumento das exportações resulta em $0,30 \%{ }^{145}$ de aumento de CT.

\footnotetext{
${ }^{141}$ Os testes Arellano Bond para autocorrelação (AB test), que tem como hipótese nula a presença de não autocorrelação, mostram que há presença de processo AR (1) nas primeiras diferenças, mas que não há um processo AR (2). O teste de Wooldridge para autocorrelação também havia indicado para a presença de autocorrelação (xtserial).

${ }_{142}^{14}$ De modo que o valor de beta em cada uma das equações não pode ser distinguido de zero.

${ }^{143}$ Em termos substantivos, por se tratar de uma relação log-log, em que tanto a variável dependente quanto a variável independente são operacionalizadas por meio do logaritmo natural dos valores originais, o impacto estimado dos coeficientes deve ser lido como a mudança em $1 \%$ na estimativa do parâmetro (beta) resulta em uma mudança de $\beta 1 \%$ em relação à variável dependente $(\% \Delta \mathrm{y}=\beta 1 \% \Delta \mathrm{xX})$ (GUJARATI, 2006).

${ }^{144}$ Valor que pode variar entre 0,03 e 0,13 , dado o intervalo de confiança (95\%).

${ }^{145}$ Valor que pode variar entre $0,12 \%$ e $0,49 \%$, dado o intervalo de confiança $(95 \%)$.
} 
Em relação aos interesses políticos do doador ${ }^{146}$, as variáveis referentes ao apoio dos países em organizações internacionais "fmi" e "onu" apresentam sinais positivos e estatisticamente significativos em todos os modelos apresentados. A variável referente à CPLP, "cplp", apresenta coeficientes positivos e estatisticamente significativos em quase todos os modelos apresentados, exceção do modelo 10. Já a variável referente ao apoio ao Brasil no Banco Mundial, “bm”, não apresenta significância estatística em nenhum dos modelos apresentados. A variável referente às viagens presidenciais, "viagem", não se mostrou estatisticamente significativa na maioria dos modelos. A variável referente à orientação política dos governos receptores, "esquerda", também não apresentou significância estatística em nenhum dos modelos analisados.

Em termos substantivos, os resultados das variáveis " $f m i$ ” e "onu” fornecem indícios de que países que demonstram apoio ao Brasil em certas instituições internacionais tenderiam a receber mais cooperação técnica brasileira do que países que não demonstram o mesmo apoio. Especialmente em votações na Assembleia Geral da ONU e no apoio em instituições financeiras internacionais como o FMI. No entanto, a variável referente ao Banco Mundial, “bm”, não apresentou o mesmo resultado. Uma análise mais detalhada acerca de quais são os países em ambas as coalizões parece indicar que embora a coalizão brasileira no Banco Mundial seja mais estável no período considerado, a coalizão brasileira no FMI passa a incorporar mais membros no período considerado, como Cabo Verde, Guiana, Nicarágua e Timor-Leste. Países que são grandes receptores de Cooperação Técnica, o que parece explicar o resultado da variável referente ao apoio no FMI. Os resultados da variável "cplp" evidenciam que os países de língua portuguesa pertencentes a essa organização tendem a receber mais cooperação técnica brasileira. O que seria de se esperar dadas as diretrizes da CTPD, que indicam explicitamente à prioridade dada aos países lusófonos. Ademais, as questões culturais e linguísticas aparentam ter um peso importante nesse processo. Já os coeficientes referentes à variável “omc” parecem indicar que não há relação aparente entre as coalizões formadas no âmbito da aquela organização e o fornecimento de cooperação técnica, o que seria esperado dado o caráter temático dessas coalizões. Por fim, os resultados da variável "esquerda" parecem contrariar o senso comum de que nas últimas décadas o Brasil teria privilegiado países governados por partidos de esquerda na medida em que os dados indicam não haver relação entre as duas variáveis.

\footnotetext{
${ }^{146}$ Nesse caso, por se tratar de uma relação nível-log, em que a variável dependente é operacionalizada por meio do logaritmo natural dos valores originais e as variáveis independentes estarem em nível, o impacto estimado dos coeficientes deve ser lido como 100 vezes a estimativa do parâmetro (beta) \% em relação à variável dependente (GUJARATI, 2006).
} 
Em relação à magnitude do efeito dos interesses políticos, o modelo Blundell-Bond indica que o fato de um país pertencer à coalizão Brasileira no FMI aumentaria o recebimento de $\mathrm{CT}$ em $381 \%^{147}$, o fato de pertencer à CPLP aumentaria em $284 \%{ }^{148}$ e a cada aumento de $1 \%$ de apoio em votações na AGNU resultaria em um aumento de 7,53\% ${ }^{149}$ de CT, ceteris paribus. Substantivamente, esses resultados embasam o modelo dos interesses políticos do doador, na medida em que se verificaria empiricamente que países que apoiam o Brasil no cenário internacional tendem a receber mais cooperação dados outros fatores constantes.

Quanto às necessidades do receptor, a variável referente à qualidade democrática dos países receptores, "polity”, se mostrou estatisticamente significativa e com sinal positivo em todos os modelos. Já a variável referente à proteção de direitos humanos, "pts”, não mostrou significância estatística em nenhum dos modelos analisados. Por fim, a variável referente ao nível de desenvolvimento dos países, "In_percapita”, se mostrou estatisticamente significativa e com sinais negativos em todos os modelos.

Substantivamente, os resultados para a variável "polity” parecem indicar que países com melhores condições democráticas tendem a receber mais cooperação por parte do Brasil. Em relação à variável “In_percapita”, os resultados apontam que, de fato, os países menos desenvolvidos são priorizados na alocação dos gastos em cooperação técnica brasileira. Já a questão da proteção aos direitos humanos parece não influenciar essa alocação. Em relação à magnitude dos efeitos, a cada ponto ganho na escala de democracia do polity IV um país receberia mais $9,4 \%^{150}$ de gastos em cooperação. E a cada aumento em $1 \%$ em sua renda per capita, tenderia a receber menos $0,53 \%^{151}$ de cooperação. Abaixo, são apresentados visualmente os efeitos marginais das estimativas para os modelos 10, 11 e 12:

\footnotetext{
${ }^{147}$ Valor que pode variar entre $186 \%$ e $577 \%$, dado o intervalo de confiança (95\%).

${ }^{148}$ Valor que pode variar entre $49 \%$ e $520 \%$, dado o intervalo de confiança (95\%).

${ }^{149}$ Valor que pode variar entre $3,49 \%$ e $11,57 \%$, dado o intervalo de confiança $(95 \%)$

${ }^{150}$ Valor que pode variar entre $2,7 \%$ e $16 \%$, dado o intervalo de confiança (95\%).

${ }^{151}$ Valor que pode variar entre $-0,89 \%$ e $-0,17 \%$, dado o intervalo de confiança (95\%).
} 
Figura 5.5.1. Efeitos marginais de cada variável sobre o recebimento de Cooperação Técnica Brasileira
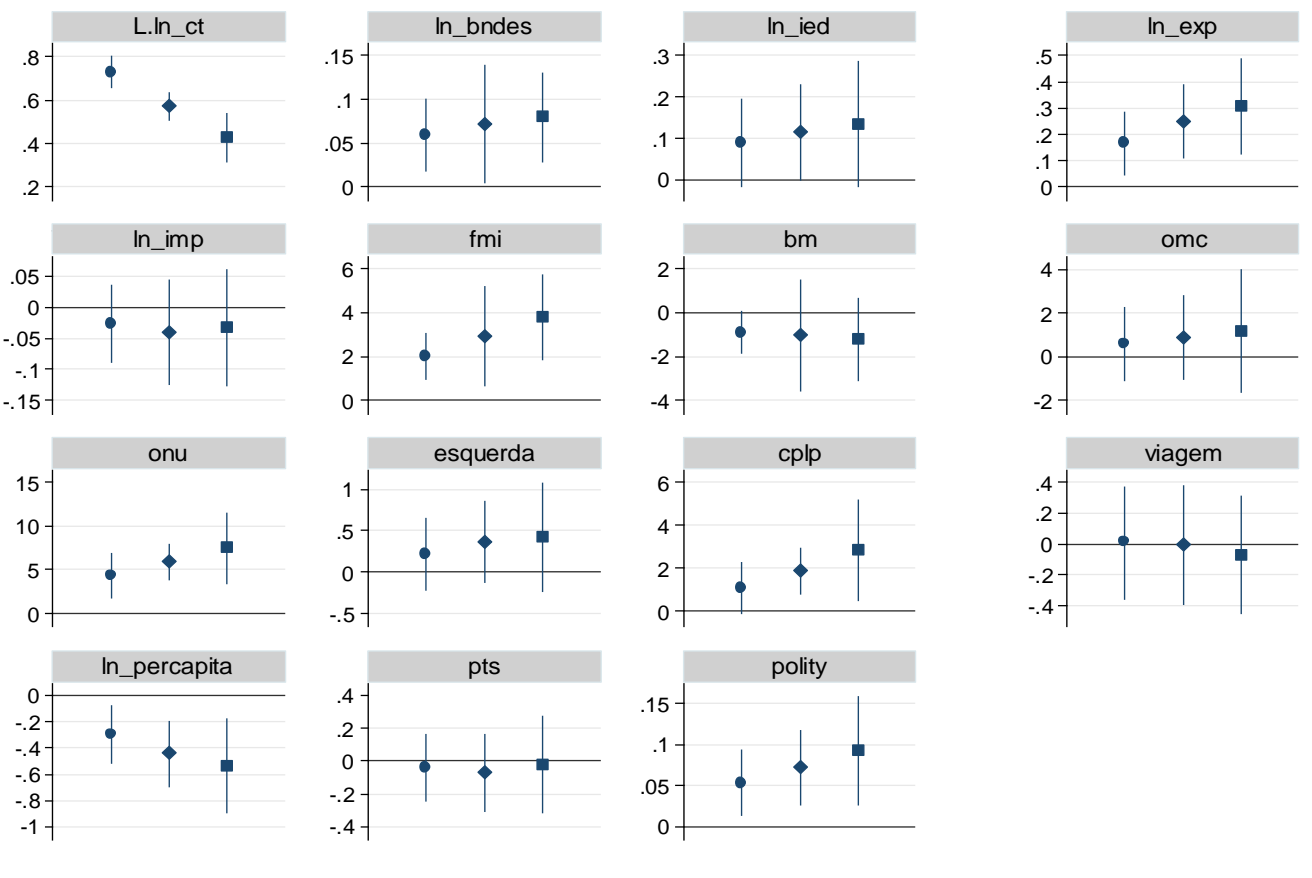

- POLS

PCSE

- GMM

Fonte: elaborada pelo autor

Os resultados indicam para uma relação entre o recebimento de cooperação técnica e o recebimento de empréstimos via BNDES e exportações brasileiras, o que corroboraria o modelo dos interesses econômicos do doador. Também parece haver uma relação entre o apoio político ao Brasil em organizações internacionais como FMI e AGNU e o recebimento de cooperação. Ser membro da CPLP também demonstra ser um determinante para o recebimento de cooperação técnica. O que sustentaria o modelo dos interesses políticos doador. Já em relação ao modelo das necessidades do receptor, os resultados referentes à qualidade democrática e ao nível de desenvolvimento econômico indicam que países mais democráticos receberiam mais cooperação técnica brasileira, assim como os menos desenvolvidos dados os demais fatores constantes. Assim, os resultados fornecem embasamento tanto para o modelo dos interesses do doador, especialmente os políticos, quanto para o modelo das necessidades do receptor, especialmente no às necessidades socioeconômicas. O que não é de todo inesperado, em virtude da narrativa de interesses mútuos da Cooperação Sul-Sul. 
Vale destacar que uma das prioridades estabelecidas para o fornecimento de cooperação técnica seria justamente a "preferência por iniciativas que provoquem um adensamento de relações e abram perspectivas à cooperação política, comercial e econômica entre o Brasil (ABC, 2016)". Além de que, uma das diretrizes seria "justamente priorizar programas de cooperação técnica que favoreçam a intensificação das relações do Brasil com seus parceiros em desenvolvimento, principalmente com os países de interesse prioritário para a política exterior brasileira" (ABC, 2016). Ademais, o site da $\mathrm{ABC}$ atualmente destaca que a cooperação técnica "tem gerado visibilidade para o Brasil no mundo, sobretudo entre países em desenvolvimento, e aberto oportunidades de exportação de bens e serviços brasileiros, criando emprego e renda no Brasil, entre outros ganhos para o País” (ABC, 2018).

Nos anexos ao final do trabalho estão disponíveis as tabelas contendo os resultados dos demais modelos para as outras variáveis dependentes para verificar em que medida os resultados poderiam variar em função dessas especificações. Para o log da proporção recebida por cada país da amostra em relação ao total fornecido no ano "In_ctprop" foi estimada a mesma regressão utilizada para a variável dependente contínua em painel (GMM) ${ }^{152}$. Para a variável dependente dicotômica, “ctdummy”, foi estimada uma regressão logística em painel (Logit) ${ }^{153}$. Para a quantitade de projetos recebido por um país em um determinado ano "ctcont", foi utilizado o modelo de contagem Poisson para painel (Poisson) ${ }^{154}$. Todos os modelos incluem dummies de ano e a variável dependente defasada ao lado direito da equação. Em geral, verifica-se uma constância em relação aos resultados apresentados nessa seção.

\footnotetext{
${ }^{152}$ Verifica-se a constância dos resultados em relação aos modelos estimados com a variável dependente referente ao total de CT recebida por cada país da amostra. As variáveis "In_bndes", "In_exp", "fmi", "onu", "cplp" e "polity" apresentam sinais positivos e estatisticamente significativos e a variável "percapita" apresenta sinal negativo e significativo.

${ }^{153}$ Os resultados para a variável dependente dicotômica também são muito similares aos modelos estimados com a variável dependente contínua. Há uma estabilidade de resultados em relação às variáveis "ln_bndes", "In_exp", "fmi", "опи" e "polity". Com todas as variáveis apresentando coeficientes positivos e significativos. A variável "percapita" apresenta significância estatística e coeficiente negativo. Difere-se apenas a ausência de significância para a variável "cplp".

${ }^{154}$ Novamente, nota-se a constância dos resultados em relação aos modelos estimados com a variável dependente referente ao total de CT recebida por cada país da amostra. As variáveis "ln_exp", "fmi", "onu" e "cplp" apresentam sinais positivos e estatisticamente significativos e a variável "percapita" apresenta sinal negativo e significativo. Difere-se a ausência de significância para as variáveis "ln_bndes" e "polity" no modelo completo.
} 


\section{CONCLUSÃO}

Esse trabalho teve como objetivo contribuir para a literatura de Cooperação Internacional para o Desenvolvimento, a partir da análise cooperação prestada por um país em desenvolvimento nas últimas décadas. O campo da CID vem sendo estudado desde suas origens por diversas áreas do conhecimento. Historicamente, os países considerados desenvolvidos foram os principais atores da CID, consistindo majoritariamente da origem dos recursos e sendo responsáveis por definir e moldar as regras desse regime. Ao longo do tempo, novos atores foram ganhando proeminência nesse campo como organizações internacionais, entidades privadas, organizações não governamentais e países em desenvolvimento.

Dentre esses atores, destacam-se os países em desenvolvimento que buscaram influenciar esse regime, alterando sua posição de meros receptores de cooperação para provedores em bases distintas da cooperação recebida, a chamada Cooperação Sul-Sul para o Desenvolvimento. Embora as origens da CSSD datem de um contexto de processos de descolonização, de busca por uma terceira via em um mundo bipolar, e de busca por alternativas à ordem econômica definida pelos países do Norte, esse objeto voltou a ganhar relevância no século XXI no contexto de emergência econômica dos países em desenvolvimento.

Na primeira década do século XXI, o Brasil, que historicamente foi basicamente um receptor de ajuda internacional, juntamente com outros países emergentes, passou a prover cooperação para o desenvolvimento internacional de forma cada vez mais expressiva. Nesse período, o Brasil estabeleceu um amplo programa de cooperação internacional com países em desenvolvimento e parou de receber recursos internacionais de certas organizações, como o FMI e Banco Mundial por exemplo. Embora o Brasil ainda receba ajuda de outros países e organizações internacionais, atualmente ocupa um papel intermediário nesse regime, apresentando um duplo papel tanto de doador quanto de receptor.

Dentre as modalidades da cooperação prestada pelo Brasil, destaca-se a Cooperação Técnica Brasileira. Embora a CT não seja a modalidade que mobilize a maior quantidade de recursos, possui um caráter de destaque na política externa brasileira. A CT brasileira tem como foco os países do Sul, buscando replicar experiências nacionais bem sucedidas, principalmente por meio da capacitação e transferência de conhecimentos em áreas que o Brasil tem projetos bem sucedidos. Ao fornecer cooperação no exterior, o Brasil busca se 
distanciar dos modelos tradicionais do CAD/OCDE, especificamente no tocante a imposição de condicionalidades na prestação da cooperação.

Essa reemergência do país no campo da CID atraiu a atenção de pesquisadores do mundo todo em relação à cooperação brasileira. Uma ampla e profícua agenda de pesquisa surgiu acerca do objeto em questão. Nos últimos anos, diversos estudos foram publicados acerca da CSSD brasileira. A grande maioria dos trabalhos publicados sobre o assunto se utilizou de metodologias qualitativas, destacando-se a utilização de estudos de caso, geralmente acerca da cooperação com países específicos, de áreas temáticas ou de projetos específicos. Também foram realizados muitos estudos comparados, geralmente comparando países receptores, projetos ou áreas temáticas.

A proposta desse trabalho foi analisar o tema por meio de metodologia quantitativa, trazendo uma nova abordagem em relação ao objeto em questão. Uma das maiores dificuldades na realização da pesquisa fora a obtenção de dados quantitativos para serem analisados por meio de modelos matemáticos. Até recentemente, governo federal não dispunha de registros sistematizados acerca de seus gastos realizados na cooperação para o desenvolvimento internacional. Ademais, inexistia nomenclatura padronizada ou publicações panorâmicas de seus gastos efetivamente realizados nessa área. A situação começou a mudar com a publicação dos relatórios COBRADI, produzidos em parceria com a ABC/MRE a partir de 2010. Ainda assim, os relatórios COBRADI trazem apenas valores agregados, não dispondo de informações discriminadas acerca dos gastos anuais realizados com cada país. Além de que as planilhas utilizadas para elaboração dos relatórios não foram disponibilizadas para o público.

A intenção inicial da pesquisa era analisar todas as modalidades da Cooperação Brasileira para o Desenvolvimento Internacional, de modo a comparar seus padrões em uma abordagem mais ampla sobre o tema. Porém, durante o período de sua realização, 2015 a 2019, só foi possível obter os dados acerca dos gastos referentes à Cooperação Técnica realizada pelo Brasil, após os mesmos terem sido fornecidos pela ABC. Assim, esse estudo se debruçou sobre essa vertente específica da Cooperação Brasileira, levando em consideração as limitações dos dados disponíveis e tomando os devidos cuidados no tratamento dos dados utilizados.

O estudo buscou fazer uma aproximação entre a literatura acerca da Cooperação SulSul para o Desenvolvimento com a literatura voltada para a Cooperação Norte-Sul para o Desenvolvimento realizada historicamente pelos países desenvolvidos, levando em 
consideração as diferenças e especificidades de cada modalidade. Para tanto, a via utilizada para essa aproximação fora a metodologia do estudo na medida em que há uma vasta literatura de cunho quantitativo acerca da Cooperação Norte-Sul para o Desenvolvimento, enquanto ainda são escassos os estudos que tentaram analisar a Cooperação Sul-Sul para o Desenvolvimento a partir desse enfoque.

Uma das questões mais exploradas acerca da ajuda externa tradicional seria acerca dos determinantes de sua alocação. Ao longo dos anos, vários pesquisadores buscaram compreender os padrões de alocação da ajuda pelo mundo. A problemática que guia essa agenda de pesquisa é, por meio da análise desses padrões, compreender os propósitos da ajuda externa, para além da análise de discursos oficiais e entrevistas com policy-makers. A ideia é que seria possível compreender os interesses e motivações por trás da cooperação a partir da análise da alocação de seus fluxos. Nesse sentido, a discussão foi estruturada em torno de dois principais modelos teóricos, o modelo dos interesses do doador e o modelo das necessidades do receptor, em que se esperaria que os fluxos de ajuda estivessem correlacionados com as variáveis referentes a cada modelo.

Dialogando com a literatura internacional acerca dos determinantes para o recebimento de ajuda internacional, esse estudo buscou analisar quais os determinantes para a alocação dos gastos em projetos de CT executados pelo Brasil mundo afora. A partir desses modelos teóricos, foi analisada a relação entre a alocação de CT brasileira e interesses geopolíticos e econômicos do Brasil. Para tanto, foi analisado a relação entre a variável referente aos gastos em CT para cada país do mundo entre os anos de 2000 e 2016 e variáveis econômicas e políticas referentes aos interesses brasileiros no cenário internacional; e variáveis socioeconômicas referentes aos países receptores.

Esses interesses econômicos foram operacionalizados como fluxos de exportações e importações, Investimento Estrangeiro Direito e empréstimos subsidiados. Os interesses político-diplomáticos foram operacionalizados como apoio em instâncias internacionais de destaque, como AGNU, FMI, Banco Mundial e OMC, parcerias internacionais como a CPLP e semelhanças em relação à orientação política dos governos do doador e receptor. Por outro lado, as variáveis referentes às necessidades dos receptores foram operacionalizadas com base em indicadores existentes acerca do nível de desenvolvimento desses países, qualidade democrática e nível de proteção aos direitos humanos.

Indo além da análise descritiva, foram analisados determinantes até então pouco explorados na literatura sobre o tema. A partir de análises em painel, foram estimados 
modelos econométricos no sentido de buscar relações entre as variáveis consideradas. Assim, como principais resultados dessa pesquisa, destacam-se a identificação de interesses econômicos e políticos na alocação da Cooperação Técnica brasileira. Em especial, a relação entre a Cooperação Técnica e a Cooperação Financeira, operacionalizada como os empréstimos subsidiados via BNDES para exportação de bens e serviços brasileiros. A relação entre a Cooperação Técnica e as exportações brasileiras. E em relação aos determinantes políticos, a relação entre a Cooperação Técnica e o apoio político ao Brasil em organizações internacionais como FMI, AGNU e CPLP. Ademais, em relação às necessidades do receptor, a constatação de que a qualidade democrática e o nível de desenvolvimento econômico teriam influência na alocação de projetos de Cooperação Técnica. Se por um lado, esses resultados preliminares se configuram como elementos contrários ao discurso oficial de solidariedade de que a Cooperação Técnica Brasileira seria isenta de interesses materiais. Por outro, parecem corroborar a narrativa mais geral de interesses mútuos da Cooperação Sul-Sul, em que tanto os interesses do doador quanto às necessidades do receptor estariam sendo contemplados.

Entretanto, essa pesquisa tomou cuidado ao utilizar uma linguagem de causalidade acerca das relações entre as variáveis. A causalidade é tema caro nas ciências sociais e como tal, o termo deve ser utilizado com cautela. A proposta desse trabalho foi analisar de forma exploratória essas relações, utilizando dados observacionais com vistas a verificar correlações entre esses indicadores. Dessa forma, apesar do cuidado em utilizar nos modelos apenas variáveis teoricamente embasadas e em se controlar para uma série de variáveis que poderiam influenciar a variável dependente, foi adotado esse tom cauteloso.

Apesar da literatura acerca dos determinantes da ajuda externa tradicional explorar com maior profundidade questões como a endogeneidade entre as variáveis e buscar inferir causalidade entre as variáveis consideradas. Entende-se que tal proposta seja menos viável para o caso brasileiro. Embora a análise dos determinantes políticos e diplomáticos da cooperação faça mais sentido sob essa abordagem, na medida em que se poderia argumentar que a partir do momento em que o Brasil passa a prover mais cooperação no cenário internacional, haveria uma tendência de que países mais próximos ao país sejam mais beneficiados com essas ações. Para os determinantes econômicos, seria mais difícil sustentar tal argumento, na medida em que se verifica que os fluxos de comércio e expansão de empresas brasileiras ocorreram de forma concomitante aos fluxos de cooperação, de modo que a dificuldade de se estabelecer uma direção para a causalidade se torna mais complexa. 
Embora esse estudo tenha tratado a cooperação como variável dependente, a intenção maior foi tentar identificar macrotendências no período considerado. Assim, embora as evidências desse trabalho deem indícios de interesses econômicos e diplomáticos na condução da CT, não fica claro qual o sentido dessa relação. Ademais, acredita-se que inferir causalidade por meio de análise quantitativa a partir de dados observacionais, por mais que se controle para uma série de variáveis, é uma tarefa complexa em termos epistemológicos.

Vale destacar também que os valores referentes à Cooperação Técnica brasileira analisados são baixos, considerando o período analisado. Entretanto, vale lembrar que apenas os valores desembolsados em si não contemplam todo o esforço brasileiro de CID. A mera quantificação dos projetos não capta os aspectos imateriais dessas atividades, em especial, no tocante à transferência e troca de conhecimentos, tecnologias, know-how e experiências. Porém, a mensuração dessas atividades apresenta um retrato, ainda que incompleto, de sua dimensão.

Esse trabalho se apresenta como uma primeira abordagem sobre o tema dentro de uma agenda maior de pesquisa que busca explorar o assunto de forma mais holística. Em uma agenda futura, caso seja possível obter os dados, seria interessante analisar a alocação, de forma desagregada, de outras modalidades de cooperação efetuadas pelo Brasil. De modo a verificar se os padrões observados seriam similares dentre as diferentes vertentes da COBRADI. Partindo para uma metodologia de cunho mais qualitativo, seria importante explorar com maior profundidade os interesses políticos e econômicos envolvidos na CID, analisando, especialmente, os interesses subnacionais e setoriais na alocação dos recursos para projetos de cooperação. Assim, seria fundamental a realização de pesquisas que considerem a atuação dos atores privados na execução dessas políticas de modo a verificar em que medida diferentes projetos de cooperação atenderiam aos interesses de diferentes atores no contexto doméstico.

Ademais, em razão da crise econômica e institucional que o país enfrenta desde 2015 e o consequente corte de gastos nas mais diversas áreas do orçamento da União, em especial no tocante à CID. Tornam-se primordiais estudos que analisem as políticas desenvolvidas nesse campo, em especial, para que se evidenciem quais os objetivos, resultados e interesses envolvidos nessas atividades. Afinal, a formação de um consenso na sociedade prócooperação internacional só será possível na medida em que essas políticas sejam transparentes e bem debatidas. Assim, essa agenda de pesquisa se mostra fundamental para se compreender qual o papel desempenhado pelo país no campo da CID nos últimos anos e qual será sua posição nesse regime nos anos vindouros. 


\section{REFERÊNCIAS BIBLIOGRÁFICAS}

ABARCA AMADOR, E. El nuevo rostro de la cooperación técnica entre países en desarrollo (CTPD) y las nuevas tendencias internacionales. Revista de Ciencias Sociales (Cr), v. IV, n. 94, 2001. Disponível em: 〈http://www.redalyc.org/resumen.oa?id=15309413〉. Acesso em: 28 dez. 2018.

ABC. MANUAL DE GESTÃo DA COOPERAÇÃO TÉCNICA SUL-SUL. Brasília: Agência Brasileira de Cooperação, 2013.

ABC. Diretrizes para o Desenvolvimento da Cooperação Técnica Internacional Multilateral e Bilateral. Brasília: Agência Brasileira de Cooperação, 2014.

ABC. Agência Brasileira de Cooperação. Disponível em: 〈http://www.abc.gov.bro〉. Acesso em: 2 jan. 2016. Acesso em: 10 jan. 2016.

ABC. Agência Brasileira de Cooperação. Histórico. Disponível em: <http://www.abc.gov.br/sobreabc/historico>. Acesso em: 2 jan. 2018.

ABDENUR, A. E.; FONSECA, J. M. E. M. D. The North's Growing Role in South-South Cooperation: keeping the foothold. Third World Quarterly, v. 34, n. 8, p. 1475-1491, 1 set. 2013.

ABDENUR, A. E.; SOUZA NETO, D. M. de. South- South cooperation and democracy in Africa: Brazil's role in Guinea-Bissau. Africa Review, v. 5, n. 2, p. 104-117, 2013.

AFONSO, M. M.; FERNANDES, A. P. Introdução à Cooperação para o

Desenvolvimento. Lisboa: Instituto Marquês de Valle Flôr/Oikos, 2005.

ALESINA, A.; DOLLAR, D. Who Gives Foreign Aid to Whom and Why? Journal of Economic Growth, v. 5, n. 1, p. 33-63, 1 mar. 2000.

ALESINA, A.; WEDER, B. Do Corrupt Governments Receive Less Foreign Aid? American Economic Review, v. 92, n. 4, p. 1126-1137, set. 2002.

ALMEIDA, C. M. de et al. Brazil's Conception of South-South "Structural Cooperation" in Health. R. Eletr. de Com. Inf. Inov. Saúde, v. 4, n. 1, p. 23-32, 2010.

ALMEIDA, E. L. de. ENTRE O DISCURSO SOLIDÁRIO E A AÇÃO PRAGMÁTICA DA COOPERAÇÃO BRASILEIRA EM MOÇAMBIQUE: os casos dos projetos de implantação da fábrica de medicamentos antirretrovirais e o ProSavana. Caderno CRH, v. 29, n. 76, 2016.

ALMEIDA, P. R. de. Uma política externa engajada: a diplomacia do governo Lula. Revista Brasileira de Política Internacional, v. 47, n. 1, p. 162-184, 2004.

AMANOR, K. S. South-South cooperation in Africa: Historical, geopolitical and political economy dimensions of international development. IDS Bulletin, v. 44, n. 4, p. 20-30, 2013.

ANTONINI, B.; HIRST, M. Pasado y presente de la Cooperación Norte-Sul para el desarrollo. Documentos de Trabajo de la Cooperación Sur-Sur, p. 9-72, 2009. 
APOLINÁRIO JÚNIOR, L. Formação de coalizões dentro das instituições financeiras internacionais: o caso do Brasil no FMI e Banco Mundial. 2014. Universidade de São Paulo, 2014. Disponível em: <http://www.teses.usp.br/teses/disponiveis/101/101131/tde07012015-114241/>. Acesso em: 9 jan. 2019.

APOLINÁRIO JÚNIOR, L. Foreign aid and the governance of international financial organizations: the Brazilian-bloc case in the IMF and the World Bank. Brazilian Political Science Review, v. 10, n. 3, 2016.

ARBIX, G.; MARTIN, S. B.; CENTER. Beyond developmentalism and market fundamentalism in Brazil: inclusionary state activism without statism. In: Workshop on "States, Development, and Global Governance". Madison: Global Legal Studies Center and the Center for World Affair. 2010.

ARELLANO, M.; BOND, S. Some tests of specification for panel data: Monte Carlo evidence and an application to employment equations. The review of economic studies, $\mathrm{v}$. 58, n. 2, p. 277-297, 1991.

ARELLANO, M.; BOVER, O. Another look at the instrumental variable estimation of errorcomponents models. Journal of econometrics, v. 68, n. 1, p. 29-51, 1995.

ARMIJO, L. E.; ROBERTS, C. The emerging powers and global governance: why the BRICS matter. In: Handbook of Emerging Economies. New York: Routledge, 2014.

ARTICULAÇÃO SUL. Articulação Sul. Disponível em: <https://articulacaosul.org/home/> . Acesso em: 24 dez. 2018.

AVELHAN, L. L. A presença brasileira na África: um estudo sobre o Programa EmbrapaMoçambique. Revista Perspectivas do Desenvolvimento, v. 2, n. 3, 2013.

AVELHAN, L. L. A Cooperação Sul-Sul Brasileira em Saúde: o Projeto de Fortalecimento da Autoridade Sanitária do Haiti. Revista Brasileira de Políticas Públicas e Internacionais RPPI, v. 3, n. 1, p. 22-49, 31 jul. 2018.

BALBIS, J.; FERNÁNDEZ, R. Por que Manter a Cooperação com a América Latina? Le Monde Diplomatique Brazil, 2011.

BALL, R.; JOHNSON, C. Political, Economic, and Humanitarian Motivations for PL 480

Food Aid: Evidence from Africa. Economic Development and Cultural Change, v. 44, n. 3, p. 515-537, 1 abr. 1996.

BAN, C.; BLYTH, M. The BRICs and the Washington Consensus: An introduction. Review of International Political Economy, v. 20, n. 2, p. 241-255, 1 abr. 2013.

BANCO CENTRAL DO BRASIL. Banco Central do Brasil. Disponível em: <https://www.bcb.gov.br/pt-br>. Acesso em: 4 jan. 2019.

BANCO NACIONAL DE DESENVOLVIMENTO ECONÔMICO E SOCIAL. BNDES - O banco nacional do desenvolvimento econômico e social. Disponível em: <http://www.bndes.gov.br/wps/portal/site/home>. Acesso em: 4 jan. 2019.

BANDYOPADHYAY, S.; VERMANN, E. K. Donor motives for foreign aid. Federal 
Reserve Bank of St. Louis Review, v. 95, n. 4, p. 327-36, 2013.

BARBOSA, P. H. B. O Brasil e a EMBRAPA: o viés instrumental da cooperação técnica horizontal. Instituto Rio Branco, Ministério das Relações Exteriores: Brasília, 2011.

BAUMANN, R.. O Brasil e os demais BRICs: comércio e política. IPEA, 2010.

BEARCE, D. H.; TIRONE, D. C. Foreign Aid Effectiveness and the Strategic Goals of Donor Governments. The Journal of Politics, v. 72, n. 3, p. 837-851, 1 jul. 2010.

BECK, N.; KATZ, J. N. What to do (and not to do) with time-series cross-section data. American political science review, v. 89, n. 3, p. 634-647, 1995.

BEGHIN, N. A Cooperação Brasileira para o Desenvolvimento Internacional na Área de Segurança Alimentar e Nutricional: Avanços e Desafios-Onde estamos e para onde vamos. Brasília: Instituto de Estudos Socioeconômicos (INESC), 2014.

BELLE, D. A. V. Media, Bureaucracies, and Foreign Aid: A Comparative Analysis of the United States, the United Kingdom, Canada, France and Japan. New York: Springer, 2004.

BERMEO, S. B. Foreign aid, foreign policy, and strategic development. Princeton University, 2008.

BERTHÉLEMY, J.; TICHIT, A. Econometric Explanation of Bilateral Donor Aid Allocation Decisions. document présenté lors d'une réunion du projet WIDER sur la viabilité du financement extérieur du développement, août, Helsinki, 2002.

BERTHÉLEMY, J.-C. Bilateral Donors’ Interest vs. Recipients' Development Motives in Aid Allocation: Do All Donors Behave the Same? Review of Development Economics, v. 10, n. 2, p. 179-194, 2006.

BERTHÉLEMY, J.-C.; TICHIT, A. Bilateral donors' aid allocation decisions-a threedimensional panel analysis. International Review of Economics \& Finance, Aid Allocations and Development Financing. v. 13, n. 3, p. 253-274, 1 jan. 2004.

BESHARATI, N.; ESTEVES, P. Os BRICS, a Cooperação Sul-Sul e o Campo da Cooperação para o Desenvolvimento Internacional. Contexto Internacional, v. 37, n. 1, p. 289-330, 2015.

BLUNDELL, R.; BOND, S. Initial conditions and moment restrictions in dynamic panel data models. Journal of econometrics, v. 87, n. 1, p. 115-143, 1998.

BOBIASH, D. South-South Aid: How Developing Countries Help Each Other. [s.1.] Springer, 1992.

BOND, P. Are BRICS “Sub-Imperialists”? Pambazuka News, n. 622, $2013 \mathrm{a}$.

BOND, P. Sub-imperialism as Lubricant of Neoliberalism: South African 'deputy sheriff' duty within brics. Third World Quarterly, v. 34, n. 2, p. 251-270, 1 mar. 2013 b.

BOONE, P. Politics and the effectiveness of foreign aid. European Economic Review, v. 40, 
n. 2, p. 289-329, 1 fev. 1996.

BOSCHINI, A.; OLOFSGÅRD, A. Foreign aid: An instrument for fighting communism? The Journal of Development Studies, v. 43, n. 4, p. 622-648, 1 maio 2007.

BOUTROS-GHALI, B. An Agenda for Development 1995: With Related UN Documents. An agenda for development 1995: with related UN documents., 1995. Disponível em: <https://www.cabdirect.org/cabdirect/abstract/19961802929>. Acesso em: 26 jan. 2019.

BRANDT, W. North-South: a programme for survival: report of the Independent Commission on International Development Issues. 1980.

BRASIL, Constituição da República Federativa do Brasil. Brasília: Senado Federal, 1988.

BRECH, V.; POTRAFKE, N. Donor ideology and types of foreign aid. Journal of Comparative Economics, v. 42, n. 1, p. 61-75, 1 fev. 2014.

BRENER, J. Trinta anos de não-alinhados. Lua Nova: Revista de Cultura e Política, v. 3, n. 3, p. 78-81, mar. 1987.

BRESSER-PEREIRA, L. C. O Brasil e o novo desenvolvimentismo. Interesse nacional, p. 76-85, 2011.

BREUSCH, T. S.; PAGAN, A. R. The Lagrange multiplier test and its applications to model specification in econometrics. The Review of Economic Studies, v. 47, n. 1, p. 239-253, 1980.

BROWNE, S. The rise and fall of development aid. [s.1.] UNU World Institute for Development Economics Research, 1997.

BRUNDTLAND, G. et al. Our common future - Brundtland report. 1987.

BRÜTSCH, C.; PAPA, M. Deconstructing the BRICS: Bargaining Coalition, Imagined Community, or Geopolitical Fad? The Chinese Journal of International Politics, v. 6, n. 3, p. 299-327, 1 set. 2013.

BUREAU OF LABOR STATISTICS. CPI Home : U.S. Bureau of Labor Statistics.

Disponível em: <https://www.bls.gov/cpi/>. Acesso em: 31 jan. 2018.

BURGES, S. W. Brazil as a bridge between old and new powers? International Affairs, v. 89, n. 3, p. 577-594, 2013.

BURNSIDE, C.; DOLLAR, D. Aid, Policies, and Growth. American Economic Review, v. 90 , n. 4, p. 847-868, set. 2000.

CAIXETA, M. B. Cooperação sul-sul como nova tendência da cooperação internacional : o discurso e a prática da cooperação técnica do Brasil com São Tomé e Príncipe para o combate à tuberculose. 2014. Universidade de Brasília, 2014. Disponível em:

<http://repositorio.unb.br/handle/10482/15924>. Acesso em: 18 jan. 2019.

CÂMARA DOS DEPUTADOS. Diário da Câmara dos Deputados - ANO LXI - No 064 QUINTA-FEIRA, 13 DE ABRIL DE 2006 - BRASÍLIA-DF, 2006a. 
CÂMARA DOS DEPUTADOS. Diário da Câmara dos Deputados - ANO LXIV - No 163 SÁBADO, 19 DE SETEMBRO DE 2009 - BRASÍLIA-DF, 2009.

CÂMARA DOS DEPUTADOS. Diário da Câmara dos Deputados - ANO LXVI - No 187 TERÇA-FEIRA, 25 DE OUTUBRO DE 2011, 2011.

CÂMARA DOS DEPUTADOS. Diário da Câmara dos Deputados - ANO LXVIII - No 144 - SEXTA-FEIRA, 23 DE AGOSTO DE 2013, 2013.

CÂMARA DOS DEPUTADOS. Diário da Câmara dos Deputados - ANO LXX - Nº 066 QUARTA-FEIRA - 29 DE ABRIL de 2015, 2015.

CÂMARA DOS DEPUTADOS. LEI Nº 11.346, DE 15 DE SETEMBRO DE 2006 -

Publicação Original - Portal Câmara dos Deputados. Disponível em:

<http://www2.camara.leg.br/legin/fed/lei/2006/lei-11346-15-setembro-2006-545529publicacaooriginal-58455-pl.html>. Acesso em: 27 jan. 2018.

CÂMARA DOS DEPUTADOS. PL 4128/2004. Disponível em:

<https://www.camara.leg.br/proposicoesWeb/fichadetramitacao?idProposicao=298929>.

Acesso em: 25 nov. 2018.

CÂMARA DOS DEPUTADOS. Seminário Política Externa: Desafios em um Mundo em Transição. Paineis: O Brasil e a Cooperação Internacional para o Desenvolvimento e Ascensão da China: Desafios para o Brasil. Comissão de Relações Exteriores e de Defesa Nacional., 2012. Disponível em: << http://www2.camara.leg.br/atividadelegislativa/comissoes/comissoespermanentes/credn/documentos/notas-taquigraficas/notasde-2012/seminario-a-politicaexterna-brasileira-no-atual-contexto-geopolitico-internacional2>.

CAMERON, A. C.; TRIVEDI, P. K. Microeconometrics: methods and applications. Cambridge: Cambridge University Press, 2005.

CANAVIRE, G. et al. Assessing the Allocation of Aid: Developmental Concerns and the Self-Interest of Donors. The Indian Economic Journal, v. 54, n. 1, p. 26-51, 1 abr. 2006.

CARMODY, P. The new scramble for Africa. [s.1.] Polity Press, 2011.

CARR, E. H. The Twenty Years' Crisis 1919-1939: An Introduction to the Study of International Relations. London: Macmillan, 1946.

CARRILLO ROA, A.; BAPTISTA E SILVA, F. R. A Fiocruz como ator da política externa brasileira no contexto da Comunidade dos Países de Língua Portuguesa: uma história revelada. História, Ciências, Saúde - Manguinhos, v. 22, n. 1, 2015. Disponível em: <http://www.redalyc.org/resumen.oa?id=386138083009>. Acesso em: 18 jan. 2019.

CASON, J. W.; POWER, T. J. Presidentialization, Pluralization, and the Rollback of Itamaraty: Explaining Change in Brazilian Foreign Policy Making in the Cardoso-Lula Era. International Political Science Review / Revue internationale de science politique, v. 30, n. 2, p. 117-140, 2009.

CASTRO, J. L. de; VILAR, R. L. A. de; GERMANO, R. M. Educação, ética e solidariedade na cooperação internacional. História, Ciências, Saúde-Manguinhos, v. 22, n. 1, 2015. 
CEPAL. Comissão Econômica para a América Latina e o Caribe. Disponível em: <https://www.cepal.org/pt-br>. Acesso em: 28 jan. 2019.

CERVO, A. L. Socializando o desenvolvimento: uma história da cooperação técnica internacional do Brasil. Revista Brasileira de Política Internacional, v. 37, n. 1, p. 37-63, 1994.

CERVO, A. L. A ação internacional do Brasil em um mundo em transformação: conceitos, objetivos e resultados (1990-2005). Relações internacionais do Brasil: temas e agendas, v. $1,2006$.

CERVO, A. L.; BUENO, C. História da política exterior do Brasil. 2002.

CERVO, A. L.; LESSA, A. C. The fall: the international insertion of Brazil (2011-2014).

Revista Brasileira de Política Internacional, v. 57, n. 2, p. 133-151, 2014.

CHANDY, L.; KHARAS, H. Why can't we all just get along? The practical limits to international development cooperation. Journal of International Development, v. 23, n. 5, p. 739-751, 2011.

CHATURVEDI, S. Characteristics and potential of triangular development cooperation (tdc): emerging trends, impact and future prospects. New York: United Nations Department of Economic and Social Affairs, 2012a. Disponível em: <http://www. un. org/en/ecosoc/newfunct/pdf/tdc_study. pdf >.

CHATURVEDI, S. India's development partnership: key policy shifts and institutional evolution. Cambridge Review of International Affairs, v. 25, n. 4, p. 557-577, 1 dez. 2012b.

CHEDIEK, J. O papel do Brasil na Cooperação Sul-Sul: um estudo analítico e histórico. In: ALMINO, J.; LIMA, S. E. M. (Org.). 30 ANOS DA ABC VISÕES DA COOPERAÇÃ̃O TÉCNICA INTERNACIONAL BRASILEIRA. Brasília: FUNAG, 2017. 30p. 41-74.

CHENERY, H. et al. Redistribution with Growth: Policies to Improve Income Distribution in Developing Countries in the Context of Economic Growth. World Bank and the Institute of Development Studies, University of Sussex. London: Oxford University Press, 1974.

CHENG, H. F. et al. A future global economy to be built by BRICs. Global Finance Journal, Global Finance Conference 2006. v. 18, n. 2, p. 143-156, 1 jan. 2007.

CHHOTRAY, V.; HULME, D. Contrasting visions for aid and governance in the 21st century: The white house millennium challenge account and DFID's drivers of change. World Development, v. 37, n. 1, p. 36-49, 2009.

CHIN, G.; QUADIR, F. Introduction: rising states, rising donors and the global aid regime. Cambridge Review of International Affairs, v. 25, n. 4, p. 493-506, 1 dez. 2012.

CHONG, A.; GRADSTEIN, M. What determines foreign aid? The donors' perspective. Journal of Development Economics, v. 87, n. 1, p. 1-13, 1 ago. 2008.

CLAESSENS, S.; KOSE, M. A.; TERRONES, M. E. What Happens during Recessions, 
Crunches and Busts? Economic Policy, v. 24, n. 60, p. 653-700, 1 out. 2009.

COMISSÃO ECONÔMICA PARA A AMÉRICA LATINA E O CARIBE. Comitê de

Cooperação Sul-Sul. Disponível em: <https://www.cepal.org/pt-br/subsidiary-bodies/comitecooperacao-sul-sul>. Acesso em: 21 jan. 2019.

COMUNIDADE DOS PAÍSES DE LÍNGUA PORTUGUESA. CPLP - Comunidade dos Países de Língua Portuguesa. Disponível em: 〈https://www.cplp.org/〉. Acesso em: 28 jan. 2019.

CONSTANTINE, J.; SHANKLAND, A. From Policy Transfer to Mutual Learning?: Political Recognition, Power and Process in the Emerging Landscape of International Development Cooperation. Novos Estudos, v. 36, n. 107, p. 99-122, 2017.

CORNETET, J. M. C. A POLÍTICA EXTERNA DE DILMA ROUSSEFF: CONTENÇÃO NA CONTINUIDADE. Conjuntura Austral, v. 5, n. 24, p. 111-150, 2 jul. 2014.

CORNIA, G.; JOLLY, R.; STEWART, F. Adjustment with a human face, Vol. I: protecting the vulnerable and promoting growth. Oxford, England: Clarendon Press, 1987.

CORRÊA, M. L. Prática Comentada da Cooperação Internacional: entre a hegemonia e a busca de autonomia. Brasília: Edição do autor, 2010.

DAUVERGNE, P.; FARIAS, D. B. The rise of Brazil as a global development power. Third World Quarterly, v. 33, n. 5, p. 903-917, 2012.

DE MESQUITA, B. B.; SMITH, A. Foreign Aid and Policy Concessions. Journal of Conflict Resolution, v. 51, n. 2, p. 251-284, 1 abr. 2007.

DINIZ, S. Interações entre os poderes executivo e legislativo no processo decisório: avaliando sucesso e fracasso presidencial. Dados-Revista de Ciências Sociais, v. 48, n. 2, 2005.

DINIZ, S.; RIBEIRO, C. O. The role of the Brazilian Congress in foreign policy: an empirical contribution to the debate. Brazilian Political Science Review (Online), v. 3, n. SE, 2008.

DOLLAR, D.; KRAAY, A. Growth is Good for the Poor. Journal of economic growth, v. 7, n. 3, p. 195-225, 2002.

DOLLAR, D.; LEVIN, V. The Increasing Selectivity of Foreign Aid, 1984-2003. World Development, v. 34, p. 12, 2006.

DOLLAR, D.; PRITCHETT, L. Assessing aid: What works, what doesn't, and why. [s.1.] World Bank Publications, 1998.

DREHER, A.; FUCHS, A. Rogue Aid? The Determinants of China's Aid Allocation.

Rochester, NY: Social Science Research Network, 6 set. 2011a. . Disponível em:

<https://papers.ssrn.com/abstract=1926471>. Acesso em: 29 dez. 2018.

DREHER, A.; FUCHS, A. Does Terror Increase Aid? Public Choice, v. 149, n. 3, p. 337, 11 out. 2011b.

DREHER, A.; NUNNENKAMP, P.; SCHMALJOHANN, M. The Allocation of German Aid: 
Self-Interest and Government Ideology. Economics \& Politics, v. 27, n. 1, p. 160-184, 2015.

DREHER, A.; NUNNENKAMP, P.; THIELE, R. Does US Aid Buy UN General Assembly Votes? A Disaggregated Analysis. Public Choice, v. 136, n. 1, p. 139-164, 1 jul. 2008.

DREHER, A.; NUNNENKAMP, P.; THIELE, R. Are 'New' Donors Different? Comparing the Allocation of Bilateral Aid Between nonDAC and DAC Donor Countries. World Development, Expanding Our Understanding of Aid with a New Generation in Development Finance Information. v. 39, n. 11, p. 1950-1968, 1 nov. 2011.

DREHER, A.; STURM, J.-E.; VREELAND, J. R. Development aid and international politics: Does membership on the UN Security Council influence World Bank decisions? Journal of Development Economics, v. 88, n. 1, p. 1-18, 1 jan. 2009a.

DREHER, A.; STURM, J.-E.; VREELAND, J. R. Global horse trading: IMF loans for votes in the United Nations Security Council. European Economic Review, v. 53, n. 7, p. 742757, 1 out. 2009 b.

DRURY, A. C.; OLSON, R. S.; VAN BELLE, D. A. The politics of humanitarian aid: US foreign disaster assistance, 1964-1995. The Journal of Politics, v. 67, n. 2, p. 454-473, 2005 .

EASTERLY, W. Can Foreign Aid Buy Growth? Journal of Economic Perspectives, v. 17, n. 3, p. 23-48, set. 2003.

EASTERLY, W. The White Man's Burden. The Lancet, v. 367, n. 9528, p. 2060, 24 jun. 2006.

ESTEVES, P.; ASSUNÇÃO, M. South-South cooperation and the international development battlefield: between the oecd and the UN. Third World Quarterly, v. 35, n. 10, p. 17751790, 26 nov. 2014.

ESTEVES, P.; FONSECA, J. M.; GOMES, G. Z. Is There a Brazilian Solution for Every African Problem? Brazilian Health Cooperation in Angola (2006-2015). Carta

Internacional, v. 11, n. 2, p. 152-176, 31 ago. 2016.

FARANI, M. Agencia Brasileira de Cooperação (ABC) e a Cooperação Técnica do Brasil a Países em Desenvolvimento In: ELIAS A. R. (Org.) Atuação Governamental e Politicas Internacionais de Previdência Social. Brasília: MPS, 2009. Disponível em: <<http://www.mpas.gov.br/arquivos/office/3_100202-164639-597.pdf>.

FARIA, C. A. P. de. O Itamaraty e a Política Externa Brasileira: Do Insulamento à Busca de Coordenação dos Atores Governamentais e de Cooperação com os Agentes Societários.

Contexto internacional, v. 34, n. 1, 2012.

FARIA, C. A. P. de; PARADIS, C. G. Humanism and solidarity in Brazilian foreign policy under Lula (2003-2010): theory and practice. Brazilian Political Science Review, v. 7, n. 2, p. 8-36, 2013.

FEDATTO, M. da S. Epidemia da AIDS e a Sociedade Moçambicana de Medicamentos: análise da cooperação brasileira. Ciência \& Saúde Coletiva, v. 22, p. 2295-2304, 2017. 
FELIU, P.; AMORIM, C. Congresso Nacional e MERCOSUL: o caso da Aprovação da Entrada da Venezuela. Meridiano, v. 47, p. 11-17, 2009.

FELIU, P.; MIRANDA, R. Congresso Nacional e Política Externa. O caso do envio de tropas ao Haiti: Argentina, Brasil e Chile. Revista Política Hoje, v. 20, n. 1, 2011.

FERRARI, D. A. O Congresso Nacional e a apreciação de tratados internacionais no contexto do Presidencialismo de Coalizão. In: O Congresso e o presidencialismo de coalizão. Rio de Janeiro: Fundação Konrad Adenauer, 2011.

FERREIRA, S. S. de; MIGON, E. X. F. G. Technical cooperation in Security \& Defense: Brazil's presence in Africa. Revista Brasileira de Estudos Africanos/Brazilian journal of African studies, v. 1, n. 2, p. 89-105, 2016.

FIGUEIRA, A. C. R. Processo decisório em política externa no Brasil. 2009. Universidade de São Paulo, 2009. Disponível em: <http://www.teses.usp.br/teses/disponiveis/8/8131/tde01122009-122258/>. Acesso em: 30 jan. 2019.

FINGERMANN, N. Será o fim dos projetos de cooperação Sul-Sul do Brasil? Observatório Brasil e o Sul, 2016. Disponível em:

<http://www.obs.org.br/cooperacao/1114-sera-o-fim-dos-projetos-de-cooperacao-sul-sul-dobrasil>. Acesso em: $31 \mathrm{dez} .2018$.

FINGERMANN, N. N. Os mitos por trás do ProSAVANA. AgroANALYSIS, v. 33, n. 08, p. 21-22, 2013.

FINGERMANN, N. N. A cooperação trilateral brasileira em Moçambique: Um estudo de caso comparado: o ProALIMENTOS e o ProSAVANA. 2014.

FINNEMORE, M. Redefining development at the World Bank. International development and the social sciences: Essays on the history and politics of knowledge, p. 203-227, 1997.

FLECK, R. K.; KILBY, C. How Do Political Changes Influence US Bilateral Aid Allocations? Evidence from Panel Data. Review of Development Economics, v. 10, n. 2, p. 210-223, 2006a.

FLECK, R. K.; KILBY, C. World Bank Independence: A Model and Statistical Analysis of US Influence. Review of Development Economics, v. 10, n. 2, p. 224-240, 2006 b.

FLECK, R. K.; KILBY, C. Changing aid regimes? U.S. foreign aid from the Cold War to the War on Terror. Journal of Development Economics, v. 91, n. 2, p. 185-197, 1 mar. 2010.

FONTAINE, D. de la; SEIFERT, J. The role of South-South cooperation in present Brazilian foreign policy: actors, interests and functions. Stockholm: Institute of Latin American Studies, 2010.

FRANÇA, C. L. de; SANCHEZ BADIN, M. R. A inserção internacional do Poder Executivo nacional brasileiro. Análises e Propostas, Friedrich Ebert Stiftung, n. 40, 2010.

FRANK, A. G. Latin America and Underdevelopment. New York: NYU Press, 1970. 
FREY, B. S.; SCHNEIDER, F. Competing models of international lending activity. Journal of Development Economics, v. 20, n. 2, p. 225-245, 1 mar. 1986.

FUCHS, A.; DREHER, A.; NUNNENKAMP, P. Determinants of Donor Generosity: A Survey of the Aid Budget Literature. World Development, v. 56, p. 172-199, 1 abr. 2014.

FUCHS, A.; KLANN, N.-H. Emergency Aid 2.0. Beiträge zur Jahrestagung des Vereins für Socialpolitik, 2013.

FUCHS, A.; VADLAMANNATI, K. C. The Needy Donor: An Empirical Analysis of India's Aid Motives. World Development, v. 44, p. 110-128, 1 abr. 2013.

FÜHRER, H. The story of official development assistance. [s.1.] Organisation for Economic Co-operation and Development, 1996.

FULQUET, G.; PELFINI, A. Brazil as a new international cooperation actor in sub-Saharan Africa: Biofuels at the crossroads between sustainable development and natural resource exploitation. Energy Research \& Social Science, Special Issue on Renewable Energy in Sub-Saharan Africa. v. 5, p. 120-129, 1 jan. 2015.

FUMAGALLI, M. The flow of Financial Resources to Countries in Course of Economic Development 1956-1959. 1963.

GANG, I. N.; LEHMAN, J. A. New directions or not: USAID in Latin America. World Development, v. 18, n. 5, p. 723-732, 1 maio 1990.

GARCIA, A.; KATO, K. Políticas públicas e interesses privados: uma análise a partir do Corredor de Nacala em Moçambique. Caderno CRH, v. 29, n. 76, 2016.

GIBNEY, M. et al. The Political Terror Scale 1976-2017. Date Retrieved, from the Political Terror Scale website: ht-tp://www.politicalterrorscale.org.

GILPIN, R. A economia política das relações internacionais. UnB, 2002.

GOLDSTEIN, M. P.; MOSS, T. J. Compassionate conservatives or conservative compassionates? US political parties and bilateral foreign assistance to Africa. Journal of Development Studies, v. 41, n. 7, p. 1288-1302, 2005.

GONÇALVES, F. C. N. I. Cooperação Sul-Sul e Política Externa: um estudo sobre a participação de atores sociais. 2011. Pontifícia Universidade Católica do Rio de Janeiro (PUC-Rio), Rio de Janeiro, 2011.

GORE, C. The New Development Cooperation Landscape: Actors, Approaches, Architecture. Journal of International Development, v. 25, n. 6, p. 769-786, 2013.

GRANT, J. R. State of the world children. UNICEF, 1990. .

GREENE, Z. D.; LICHT, A. A. Domestic Politics and Changes in Foreign Aid Allocation: The Role of Party Preferences. Political Research Quarterly, v. 71, n. 2, p. 284-301, 1 jun. 2018. 
GREENHILL, R.; PRIZZON, A. Who foots the bill after 2015? What new trends in development finance mean for the post-MDGs. London: Overseas Development Institute (Working Paper 360), 2012.

GRIFFITH-JONES, S. A Brics Development Bank: A Dream Coming True? UNCTAD Discussion Papers. [s.1.] United Nations Conference on Trade and Development, 2014. . Disponível em: <https://ideas.repec.org/p/unc/dispap/215.html>. Acesso em: 28 dez. 2018.

GRIGGS, D. et al. Policy: Sustainable development goals for people and planet. Nature, v. 495, n. 7441, p. 305, 2013.

GRINDLE, M. S. Good enough governance: poverty reduction and reform in developing countries. Governance, v. 17, n. 4, p. 525-548, 2004.

GRINDLE, M. S. Good enough governance revisited. Development policy review, v. 25, n. 5, p. 533-574, 2007.

GU, J. et al. Introduction: International Development, South-South Cooperation and the Rising Powers. In: GU, J.; SHANKLAND, A.; CHENOY, A. (Ed.). The BRICS in International Development. International Political Economy Series. London: Palgrave Macmillan UK, 2016. p. 1-24.

GUJARATI, D. N. Econometria Basica. [s.1.] Elsevier Brasil, 2006.

HAAN, A. de. How the Aid Industry Works: An Introduction to International Development. [s.1.] Kumarian Press, 2009.

HARDT, M. S.; MOURON, F.; APOLINÁRIO JÚNIOR, L. Rising Donors in a Transitional World: Challenges and Opportunities for Brazilian Technical Cooperation. Brazil: Geopolitical Challenges in a Multipolar World, p. 55, 2017.

HARMER, A.; COTTERRELL, L.; LONDON OVERSEAS DEVELOPMENT INSTITUTE. Diversity in donorship: The changing landscape of official humanitarian aid. [s.l.] Humanitarian Policy Group, Overseas Development Institute, 2005.

HAUSMAN, J. A. Specification tests in econometrics. Econometrica: Journal of the econometric society, p. 1251-1271, 1978.

HAYTER, T.; WATSON, C. Aid: Rhetoric and Reality. [s.l.] Pluto Press, 1985.

HICKMAN, J. Cue Taking and the Distribution of Japanese ODA among African Countries. African Development Review, v. 5, n. 1, p. 62-69, 1993.

HIRST, M. Brazil's renewed responsibilities in cooperation for development and international security. Center on International Cooperation, 2011.

HIRST, M.; DE LIMA, R. S.; PINHEIRO, L. A política externa brasileira em tempos de novos horizontes e desafios. Revista Nueva Sociedad, p. 20, 2010.

HJERTHOLM, P.; WHITE, H. Aid in Historical Perspective. In: TARP, F. (Ed.). Foreign Aid and Development. London: Routledge, 2000a. p. 80-104. 
HJERTHOLM, P.; WHITE, H. Survey of Foreign Aid: History, Trends and Allocation. Discussion Papers. Department of Economics. University of Copenhagen. 2000b.

HOLTZ-EAKIN, D.; NEWEY, W.; ROSEN, H. S. Estimating vector autoregressions with panel data. Econometrica: Journal of the Econometric Society, p. 1371-1395, 1988.

HSIAO, C. Analysis of panel data. Cambridge: Cambridge University Press, 2003.

HULME, D. The Millennium Development Goals (MDGs): a short history of the world's biggest promise. Brooks World Poverty Institute, 2009.

HURRELL, A. Hegemony, Liberalism and Global Order: What Space for Would-Be Great Powers? International Affairs, v. 82, n. 1, p. 1-19, 2006.

HURRELL, A. Os BRICS e a ordem global. In: Rio de Janeiro: Editora FGV, 2009. p. 43-73.

HURRELL, A. Brazil and the New Global Order. Current History, v. 109, n. 725, p. 60-66, 2010.

HYNES, W.; SCOTT, S. The Evolution of Official Development Assistance. OECD Development Co-operation Working Papers, 2013. Disponível em: <https://www.oecdilibrary.org/content/paper/5k3v1dv3f024-en>. Acesso em: $31 \mathrm{dez} .2018$.

IKENBERRY, G. J.; WRIGHT, T. Rising powers and global institutions. Washington, DC, The Century Foundation, v. 10, 2008.

IKENBERRY, G. J. The Rise of China and the Future of the West - Can the Liberal System Survive. Foreign Affairs, v. 87, p. 23, 2008.

INOUE, C. Y. A.; VAZ, A. C. Brazil as 'Southern donor': beyond hierarchy and national interests in development cooperation? Cambridge Review of International Affairs, v. 25, n. 4, p. 507-534, 2012.

INTERNATIONAL MONETARY FUND. IMF -- International Monetary Fund Home Page. Disponível em: <https://www.imf.org/external/index.htm>. Acesso em: 4 jan. 2019.

IPEA/ABC. Cooperação Brasileira para o Desenvolvimento Internacional (2005-2009). Brasília: Instituto de Pesquisa Econômica Aplicada / Agência Brasileira de Cooperação, 2010.

IPEA/ABC. Cooperação Brasileira para o Desenvolvimento Internacional (2010).

Brasília: Instituto de Pesquisa Econômica Aplicada / Agência Brasileira de Cooperação, 2013.

IPEA/ABC. Cooperação Brasileira para o Desenvolvimento Internacional: 2011-2013.

Brasília: Instituto de Pesquisa Econômica Aplicada / Agência Brasileira de Cooperação, 2016.

IPEA/ABC. Cooperação Brasileira para o Desenvolvimento Internacional: 2014-2016.

Brasília: Instituto de Pesquisa Econômica Aplicada / Agência Brasileira de Cooperação, 2018.

IZUEL, E. B. Multilateralismo: Adaptación a un Mundo Con Potencias Emergentes. Revista Española de Derecho Internacional, v. 62, n. 2, p. 21-50, 2010.

JULES, T. D. How different disciplines have approached South-South cooperation and 
transfer. Society for International Education Journal, v. 5, n. 1, 2008.

KAJA, A.; WERKER, E. Corporate Governance at the World Bank and the Dilemma of Global Governance. The World Bank Economic Review, v. 24, n. 2, p. 171-198, 1 jan. 2010.

KATADA, S. N. Two aid hegemons: Japanese-US interaction and aid allocation to Latin America and the Caribbean. World Development, v. 25, n. 6, p. 931-945, 1 jun. 1997.

KATES, R. W.; PARRIS, T. M.; LEISEROWITZ, A. A. What is sustainable development? Goals, indicators, values, and practice. Environment (Washington DC), v. 47, n. 3, p. 8-21, 2005.

KAUL, I. Public Goods: Taking the Concept to the 21st Century. The Market of the Public Domain, p. 255-273, 2001.

KAUL, I.; FAUST, M. Global public goods and health: taking the agenda forward. Bulletin of the World Health Organization, v. 79, p. 869-874, 2001.

KEOHANE, R. International Institutions and State Power: Essays in International Relations Theory. Boulder: Westview, 1989.

KEOHANE, R. O.; NYE (JR.), J. S.; HOFFMANN, S. After the Cold War: International Institutions and State Strategies in Europe, 1989-1991. Cambridge: Harvard University Press, 1993.

KHARAS, H.; ROGERSON, A. Don't TOSSD the baby out with the bathwater: The need for a new way to measure development cooperation, not just another (bad) acronym. Brookings, 2018. Disponível em: <https://www.brookings.edu/blog/futuredevelopment/2016/04/15/dont-tossd-the-baby-out-with-the-bathwater-the-need-for-a-newway-to-measure-development-cooperation-not-just-another-bad-acronym/>. Acesso em: 24 jan. 2019.

KILBY, C. Donor Influence in Multilateral Development Banks: The Case of the Asian Development Bank. The Review of International Organizations, v. 1, n. 2, p. 173-195, 1 jun. 2006.

KILBY, C.; DREHER, A. The impact of aid on growth revisited: Do donor motives matter? Economics Letters, v. 107, n. 3, p. 338-340, 1 jun. 2010.

KILLEN, B.; ROGERSON, A. Global governance for international development: who's in charge. Development Brief, Consultation Draft 2, 2010.

KIM, E. M.; LEE, J. E. Busan and beyond: South Korea and the transition from aid effectiveness to development effectiveness. Journal of International Development, v. 25, n. 6, p. 787-801, 2013.

KIM, E. M.; OH, J. Determinants of Foreign Aid: The Case of South Korea. Journal of East Asian Studies, v. 12, n. 2, p. 251-274, maio 2012.

KINDORNAY, S.; SAMY, Y. Establishing a Legitimate Development Cooperation Architecture in the Post-Busan Era. In: BESADA, H.; KINDORNAY, S. (Ed.). Multilateral 
Development Cooperation in a Changing Global Order. International Political Economy Series. London: Palgrave Macmillan UK, 2013. p. 271-294.

KNORR, K. Power and Wealth: The Political Economy of International Power. 1973.

KRAGELUND, P. The Return of Non-DAC Donors to Africa: New Prospects for African Development? Development Policy Review, v. 26, n. 5, p. 555-584, 2008.

KRAGELUND, P. Back to BASICs? The rejuvenation of non-traditional donors' development cooperation with Africa. Development and change, v. 42, n. 2, p. 585-607, 2011.

KRAYCHETE, E. S. Desenvolvimento e cooperação internacional. Caderno CRH, v. 25, n. 65, p. 183-186, 2012.

KUZIEMKO, I.; WERKER, E. How Much Is a Seat on the Security Council Worth? Foreign Aid and Bribery at the United Nations. Journal of Political Economy, v. 114, n. 5, p. 905930, 1 out. 2006.

LAFER, C. A identidade internacional do Brasil e a política externa brasileira: passado, presente e futuro. [s.1.] Editora Perspectiva, 2001.

LE MONDE DIPLOMATIQUE. Brasil, um país doador. Disponível em: <https://diplomatique.org.br/brasil-um-pais-doador/>. Acesso em: 16 jan. 2019.

LANCASTER, C. Foreign Aid: Diplomacy, Development, Domestic Politics. Chicago: University of Chicago Press, 2007.

LECTURER, M. P. G.; FELLOW, T. J. M. R. Compassionate conservatives or conservative compassionates? US political parties and bilateral foreign assistance to Africa. The Journal of Development Studies, v. 41, n. 7, p. 1288-1302, 1 out. 2005.

LEIBENSTEIN, H. The Theory of Underemployment in Backward Economies. Journal of Political Economy, v. 65, n. 2, p. 91-103, 1 abr. 1957.

LEITE, I. C. Cooperação Sul-Sul: conceito, história e marcos interpretativos. Observador on-line, v. 7, n. 3, p. 41, 2012.

LEITE, I. C.; POMEROY, M.; SUYAMA, B. Brazilian south-south development cooperation: The case of the Ministry of Social Development in Africa. Journal of International Development, v. 27, n. 8, p. 1446-1461, 2015.

LEITE, I. C.; SUYAMA, B.; WAISBICH, L. T. Para além do tecnicismo: a Cooperação Brasileira para o Desenvolvimento Internacional e caminhos para sua efetividade e democratização. Policy Brief, Julho, 2013.

LEITE, I. et al. Brazil's Engagement in International Development Cooperation: The State of the Debate. Institute of Development Studies (IDS), maio 2014. . Disponível em: <https://opendocs.ids.ac.uk/opendocs/handle/123456789/3894>. Acesso em: 12 dez. 2018.

LEITE, P. S. O Brasil e a operação Sul-Sul em três momentos: os governos Jânio Quadros. João Goulart, Ernesto Geisel e Luiz Inácio Lula da Silva. Brasília: FUNAG, 
2011a.

LEITE, P. S. O Brasil e a cooperação sul-sul em três momentos de política externa: os governos Jânio Quadros/João Goulart, Ernesto Geisel e Luiz Inácio Lula da Silva. Brasília: FUNAG, 2011b. v. 527.

LIM, D. Y. M.; VREELAND, J. R. Regional Organizations and International Politics: Japanese Influence over the Asian Development Bank and the UN Security Council. World Politics, v. 65, n. 1, p. 34-72, jan. 2013.

LIMA, M. R. S. de. A política externa brasileira e os desafios da cooperação Sul-Sul. Revista Brasileira de Política Internacional, v. 48, n. 1, 2005a.

LIMA, M. R. S. de. Relações Interamericanas: a nova agenda sul-americana e o Brasil. Lua Nova, n. 90, 2013.

LIMA, M. R. S. de; HIRST, M. Brazil as an intermediate state and regional power: action, choice and responsibilities. International affairs, v. 82, n. 1, p. 21-40, 2006.

LIMA, J.; CAMPOS, R.; NEVES, J. O perfil da cooperação brasileira para o desenvolvimento internacional na América Latina e o Caribe em 2010: aportes à reflexão sobre a política brasileira de cooperação internacional. In: MELLO e SOUZA, A. (Org.). Repensando a Cooperação Internacional para o Desenvolvimento. Brasília: IPEA, 2014. p. 203-250.

LIMA, M. R. S. Aspiração internacional e política externa. Revista Brasileira de Comércio Exterior, v. 82, p. 4-19, 2005 b.

LIMA, T. G. S.; CAMPOS, R. P. de. O Perfil Dos Projetos de Cooperação Técnica Brasileira Em Aids No Mundo: Explorando Potenciais Hipóteses de Estudo. Revista Eletrônica de Comunicação, Informação e Inovação em Saúde, v. 4, n. 1, 31 mar. 2010. Disponível em: <https://www.reciis.icict.fiocruz.br/index.php/reciis/article/view/718>. Acesso em: 18 jan. 2019.

LISKA, G. The New Statecraft: Foreign Aid in American Foreign Policy. Chicago: Chicago U.P, 1960.

LOPES, L.; COSTA, J. À procura da Cooperação Sul-Sul no Orçamento Federal. Articulação Sul / Oxfam, 2018.

LOPES, L. L. A. A cooperação técnica entre países em desenvolvimento (CTPD) da Agência Brasileira de Cooperação (ABC-MRE): o Brasil como doador. 2008.

LOPES, R. N. O governo brasileiro e a cooperação Sul-Sul com Moçambique no campo da saúde pública. 2013. Universidade do Grande Rio, 2013. Disponível em: <http://localhost:8080//handle/tede/235>. Acesso em: $28 \mathrm{dez} .2018$.

LUCAS, R. E. On the mechanics of economic development. Journal of Monetary Economics, v. 22, n. 1, p. 3-42, 1 jul. 1988.

LUMSDAINE, D. H. Moral Vision in International Politics: The Foreign Aid Regime, 1949-1989. Princeton: Princeton University Press, 1993. 
LUNDSGAARDE, E.; BREUNIG, C.; PRAKASH, A. Instrumental Philanthropy: Trade and the Allocation of Foreign Aid. Canadian Journal of Political Science/Revue canadienne de science politique, v. 43, n. 3, p. 733-761, set. 2010.

MAGALHÃES, R. N. Os determinantes da ajuda externa brasileira. 2013. Universidade de São Paulo, 2013. Disponível em: <http://www.teses.usp.br/teses/disponiveis/8/8131/tde17032014-104757/>. Acesso em: 19 jan. 2019.

MAIZELS, A.; NISSANKE, M. K. Motivations for aid to developing countries. World Development, v. 12, n. 9, p. 879-900, 1 set. 1984.

MALUF, R. S.; SANTARELLI, M.; PRADO, V. A cooperação brasileira em segurança alimentar e nutricional: determinantes e desafios presentes na construção da agenda internacional. R. Janeiro, CERESAN/UFRRJ, p. 43, 2014.

MANNING, R. Will 'Emerging Donors' Change the Face of International Co-Operation? Development Policy Review, v. 24, n. 4, p. 371-385, 2006.

MANSUR, Y. S.; TEODÓSIO, A. dos S. de S. The participation of civil society in SouthSouth Cooperation: in search of an analytical model for management studies. Cadernos EBAPE. BR, v. 14, n. 3, p. 676-694, 2016.

MARSHALL, M. G.; JAGGERS, K.; GURR, T. R. Polity IV Annual Time-Series, 18002013. Center for International Development and Conflict Management at the University of Maryland College Park, 2014.

MASAGÃO, V. Alô, Alô, Brasil com W. Le Monde Diplomatique Brazil, 2011.

MASAGÃO, V.; SUYAMA, B.; LOPES, L. Emerging Brazilian cooperation: Reflections on its parameters and public-private boundaries. Reality of Aid Report, 2012.

MAWDSLEY, E. The changing geographies of foreign aid and development cooperation: contributions from gift theory. Transactions of the Institute of British Geographers, v. 37, n. 2, p. 256-272, 1 abr. 2012.

MAWDSLEY, E. Development Geography 1: Cooperation, Competition and Convergence between 'North' and 'South'. Progress in Human Geography, v. 41, n. 1, p. 108-117, 1 fev. 2017.

MAWDSLEY, E.; RIGG, J. A Survey of the World Development Reports I: Discursive Strategies. Progress in Development Studies, v. 2, n. 2, p. 93-111, 1 abr. 2002.

MAWDSLEY, E.; SAVAGE, L.; KIM, S.-M. A 'post-aid world'?? Paradigm shift in foreign aid and development cooperation at the 2011 Busan High Level Forum'. The Geographical Journal, v. 180, n. 1, p. 27-38, 1 mar. 2014.

MCEWAN, C. et al. Enrolling the Private Sector in Community Development: Magic Bullet or Sleight of Hand? Development and Change, v. 48, n. 1, p. 28-53, 2017.

MCEWAN, C.; MAWDSLEY, E. Trilateral Development Cooperation: Power and Politics in Emerging Aid Relationships. Development and Change, v. 43, n. 6, p. 1185-1209, 2012. 
MCGILLIVRAY, M. Modelling aid allocation: Issues, approaches and results. [s.1.] WIDER Discussion Paper, 2003. . Disponível em:

<https://www.econstor.eu/handle/10419/52825>. Acesso em: 29 dez. 2018.

MCGILLIVRAY, M.; OCZKOWSKI, E. Modelling the Allocation of Australian Bilaterial Aid: A Two-Part Sample Selection Approach*. Economic Record, v. 67, n. 2, p. 147-152, 1991.

MCGILLIVRAY, M.; OCZKOWSKI, E. A two-part sample selection model of British bilateral foreign aid allocation. Applied Economics, v. 24, n. 12, p. 1311-1319, 1 dez. 1992.

MCKINLAY, R. D.; LITTLE, R. A Foreign-Policy Model of the Distribution of British Bilateral Aid, 1960-70. British Journal of Political Science, v. 8, n. 3, p. 313-331, jul. 1978.

MCKINLEY, R. D.; LITTLE, R. A Foreign Policy Model of US Billateral Aid Allocation. World Politics, v. 30, n. 1, p. 58-86, 1977.

MEERNIK, J.; KRUEGER, E. L.; POE, S. C. Testing models of US foreign policy: Foreign aid during and after the Cold War. The journal of Politics, v. 60, n. 1, p. 63-85, 1998.

MELLO E SOUZA, A. A cooperação para o desenvolvimento Sul-Sul os casos do Brasil, da Índia e da China. Cadernos Adenauer, v. XIII, n. 2, 2012.

MENDONÇA JÚNIOR, W.; FARIA, C. A. P. D. A cooperação técnica do Brasil com a África: comparando os governos Fernando Henrique Cardoso (1995-2002) e Lula da Silva (2003-2010). Revista Brasileira de Política Internacional, v. 58, n. 1, 2015.

MENON, B. P. Bridges across the South: Technical cooperation among developing countries. 1980 .

MILANI, C. ABC 30 anos: história e desafios futuros. Brasília: Agência Brasileira de Cooperação, p. 224, 2017.

MILANI, C. R. Atores e agendas no campo da política externa brasileira de direitos humanos. In: PINHEIRO, L; MILANI, C. (Orgs.) Política Externa Brasileira: As Práticas da Política e a Política das Práticas. Rio de Janeiro, FGV Editora, 2012a. p. 33-70.

MILANI, C. R. Learning with history: critique to the experience of the North-South Cooperation and present challenges to the South-South Cooperation. Caderno CRH, v. 25, n. 65, p. 211-231, 2012b.

MILANI, C. R.; CONCEIÇÃO, F. C. da; M'BUNDE, T. S. Cooperação sul-sul em educação e relações brasil-palop. Caderno CRH, v. 29, n. 76, 2016.

MILANI, C. R. S. Evolução Histórica da Cooperação Norte-Sul. In: MELLO e SOUZA, A. (Org.). Repensando a Cooperação Internacional para o Desenvolvimento. Brasília: IPEA, 2014. p. 33-56.

MILANI, C. R. S. Solidariedade e Interesse: Motivações e estratégias na cooperação internacional para o desenvolvimento. Curitiba: APPRIS, 2018.

MILANI, C. R. S.; CARVALHO, T. C. O. Cooperação Sul-Sul e Política Externa: Brasil e 
China no continente africano. Estudos internacionais: revista de relações internacionais da PUC Minas, v. 1, n. 1, 29 abr. 2013. Disponível em:

<http://200.229.32.55/index.php/estudosinternacionais/article/view/5158>. Acesso em: 21 dez. 2018.

MILANI, C. R. S.; LOPES, L. L.; SUYAMA, B. Políticas de Cooperação Internacional para o Desenvolvimento no Norte e no Sul: que lições e desafios para o Brasil? Friedrich Ebert Stiftung, 2013.

MILANI, C. R. S.; LOPES, R. N. Cooperação Sul-Sul e Policy Transfer em Saúde Pública: análise das relações entre Brasil e Moçambique entre 2003 e 2012. Carta Internacional, v. 9, n. 1, p. 59-78, 2014.

MILANI, C. R. S.; PINHEIRO, L. Política Externa Brasileira: Os Desafios de sua Caracterização como Política Pública. Contexto Internacional, v. 35, n. 1, p. 11-41, 2013.

MILANI, C. R. S.; PINHEIRO, L.; DE LIMA, M. R. S. Brazil's Foreign Policy and the 'Graduation Dilemma'. International Affairs, v. 93, n. 3, p. 585-605, 1 maio 2017.

MILEVA, E. Using Arellano-Bond dynamic panel GMM estimators in Stata. Economics Department, Fordham University, p. 1-10, 2007.

MILNER, H. V.; TINGLEY, D. H. The Political Economy of U.s. Foreign Aid: American Legislators and the Domestic Politics of Aid. Economics \& Politics, v. 22, n. 2, p. 200-232, 2010 .

MINISTÉRIO DAS RELAÇÕES EXTERIORES. Viagens oficiais de Fernando Henrique Cardoso 1995 - 2002, 2003.

MINISTÉRIO DAS RELAÇÕES EXTERIORES. Visitas internacionais do Presidente Lula e visitas ao Brasil de Chefes de Estado e de Chefes de Governo: 2003 a 2010, 2011.

MORGENTHAU, H. Politics Among Nations: The struggle for power and peace. New York: Alfred Kopf, 1948.

MORGENTHAU, H. J. A Political Theory of Foreign Aid, 1962.

MORVARIDI, B.; HUGHES, C. South-South Cooperation and Neoliberal Hegemony in a Post-Aid World. Development and Change, v. 49, n. 3, p. 867-892, 2018.

MOSS, T. J.; PETTERSSON GELANDER, G.; VAN DE WALLE, N. An Aid-Institutions Paradox? A Review Essay on Aid Dependency and State Building in Sub-Saharan Africa. Rochester, NY: Social Science Research Network, 1 jan. 2006. . Disponível em: <https://papers.ssrn.com/abstract=860826>. Acesso em: 29 dez. 2018.

MOSS, T. J.; STANDLEY, S.; ROODMAN, D. The Global War on Terror and U.S. Development Assistance: Usaid Allocation by Country, 1998-2005. Working Paper 62, Center for Global Development, 1 jul. 2005.

NABLI, M. K.; NUGENT, J. B. The New Institutional Economics and its applicability to development. World Development, v. 17, n. 9, p. 1333-1347, 1 set. 1989. 
NAIM, M. Rogue aid: What is wrong with the foreign aid programs of China, Venezuela and Saudi Arabia? They are enormously generous. And they are toxic. Foreign Policy, p. 96-97, 2007.

NARLIKAR, A. et al. The Oxford Handbook on The World Trade Organization. Oxford: Oxford University Press, 2012.

NARLIKAR, A. Negotiating the Rise of New Powers. International Affairs, v. 89, n. 3, p. 561-576, 2013.

NEST. Developing a Conceptual Framework for South-South Cooperation: Working Document, 2015. . Disponível em: <https://saiia.org.za/wp-content/uploads/2015/09/201509-23-Final-draft-SSC-Framework-rev_20151127.pdf>. Acesso em: 20 jan. 2019.

NEST. A Monitoring and Evaluation Framework for South-South Cooperation: Working Document. South African Institute of International Affairs (SAIIA), 2017.

NEST. Network of Southern Think Tanks (NeST). Disponível em: <http://southernthinktanks.org/>. Acesso em: 24 jan. 2019.

NEUMAYER, E. Do Human Rights Matter in Bilateral Aid Allocation? A Quantitative Analysis of 21 Donor Countries*. Social Science Quarterly, v. 84, n. 3, p. 650-666, 2003.

NEUMAYER, E. Arab-Related Bilateral and Multilateral Sources of Development Finance: Issues, Trends, and the Way Forward. The World Economy, v. 27, n. 2, p. 281-300, 2004.

NOËL, A.; THÉRIEN, J.-P. From Domestic to International Justice: The Welfare State and Foreign Aid. International Organization, v. 49, n. 3, p. 523-553, 1995.

NOGUEIRA, I.; OLLINAHO, O. From Rhetoric to Practice in South-South Development Cooperation: A case study of Brazilian interventions in the Nacala corridor development program. Institute of Socioeconomics, University of Geneva, Geneva, Switzerland, 2013.

NORTH, D. C. A Transaction Cost Theory of Politics. Journal of Theoretical Politics, v. 2, n. 4, p. 355-367, 1 out. 1990.

NURKSE, R. Problems of capital formation in developing countries. New York: Columbia University Press, 1953.

OBSERVATÓRIO O BRASIL E O SUL. Redes de Think-Tanks do Sul - Observatório Brasil e o Sul. Disponível em: <http://obs.org.br/rede-de-think-tanks-do-sul/conteudo/92sobre-a-nest>. Acesso em: 20 jan. 2019.

O'CONNELL, S. A.; SOLUDO, C. C. Aid intensity in Africa. World Development, v. 29, n. 9, p. 1527-1552, 2001.

OECD. The Busan Partnership for Effective Development Co-operation - OECD, 2011. . Disponível em: <http://www.oecd.org/development/effectiveness/busanpartnership.htm>. Acesso em: 25 jan. 2019.

OECD. Measuring total official support for sustainable development, 2017a. 
OECD. TOSSD: A NEW STATISTICAL MEASURE FOR THE SDG ERA, $2017 \mathrm{~b}$.

OECD. DAC Working Party on Development Finance Statistics. DRAFT REVISED STATISTICAL REPORTING DIRECTIVES FOR DAC STATISTICS. Chapters 1-6. DCD/DAC/STAT., 2018a.

OECD. Development finance standards - OECD. Disponível em:

$<$ http://www.oecd.org/dac/financing-sustainable-development/development-financestandards/>. Acesso em: $31 \mathrm{dez} .2018 \mathrm{~b}$.

OECD. Humanitarian Assistance - OECD. Disponível em:

<http://www.oecd.org/dac/stats/humanitarian-assistance.htm>. Acesso em: 28 jan. 2018c.

OECD. OECD Glossary of Statistical Terms. Disponível em:

<https://stats.oecd.org/glossary/detail.asp?ID=2686>. Acesso em: 15 jan. 2018d.

OECD. Official development assistance (ODA) - Food aid - OECD Data. Disponível em: <http://data.oecd.org/oda/food-aid.htm>. Acesso em: 22 dez. 2018e.

OECD. What is total official support for sustainable development (TOSSD)? - OECD. Disponível em: <http://www.oecd.org/dac/financing-sustainable-development/tossd.htm>. Acesso em: $26 \mathrm{dez} .2018 \mathrm{f}$.

OLIVEIRA, A. J. N.; ONUKI, J. South-South Cooperation and Brazilian Foreign Policy. Foreign Policy Research Center Journal, v. 3, p. 80-99, 2012.

OLIVEIRA, A. N. D. Legislativo e Política Externa: Das (in) conveniências da abdicação. Working Papers Caeni, n. 3, 2003.

OLIVEIRA, A. J. N. de; ONUKI, J.; OLIVEIRA, E. de. Coalizões Sul-Sul e Multilateralismo: Índia, Brasil e África do Sul. Contexto Internacional, v. 28, n. 2, p. 465, 2006.

OLIVEIRA, A. J. de; ONUKI, J. Política comercial e Legislativo: a atuação do empresariado brasileiro. Estado empresariado e desenvolvimento no Brasil. São Paulo: Cultura, 2010.

OLIVEIRA, A. J. S. N. de; ALBUQUERQUE, J. A. G. O papel da coalizão empresarial brasileira e as negociações da ALCA. 2003. Universidade de São Paulo, São Paulo, 2003.

ONU. NUEVAS ORIENTACIONES DE LA COOPERACIÓN TÉCNICA ENTRE LOS PAÍSES EN DESARROLLO, 1995.

ONU. Conferência Internacional sobre Financiamento para o Desenvolvimento, 2002.

ONU. A Brief History | UNITED NATIONS ECONOMIC and SOCIAL COUNCIL.

Disponível em: <https://www.un.org/ecosoc/en/a-brief-history>. Acesso em: 25 jan. 2019.

PARK, K. New development partners and a global development partnership. In: Catalyzing Development, Kharas H, Jung W, Makino K (eds). Washington, DC: Brookings Institution Press, 2011.

PEARSON, L. B. Partners in development; report of the Comission on International Development. 1969. 
PECEQUILO, C. S. A política externa do Brasil no século XXI: os eixos combinados de cooperação horizontal e vertical. Revista Brasileira de Política Internacional, p. 136-156, 2008.

PIFCSS. Programa Ibero-Americano para o Fortalecimento da Cooperação Sul-Sul. 38 anos do Plano de Ação de Buenos Aires, 2017.

PIMENTEL, J. V. de S. O Brasil, os BRICS e a agenda internacional. 2. ed. Brasília: FUNAG, 2013.

PINHEIRO, L. Os véus da transparência: política externa e democracia no Brasil. PUC, 2003.

PINHEIRO, L.; GAIO, G. Cooperation for Development, Brazilian Regional Leadership and Global Protagonism. Brazilian Political Science Review, v. 8, n. 2, p. 8-30, set. 2014.

PINO, B. A. O Sistema Internacional de Cooperação ao Desenvolvimento e seu estudo nas Relações Internacionais: a evolução histórica e as dimensões teóricas. Revista de Economia Política e Relações Internacionais, v. 5, n. 8, 2006.

PINO, B. A. La Cooperación Internacional para el Desarrollo: fundamentos y justificaciones en la perspectiva de la Teoría de las Relaciones Internacionales. Carta internacional, v. 2, n. 2, p. 32-47, 2007.

PINO, B. A. Os debates sobre a eficácia da cooperação e o papel dos emergentes: o Brasil e a cooperação triangular. Carta Internacional, v. 5, n. 2, p. 1-10, 2010a.

PINO, B. A. La cooperación de Brasil: un modelo en construcción para una potencia emergente. Boletín Elcano, p. 9 p., 28 out. 2010b.

PINO, B. A. A cooperação triangular e as transformações da cooperação internacional para o desenvolvimento. [s.1.] Texto para Discussão, Instituto de Pesquisa Econômica Aplicada (IPEA), 2013. . Disponível em: <https://www.econstor.eu/handle/10419/90971>. Acesso em: 28 dez. 2018.

PINO, B. A. Evolução Histórica da Cooperação Sul-Sul. In: MELlO e SOUZA, A. (Org.). Repensando a Cooperação para o Desenvolvimento Internacional. Brasília: IPEA, 2014. p. $57-86$.

PINO, B. A.; LEITE, I. C. O Brasil e a Cooperação Sul-Sul: Contribuições e Desafios. Boletim Meridiano 47, 2009.

PINO, B. A.; LEITE, I. C. La cooperacion Sur-Sur de Brasil: ?Instrumento de politica exterior y/o manifestacion de solidaridad internacional? Mural Internacional, 1 jan. 2010.

PINO, B. A.; NOGUEIRA, L. M.; PUERTO, L. M. Asociados para el desarrollo. Propuestas para la cooperación España-Brasil. Documentos de Trabajo (Fundación Carolina), n. 12, p. $1,2007$.

PLEASE, S. The World Bank: Lending for Structural Adjustment. In: FEINBERG, R. R.; KALLAB, V. (Eds.). Adjustment crisis in the Third World. Piscataway: Transaction Publishers, 1984. p. 83-98. 
POMEROY, M.; WAISBICH, L. T. O lugar do Sul na política externa brasileira do governo provisório. Carta Capital, 2016. Disponível em:

$<$ https://www.cartacapital.com.br/blogs/blog-do-grri/o-lugar-do-sul-na-politica-externabrasileira-do-governo-provisorio>. Acesso em: $31 \mathrm{dez} .2018$.

PRASHAD, V. Neoliberalism with Southern characteristics. New York Office: Rosa Luxemburg Stiftung, 2013.

PRESIDÊNCIA DA REPÚBLICA. Viagens Internacionais da Presidenta da República/2011, 2011.

PRESIDÊNCIA DA REPÚBLICA. Viagens Internacionais da Presidenta da República/2012, 2012.

PRESIDÊNCIA DA REPÚBLICA. Viagens Internacionais da Presidenta da República/2013, 2013.

PRESIDÊNCIA DA REPÚBLICA. Viagens Internacionais da Presidenta da República/2014, 2014.

PRESIDÊNCIA DA REPÚBLICA. Viagens Internacionais da Presidenta da República/2015, 2015.

PRESIDÊNCIA DA REPÚBLICA. Viagens Internacionais do Presidente da República/2016, 2016.

PRETO, A. F. O conceito de diplomacia presidencial: o papel da Presidência da República na formulação de política externa. 2006.

PUENTE, C. A. I. A cooperação técnica horizontal brasileira como instrumento da política externa: a evolução da cooperação técnica com países em desenvolvimentoCTPD-no período 1995-2005. Brasília: FUNAG, 2010.

QUADIR, F. Rising Donors and the New Narrative of 'South-South' Cooperation: what prospects for changing the landscape of development assistance programmes? Third World Quarterly, v. 34, n. 2, p. 321-338, 1 mar. 2013.

RAPLEY, J. Understanding Development: Theory and Practice in the Third World. 3. ed. Boulder: Lynne Rienner Publishers, 2007.

REGINA, F. L. Cooperação técnica entre países em desenvolvimento: o caso do Ministério da Saúde brasileiro no Haiti. 2016. Universidade de São Paulo, São Paulo, 2016.

RENZIO, P. de; SEIFERT, J. South-South cooperation and the future of development assistance: mapping actors and options. Third World Quarterly, v. 35, n. 10, p. 1860-1875, 26 nov. 2014.

RODRIGUES, R. D. Cooperação internacional da Fiocruz: o caso do projeto de instalação da Fábrica de Medicamentos em Moçambique. 2014. Fundação Oswaldo Cruz. Instituto de Tecnologia em Fármacos., Rio de Janeiro, 2014. Disponível em: <https://www.arca.fiocruz.br/handle/icict/18028>. Acesso em: 18 jan. 2019. 
ROMER, P. M. Endogenous Technological Change. Journal of Political Economy, v. 98, n. 5, Part 2, p. S71-S102, 1 out. 1990.

ROODMAN, D. xtabond2: Stata module to extend xtabond dynamic panel data estimator. The Stata Journal, v. 9, n. 1, p. 86-136, 2009.

ROSENSTEIN-RODAN, P. N. Problems of Industrialisation of Eastern and South-Eastern Europe. The Economic Journal, v. 53, n. 210/211, p. 202-211, 1943.

ROSTOW, W. W. The Take-Off Into Self-Sustained Growth. The Economic Journal, v. 66, n. 261, p. 25-48, 1956.

ROUND, J. I.; ODEDOKUN, M. Aid effort and its determinants. International Review of Economics \& Finance, Aid Allocations and Development Financing. v. 13, n. 3, p. 293-309, 1 jan. 2004.

SÁ E SILVA, M. South-South Cooperation: past and present conceptualization and practice. South-South cooperation in education and development, p. 39-59, 2009.

SACHS, J. D. From millennium development goals to sustainable development goals. The Lancet, v. 379, n. 9832, p. 2206-2211, 2012.

SÁNCHEZ, E. R. Cooperación y desarrollo: nueve preguntas sobre el tema. [s.l.] Amycos, 2002.

SANTOS, V. S. dos. Cooperação Sul-Sul brasileira entre 2003-2014 : desafios institucionais em análise. 31 jan. 2018. Disponível em: <http://bdm.unb.br/handle/10483/19228>. Acesso em: 31 dez. 2018.

SANTOS, T. da C. e S. S. Entre o Norte e o Sul: um estudo sobre o papel das organizações da sociedade civil brasileira na cooperação internacional para o desenvolvimento. 2013. Universidade Federal da Bahia, 2013.

SARAIVA, M. G. As estratégias de cooperação Sul-Sul nos marcos da política externa brasileira de 1993 a 2007. Revista Brasileira de Política Internacional, v. 50, n. 2, p. 42-59, 2007.

SARAIVA, M. G. Balanço da política externa de Dilma Rousseff: perspectivas futuras? Relações Internacionais (RI), n. 44, p. 25-35, dez. 2014.

SCARTASCINI, C.; CRUZ, C.; KEEFER, P. The Database of Political Institutions 2017 (DPI2017). [s.1.] Inter-American Development Bank, 16 mar. 2018. . Disponível em: <http://publications.iadb.org/11319/8806>. Acesso em: 20 mar. 2018.

SCHLEICHER, R. T.; PLATIAU, A. F. What is the relation between Brazilian Foreign Policy and the implementation of bilateral technical cooperation projects in African Countries? Lessons from a South-South cooperation project implemented by the Brazilian National School of Public Administration-ENAP (2009-2012). Revista Brasileira de Política Internacional, v. 60, n. 1, 2017.

SCHLESINGER, S. Cooperação e Investimentos Internacionais do Brasil: a internacionalização do etanol e do biodiesel. FASE/Oxfam, p. 26, 2012. 
SCHRAEDER, P. J.; HOOK, S. W.; TAYLOR, B. Clarifying the Foreign Aid Puzzle: A Comparison of American, Japanese, French, and Swedish Aid Flows. World Politics, v. 50, n. 2, p. 294-323, jan. 1998.

SEGIB. Relatório da Cooperação Sul-Sul em Ibero-América 2017 | SEGIB, 2017.

Disponível em: <https://www.segib.org/pt-br/?document=informe-de-cooperacion-sur-sur-eniberoamerica-2017>. Acesso em: 23 jan. 2019.

SEGIB. Secretaría General Iberoamericana - SEGIB, 2018. . Disponível em: <https://www.segib.org/pt-br/>. Acesso em: 21 jan. 2019.

SENNES, R. Nem restauradores, nem reformadores: o engajamento internacional minimalista e seletivo dos BRICS. Mesa-Redonda: O Brasil, os BRICS e a Agenda Internacional, p. 217-233, 2012.

SEVERINO, J.-M.; RAY, O. The End of ODA: Death and Rebirth of a Global Public Policy Working Paper 167. Center for Global Development, 2009.

SHANKLAND, A.; GONÇALVES, E. Imagining agricultural development in South-South cooperation: the contestation and transformation of ProSAVANA. World Development, v. 81, p. 35-46, 2016.

SILVA. Discurso do senhor presidente da República na sessão de posse - Luiz Inácio Lula da Silva, 2003.

SILVA, A. L. R. Geometria variável e parcerias estratégicas: a diplomacia multidimensional do governo Lula (2003-2010). Contexto Internacional, v. 37, n. 1, p. 143, 2015.

SILVA, D. M. et al. Panorama do Monitoramento dos Fluxos da Cooperação Internacional para o Desenvolvimento: Oportunidades e Desafios para construção de uma Metodologia Brasileira. Articulação Sul, 2016.

SILVA, S. A. G. da; DUARTE, R. G.; CASTRO, J. M. de. Transferência de conhecimento na cooperação internacional: o caso Farmanguinhos-SMM. Revista de Saúde Pública, v. 51, p. $1-9,2017$.

SILVA, E. C. G.; SPÉCIE, P.; VITALE, D. Atual arranjo institucional da política externa brasileira. Texto para Discussão, Instituto de Pesquisa Econômica Aplicada (IPEA), 2010. Disponível em: <https://www.econstor.eu/handle/10419/91344>. Acesso em: 18 jan. 2019.

SIQUEIRA, M. T. Transferência de tecnologia para a produção pública de medicamentos: elementos para discussão do caso de Moçambique. 2014. Fundação Oswaldo Cruz. Escola Nacional de Saúde Pública Sergio Arouca, Rio de Janeiro, 2014. Disponível em: <https://www.arca.fiocruz.br/handle/icict/14858>. Acesso em: 18 jan. 2019.

SOARES, G. A Cooperação Técnica Internacional. In: MARCOVITCH, J. (Org.) Cooperação Internacional: Estratégia e Gestão. São Paulo: Edusp, 1994.

SOUTO MAIOR, L. A. Dois anos de 'presença soberana': uma reflexão sobre a política externa do Governo Lula”. Cena Internacional, v. 6, n. 2, p. 53-72, 2004.

SPEKTOR, M. Kissinger e o Brasil. Rio de Janeiro: Zahar, 2009. 
STOKKE, O. Western middle powers and global poverty: the determinants of the aid policies of Canada, Denmark, the Netherlands, Norway, and Sweden. Uppsala: The Scandinavian Institute of African Studies, in cooperation with the Norwegian Institute of International Affairs, 1989.

STOKKE, O. Aid and Political Conditionality. London: Routledge, 2013.

STOLTE, C. Brazil in Africa: Just another BRICS country seeking resources? Chatham House London, 2012.

STRANGE, A. M. et al. Tracking Underreported Financial Flows: China's Development Finance and the Aid-Conflict Nexus Revisited. Journal of Conflict Resolution, v. 61, n. 5, p. 935-963, 1 maio 2017.

STREETEN, P. et al. First things first: meeting basic human needs in the developing countries. New York: Oxford Univ. Press, 1981.

STUENKEL, O. The financial crisis, contested legitimacy, and the genesis of intra-BRICS cooperation. Global governance, v. 19, n. 4, p. 611-630, 2013.

SUYAMA, B.; SILVA, D. M.; WAISBICH, L. T. Guia para o Monitoramento e Mensuração da Cooperação Sul-Sul Brasileira. Articulação Sul, 2017.

THE ECONOMIST. The Beijing consensus is to keep quiet. The Economist, 6 maio 2010. Disponível em: <https://www.economist.com/asia/2010/05/06/the-beijing-consensus-is-tokeep-quiet>. Acesso em: 29 dez. 2018.

THÉRIEN, J.-P.; NOËL, A. Political Parties and Foreign Aid. American Political Science Review, v. 94, n. 1, p. 151-162, mar. 2000.

THIELE, R.; NUNNENKAMP, P.; DREHER, A. Sectoral Aid Priorities: Are Donors Really Doing Their Best to Achieve the Millennium Development Goals? Rochester, NY: Social Science Research Network, 1 jan. 2006. Disponível em: <https://papers.ssrn.com/abstract=881553>. Acesso em: 29 dez. 2018.

THORBECKE, E. The Evolution of the Development Doctrine, 1950-2005. In: MAVROTAS, G.; SHORROCKS, A. (Ed.). Advancing Development: Core Themes in Global Economics. Studies in Development Economics and Policy. London: Palgrave Macmillan UK, 2007. p. 3-36.

TIERNEY, M. J. et al. More Dollars than Sense: Refining Our Knowledge of Development Finance Using AidData. World Development, Expanding Our Understanding of Aid with a New Generation in Development Finance Information. v. 39, n. 11, p. 1891-1906, 1 nov. 2011.

TINGLEY, D. Donors and domestic politics: Political influences on foreign aid effort. The Quarterly Review of Economics and Finance, Special Section: Foreign Aid. v. 50, n. 1, p. 40-49, 1 fev. 2010.

TUMAN, J.; AYOUB, A. The Determinants of Japanese Official Development Assistance in Africa: A Pooled Time Series Analysis. International Interactions, v. 30, n. 1, p. 43-57, 1 jan. 2004. 
TUMAN, J. P.; EMMERT, C. F.; STERKEN, R. E. Explaining Japanese Aid Policy in Latin America: A Test of Competing Theories. Political Research Quarterly, v. 54, n. 1, p. 87101, 1 mar. 2001.

TUMAN, J. P.; STRAND, J. R. The Role of Mercantilism, Humanitarianism, and Gaiatsu in Japan's ODA Programme in Asia. International Relations of the Asia-Pacific, v. 6, n. 1, p. 61-80, 1 jan. 2006.

UL HAQ, M. Changing emphasis of the Bank's lending policies. Finance and Development, v. 15 , n. 2, p. $12,1978$.

UNDP. Human Development Report 1990 | Human Development Reports, 1990.

Disponível em: <http://hdr.undp.org/en/reports/global/hdr1990>. Acesso em: 26 jan. 2019.

UNDP. Human Development Report 2007/8 | Human Development Reports, 2008

Disponível em: <http://hdr.undp.org/en/content/human-development-report-20078>. Acesso em: 26 jan. 2019.

UNESCO. What is technical assistance? | 2005 Convention | United Nations Educational, Scientific and Cultural Organization. Disponível em:

$<$ http://www.unesco.org/new/en/culture/themes/cultural-diversity/cultural-

expressions/programmes/technical-assistance/what-is-technical-assistance/>. Acesso em: 31 dez. 2018.

UNITED NATIONS STATISTICS DIVISION. UN Comtrade | International Trade

Statistics Database. Disponível em: <https://comtrade.un.org/>. Acesso em: 29 jan. 2018.

VALLER FILHO, W. O Brasil e a crise haitiana: a cooperação técnica como instrumento de solidariedade e de ação diplomática. Brasília: FUNAG, 2007.

VEEN, A. M. van der. Ideas, Interests and Foreign Aid. Cambridge: Cambridge University Press, 2011.

VIANA, S. M. K. Cooperação internacional para o desenvolvimento e interesses organizados: os atores privados na cooperação técnica entre países em desenvolvimento brasileira. 2015. Universidade de São Paulo, 2015.

VIGEVANI, T.; CEPALUNI, G. A política externa de Lula da Silva: a estratégia da autonomia pela diversificação. Contexto internacional, v. 29, n. 2, p. 273-335, 2007.

VILLANGER, E. Arab Foreign Aid: Disbursement Patterns, Aid Policies and Motives. Forum for Development Studies, v. 34, n. 2, p. 223-256, 1 dez. 2007.

VISENTINI, P. G. F. De FHC a Lula: uma década de política externa. Civitas: revista de ciências sociais. Porto Alegre, RS. Vol. 5, n. 2 (jul./dez. 2005). p. 381-397, 2005.

VISENTINI, P. G. F.; SILVA, A. L. R. da. Brazil and the economic, political, and environmental multilateralism: the Lula years (2003-2010). Revista brasileira de política internacional, v. 53, n. SPE, p. 54-72, 2010.

VOETEN, E.; STREZHNEV, A.; BAILEY, M. United Nations General Assembly Voting

Data (Erik Voeten, Ed.) Harvard Dataverse, 2009. . Disponível em: 
<https://hdl.handle.net/1902.1/12379>.

VREELAND, J. R. Foreign Aid and Global Governance: Buying Bretton Woods - the SwissBloc Case. The Review of International Organizations, v. 6, n. 3, p. 369-391, 1 set. 2011.

WAISBICH, L. T.; SILVA, D. M.; SUYAMA, B. Aprimorando o monitoramento e a mensuração dos fluxos da cooperação Sul-Sul do Brasil: Rumo a uma metodologia participativa, pública e inclusiva. Articulação Sul, 2017.

WALTZ, K. Theory of international politics. Reading: Addison-Wesley, 1979.

WARNER, J. South-South Cooperation: Brazilian Soy Diplomacy Looking East? Food Security, v. 7, n. 6, p. 1175-1185, 1 dez. 2015.

WEBER, M. Ciência E Política: Duas Vocações. Editora Cultrix, 2004.

WECK-HANNEMANN, H.; SCHNEIDER, F. Determinants of foreign aid under alternative institutional arrangements. Diskussionsbeiträge: Serie II,

Sonderforschungsbereich 178 "Internationalisierung der Wirtschaft", Universität Konstanz, 1988. Disponível em: <https://www.econstor.eu/handle/10419/101660>. Acesso em: 29 dez. 2018.

WEISSMAN, S. R. The Trojan Horse: A Radical Look at Foreign Aid. San Francisco: Ramparts Press, 1975.

WILLIAMSON, O. E. Comparative Economic Organization: The Analysis of Discrete Structural Alternatives. Administrative Science Quarterly, v. 36, n. 2, p. 269-296, 1991.

WOOD, R. E. From Marshall Plan to Debt Crisis: Foreign Aid and Development Choices in the World Economy. Berkeley: University of California Press, 1986.

WOODS, N. Whose Aid? Whose Influence? China, Emerging Donors and the Silent Revolution in Development Assistance. International Affairs, v. 84, n. 6, p. 1205-1221, 1 nov. 2008.

WOOLDRIDGE, J. M. Econometric analysis of cross section and panel data. Cambridge: MIT press, 2010.

WORLD BANK. World development report 1990: poverty. The World Bank, 1 jun. 1990. Disponível em: <http://documents.worldbank.org/curated/en/424631468163162670/Worlddevelopment-report-1990-poverty>. Acesso em: 26 jan. 2019.

WORLD BANK. Effective Implementation: Key to Development Impact: Report of the World Bank's Portfolio Management Task Force. World Bank, 1992.

WORLD BANK. World Bank Group - International Development, Poverty, \& Sustainability. Disponível em: <https://www.worldbank.org/>. Acesso em: 4 jan. 2018.

WORLD BANK. World Development Indicators (WDI) | Data Catalog. Disponível em: <https://datacatalog.worldbank.org/dataset/world-development-indicators>. Acesso em: 17 jan. 2018b. 
WORLD TRADE ORGANIZATION. World Trade Organization - Global trade.

Disponível em: <https://www.wto.org/index.htm>. Acesso em: 4 jan. 2018.

YOUNAS, J. Motivation for bilateral aid allocation: Altruism or trade benefits. European Journal of Political Economy, v. 24, n. 3, p. 661-674, 1 set. 2008.

ZAKARIA, F. Facing a Post-American World. New Perspectives Quarterly, v. 25, n. 3, p. 7-12, 2008a.

ZAKARIA, F. The Future of American Power: How America Can Survive the Rise of the Rest. Foreign Affairs, v. 87, n. 3, p. 18-43, 2008b.

ZANELLA, M.; CASTRO, C. M. de. A Faca Internacional de uma Disputa de Modelos Rurais: A Economia Política da Cooperação Brasileira em Agricultura com Moçambique. REVISTA NERA, v. 0, n. 38, p. 255-279, 2017.

ZARPELON, J. T. G. Doador emergente do sul: cooperação técnica internacional prestada pelo Brasil na área da saúde no governo Lula. 2016. Universidade Federal de Santa Catarina, Florianópolis, 2016. Disponível em:

<https://repositorio.ufsc.br/handle/123456789/168095>.

ZIMMERMANN, F.; SMITH, K. More Actors, More Money, More Ideas for International Development Co-Operation. Journal of International Development, v. 23, n. 5, p. 722-738, 2011. 


\section{ANEXOS}

\section{A. Lista de variáveis}

bm: variável dicotômica correspondente à participação de determinado país no bloco brasileiro nos diretórios executivos do Banco Mundial em determinado ano. Codificada com base nos dados fornecidos no site da instituição (www.worldbank.org).

bndes: variável referente ao total de IED brasileiro para cada país em cada ano da amostra entre 2000 e 2016. Operacionalizada como os financiamentos via BNDES às exportações de bens e serviços de empresas brasileiras para obras no exterior (www.bndes.gov.br).

cplp: variável dicotômica indicando se um país faz parte da Comunidade dos Países de Lingua Portuguesa (www.cplp.org).

ct: variável relativa aos valores totais gastos por ano para cada país da amostra em projetos de cooperação técnica bilateral executados pelo Brasil entre os anos de 2000 e 2016 em dólares (valores constantes U\$2016). Construída a partir do banco de dados fornecido pela ABC.

ctcont: variável referente ao número de projetos de Cooperação Técnica realizados pelo Brasil em um país em um determinado ano. Elaborada a partir do bando de dados fornecido pela $\mathrm{ABC}$.

ctdummy: variável referente à presença (ou não) de projetos de Cooperação Técnica Brasileira em um país em um determinado ano. Codificada como 1 para presença de projetos e 0 para ausência. Elaborada a partir do banco de dados fornecido pela ABC.

ctprop: variável relativa aos valores gastos por ano para cada país da amostra em projetos de cooperação técnica bilateral executados pelo Brasil entre os anos de 2000 e 2016 em dólares (valores constantes U\$2016), proporcionalmente ao tamanho da população de cada país receptor. Elaborada a partir do banco de dados fornecido pela $\mathrm{ABC}$.

esquerda: variável dicotômica para os governos de posição ideológica de esquerda (Database of Political Institutions).

exp: variável referente à ao total exportações brasileiras em dólares para cada país em cada ano da amostra entre 2000 e 2016 (valores constantes U\$2011) (www.comtrade.un.org).

fmi: variável dicotômica correspondente à participação de determinado país no bloco brasileiro no diretório executivo do FMI em determinado ano. Codificada com base nos dados fornecidos no site da instituição (www.imf.org).

ied: variável referente ao total de investimento estrangeiro direto brasileiro realizado em cada país para cada ano da amostra entre os anos 2006 e 2016. Codificada com base nos dados disponíveis no site do Banco Central do Brasil (www.bcb.gov.br).

imp: variável referente à ao total importações brasileiras em dólares para cada país em cada ano da amostra entre 2000 e 2016 (valores constantes U\$2011) (www.comtrade.un.org). 
In_bndes: logarítimo natural da variável "bndes".

In_percapita: logarítimo natural da variável "percapita".

In_ct: logarítimo natural da variável "ct".

In_ctprop: logarítimo natural da variável “ctprop”.

In_exp: logarítimo natural da variável "exp".

In_ied: logarítimo natural da variável "ied".

In_imp: logarítimo natural da variável “imp”.

omc: variável referente à participação dos países nas coalizões que o Brasil participa no ambito da Organização Mundial do Comércio. Operacionalizada como a razão de participação em cada uma das coalizões conjuntas com o Brasil na OMC pelo total de coalizões que o Brasil integrou no período: NAMA-11, Mercosul, W-52, FANs, G20T e grupo de Cairns (www.wto.org).

onu: índice de similaridade de votações (0-1) igual ao total de votos em que dois estados concordam divido pelo total de votos conjuntos. Computado usando três categorias (1: sim ou aprovação sobre um assunto, 2: abstenção, 3: não ou desaprovação sobre um assunto) (Strezhnev \& Voeten, 2014).

percapita: variável utilizada para mensurar o nível de desenvolvimento de um país. Operacionalizada como PIB per capita de cada país entre os anos de 2000 e 2016 em dólares (valores constantes U\$2010) (World Development Indicators).

polity: variável utilizada para captar o nível de democracia nos países receptores. Classificada de -10 (menos democrático) para +10 (mais democrático) (Polity IV database).

pts: variável utilizada para mensurar o nível de proteção aos direitos humanos nos países receptores. Operacionalizada com base nos dados fornecidos pela Anistia Internacional. Escala de 1 (mais proteção) a 5 (menos proteção) (Political Terror Scale database).

viagem: variável relativa ao número total de viagens presidências brasileiras para cada país em cada ano da amostra entre 2000 e 2016 (www.itamaraty.gov.br/ http://www2.planalto.gov.br/). 


\section{B. Resultados estatísticos}

Tabela B1. Modelos em Painel Dinâmico para a alocação de Cooperação Técnica Brasileira

\begin{tabular}{|c|c|c|c|c|c|c|c|c|c|c|c|c|}
\hline & GMM & Logit & Poisson & GMM & Logit & Poisson & GMM & Logit & Poisson & GMM & Logit & Poisson \\
\hline \multirow[t]{2}{*}{ Lag $\operatorname{VD}_{t-1}$} & $0.594 * * *$ & $4.406 * * *$ & $0.139 * * *$ & $0.628 * * *$ & $3.480 * * *$ & $0.0748 * * *$ & $0.660 * * *$ & $4.383 * * *$ & $0.128 * * *$ & $0.425 * * *$ & $3.404 * * *$ & $0.0678 * * *$ \\
\hline & $(0.0382)$ & $(0.247)$ & $(0.00958)$ & $(0.0345)$ & $(0.236)$ & $(0.0112)$ & $(0.0425)$ & $(0.254)$ & $(0.0111)$ & $(0.0641)$ & $(0.313)$ & $(0.0125)$ \\
\hline \multirow[t]{2}{*}{ In_bndes } & $0.356^{* *}$ & $0.109 * *$ & $0.0399 * * *$ & & & & & & & $0.251^{* *}$ & $0.0987 * *$ & 0.0137 \\
\hline & $(0.110)$ & $(0.0365)$ & $(0.0113)$ & & & & & & & $(0.0897)$ & $(0.0382)$ & $(0.0136)$ \\
\hline \multirow[t]{2}{*}{ ln_ied } & 0.0995 & 0.0122 & 0.0287 & & & & & & & $0.703^{*}$ & $0.180^{*}$ & 0.0305 \\
\hline & $(0.212)$ & $(0.0470)$ & $(0.0439)$ & & & & & & & $(0.312)$ & $(0.0707)$ & $(0.0684)$ \\
\hline \multirow[t]{2}{*}{ ln_exp } & $0.577 * * *$ & $0.160 * * *$ & $0.199 * * *$ & & & & & & & $1.238 * *$ & $0.232 * *$ & $0.165^{*}$ \\
\hline & $(0.139)$ & $(0.0393)$ & $(0.0533)$ & & & & & & & $(0.380)$ & $(0.0776)$ & $(0.0775)$ \\
\hline \multirow[t]{2}{*}{ ln_imp } & $-0.277 * *$ & $-0.0813 * * *$ & $-0.0788 * *$ & & & & & & & -0.178 & -0.0383 & -0.0333 \\
\hline & $(0.106)$ & $(0.0231)$ & $(0.0274)$ & & & & & & & $(0.202)$ & $(0.0354)$ & $(0.0288)$ \\
\hline \multirow[t]{2}{*}{ fmi } & & & & $10.33 * * *$ & $2.779 * * *$ & $1.312 * * *$ & & & & $13.61 * * *$ & $2.106 * * *$ & $1.335^{* * *}$ \\
\hline & & & & $(1.942)$ & $(0.463)$ & $(0.195)$ & & & & $(3.636)$ & $(0.510)$ & $(0.322)$ \\
\hline $\mathrm{bm}$ & & & & -2.628 & $-1.115^{*}$ & 0.0499 & & & & -4.779 & $-1.214 * * *$ & -0.264 \\
\hline \multirow[t]{2}{*}{ omc } & & & & $10.48 * *$ & $2.018 * *$ & $2.055 * *$ & & & & 4.703 & 0.312 & 0.494 \\
\hline & & & & (3.189) & $(0.682)$ & $(0.676)$ & & & & $(5.663)$ & $(0.897)$ & $(0.911)$ \\
\hline \multirow[t]{2}{*}{ onu } & & & & $13.45^{* * *}$ & $8.284 * * *$ & $7.331 * * *$ & & & & $30.55^{* * *}$ & $8.057 * * *$ & $8.434 * * *$ \\
\hline & & & & $(2.517)$ & $(1.201)$ & $(1.516)$ & & & & $(8.435)$ & (1.771) & $(2.214)$ \\
\hline \multirow[t]{2}{*}{ esquerda } & & & & 1.212 & 0.200 & $0.486^{* *}$ & & & & 1.437 & 0.142 & 0.302 \\
\hline & & & & $(0.730)$ & $(0.206)$ & $(0.178)$ & & & & (1.300) & $(0.260)$ & $(0.234)$ \\
\hline \multirow[t]{2}{*}{ cplp } & & & & $9.164 * * *$ & $2.078 * *$ & $1.330 * * *$ & & & & $8.936^{*}$ & 1.159 & $0.924 * *$ \\
\hline & & & & $(2.525)$ & $(0.657)$ & $(0.229)$ & & & & (4.022) & $(0.610)$ & $(0.331)$ \\
\hline \multirow[t]{2}{*}{ viagem } & & & & 1.271 & $0.641 * *$ & $0.221 *$ & & & & -0.817 & -0.0961 & 0.140 \\
\hline & & & & $(0.924)$ & $(0.208)$ & $(0.0869)$ & & & & $(0.880)$ & $(0.243)$ & $(0.0939)$ \\
\hline
\end{tabular}




\begin{tabular}{|c|c|c|c|c|c|c|c|c|c|c|c|c|}
\hline \multirow[t]{2}{*}{ ln_percapita } & & & & & & & $-1.099 * * *$ & $-0.308 * * *$ & $-0.221^{*}$ & $-1.916 * *$ & $-0.350 *$ & -0.193 \\
\hline & & & & & & & $(0.292)$ & $(0.0765)$ & $(0.0957)$ & $(0.705)$ & $(0.138)$ & $(0.140)$ \\
\hline \multirow[t]{2}{*}{ pts } & & & & & & & 0.00994 & 0.0179 & -0.0185 & 0.173 & -0.0399 & -0.163 \\
\hline & & & & & & & $(0.378)$ & $(0.0980)$ & $(0.115)$ & $(0.613)$ & $(0.111)$ & $(0.0966)$ \\
\hline \multirow[t]{2}{*}{ polity } & & & & & & & $0.185^{* *}$ & $0.0570 * *$ & 0.0737 & $0.373 * *$ & $0.0652 * *$ & 0.0726 \\
\hline & & & & & & & $(0.0617)$ & $(0.0207)$ & $(0.0395)$ & $(0.133)$ & $(0.0236)$ & $(0.0383)$ \\
\hline cons & 0 & $-4.158 * * *$ & $-2.857 * * *$ & 0 & $-11.59 * * *$ & $-9.518^{* * *}$ & 0 & -1.324 & -0.737 & 0 & $-10.82 * * *$ & $-9.078 * * *$ \\
\hline $\mathrm{N}$ & 2092 & 2092 & 2092 & 2654 & 2654 & 2654 & 2078 & 2078 & 2078 & 1100 & 1100 & 1100 \\
\hline \multirow[t]{2}{*}{$\mathrm{AB}$ test (AR1) } & -7.21 & & & -8.21 & & & -7.04 & & & -5.87 & & \\
\hline & 0.000 & & & 0.000 & & & 0.000 & & & 0.000 & & \\
\hline \multirow[t]{2}{*}{$\mathrm{AB}$ test (AR2) } & 1.60 & & & 2.12 & & & 2.41 & & & 2.07 & & \\
\hline & 0.109 & & & 0.034 & & & 0.016 & & & 0.038 & & \\
\hline
\end{tabular}

Erros padrão entre parênteses

$* \mathrm{p}<0.05, * * \mathrm{p}<0.01, * * * \mathrm{p}<0.001$ 
Figura B1. Efeitos marginais de cada variável sobre o recebimento de Cooperação Técnica Brasileira
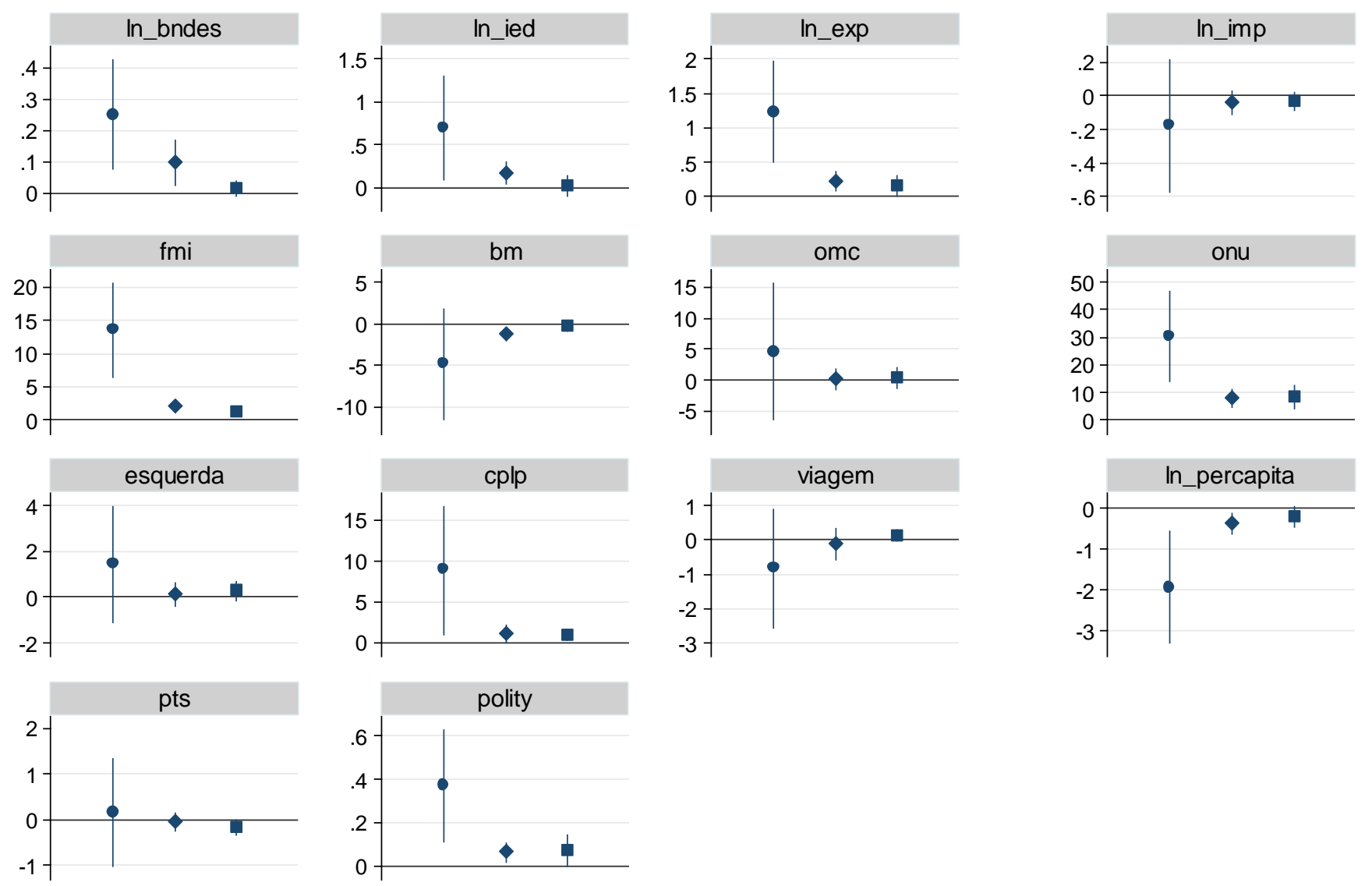

- GMM $\bullet$ Logit $\quad$ Poisson

Fonte: elaborada pelo autor 
Tabela B2. Tabela de correlação entre as variáveis independentes

\begin{tabular}{|c|c|c|c|c|c|c|c|c|c|c|c|c|c|c|}
\hline & ln_bndes & ln_ied & In_exp & ln_imp & fmi & bm & omc & onu & esquerda & cplp & viagem & In_percapita & pts & polity \\
\hline ln_bndes & 1.0000 & & & & & & & & & & & & & \\
\hline In_ied & 0.1180 & 1.0000 & & & & & & & & & & & & \\
\hline ln_exp & 0.1441 & 0.3629 & 1.0000 & & & & & & & & & & & \\
\hline ln_imp & 0.1160 & 0.3497 & 0.7477 & 1.0000 & & & & & & & & & & \\
\hline fmi & 0.1331 & 0.0515 & 0.0889 & -0.0017 & 1.0000 & & & & & & & & & \\
\hline bm & 0.1402 & 0.0817 & 0.1258 & 0.0661 & 0.8056 & 1.0000 & & & & & & & & \\
\hline omc & 0.1977 & 0.2008 & 0.4349 & 0.3884 & 0.0360 & 0.1216 & 1.0000 & & & & & & & \\
\hline onu & 0.0906 & -0.2557 & -0.0988 & -0.2123 & 0.1276 & 0.1240 & 0.1116 & 1.0000 & & & & & & \\
\hline esquerda & 0.1378 & 0.1182 & 0.1619 & 0.1758 & 0.0443 & -0.0228 & 0.1684 & 0.0526 & 1.0000 & & & & & \\
\hline cplp & 0.1040 & -0.0094 & -0.0351 & -0.0342 & 0.0322 & -0.0398 & -0.0505 & 0.0917 & 0.1004 & 1.0000 & & & & \\
\hline viagem & 0.2125 & 0.3311 & 0.3207 & 0.3049 & 0.0470 & 0.0533 & 0.2834 & -0.0786 & 0.1458 & 0.0383 & 1.0000 & & & \\
\hline In_percapita & 0.0050 & 0.3673 & 0.3513 & 0.4562 & -0.0174 & -0.0134 & 0.0321 & -0.4449 & -0.0275 & -0.0928 & 0.1394 & 1.0000 & & \\
\hline pts & 0.0022 & -0.2126 & -0.1037 & -0.1514 & 0.0197 & 0.0716 & -0.0207 & 0.2663 & -0.0799 & -0.0200 & -0.0628 & -0.4834 & 1.0000 & \\
\hline polity & 0.0213 & 0.3037 & 0.2460 & 0.2382 & 0.1137 & 0.1095 & 0.2517 & -0.3815 & 0.0483 & 0.0110 & 0.1682 & 0.3030 & -0.3667 & 1.0000 \\
\hline
\end{tabular}

Fonte: elaborada pelo autor 